\title{
MÉTODOS ATUARIAIS APLICADOS À DETERMINAÇÃO DA TAXA DE PRÊMIO DE CONTRATOS DE SEGURO AGRÍCOLA: UM ESTUDO DE CASO
}

\author{
VITOR AUGUSTO OZAKI
}

\begin{abstract}
Tese apresentada à Escola Superior de Agricultura "Luiz de Queiroz", Universidade de São Paulo, para obtenção do título de Doutor em Ciências, Área de Concentração: Economia Aplicada.
\end{abstract}

P I R A C I C A B A

Estado de São Paulo - Brasil

Março - 2005 


\title{
MÉTODOS ATUARIAIS APLICADOS À DETERMINAÇÃO DA TAXA DE PRÊMIO DE CONTRATOS DE SEGURO AGRÍCOLA: UM ESTUDO DE CASO
}

\author{
VITOR AUGUSTO OZAKI \\ Engenheiro Agrônomo
}

Orientador: Prof. Dr. RICARDO SHIROTA

\begin{abstract}
Tese apresentada à Escola Superior de Agricultura "Luiz de Queiroz", Universidade de São Paulo, para obtenção do título de Doutor em Ciências, Área de Concentração: Economia Aplicada.
\end{abstract}

P I R A C I C A B A

Estado de São Paulo - Brasil

Março - 2005 
Dados Internacionais de Catalogação na Publicação (CIP) DIVISÃO DE BIBLIOTECA E DOCUMENTAÇÃO - ESALQ/USP

\section{Ozaki, Vitor Augusto}

Métodos atuariais aplicados à determinação da taxa de prêmio de contratos de seguro agrícola: um estudo de caso / Vitor Augusto Ozaki. - - Piracicaba, 2005. $324 \mathrm{p}$.

Tese (doutorado) - - Escola Superior de Agricultura Luiz de Queiroz, 2005. Bibliografia.

1. Inferência Bayesiana 2. Inferência não-paramétrica 3. Inferência paramétrica 4. Seguro agrícola 5. Teoria da informação I. Título

CDD 338.13 
"An approximate answer to the right question is worth a good deal more than the exact answer to an approximate problem".

John W. Tukey (1915 - 2000) 


\section{DEDICO}

Aos meus Avôs,

Shoji Ozaki (in memoriam)

Minori Kawatoko(in memoriam) 


\section{AGRADECIMENTOS}

Tentarei expressar nestes poucos parágrafos apenas uma pequena fração da minha gratidão em relação a algumas pessoas que participaram direta ou indiretamente na consecução desta pesquisa. Seja pelo convívio diário no ambiente profissional ou até mesmo nas intensas discussões nas mesas de botequins.

De fato, tantos entes iluminados passaram pelo meu caminho que fizeram destes últimos anos um período único na minha vida (felizmente, alguns ainda insistem em continuar nele). Foram tantas as experiências felizes, outras um tanto quanto tristes, que tornam a transcrição destas poucas páginas um trabalho árduo. Antecipadamente expresso minhas desculpas àqueles não mencionados nestes parágrafos, mas que de maneira alguma, são menos importantes para mim.

Ofereço esta obra a duas pessoas muito especiais e que sempre foram meu ponto de referência: meus pais, Luiz e Fumie. Ao meu pai, uma pessoa particularmente iluminada, com caráter e personalidade inabaláveis, permitiu que eu tivesse acesso ao meu bem mais importante, o conhecimento. À minha mãe, centro intocável da minha família, sempre incentivou e colocou nossa formação educacional (minha e a da minha querida irmã Iza) em primeiro lugar.

Sou grato ao Mauro (Saidera), pessoa que me ensinou o sentido da palavra generosidade e humildade. Ao Nelson, por ter enfrentado tantos altos e baixos na vida, me mostrou a importância de ser persistente e de sempre lutar. Para você, meu camarada, relembro aquele famoso refrão: “...Ali onde eu chorei qualquer um chorava, dar a volta por cima 
que eu dei, quero ver quem dava” (Noite Ilustrada). Dois grandes amigos que estarão sempre presentes, apesar da distância.

Um agradecimento especial devo ao meu grande "mestre” e amigo Ricardo Shirota, grande apreciador dos "pequenos prazeres" da vida. Sua profunda sapiência e seu olhar sempre afrente do seu tempo foram fatores fundamentais na minha formação profissional. Exemplo de professor e orientador, suas idéias e críticas (sempre construtivas) foram fundamentais na elaboração desta obra.

Pelas valiosas sugestões apontadas no decorrer do trabalho, sou grato aos professores Silvio Sandoval Zocchi, Roseli Aparecida Leandro, Joaquim Bento de Souza Ferreira Filho, Alexandre Lahoz Mendonça de Barros, Evaristo Marzabal Neves e Adriano Júlio de B. V. de Azevedo Filho. Gratifico também: Pedro Scardua, Elenice, Helena, Márcia, Cris, André, Álvaro, Ligiana e, especialmente, à Maielli, funcionária exemplar.

To Dr. Jon Brandt and his secretary Miss Warrick for all efforts spent. A special thanks to two brilliant minds: Dr. Barry K. Goodwin (Department of Agricultural and Resource Economics/North Carolina State University-NCSU) and Dr. Sujit K. Ghosh (Department of Statistics//North Carolina State University) for giving me precious advices and the opportunity to develop part of my dissertation at NCSU. And last but not least, thanks to the staff in the Department: Brandon, Chris, Miss Kathuria, Parker, Miss Seale, Miss Smith and specially to Scott Cravens.

À Roberta, pelo carinho, companheirismo e intensa dedicação. Sua bondade, alegria e imensa generosidade tornaram todos os segundos vividos nestes últimos anos eternos. $\mathrm{O}$ tempo moldou a beleza que os meus olhos viram em você. Mas o que é tempo, senão uma sucessão de segundos. Segundos estes, que sempre passam e não voltam mais. Obrigado pelos meus melhores segundos vividos. 
Com muito carinho aos amigos da pós. Momentos inesquecíveis que compartilhei com estas figuras: Alex (Nicolella), Alexandre (Conchas), Bel, Carlos Pena (Chuck), Daniel (Mifunga), Davi (Lanterna), Henrique (Grotoxo), “Captain” Humberto, “mestre” João Maurício, Lu (Biblioteca), Mauro, Roberto, “grande” Roger, Sérgio, Silvio e, não se esqueçam, meus caros amigos, “a saidera é tão importante quanto a primeira”.

Algumas pessoas contribuiram para que eu pudesse entender melhor o mercado de seguro agrícola sob a ótica das seguradoras e empresas de consultoria: Roberto da Rocha Azevedo (Gerenseg), Antonio C. F. Gimenes e Marcos Horiguti (Cosesp), Joaquim F. R. Cesar Neto (Brasileira Rural Seguradora) e Carlos Toledo (Rain Hail/Brasil). À eles expresso meus agradecimentos pelas informações e tempo despendido.

À Castrolanda, à Fundação ABC e a Impar, pela suporte e cooperação no andamento da projeto. Em especial agradeço ao Sr. Marco Antônio Prado, Sr. Rodrigo de Araújo Rodrigues, ao Sr. Willem B. Bouwman, Sr. Eltje Jan Loman Filho, e aos pesquisadores Carlos Proença, Rodrigo Tsukahara e, atenciosamente, a Leandro Gimenez.

Finalmente, agradeço à Coordenação de Aperfeiçoamento de Pessoal de Nível Superior (CAPES) por todo o suporte financeiro durante a fase de doutoramento. 
SUMÁRIO

Página

LISTA DE FIGURAS............................................................................... xii

LISTA DE TABELAS.................................................................................. xvi

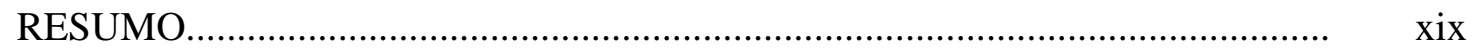

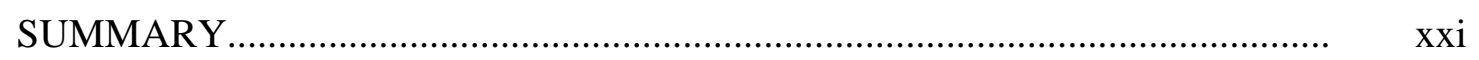

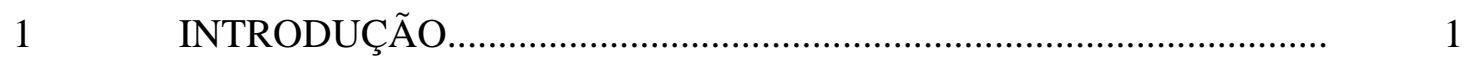

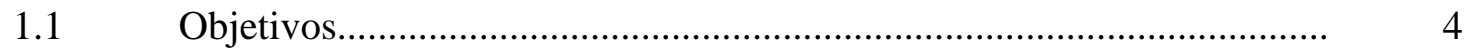

$1.2 \quad$ Organização do trabalho.........................................................................

2 SEGURO AGRÍCOLA: ORIGEM, EVOLUÇÃO E TENDÊNCIAS.... 7

$2.1 \quad$ O seguro agrícola nos EUA................................................................

2.1.1 Contexto histórico.........................................................................

2.1.1.1 Caracterização dos diferentes tipos de contratos....................................... 26

2.1.1.1.1 Proteção da renda (Income Protection) - IP........................................... 26

2.1.1.1.2 Seguro da renda (Revenue Assurance) - RA......................................... 29

2.1.1.1.3 Cobertura da renda agrícola (Crop Revenue Coverage) - CRC.............. 35

2.1.1.1.4 Plano de risco grupal (Group Risk Plan) - GRP e plano de risco da renda grupal (Group Risk Income Plan) - GRIP.................................. 37

2.1.1.1.5 Renda bruta ajustada (Adjusted Gross Revenue) - AGR........................ $\quad 40$

2.1.1.2 Subsídio e participação no seguro agrícola americano............................. 46

2.2 Seguro agrícola no Brasil.................................................................... 54

2.2.1 Contexto nacional........................................................................... 54

2.2.1.1 Programa de garantia da atividade agropecuária - PROAGRO............... 72 


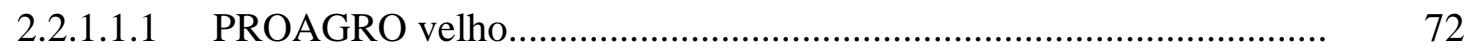

2.2.1.1.2 PROAGRO novo....................................................................... $\quad 78$

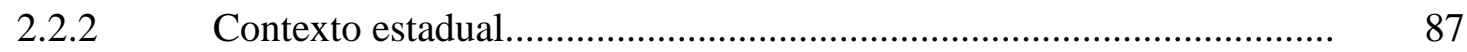

2.2.2.1 O Seguro agrícola no Estado de São Paulo............................................ 87

2.2.2.1.1 Companhia de seguros do Estado de São Paulo - COSESP................. 94

2.2.2.1.1.1 O Seguro de custeio agrícola............................................................... 98

2.2.2.2 O seguro rural estatal em outros Estados.............................................. 119

2.2.2.2.1 A experiência de Minas Gerais............................................................ 119

2.2.2.2.2 Rio de Janeiro............................................................................... 120

2.2.2.2.3 Rio Grande do Sul......................................................................... 121

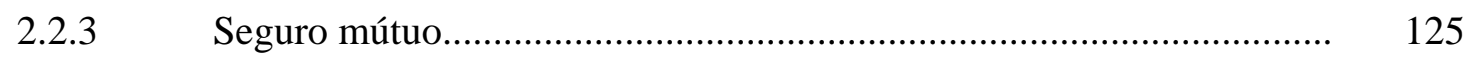

2.2.3.1 Cooperativa agropecuária batavo Ltda.............................................. 126

2.2.3.2 Cooperativa agrária mista entre rios Ltda........................................... 127

2.2.3.3 Associação dos fumicultores do Brasil - AFUBRA............................ 128

2.2.3.4 Instituto riograndense do arroz - IRGA.......................................... 130

2.2.4 Novas iniciativas privadas.............................................................. 131

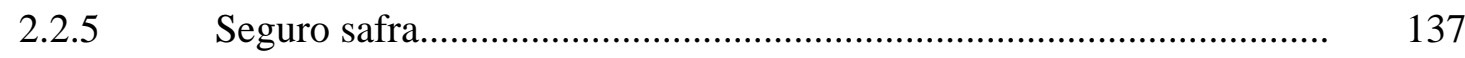

2.2.6 Projetos de lei.................................................................................. 139

2.2.7 Fundo de estabilidade do seguro rural - FESR...................................... 144

2.2.8 Instituto de resseguros do Brasil - IRB............................................... 148

3 REVISÃO TEÓRICA E METODOLÓGICA................................... 152

3.1 Aspectos microeconômicos do seguro................................................. 152

3.1.1 A teoria dos mercados contingentes................................................. 152

3.1.1.1 A economia do seguro......................................................................... 161

3.1.1.1.1 A escolha individual....................................................................... 169

3.1.1.1.2 O problema da seleção adversa.......................................................... 177

3.1.1.1.2.1 O equilíbrio conjunto........................................................................... 178

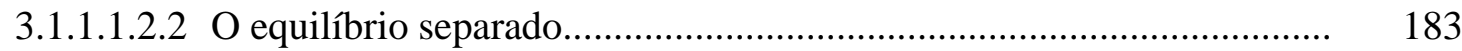


3.1.1.1.3 O problema do risco moral.................................................................. 185

O seguro agrícola........................................................................... 193

3.2.1 Algumas considerações teóricas.......................................................... 195

3.2.2 O seguro agrícola baseado em índices regionais................................. 199

3.2.2.1 O seguro de produtividade regional....................................................... 200

3.2.2.2 O seguro de índices climáticos........................................................... 208

3.3 A modelagem da produtividade agrícola: implicações para a precificação de contratos de seguro agrícola........................................ 214

$4 \quad$ METODOLOGIA...................................................................... 228

4.1 Análise paramétrica e não-paramétrica na determinação das taxas de prêmio de um contrato de seguro agrícola............................................ 228

4.1.1 Peculiaridades na modelagem de dados de produtividade agrícola...... 229

Análise paramétrica......................................................................... 232

4.1.3 Análise não-paramétrica...................................................................... 233

4.1.4 Heteroscedasticia e tendência............................................................... 237

4.2 Modelagem espaço-temporal de dados de produtividade agrícola aplicados à precificação de contratos de seguro agrícola..................... 238

4.2.1 Modelagem estatística.................................................................... 239

4.2.2 Modelagem temporal.................................................................... 244

4.2.3 Modelagem espacial................................................................... 246

4.2.4 Modelagem espaço-temporal.............................................................. 249

4.2.5 Seleção de modelos e escolha.............................................................. 251

Correlação e risco sistêmico............................................................... 254

Correlação espacial....................................................................... 261

$5 \quad$ RESULTADOS E DISCUSSÃO ...................................................... 266

5.1 Resultados da análise paramétrica e não-paramétrica na

5.1.1 Análise dos dados e precificação de um contrato de seguro agrícola... 266 
5.2 Resultados do modelo espaço-temporal............................................... 278

5.2.1 Análise empírica............................................................................. 278

5.2.2 Aplicação: precificação de um contrato de seguro agrícola................... 285

5.3 Quantificação do risco sistêmico e da correlação entre a produtividade individual e regional..................................................... 287

5.3.1 Nível de agregação: municipal.......................................................... 287

5.3.2 Nível de agregação: cluster.............................................................. 295

5.4 Resultados da correlação espacial......................................................... 300

$6 \quad$ CONCLUSÕES.......................................................................... 303

REFERÊNCIAS BIBLIOGRÁFICAS............................................................. 308 


\section{LISTA DE FIGURAS}

Página

1 Evolução do índice de sinistralidade do seguro agrícola nos EUA, 1939 a 1947

2 Evolução do índice de sinistralidade do seguro agrícola nos EUA, 1948 a 1959.

3 Evolução do índice de sinistralidade do seguro agrícola nos EUA, 1970 a 1978

4 Evolução do índice de sinistralidade do seguro agrícola nos EUA, 1981 a 1994

5 Procedimento de cálculo ilustrativo da produtividade APH, de acordo com o número de dados disponíveis.

6 Exemplo hipotético da indenização na cobertura CAT, para a cultura da soja.

7 Exemplo de cálculo da indenização e do prêmio no MPCI............................... 22

8 Estados americanos cobertos pelo AGR, em verde.......................................... 27

9 Cálculo da indenização do seguro IP, ao nível de cobertura de 75\%, para o milho, em uma área de mil acres.

10 Estados americanos cobertos pelo RA, em azul.............................................. 29

11 Área cultivada de milho, soja e trigo em determinado setor............................ 31

12 Cálculo do valor índice de receita, para a unidade básico.............................. 31

13 Cálculo do valor índice de receita, para a unidade empresa e fazenda............. 32 
14 Cálculo da receita garantida no seguro RA, para o nível de cobertura de $75 \%$, por unidades selecionadas.

15 Cálculo da receita efetiva, por unidade selecionada. 34

16 Cálculo da receita efetiva e indenização, por unidade...................................... 34

17 Cálculo da garantia final, receita calculada e indenização................................ 36

18 Estados americanos cobertos pelo GRP, em azul....................................... 38

19 Principais etapas para o cálculo da indenização no GRP e GRIP..................... 40

20 Estados americanos cobertos pelo AGR, em azul.............................................. 41

21 Procedimento de cálculo da indenização do AGR............................................ 42

22 Número mínimo de culturas a serem implantadas, de acordo com o nível de cobertura e taxa de pagamento

23 Principais características dos programas de seguro de produtividade............... 44

24 Principais características dos programas de seguro de renda........................... 45

25 Prêmio total, subsídio ao prêmio, em milhões de dólares, e percentual de subsídio em relação ao prêmio do seguro MPCI, no período de 1981 a 1994. ..

26 Prêmio total, subsídio ao prêmio, em milhões de dólares, e percentual de subsídio em relação ao prêmio do seguro MPCI, por tipo de seguro, no período de 1995 a 2001.

27 Área segurada total, em milhões de acres, no período de 1981 a 2001............ 51

28 Índice de sinistralidade, por tipo de seguro, no período de 1995 a 2001...........

29 Montante de subsídio administrativo e operacional resgatado pelas seguradoras, em milhões de dólares, no período de 1981 a 1999..................... 54

30 Organograma representativo da estrutura de funcionamento do

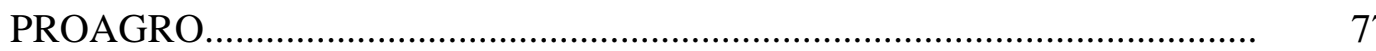

31 Índice de sinistralidade do PROAGRO, no período de 1980 a 1991....................... 78

32 Principais diferenças entre o seguro agrícola e PROAGRO...................................... 80

33 Organograma representativo da proposta de reestruturação do PROAGRO.... 84 
34 Índice de sinistralidade do PROAGRO, no período de 1991 a 1997

35 Índice de sinistralidade da carteira de seguro contra granizo para viticultores, no período de 1952/53 a 1969/70.

36 Índice de sinistralidade para a carteira de seguro contra o granizo para a lavoura algodoeira, no período de 1939/40 a 1969/70

37 Sinistralidade na carteira de seguro de geada para fruticultores, horticultores e floricultores.

38 Evolução do número de seguros realizados (mil unidades): total agrícola e seguro para o algodão, sinistros pagos e participação do algodão no total, no período 1979/80 a 1989/90

39 Sinistralidade para a cultura algodoeira, no período 1979/80 a 1989/90......... 105

40 Principais sinistros ocorridos em 1990

41 Evolução do número de seguros realizados de algodão, feijão, tomate, trigo e outros, no período 1991/92 a 2001/02.

42 Número de contratos (mil) de soja, milho e total e percentual de participação de milho e soja no total, no período de 1991/92 a 2001/02.

43 Percentual de prêmio arrecadado, por modalidade, no período 1991/92 a 2001/02.

44 Evolução do número de sinistros pagos (mil), por modalidade, no período 1991/92 a 2001/02.

45 Evolução da área segurada, por principais modalidades, em 1000 hectares, no período 1991/92 a 2001/02.

46 Percentual da área sinistrada em relação à área segurada das respectivas culturas, nos ciclos agrícolas de 1997/98 a 2001/02

47 Evolução do índice de sinistralidade da carteira agrícola da COSESP, no período 1991/92 a 2001/02.

48 Culturas seguradas e riscos cobertos.

49 Riscos cobertos e excluídos. 
50 Riscos cobertos e excluídos............................................................................. 116

51 Bens segurados e taxas anuais (\%) do seguro porteira fechada........................ 117

52 Principais seguradoras que operam ou já operaram o seguro rural................... 132

53 Principais culturas e abrangência territorial do Seguro Ouro Agrícola, no

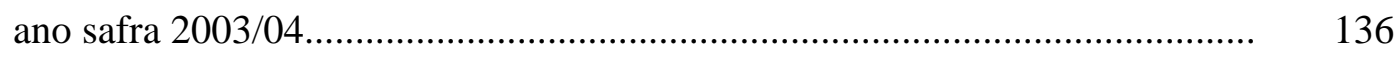

54 O mercado de commodities contingentes...................................................... 154

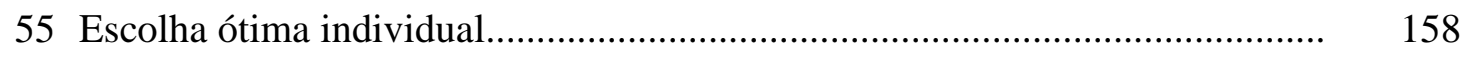

56 Preços justos e não justos e a escolha do consumidor........................................ 160

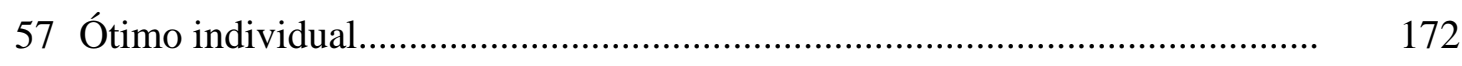

58 Custos incidentes....................................................................................... 177

59 O contrato ofertado para ambos os grupos ao prêmio justo............................... 180

60 Contratos ofertados aos indivíduos de baixo risco............................................. 182

61 Contratos ofertados separadamente para cada grupo........................................ 184

62 O risco moral...................................................................................... 187

63 Contrato com cobertura parcial..................................................................... 190

64 Evolução da produtividade do milho, soja e trigo, nos municípios do Estado do Paraná, em 1990, 1996 e 2002, em kg/ha.

65 Comparação das densidades não-paramétricas $\left(10^{-4}\right)$ para as culturas do milho, soja e trigo, em função da distância d escolhida................................... 268

66 Comparação das densidades não-paramétricas $\left(10^{-4}\right)$ para as culturas do milho, soja e trigo, das séries corrigidas e não corrigidas para a

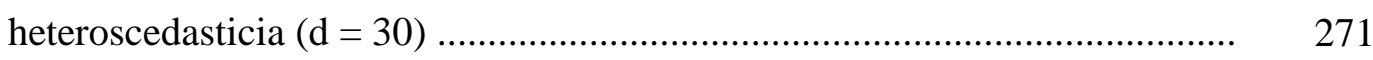

67 Modelo 1 expresso graficamente.................................................................. 281

68 Decomposição de $u_{i t}$ em suas componentes determinística e estocástica........ 282

69 Densidades a posteriori de $\zeta_{1}, \zeta_{2}$ e $\rho$, respectivamente, para os municípios de Castro, Ponta Grossa, Marilândia do Sul, Tibagi, Catanduvas e Rolândia. 283

70 Semivariograma ajustado para o milho, em 2002 (distâncias em km)............. 302 


\section{LISTA DE TABELAS}

Página

1 Percentuais da produtividade de transição utilizados para o cálculo da produtividade APH (série de quatro anos)

2 Evolução dos percentuais de subsídio por nível cobertura, para o seguro MPCI, no período de 1998 a 2001

3 Evolução dos percentuais de subsídio por nível cobertura, para o seguro CRC, no período de 1998 a 2001

4 Prêmios (taxa de 8\%) e indenizações da carteira de seguro contra granizo para viticultores realizados no período de 1952/53 a 1969/70, em R \$, deflacionados para Setembro de 2004.

5 Resultados do seguro agrícola do algodão, nos anos safras 1974/75 a $1977 / 78$

6 Resseguros e cosseguros retidos.

7 Dados estatísticos referentes aos seguros oferecidos pela COSEMIG, no período de 1974/75.

8 Resultado seguro agrícola estadual, no período de janeiro a novembro de 2001, em R\$

9 Resseguro automático e retenção do IRB-Brasil Re no ramo rural.................... 150

10 Situação do indivíduo com e sem seguro nos estados 1 e 2............................... 170

11 Taxas de prêmio (\%) para soja, no município de Cascavel, calculadas pelo método empírico. 
12 Taxas de prêmio (\%) para soja, no município de Cascavel, calculadas pelo método não-paramétrico.

13 Taxas empíricas de prêmio (\%) para milho, no município de Guarapuava........

14 Taxas de prêmio (\%) para milho, no município de Guarapuava, calculadas pelo método não-paramétrico.

15 Taxas empíricas de prêmio (\%) para o trigo, no município de Tibagi..

16 Taxas de prêmio (\%) para o trigo, no município de Tibagi, calculadas pelo método não-paramétrico.

17 Escolha dos modelos.

18 Valores preditos da produtividade, desvio padrão e percentis 5, 50 e 95\%, para os municípios selecionados, nos anos de 2003 e 2004.

19 Taxas de prêmio atuarialmente justas (\%), calculadas para os municípios de Castro, Ponta Grossa, Marilândia do Sul, Tibagi, Catanduvas e Rolândia....

20 Coeficiente de correlação, $\beta_{i}$, redução do risco e percentual da redução do risco, em relação ao risco total das séries de produtividade de milho, para diferentes $\alpha_{i}{ }^{\text {'s }}$, tal que $i=1$ a 26, no município de Castro, no Estado do Paraná, no período de 1994 a 2002

21 Coeficiente de correlação, $\beta_{i}$, redução do risco e percentual da redução do risco, em relação ao risco total das séries de produtividade de soja, para diferentes $\alpha_{i}{ }^{\text {'s }}$, tal que $i=1$ a 40, no município de Castro, no Estado do Paraná, no período de 1994 a 2002.

22 Nível ótimo de cobertura $\phi_{i}^{*}$, para o milho.

23 Nível ótimo de cobertura $\phi_{i}^{*}$, para a soja

24 Máxima redução do risco sistêmico em virtude da aquisição do seguro, para o milho

25 Máxima redução do risco sistêmico em virtude da aquisição do seguro, para a soja. 
26 Comparação das produtividades ( $\mathrm{kg} / \mathrm{ha})$ de soja e milho, por nível de agregação municipal e cluster, para Castro.

27 Coeficiente de correlação, $\beta_{i}$ e redução do risco e percentual da redução do risco, em relação ao risco total, das séries de produtividade de milho, ao nível de agregação cluster, em 26 fazendas, no município de Castro, no Estado do Paraná, no período de 1994 a 2003

28 Coeficiente de correlação, $\beta_{i}$ e redução do risco e percentual da redução do risco, em relação ao risco total das séries de produtividade de soja, ao nível de agregação cluster, em 40 fazendas, no município de Castro, no Estado do Paraná, no período de 1994 a 2003.

29 Distância, em Km, estimado pelo método da máxima verossimilhança, no período de 1990 a 2004, no Estado do Paraná 


\title{
MÉTODOS ATUARIAIS APLICADOS À DETERMINAÇÃO DA TAXA DE PRÊMIO DE CONTRATOS DE SEGURO AGRÍCOLA: UM ESTUDO DE CASO
}

\author{
Autor: VITOR AUGUSTO OZAKI \\ Orientador: Prof. Dr. RICARDO SHIROTA
}

\section{RESUMO}

O presente trabalho tem como principal objetivo, propor e testar métodos alternativos de precificação de contratos de seguro agrícola, baseados em um indicador de produtividade regional. A taxa de prêmio é calculada utilizando a abordagem nãoparamétrica de estimação da densidade da produtividade agrícola, a abordagem paramétrica utilizando as distribuições Normal e Beta e modelos hierárquicos Bayesianos. Na recuperação do processo gerador destes dados, são considerados os efeitos temporal, espacial e espaço-temporal visando a predição e a precificação de um contrato de seguro agrícola regional. Os dois primeiros métodos são aplicados a um conjunto de dados de produtividade municipal do Instituto Brasileiro de Geografia e Estatística (IBGE), no período de 1990 a 2002, para as culturas da soja, milho e trigo, no Estado do Paraná. Na análise empírica do modelo Bayesiano, são utilizados dados de produtividade municipal de milho, no Estado do Paraná, nos anos de 
1990 a 2002. A escolha do melhor modelo dentre os modelos não-aninhados ajustados, é baseado no critério da preditiva a posteriori. As metodologias utilizadas nesta pesquisa incorporam melhorias no cálculo atuarial da taxa de prêmio, tendo em vista o pequeno número de observações de produtividade agrícola existentes. Além de propor novas metodologias, estudou-se a viabilidade de implantar um esquema de seguro agrícola regional na região de Castro, no Estado do Paraná, levando em conta a quantificação e redução do risco sistêmico proveniente da aquisição do seguro e da correlação da produtividade individual e regional. Para melhor entendimento dos diversos aspectos do problema, é feito um amplo levantamento histórico e principais tendências do seguro agrícola no Brasil e nos EUA, ressaltando os aspectos legal, institucional e operacional. O estudo mostrou que se o seguro regional de produtividade for oferecido na região de Castro, os produtores se beneficiariam devido à redução do risco proveniente do seguro e também devido ao prêmio relativamente menor do que aquele cobrado pelas seguradoras para os mesmos municípios estudados. 


\title{
ACTUARIAL METHODS APPLIED TO THE DETERMINATION OF THE PREMIUM RATE OF CROP INSURANCE CONTRACTS: A CASE STUDY
}

\author{
Author: VITOR AUGUSTO OZAKI
}

Advisor: Prof. Dr. RICARDO SHIROTA

\section{SUMMARY}

This research analyses alternative methods of pricing agricultural insurance contract based on regional yields. The premium rate is calculated using three different approaches: nonparametric method to estimate the density of the agricultural yield; parametric approach fitting the Normal and Beta distributions; and, hierarchical Bayesian models. The data generating process is recovered considering the temporal, spatial and spatio-temporal aspects to make predictions and pricing for area-yield insurance contract. The data used are county yields, collected by the Brazilian Institute of Geography and Statistics (IBGE), 1990 through 2002. The first two methods were applied to soybean, corn and wheat in the State of Paraná. In the Bayesian model, the empirical analysis limited to corn, in the State of the Paraná, from 1990 through 2002. The choice of the best model among the several non-nested models tested was based on the posterior predictive criteria. The methods proposed in this research intend to improve the actuarial calculation of the premium rate, taking into account the small size of data 
regarding agricultural yields. Besides proposing different methodologies, a case study of the viability was carried out. The possibility of implementation of an are-yield agricultural insurance was studied in the region of Castro, in the State of the Paraná. This case study considers the quantification and reduction of the systemic risk and also the correlation of the individual and regional yield. To better understand the problem involving the agricultural insurance, a broad historical review of literature was made in Brazil and U.S.A., considering its legal, institutional and operational aspects. The study shows that if a regional yield insurance contract is offered in the Castro region, producers would benefit from exposure to lower risk levels and also a relatively smaller premium rate than the rates charged by insurance companies in the same region. 
A agricultura é uma atividade econômica tipicamente caracterizada pela sua vulnerabilidade a eventos que estão fora do controle do produtor. Notadamente, as principais causas da redução da produtividade agrícola são os eventos climáticos (seca, geada, chuva excessiva, granizo e biológicos, entre outros) que podem afetar as diversas culturas em diferentes estágios de desenvolvimento.

Todos os anos, os produtores tomam decisões a respeito do tamanho da área e qual cultura implantar, com base em expectativas de produtividade e do preço final $^{1}$ da safra agrícola. Quanto maior for a imprevisibilidade da ocorrência de um evento climático ou biológico, que cause grandes prejuízos, menor será a confiabilidade da estimativa da produtividade agrícola no final da safra.

O foco principal do presente trabalho será o estudo da variabilidade da produtividade. Todos os anos diversos eventos climáticos e/ou pragas e doenças afetam a produção agrícola.

Em Santa Catarina, segundo estimativas da Empresa de Pesquisa Agropecuária e Extensão Rural (Epagri), no ano de 1999, os impactos da seca no oeste catarinense, causaram prejuízos de R\$ 11,5 milhões (Souza, 2003).

Um estudo concluído pela Empresa Brasileira de Pesquisa Agropecuária $\left(\right.$ Embrapa $\left.^{2}\right)$, concluiu que a ferrugem asiática provocou perdas de cerca de 4,5 milhões

\footnotetext{
${ }^{1}$ Uma estimativa do preço final da soja, por exemplo, pode ser observada na Bolsa de Mercadorias e Futuro (BM\&F), no país ou na Chicago Board of Trade (CBOT), nos EUA. Porém, as oscilações de preço e seus respectivos mecanismos de controle embora importantes não serão analisadas neste estudo.

2 EMPRESA BRASILEIRA DE PESQUISA AGROPECUÁRIA. Embrapa aponta perdas de U\$2 bilhões com ferrugem da soja na safra 2003/2004. http://www.cnpso.embrapa.br/noticia/ ver_noticia.php?cod_noticia=127\&desl=1 (10 jul. 2004)
} 
de toneladas de soja, na safra 2003/04, totalizando um custo de aproximadamente US\$ 2 bilhões.

Diante deste problema, os produtores desenvolveram diversos mecanismos de defesa e mitigação do risco $^{3}$, tais como a diversificação de culturas, diversificação espacial, inter-setorial e a utilização de mecanismos de seguro.

Dentre estes mecanismos, o seguro permite a proteção da renda em momentos de infortúnio. Neste sentido, este mecanismo permite ao indivíduo igualar a renda quando ocorre um evento que cause danos econômicos à situação em que tal evento não ocorre, mediante o pagamento de um prêmio e o recebimento de uma compensação, caso ocorra o sinistro.

Neste contexto, o seguro agrícola pode ser visto como um importante instrumento de transferência do risco para outros agentes econômicos. Porém, este tipo de mecanismo embora seja teoricamente eficaz, na prática, o seguro agrícola tradicional ${ }^{4}$ tem-se mostrado insustentável economicamente a médio-longo prazo.

Em diversos países, como Brasil, EUA, Japão, Canadá e Índia, o total de prêmios arrecadados tem sido bem inferior ao montante de indenizações pagas. Além disso, estes programas são subsidiados, recebendo um forte apoio governamental (Ray, 1985; Dandekar, 1985; Gardner e Kramer, 1986; Lopes e Dias, 1986; Yamauchi, 1986; Sigurdson e Sin, 1994; Wright e Hewitt, 1994; Goodwin e Smith, 1995; Mosley e Krishnamurthy, 1995; Miranda, et al. 1999).

Dentre os diversos problemas do mercado segurador, pode-se apontar quatro problemas que afetam, sobremaneira, o mercado de seguro agrícola ${ }^{5}$ : problemas relacionados a assimetria de informação, tais como, o risco moral e a seleção adversa ou

\footnotetext{
${ }^{3}$ Neste trabalho, os conceitos de risco e incerteza serão utilizados tendo a mesma definição. Risco ou incerteza é a impossibilidade ou inabilidade de um agente econômico em prever o valor ou magnitude de uma determinada variável relevante em um certo momento futuro Nelson (1961). Por exemplo, no setor agrícola, o risco pode ser caracterizado pela inabilidade do produtor em conhecer com certeza o valor da produção na época da colheita. De modo geral, o risco pode ser considerado como proveniente de vários fatores: produção, mercado, financeiro, legal e ambiental e de natureza pessoal (Musser e Patrick, 2002).

${ }^{4}$ Aquele em que o mecanismo de compensação está atrelado somente à produtividade individual, cobrindo riscos múltiplos.

${ }^{5}$ Salientando que todos os problemas citados e os principais conceitos serão abordados nos próximos capítulos, em maior nível de detalhamento.
} 
anti-seleção, o risco sistêmico, a falta de dados de produtividade agrícola relativamente longa, que possam refletir, de maneira precisa, a estrutura de risco dos produtores.

Este último ponto somado a falta de metodologias atuariais adequadas de precificação de contratos de seguro agrícola, resultam em taxas de prêmio inexatas e mal calculadas tendo severas implicações no problema da seleção adversa.

Como consequência direta deste fato, em virtude do seguro ser facultativo, apenas aqueles que possuem maior risco demandam pelo contrato, tornando a carteira de segurados altamente deficitária ${ }^{6}$.

Precificar contratos individuais, a partir de observações médias introduzem a seleção adversa na carteira de seguros, pois dados de produtividade média são um indicador imperfeito da variablidade individual da produtividade (Goodwin, 1994).

Tendo em vista este problema, este trabalho aborda métodos atuariais alternativos visando precificar contratos de seguro agrícola com base em um indicador regional $^{7}$, utilizando dados de produtividade municipal. Tais métodos também podem ser aplicados na precificação de contratos de seguro de produtividade individual, contanto que existam séries relativamente longas de produtividade individual para se levar adiante tal estudo.

A falta de uma metodologia adequada é apontada um dos principais entraves para o desenvolvimento de um mercado de seguro agrícola, no Brasil. O trecho a seguir, ilustra tal preocupação:

\footnotetext{
${ }_{7}^{6}$ No Brasil, a falta de metodologias e de dados tornam este problema ainda mais perverso.

${ }^{7}$ A partir deste ponto, o seguro agrícola baseado em um indicador regional será também denominado seguro de produtividade regional (SPR).
} 
“ As dificuldades do PROAGRO e o insucesso ou pouco interesse das Companhias Seguradoras somente serão contornados quando (...) for formulada uma metodologia atuarial adequada à complexidade do risco agrícola, condições esta indispensáveis à implantação de uma seguridade agrícola sadia.” (Rossetti, 1998, p.1; Rossetti, 2001, p.387)

A opção pelo indicador de produtividade regional, deve-se ao fato do mecanismo de compensação estar atrelado somente à redução da produtividade regional e não à individual. Uma vantagem neste tipo de seguro é a eliminação, total ou parcial, do problema assimetria de informação que reduz os altos custos associados à fiscalização e verificação do sinistro, principalmente quando o evento causador do prejuízo atinge uma área relativamente extensa (Miranda, 1991).

O seguro de produtividade regional é largamente difundido nos Estados Unidos, India, Suécia e Canadá (Miranda, Hazel, Skees, 1999) e, atualmente, é também oferecido no Estado do Rio Grande do Sul.

\subsection{Objetivos}

O objetivo geral da pesquisa é analisar métodos atuariais alternativos para a determinação de taxas de prêmio justas.

Para atingir tal objetivo, quatro objetivos específicos são propostos:

i. Analisar historicamente, a evolução e principais tendências do seguro agrícola no Brasil e EUA, levando-se em conta, os aspectos intitucional, legal e operacional, para o melhor entendimento do mercado de seguro agrícola;

ii. Modelar os dados de produtividade agrícola, através da análise paramétrica e da abordagem não-paramétrica, de modo a recuperar a densidade da produtividade 
condicional e obter estimativas mais precisas da distribuição de probabilidade da produtividade;

iii. Analisar uma série de modelos estatísticos, dentre eles modelos espaciais, temporais e espaço-temporais através da abordagem de modelos hierárquicos Bayesianos, a fim de recuperar o processo gerador dos dados; e,

iv. Estudar a viabilidade do seguro agrícola de produtividade regional para os municípios na região de Castro, no Estado do Paraná.

\subsection{Organização do trabalho}

O trabalho está organizado na forma tradicional. Assim, o segundo capítulo apresenta uma análise da evolução e principais tendências do seguro agrícola no Brasil e EUA, para fornecer melhor entendimento deste ramo de seguro nestes dois países.

O capítulo 3 apresenta a teoria das commodities contingentes e, a partir dela, explicar o mercado de seguros e seus principais problemas (subseção 3.1). Este capítulo apresenta ainda, uma breve revisão da literatura sobre o seguro baseado em um indicador de produtividade regional e de índices climáticos (subseção 3.2), seguida de uma subseção que revela alguns aspectos referentes a modelagem de dados de produtividade agrícola (subseção 3.3).

No capítulo 4 são apresentados em detalhes a modelagem estatística dos dados de produtividade agrícola. A subseção 4.1, apresenta a abordagem paramétrica, considerando que as observações seguem uma distribuição de probabilidade conhecida. Esta pressuposição é então relaxada para introduzir o método não-paramétrico. Esta seção ainda discute as implicações no cálculo da taxa de prêmio.

A subseção 4.2, analisa diversos modelos estatísticos dentro do contexto de modelos hirerárquicos Bayesianos, considerando os efeitos espacial, temporal e a interação destes efeitos, resultando em modelos espaço-temporais. Ainda nesta subseção 
é descrito o critério de seleção do modelo, baseado no critério do erro predito quadrático.

A subseção 4.3, apresenta os conceitos e o modo de se quantificar o risco sistêmico e a correlação entre a produtividade individual e a regional. Na próxima subseção 4.4, é descrito o método de estudo da correlação espacial.

Aplicações na precificação de contratos de seguro agrícola e no estudo da viabilidade deste contrato na região de Castro (PR) são apresentados no capítulo 5. No capítulo 6 estão as conclusões. 


\section{SEGURO AGRÍCOLA: ORIGEM, EVOLUÇÃO E TENDÊNCIAS}

Historicamente, uma das primeiras experiências mundiais em larga escala com o seguro agrícola formal foi observado em fins do século 19, nos EUA. Posteriormente, em outros países o seguro agrícola também foi implantado em outros países, de modo a reduzir o risco enfrentado pelos produtores ${ }^{8}$.

\subsection{O seguro agrícola nos EUA ${ }^{9}$}

\subsubsection{Contexto histórico}

Nos EUA, a primeira experiência com o seguro agrícola privado de riscos múltiplos ocorreu na região de Minneapolis, em 1899. Até então, havia apenas seguros cobrindo riscos específicos como, por exemplo, a queda de granizo.

O seguro durou apenas um ano e abrangia a lavoura de trigo. Posteriormente, em 1917, o seguro serviço foi ofertado para os Estados de Dakota do Norte, Dakota do Sul e Montana, por três seguradoras privadas, que sofreram prejuízos devido à seca e à limitada abrangência geográfica do seguro.

\footnotetext{
${ }^{8}$ No Japão, o seguro agrícola iniciou-se em 1939, na Índia, em 1947, Sri Lanka, 1958, Suécia, 1961 e México, 1964. (Wright e Hewitt, 1994)

${ }^{9}$ Subseção baseada em Formiga (1983), Kramer (1983), Gardner e Kramer (1986), Gardner (1994), Just e Calvin (1994).
} 
Três anos mais tarde, em 1920, a Companhia de Seguros Hartford Fire ofereceu um contrato no qual cobria variações na renda e no preço. As fortes quedas nos preços das commodities agrícolas aumentaram o montante de indenizações de modo a exceder o total de prêmios recolhidos em US\$1,7 milhões.

Outras experiências com seguro agrícola de riscos múltiplos não obtiveram sucesso ao longo dos anos em diversas regiões daquele país.

Um estudo mostrando as principais causas da quebra de safra no período de dez anos iniciado em 1909, mostrou que a seca foi a principal responsável pela redução da produtividade no período, seguida da geada, excesso de umidade, pragas e doenças. O granizo foi responsável por apenas $2 \%$ dos prejuízos causados às lavouras.

No início da década de 20 tramitaram no Congresso norte-americano diversas propostas sobre seguro agrícola, apresentadas como um mecanismo de proteção ao produtor. Mas a pouca experiência das firmas seguradoras na operacionalização neste ramo de seguro, impediu que o governo federal iniciasse um programa específico.

Para o melhor entendimento da problemática envolvendo esse tipo de seguro, reuniram-se representantes do governo, das seguradoras e dos produtores. A conclusão geral foi a de que um programa de seguro agrícola deveria ter abrangência nacional e estar pautado em estatísticas mais confiáveis.

Em 1933, um programa que apresentava características de seguro foi iniciado. Ele consistia no pagamento de um prêmio e recebimento de uma indenização na forma de grãos em vez de unidades monetárias. O objetivo era a estabilização da oferta e dos preços das commodities.

Alguns anos mais tarde, a possibilidade da emergência de um programa de seguro agrícola tornava-se cada vez mais concreta, visto que uma quantidade considerável de dados de produtividade do trigo e algodão foi acumulada, a individual, por diversos produtores destas duas culturas. Além disto, a seca ocorrida em 1934 e em 1936 propiciou um ambiente favorável à aceleração da implantação do seguro agrícola. 
Nesse contexto foi criada, por legislação, em 1938, a Companhia Federal de Seguro Agrícola (FCIC) ${ }^{10}$, ligada ao Departamento de Agricultura dos Estados Unidos (USDA) ${ }^{11}$. A agência central se localizava no Estado de Washington e era responsável pela formulação das políticas, administração, pesquisa e coordenação com outras agências.

A companhia entrou em operação em 1939, inicialmente abrangendo a lavoura de trigo, com cobertura compreensiva, ou seja, cobrindo diversos riscos, tais como seca, inundação, granizo, vento, relâmpago, tornado, pragas, doenças e outras causas de danos incontroláveis determinados pela Companhia.

O prêmio era calculado por meio de uma estimativa da perda, utilizandose como base a produtividade média a nível local. A proteção foi fixada entre $50 \%$ e 75\% deste valor, após comparação com a de anos anteriores. Posteriormente, ponderavase a indenização média pela perda regional para determinação da taxa de prêmio.

Nos três primeiros anos de operação, a companhia apresentou resultados pouco satisfatórios. O índice de sinistralidade ${ }^{12}$ de 1,62, em 1939, foi para 1,51 em 1940 e 1,68 em 1941 (figura 1). Tais resultados ocorreram principalmente devido aos métodos incorretos de precificação e estimativa da produtividade e, também, por problemas de seleção adversa. Como resultado, o Tesouro norte-americano transferiu cerca de US\$ 28 milhões para cobrir o déficit gerado.

\footnotetext{
${ }^{10}$ Do termo em inglês, Federal Crop Insurance Corporation (FCIC).

${ }^{11}$ Do termo em inglês, United States Departament of Agriculture (USDA).

${ }^{12}$ Relação entre o montante de indenizações pagas e o total de prêmios arrecadados.
} 


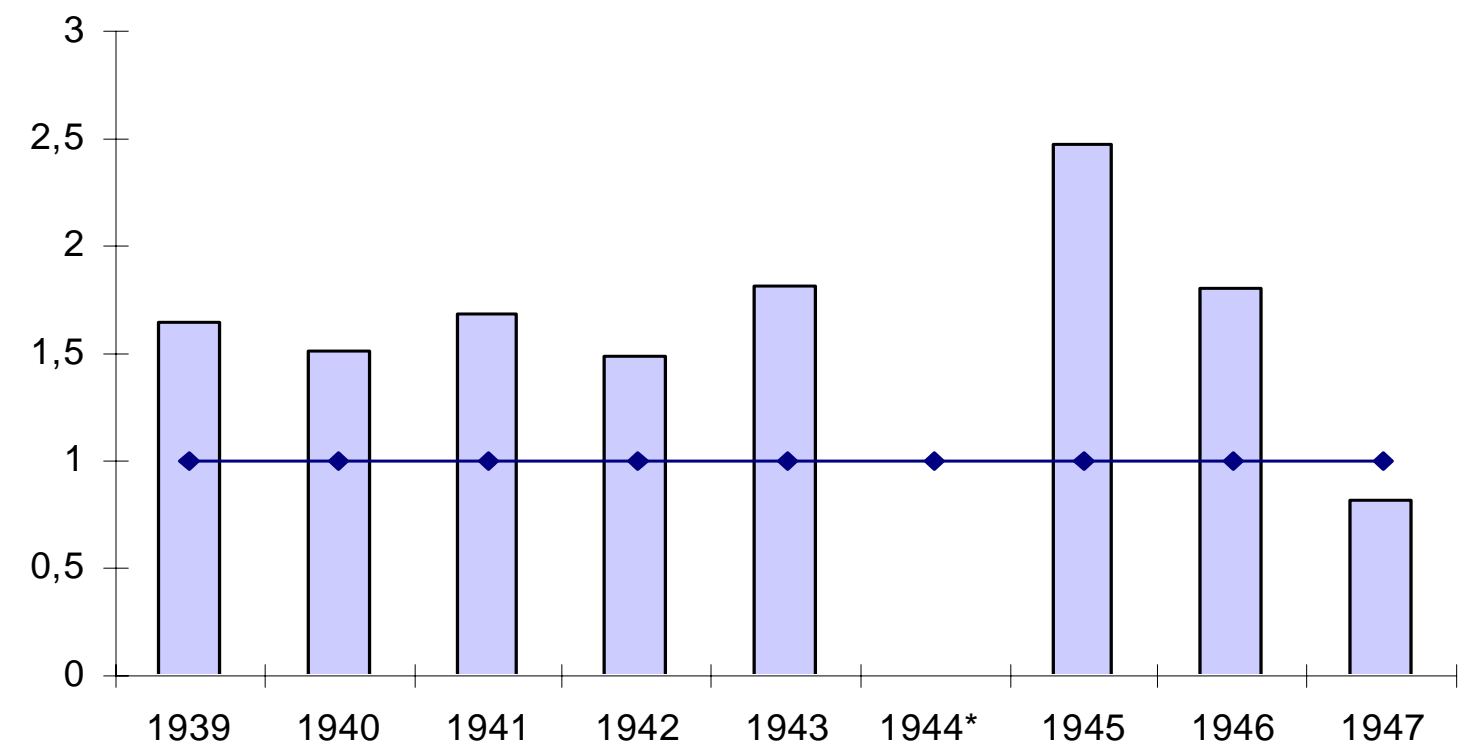

Figura 1 - Evolução do índice de sinistralidade do seguro agrícola nos EUA, de 1939 a 1947

Fonte: USDA, extraído de Formiga (1983)

* Seguro não oferecido neste ano

O programa parecia dar sinais de que não poderia se auto-sustentar a médio e longo prazos. Se os custos administrativos fossem incluídos, o déficit acima aumentaria ainda mais.

Além disso, curiosamente, esses resultados ocorreram em anos relativamente normais, sem fenômenos climáticos adversos mais graves e/ou extensos que tivessem afetado sobremaneira a atividade agrícola.

A Lei Federal do Seguro Agrícola $^{13}$, de 1938, autorizou a FCIC a conduzir pesquisas referentes ao assunto. Logo após a aprovação da referida lei, foram iniciados estudos sobre a viabilidade da cobertura do algodão.

${ }^{13}$ Do termo em Inglês, 1938 Federal Crop Insurance Act. 
Em 1940, foi aprovado o documento que incluiu o algodão no programa de seguro agrícola, mas sua operacionalização ocorreu por apenas dois anos (1942 e 1943). Da mesma maneira que o seguro para o trigo, o seguro para o algodão apresentou resultados muito insatisfatórios.

Duramente criticado pelos congressistas norte-americanos, o programa foi suspenso em 1944, fato motivado pelos excessivos déficits nos cinco anos de operação e pela baixa taxa de participação. Mas no mesmo ano, por meio de uma emenda na Lei de Ajustamento Agrícola, de 1938, a iniciativa foi reinicializada e expandida.

Em 1945, a FCIC incluiu o linho na lista de culturas seguráveis. Naquele ano, por causa do algodão, os resultados novamente não foram satisfatórios. A sinistralidade da carteira quase atingiu o valor de 2,5. Para as culturas de trigo, linho e algodão o índice atingiu, respectivamente, 0,43, 0,58 e 3,35.

No mesmo ano o seguro foi ofertado, em caráter experimental, para a cultura do milho (em 15 municípios) ${ }^{14}$ e fumo, (em 12).

O seguro para milho era de dois tipos: plano de produtividade e plano do custo de investimento. O primeiro cobria no mínimo 75\% da produtividade média do produtor e, o segundo, pelo menos $75 \%$ do custo de investimento na lavoura. Do mesmo modo, o seguro para o fumo abrangia dois planos: de qualidade da produtividade e do custo de investimento.

Com o intuito de reduzir o risco moral, a companhia criou o Plano de Proteção Progressiva, que consistia na proteção da cultura proporcionalmente ao seu desenvolvimento.

Desse modo, se o sinistro ocorresse no início da fase de desenvolvimento, se não fosse possível uma nova semeadura e se não houvesse como liberar a área para outras finalidades, o valor segurado seria reduzido para $40 \%$ ou $50 \%$ do valor correspondente à fase final de desenvolvimento da cultura.

Para evitar os diversos problemas enfrentados pela companhia, algumas inovações foram introduzidas, em 1946. Dentre elas, destacam-se:

\footnotetext{
${ }^{14}$ No trabalho, este termo será utilizado como tradução de “county”, que é uma subdivisão do Estado.
} 
i) Contratos de três anos para a cultura do trigo, com o objetivo de reduzir o problema da seleção adversa ${ }^{15}$ (pelo menos no segundo e terceiro anos de vigência);

ii) Contratos contínuos para a cultura do algodão ${ }^{16}$, que é um caso mais geral do contrato anterior;

iii) O prêmio para todas as culturas seria calculado a partir de dados municipais, visto que a variação da produtividade seria captada de maneira mais correta nas séries municipais por serem mais longas do que as verificadas em âmbito local;

iv) Introdução da cobertura parcial nos contratos para reduzir o problema do risco moral. Optando por uma abrangência de cobertura menor, o indivíduo pagaria um prêmio relativamente mais baixo.

Nesse período, o programa passou a incluir novas culturas. Os contratos sofreram ajustamentos e melhorias que resultaram na relativa estabilização do índice de sinistralidade (figura 2).

Em parte como resultado das mudanças introduzidas, o índice de sinistralidade melhorou muito em 1947 (figura 1). Porém, ironicamente, o governo norte-americano limitou as operações da FCIC, estabelecendo em 200 o número mínimo de propriedades seguradas no município ou um terço das propriedades que cultivavam determinada commodity.

Por outro lado, o volume segurado sofreu redução significativa. O total, que tinha sido de US\$ 470 milhões em 1947, passou para US\$ 240 milhões em 1950 e US\$ 271 milhões em 1959.

\footnotetext{
15 Aparentemente, os produtores eram capazes de estimar o risco dessa cultura de acordo com a quantidade de umidade do solo um mês antes do plantio.

${ }^{16}$ Este contrato se manteria indefinidamente, a menos que fosse cancelado pelo segurado.
} 
Adicionalmente, na seca do início da década de 50, o seguro agrícola mostrou ser um mecanismo eficaz de transferência de renda do governo para o setor agrícola em épocas de eventos desfavoráveis para a lavoura.

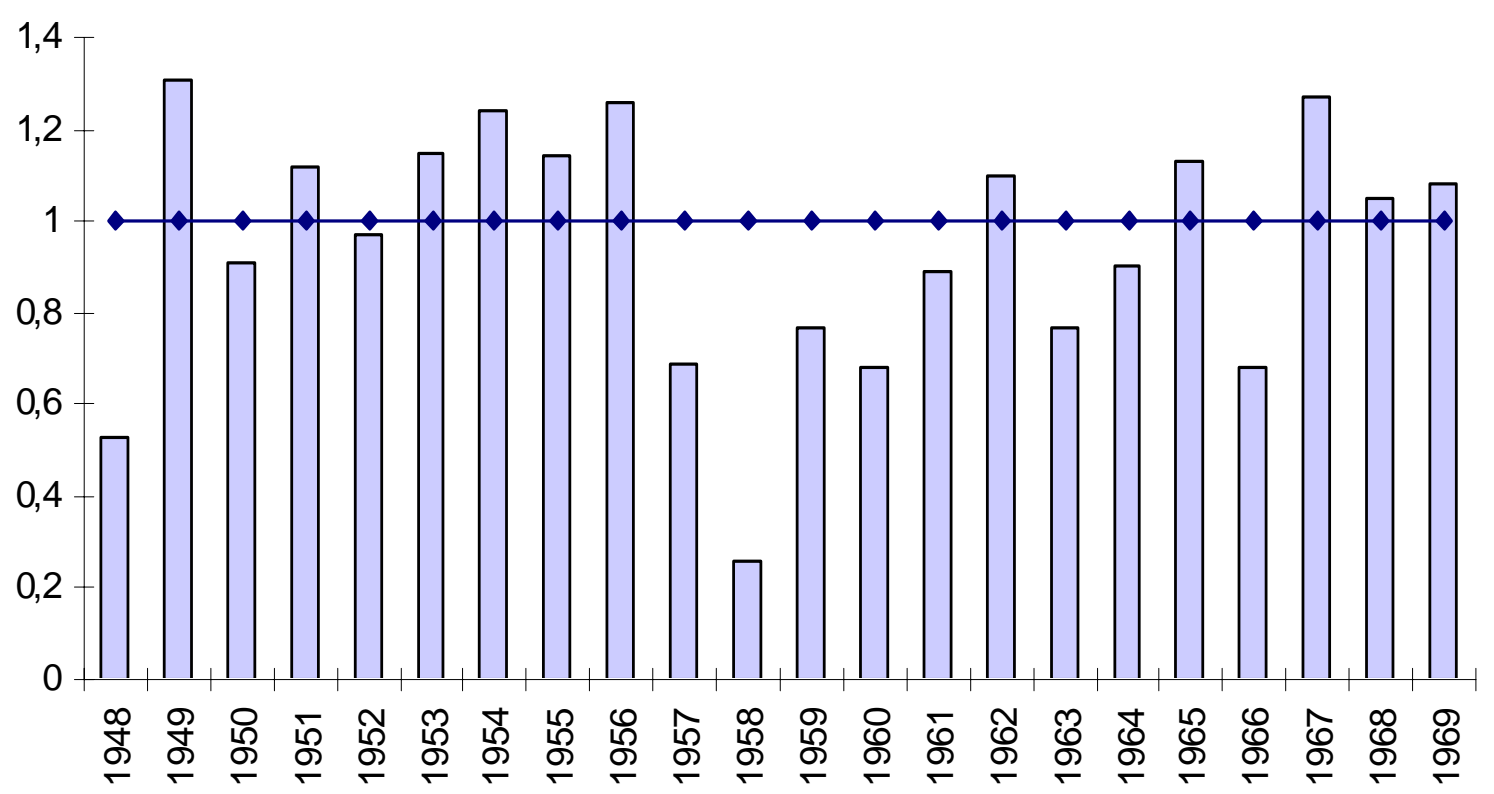

Figura 2 - Evolução do índice de sinistralidade do seguro agrícola nos EUA, de 1948 a 1959

Fonte: USDA, extraído de Formiga (1983)

No período de 1948 a 1952, o montante arrecadado em prêmios superou em US\$ 2,25 milhões o total de indenizações. Em três dos cinco anos, a sinistralidade ficou abaixo de 1. Nota-se que, de 1948 a 1959, a sinistralidade média ficou em 0,95.

Em 1956, o seguro foi ofertado em 948 municípios, cobrindo 24 culturas diferentes. No período de 1957 a 1961 o programa foi superavitário em todos os anos, ressaltando-se o resultado de 1958, com índice de 0,26, o mais baixo de toda a história do seguro agrícola (figuras 1, 2 e 3). 
Esse superávit foi favorecido pelas boas condições para o desenvolvimento das culturas e, também, pelo fato de a companhia ter excluído do programa 14 municípios de alto risco nos Estados do Texas, Colorado e Novo México.

Novas culturas foram incorporadas nesse período, como pêssego, em moldes experimentais, laranja, sorgo, aveia e arroz.

A década de 60 caracterizou-se pelo rápido crescimento da cobertura, chegando a US\$ 920 milhões em 1969, com índice de sinistralidade médio de 0,96 nesta década.

Em 1970, um grupo de trabalho composto por técnicos que não pertenciam ao governo foi formado com o intuito de apontar os erros cometidos pela FCIC no exercício do programa. Os profissionais detectaram como principais problemas o estabelecimento da produtividade garantida e do prêmio em bases regionais. O programa deveria ser modificado, de modo a incorporar as características e os riscos individuais do produtor e, com isto, incentivar a participação no programa. De fato, em 1974, apenas 7,5\% de toda área colhida estava segurada e a cobertura da companhia correspondia a $2,9 \%$ do valor total da produção.

Experimentalmente, em 1978, a FCIC iniciou um programa-piloto de contratos individualizados em 20 municípios, que se expandiu para 40 no ano seguinte. Apesar da baixa adesão, os resultados foram satisfatórios. No período entre 1970 e 1978, a sinistralidade média ficou em 0,93. Em seis dos nove anos, o seu valor foi menor do que 1 (figura 3). 


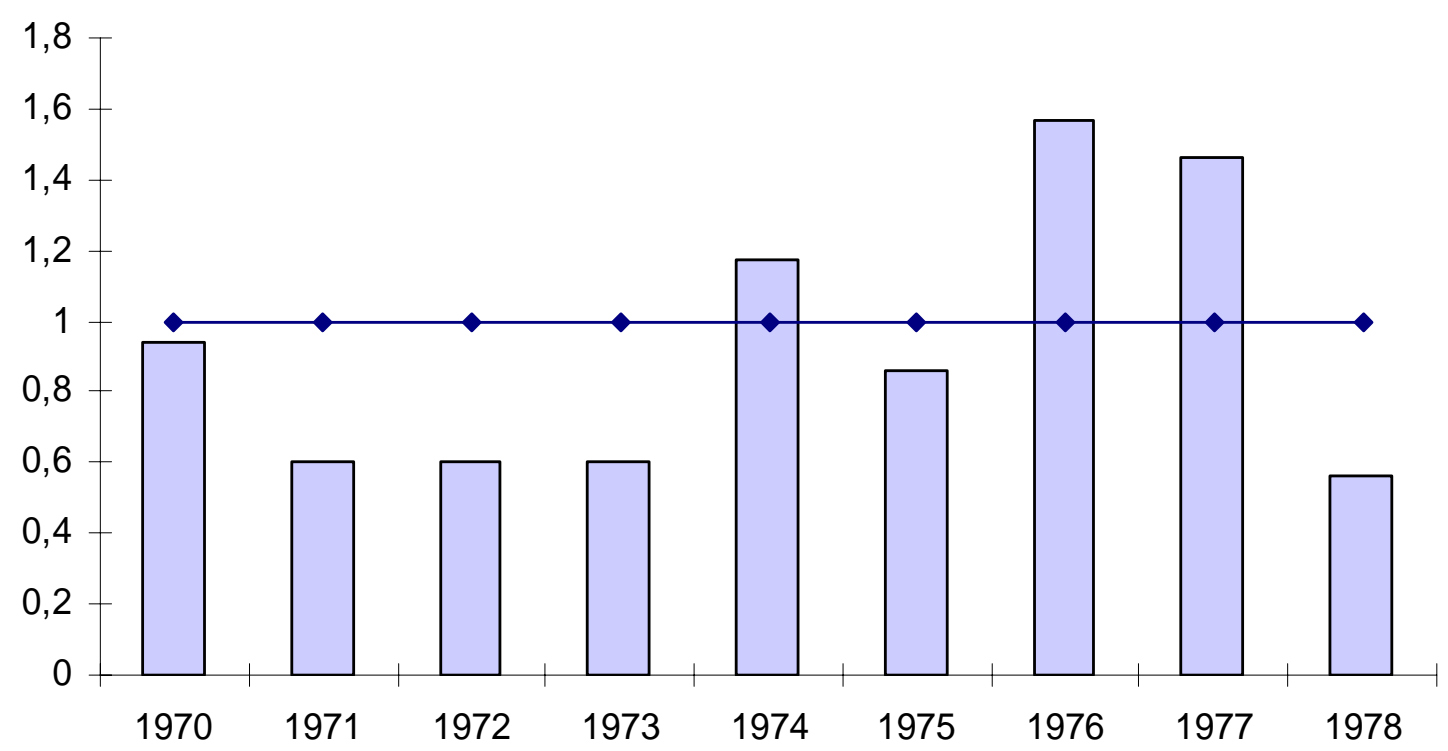

Figura 3 - Evolução do índice de sinistralidade do seguro agrícola nos EUA, de 1970 a 1978

Fonte: USDA, extraído de Formiga (1983)

De acordo com a Lei Federal do Seguro Agrícola de $1980^{17}$, o Programa de Seguro Agrícola Múltiplos Riscos (MPCI) ${ }^{18}$ seria garantido como a principal forma de proteção contra desastres.

Além disso, retirou-se o limite anual de expansão, que era de 150 municípios e três commodities, permitindo a inclusão de todas as localidades com atividades agrícolas significativas, para qualquer cultura, se existissem dados suficientes.

Para incentivar a participação dos produtores no programa, a lei estabeleceu ainda o subsídio de, no mínimo, 30\% do prêmio para os níveis garantidos de produtividade de $50 \%$ e $65 \%$.

\footnotetext{
${ }^{17}$ Do termo em Inglês, 1980 Federal Crop Insurance Act.

${ }^{18}$ Do termo em Inglês, Multiple Peril Crop Insurance.
} 
O programa MPCI garantia cobertura toda vez que a produtividade não conseguisse atingir determinado valor pré-estabelecido, denominado produtividade crítica ou garantida. Este valor era calculado como um percentual de 50\%, 65\% ou 75\% sobre a produtividade média.

O produtor podia optar por escolher uma das três opções de níveis de preços, chamado “preço eleito" ${ }^{19}$, que era aplicado sobre a diferença entre a produtividade garantida e a observada, determinando-se, assim, a importância segurada por unidade de área. O valor resultante correspondia à indenização devida pela seguradora.

Em 1981, a área segurada aumentou 81\%, passando de 26,3 para 47,7 milhões de acres, abrangendo aproximadamente três mil municípios. Este aumento foi devido, principalmente, ao subsídio ao prêmio dado pelo governo e ao subsídio tradicional ao custo administrativo e de operação das firmas seguradoras.

Nesse período, os produtores com no mínimo três anos de dados de produtividade podiam optar pelo seguro baseado na produtividade individual (IYC) ${ }^{20}$ ou na produtividade regional (Knight e Coble, 1997). Posteriormente, o IYC foi substituído pelo método da produção histórica atual (APH) ${ }^{21}$, que era baseado em dados de dez anos de produtividade individuais. Caso o número de dados não fosse suficiente, eram utilizados dados regionais.

A partir de 1987, recursos governamentais foram alocados para garantir a atividade agrícola em caso de desastres naturais. Tais medidas assistenciais operavam, concomitantemente, com o programa de seguro agrícola e foram justificadas como causa principal dos resultados insatisfatórios gerados pelo MPCI.

\footnotetext{
${ }^{19}$ Do termo original price election.

${ }^{20}$ Do termo em Inglês, Individual Yield Coverage.

${ }^{21}$ Do termo em Inglês, Actual Production History.
} 
De 1981 a 1994, o programa apresentou déficits consideráveis. O índice médio de sinistralidade do período ficou em 1,41 e, em apenas um ano (1994), foi menor do que 1 (figura 4). Além disto, as indenizações pagas superaram o total de prêmios arrecadados em US\$ 3,3 bilhões.

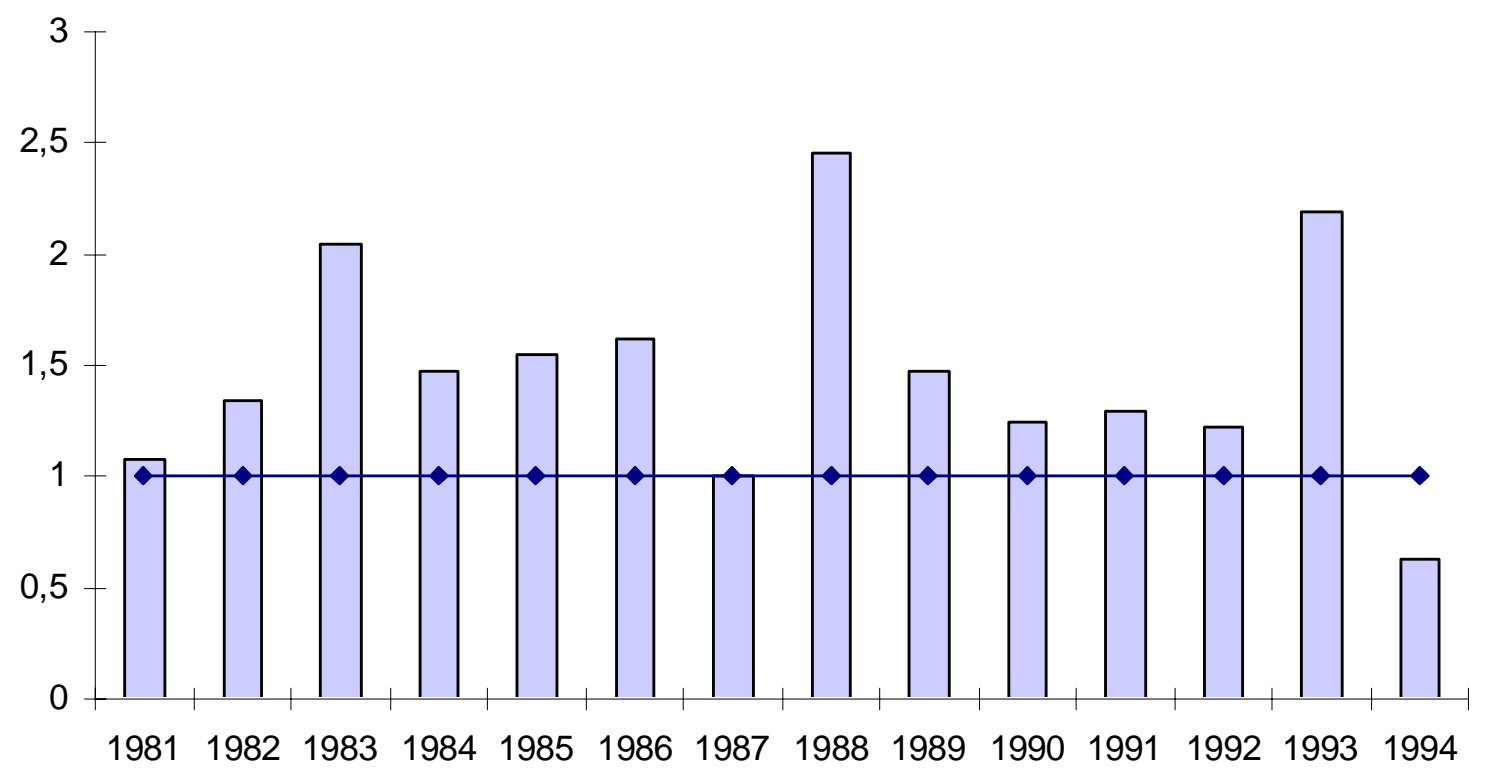

Figura 4 - Evolução do índice de sinistralidade do seguro agrícola nos EUA, de 1981 a 1994

Fonte: USDA, extraído de Dismukes (2003)

O programa foi criticado, também, por não conseguir obter uma alta taxa de popularidade, deixando de proteger um grande número de produtores rurais contra eventuais quedas de produtividade. 
A taxa de participação aumentou lentamente: de 10\%, em 1980, para 38\%, em 1994. Colaborou para esta expansão a obrigatoriedade de adesão ao MPCI dos beneficiários do programa de "assistência desastre"22.

A Lei Agrícola Norte-Americana, de $1990^{23}$, determinou que as taxas de prêmio fossem aumentadas, as metas de sinistralidade fossem estabelecidas para todas as culturas seguradas e que novos produtos fossem desenvolvidos e experimentados. Além disto, a FCIC foi autorizada a ressegurar e subsidiar produtos desenvolvidos pela iniciativa privada. Deste modo, a companhia iniciou, nesta época, um projeto-piloto cuja indenização era baseada em indicadores de produtividade regional.

Em 1993, um quarto nível de cobertura, de 35\% da produtividade média, foi adicionado ao MPCI. A Lei de Reforma do Seguro Agrícola, de $1994^{24}$, eliminou tal opção e permitiu que o percentual do nível de cobertura variasse entre 50\% e 75\%, em múltiplos de 5\%.

Reformas adicionais foram sancionadas por meio da referida lei. Dentre elas, destacam-se a descontinuidade das medidas assistenciais de desastres e a criação de um programa de apoio para culturas não cobertas pelo seguro (NAP) ${ }^{25}$, tornando compulsória a participação no MPCI dos agricultores interessados em beneficiar-se dos outros programas agrícolas governamentais. As medidas introduziram, também, a cobertura catastrófica (CAT) ${ }^{26}$ como o nível de cobertura mínima do MPCI, com o objetivo de substituir os programas assistenciais de desastres (Dismukes, 1999).

Como resultado imediato, a responsabilidade da FCIC aumentou de, aproximadamente, US\$ 13,5 bilhões em 1994 para US\$ 23,7 bilhões em 1995.

\footnotetext{
${ }^{22}$ Programa de ajuda governamental voltado aos produtores que forem atingidos por um evento climático generalizado.

${ }^{23}$ Do termo em Inglês, 1990 Food, Agriculture, Conservation and Trade Act.

${ }^{24}$ Do termo em Inglês, 1994 Federal Crop Insurance Reform Act.

${ }^{25}$ Do termo em Inglês, Non-Insured Assistance Program. Atualmente, o NAP oferece, para o produtor que não está segurado, a mesma proteção que a cobertura CAT, ou seja, 50\% da produtividade média e 55\% do preço eleito pagando um taxa de US\$100, por cultura e por município ou US\$ 300 por produtor e por município, mas não excedendo US\$ 900 por produtor.

${ }^{26}$ Do termo em Inglês, castastrophic coverage level.
} 
Inicialmente, a cobertura catastrófica garantia a proteção mínima de $50 \%$ da produtividade $\mathrm{APH}^{27}$ e $60 \%$ do preço de mercado projetado pelo USDA/RMA ${ }^{28}$,.

O produtor ficava isento prêmio, mas devia pagar uma taxa administrativa de US\$ 50 por cultura e por município. Atualmente, o nível de cobertura sobre a produtividade esperada é a mesma, mas cobre apenas 55\% do preço e a taxa de administração aumentou para US\$100. Pode-se optar por um nível de cobertura maior (buy-up), mas com percentuais de subsídios menores.

Para participar desse programa o produtor deve possuir um histórico de produtividade de, no mínimo, quatro e, no máximo, dez anos consecutivos para que se possa estabelecer sua produção histórica atual (APH) ${ }^{29}$.

A produtividade APH opera dentro de um intervalo mínimo e máximo de, respectivamente, $10 \%$ e $20 \%$, toda vez que um novo dado é incluído na série. Por exemplo, se é relatada uma baixa produtividade em determinado ano, o APH não pode reduzir mais do que $10 \%$.

Se não for possível apresentar o número mínimo necessário de dados de produtividade, o produtor pode substituí-lo por uma produtividade de transição ${ }^{30}$ (transitional yield) ou “T”. A tabela 1, abaixo, mostra o percentual incidente sobre a produtividade de transição na ausência de dados.

\footnotetext{
${ }^{27}$ Produção histórica atual. Tradução do termo em Inglês actual production history.

${ }^{28}$ Do termo em Inglês, Risk Management Agency.

${ }^{29}$ Uma vez que exista um dado de produtividade faltante na série, utilizam-se apenas os dados após este ano até o ano mais recente.

${ }^{30}$ A produtividade de transição é baseada na produtividade média histórica do município dos últimos dez anos.
} 
Tabela 1. Percentuais da produtividade de transição utilizados para o cálculo da produtividade APH (série de quatro anos)

\begin{tabular}{cc}
\hline Dados de produtividade existentes & Substituição por \% de "T” \\
\hline 3 & 100 \\
2 & 90 \\
1 & 80 \\
0 & 65 \\
\hline
\end{tabular}

Fonte: Crop Insurance Handbook (2003)

Conforme observado, se o produtor possui apenas três anos consecutivos de informações sobre sua produtividade relatadas, pode substituir o quarto por $100 \%$ de “T”. Para dois, um ou nenhum ano registrado, utilizam-se os respectivos percentuais mostrados nesta Tabela. A figura 5 exemplifica o cálculo da produtividade APH.

\begin{tabular}{|c|c|c|c|}
\hline \multicolumn{4}{|c|}{ Produtividade “T” para soja é de 45 bu/ac } \\
\hline \multirow{5}{*}{\multicolumn{2}{|c|}{$\begin{array}{c}\text { Produtividade - ano } 4 \text { (mais recente) } \\
\text { Produtividade - ano } 3 \\
\text { Produtividade - ano } 2 \\
\text { Produtividade - ano } 1 \\
\text { Produtividade APH }\end{array}$}} & \multirow{5}{*}{\multicolumn{2}{|c|}{$\begin{array}{c}52 \\
60 \\
32 \\
75 \\
54,8\end{array}$}} \\
\hline & & & \\
\hline & & & \\
\hline & & & \\
\hline & & & \\
\hline \multicolumn{4}{|c|}{ Dados de produtividade existentes: } \\
\hline Três & Dois & $\mathrm{Um}$ & Nenhum \\
\hline 52 & 52 & 52 & 29,25 (65\% “T”) \\
\hline 60 & 60 & 36 (80\% “T”) & 29,25 (65\% “T”) \\
\hline 32 & 40,5 (90\% “T”) & 36 (80\% “T”) & 29,25 (65\% “T”) \\
\hline 45 (100\% “T”) & 40,5 (90\% “T”) & 36 (80\% “T”) & 29,25 (65\% “T”) \\
\hline 47,25 (média) & 48,25 (média) & 40 (média) & 29,25 (média) \\
\hline
\end{tabular}

Figura 5 - Procedimento de cálculo ilustrativo da produtividade APH, de acordo com o número de dados disponíveis 
Percebe-se que, para apenas um dado de produtividade relatado, o APH não deve ser menor do que 70\% da produtividade “T”. Para os produtores que possuem de dois a quatro anos de dados existentes, este percentual é de $75 \%$ e de $80 \%$ para o intervalo de cinco ou mais anos consecutivos.

Além disso, o produtor pode, ainda, substituir um valor baixo de produtividade obtido em determinado ano por $60 \%$ da produtividade “T”. Este ajuste pode ser realizado para qualquer valor passado utilizado no cálculo da APH (Edwards, 2003).

Para exemplificar o funcionamento do CAT, considere as informações na figura 6:

\begin{tabular}{|lcc|}
\hline Área plantada, em ac (acres) & 500 & \\
Produtividade (APH), em bu/ac & 35 & \\
Preço projetado (RMA), em US\$/bu & 5,15 & \\
Taxa, em dólares (subsídio de 100\%) & 100 & \\
Preço (55\%) & 2,83 & \\
Produtividade garantida (50\%), em bu/ac & 17,5 & \\
\hline \hline Produtividade efetiva, em bu/ac & & 30 \\
\hline Indenização, em US\$/ac & 12 & 0 \\
\hline Indenização total, em US\$ & 15,57 & 0 \\
\hline
\end{tabular}

Figura 6 - Exemplo hipotético da indenização na cobertura CAT, para a cultura da soja

Para os níveis de cobertura acima do CAT (buy-up), o produtor recebe um montante crescente de indenização pagando, além do prêmio, uma taxa administrativa de US\$ 100 para níveis de cobertura menores do que 65\% da produtividade APH e 100\% do preço estabelecido pelo RMA. Para níveis de cobertura maiores, a taxa diminui para US\$ 30.

Nota-se que o MPCI possibilita a redução da taxa de prêmio quanto maior o nível de produtividade. Segundo Barnaby (2002), um produtor que tem um nível de produtividade média alto dentro de um determinado município paga uma taxa 
equivalente a um terço da taxa paga por outro cuja produtividade média se situe em níveis bem menores do que a média municipal.

Os níveis de cobertura do programa variam de 50\% (CAT) a 85\%, em múltiplos de 5\%. Para fins de composição do APH, se o produtor não possuir, no mínimo, quatro anos de dados de produtividade consecutivos, como no CAT, será utilizada a produtividade de transição.

Os produtores podem escolher o preço eleito dentro de uma faixa de 55\% a 100\% do máximo eleito. Em 2003, os preços máximos fixados pelo RMA foram para milho, trigo, soja, aveia e sorgo, respectivamente, 2,20, 2,90, 5,15, 1,40 e 2,10, em US\$/bushel.

A figura 7, abaixo, mostra como a indenização e o prêmio são calculados, retomando os parâmetros utilizados no exemplo da figura 6. Além disto, supõe-se que o nível de cobertura seja de 75\%, a taxa de prêmio 4,5\% e o percentual de subsídio, 55\%.

\begin{tabular}{|lc|}
\hline \multicolumn{2}{|c|}{ Indenização } \\
\hline Produtividade garantida, em bu/ac (75\% da produtividade APH) & 26,25 \\
Preço eleito, em US\$/bu (100\%) & 5,15 \\
Produtividade observada, em bu/ac & 12 \\
Indenização, em US\$/ac & 73,39 \\
Indenização total, em US\$/ac & $36.693,75$ \\
\hline \multicolumn{2}{|c|}{ Prêmio } \\
\hline Responsabilidade ou valor segurado,em US\$/ac \\
Prêmio, em US\$/ac
\end{tabular}

Figura 7 - Exemplo de cálculo da indenização e do prêmio no MPCI

Os prêmios podem ser pagos no final do ciclo e subtraídos de qualquer quantia a ser indenizada pela firma seguradora, de acordo com Dismukes (2003). Além disto, se o produtor optar por segurar sua área total com a mesma cultura como uma unidade simples, o prêmio será descontado em 10\%. 
Caso o produtor não realize o plantio até a data-limite (que é $1^{\circ}$ de junho para o milho e 16 de junho para a soja), devido à ocorrência de um evento climático adverso, o MPCI ainda oferece uma cobertura de plantio tardio ${ }^{31}$.

Nesse esquema, a produção garantida é reduzida em 1\% para cada dia que ultrapassar a data-limite, até um máximo de 25 dias ou 25\%. Por exemplo, considere que a produtividade APH para soja de um indivíduo seja 35 bu/ac, a um nível de cobertura de 75\%. A produtividade garantida, neste caso, será de 26,25 bu/ac.

Suponha que o produtor inicie seu plantio em 26 de junho, por causa de uma chuva excessiva. A redução na produtividade garantida será percentualmente igual ao número de dias que exceder a data-limite, que será de 10\% (1\% multiplicado por dez dias). A garantia recalculada será de 23,63 bu/ac (Hofstrand e Edwards, 2003).

Caso o produtor exceda o prazo máximo permitido, ou seja, 25 de junho para o milho e 10 de julho para a soja, o nível de cobertura será de $60 \%$ da produtividade coberta inicialmente.

Quando o produtor é impedido de plantar uma cultura em toda a unidade segurada, o MPCI cobre $60 \%$ da produtividade coberta originariamente. Este tipo de cobertura é chamado de Cobertura de Plantio Preventivo ${ }^{32}$.

As coberturas preventiva e tardia não são ofertadas para áreas menores do que 20 acres ou 20\% da área (20/20) que se pretende plantar na unidade para unidades maiores do que 100 acres.

Quando a lavoura sofre o sinistro e não produz, no mínimo, 90\% da produtividade garantida, o segurado poderá receber o pagamento equivalente ao custo de reposição da cultura ${ }^{33}$.

Nesse caso, o valor segurado será calculado multiplicando-se o preço eleito pelo menor valor entre a máxima cobertura de replantio, igual a $20 \%$ da produtividade garantida ou 8 bu/ac para o milho e 3 bu/ac para a soja.

\footnotetext{
${ }^{31}$ Do termo em Inglês, late planting insurance coverage.

${ }^{32}$ Do termo em Inglês, preventing planting coverage.

${ }^{33}$ Este tipo de cobertura é denominada replanting coverage.
} 
Exemplificando, considere que determinada lavoura seja atingida pela geada, de modo que a produtividade prevista após o fenômeno seja de 20 bu/ac. A produtividade garantida, ao nível de 75\%, será de 26,25 bu/ac. Nesta situação, a previsão de 20 bu/ac é menor do que 90\% da produtividade garantida (23,6 bu/ac).

O novo valor segurado será calculado multiplicando-se o preço eleito (US\$ 5,15/bu) pelo limite inferior da produtividade (3 bu/ac), pois é menor do que os $20 \%$ da produtividade garantida (que é igual a 5,25 bu/ac). Assim, a responsabilidade da seguradora será de US\$15,45/ac.

Outro ponto relevante para a determinação da garantia, do prêmio e da

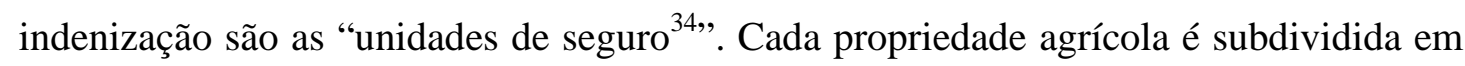
talhão. As unidades compreendem todos os talhões que podem ser segurados independentemente de outros talhões. Existem quatro tipos de unidades:

i) Básico (Basic): compreende toda a extensão de terra pertencente ou arrendada ${ }^{35}$ (monetariamente) e toda a extensão de terra arrendada $^{36}$ (produção) pelos produtores dentro de um município. Estas unidades são separadas por tipo de cultura e extensões de terra em diferentes localidades. Além disto, a produtividade efetiva deve ser registrada para cada unidade, separadamente. Pode-se optar, para cada cultura, por tipos diferentes de apólice e níveis de cobertura, sendo que a indenização devida é paga independentemente das outras unidades.

ii) Opcional (Optional): compreende todas as propriedades pertencentes ou arrendadas (monetariamente) pelos produtores e localizadas em diferentes setores ${ }^{37}$ de determinado distrito ${ }^{38}$. As lavouras implantadas com diferentes tecnologias de produção (exemplo, o uso de irrigação) são enquadradas nesta unidade;

\footnotetext{
${ }^{34}$ Do termo em Inglês, insurance units.

${ }^{35}$ Este arrendamento é do tipo cash rent lease, ou seja, o arrendatário se compromete legalmente a pagar um aluguel pelo uso da terra, em valor monetário.

${ }^{36}$ Do tipo crop share lease, ou seja, o arrendatário se compromete legalmente a pagar um aluguel pelo uso da terra, em unidades físicas.

${ }^{37}$ Divisão administrativa do distrito.

${ }^{38}$ Divisão administrativa do condado ou município .
} 
iii) Empresa (Enterprise): combina toda a área cultivada por determinada cultura em um município, sem considerar o número de proprietários envolvidos e se as terras são arrendadas ou não. Os prêmios são relativamente menores e cada unidade deve ter, no mínimo, 50 acres. Exemplo: o produtor de soja e milho pode combinar toda a área plantada de soja em determinado município em uma unidade e toda a área plantada de milho em outra unidade;

iv) Fazenda (Whole Farm): os produtores podem combinar a área de todas as culturas em apenas uma unidade, recebendo em troca um desconto adicional no prêmio. Este desconto varia em função da área total plantada de cada cultura.

A Lei Agrícola de $1996^{39}$ retirou a obrigatoriedade da aquisição de seguro agrícola pelos produtores que optassem por programas agrícolas governamentais, além de permitir o início do desenvolvimento, pelo FCIC, do seguro de renda como alternativa ao MPCI.

Nesse mesmo ano foi criada a Agência de Administração de Risco (RMA), vinculado ao USDA, que administra os programas da FCIC.

Desde então, a RMA e a FCIC têm regulado as operações de seguro agrícola, estabelecendo as taxas atuariais, responsabilidades máximas permitidas para cada seguradora e analisando novos produtos desenvolvidos pela iniciativa privada.

Além disso, a agência promove a popularização do seguro agrícola por meio de atividades educacionais e de extensão.

\footnotetext{
${ }^{39}$ Do termo em Inglês, 1996 Federal Agriculture Improvement and Reform Act.
} 
A partir da Lei Agrícola de 1996, diversos tipos de seguro de renda foram desenvolvidos, como a proteção da renda (IP), cobertura da renda agrícola (CRC), seguro da renda (RA), proteção da renda de risco grupal (GRIP) e renda bruta ajustada, (AGR).

Esses seguros cobrem não apenas a redução na produtividade, como no MPCI, mas reduções na renda provenientes de quedas no nível de preço, produtividade ou ambos.

A seguir serão caracterizados os diferentes tipos de produtos encontrados atualmente no mercado segurador norte-americano.

\subsubsection{Caracterização dos diferentes tipos de contratos}

\subsection{Proteção da Renda (Income Protection - IP)}

Esse seguro foi desenvolvido pela RMA e iniciado como projeto-piloto, na primavera de 1996, para o milho, algodão e trigo de primavera em 29 municípios e para trigo de inverno em outros 18, no outono do mesmo ano. Na primavera de 1997, a FCIC expandiu o seguro para a soja em 56 municípios e, sorgo, em 24 (Harwood et al., 1997).

Atualmente, o IP é ofertado em 14 Estados: Alabama (AL), Georgia (GA), Idaho (ID), Illinois (IL), Indiana (IN), Iowa (IA), Kansas (KS), Minnesota (MN), Montana (MT), Dakota (ND), Oregon (OR), South Dakota (SD), Texas (TX) e Washington (WA), conforme pode ser visto na figura 8. 


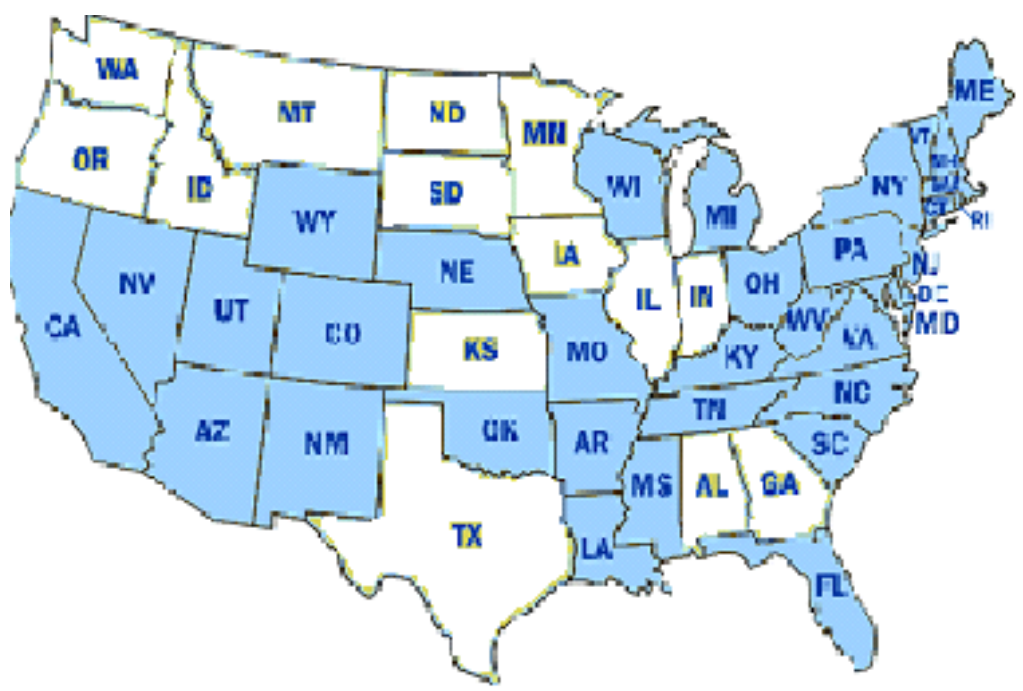

Figura 8 - Estados norte-americanos cobertos pelo AGR, em branco

Fonte: Rain e Hail (2003)

A indenização é calculada obtendo-se, inicialmente, um valor-índice de receita determinado a partir da multiplicação da produtividade média histórica do produtor (APH) pelo preço projetado (projected price), que é igual à média do preço de fechamento para o contrato futuro referente a dezembro (durante o mês de fevereiro para o milho) e igual à média do preço de fechamento para o contrato futuro referente a novembro (durante o mês de fevereiro para a soja).

O preço projetado é baseado nos contratos futuros da Chicago Board of Trade (CBOT) e varia de um ano para o outro. Exemplificando: para o milho, o preço projetado foi US\$ 2,84 em 1998, US\$ 2,40 em 1999, US\$ 2,51 em 2000 e US\$ 2,46 em 2001.

A receita garantida é baseada em um percentual do valor-índice de receita e determinada sobre a área total plantada. A receita efetiva ou realizada é calculada multiplicando-se a produtividade obtida ou observada pelo preço na época da safra ou, simplesmente, preço-safra. 
Da mesma forma que o preço projetado, o preço-safra é baseado nos contratos futuros da CBOT. Para o milho, é igual à média do preço de fechamento para dezembro durante o mês de novembro. Para a soja, igual à média do preço de fechamento de novembro durante outubro (Schnitkey, 2002).

Sempre que a receita efetiva for menor do que a garantida, o segurado recebe o pagamento da indenização em um valor equivalente à diferença. Os níveis de cobertura variam de $50 \%$ a $75 \%$, em múltiplos de $5 \%$, e de $80 \%$ e $85 \%$ para certas culturas em municípios selecionados.

A figura 9, ilustra o cálculo da indenização para diferentes produtividades observadas e preços-safra.

\begin{tabular}{|l|ccccc|}
\hline Produtividade APH (bu/ac) & \multicolumn{5}{|c|}{200} \\
\hline Preço projetado para 2001 & \multicolumn{5}{|c|}{2,46} \\
(US\$/bu) & \multicolumn{7}{|c}{369} \\
\hline Receita garantida (US\$/ac) & 150 & 260 & 70 & 210 & 110 \\
\hline \hline Produtividade efetiva (bu/ac) & 2,40 & 2,30 & 2,75 & 2,35 & 2,65 \\
Preço-safra (US\$/bu) & 360 & 598 & 192,5 & 493,5 & 291,5 \\
Receita realizada (US\$/ac) & 9 & 0 & 176,5 & 0 & 77,5 \\
Indenização (US\$/ac) & 9.000 & 0 & 176.500 & 0 & 77.500 \\
Indenização total (US\$) &
\end{tabular}

Figura 9 - Cálculo da indenização do seguro IP, ao nível de cobertura de 75\% para o milho, em uma área de mil acres

O prêmio por unidade de área é subsidiado e determinado em função do município em que a cultura está instalada, da produtividade APH e do nível de cobertura selecionada, de modo que, para o nível de cobertura maior ou igual a 65\%, o subsídio será de $75 \%$ do prêmio para 50\% da cobertura.

Para o nível de cobertura menor do que 65\%, o subsídio será de 55\% do prêmio para 50\% da cobertura. A unidade de seguro disponível para o programa IP é somente a "empresa". 


\subsection{Seguro da Renda (Revenue Assurance - RA)}

O Seguro da Renda foi desenvolvido pela Farm Bureau Mutual Insurance (Iowa Farm Bureau) e, atualmente, está sendo administrado pela American Farm Bureau Insurance Services.

Inicialmente, o RA foi ofertado para todos os municípios do Estado de Iowa para a cultura da soja e milho, em 1997. Em 2003, o programa RA foi ofertado em 21 Estados, conforme mostra a figura 10, abaixo: Arkansas (AR), Colorado (CO), Idaho (ID), Illinois (IL), Indiana (IN), Iowa (IA), Kansas (KS), Kentucky (KY), Louisiana (LA), Michigan (MI), Minnesota (MN), Missouri (MO), Montana (MT), Nebraska (NE), North Carolina (NC), North Dakota (ND), Ohio (OH), Oklahoma (OK), South Dakota (SD), Tennessee (TN), Virginia (VA).

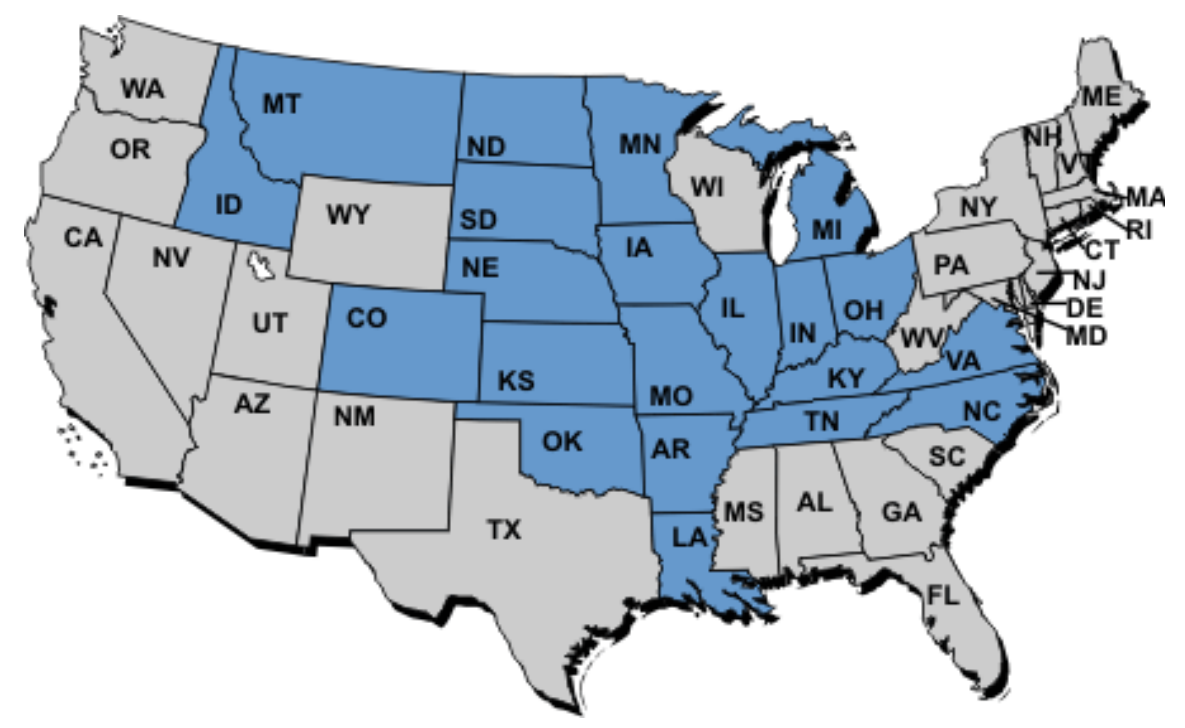

Figura 10 - Estados norte-americanos cobertos pelo RA, em escuro Fonte: Rain e Hail (2003) 
Esse seguro permite segurar a receita similarmente ao IP. A diferença é que, no RA, o segurado pode obter um desconto no prêmio se selecionar, por exemplo, a unidade “empresa”. O desconto é em função do número de distritos incluídos na unidade (Ackerman, 1997).

Assim, para os produtores que operam em diferentes distritos dentro de um mesmo município, os prêmios são reajustados de modo a refletir o menor risco atrelado a este produtor em relação a outro que concentre toda a sua produção em apenas uma localidade.

O mesmo ocorre com o número de culturas existentes na unidade. Quanto mais diversificada ela for, menor o prêmio.

O programa RA inclui, além da unidade empresa, a básico, opcional e fazenda, para todas as culturas cobertas. Para o trigo de inverno, particularmente, não está disponível a unidade fazenda. Além disto, o seguro oferece cobertura de plantio tardio, preventivo e replantio.

O valor-índice de receita é calculado em função da unidade selecionada pelo produtor. Para as unidades básico e opcional, o valor-índice é igual à produtividade APH multiplicada pelo preço projetado, o mesmo utilizado no seguro IP.

Nas unidades empresa e fazenda, os valores-índice são, respectivamente, a média ponderada dos valores-índice de receita por cultura, para cada uma das unidades básico ou opcional, e a média ponderada dos valores-índice de receita para cada uma das unidades básico ou opcional para todas as culturas em um município.

Para o cálculo do valor-índice, com diferentes tipos de unidades, considere a figura 11, abaixo. Neste esquema, um produtor (proprietário) explora diferentes culturas, em área distintas dentro de um município, em certo distrito e setor. 


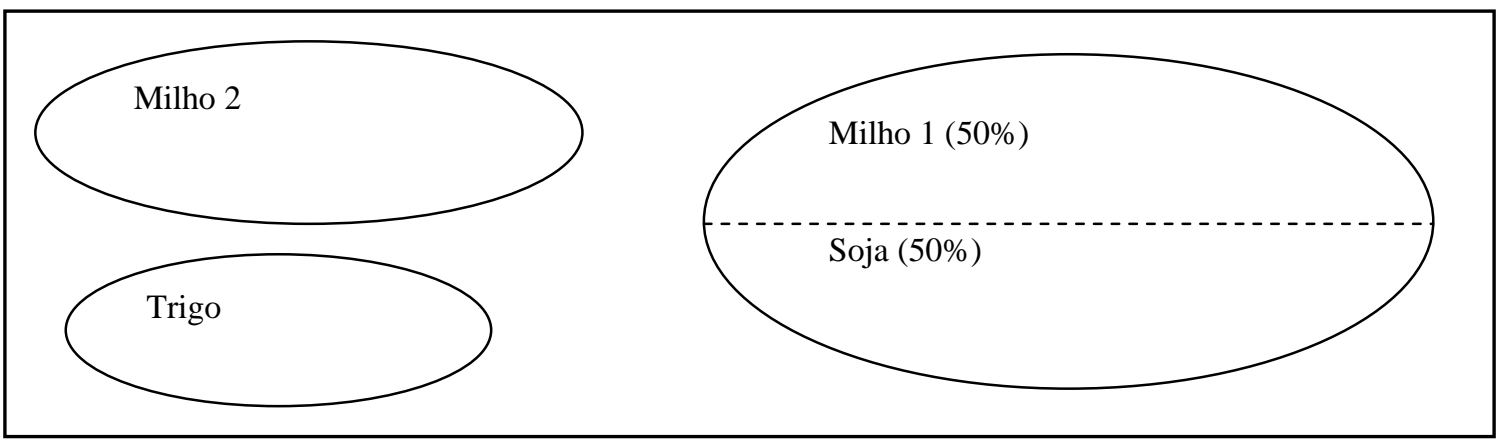

Figura 11 - Área cultivada de milho, soja e trigo em determinado setor

Caso as unidades sejam enquadradas como básico, então o procedimento de cálculo do valor-índice é ilustrado na figura 12.

\begin{tabular}{|l|c|c|c|c|}
\hline & Milho 1 & Milho 2 & Soja & Trigo \\
\hline Produtividade APH (bu/ac) & 170 & 120 & 50 & 40 \\
\hline Preço projetado (US\$/bu) & 2,60 & 2,60 & 7,50 & 3,50 \\
\hline \hline Valor-índice (US\$/ac) & 442 & 312 & 375 & 140 \\
\hline
\end{tabular}

Figura 12 - Cálculo do valor-índice de receita, para a unidade básico

Fonte: United States Department of Agriculture (USDA) (2003i), modificado pelo autor

Para as unidades empresa e fazenda, o procedimento é mostrado na figura 13. 


\begin{tabular}{|l|c|c|c|c|}
\hline & Milho 1 & Milho 2 & Soja & Trigo \\
\hline Área (ac) & 100 & 100 & 100 & 80 \\
\hline Percentual implantado com a cultura (\%) & 50 & 100 & 50 & 100 \\
\hline Valor-índice - básico (US\$/ac) & 442 & 312 & 375 & 140 \\
\hline Valor-índice - empresa & $355,33 *$ & 355,33 & 375 & 140 \\
\hline Valor-índice - fazenda & 297,32 & 297,32 & 297,32 & 297,32 \\
\hline
\end{tabular}

Figura 13 - Cálculo do valor-índice de receita, para a unidade empresa e fazenda

Fonte: USDA (2003i), modificado pelo autor

* este valor corresponde à média ponderada do valor-índice (básico) pela área da respectiva cultura, isto é, $(442 \times 50+312$ x 100) / (100 x 0,5 + 100 x 1)

Uma vez determinado o índice de receita, a receita garantida é calculada, para as unidades básico e opcional, multiplicando-se o nível de cobertura ${ }^{40}$ pela produtividade APH e pelo maior valor entre o preço projetado e o preço-safra de outono (fall harvest price) (USDA, 2003j).

A opção do preço-safra de outono permite ajustar a receita garantida quando o preço próximo à safra é maior do que o projetado.

Para o milho, por exemplo, o preço-safra de outono corresponde à média do preço de fechamento em novembro para o contrato futuro de dezembro na CBOT e, para soja, a média do preço de fechamento no mês de outubro para o contrato futuro de novembro. A FCIC libera o preço-safra de outono para as culturas cobertas no período de agosto a dezembro de um ano.

Em relação à unidade empresa, a receita garantida será igual a uma média ponderada igual para toda área segurada, por tipo de cultura. Para a fazenda será igual a uma média ponderada, igual para toda a área segurada em um município (figura 14, abaixo).

\footnotetext{
${ }^{40}$ O nível de cobertura varia de 65\% a 85\%, em múltiplos de 5\%.
} 


\begin{tabular}{|l|c|c|c|c|}
\hline & Milho 1 & Milho 2 & Soja & Trigo \\
\hline Área (ac) & 100 & 100 & 100 & 80 \\
\hline $\begin{array}{l}\text { Percentual implantado com a cultura } \\
(\%)\end{array}$ & 50 & 100 & 50 & 100 \\
\hline \hline Valor-índice - básico (US\$/ac) & 442 & 312 & 375 & 140 \\
\hline Valor-índice - empresa & 355,33 & 355,33 & 375 & 140 \\
\hline Valor-índice - fazenda & 297,32 & 297,32 & 297,32 & 297,32 \\
\hline \hline Receita garantida - básico (US\$) & 16.575 & 23.400 & $14.062,5$ & 8.400 \\
\hline Receita garantida - empresa & $39.974,63^{*}$ & $39.974,63$ & $14.062,5$ & 8.400 \\
\hline Receita garantida - fazenda & $62.437,2$ & $62.437,2$ & $62.437,2$ & $62.437,2$ \\
\hline
\end{tabular}

Figura 14 - Cálculo da receita garantida no seguro RA, para o nível de cobertura de $75 \%$, por unidades selecionadas

Fonte: USDA (2003i), modificado pelo autor

* este valor corresponde a 75\% do valor-índice (empresa) multiplicada pela média ponderada da área da respectiva cultura, isto é, $(355,33$ x 0,75) x $(100 \times 0,5+100$ x 1)

No final da safra estima-se a receita efetiva, fazendo-se a multiplicação da produtividade em cada unidade pelo preço-safra de outono, para cada cultura (figura 15). 


\begin{tabular}{|l|c|c|c|c|}
\hline & Milho 1 & Milho 2 & Soja & Trigo \\
\hline Área (ac) & 100 & 100 & 100 & 80 \\
\hline Percentual implantado com a cultura (\%) & 50 & 100 & 50 & 100 \\
\hline Produtividade observada (bu/ac) & 140 & 125 & 25 & 40 \\
\hline Preço de safra de outono(US\$/bu) & 2,70 & 2,70 & 7,20 & 3,30 \\
\hline \hline Receita efetiva - básico (US\$/ac) & 378 & 337,5 & 180 & 132 \\
\hline Receita efetiva - empresa & $351^{*}$ & 351 & 180 & 132 \\
\hline Receita efetiva - fazenda & 257,9 & 257,9 & 257,9 & 257,9 \\
\hline \hline Receita efetiva total - básico (US\$) & 18.900 & 33.750 & 9.000 & 10.560 \\
\hline Receita efetiva total - empresa & $52.650^{* *}$ & 52.650 & 9.000 & 10.560 \\
\hline Receita efetiva total - fazenda & 72.212 & 72.212 & 72.212 & 72.212 \\
\hline
\end{tabular}

Figura 15 - Cálculo da receita efetiva, por unidade selecionada

Fonte: USDA (2003i), modificado pelo autor

* este valor corresponde à média ponderada do valor-índice (básico) pela área da respectiva cultura, isto é, $(378 \times 50+337,5 \times 100) /(100 \times 0,5+100 \times 1)$

** este valor corresponde a (351 x 100 x 0,5 + 351 x 100 x 1)

O pagamento da indenização é devido sempre que a receita efetiva da unidade for menor do que a garantida (figura 16).

\begin{tabular}{|l|c|c|c|c|}
\hline & Milho 1 & Milho 2 & Soja & Trigo \\
\hline Receita garantida - básico (US\$) & 16.575 & 23.400 & $14.062,5$ & 8.400 \\
\hline Receita efetiva total - básico (US\$) & 18.900 & 33.750 & 9.000 & 10.560 \\
\hline Indenização & 0 & 0 & $5.062,5$ & 0 \\
\hline \hline Receita garantida - empresa & $39.974,63$ & $39.974,63$ & $14.062,5$ & 8.400 \\
\hline Receita efetiva total - empresa & $52.650^{* *}$ & 52.650 & 9.000 & 10.560 \\
\hline Indenização & 0 & 0 & $5.062,5$ & \\
\hline \hline Receita garantida - fazenda & $62.437,20$ & $62.437,20$ & $62.437,20$ & $62.437,20$ \\
\hline Receita efetiva total - fazenda & 72.212 & 72.212 & 72.212 & 72.212 \\
\hline Indenização & 0 & 0 & 0 & 0 \\
\hline
\end{tabular}

Figura 16 - Cálculo da receita efetiva e indenização, por unidade

Fonte: USDA (2003i), modificado pelo autor 


\subsection{Cobertura da Renda Agrícola (Crop Revenue Coverage - CRC)}

O CRC foi desenvolvido pela iniciativa privada, por uma seguradora denominada Redland Insurance Company. O seguro foi ofertado, inicialmente, nos Estados de Iowa e Nebraska, para a soja e milho, na primavera de 1996.

No ano seguinte, o programa passou a cobrir o algodão, o trigo e o sorgo, além de expandir sua área geográfica de atuação. Atualmente, o CRC cobre todos os Estados norte-americanos.

Como nos seguros IP e RA, o CRC também é um seguro de renda que protege o produtor de variações na produtividade, no preço ou em ambos. O nível coberto segue as normas do seguro MPCI, por meio do APH.

Dessa forma, o segurado pode optar por escolher o nível de cobertura entre $50 \%$ a $75 \%$, em múltiplos de $5 \%$, e $80 \%$ e $85 \%$ para culturas e municípios selecionados. O CRC também oferece cobertura para plantio preventivo, tardio e replantio.

Para a fixação do nível de preço, o CRC define o preço-base ${ }^{41}$ e o preçosafra para cada cultura coberta.

Para o milho, por exemplo, o preço-base e o safra correspondem, respectivamente, ao preço médio no mês de fevereiro para o contrato futuro de dezembro e o preço médio no mês de outubro para o contrato futuro de dezembro (USDA, 2003e).

Para a soja esses preços são, respectivamente, o preço médio no mês de fevereiro para o contrato futuro de novembro e o preço médio em outubro para o contrato futuro de novembro.

Nota-se que, para o milho, por exemplo, o preço-safra não pode ser maior/menor do que o preço-base mais/menos US\$ 1,50, sendo liberado pelo FCIC no dia 10 de novembro do ano-safra.

\footnotetext{
${ }^{41}$ Corresponde ao preço projetado utilizado no seguro RA e IP.
} 
A receita garantida, denominada no CRC como garantia final, será o maior valor entre a garantia mínima e a garantia da safra.

A garantia mínima é calculada multiplicando-se a produtividade APH pelo preço-base e pelo nível de cobertura. A garantia da safra resulta do produto entre a produtividade APH, o preço-safra e o nível de cobertura.

A figura 17, ilustra os principais cálculos e operações no seguro CRC, para o milho, em uma unidade ${ }^{42}$ com área igual a 400 acres e um nível de cobertura de 75\%. Neste exemplo, para o cálculo da garantia da safra utilizou-se um preço-safra maior e menor do que o preço-base.

\begin{tabular}{|l|c|c|}
\hline Produtividade APH (bu/ac) & 140 & 140 \\
\hline Preço-base (US\$/bu) & 2,60 & 2,60 \\
\hline Garantia mínima (US\$/ac) & 273 & 273 \\
\hline \hline Preço-safra (US\$/bu) & 2,75 & 2,40 \\
\hline Garantia da safra (US\$/ac) & 288,8 & 252 \\
\hline \hline Garantia final (US\$/ac) & 288,8 & 273 \\
\hline \hline Produtividade observada (bu/ac) & 60 & 120 \\
\hline Preço-safra (US\$/bu) & 2,75 & 2,40 \\
\hline Receita calculada (US\$/ac) & 165 & 288 \\
\hline \hline Indenização (US\$/ac) & 123,8 & 0 \\
\hline Indenização total (US\$) & 49.520 & 0 \\
\hline
\end{tabular}

Figura 17 - Cálculo da garantia final, receita calculada e indenização Fonte: USDA (2003d), modificado pelo autor

O prêmio é subsidiado pelo governo norte-americano e baseado no preço-base, permanecendo constante mesmo se o preço-safra for maior do que o base. Além do prêmio, o segurado deve pagar uma taxa administrativa pela cobertura CRC de US\$ 30 por cultura e por município.

\footnotetext{
${ }^{42}$ Os produtores podem selecionar as unidades básico, opcional e empresa.
} 
2.1.1.1.4 Plano de Risco Grupal (Group Risk Plan - GRP) e Plano de Risco da Renda Grupal (Group Risk Income Plan - GRIP)

O GRP é um seguro que fornece proteção contra a redução na produtividade. Sua operacionalização assemelha-se ao MPCI, mas a diferença consiste na determinação dos parâmetros do mecanismo de compensação, ou seja, a produtividade garantida é calculada pelo produto entre a produtividade regional esperada e o nível de cobertura, que pode variar de 70\% a 90\%, em múltiplos de 5\% (Edwards, 1999).

O GRP é ofertado, atualmente, nos Estados do Alabama (AL), Arkansas (AR), Georgia (GA), Kansas (KS), Kentucky (KY), Louisiana (LA), Maryland (MD), Michigan (MI), Minnesota (MN), Mississippi (MS), Missouri (MO), Montana, (MT), Nebraska (NE), Nevada (NV), North Carolina (NC), North Dakota (ND), Ohio, (OH), Pennsylvania (PA), South Carolina (SC), South Dakota (SD), Tennessee (TN), Texas (TX), Virginia (VA), Wisconsin (WI). A abrangência do GRP é ilustrada na figura 18, abaixo. 


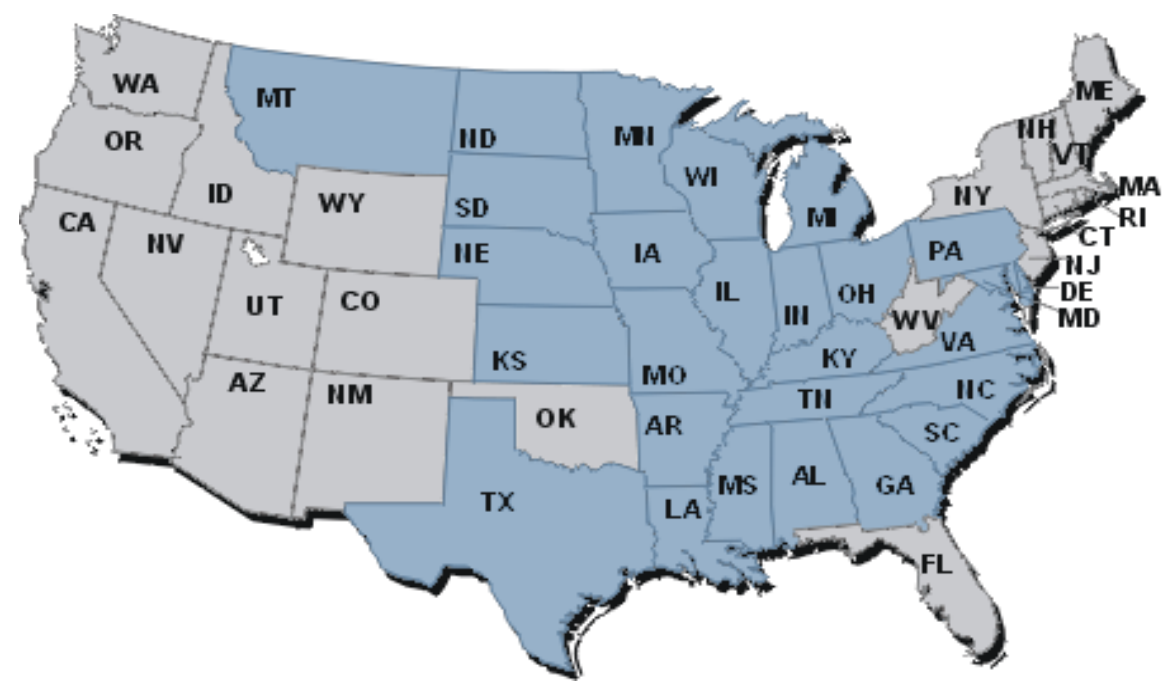

Figura 18 - Estados norte-americanos cobertos pelo GRP, em escuro

Fonte: Rain e Hail (2003)

O nível mínimo de cobertura para o GRP, denominado proteção de risco catastrófico, cobre 65\% da produtividade regional esperada e 55\% da importância máxima segurada, com taxa de US\$ 100.

Pode-se optar pela cobertura adicional, ou seja, a quantidade de proteção acima do nível mínimo, sendo cobrada uma taxa de US\$ 30 por cultura e por município, para todas as coberturas adicionais (USDA, 2003g).

O pagamento da indenização é realizado toda vez que a produtividade regional atual ${ }^{43}$ for menor do que a garantida, em termos percentuais. O valor da indenização é calculado multiplicando-se este índice de perda pelo nível de proteção ${ }^{44}$ (USDA, 2003f).

No seguro de renda GRIP, a receita regional garantida corresponde à multiplicação da produtividade regional efetiva pelo preço esperado e pelo nível de cobertura, que pode variar de $70 \%$ a $90 \%$, em múltiplos de $5 \%$.

\footnotetext{
${ }^{43}$ Estimada pelo National Agricultural Statistics Service (NASS).

${ }^{44}$ O nível de proteção corresponde de $60 \%$ a $100 \%$ da máxima importância segurada por unidade de área especificada no contrato.
} 
O preço esperado é definido como a média do preço de fechamento dos últimos cinco dias úteis no mês de fevereiro para o contrato futuro de dezembro, no caso do milho, e a média do preço de fechamento dos últimos cinco dias úteis em fevereiro para o contrato futuro de novembro, para o contrato futuro da soja.

A renda efetiva regional é obtida pela multiplicação da produtividade regional atual pelo preço-safra, que é a média do preço de fechamento no mês de novembro para o contrato futuro de dezembro, no caso do milho, e a média do preço de fechamento no mês de outubro para o contrato futuro de novembro, para o contrato futuro da soja (USDA, 2003h).

A indenização ocorre quando a renda efetiva regional for menor do que a garantida, em termos percentuais. O valor do pagamento é igual ao percentual de redução multiplicado pelo nível de proteção. A figura 19, abaixo, mostra as principais etapas para o cálculo da indenização para a soja.

O subsídio ao prêmio para o GRIP será o mesmo que o subsídio dado ao GRP, para o mesmo município, cultura e nível de cobertura. Existe apenas uma unidade GRIP por município e não são oferecidas as coberturas tardia, preventiva e de replantio.

\begin{tabular}{|l|c|c|}
\hline & GRP & Grip \\
\hline Produtividade regional esperada (bu/ac) & \multicolumn{2}{|c|}{50} \\
\hline Nível de cobertura (\%) & \multicolumn{2}{|c|}{7} \\
\hline Produtividade garantida (bu/ac) & \multicolumn{2}{|c|}{100} \\
\hline Preço esperado (US\$/bu) & \multicolumn{2}{|c|}{$350^{*}$} \\
\hline Receita regional garantida (US\$/ac) & \multicolumn{2}{|c|}{6,5} \\
\hline Percentual de proteção (\%) & 40 & - \\
\hline Valor protegido (US\$/ac) & - & 260 \\
\hline Preço-safra (US \$/bu) & 20 & 17,5 \\
\hline Produtividade regional atual (bu/ac) & $70^{* *}$ & $61^{* *}$ \\
\hline Receita regional atual (US \$/ac) & & \\
\hline Percentual de perda (\%) & & \\
\hline Indenização (US \$/ac) & & \\
\hline
\end{tabular}

Figura 19 - Principais etapas para o cálculo da indenização no GRP e GRIP

* este valor corresponde à seguinte operação: 50 x 7 x 1,0

* * este valor corresponde à multiplicação do percentual de perda pelo valor protegido 


\subsection{Renda Bruta Ajustada (Adjusted Gross Revenue - AGR)}

O AGR foi inicialmente ofertado em cinco Estados como um projeto-piloto, em 1999. Posteriormente, em 2003, foi expandido para 18 Estados (figura 20, abaixo). São eles: Califórnia (CA), Connecticut (CT), Delaware (DE), Florida (FL), Idaho (ID), Maine (ME), Maryland (MD), Massachusetts (MA), Michigan (MI), New Hampshire (NH), New Jersey (NJ), New York (NY), Oregon (OR), Pennsylvania (PA), Rhode Island (RI), Vermont (VT), Virginia (VA), Washington (WA).

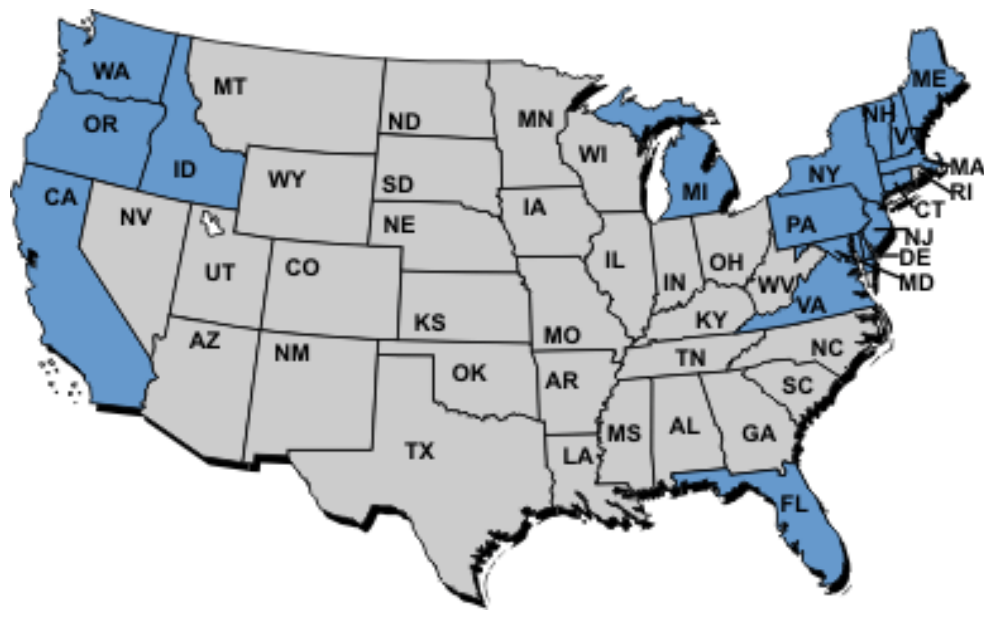

Figura 20 - Estados norte-americanos cobertos pelo AGR, em escuro Fonte: Rain e Hail (2003)

O AGR é um seguro que garante a renda do empreendimento total e não apenas de culturas individuais, como ocorre nos outros programas. 
O programa oferece cobertura para certo percentual da receita bruta decorrente das atividades exploradas dentro da propriedade, incluindo um montante de renda proveniente da atividade pecuária.

Para participar do programa o produtor deve ter declarado o imposto, no mínimo, cinco anos consecutivos, não exceder a responsabilidade de US\$ 6,5 milhões e adquirir o seguro agrícola federal tradicional, quando mais do que $50 \%$ da renda esperada, proveniente da exploração de uma ou mais culturas, forem passíveis de cobertura com os programas existentes. Além disso, a renda esperada vinda da atividade pecuária não deve ser superior a 35\%.

O AGR pode ser utilizado de modo complementar aos programas de seguro ofertados pela FCIC, tais como o MPCI, CRC, IP e RA, resultando em uma maior cobertura do risco pelo produtor.

Quando ocorre esse tipo de complementação, o prêmio pago pelo segurado é reduzido. Nota-se que, além do prêmio, o produtor deve arcar com uma taxa administrativa de US\$ 30.

A figura 21, ilustra o procedimento de cálculo da indenização pelo AGR (USDA, 2003c). 


\begin{tabular}{|c|c|c|c|c|c|}
\hline \multirow{6}{*}{ Renda AGR (US\$) } & 1998 & 230.000 & \multirow{6}{*}{$\begin{array}{l}\text { Gastos } \\
\text { admissíveis } \\
\text { declarados } \\
\text { (US\$) }\end{array}$} & 1998 & 180.000 \\
\hline & 1999 & 290.000 & & 1999 & 160.000 \\
\hline & 2000 & 245.000 & & 2000 & 125.000 \\
\hline & 2001 & 235.000 & & 2001 & 200.000 \\
\hline & 2002 & 250.000 & & 2002 & 185.000 \\
\hline & Média & 250.000 & & Média * & 170.000 \\
\hline Renda histórica AG & & & & 275.000 & \\
\hline Renda projetada (A & & & & 290.000 & \\
\hline Nível de cobertura & agament & (\%) & & $80 / 90$ & \\
\hline Gastos admissíveis & & & & 115.000 & \\
\hline AGR aprovada (US & & & & 275.000 & \\
\hline AGR ajustada** (U & & & & 268.529 & \\
\hline Receita garantida (L & & & & 214.823 & \\
\hline Receita efetiva (US & & & & 194.000 & \\
\hline Perda (US\$) & & & & 20.823 & \\
\hline Indenização (US\$) & & & & 18.741 & \\
\hline
\end{tabular}

Figura 21 - Procedimento de cálculo da indenização do AGR

Fonte: USDA (2003b), modificado pelo autor

* Média dos cinco anos dos gastos (declarados no Schedule F) admissíveis

** A AGR aprovada será ajustada, pois o valor dos gastos admissíveis (115.000) é menor do que $70 \%$ do gasto admissível declarado médio $(70$ x $170.000=119.000)$. A AGR ajustada será igual a 275.000 x $\{1-[(0,7$ x $170.000-115.000) / 170.000]\}$ $=268.529$

Para fins de cálculo da receita garantida utiliza-se a receita bruta aprovada, ou AGR aprovada, que representa o menor valor entre a média das informações dos últimos cinco anos da declaração do imposto de renda da atividade agropecuária (Schedule F tax forms), denominada renda histórica AGR, e a renda projetada pelo Annual Farm Report (AFR) (USDA, 2003b). 
A receita garantida é calculada multiplicando-se a AGR aprovada ${ }^{45}$ (ou AGR ajustado) pelo nível de cobertura, que é escolhido pelo produtor dentre os seguintes percentuais: $65 \%$, $75 \%$ e $80 \%$.

A indenização ocorre quando a diferença entre a renda garantida e a renda efetiva ou realizada for maior do que zero. Sobre este valor incide a taxa de pagamento, que pode ser de $75 \%$ ou $90 \%$, obtendo-se, desta forma, o valor da indenização que será pago ao produtor.

A figura 22, mostra o número mínimo de culturas a serem implantadas, de acordo com o nível de cobertura e taxa de pagamento.

\begin{tabular}{|c|c|c|}
\hline Nível de cobertura (\%) & Taxa de pagamento (\%) & Número mínimo * \\
\hline \multirow{2}{*}{65} & 75 & Não há \\
\cline { 2 - 3 } & 90 & 2 \\
\hline \multirow{2}{*}{75} & 75 & 2 \\
\cline { 2 - 3 } & 90 & 2 \\
\hline \multirow{2}{*}{80} & 75 & 4 \\
\cline { 2 - 3 } & 90 & 4 \\
\hline
\end{tabular}

Figura 22 - Número mínimo de culturas a serem implantadas, de acordo com o nível de cobertura e taxa de pagamento

Fonte: USDA (2003b), modificado pelo autor

* cada cultura deve contribuir com determinado percentual da receita

As principais características dos programas de seguro de produtividade e renda são mostrados, respectivamente, nas figuras 23 e 24:

\footnotetext{
${ }^{45}$ A AGR aprovada poderá ser ajustada se os gastos admissíveis caírem a um patamar menor do que 70\% da média dos cinco anos dos gastos (declarados no Schedule F) admissíveis. O ajuste será denominado AGR ajustada.
} 


\begin{tabular}{|l|c|c|c|}
\hline & MPCI & CAT & GRP \\
\hline Base do mecanismo de compensação & $\begin{array}{c}\text { Produtividade } \\
\text { individual }\end{array}$ & $\begin{array}{c}\text { Produtividade } \\
\text { individual }\end{array}$ & $\begin{array}{c}\text { Produtividade } \\
\text { regional }\end{array}$ \\
\hline Nível de cobertura - produtividade & $\begin{array}{c}50 \% \text { a } 85 \% \text { da } \\
\text { produtividade APH }\end{array}$ & $\begin{array}{c}50 \% \text { da } \\
\text { produtividade APH }\end{array}$ & $\begin{array}{c}70 \% \text { a } 90 \% \text { da } \\
\text { produtividade } \\
\text { regional }\end{array}$ \\
\hline Nível de cobertura - preço & $\begin{array}{c}55 \% \text { a } 100 \% \text { do } \\
\text { preço fixado pela } \\
\text { RMA }\end{array}$ & $\begin{array}{c}55 \% \text { do preço } \\
\text { fixado pela RMA }\end{array}$ & $\begin{array}{c}60 \% \text { a } 100 \% \\
\text { do preço RMA }\end{array}$ \\
\hline $\begin{array}{l}\text { Taxa de administração por cultura } \\
\text { (US\$) }\end{array}$ & $100 *$ e $30^{* *}$ & $\begin{array}{c}100 \text { (totalmente } \\
\text { subsidiado) }\end{array}$ & $100^{*}$ e $30^{* *}$ \\
\hline Prêmio & Sim & Não & Sim \\
\hline Subsídio ao prêmio & $\begin{array}{c}\text { Sim, em função do } \\
\text { nível de cobertura }\end{array}$ & Não & Sim \\
\hline Unidades disponíveis & Básico e opcional & Básico & Nenhuma \\
\hline Cobertura para plantio tardio & Sim & Sim & Não \\
\hline Cobertura preventiva & Sim & Sim & Não \\
\hline Cobertura para replantio & Sim & Não & Não \\
\hline Cobertura suplementar & Granizo e fogo & Granizo e fogo & Não \\
\hline
\end{tabular}

Figura 23 - Principais características dos programas de seguro de produtividade Fonte: elaborado pelo autor

* Para o nível de cobertura mínimo (CAT)

** Para níveis de cobertura superiores ao CAT 


\begin{tabular}{|c|c|c|c|c|c|}
\hline & CRC & IP & RA & GRIP & AGR \\
\hline $\begin{array}{c}\text { Base do } \\
\text { mecanismo de } \\
\text { compensação }\end{array}$ & $\begin{array}{c}\text { Renda } \\
\text { individual }\end{array}$ & $\begin{array}{c}\text { Renda } \\
\text { individual }\end{array}$ & $\begin{array}{c}\text { Renda } \\
\text { individual }\end{array}$ & $\begin{array}{l}\text { Renda } \\
\text { regional }\end{array}$ & $\begin{array}{c}\text { Renda bruta } \\
\text { da } \\
\text { propriedade }\end{array}$ \\
\hline $\begin{array}{l}\text { Referência de } \\
\text { preço para a } \\
\text { garantia do } \\
\text { seguro }\end{array}$ & $\begin{array}{c}100 \% \text { do } \\
\text { maior valor } \\
\text { entre o preço- } \\
\text { safra e o base } \\
\text { (1) }\end{array}$ & $\begin{array}{l}100 \% \text { do preço } \\
\text { projetado }\end{array}$ & $\begin{array}{c}100 \% \text { do } \\
\text { preço } \\
\text { projetado (2) }\end{array}$ & $\begin{array}{l}100 \% \text { do } \\
\text { preço } \\
\text { esperado }\end{array}$ & $\begin{array}{l}\text { A receita } \\
\text { garantida é } \\
\text { baseada na } \\
\text { AGR } \\
\text { aprovada }\end{array}$ \\
\hline $\begin{array}{c}\text { Preço: oscilação } \\
\text { máxima } \\
\text { permitida }\end{array}$ & $\begin{array}{c} \pm \text { US } \$ 1,50 / \text { bu } \\
\text { para milho, } \\
\pm 3,00 / \text { bu para } \\
\text { soja, } \\
\pm 2,00 / \text { bu para } \\
\text { trigo }\end{array}$ & Não há & Não há & Não há & Não há \\
\hline $\begin{array}{l}\text { Nível de } \\
\text { cobertura }\end{array}$ & $\begin{array}{l}\text { 50\%-75\%, em } \\
\text { incrementos de } \\
5 \%, 80 \% \text { e } \\
85 \% \text { (certas } \\
\text { culturas/ } \\
\text { municípios } \\
\text { selecionados) }\end{array}$ & $\begin{array}{l}\text { 50\%-75\%, em } \\
\text { incrementos de } \\
5 \%, 80 \% \text { e } \\
85 \% \text { (certas } \\
\text { culturas/ } \\
\text { municípios } \\
\text { selecionados) }\end{array}$ & $\begin{array}{c}50 \%-85 \% \text {, em } \\
\text { incrementos } \\
\text { de } 5 \% \text { para } \\
\text { todas as } \\
\text { unidades (3) }\end{array}$ & $\begin{array}{c}\text { 70\% a } 90 \%, \\
\text { em } \\
\text { incrementos } \\
\text { de } 5 \% \text {, sobre } \\
\text { a renda } \\
\text { regional } \\
\text { esperada (4) }\end{array}$ & $\begin{array}{l}65 \%, 75 \% \text { e } \\
80 \% \text {, que } \\
\text { incide sobre } \\
\text { a AGR } \\
\text { aprovada (5) }\end{array}$ \\
\hline $\begin{array}{l}\text { Base para } \\
\text { garantia da } \\
\text { receita }\end{array}$ & $\begin{array}{l}\text { Maior valor } \\
\text { entre a } \\
\text { garantia } \\
\text { mínima e a } \\
\text { garantia da } \\
\text { safra } \\
\text { determina a } \\
\text { garantia final }\end{array}$ & $\begin{array}{l}\text { Produtividade } \\
\text { APH x preço } \\
\text { projetado x } \\
\text { nível de } \\
\text { cobertura }\end{array}$ & $\begin{array}{c}\text { Produtividade } \\
\text { APH x preço } \\
\text { projetado x } \\
\text { nível de } \\
\text { cobertura (6) }\end{array}$ & $\begin{array}{l}\text { Produtividade } \\
\text { regional } \\
\text { efetiva x } \\
\text { preço } \\
\text { esperado x } \\
\text { pelo nível de } \\
\text { cobertura }\end{array}$ & $\begin{array}{c}\text { AGR } \\
\text { aprovada x } \\
\text { nível de } \\
\text { cobertura }\end{array}$ \\
\hline $\begin{array}{c}\text { Taxa de } \\
\text { administração } \\
\text { por cultura }\end{array}$ & $\begin{array}{c}\text { US\$ } 30 \text { por } \\
\text { cultura e por } \\
\text { município }\end{array}$ & $\begin{array}{c}\text { US\$ } 100 \text { por } \\
\text { cultura e por } \\
\text { município } \\
\end{array}$ & $\begin{array}{c}\text { US\$ } 30 \text { por } \\
\text { cultura e por } \\
\text { município } \\
\end{array}$ & $\begin{array}{c}\text { US\$ } 100(7) \\
\text { e } 30(8)\end{array}$ & US\$ 30 \\
\hline $\begin{array}{c}\text { Subsídio ao } \\
\text { prêmio }\end{array}$ & Sim & Sim & Sim & Sim & Sim \\
\hline $\begin{array}{l}\text { Unidades } \\
\text { disponíveis }\end{array}$ & $\begin{array}{l}\text { Básico, } \\
\text { opcional e } \\
\text { empresa }\end{array}$ & Empresa & $\begin{array}{l}\text { Básico, } \\
\text { opcional, } \\
\text { empresa e } \\
\text { fazenda }\end{array}$ & Nenhuma & Fazenda \\
\hline $\begin{array}{c}\text { Cobertura para } \\
\text { plantio tardio }\end{array}$ & Sim & Sim & Sim & Não & Não \\
\hline $\begin{array}{l}\text { Cobertura } \\
\text { preventiva }\end{array}$ & Sim & Sim & Sim & Não & Não \\
\hline $\begin{array}{c}\text { Cobertura para } \\
\text { replantio }\end{array}$ & Sim & Sim & Sim & Não & Sim \\
\hline $\begin{array}{c}\text { Cobertura } \\
\text { suplementar }\end{array}$ & Não & Não & Não & Não & Não \\
\hline
\end{tabular}

Figura 24 - Principais características dos programas de seguro de renda

Fonte: USDA (2003a), modificado pelo autor 
(1) Possibilidade da garantia aumentar no decorrer do ciclo

(2) Possibilidade da garantia aumentar se escolhida a opção preço-safra de outono

(3) $80 \%$ e $85 \%$ somente para municípios ou culturas em que o MPCI oferece tal cobertura

(4) O nível de proteção variando de 60\% a 100\% da máxima importância segurada

(5) A taxa de pagamento corresponde a $75 \%$ ou $90 \%$ e incide sobre a diferença entre a renda garantida e efetiva

(6) Se a opção preço-safra de outono for selecionada e for maior do que o preço projetado, então: produtividade APH x preço-safra de outono x nível de cobertura

(7) Taxa para proteção de risco catastrófico

(8) Coberturas adicionais

\subsubsection{Subsídio e participação no seguro agrícola norte-americano}

O subsídio ao prêmio tem sido uma característica inerente ao programa de seguro agrícola norte-americano desde o início da década de 80, reduzindo consideravelmente o custo do seguro para os produtores agrícolas (Dismukes e Vandeveer, 2001).

A partir de 1998, descontos ao prêmio foram adicionados ao subsídio já existente, além disso, a Lei de Proteção ao Risco Agrícola de 2000 (Arpa) ${ }^{46}$ revisou as taxas de subsídio e aumentou a provisão de recursos financeiros para o subsídio ao prêmio no qüinqüênio 2001/2005.

\footnotetext{
${ }^{46}$ Do termo em Inglês, 2000 Agricultural Risk Protection Act.
} 
A referida lei ainda mantém a estrutura de comercialização anterior. Por meio das companhias privadas, os contratos de seguro são ofertados ao público. Cada seguradora possui um grupo de corretores ou agentes ${ }^{47}$ responsáveis pela venda destes contratos diretamente aos produtores.

No ano de 2000, 17 companhias operaram neste ramo, sendo que as quatro maiores responderam por aproximadamente dois terços do volume total de prêmios. Além disso, três das quatro maiores seguradoras estavam presentes em 48 dos 50 Estados cobertos pelo seguro.

O nível de subsídio incidente sobre o valor do prêmio varia de acordo com o percentual de cobertura. Desta maneira, quanto maior o nível de cobertura, maior a taxa de prêmio e menor será o subsídio.

A Arpa revisou os níveis de subsídio, aumentando os valores para todos os níveis de cobertura em relação aos valores vigentes anteriormente. A tabela 2, abaixo, mostra os novos percentuais de subsídio vigentes atualmente no seguro multi-risco norte-americano.

Tabela 2. Evolução dos percentuais de subsídio por nível cobertura para o seguro MPCI, no período de 1998 a 2001

\begin{tabular}{ccccc}
\hline Nível de cobertura / Ano & 1998 & 1999 & 2000 & $2001^{*}$ \\
\hline 65 & 41,7 & 59,2 & 56,3 & 59,0 \\
70 & 31,9 & 52,3 & 48,9 & 59,0 \\
75 & 23,5 & 46,4 & 42,6 & 55,0 \\
80 & 17,3 & 42,1 & 38,0 & 48,0 \\
85 & 13,0 & 39,1 & 34,7 & 38,0 \\
\hline
\end{tabular}

Fonte: USDA, extraído de Dismukes (2003)

* Estas taxas de subsídio serão fixas durante o qüinqüênio 2001/05

Notas: Para os anos de 1999 e 2000, as referidas taxas de subsídio ao prêmio já incluem os descontos ao prêmio que foram, respectivamente, de $30 \%$ e $25 \%$

\footnotetext{
${ }^{47}$ A maioria dos 18 mil corretores de seguro agrícola trabalham de maneira independente, podendo estar ligados a mais de uma seguradora. São comissionados e recebem uma certa proporção do prêmio pago por contrato. Nota-se que, além do ramo agrícola, outros tipos de contratos podem ser ofertados pelos mesmos corretores.
} 
Nesse mesmo período, o subsídio ao prêmio do seguro para a faixa de cobertura de $50 / 100^{48}$ passou de $57 \%$ para $67 \%$. Para a faixa de $55 / 100$, aumentou de $48 \%$ para $64 \%$ e de $39 \%$ para $64 \%$ para a faixa de cobertura de $60 / 100$.

Para outros tipos de seguro, como por exemplo, o CRC, a Arpa determinou que o percentual de subsídio fosse igual ao utilizado no MPCI, por nível de cobertura.

Anteriormente à Arpa, o seguro CRC recebia o mesmo valor monetário de subsídio que o MPCI. Como a taxa de prêmio é maior no seguro de renda do que no MPCI, então, para os mesmos níveis de cobertura o percentual de subsídio será menor para o CRC (tabela 3).

Tabela 3. Evolução dos percentuais de subsídio por nível cobertura para o seguro CRC, no período de 1998 a 2001

\begin{tabular}{ccccc}
\hline Nível de cobertura / Ano & 1998 & 1999 & 2000 & 2001 \\
\hline 65 & 33,4 & 53,4 & 50,0 & 59,0 \\
70 & 25,5 & 47,8 & 44,1 & 59,0 \\
75 & 18,8 & 43,2 & 39,1 & 55,0 \\
80 & 13,9 & 39,7 & 35,4 & 48,0 \\
85 & 10,4 & 37,2 & 32,8 & 38,0 \\
\hline
\end{tabular}

Fonte: USDA, extraído de Dismukes (2003)

Desta forma, a Arpa modificou a relação entre o montante de subsídio e o prêmio pago de modo a igualar tal relação com o seguro MPCI. Conseqüentemente, os produtores que optarem pelo seguro de renda poderão receber um volume maior de subsídios em relação aos anos anteriores.

O volume de subsídios e prêmios arrecadados pode ser observado na figura 25, abaixo.

\footnotetext{
${ }^{48}$ Isto significa que a abrangência de cobertura incidente sobre a produtividade é de $50 \%$ e a cobertura sobre o nível de preço é de $100 \%$.
} 
Nota-se que o montante de subsídio aumentou 94\% de 1981 para 1982 e se situou, nos anos de 1982 a 1994, em um patamar médio ao redor de 25\%. Em 1994, o total de prêmios arrecadados atingiu, aproximadamente, US\$ 950 milhões e o subsídio ao redor de US\$ 255 milhões.

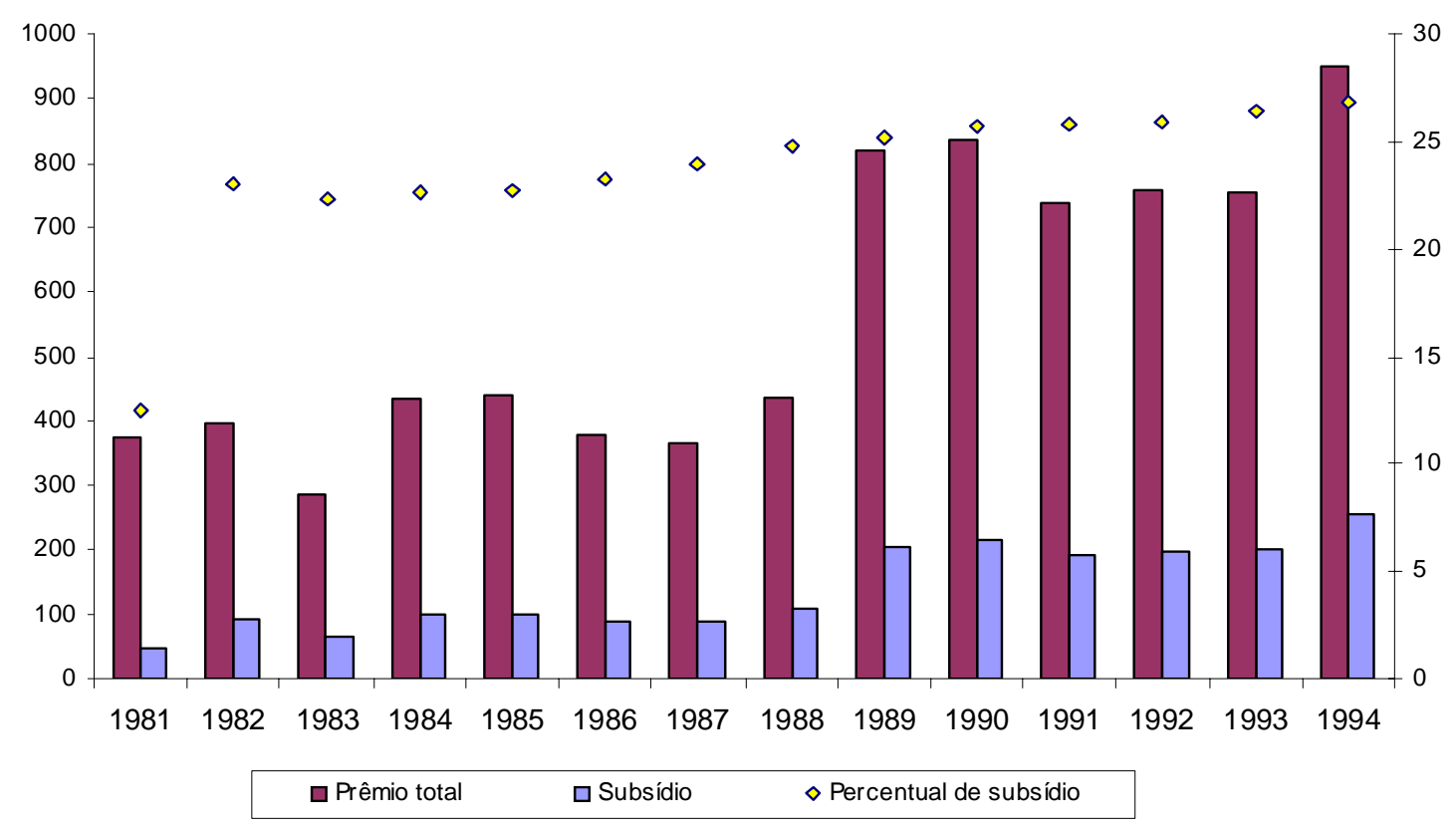

Figura 25 - Prêmio total, subsídio ao prêmio, em milhões de dólares, e percentual de subsídio em relação ao prêmio do seguro MPCI, no período de 1981 a 1994 Fonte: USDA, extraído de Dismukes (2003)

A partir de 1995, o seguro MPCI de cobertura mínima, CAT, passou a ser ofertado com prêmio totalmente subsidiado pelo governo.

Além disso, houve um aumento da demanda por contratos com cobertura superior ao CAT (buy-up). 
No ano de 1996, foram ofertados contratos de seguro de renda em bases experimentais e com abrangência limitada.

Nota-se que os seguros de renda apresentaram um aumento no prêmio total arrecadado de aproximadamente US\$ 146 milhões para US\$ 1400 de 1996 a 2001. O montante de subsídios acompanhou a tendência de crescimento do prêmio arrecadado (figura 26).

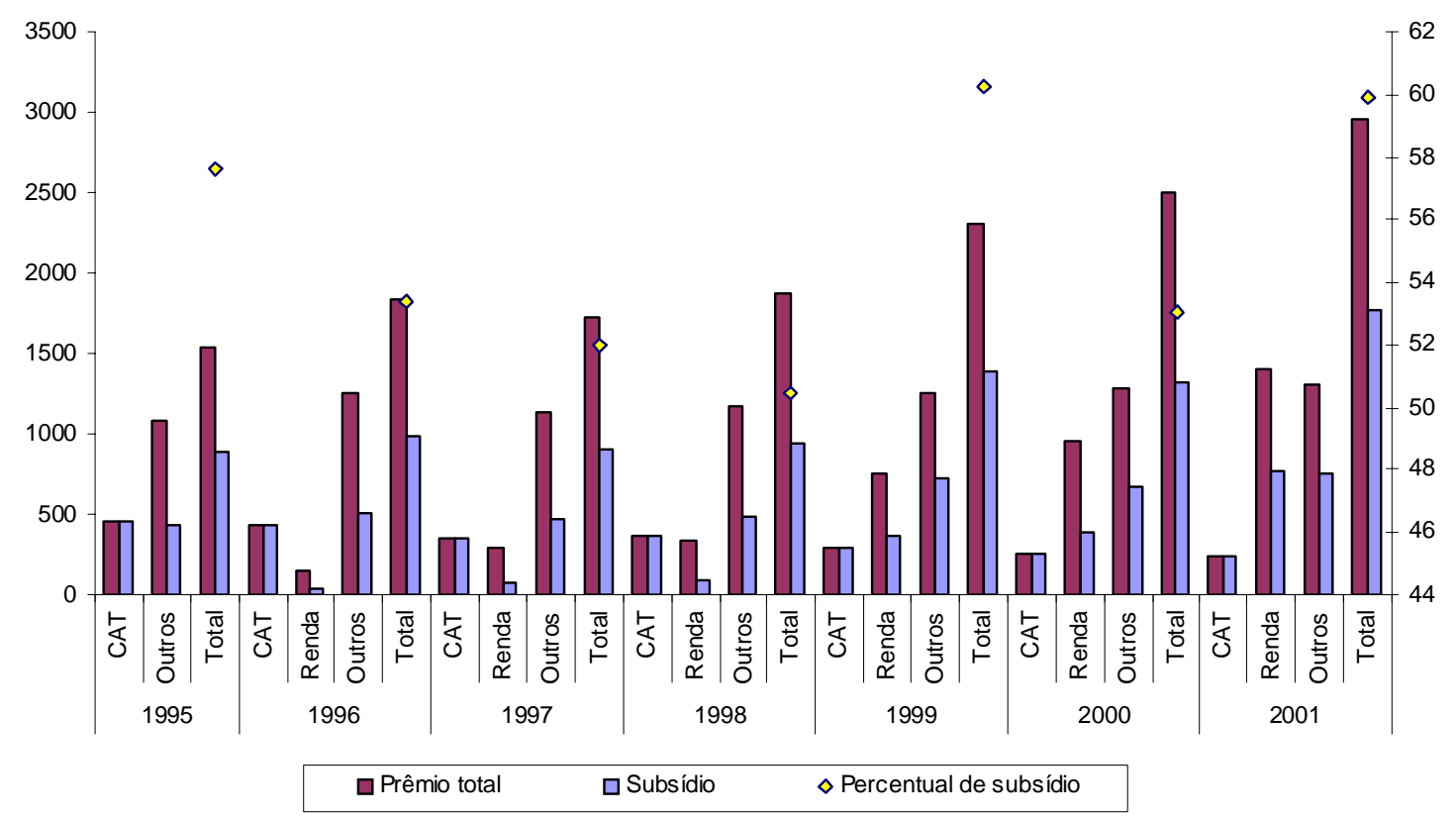

Figura 26 - Prêmio total, subsídio ao prêmio, em milhões de dólares, e percentual de subsídio em relação ao prêmio do seguro MPCI, por tipo de seguro, no período de 1995 a 2001

Fonte: USDA, extraído de Dismukes (2003)

Nesse período, o percentual de subsídio médio ficou em 55\%, atingindo o máximo igual a 60\% em 1999 e 2001. 
O prêmio total arrecadado no seguro CAT apresentou uma redução de, aproximadamente, US\$ 456 milhões em 1995, para US\$ 245 milhões, em 2001, enquanto o prêmio arrecadado com todos os outros tipos de seguro teve um modesto crescimento de $20 \%$ neste mesmo período.

A área segurada aumentou consideravelmente no período de 1981 a 2001. Percebe-se pela figura 27, abaixo, que o salto ocorrido de 1994 para 1995 se deve, principalmente, à introdução do seguro de cobertura mínima, CAT, e sua aquisição por grande parte dos produtores. Da área total segurada em 1995 (aproximadamente 220 milhões de acres) 52\% era coberta pelo CAT.

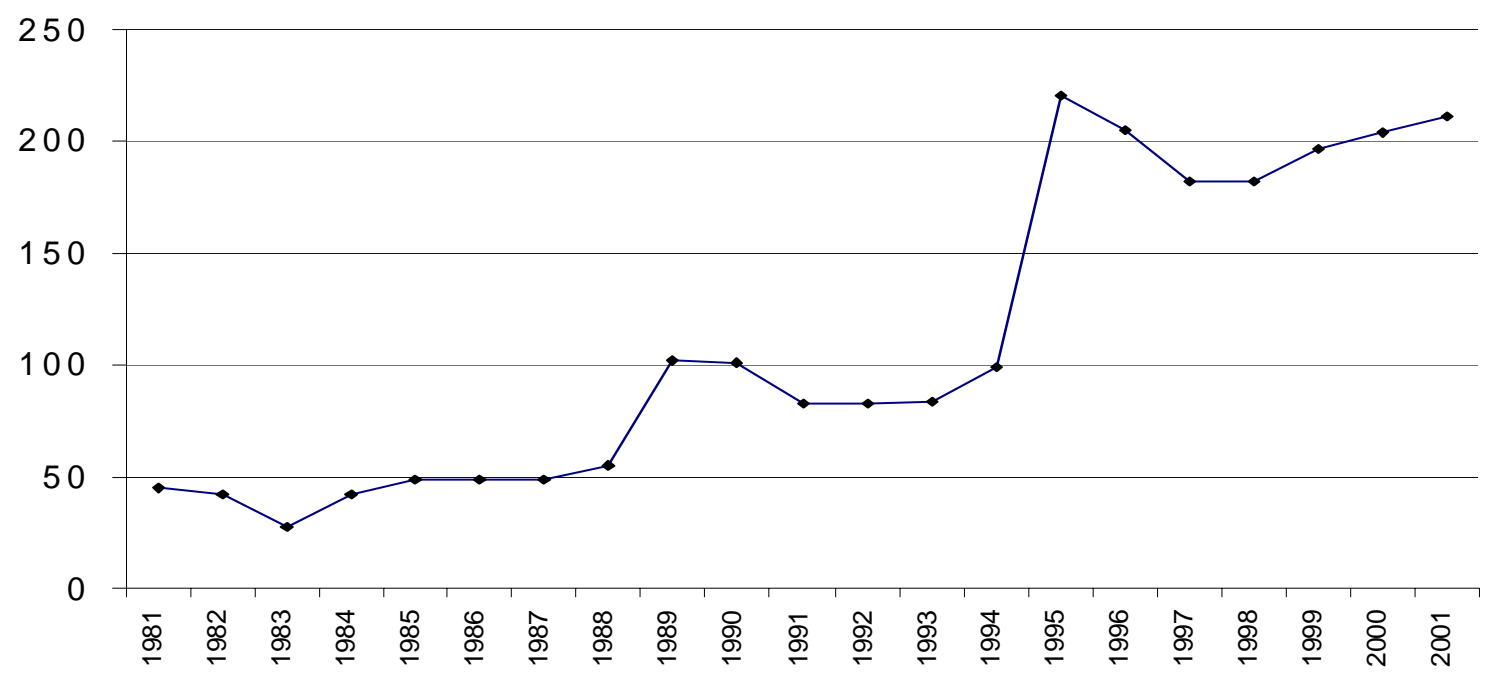

Figura 27 - Área segurada total, em milhões de acres, no período de 1981 a 2001 Fonte: USDA, extraído de Dismukes (2003)

O desconto ao prêmio instituído em 1999, que representou um subsídio adicional reduzindo o custo do seguro da cobertura buy-up em 30\%, resultou em um aumento da aquisição de contratos de seguro pelos produtores, conforme pode ser visto na figura 27, acima. 
Dentre os contratos buy-up, a cobertura de $65 \%$ da produtividade é a mais demandada pelos produtores, apesar da redução de sua participação no período de 1998 a 2001.

O percentual da área segurada passou de pouco mais de 46\% para 26\% enquanto as coberturas mais elevadas $(70 \%, 75 \%, 80 \%$ e $85 \%)$ aumentaram suas participações neste mesmo período.

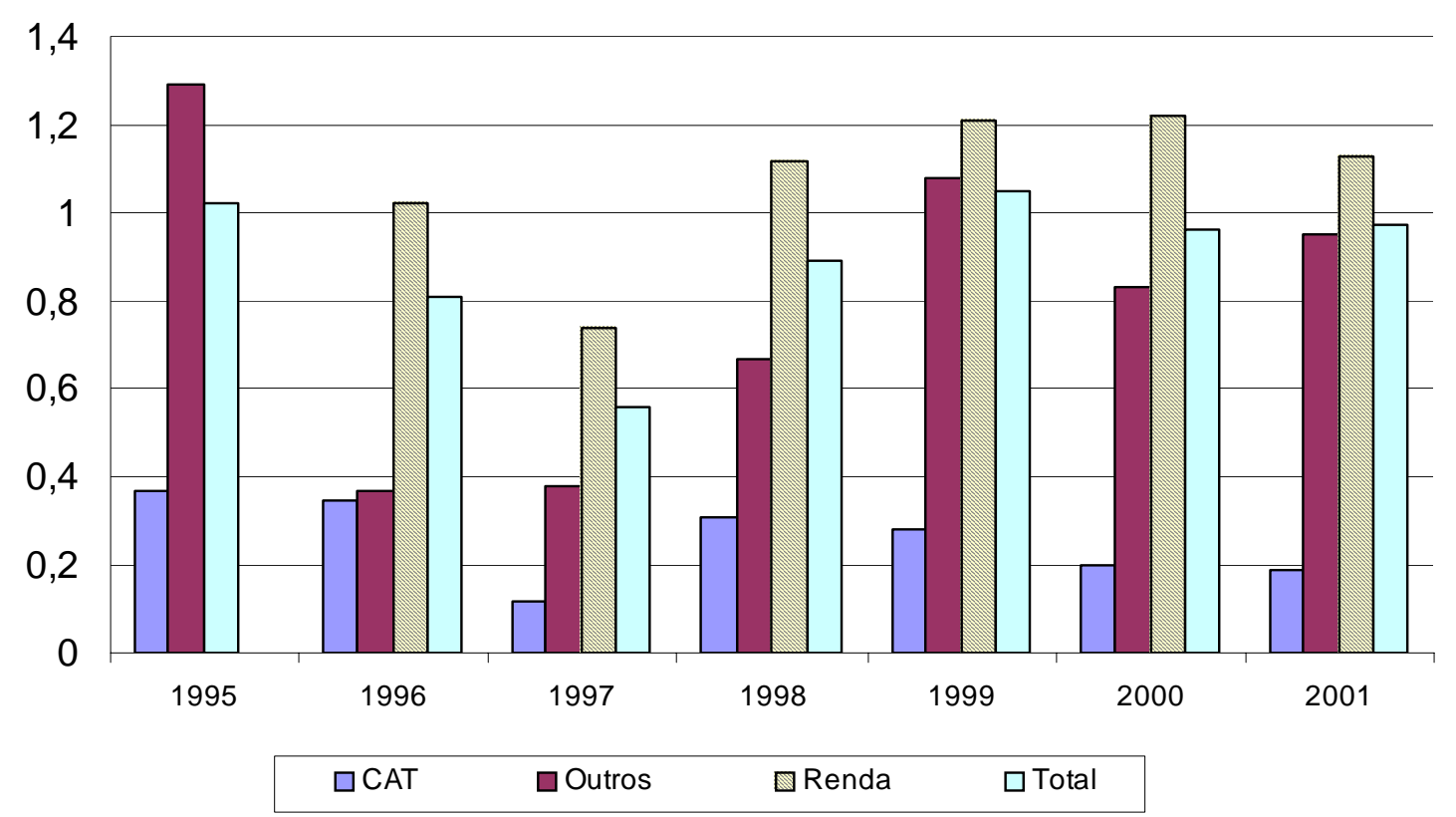

Figura 28 - Índice de sinistralidade, por tipo de seguro, no período de 1995 a 2001 Fonte: USDA, extraído de Dismukes (2003)

O índice de sinistralidade total $^{49}$ apresentou resultados satisfatórios, situando-se em um patamar um pouco acima de um apenas nos anos de 1995 e 1999, de acordo com a figura 28.

\footnotetext{
${ }^{49}$ Relação entre o total pago em indenizações e o total de prêmios arrecadado.
} 
Nos anos de 1995 a 2001 nota-se que os seguros de renda apresentaram sinistralidade acima de um em quase todos os anos, exceto 1997.

O CAT, ao contrário dos seguros de renda, atingiu um bom índice, ficando abaixo de 0,4 em todos os anos deste período. Percebe-se, desta forma, que o seguro agrícola nos Estados Unidos passou por um longo processo de amadurecimento, iniciado com a criação da FCIC, em 1938. Desde então, diversos ajustamentos foram realizados para que o programa apresentasse resultados satisfatórios.

Um ponto importante a ressaltar é a participação e o suporte dado pelo governo. O subsídio ao prêmio, instituído inicialmente em 1980 juntamente com a substituição do programa de pagamentos catastróficos pelo seguro agrícola, proporcionou um aumento da demanda por contratos de seguro MPCI.

Durante a década de 90, novos produtos, desenvolvidos por seguradoras privadas, foram ofertados no mercado e aprovados após análise rigorosa da agência de administração de risco (RMA). Além do subsídio, foi aprovado em fins da década de 90 um certo percentual de desconto ao prêmio para coberturas superiores ao CAT (buy-up).

Além de incentivar o produtor a demandar por seguro agrícola por meio do subsídio ao prêmio, o governo norte-americano ainda subsidia o custo administrativo e operacional das seguradoras ${ }^{50}$ (figura 29). O resseguro é realizado diretamente com o governo, por intermédio do FCIC.

\footnotetext{
${ }^{50}$ A taxa de subsídio sobre o valor do prêmio total para a maioria dos seguros de produtividade e renda é de $24,5 \%$ e de $22,7 \%$ para o seguro GRP.
} 


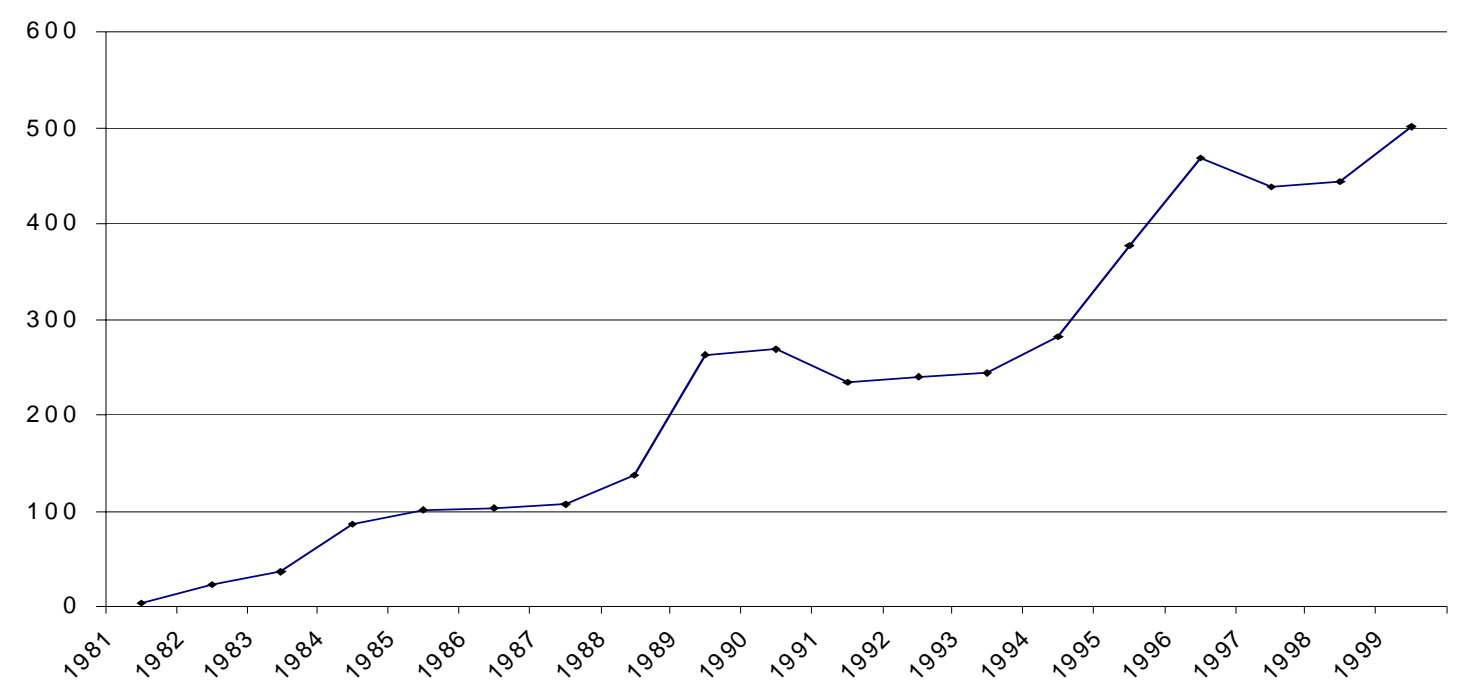

Figura 29 - Montante de subsídio administrativo e operacional resgatado pelas seguradoras, em milhões de dólares, no período de 1981 a 1999

Fonte: USDA, extraído de Dismukes (2003)

\subsection{Seguro agrícola no Brasil}

\subsubsection{Contexto nacional}

No ano de 1948, tramitou no Senado Federal o projeto de lei enviado pelo senador Attilio Vivacqua, que em parte viria a se transformar na Lei $n^{\circ} 2.168$, de 11 de janeiro de 1954. Neste projeto foram estabelecidas as bases para a implantação do seguro agrícola no País.

Além disso, realizou-se um levantamento a respeito das poucas experiências com o seguro rural no País, entre elas, as operações relacionadas à cobertura de riscos de determinados rebanhos e ao seguro de colheita feito pela 
Secretaria de Agricultura do Estado de São Paulo, além de relatar a atuação de outros países, como por exemplo, Estados Unidos, Argentina, Uruguai e França.

Percebe-se que a problemática circunferente ao tema do seguro agrícola é relativamente antiga. O projeto, previamente mencionado, já o destacava como um importante mecanismo de amparo e desenvolvimento da agricultura do País.

\begin{abstract}
“O seguro agro-pecuário...é elemento essencial para a organização e generalização do crédito agrícola especializado, que o Estado deve instituir e desenvolver... Garante e estimula o trabalho e a produção salvaguardando o patrimônio agrícola do país e permitindo estabelecer os fundamentos reais de uma política de garantia dos preços de produtos de subsistência... Cria condições psicológicas de tranqüilidade para o lavrador, que são fatores de estabilidade da família e das instituições em geral, favorecendo, de modo especial, a fixação do homem no campo...” (Luz Filho, 1949, p. 65)
\end{abstract}

A transcrição acima deixava clara, já naquela época, a preocupação de se elaborar um mecanismo de seguro agrícola que pudesse proteger não apenas o produtor, mas as instituições que operassem com este setor. Além disto, como foi bem colocado no trabalho, especial atenção foi voltada ao problema da negligência do produtor em fases importantes da cultura ou cuidados com o rebanho.

Tais problemas exercem forte influência sobre o risco e, conseqüentemente, sobre o cálculo da taxa de prêmio. Neste ponto, nota-se que não era possível a fixação de um prêmio acessível pelas seguradoras, em função do alto risco intrínsico à atividade agrícola, desencorajando a entrada das empresas no mercado de seguro agrícola.

Tendo como base o referido projeto, foram iniciadas pelo Governo Federal, em 1954, a regulamentação e o estabelecimento de normas para o ramo de seguro rural no País. 
A Lei $n^{\circ} 2.168$, de janeiro de 1954, instituiu que o seguro rural destinavase à preservação das colheitas e dos rebanhos contra a eventualidade de risco que lhes são peculiares.

Permitiu que o Instituto de Resseguros do Brasil (IRB) ${ }^{51}$ fizesse os estudos, levantamentos e planejamentos para a instituição do seguro rural em todo o território nacional em colaboração com os serviços técnicos das repartições federais, estaduais, municipais, de autarquias e dos estabelecimentos bancários oficiais de financiamento à agricultura e pecuária, e também, elaborasse as condições das apólices e taxas de prêmios de seguros que, depois de aprovadas pelo Departamento Nacional de Seguros Privados e Capitalização, fossem colocadas em vigor mediante decretos (Brasil, 1954).

Sendo assim, no ano seguinte, foram declaradas em vigor as condições gerais das apólices e as tarifas do seguro pecuário de bovinos, trigo, café, videiras, arroz, algodão herbáceo, pequena lavoura de culturas múltiplas, agrário de colheita e pecuário de eqüídeos, aprovadas pelo Departamento Nacional de Seguros Privados e Capitalização.

Os seguintes decretos vigoraram para os respectivos contratos nos ramos agrícola e pecuário:

1. Seguro pecuário de bovinos criado pelo Decreto $n^{\circ} 37.043$, de 16 de março de 1955, e posteriormente modificado pelo Decreto $n^{\circ}$ 44.872, de 26 de novembro de 1958, que declarou as novas condições da proposta, apólice e a tarifa de seguro pecuário de bovinos. Este seguro garantia o pagamento de uma indenização ao segurado, em caso de morte de animal ocorrida dentro da propriedade e causada diretamente por:

\footnotetext{
${ }^{51}$ Criado a partir do Decreto-Lei no 1.186 , de 3 de abril de 1939, com o objetivo de regular as operações de resseguro, cosseguro e retrocessão no País e desenvolver a atividade seguradora de modo geral. Tal decreto instituiu a obrigatoriedade das operações de resseguro pelas seguradoras por meio do IRB (Brasil, 1939).
} 
i) Acidente (evento externo, súbito, fortuito e involuntário por parte do segurado ou, seus prepostos, causador de lesões físicas que por si só e, independentemente, de qualquer outra causa, tenham como conseqüência direta do animal segurado);

ii) Incêndio, raio, eletrocussão e isolação;

iii) Asfixia por enforcamento ou afogamento;

iv) Mordedura, luta ou ataque de animais, inclusive os casos de envenenamento deles decorrentes;

v) Carbúnculo hermático (verdadeiro), carbúnculo sintomático (manguena), tuberculose, raiva, febre aftose, brucelose, piroplasmose, anaplasmose, pasteurelose bovina, septictemia gangrenosa, actinomicose actinobacilose, emeriose e helmintose;

vi) Parto ou abortamento;

vii) Se a doença ou lesão, provocada pelas causas acima enumeradas, exigir o sacrifício do animal, a companhia só reconhecerá a sua responsabilidade quando o tiver expressamente autorizada ou julgando ele resultar de determinação de autoridade sanitária competente (Brasil, 1955).

2. Seguro agrícola de trigo criado pelo Decreto $\mathrm{n}^{\circ}$ 37.272, de 28 de abril de 1955 e alterado pelo Decreto $\mathrm{n}^{\circ}$ 44.041, de 12 de julho de 1958, declarou as novas condições da proposta, apólice e a tarifa de seguro agrário do trigo. O segurado receberia a indenização correspondente à diferença entre a importância segurada e o valor da colheita, calculado de acordo com o preço previamente indicado, desde que tenha sido comprovada a perda ou diminuição de safra causada diretamente pela incidência de chuvas excessivas, geadas, granizo, secas, ventos fortes e em geral por qualquer fenômeno meteorológico, por incêndio conseqüente de raio ou, ainda, por nuvens de gafanhotos. A região, o tipo de cultura, se mecanizada ou não e o tipo de solo foram as variáveis levadas em conta para a fixação da taxa (Brasil, 1955). 
3. Seguro agrícola de café: Decreto $\mathrm{n}^{\circ}$ 37.449, de 7 de junho de 1955 . A indenização seria efetivada desde que tivessem ocorrido, comprovadamente, danos na plantação de café que tivessem como causa os mesmos fenômenos climáticos citados anteriormente, excluindo as nuvens de gafanhoto. As taxas foram fixadas de acordo com a região e o tipo de cultura, se sombreadas ou não (Brasil, 1955).

4. Videira - Decreto $\mathrm{n}^{\circ}$ 37.600, de 12 de julho de 1955. O segurado seria indenizado caso fosse comprovado danos na plantação causados por incidência de chuvas excessivas, geada, granizo, seca, ventos fortes ou, ainda, por incêndio causado por raio. As tarifas foram fixadas de acordo com a região, utilização, se destinadas à vinificação ou ao consumo de mesa e à cultura, se corretamente manejada ou não (Brasil, 1955).

5. Arroz - Decreto $\mathrm{n}^{\circ}$ 37.847, de 2 de setembro de 1955. O portador do seguro receberia o pagamento de uma indenização, correspondente à diferença entre a importância segurada e o valor da colheita, calculado de acordo com o preço previamente indicado, desde que tivesse ocorrido, comprovadamente, perda ou diminuição de safra causada por fenômenos climáticos. As tarifas variavam de acordo com a região, irrigação e culturas mecanizadas ou não (Brasil, 1955).

6. Algodão herbáceo - Decreto $n^{\circ}$ 37.882, de 13 setembro de 1955. As tarifas foram avaliadas de acordo com a região e tipo de cultura, se mecanizadas, semimecanizadas ou com mecanização alguma. A indenização ao segurado era efetivada pela da cobertura de colheita ou da de danos na plantação, definidas a seguir:

i) Cobertura de colheita: o valor da indenização correspondia à diferença entre a importância segurada e o valor da colheita, calculada de acordo com o preço previamente indicado, desde que tivesse ocorrido, comprovadamente, 
perda ou diminuição de safra, causada diretamente pela incidência de chuvas excessivas, geada, granizo, seca, ventos e em geral, por qualquer fenômeno meteorológico, ou, ainda, por incêndio conseqüente de raio;

ii) Cobertura de danos na plantação: o valor da indenização correspondia ao dano que viesse a ser causado à plantação pela incidência direta de granizo. Nas condições particulares deveria ser mencionada, expressamente, a cobertura garantida na apólice (Brasil, 1955).

7. Pequena lavoura de culturas múltiplas - Decreto $\mathrm{n}^{\circ} 40.810$, de 23 de janeiro de 1957. O documento declarava em vigor as condições gerais da apólice e a tarifa de seguro agrário, de pequena lavoura de culturas múltiplas, e garantia o pagamento de uma indenização máxima ao segurado de Cr\$ 20 mil (R\$ 4.390) ${ }^{52}$, Cr\$ 40 mil (R\$ 8.780) ou Cr\$ 50 mil (R\$ 10.900), desde que tivessem sido registrados, comprovadamente, danos em culturas específicas causados pela incidência direta da geada, granizo, vento forte, raio ou fogo. Além disto, o seguro cobria o pagamento de danos causados pela seca, desde que esta tivesse provocado a morte do objeto segurado. O prêmio relativo a este seguro equivalia a uma percentagem básica sobre o valor da importância segurada, ou seja, 5\%, 4,5\% ou 4\%, conforme as respectivas importâncias seguradas de Cr\$ 20 mil, Cr\$ 40 mil ou Cr\$ 50 mil, menos para as propriedades situadas nos Estados do Ceará, Rio Grande do Norte, Paraíba, Pernambuco, Alagoas, Sergipe e Bahia, para as quais a percentagem básica sofria um acréscimo de $25 \%$ e mais uma percentagem adicional de $10 \%$ da percentagem básica, por hectares ou fração de hectare, excedente de cinco hectares. Haja visto que se o segurado, durante o período de dois anos consecutivos, não tivesse recebido indenizações superiores a $10 \%$ dos prêmios pagos naquele período, teria direito ao desconto de $25 \%$ sobre o prêmio relativo ao período subseqüente (Brasil, 1957).

\footnotetext{
${ }^{52}$ Neste trabalho, todos as quantias monetárias serão deflacionadas para setembro/2004, pelo IGP-DI.
} 
8. Agrário de colheita - Decreto $\mathrm{n}^{\circ}$ 48.946, de 15 de setembro de 1960. Esta apólice efetivava o pagamento da indenização correspondente à diferença entre a importância segurada e o valor da produção alcançada em lavoura, ao preço previamente estipulado, desde que a quebra ou diminuição inevitável da safra decorresse, comprovadamente, da incidência dos seguintes riscos cobertos:

i) Fenômenos meteorológicos (chuvas excessivas, granizo, secas, ventos fortes, vendavais, furacões, ciclones e tornados);

ii) Enchentes, inundações, transbordamentos de cursos d’água, lagoas, lagos, açudes e represas;

iii) Doenças, para as quais não existissem métodos de prevenção e combate, a critério da Secretária de Agricultura do Estado de São Paulo;

iv) Incêndio, raio e suas conseqüências; terremotos, tremores de terra, erupções vulcânicas e quedas de aeronaves;

A taxa mínima aplicada para este seguro era a de 17,50 cruzeiros (Cr\$ 17,50, equivalentes a R\$2) e correspondia à importância segurada de 1 mil cruzeiros (Cr\$ 1 mil , atuais R\$ 105), pelo prazo de um ano, ou o período necessário à produção de uma safra (Brasil, 1960).

9. Pecuário de eqüídeos - Decreto n 52.435, de 2 de setembro de 1963 (Brasil, 1963).

A Lei $n^{\circ}$ 2.168/54 também estabeleceu a criação do Fundo de Estabilidade de Seguro Agrário, com a finalidade de garantir a estabilidade do mercado, permitir o ajustamento gradual das taxas de prêmios, cobrir riscos de catástrofe, bem como de quaisquer outras iniciativas relativas ao aperfeiçoamento e à ampliação do seguro. A administração dos recursos do fundo ficava a cargo do IRB, por meio do seu conselho técnico. 
A captação de recursos para o fundo era proveniente das seguintes fontes:

i) Reembolso pelas retrocessionárias relativo à quantia correspondente aos lucros excedentes do máximo admissível, tecnicamente para essas operações de seguros;

ii) Percentual correspondente a 50\% dos lucros líquidos da União;

iii) Por contribuições e participações nas operações de seguro rural ou quaisquer outras, estabelecidas pelo Conselho Técnico do IRB;

iv) Por dotações orçamentárias anuais, durante os dez primeiros anos;

v) Por $10 \%$ dos lucros líquidos dos estabelecimentos bancários pertencentes à União destinados ao financiamento da agricultura e pecuária;

vi) Pela contribuição dos Estados e municípios.

A mesma lei ainda autoriza o Poder Executivo a organizar uma sociedade de economia mista, com sede e foro na cidade do Rio de Janeiro, com o objetivo de desenvolver progressivamente operações de seguros rurais sob a denominação de Companhia Nacional de Seguro Agrícola (CNSA).

O Decreto $\mathrm{n}^{\circ}$ 35.370, de 12 de abril de 1954, regulamentou as operações de seguro rural no País e conferiu à CNSA a exploração. De acordo com este documento a companhia não poderia reter, em cada risco isolado, responsabilidade superior a $5 \%$ do capital social realizado e reservas patrimoniais.

Entende-se por risco isolado o conjunto de responsabilidades assumidas, num mesmo estabelecimento, agrícola ou pecuário, pertencente a um mesmo proprietário ou sob uma mesma administração, para cada modalidade do seguro rural (Brasil, 1954).

Todas as responsabilidades não assumidas pelas companhias seguradoras ou pela CNSA eram resseguradas no IRB. Se elas não encontrassem colocação no País para o resseguro dessas responsabilidades poderiam, por intermédio do IRB, realizar tal operação no Exterior.

Caso o IRB rejeitasse ou cancelasse tais responsabilidades, era possível ressegurar em outras firmas no País ou na própria CNSA. 
Em 28 de abril de 1954, o Decreto $n^{\circ} 35.409$ aprovou os estatutos da CNSA. O capital inicial de 100 milhões de cruzeiros (Cr\$ 100 milhões) ${ }^{53}$ foi dividido em 100 mil ações ordinárias, no valor de 1 mil cruzeiros (Cr\$ 1 mil ou R\$ 360) cada uma e foram subscritas pela referida lei da seguinte maneira (Brasil, 1954):

i) Tesouro Nacional, 30 mil ações;

ii) Entidades de economia mista, bancária, resseguradoras e às autarquias destinadas ao amparo e fomento da agricultura, 50 mil ações;

iii) Sociedades de seguro e capitalização, nacionais ou estrangeiras, em funcionamento no País, 20 mil ações.

O Decreto estabeleceu que a companhia era obrigada a constituir, em garantia de suas operações, as seguintes reservas técnicas:

i) Riscos não expirados;

ii) Sinistros a liquidar;

iii) Contingência.

Além das reservas acima, era obrigada também a manter os seguintes fundos:

i) Garantia de retrocessões;

ii) Estabilização;

iii) Oscilação de títulos.

Especificamente, o objetivo do Fundo de Estabilização era garantir a estabilidade das operações da companhia, principalmente na parte referente às suas retenções próprias, ajuste gradual das tarifas de prêmios e atender aos casos de catástrofe ou de insuficiência das demais reservas. O fundo foi constituído:

\footnotetext{
${ }^{53}$ Aproximadamente R\$ 36 milhões.
} 
i) Por $10 \%$ dos lucros da companhia;

ii) Pelos dividendos referentes às ações do Tesouro Nacional;

iii) Orçamento da União e outras contribuições que venham a ser estabelecidas por lei ou por acordos com a União, Estados, Municípios ou quaisquer entidades;

iv) Recursos destinados pelos estatutos ou votados pela Assembléia Geral.

A CNSA estava subdividida em cinco filiais, que atuavam no Centro-Sul do País.

i) Filial metropolitana: atuava no Estado do Rio de Janeiro, sul do Espírito Santo, Zona da Mata e sul de Minas Gerais até a Capital, resultando em um total de 200 municípios;

ii) Filial de Porto Alegre: responsável pelo Estado do Rio Grande do Sul, além de 14 municípios de Santa Catarina, em um total de 128 municípios;

iii) Filial de Curitiba: abrangia 150 municípios no Estado do Paraná e 53 de Santa Catarina;

iv) Filial de São Paulo: cobria 142 municípios de São Paulo e 58 de Minas Gerais;

v) Filial de Uberaba: abrangendo 120 municípios de Minas Gerais e 18 de Goiás.

A CNSA oferecia, basicamente, dois tipos de seguros agrícolas: o de colheitas mínimas, aplicada ao algodão herbáceo, trigo e ao arroz, e o seguro de danos nas plantações, que cobria a cultura do café e videira.

Esse último era baseado no valor convencional do pé e, a indenização, calculada pelo número de pés existentes. A companhia também oferecia seguro pecuário, cobrindo riscos de rebanhos bovinos.

A companhia realizou operações durante 13 anos, interrompendo suas atividades em função do Decreto-Lei n 73, de 21 de novembro de 1966, por meio do artigo $\mathrm{n}^{\circ}$ 141, que dissolvia a CNSA (Brasil, 1966). 
O insucesso da companhia deveu-se a alguns fatores destacados na literatura. A excessiva centralização da administração na cidade do Rio de Janeiro, por exemplo, foi uma das principais causas para o fracasso do empreendimento (Paim, 1960).

Mesmo com as filiais espalhadas em boa parte do Centro-Sul do País, a administração central monopolizava grande parte das decisões. Medidas de extrema importância para a elaboração de um programa de seguro agrícola não foram levadas em consideração, tais como a composição de planos regionais, de acordo com as peculiaridades do meio ambiente, limitação da área a ser segurada e seleção dos produtores. Sem estas condições não há como, de modo razoável, estabelecer prêmios acessíveis aos produtores e, com isto, manter o contrato sustentável. Em vez disto, a companhia adotou planos que se aplicavam de maneira indistintas em todo o País.

Nesse ponto, destacam-se os comentários de Luz Filho (1949, p. 72), que em pouco mais de uma década e meia antes da aprovação do Decreto-Lei $n^{\circ} 73$ já apontava tais problemas:

“... a criação de uma entidade autárquica... importaria em criar mais um organismo governamental, provavelmente burocrático e absorvente, em geral, acessível às nefastas influências partidárias (...) Será sempre de temer-se uma organização centralizadora, que não atenda as diferenciações geo-econômicas do país, com a sensibilidade e precisão exigidas pelas condições e circunstâncias locais peculiares ao seguro rural.”

A CNSA, pelo fato de ser caracterizada como uma sociedade de economia mista, regulamentada pela Lei das Sociedades Anônimas, deveria se sustentar com os próprios recursos, não onerando os orçamentos públicos em caso de incorreta administração. 
Além disso, as dotações provenientes dos Estados e municípios destinadas a reforçar as reservas da CNSA poderiam ser mais eficientemente utilizadas em outros programas públicos.

Outra crítica relevante, apontada por Paim (1960), se refere à maneira como o capital social foi investido inicialmente. Aproximadamente 30\% dele foi utilizado na compra de imóveis no Rio de Janeiro e em São Paulo. Outros 20\% em financiamentos de máquinas e implementos e, o restante, destinado à implantação do seguro rural no País.

Os administradores, sediados em um local alheio àquele em que os seguros são desenvolvidos e expostos aos interesses políticos-partidários que interferem na tomada de decisão das sociedades de economia mista, se encontravam em uma situação incômoda frente às suas obrigações

Uma análise mais detalhada da companhia, nos seus 13 anos de existência, é feita por Santos (1967), que dividiu a análise em três fases distintas.

No primeiro período, que vai da sua criação, em 1954, até 1958, foi caracterizada pelo pequeno volume de negócios como conseqüência da baixa receptividade do produto por parte dos agricultores. Além disto, ressalta-se o problema da anti-seleção ou seleção adversa e o elevado custo administrativo.

Nos dois anos seguintes, a companhia atrelou o financiamento realizado pela carteira de crédito agrícola e industrial do Banco do Brasil com o seguro da lavoura tritícola. Caso o produtor segurasse a lavoura, este ficava dispensado, já na safra 59/60, de grande parte das exigências e formalidades obrigatórias para a obtenção do financiamento. Cerca de 3.200 propriedades realizaram o seguro.

Nesse período, os prêmios arrecadados com o seguro da lavoura tritícola e outras modalidades de seguro não cobriram as indenizações pagas. De acordo com o autor: 
" Sem contar com a infra-estrutura adequada a aceitação de tal volume de negócios cuja administração transferiu a terceiros, e sem a compensação favorável do resultado das operações em outras modalidades de seguro, a Companhia presenciou, neste período, a liquidação de todas as suas reservas, chegando praticamente à insolvência" (Santos, 1967, p.21).

O terceiro período, que se estende de 1961 a 1966, foi apenas um prolongamento da difícil situação em que se encontrava a companhia até então.

O Decreto $\mathrm{n}^{\circ}$ 1.224, de 22 de junho de 1962, dispunha sobre o seguro agrícola da lavoura e rebanhos financiados pelos bancos da União ou de economia mista em que ela fosse acionista. $\mathrm{O}$ artigo $1^{\circ}$ deste decreto obrigava que estes bancos atrelassem a concessão dos financiamentos à lavoura e a pecuária à efetivação do seguro agrícola (Brasil, 1962).

Sendo assim, utilizando-se deste instrumento legal, tentou-se incentivar o aumento do volume de negócios suficiente para estabilizar a situação da empresa, além de garantir o investimento necessário à reforma e a ampliação dos serviços.

Para complementar o decreto anterior, a Lei $\mathrm{n}^{\circ} 4.430$, de 20 de outubro de 1964, regulamentada pelo Decreto $n^{\circ}$ 55.801, de 26 de fevereiro de 1965, alterava a constituição da CNSA e concedia recursos suplementares (Brasil, 1964). A seguir, serão destacadas as principais medidas contidas na lei:

i) O capital da CNSA foi elevado para 1 bilhão de cruzeiros (Cr\$ 1 bilhão, pouco mais de R\$ 14 milhões);

ii) O Fundo de Estabilidade do Seguro Agrário foi complementado por dotações orçamentárias anuais, durante os dez anos seguintes, até atingir quantia anual não inferior a 100 milhões de cruzeiros (Cr\$ 100 milhões) ou o necessário para cobrir o déficit operacional anterior;

iii) O Fundo de Estabilização foi integralizado pela quantia de 1 bilhão de cruzeiros (Cr\$ 1 bilhão), por meio do crédito especial aberto pela União; 
iv) Os estabelecimentos bancários da União, ou aqueles em que esta fosse a principal acionista, que concediam financiamentos à agricultura e à pecuária, deveriam promover, concomitante e automaticamente, os contratos de financiamento e de seguro agrícola.

Este decreto instituiu que o seguro agrícola se destinava à cobertura contra riscos peculiares e conferia direitos ${ }^{54}$ de exploração das suas operações (Brasil, 1965).

Coube à CNSA organizar e dirigir o Consórcio de Cosseguro Agrícola, com a co-participação da própria companhia e das sociedades cooperativas de seguro agrícola, para a distribuição das responsabilidades assumidas. Além disso, a empresa não poderia reter, em cada risco isolado, responsabilidade superior a $5 \%$ da soma do capital social realizado com as reservas patrimoniais.

A CNSA teve como objetivo explorar e desenvolver, progressivamente, as operações de seguro rural, tendo em vista a conveniência do País, a análise atuarial do contrato e as suas possibilidades econômico-financeiras. Além disto, ela deveria estabelecer as condições das apólices e respectivas tarifas de prêmio de seguro agrícola aprovadas pelo Departamento Nacional de Seguros Privados e Capitalização, que seriam postas em vigor mediante portaria do Ministério da Agricultura.

Todas as responsabilidades que não fossem retidas pelas companhias de seguro, pelo Consórcio de Cosseguro Agrícola ou pela CNSA, seriam resseguradas no Instituto de Resseguros do Brasil.

Apesar de esse decreto ter atribuído à CNSA uma importante função na organização e desenvolvimento do seguro agrícola em âmbito nacional, ela não conseguiu demonstrar bom desempenho. As principais causas para o fracasso da CNSA foram (Formiga, 1983):

i) Concentração dos riscos em um pequeno volume de negócios;

\footnotetext{
${ }^{54}$ Estes direitos cabiam à CNSA, às companhias sujeitas ao Decreto-Lei $n^{\circ} 2.063$, de 7 de março de 1940 , e às cooperativas de seguro agrícola.
} 
ii) A obrigatoriedade do seguro;

iii) Insuficiência de recursos operacionais;

iv) Inadequabilidade dos planos adotados;

v) Não-permissão de operar com outros seguros mais rentáveis, contribuindo assim para o equilíbrio de sua carteira;

vi) Falta de apoio e colaboração das instituições governamentais e financeiras.

Desse modo, devido à incapacidade de a CNSA operar com superávits operacionais, o Poder Público ${ }^{55}$ resolveu dissolvê-la (Brasil, 1966).

Além disso, o referido decreto-lei, ainda:

1. Constituiu o Fundo de Estabilidade do Seguro Rural (FESR), com a finalidade de garantir a estabilidade das operações e a cobertura suplementar dos riscos catastróficos, de acordo com o artigo 16;

2. Atrelou o seguro rural, concomitante e automaticamente, por meio do artigo 18, ao financiamento das instituições financeiras ligadas ao Sistema Nacional de Crédito Rural (SNCR) para as atividades relacionadas à agricultura e à pecuária. Além disto, o inciso $1^{\circ}$ estabeleceu que o seguro deveria obedecer às normas e limites fixados pelo CNSP, sendo compulsório o financiamento dos prêmios pelas instituições financeiras. Já o inciso $2^{\circ}$ considerava que o seguro obrigatório ficaria limitado ao valor do financiamento, o que tornaria a instituição financiadora beneficiária;

3. Determinou que as operações de seguro rural ficariam isentas de qualquer tipo de tributação federal;

\footnotetext{
${ }^{55}$ Por meio do Decreto-Lei n ${ }^{\circ} 73 / 66$.
} 
4. Instituiu o Sistema Nacional de Seguros Privados, constituído pelo Conselho Nacional de Seguros Privados (CNSP), Superintendência de Seguros Privados (Susep), Instituto de Resseguros do Brasil (IRB), sociedades autorizadas a operarem em seguros privados e corretores habilitados.

O CNSP, de acordo com o seu artigo 32, teria as seguintes atribuições:

- Fixar as diretrizes e normas gerais da política de seguros privados e das operações de resseguro;

- Regular a constituição, organização, funcionamento e fiscalização dos que exercerem atividades subordinadas ao referido decreto-lei, bem como a aplicação das penalidades previstas;

- Fixar as características gerais dos contratos de seguros, além dos índices, tarifas, investimentos e outras relações patrimoniais a serem observadas pelas sociedades seguradoras;

- Fixar normas gerais de contabilidade e estatística a serem observadas pelas sociedades seguradoras;

- Delimitar o capital do IRB e das sociedades seguradoras;

- Disciplinar as operações de cosseguro, nas hipóteses em que o IRB não aceite resseguro do risco ou quando se tornar conveniente promover melhor distribuição direta dos negócios pelo mercado;

À Susep, de acordo com o artigo 36, caberia:

- Baixar instruções e expedir circulares relativas à regulamentação das operações de seguro, de acordo com as diretrizes do CNSP;

- Fixar condições de apólices, planos de operações e tarifas a serem utilizadas obrigatoriamente pelo mercado segurador nacional;

- Aprovar os limites de operações das sociedades seguradoras, de conformidade com o critério fixado pelo CNSP; 
- Examinar e aprovar as condições de coberturas especiais, bem como fixas as taxas aplicáveis;

- Autorizar a movimentação e liberação dos bens e valores obrigatoriamente inscritos em garantia das reservas técnicas e do capital vinculado;

- Fiscalizar a execução das normas gerais de contabilidade e estatística fixadas pelo CNSP para as sociedades seguradoras;

- Fiscalizar as operações das sociedades seguradoras, inclusive o exato cumprimento deste decreto-lei, de outras leis pertinentes, disposições regulamentares em geral, resoluções do CNSP e aplicar as penalidades cabíveis;

- Proceder à liquidação das sociedades seguradoras que tiverem cassada a autorização para funcionar no País;

- Organizar seus serviços, elaborar e executar seu orçamento.

Já ao IRB, o artigo 44 designava as funções de:

- Elaborar e expedir normas reguladoras de cosseguro, resseguro e retrocessão;

- Aceitar o resseguro obrigatório e facultativo, do País ou do Exterior, além de reter o resseguro aceito, na totalidade ou em parte;

- Colocar no Exterior o seguro que não fosse de interesse do País ou que nele não encontrasse cobertura;

- Penalizar as sociedades seguradoras por infrações cometidas na qualidade de cosseguradoras, resseguradas ou retrocessionárias;

- Organizar e administrar consórcios, recebendo cessão integral de seguros;

- Proceder à liquidação de sinistros, de conformidade com os critérios traçados pelas normas de cada ramo de seguro;

- Distribuir pelas sociedades a parte dos resseguros que não retiver e colocar no Exterior as responsabilidades excedentes da capacidade do mercado segurador interno ou aquelas cuja cobertura fora do País convenha aos interesses nacionais;

- Representar as retrocessionárias nas liquidações de sinistros amigáveis ou judiciais; 
- Publicar revistas especializadas e toda capacidade do mercado nacional de seguros;

- Promover o desenvolvimento das operações de seguro, dentre outras atividades.

As sociedades seguradoras autorizadas a operarem em seguros privados (artigo 88) ficariam obrigadas a obedecerem às normas e instruções da Susep e do IRB sobre operações de seguro, cosseguro, resseguro e retrocessão, bem como fornecer dados e informações atinentes a quaisquer aspectos de suas atividades.

$\mathrm{O}$ artigo 122 do referido decreto determinou, ainda, que corretores de seguros, pessoas físicas ou jurídicas, habilitados, seriam os intermediários legalmente autorizados a angariarem e promoverem contratos de seguro entre as sociedades seguradoras e as pessoas físicas ou jurídicas de direito privado.

Recentemente, o Governo Federal aprovou a Lei $\mathrm{n}^{0}$ 10.823, de 19 de dezembro de 2003, que concede subvenção em parte do prêmio pago pelo produtor. De acordo com o artigo $2^{\circ}$, a subvenção será de acordo com a modalidade do seguro, tipo de cultura e espécie animal, categoria em que se enquadram os produtores e as regiões de produção, de modo que aquelas consideradas redutoras de risco ou indutoras de tecnologia são tidas como prioritárias.

Tal medida veio a incentivar o mercado segurador em seu ramo mais deficitário, dando mais incentivo ao produtor agrícola em demandar pelo seguro. Este movimento tende a impulsionar a entrada de novas seguradoras privadas no mercado.

Além disto, tem ocorrido uma maior diversificação dos produtos oferecidos pelas empresas observado nos últimos. Exemplos são os seguros de produção individual e os baseados em índices regionais de produtividade.

\subsubsection{Programa de Garantia da Atividade Agropecuária (Proagro)}

Passados sete anos da dissolução da CNSA, o Governo Federal tomou uma iniciativa que assegurava a capacidade do sistema financeiro caso o produtor 
ficasse inadimplente junto ao agente financeiro em decorrência de um evento que causasse prejuízos à sua atividade. A medida, criada para oferecer ao setor produtivo segurança quanto ao permanente fornecimento de crédito, ficou conhecida como Programa de Garantia da Atividade Agropecuária (Proagro).

Historicamente, o Proagro pode ser dividido em duas fases distintas: o “velho”, que cobre o período entre 1975, início de sua operacionalização, até 1991, e o “novo”, que se estende de 1991 em diante.

\title{
2.2.1.1.1 Proagro "velho"
}

O Proagro, criado pela Lei ${ }^{0}$ 5969, de 11 de dezembro de $1973^{56}$, iniciou suas operações em janeiro de 1975 e tinha como objetivos:

\begin{abstract}
“exonerar o produtor rural de obrigações financeiras relativas às operações de crédito rural de custeio e/ou investimento e para cujo cumprimento venha a ficar impedido pela ocorrência extraordinária de fenômenos naturais, pragas e doenças que prejudiquem rebanhos e plantações, de modo a comprometer total ou parcialmente os seus rendimentos” (Ministério da Agricultura Pecuária e Abastecimento, Brasil, 2003 ${ }^{57}$ ).
\end{abstract}

Desta forma, percebe-se que o Proagro surge como um seguro de crédito, limitado apenas para aqueles que utilizam o crédito rural. Isto permitiu que o mercado de seguros continuasse a oferecer coberturas nas demais modalidades do seguro rural. Ele

\footnotetext{
${ }^{56}$ Sua normatização e regulamentação foram feitas pela Resolução nº 301, de 9 de outubro de 1974, e pela Circular $n^{\circ}$ 241, de 23 de dezembro de 1974, do Banco Central. Posteriormente, ele foi incluído no Manual de Crédito Rural.

${ }^{57}$ BRASIL. Ministério da Agricultura Pecuária e Abastecimento. Proagro. http://masrv60.agricultura.gov .br/html/ leis.asp?lei=5969 (29 jul. 2003)
} 
também funcionava como um incentivo à modernização do setor agropecuário por não cobrir o custeio singular ${ }^{58}$.

A administração ficava a cargo do Banco Central, que tinha como principais atributos a formulação e o aperfeiçoamento das normas, a fiscalização, a movimentação dos recursos e a análise dos pedidos de reconsideração.

As instituições financeiras autorizadas a operar crédito rural intermediavam a transação entre o Banco Central e os mutuários, representados pelos produtores ou cooperativas ${ }^{59}$.

Os órgãos de fiscalização, que estavam filiados à Empresa Brasileira de Assistência Técnica e Extensão Rural (Embrater), eram responsáveis pela realização dos laudos de inspeção de danos.

As receitas do programa eram provenientes de três fontes distintas: adicional de 1\%, pago pelo mutuário sobre o saldo devedor do financiamento, e multas pagas pelos agentes financeiros; receitas provenientes do Conselho Monetário Nacional e, por último, as dotações monetárias do Orçamento da União, para cobertura de déficits que eventualmente viessem a ocorrer.

Durante os primeiros anos de operação, algumas modificações ocorreram nos limites de cobertura e no adicional ${ }^{60}$. Em virtude da Resolução ${ }^{\circ} 548$, de 30 de maio de 1979, os juros devidos também passaram a ser cobertos ${ }^{61}$.

Ainda neste mesmo ano, a Resolução n 572 , de 24 de outubro de 1979, modificou o limite de cobertura para $100 \%$ do saldo devedor do principal e incluiu a parcela de recursos próprios, caso o produtor a tivesse incluído no contrato.

\footnotetext{
${ }^{58}$ Aquele cujo montante destinado à aquisição de insumos modernos não atingisse $15 \%$ do valor total do custeio agrícola no momento do financiamento.

${ }^{59}$ Desde que os financiamentos fossem repassados aos cooperados.

${ }^{60}$ Inicialmente, o limite de cobertura foi fixado em $80 \%$ do saldo do principal da dívida, apurado na data do evento, deduzidas as receitas decorrentes da atividade.

${ }^{61}$ No caso de perda total ou parcial, mediante recolhimento da receita.
} 
Em junho de 1980, o limite voltou ao patamar de 80\% do valor básico de custeio (VBC) ${ }^{62}$, sendo novamente modificado, no mesmo ano, reduzindo-se para $70 \%$ do VBC.

Do início do programa até outubro de 1979, não houve alteração do adicional. Posteriormente a esta data, o adicional incidia sobre o valor nominal do financiamento, mais o montante dos recursos próprios. Em dezembro de 1980, os adicionais tornaram-se progressivos, variados e vinculados ao limite de cobertura. ${ }^{63}$

Quanto à forma de adesão ao programa, era obrigatória para os agentes financeiros que operavam com crédito rural. Para os mutuários foi, inicialmente, facultativa, tornando-se obrigatória em função da Resolução nº 548/79, nas operações de custeio agrícola ou pecuário, permanecendo facultativa no caso do crédito de investimento.

De acordo com Figueiredo (1993), o Proagro teve praticamente as mesmas coberturas que o seguro rural, diferindo em alguns aspectos:

i) O Proagro não dispõe de um fundo específico para garantir a estabilidade de suas operações no caso de ocorrência de um evento catastrófico, dependendo totalmente do repasse de recursos do Poder Público, conforme regulamentado;

ii) O seguro agrícola, no caso de sinistro total ou parcial, indeniza o segurado imediatamente, enquanto o Proagro, devido à sistemática de operacionalização, que exige a intermediação do órgão de assistência técnica e do agente financeiro, o faz somente após a colheita;

iii) No Proagro o beneficiado será indenizado somente quando o valor remanescente da colheita não for suficiente para cobrir o saldo devedor, enquanto, o seguro agrícola, indeniza efetivamente a redução da produção ocorrida na lavoura;

\footnotetext{
${ }^{62}$ Representa a composição dos custos diretos do empreendimento agrícola, tais como mão-de-obra para aração, gradeação, adubação, plantio, irrigação, tratos culturais, gastos com insumos, aquisição de sementes e mudas, corretivos, fertilizantes e defensivos. O VBC também é utilizado como base para cálculo do valor do financiamento concedido pelas instituições financeiras e seu valor fixado pela Comissão de Financiamento da Produção, órgão vinculado ao Ministério da Agricultura.

${ }^{63}$ Para o trigo, por exemplo, o adicional passaria de $1 \%$ para $3 \%$.
} 
iv) As taxas do Proagro não são formuladas levando-se em conta metodologias atuariais;

v) Ainda, se o VBC não cobrir os custos efetivamente envolvidos na produção o programa não cobrirá o risco resultante do produtor.

Até 1988 as dívidas do programa eram quitadas pelo Banco Central, que era ressarcido pelo Tesouro Nacional no fim de cada exercício financeiro. Posteriormente, os adicionais recolhidos eram, então, revertidos à conta do Tesouro.

Mas, com a aprovação do artigo 164 da Constituição Federal, o Banco Central ficou impedido de adiantar recursos ao Tesouro. Com isto, em 1989, o Banco Central parou de efetuar os ressarcimentos das indenizações determinadas pelos agentes do programa, gerando uma crise profunda.

A partir de então, as despesas passaram a ser cobertas exclusivamente com os adicionais recebidos, demonstrando serem insuficientes para saldar todas as dívidas do programa. Em vista disto, o Banco do Brasil, em junho de 1989, suspendeu o recolhimento dos adicionais, com o objetivo de reduzir as dívidas contraídas em anos anteriores, dado que houve paralisação dos ressarcimentos por parte do Tesouro.

Em agosto de 1990, o Banco do Brasil suspendeu as indenizações aos beneficiados. Diante deste fato, foi instituído, pela Portaria Interministerial n ${ }^{\circ}$ 479, de 15 de agosto de 1990, um grupo de trabalho com o objetivo de realizar uma profunda avaliação no Proagro e propor medidas que viabilizassem o seguro rural de acordo com o Decreto-Lei 73/66 (Seguro ... ,1991).

Em novembro de 1991, o grupo encerrou suas atividades e concluiu que:

i) A administração do Proagro deveria passar para o IRB, que contaria com a colaboração de uma Comissão Consultiva de Seguro Agrícola, constituída por representantes de diversos setores do agronegócio brasileiro;

ii) No prazo de três anos, o Proagro deixaria de atuar em algumas regiões e para algumas culturas, sendo substituído pelas seguradoras; 
iii) O Fundo de Estabilidade do Seguro Rural (FESR) passaria a denominar-se Fundo de Estabilidade do Seguro Agrícola (Fesa), administrado pelo IRB, que garantiria a estabilidade das operações e daria cobertura de riscos catastróficos;

iv) A receita do Fesa seria proveniente de dotações da União e dos Estados;

v) O seguro seria de caráter obrigatório para o crédito rural de custeio e investimento e facultativo em lavouras conduzidas com capital próprio, vinculado ou não ao financiamento.

No ano de 1991, para iniciar uma tentativa de recuperação do Proagro, o governo brasileiro liberou recursos para saldar metade das dívidas junto aos produtores, no equivalente a pouco mais de 290 bilhões de cruzeiros (equivalente a cerca de R \$ 1,6 bilhões). Até então, a estrutura organizacional do Proagro podia ser descrita, de acordo com o organograma representado pela figura 30: 


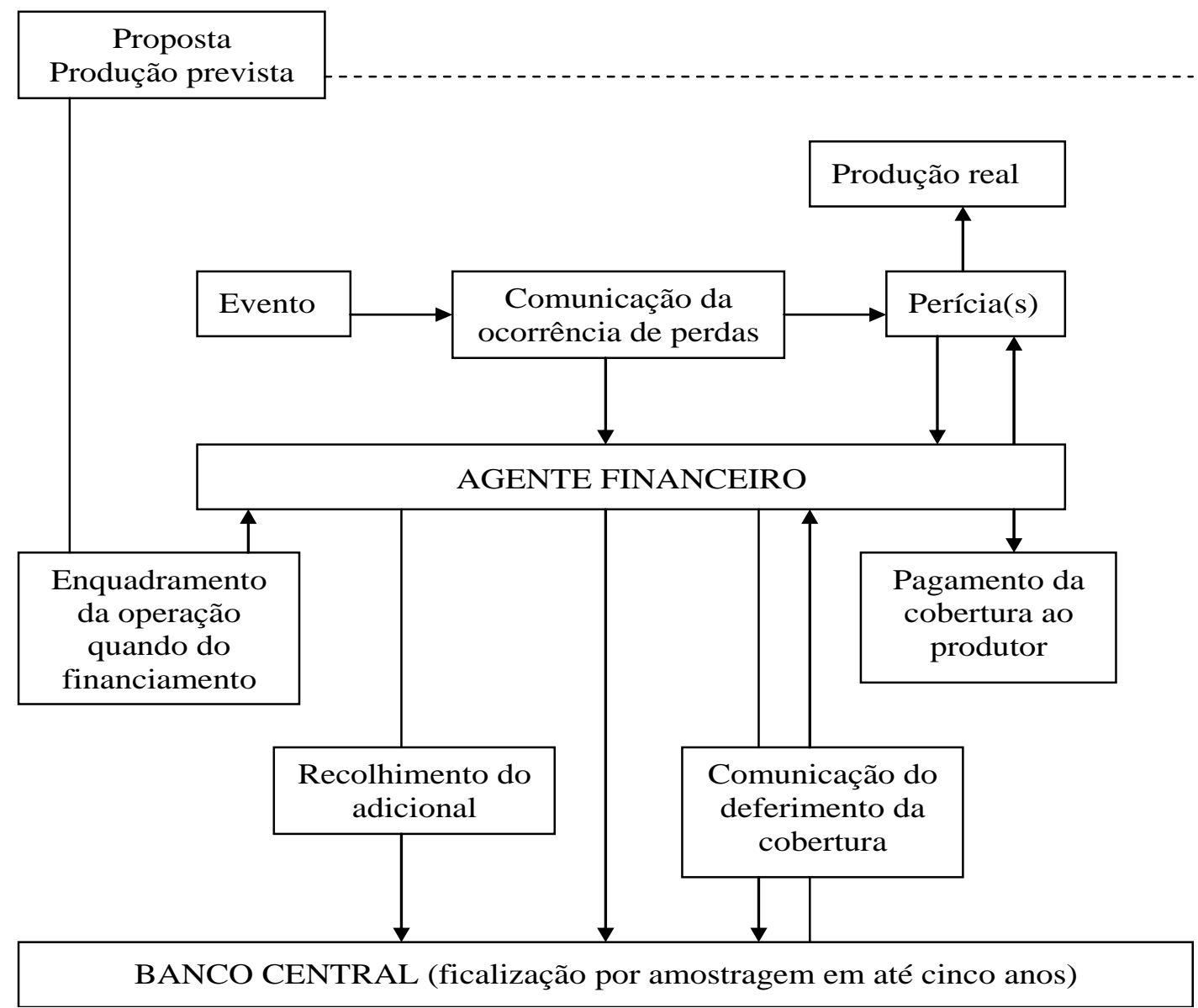

Figura 30 - Organograma representativo da estrutura de funcionamento do Proagro Fonte: Rosseti (2001)

Desde o início de suas atividades, até meados de 1993, o programa acumulou vultosos déficits da ordem de US\$ 1,6 bilhões. Diversos problemas acabaram por desacreditá-lo, embora tenha sido considerado de grande importância para a agricultura brasileira. Dentre as dificuldades destacam-se os atrasos e o não-pagamento dos débitos pendentes, as deficiências técnico-operacionais e a ocorrência de fraudes.

Segundo Gemignani (1999), os fraudadores compunham uma categoria especial de produtores denominados “agroestelionatários” ou “plantadores de Proagro”. 
Os resultados nos primeiros cinco anos podem ser considerados desastrosos (figura 31). Os índices de sinistralidade foram de 84,8 (1975), 8,2 (1976), 10,1 (1977), 9,3 (1978) e 16,5 (1979).

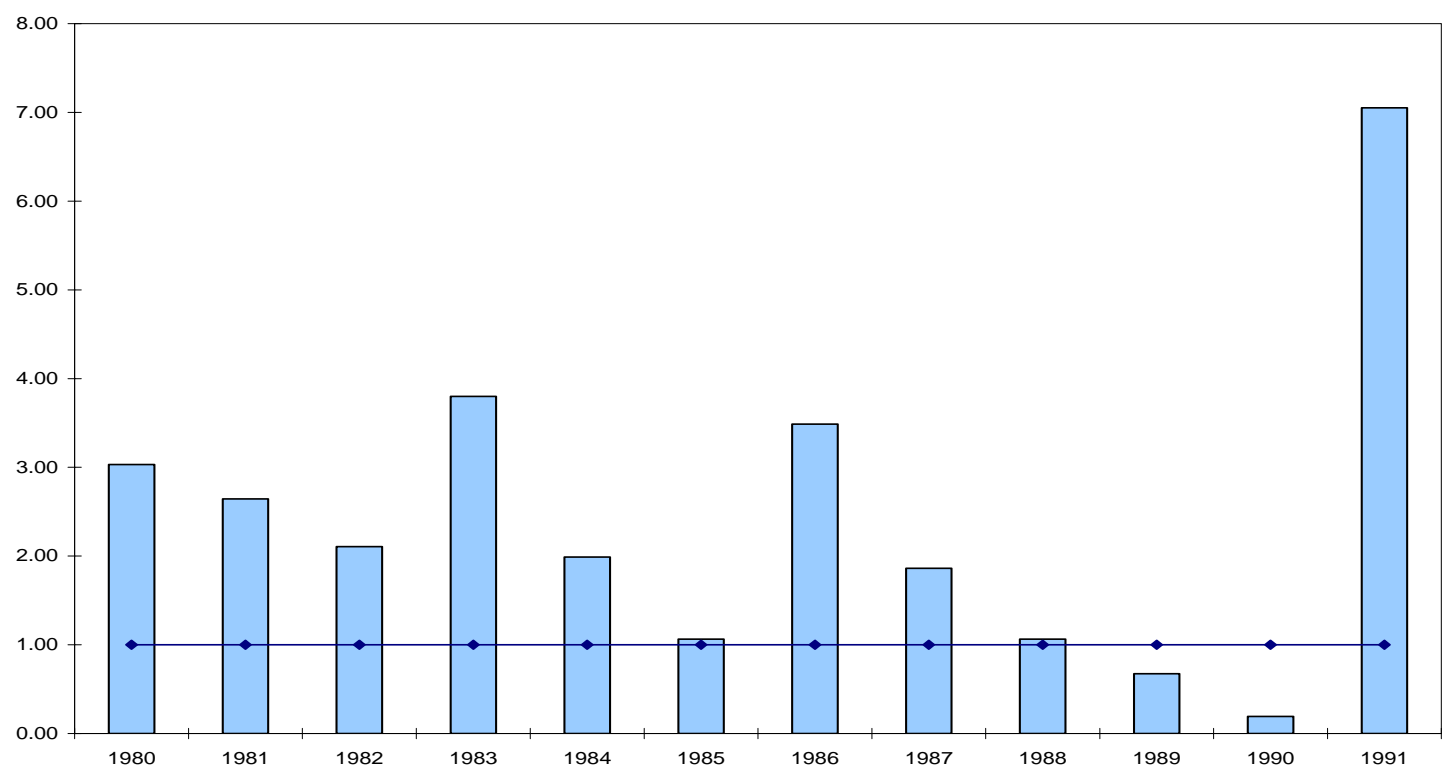

Figura 31 - Índice de sinistralidade do Proagro no período de 1980 a $1991^{64}$ Fonte: Banco Central (2003) ${ }^{65}$

\subsection{Proagro "novo"}

No ano de 1991 foi promulgada a Lei Agrícola $^{66}$, regulamentada pelo Decreto n. ${ }^{0}$ 175, de 10 de julho de 1991, e pela Resolução $\mathrm{n}^{\circ}$ 1855, de 14 de agosto de 1991, que introduziu importantes modificações no programa. Em seu capítulo 16 (artigo

\footnotetext{
${ }^{64}$ Resultados até 14 de agosto.

${ }^{65}$ BANCO CENTRAL DO BRASIL. Relatório do Proagro. http://www.bcb.gov.br/?PROAGRO (15 jul. 2003)

${ }^{66}$ Lei $\mathrm{n}^{\circ}$ 8171, de 17 de janeiro de 1991.
} 
59), estabelece que o Programa de Garantia da Atividade Agropecuária (Proagro), assegurará ao produtor rural:

i) “a exoneração de obrigações financeiras relativas à operação de crédito rural de custeio, cuja liquidação seja dificultada pela ocorrência de fenômenos naturais, pragas e doenças que atinjam bens, rebanhos e plantações;

ii) a indenização de recursos próprios utilizados pelo produtor em custeio rural, quando ocorrer perda em virtude dos eventos citados no inciso anterior.”

O documento estabeleceu, ainda, que os recursos para o financiamento do programa seriam feitos por três fontes: provenientes dos próprios produtores, outros recursos alocados ao programa e as receitas geradas pela aplicação destes recursos (artigo 60).

A cobertura parcial ou total incidiria sobre o financiamento do custeio rural e sobre os recursos próprios investidos pelo produtor no custeio, atrelados ou não a financiamentos agrícolas (artigo 65).

O processo de indenização ocorre a partir da comunicação formal pelo produtor ao agente do programa, responsável pela solicitação de perícia, executada por órgãos de assistência técnica, profissionais autônomos ou do próprio quadro da instituição financeira.

Cabe ao agente analisar o pedido e divulgar a decisão dentro de 15 dias úteis, contados do recebimento do laudo pericial. O produtor não satisfeito com a decisão tem o direito de recorrer à Comissão Especial de Recursos (CER).

Nesse ponto, vale ressaltar algumas diferenças entre seguro agrícola e o Proagro. A Lei $n^{\circ}$ 8.171/91, em seu capítulo XV (artigo 56), determina que o seguro agrícola é destinado a cobrir prejuízos decorrentes de sinistros que atinjam bens fixos e semifixos ou semoventes. Cobre prejuízos causados por fenômenos naturais, pragas, doenças e outros que atinjam as plantações. 
As atividades florestais e pesqueiras também podem ser amparadas pelo seguro agrícola previsto nesta lei. Além disto, a apólice de seguro agrícola pode constituir garantia nas operações de crédito rural.

Com base na legislação mencionada, percebe-se a diferença entre o seguro agrícola e o Proagro. O seguro agrícola é um seguro propriamente dito, regulamentado e fiscalizado pelos órgãos que tratam do seguro privado, enquanto o Proagro constitui um programa governamental de apoio à produção agrícola, havendo a possibilidade de captação de recursos orçamentários sob a orientação da política agrícola do governo.

A figura 32, mostra as principais diferenças entre o seguro agrícola e o Proagro.

\begin{tabular}{|c|c|}
\hline SEGURO AGRÍCOLA & PROAGRO \\
\hline $\begin{array}{l}\text { É um seguro, pois é regulamentado pela } \\
\text { Superintendência de Seguros Privados. }\end{array}$ & $\begin{array}{l}\text { Não é um seguro, pois é aprovado pelo Banco } \\
\text { Central. }\end{array}$ \\
\hline $\begin{array}{l}\text { Valor Segurado é o valor financiado, no caso do seguro } \\
\text { de custeio, existindo a opção de se incluir a parcela de } \\
\text { recursos próprios, mas limitado ao orçamento total. }\end{array}$ & Valor Segurado é o valor financiado. \\
\hline $\begin{array}{l}\text { Riscos Cobertos: chuvas excessivas, geada, granizo, } \\
\text { incêndio e raio, seca, tromba d'água, ventos fortes/frios e } \\
\text { variação excessiva de temperatura. }\end{array}$ & $\begin{array}{l}\text { Riscos Cobertos: Em função da cultura e do } \\
\text { zoneamento (seca ou chuva excessiva). }\end{array}$ \\
\hline $\begin{array}{l}\text { Regulação: vistorias realizadas juntamente com o } \\
\text { segurado, que assina o laudo se aprová-lo. }\end{array}$ & $\begin{array}{l}\text { Regulação: comunicação ao agente do programa, } \\
\text { responsável pela solicitação de perícia e posterior } \\
\text { análise do pedido. A divulgação da decisão ocorre } \\
\text { dentro de } 15 \text { dias úteis, contados do recebimento do } \\
\text { laudo pericial. }\end{array}$ \\
\hline $\begin{array}{l}\text { Indenização: Prejuízos totais, em parte ou totalidade da } \\
\text { área, de acordo com o estágio da cultura, têm pagamento } \\
\text { imediato no momento do sinistro. }\end{array}$ & $\begin{array}{l}\text { Indenização: Prejuízos totais, quando for na área } \\
\text { total, e prejuízos parciais. O pagamento é realizado } \\
\text { somente no final da colheita, com o aval do Banco } \\
\text { Central (Bacen). }\end{array}$ \\
\hline $\begin{array}{l}\text { Pagamento: Após o recebimento da documentação } \\
\text { completa. }\end{array}$ & Pagamento: Somente após a liberação do Bacen. \\
\hline
\end{tabular}

Figura 32 - Principais diferenças entre o seguro agrícola e Proagro

Fonte: O IRB ... (2000), modificado pelo autor 
O quadro institucional foi reestruturado, em função de Lei Agrícola, de modo que:

i) O Banco Central permaneceu responsável pela administração do programa e elaboração de normas conjuntamente com o Conselho Nacional de Política Agrícola (CNPA) sujeitas à aprovação do Conselho Monetário Nacional;

ii) As instituições financeiras foram consideradas como agentes do programa e responsáveis pela apuração das perdas e pagamento das indenizações;

iii) Ao Comitê Permanente coube o acompanhamento e avaliação do programa nos anos subseqüentes;

iv) À Comissão Especial de Recursos (CER) atribuiu-se a análise dos pedidos recursais relativos à apuração dos danos, sendo que a comissão daria a última palavra sobre o assunto abordado.

A mudança na regulamentação tinha o objetivo de tornar o programa auto-sustentável, no sentido da sua receita ser capaz de cobrir seu déficit ao final de cada período. Para isto, as alíquotas dos adicionais foram elevadas e, as normas, simplificadas com o claro objetivo de reduzir custos.

Se, por um lado, esforços foram realizados para tornar o sistema mais eficiente, por outro, o controle das informações e o monitoramento das operações foram relegados a segundo plano, dificultando a administração financeira do programa.

Além disso, o Tesouro Nacional só viria a intervir em caso de eventos catastróficos, desde que os recursos provenientes do próprio programa fossem insuficientes para quitar as dívidas.

Tais medidas adotadas não foram suficientes para estancar o déficit restando, em maio de 1994, um saldo devedor da ordem de US\$ 264,6 milhões. Deste modo, em agosto de 1994, a Resolução ${ }^{0}$ 2.103, aprovada pelo Conselho Monetário Nacional, determinou, novamente, modificações no programa. 
Segundo Rossetti (1998), optou-se por realizar reparos operacionais, mantendo-se, de modo geral, a mesma estrutura com seus vícios e defeitos. Tais alterações são descritas abaixo:

i) Definição clara sobre a vigência da cobertura do programa ${ }^{67}$ e das situações de adversidade climática;

ii) Recomendação do uso de insumos e análise química do solo;

iii) Recolhimento automático do adicional pelo Banco Central, a partir do quinto dia útil após o cadastramento da operação;

iv) Dados sobre ocorrência de perdas informatizadas no Banco Central;

v) Prorrogação obrigatória do vencimento original de, no máximo, 120 dias;

vi) Transferência imediata do valor da cobertura ao segurado, em conta específica denominada "Proagro a receber", reduzindo o trâmite burocrático do pagamento da indenização;

Além disso, algumas deficiências persistiam:

i) Falta de acompanhamento e monitoramento das operações, principalmente no referente à apuração das perdas e no pagamento das indenizações;

ii) O processo de fiscalização era inapropriado, ou seja, era realizado em até cinco anos, pelo Banco Central, por meio de amostragem e, além disto, havia atraso no pagamento das indenizações;

iii) Falta de adequação de tecnologia por órgãos de pesquisa ${ }^{68}$;

iv) Multiplicidade de riscos cobertos;

v) Ocorrência de déficits constantes ${ }^{69}$.

\footnotetext{
${ }^{67}$ Com início na emergência ou no transplantio da planta.

${ }^{68}$ Nota-se que esta função deveria ser exercida por um órgão de pesquisa competente, mas era conduzida por órgãos de assistência técnica e extensão.

${ }^{69}$ Mesmo com alíquotas variando de 1,2\% para o custeio pecuário, até $11,7 \%$ para custeio de arroz de sequeiro, feijão, aveia, centeio, cevada, trigo e triticale, tornando elevado o custo do empreendimento para as culturas consideradas.
} 
Segundo Rosseti (2001), além das mudanças ocorridas no programa, citadas anteriormente, outros procedimentos deveriam ser seguidos, de forma complementar:

i) Utilização de técnicas adequadas pelos produtores, tais como preparo do solo, utilização de sementes e épocas de semeadura, como condições básicas para a participação no programa;

ii) Enquadramento antes da semeadura e especificação dos direitos e deveres dos produtores e dos agentes do programa;

iii) Desvinculação do Proagro da realização do crédito rural e monitoramento constante do funcionamento do programa, no tocante ao cumprimento de suas normas, pagamento das responsabilidades e acompanhamento da incidência dos eventos sinistrantes;

iv) Garantia do programa após a emergência da cultura, exceto para tromba d’água, que passaria a vigorar no início do enquadramento;

v) Realização de relatórios em períodos pré-determinados pelos agentes do programa, como, por exemplo, logo após a emergência da cultura, pré-colheita e acompanhamento da safra;

vi) Elaboração de um banco de dados específico como um importante mecanismo de suporte à tomada de decisão dos responsáveis pela Política Agrícola Nacional;

vii) Mapeamento do Brasil de acordo com o risco característico de cada região;

viii) Utilização de procedimentos atuariais adequados para o cálculo das alíquotas a serem cobradas, fator imprescindível para o sucesso do programa;

ix) Os exames dos pedidos de indenização seriam analisados pelos agentes do programa, após a realização dos laudos de perícia pelos órgãos assistenciais credenciados;

x) Restringir a abrangência das coberturas. 
Tendo em vista os aspectos relacionados acima, Rosseti (2001) propõe uma reestruturação do programa, conforme o organograma representado pela figura 33:

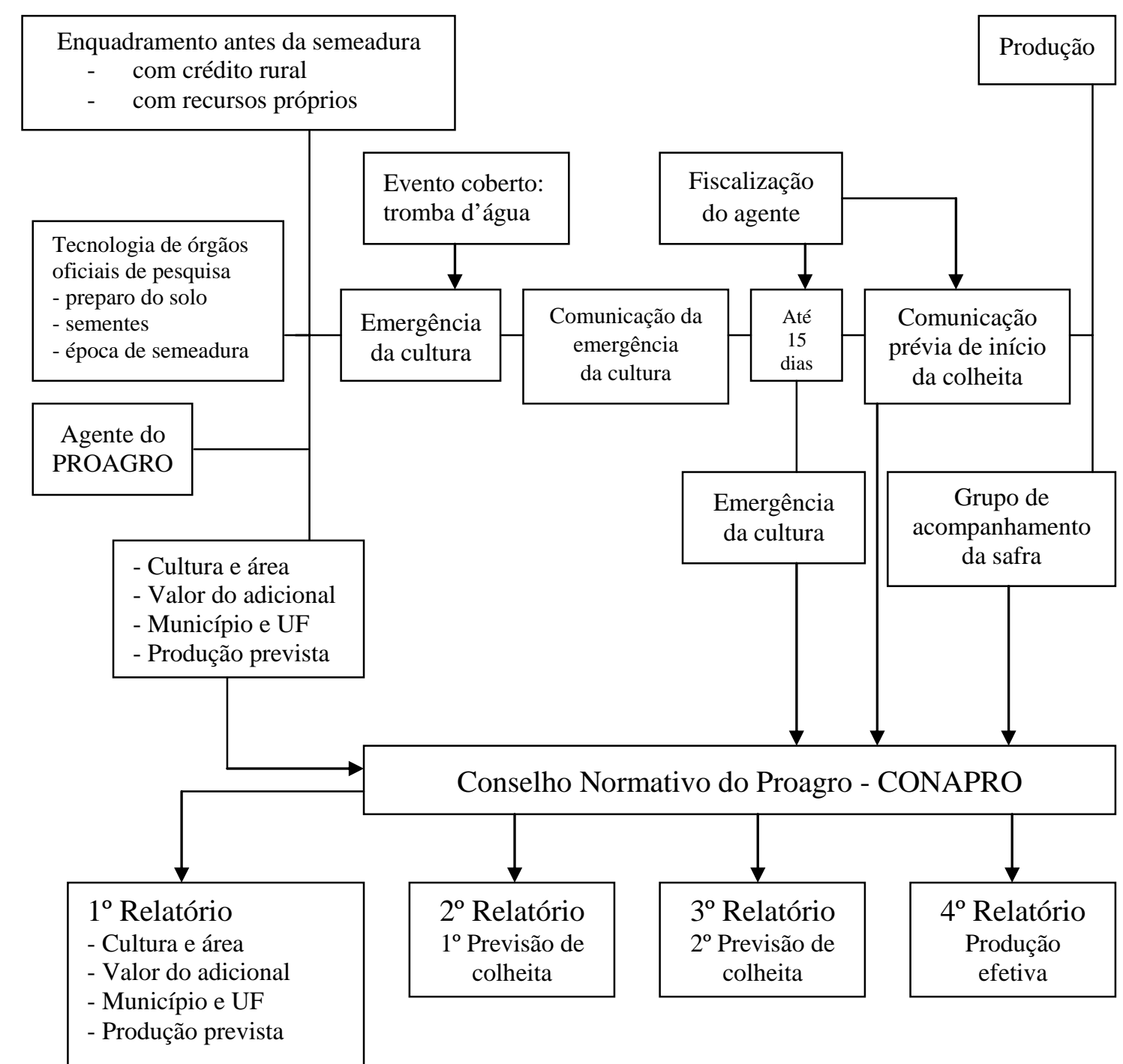

Figura 33 - Organograma representativo da proposta de reestruturação do Proagro

Fonte: Rosseti (2001) 
A partir de outubro de 1995, o Ministério da Agricultura e do Abastecimento implantou o Projeto de Redução de Riscos Climáticos na Agricultura, juntamente com a Fundação de Empreendimentos Científicos e Tecnológicos (Finatec) e da Universidade de Brasília $^{70}$ (UNB), que tinha como objetivo elaborar uma metodologia para a redução da perda da produção agrícola e indução de tecnologia por meio de técnicas que o produtor poderia utilizar para gerenciar melhor o risco climático, originário do regime de chuvas.

O projeto foi concluído em agosto de 1996 e, a partir de então, o Conselho Monetário Nacional, atendendo às recomendações devidamente aprovadas pelo Grupo de Coordenação de Política Agrícola, redefiniu os rumos tomados pelo Proagro, mediante regulamentação legal.

Aos produtores que aderissem ao zoneamento agrícola seriam cobrados adicionais diferenciados. Além disto, o projeto determinou o período de plantio por município para a cultura do arroz, algodão, soja, milho e feijão em âmbito nacional e para o trigo na região Centro-Sul.

Houve redução da alíquota do adicional do trigo de 11,7\% para 4\% para aqueles que respeitassem o cronograma de plantio nos Estados do Paraná, Rio Grande do Sul, Santa Catarina e Mato Grosso do Sul, de acordo com a Resolução n ${ }^{\circ} 2.273$, de 23 de abril de 1996, que dispõe sobre o zoneamento agrícola para o trigo. Além disto, reduziu-se o número de riscos cobertos ${ }^{71}$.

Na safra de 1997 o adicional foi reduzido para 3\%, se o produtor optasse pelo plantio direto. Também o agente passou a ser remunerado no montante de $10 \%$ do adicional nas operações em que o segurado aderisse ao zoneamento agrícola.

Algumas condições especiais foram estabelecidas nos Estados de Goiás, Mato Grosso, Mato Grosso do Sul, Minas Gerais, São Paulo e Tocantins, caso o

\footnotetext{
${ }^{70}$ Além dos órgãos citados participaram do projeto a Empresa Brasileira de Pesquisa Agropecuária / Distrito Federal (Embrapa/DF), Instituto Agronômico de Campinas (IAC), Instituto Agronômico do Paraná (Iapar), Empresa de Pesquisa Agropecuária e Extensão Rural de Santa Catarina (Epagri), Universidade Estadual de Campinas (Unicamp), Instituto Nacional de Meteorologia (Inmet) e Agência Nacional de Energia Elétrica (Aneel).

${ }^{71}$ Abrangendo apenas a geada, granizo, tromba d’água e vendaval.
} 
produtor optasse por aplicar as recomendações técnicas ${ }^{72}$, em função da Resolução $\mathrm{n}^{0}$ 2.294, de 28 de junho de 1996, que dispunha sobre o zoneamento agrícola para a safra de verão 1996/97 nas operações de custeio de arroz, feijão, milho e soja.

Para as culturas de arroz e feijão, o adicional reduziu de $11,7 \%$ para 6,7\%, respectivamente. Para o milho e soja houve diminuição de 7\% para 3,9\%. Os eventos cobertos foram restritos somente ao granizo, tromba d’água, seca e vendaval.

Para culturas irrigadas em todo o território nacional, a alíquota caiu de 4,7\% para 1,7\% para coberturas de perdas decorrentes de granizo, tromba d'água e vendaval.

Tarifa única de $2 \%$ para os beneficiários do Programa Nacional de Fortalecimento da Agricultura Familiar (Pronaf) e de 1\% para as lavouras de feijão, milho e soja, desde que os produtores adotassem a técnica do plantio direto.

Para a safra 1997/98 foram incluídos os Estados do Paraná, Rio Grande do Sul, Santa Catarina e Distrito Federal, de acordo com a Resolução no 2.403, de 25 de junho de 1997

Na cultura do algodão, a alíquota foi reduzida de 7\% para 3,9\%. Para o feijão, a alíquota passou para 5,7\% e para 2,9\% nas culturas de milho e soja, se o beneficiário optasse por utilizar a técnica de plantio direto.

A Resolução $\mathrm{n}^{0}$ 2.422, de 10 de setembro de 1997, restringiu o enquadramento no programa a empreendimentos conduzidos na área de abrangência e sob as condições do zoneamento agrícola, inclusive no caso do Pronaf e ao Programa Especial de Crédito para a Reforma Agrária (Procera).

Além disso, estendeu o programa para o sudoeste da Bahia, sul do Maranhão e sul do Piaú. Adicionou-se a cobertura de perdas decorrentes de doença fúngica ou praga sem método difundido de combate, controle ou profilaxia.

A Resolução ${ }^{0}$ 2.427, de 1 de outubro de 1997, estendeu as normas do zoneamento agrícola divulgadas pela Resolução n. 2.403/97 às operações de algodão de sequeiro na região Nordeste e de arroz irrigado, em âmbito nacional, observadas as condições da Resolução n. 2.422/97.

\footnotetext{
${ }^{72}$ Como, por exemplo, cronograma de plantio, uso de sementes e grau de aptidão do solo.
} 
Como resultado houve uma melhora significativa nos resultados do programa, como pode ser visto na figura 34:

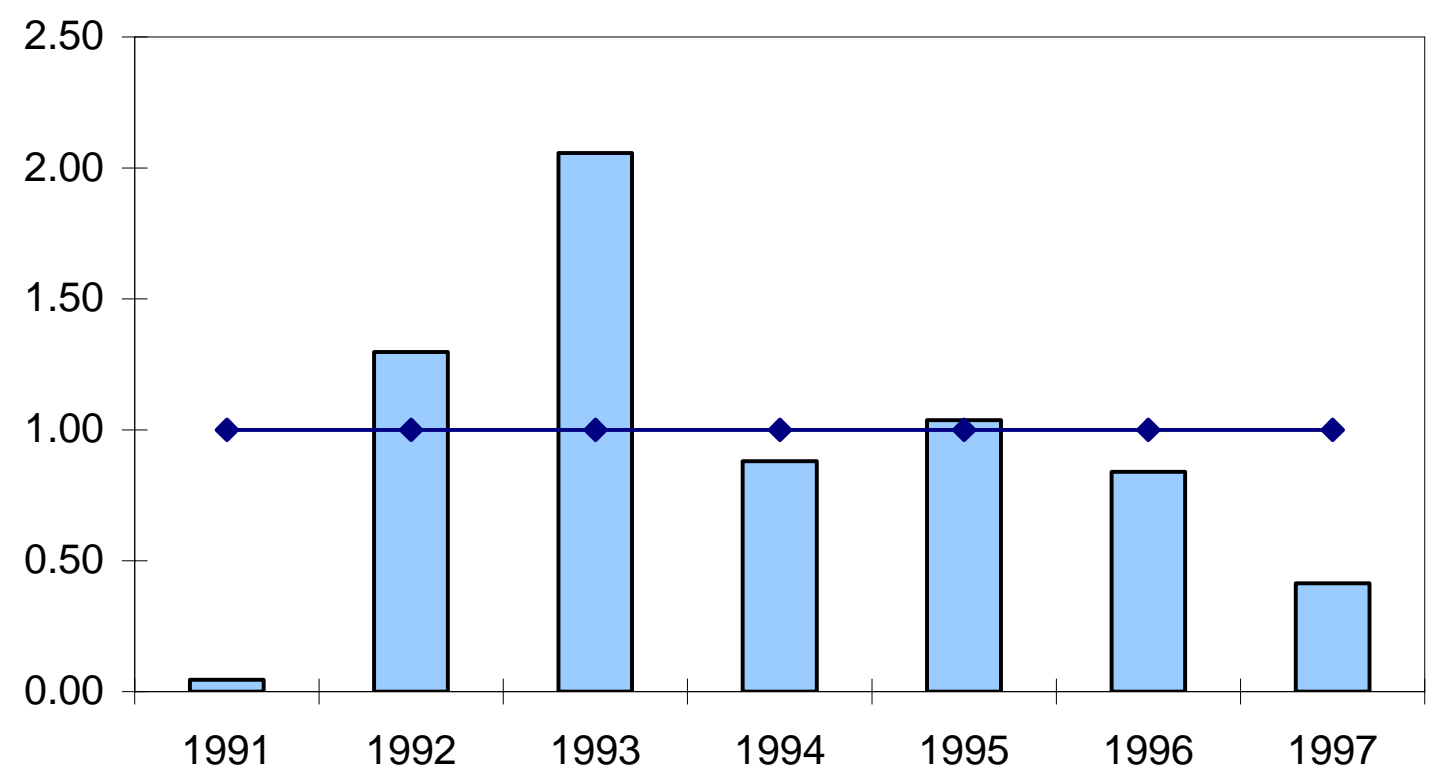

Figura 34 - Índice de sinistralidade do Proagro no período de 1991 a 1997.

Fonte: Banco Central (2003)

Nota: os valores relativos a 1991 são após 14 de agosto

\subsubsection{Contexto estadual}

\subsubsection{O Seguro Agrícola no Estado de São Paulo}

A primeira experiência com o seguro rural no Estado de São Paulo ocorreu em 1938, com a cultura do algodão.

O Decreto $\mathrm{n}^{\circ}$ 9.865, de 27 de dezembro de 1938, por meio do artigo 10, autorizou o Instituto Agronômico do Estado a realizar operações financeiras mediante 
créditos bancários rotativos, necessárias à compra e venda de sementes de algodão (São Paulo, 1938).

Em outubro do ano seguinte, o Decreto $\mathrm{n}^{\circ} 10.554$, de 4 de outubro de 1939, regulou a forma de escrituração das importâncias correspondentes à venda de sementes de algodão aos agricultores. $\mathrm{O}$ artigo 2 determinava que o preço de venda seria calculado tendo em vista:

i) Valor da semente adquirida dos cooperadores;

ii) Juros de crédito rotativo;

iii) Sacaria;

iv) Beneficiamento;

v) Seguro contra granizo.

A importância relativa ao seguro contra granizo foi escriturada à parte, constituindo o Fundo de Defesa da Lavoura Algodoeira Contra o Granizo.

Os recibos emitidos pelo instituto correspondentes à venda das sementes constituíam um certificado de seguro contra granizo.

O limite máximo segurável foi estabelecido em 500 mil réis por alqueire, caso tivesse ocorrido prejuízo total da lavoura. Se ele fosse parcial, a indenização seria proporcional ao dano verificado (São Paulo, 1939).

Devido ao grande desenvolvimento desse seguro, foi criado pelo Decreto $\mathrm{n}^{\circ}$ 11.379, de 4 de setembro de 1940, sob a forma de fundos, a Carteira de Seguro Contra o Granizo.

Os resultados satisfatórios dessa iniciativa, nos anos seguintes, permitiram a criação da Carteira Agrícola de Seguros Contra o Granizo para os viticultores do Estado de São Paulo, por meio da Lei nº 111, de 19 de julho de 1948 e regulamentada pelo Decreto n 19.483, de 9 de junho de 1950 (São Paulo, 1971).

De acordo com o referido decreto, a carteira ficou subordinada à Comissão de Produção Agropecuária, criada pelo Decreto n 18.437, de 30 de dezembro de 1948, com a finalidade de promover o desenvolvimento da atividade agrícola nas 
propriedades agrícolas pertencentes à Secretaria da Agricultura, aproveitando as áreas disponíveis das fazendas, de forma racional, constituindo não apenas um alto patrimônio financeiro, mas também educativo.

A comissão era diretamente subordinada à Secretaria da Agricultura do Estado de São Paulo (São Paulo, 1948).

Os fundos da carteira agrícola destinada aos viticultores foram constituídos pela arrecadação da taxa de seguro, à razão de 8\% sobre a indenização total pretendida pelo segurado.

Tabela 4. Prêmios (taxa de 8\%) e indenizações da carteira de seguro contra granizo para viticultores realizados no período de 1952/53 a 1969/70, em R\$, deflacionados para setembro de 2004

\begin{tabular}{cccc}
\hline Ano-safra & Prêmio (P) & Indenização (I) & P - I \\
\hline $1952 / 53$ & 47 & 184 & -136 \\
$1953 / 54$ & 234 & 140 & 93 \\
$1954 / 55$ & 370 & 743 & -373 \\
$1955 / 56$ & 281 & 559 & -278 \\
$1956 / 57$ & 85 & 108 & -23 \\
$1957 / 58$ & 64 & 86 & -22 \\
$1958 / 59$ & 87 & 103 & -16 \\
$1959 / 60$ & 298 & 156 & 142 \\
$1960 / 61$ & 273 & 496 & -223 \\
$1961 / 62$ & 76 & 279 & -202 \\
$1962 / 63$ & 511 & 181 & 330 \\
$1963 / 64$ & 209 & 299 & -90 \\
$1964 / 65$ & 417 & 142 & 275 \\
$1965 / 66$ & 394 & 289 & 106 \\
$1966 / 67$ & 79038 & 59554 & 19484 \\
$1967 / 68$ & 480752 & 780524 & -299772 \\
$1968 / 69$ & 670541 & 1002880 & -332339 \\
$1969 / 70$ & 947071 & 1031552 & -84481 \\
total & 2180749 & 2878274 & -697525 \\
\hline
\end{tabular}

Fonte: São Paulo (1971) 
Observa-se pela tabela acima, que, dos 18 anos analisados, apenas em seis o total arrecadado em prêmios superaram as indenizações pagas.

No período total, as indenizações excederam os prêmios em quase 700 mil reais. Na figura 35, nota-se que o índice de sinistralidade foi extremamente elevado para o ano de 1952/53 (3,87), seguido dos anos de 1954/55 e 1955/56 (aproximadamente 2).

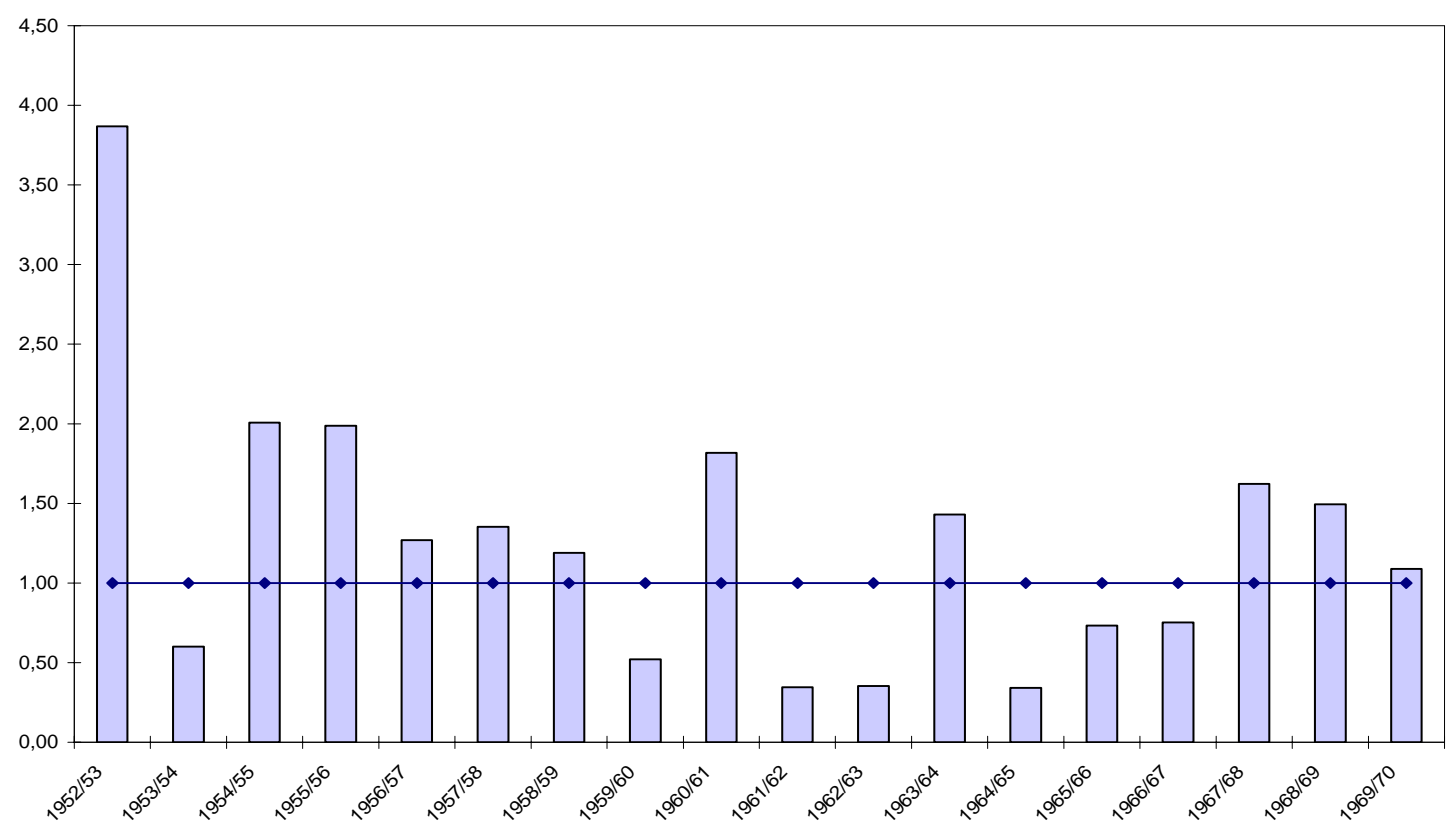

Figura 35 - Índice de sinistralidade da carteira de seguros contra o granizo para viticultores no período de 1952/53 a 1969/70

Fonte: São Paulo (1971)

A Carteira de Seguros Contra o Granizo, criada pelo Decreto $n^{\circ} 11.379$, passou a ser subordinada à Comissão de Produção Agropecuária, por meio do Decreto $\mathrm{n}^{\circ}$ 19.211, de 2 de março de 1950. Posteriormente, foi alterada pelo Decreto $\mathrm{n}^{\circ} 20.211$, de 15 de janeiro de 1951, e passou a ser denominada Carteira de Seguro Contra o Granizo para a Lavoura Algodoeira. 
O artigo 5 desse decreto determinou as seguintes aplicações do total da arrecadação da quota de seguro contra o granizo:

i) $5 \%$ para a reserva técnica da carteira;

ii) 25\% para despesas operacionais;

iii) $70 \%$ para pagamento de indenizações verificadas dentro do ano agrícola.

Contrariamente à carteira de seguros contra granizo para viticultores, a destinada à lavoura algodoeira apresentou bons resultados em 31 anos de existência (figura 36, abaixo). Apenas nos anos de 1962/63 e 1963/64 as indenizações superaram os prêmios arrecadados.

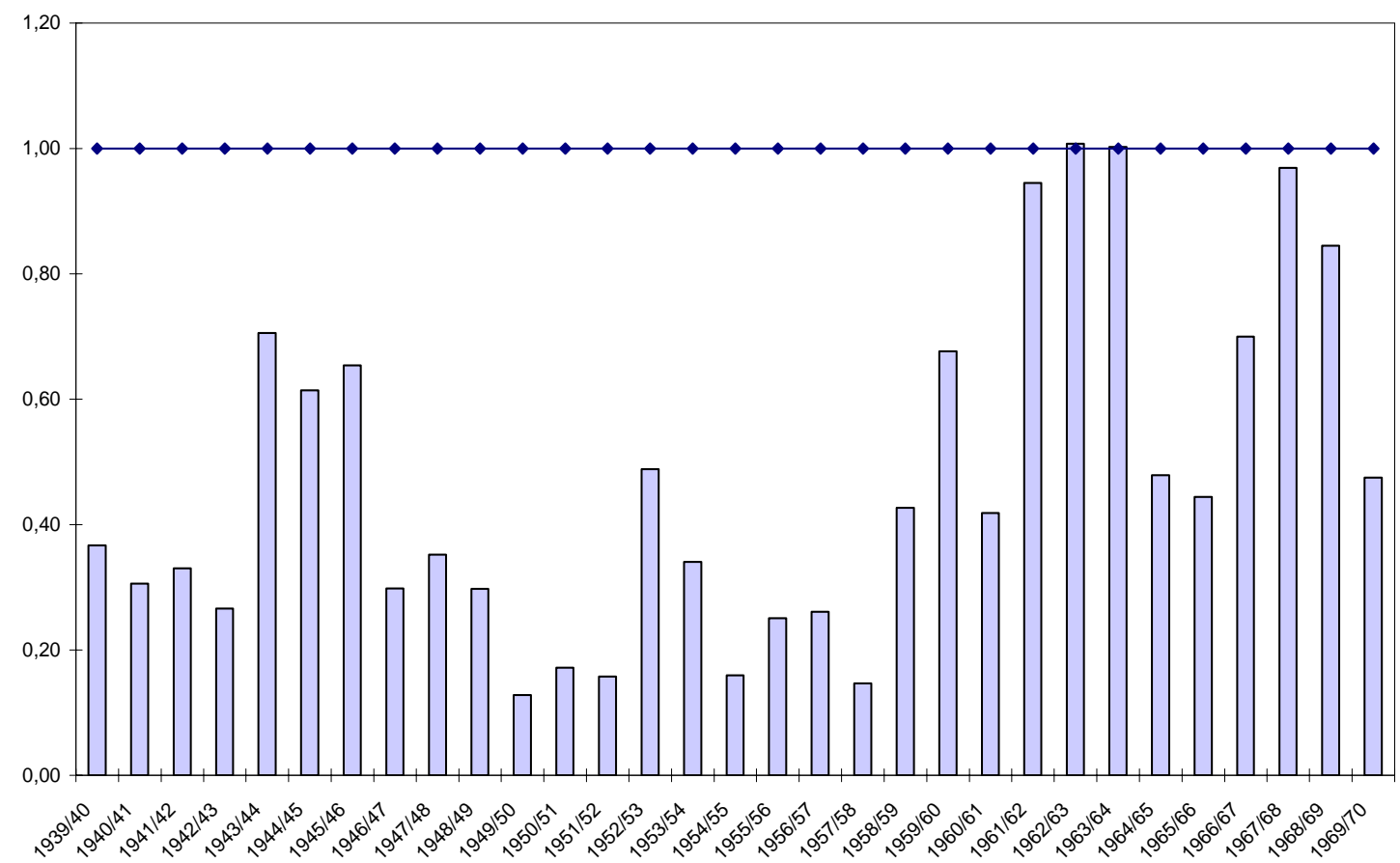

Figura 36 - Índice de sinistralidade para a carteira de seguros contra o granizo para a lavoura algodoeira no período de 1939/40 a 1969/70

Fonte: São Paulo (1971) 
Dando prosseguimento ao desenvolvimento de seguros rurais, o governo do Estado de São Paulo sancionou a Lei n ${ }^{\circ}$ 8.375, de 28 de outubro de 1964, que criou na Secretaria da Agricultura a Carteira Agrícola de Seguros Contra a Geada para Horticultores, Floricultores e Fruticultores (São Paulo, 1964).

A carteira teve como finalidade o amparo e a defesa dos horticultores, floricultores e fruticultores, cujas lavouras foram afetadas e danificadas por geadas.

Essa adversidade climática foi definida como sendo o fenômeno que, em decorrência de abaixamento da temperatura ambiente, determina ou provoca congelamentos internos nos tecidos das plantas acarretando, como conseqüência, o dano parcial ou total do vegetal.

As tarifas e prêmios variavam de acordo com a altitude da propriedade. Para terrenos localizados acima de 700 metros, haveria um acréscimo:

i) De $10 \%$ em altitudes até 800 metros;

ii) De 20\% para altitudes até 900 metros;

iii) De 35\% em altitudes até 1.000 metros;

iv) De 50\% para altitudes acima de 1.000 metros.

O seguro era compulsório no caso do algodão e não existia emissão de apólice, sendo o prêmio atrelado ao preço pago pela semente. Desta maneira, o produtor se dirigia à Casa da Agricultura para a aquisição do insumo e no ato da transação pagava $1,1 \%$ sobre o valor do saco da semente.

Para o caso do seguro de granizo para os viticultores e seguro de geada para fruticultores, horticultores e floricultores, a apólice era de caráter facultativo. Novamente o produtor se dirigia à Casa da Agricultura e adquiria a apólice de seguro mediante trâmite burocrático necessário para a especificação do contrato.

Em caso de sinistro, o portador do contrato, dentro do prazo estipulado, se dirigia à Casa da Agricultura solicitando vistoria imediata da ocorrência.

O engenheiro agrônomo regional verificava "in loco" o sinistro e, posteriormente, realizava o cálculo da indenização, em laudo próprio, de acordo com o 
percentual de perdas no estágio de desenvolvimento da cultura, que já tinha os seus valores pré-estabelecidos. Após a verificação e aprovação pela autoridade responsável, o produtor era indenizado.

Na figura 37, percebe-se que o índice de sinistralidade excedeu a unidade em quatro anos, sendo o caso mais drástico o ano de 1969 (6,34), no período de 1965 a 1970.

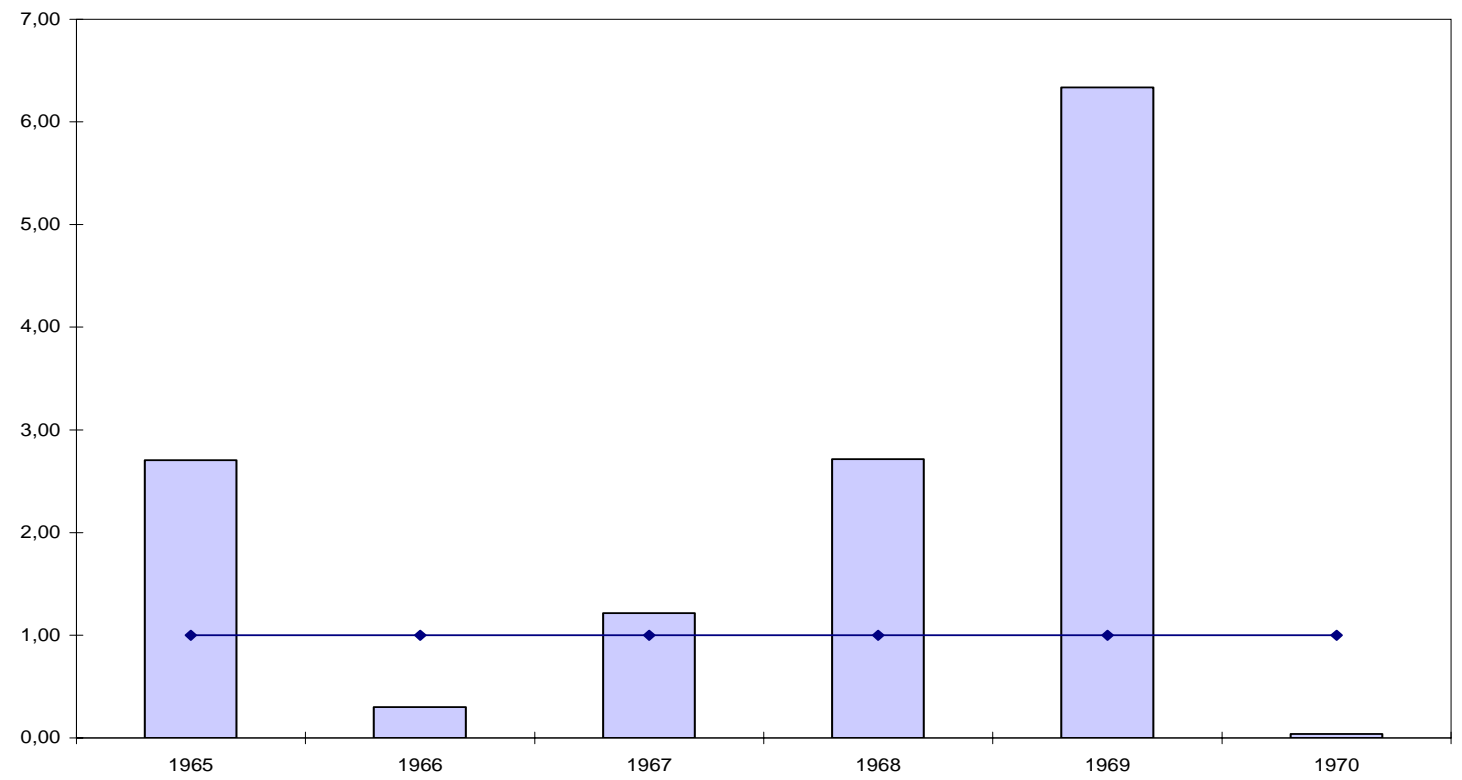

Figura 37- Sinistralidade na carteira de seguro de geada para fruticultores, horticultores e floricultores

Fonte: São Paulo (1971) 
De modo geral, nesses seis anos, as indenizações superaram os prêmios em pouco mais do que 402 mil cruzeiros (CR\$ $402 \mathrm{mil})^{73}$. Isto representa quase duas vezes mais o valor do prêmio arrecadado neste período.

A carteira cobria as seguintes culturas:

i) Horticultura: alface, abóbora, batatinha, ervilha, feijão, vagem, pimentão, pepino, tomate e quiabo;

ii) Fruticultura: banana, citrus, mamão, melancia, melão, morango, pêssego e abacaxi;

iii) Floricultura: antúrios, gladíolos, roseiras, rosas, strelitzias e cravos.

Até o ano de 1967, as operações de seguro estavam sob o controle da Comissão de Produção Agropecuária, órgão ligado ao governo do Estado. Como o Decreto-Lei $n^{\circ}$ 73/66 impediu a Secretaria da Agricultura do Estado de São Paulo de continuar operando, houve necessidade de se constituir uma seguradora própria do Estado.

Deste modo, no mesmo ano foi criado a Ipesp - Seguros Gerais S/A, que absorveu as carteiras de seguro agrícola da Secretaria da Agricultura e o Serviço Autônomo de Seguros Ipesp, Instituto de Previdência Social do Estado, que segurava o patrimônio de imóveis do governo estadual.

Nota-se que nenhuma modificação em relação ao sistema de atuação das carteiras, ocorreu em detrimento da Lei $n^{\circ}$ 2.168/54 e do Decreto-lei n 73/66 (Martins, 1987).

\subsection{Companhia de Seguros do Estado de São Paulo (Cosesp)}

Dois anos depois, a Ipesp - Seguros Gerais S/A passou a denominar-se Companhia de Seguros do Estado de São Paulo.

\footnotetext{
${ }^{73}$ Pouco mais de R\$1,7 milhão.
} 
O Decreto $\mathrm{n}^{\circ}$ 50.890, de 19 de novembro de 1968, obrigou que todos os seguros contratados por órgãos do poder público estadual, sociedades anônimas, autarquias e entidades de economia mista fossem realizados por meio da Cosesp.

A Resolução n 5 do CNSP, de 14 de julho de 1970, publicada no Diário Oficial de 19 de agosto de 1970, aprovou as normas tarifárias e condições gerais de seguro rural para aplicação, inicialmente, em caráter experimental por meio da Cosesp, no Estado de São Paulo.

Além disso, determinou que o seguro rural obrigatório e facultativo ${ }^{74}$ fossem tais que:

1. O seguro rural obrigatório seria iniciado automaticamente, a partir da data de assinatura do contrato de financiamento, abrangendo as seguintes responsabilidades:

i) Custeio agrícola e pecuário, pelo valor do crédito aprovado;

ii) Bens financiados, pelo valor do crédito aprovado;

iii) Bens dados em garantias, pelo valor atribuído pelo estipulante ${ }^{75}$;

iv) Saldos de financiamentos concedidos a produtores no caso de morte do financiado.

\footnotetext{
${ }^{74} \mathrm{O}$ seguro pode ser caracterizado como sendo obrigatório e facultativo. No primeiro caso, o estipulante estabelece a compra do seguro, que está atrelado à garantia do financiamento adquirido pelo produtor. No caso do algodão, o produtor tem de realizar o seguro para adquirir as sementes, já que o estipulante (a Secretaria do Estado de São Paulo) detém o monopólio de vendas. No segundo, o próprio produtor procura órgãos competentes, neste caso a Cosesp, para contratar o seguro. O seguro obrigatório foi regulamentado pelo Decreto $\mathrm{n}^{\circ}$ 61.867, de 7 de dezembro de 1967. Pelo artigo 16, o seguro rural obrigatório destina-se a ressarcir os danos causados por acidentes, fenômenos da natureza, praga ou doenças, a rebanhos, plantações e outros bens ligados à atividade ruralista. Podem ter acesso a este tipo de seguro as cooperativas rurais e as pessoas físicas ou jurídicas que explorem atividades agrícolas ou pecuárias. O seguro de crédito rural foi disciplinado pelo CNSP e regulamentado pelo Decreto $\mathrm{n}^{0}$ 60.459/67. Tal documento estipula que as instituições financeiras do Sistema Nacional de Crédito Rural que concederem financiamento à agricultura e à pecuária, promoveriam os contratos, concomitante e automaticamente, de financiamento e de seguro rural, sendo obrigatório o financiamento dos prêmios pelas instituições financeiras e, além disso, o seguro obrigatório ficaria limitado ao valor do financiamento, sendo a instituição financeira considerada como beneficiária.

${ }^{75}$ Estipulante é a pessoa, física ou jurídica, que contrata o seguro a favor do segurado. Não necessariamente a pessoa do estipulante é a mesma que a pessoa do segurado, podendo ser o representante ou mandatário do segurado.
} 
2. O seguro de crédito rural cobriria perdas líquidas realizadas pelas instituições financeiras decorrentes dos financiamentos concedidos para a comercialização dos produtos;

3. O seguro rural facultativo diz respeito às responsabilidades não abrangidas pelo seguro rural obrigatório (Zini, 1979);

As seguintes modalidades de cobertura foram regulamentadas:

1. Seguro agrícola: destinado às operações de custeio agrícola, cobrindo perdas decorrentes de eventos climáticos, pragas e doenças;

i) Obrigatório:

- $\quad$ Para a cultura do algodão, sendo a estipulante do seguro a Secretaria do Estado de São Paulo;

- Destinado às culturas do arroz irrigado, amendoim, cana-de-açúcar, feijão, olerícolas, milho, soja, sorgo e trigo irrigado e estipulado pela Caixa Econômica do Estado de São Paulo e Banespa;

ii) Facultativo:

- Para a cultura da videira, estipulado pela Secretaria da Agricultura do Estado de São Paulo;

- Direcionados às culturas do arroz irrigado, amendoim, cana-de-açúcar, feijão, tomate e batata, milho, soja, sorgo e trigo irrigado realizados pelo Banco América do Sul, Banco do Brasil, Banco Mercantil de São Paulo, Bradesco e Unibanco;

- $\quad$ Por meio de apólices individuais para florestas de pinus e eucalipto. 
2. Seguro Pecuário ${ }^{76}$ : cobre morte de animais decorrentes de acidentes ou doença, sejam estes provenientes de financiamentos ou recebidos em garantia;

3. Seguro de Bens, Benfeitorias e Produtos Agropecuários ${ }^{77}$ : voltado aos financiamentos de investimento, pré-comercialização e outros. Cobre as construções, instalações ou equipamentos fixos, safras removidas do campo de colheita, veículos rurais mistos ou de carga, máquinas agrícolas e seus implementos;

4. Seguro Temporário de $\operatorname{Vida}^{78}$ : destinado à garantia de liquidação dos financiamentos voltados ao pequeno produtor no caso de morte do financiado;

5. Seguro de Crédito para Comercialização de Produtos Agropecuários: cobertura das perdas líquidas que o segurado (instituição financeira) venha a sofrer nos financiamentos concedidos para a comercialização de produtos (Rocha, 1989).

Dois anos mais tarde, a Resolução n ${ }^{\circ} 5$ do CNSP, de 27 de junho de 1972, estendeu as normas e condições para o Estado de Minas Gerais e, posteriormente, para os Estados do Rio de Janeiro e Rio Grande do Sul, por meio das Resoluções $n^{\circ}$ 15, de 28 de junho de 1976 e $\mathrm{n}^{\circ} 10$, de 14 de maio de 1978, respectivamente.

Até o ano de 1970, especificamente para o setor agropecuário paulista, além do seguro agrícola com coberturas específicas as seguradoras já exploravam diversas modalidades tradicionais de seguro voltadas para o setor, entre elas, automóveis, crédito interno, incêndio, transporte, riscos diversos e vida.

\footnotetext{
${ }^{76}$ Facultativo para eqüinos e bovinos e por meio de apólices coletivas ou individuais.

${ }^{77}$ Compulsório e estipulados pela Caixa Econômica do Estado de São Paulo e Banespa.

${ }^{78}$ Estipulado pelo Banespa.
} 
Além destas modalidades, segundo Soares Jr et al. (1971), o produtor tinha a opção do seguro de bens, de vida com capital decrescente nos empréstimos sem garantia real e de crédito na comercialização dos produtos pelo produtor.

O primeiro tinha como objetivo segurar os instrumentos de trabalho, tais como benfeitorias, imóveis, instalações, máquinas e implementos agrícolas e automóveis, e o valor da produção colhida. Nesta modalidade, a importância segurada deveria ser igual ao valor da reposição do bem segurado, sem aplicação da cláusula de rateio $^{79}$.

O segundo garantia a quitação da dívida do financiado ou segurado no caso de sua morte para os empréstimos concedidos sem garantia real, até no máximo 50 vezes o salário mínimo vigente no País.

O terceiro cobria a instituição financeira na comercialização de produtos com desconto pelo produtor dos títulos representativos da venda financiada.

A Cosesp contava, ainda, com o apoio operacional da infra-estrutura técnico-agronômica da Secretaria da Agricultura do Estado de São Paulo, do IRB e do Fundo de Estabilização do Seguro Rural.

\subsection{O Seguro de Custeio Agrícola}

A operacionalização das normas contidas na Resolução $n^{0}$ 5/70 ocorreu somente no ano de 1974. A partir de então, a Cosesp, juntamente com a Secretaria da Agricultura, iniciou o seguro de riscos múltiplos no Estado por meio do Seguro Agrícola para a Cultura Algodoeira (Gimenes, 1979).

Pela tabela 5 observa-se que, nos primeiros quatro ciclos agrícolas, apenas em 1976/77 o índice de sinistralidade ficou abaixo de 1. Além disto, o número

\footnotetext{
${ }^{79}$ A cláusula de rateio, para fins de cálculo da indenização, significa que quando for constatada a insuficiência do seguro, isto é, quando a importância segurada for menor que o valor do bem/objeto no momento do sinistro (valor em risco), o segurado participará dos prejuízos na mesma proporção desta insuficiência.
} 
médio de seguros realizados e sinistros pagos foram, respectivamente, de 28.779 e 1.890

Tabela 5. Resultados do seguro agrícola do algodão, nos anos-safra de 1974/75 a $1977 / 78$

\begin{tabular}{lccccc}
\hline Safra & $\begin{array}{c}\text { Seguros } \\
\text { Realizados }\end{array}$ & $\begin{array}{c}\text { Área Segurada } \\
\text { (hectares) }\end{array}$ & $\begin{array}{c}\text { Sinistros } \\
\text { Pagos }\end{array}$ & $\begin{array}{c}\text { Área } \\
\text { Sinistrada } \\
\text { (hectares)) }\end{array}$ & Sinistralidade \\
\hline $1974 / 75$ & 37.205 & 333.654 & 1.369 & 19.961 & 1,035 \\
$1975 / 76$ & 20.103 & 220.517 & 1.838 & 30.201 & 2,032 \\
$1976 / 77$ & 30.803 & 358.039 & 1.734 & 39.625 & 0,814 \\
$1977 / 78$ & 27.003 & 339.029 & 2.618 & 47.698 & 2,152 \\
Total & 115.117 & 1.251 .239 & 7.559 & 137.485 & 1,550 \\
\hline
\end{tabular}

Fonte: Gimenes (1979)

Posteriormente, a Cosesp implantou o seguro multi-risco facultativo, com emissão de apólices específicas para a cultura do amendoim, banana, milho e soja $(5 \%)^{80}$, tomate e batata (6\%), uva e trigo (7\%) e de caráter obrigatório para a cultura do algodão, que era responsável pelo maior volume de seguros realizados na carteira da companhia até então.

Nota-se que essas apólices não estavam vinculadas à Resolução CNSP $n^{\circ}$ 5/70. Deste modo, a estipulante era a Secretaria de Agricultura do Estado de São Paulo e o seguro era ofertado em todas as Casas da Agricultura nos municípios do Estado.

Os riscos cobertos pelas apólices de seguro compreendiam os eventos climáticos tais como granizo, geada, seca, chuva excessiva, tromba d’água, ventos fortes/frios e incêndios, pragas e doenças sem método de controle conhecidos ou economicamente viáveis.

As taxas de prêmios definidos pela Susep variavam de acordo com a cultura e o nível tecnológico utilizado, que refletia a produtividade de cada propriedade.

\footnotetext{
${ }^{80}$ Respectiva taxa de prêmio.
} 
Essas taxas eram aplicadas sobre o valor segurado, ou seja, o montante de crédito financiado pelo produtor, tendo como base o orçamento de custeio ou o valor básico de custeio (VBC) das culturas periódicas ou orçamento das despesas anuais de manutenção das culturas permanentes.

O valor ou importância segurada representa a máxima responsabilidade assumida pela seguradora no último estágio da produção, ou seja, a colheita.

O produtor poderia optar pelo seguro do crédito complementar ${ }^{81}$ ou da parcela de capital próprio, desde que o segurado arcasse com taxas de prêmios proporcionalmente maiores para as respectivas culturas.

Para efeito do cálculo dos níveis de cobertura determinam-se os valores convencionados, denominados de A, B e C.

Para o tipo A, utiliza-se o melhor nível de tecnologia disponível e são orçadas todas as despesas para a exploração de cultivo. No tipo B, o valor convencionado assemelha-se ao custo médio do Estado. O tipo C agrega os produtores que adotam tecnologias mais rudimentares.

As indenizações podem variar conforme o percentual de perdas e área sinistrada. Desta maneira, pode-se destacar três situações:

1. Perdas de $100 \%$ da produção em toda a área segurada. Nesta situação, se:

i) O produtor não tiver realizado o replantio, com a cultura segurada, então a indenização seria equivalente a todas as operações, aquisições e gastos com encargos realizados pelos produtores, desde o plantio até a data do sinistro;

ii) O replantio foi realizado, o técnico elaboraria o orçamento de custeio de replantio, tais como as operações, aquisições e gastos com encargos necessários para a operação de replantio, e a indenização se processaria imediatamente ao produtor.

\footnotetext{
${ }^{81}$ Aquela parcela do VBC que ultrapassa o limite de adiantamento definido para cada produto, de acordo com o tipo de produtor.
} 
2. Perdas de $100 \%$ da produção em parte da área segurada. Se o laudo técnico comprovar perda total, independentemente de o evento ter ocorrido na área restante, o pagamento da indenização é realizado de imediato ${ }^{82}$.

3. Perdas parciais ${ }^{83}$.

As tarifas variavam em função do nível de tecnologia, da possibilidade de reclassificação, dos valores de orçamento, dos tetos por fase de cultura e do valor convencional por hectare.

No ano de 1981, instituiu-se o seguro obrigatório para culturas vinculadas ao programa estadual "pró-feijão" tendo como objetivo garantir a dívida do produtor junto ao agente financeiro, que era o estipulante.

Em 1983, a companhia implementou o seguro obrigatório, com o mesmo objetivo e taxas definidas pela Susep. Para as culturas de amendoim, soja e feijão, as taxas foram de 3\%, tomate e batata, 3,5\%, milho e feijão irrigado, 2,5\%. O seguro obrigatório de crédito de custeio cobria também os juros referentes ao principal e à correção monetária da dívida.

Nesse ponto, ressaltam-se algumas diferenças entre o seguro facultativo e obrigatório. A taxa mínima que era aplicada aos seguros obrigatórios, de acordo com a Resolução CNSP n ${ }^{0}$ 5/70, era de 2,5\%, enquanto que a taxa para o seguro facultativo podia variar, conforme a peculiaridade de cada cultura, sendo normalmente aplicada em percentuais mais elevados.

\footnotetext{
${ }^{82}$ Segundo Gimenes (1979), se a Cosesp aguardasse a colheita da área remanescente, o segurado poderia optar por não conduzir a lavoura de maneira correta aumentando o prejuízo e, conseqüentemente, o montante devido como indenização.

${ }^{83}$ De acordo com o laudo técnico, a perda pode ser caracterizada como total ou parcial. Este último caso ocorre quando ainda é econômico continuar com a cultura implantada, sendo que a área atingida deve ser colhida.
} 
Conforme destaca Gimenes, até meados do final da década de 70 notavase a baixa receptividade pelos produtores em demandar pelo seguro facultativo, mesmo com altos índices de sinistralidade, devido principalmente a problemas relacionados à falta de divulgação e conscientização do setor rural. Outro problema se refere ao fato de o pagamento do prêmio coincidir com a época em que o produtor teria de arcar com as despesas de custeio.

A partir de 1988, o número de estipulantes aumentou. Além dos bancos estaduais, Banco do Brasil, Bradesco e Banco América do Sul, a Cooperativa Agrícola de Cotia, Cooperativa Sul Brasil e a Federação da Agricultura do Estado de São Paulo (Faesp) também passaram a operar como estipulantes mediante convênios, segundo Safra ... (1989).

Devido aos problemas enfrentados pelo setor algodoeiro paulista no final da década de 80 e início de 90 e às reivindicações, principalmente por parte dos produtores da região oeste do Estado, em reduzir os custos de produção pela diminuição do preço da semente, que era monopólio do Estado, fizeram com que a Secretaria de Agricultura e Abastecimento desvinculasse o seguro obrigatório da venda das sementes.

Historicamente o governo estadual, por meio de seus órgãos competentes, incentivou o desenvolvimento deste setor, fosse pelo melhoramento das variedades pelo Instituto Agronômico de Campinas (IAC) ou pela administração do risco via seguro compulsório.

Durante toda a década de 80, o seguro do algodão foi o mais importante em volume de seguros realizados (figura 38). Neste período, foram operacionalizados, em média, 23.353 seguros, com um total de 256.884. No ano-safra 1984/85, o número de seguros realizados atingiu o patamar máximo de 30.647. 


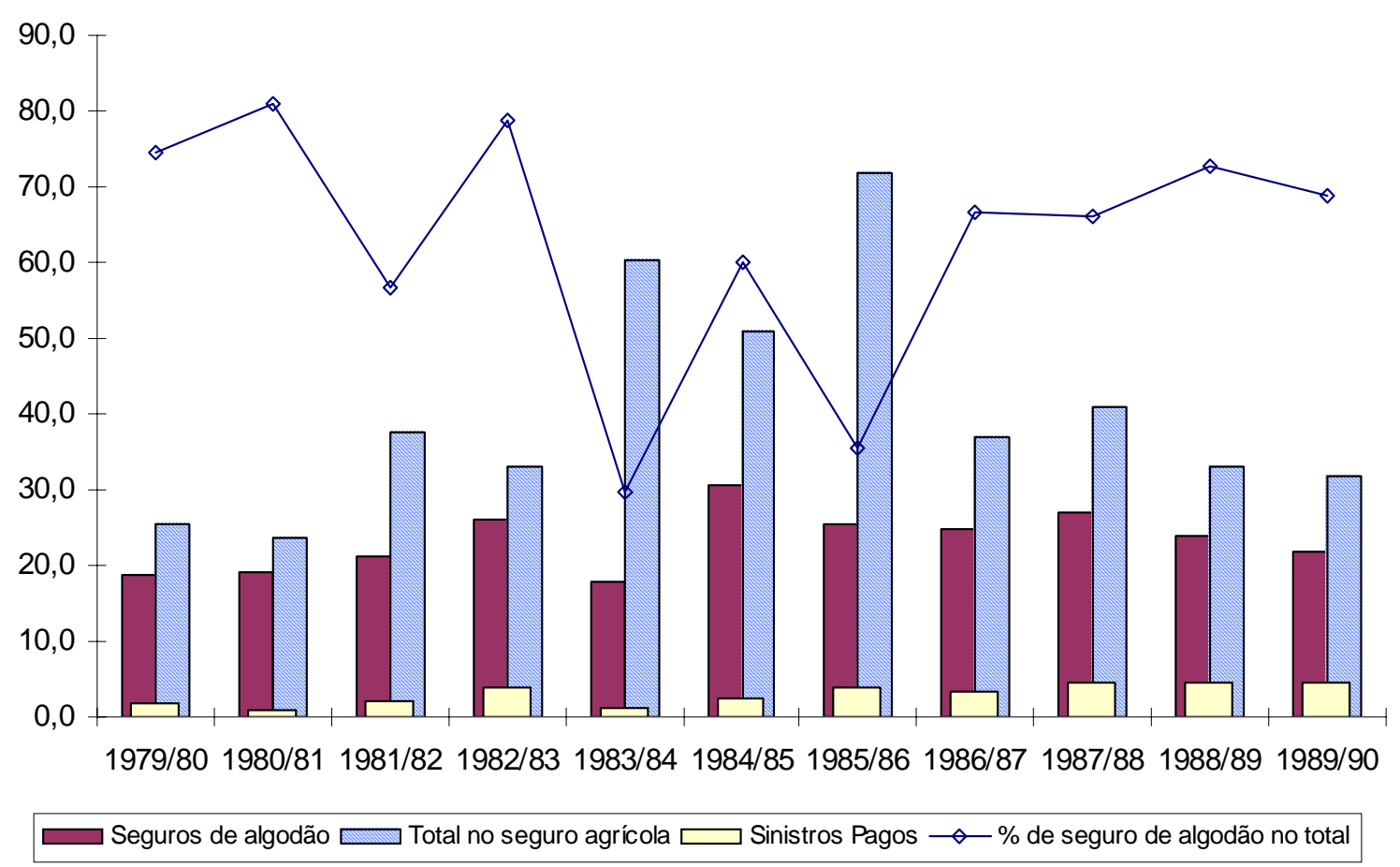

Figura 38 - Evolução do número de seguros realizados (mil unidades): total agrícola e seguro para o algodão, sinistros pagos e participação do algodão no tota, no período 1979/80 a 1989/90

Fonte: Cosesp (2002) $)^{84}$

De acordo com Martins (1991), a desvinculação do seguro obrigatório à compra da semente incluiu o algodão como uma modalidade de seguro agrícola oferecido de modo facultativo pela Cosesp.

Desse modo, até a safra 1989/90 o seguro para o algodão era ofertado com taxas diferenciadas, de acordo com o nível tecnológico. Para o nível A, a taxa era de 5\%, para o nível B, 6\% e, para o C, 7\%.

${ }^{84}$ Companhia de Seguros do Estado de São Paulo, São Paulo. Comunicação pessoal, 2002. 
Na safra seguinte, a companhia resolveu unificar as taxas, que se situaram no patamar de 5,5\%. Além disto, iniciou-se a cobertura contra cancro cítrico, com a participação da Bradesco Seguros, em regime de cosseguro com a Cosesp.

No ciclo 1991/92 , devido à extinção da obrigatoriedade da aquisição de seguro pelos produtores de algodão, novas taxas foram apresentadas ao mercado, diferenciadas regionalmente, que se situaram em um patamar médio de 7,5\%, de acordo com o risco característico de cada área.

Por exemplo, na região de Presidente Prudente, localizada no Oeste Paulista, a taxa era de 13\%, enquanto que em Campinas, São José do Rio Preto e Ribeirão Preto ${ }^{85}$ era bem menor, em torno de 4\%. Esta última, menor que a taxa vigente no seguro obrigatório no período, que era de 5,5\%, uniforme para todas as regiões produtoras.

Os resultados mostram que o índice de sinistralidade para o algodão foi maior do que 1 em quase em todos os anos, exceto nos ciclos agrícolas 1980/81 (0,77) e 1983/84 (0,84) (figura 39).

O índice médio ficou em 1,79 no período, atingindo o máximo em 1988/89 (3,18). Neste período, a diferença entre o total de sinistros pagos e o total de prêmios arrecadados foi mais do que o dobro do que o total de prêmios arrecadados.

Em 1990, os principais sinistros foram causados por fatores climáticos, como a seca e chuvas excessivas, responsáveis por pouco menos de 65\% do total (figura 40).

\footnotetext{
${ }^{85}$ Este município apresentava no período uma produtividade média em torno de 1.080 quilos/hectare, bem abaixo de municípios mais eficientes, em termos de produtividade, como, por exemplo, Campinas, São José do Rio Preto e Ribeirão Preto que apresentavam produtividade média ao redor de 1920 quilos/hectare.
} 


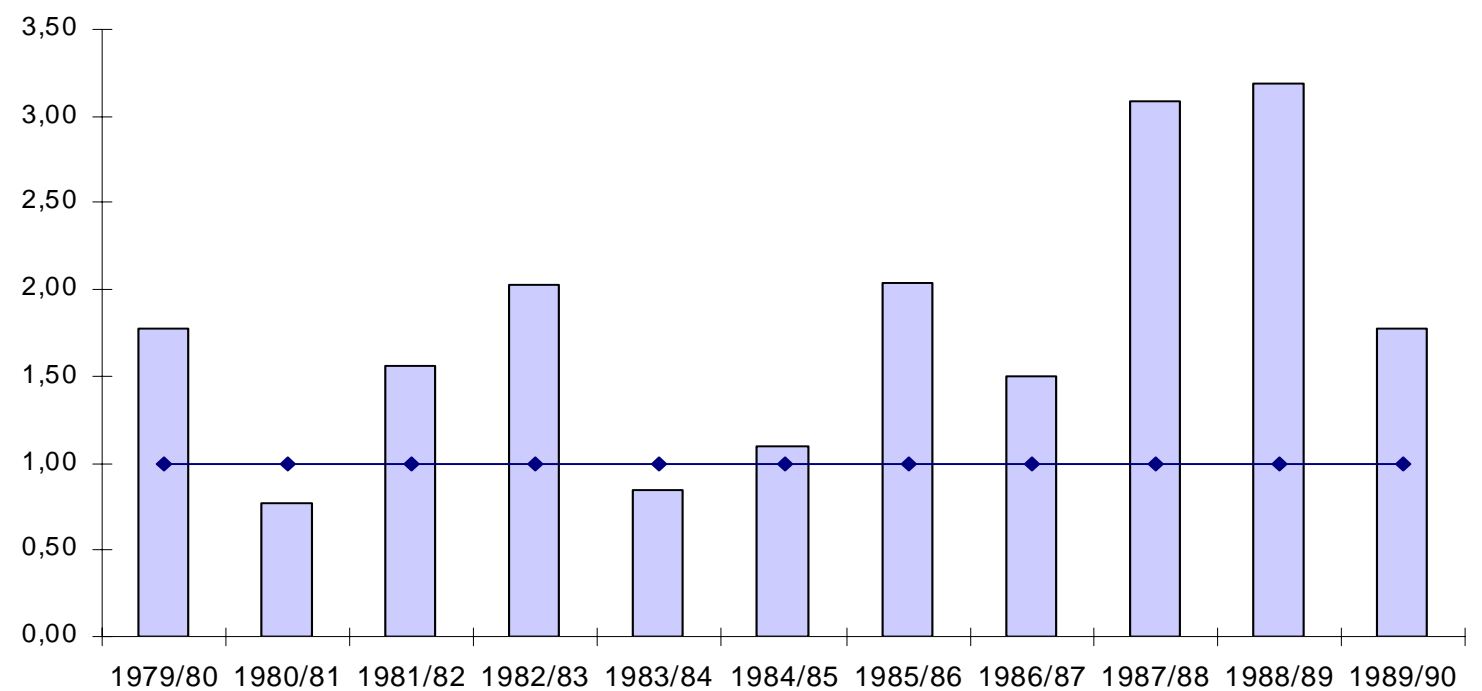

Figura 39 - Sinistralidade para a cultura algodoeira no período 1979/80 a 1989/90 Fonte: Cosesp (2002)

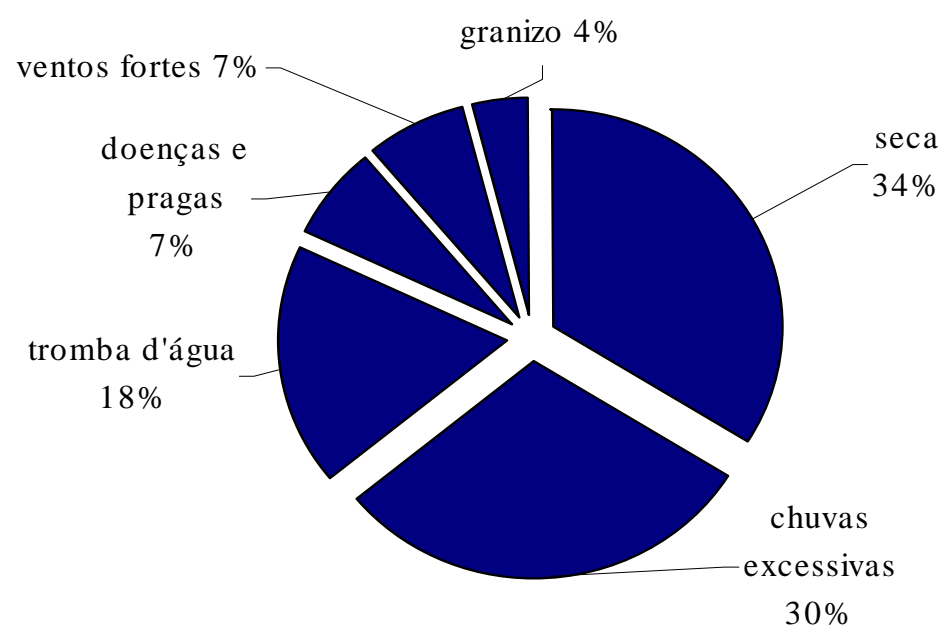

Figura 40 - Principais sinistros ocorridos em 1990

Fonte: Cosesp (2002) 
Na década de 90, com o fim da obrigatoriedade da aquisição de seguro pelos produtores de algodão, essa modalidade perdeu relativamente sua importância na carteira agrícola da Cosesp (Figura 41).

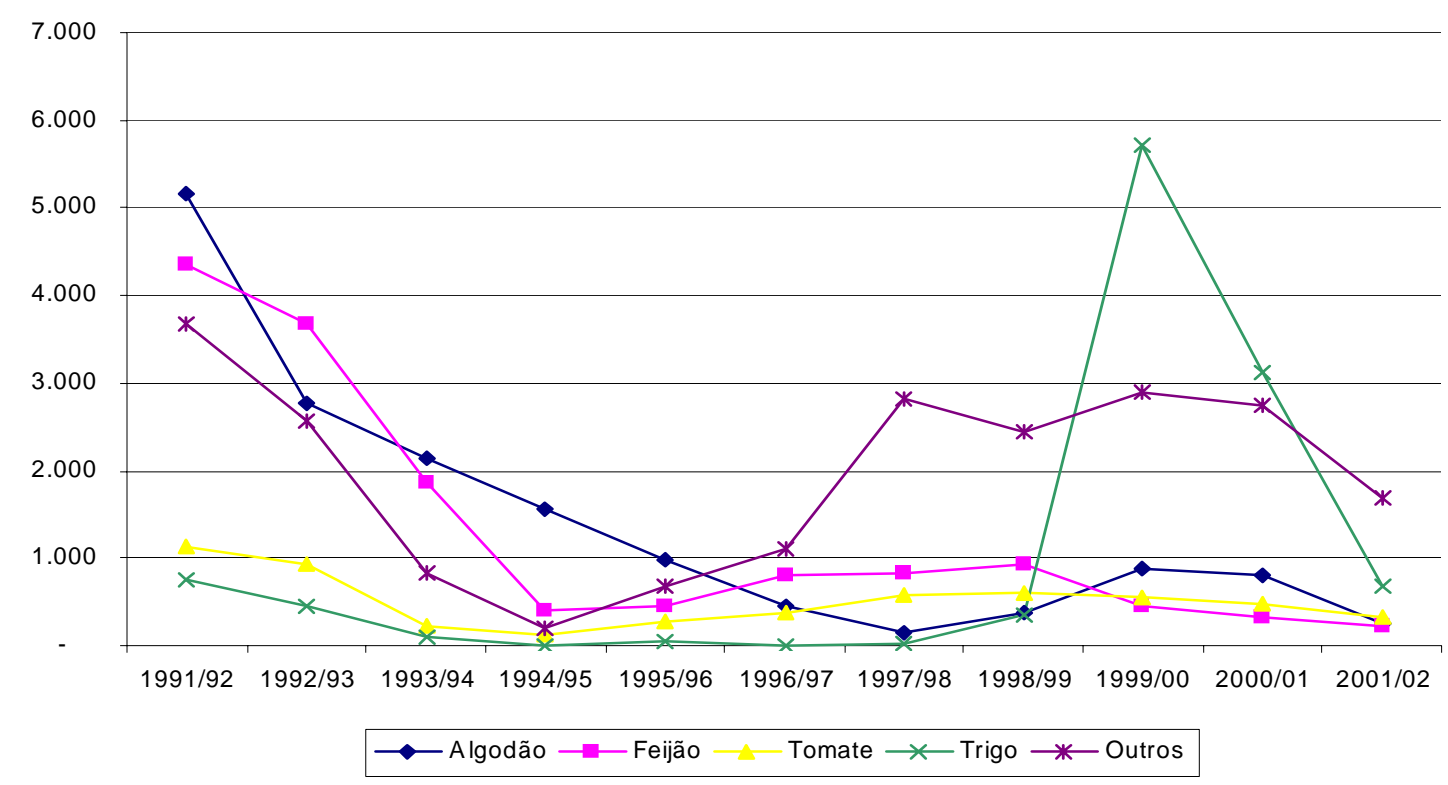

Figura 41 - Evolução do número de seguros realizados de algodão, feijão, tomate, trigo e outros no período 1991/92 a 2001/02

Fonte: Cosesp (2002)

Em 1991/92, foram realizados 5.167 seguros. Desde então, seguiu-se uma tendência de redução deste número chegando a 264 apólices contratadas em 2001/02. A partir de 1998/99, a Cosesp passou a cobrir a cultura do trigo no Paraná, que passou a ser o Estado mais importante em termos de número de seguros realizados nesta modalidade, até o ano-safra 2000/01, chegando ao valor máximo de 5.674 em 1999/00.

Durante toda a década de 90, o milho e a soja foram responsáveis por grande parte dos seguros realizados pela Cosesp, substituindo o algodão. A partir do 
ciclo agrícola 1997/98, a companhia ampliou suas atividades para o Estado do Paraná, para as culturas do milho e soja (Neto, 1997) ${ }^{86}$.

Essas duas modalidades corresponderam a pouco mais de $50 \%$ em 1991/92, aumentando significativamente suas participações, ao longo da década, chegando a 83,4\% em 2001/02 (Figura 42).

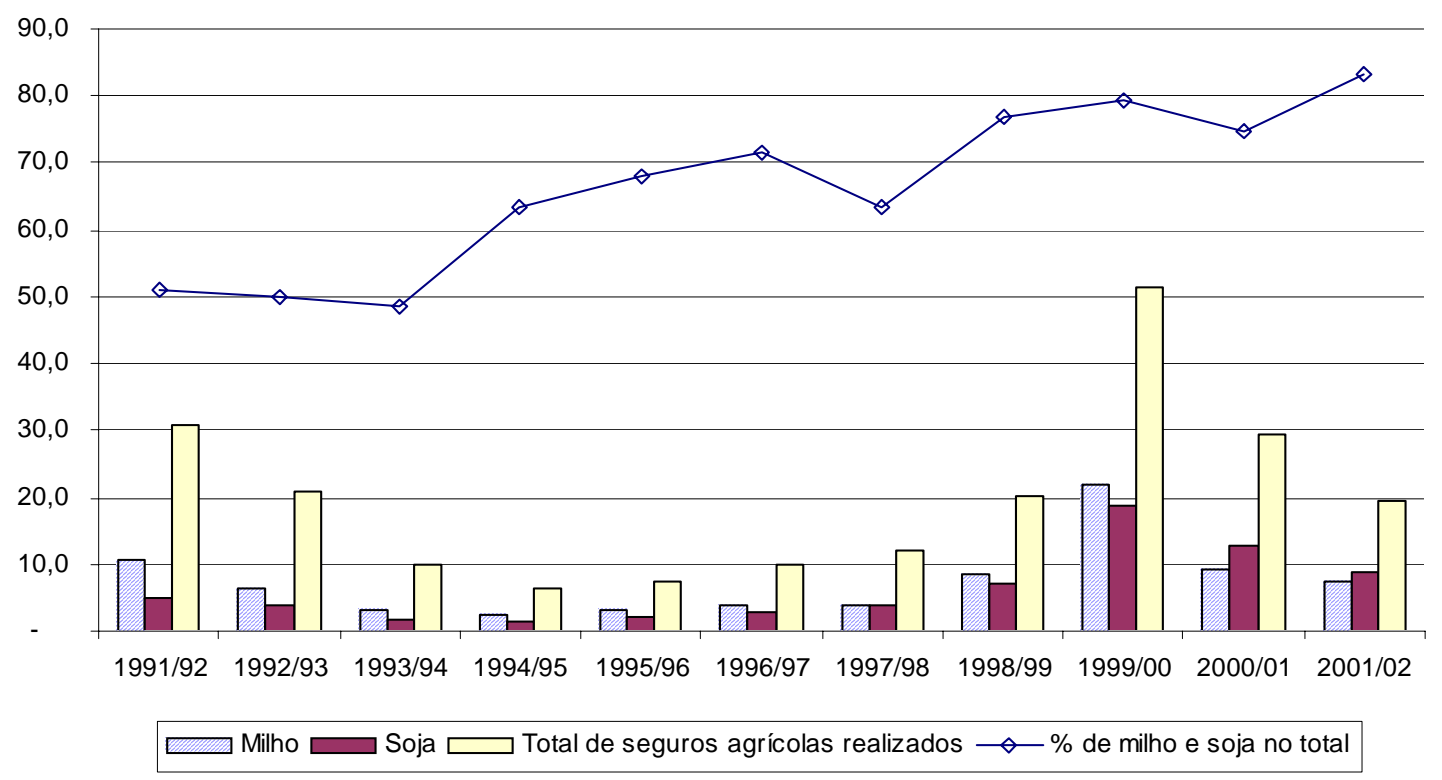

Figura 42 - Número de contratos (mil) de soja, milho e total e percentual de participação de milho e soja no total no período de 1991/92 a 2001/02

Fonte Cosesp (2002)

Além disso, inicialmente, o número de seguros realizados com o milho era maior que o seguro de soja. A partir de 1999/00, tal processo se inverteu.

As modalidades que mais contribuíram para a arrecadação de prêmios no período analisado foram, em termos médios, o milho (30,6\%), a soja (20,4\%), algodão

\footnotetext{
86 NETO, J.M.A. Melhor forma de proteger lavouras. http://www.Estado.estadao.com.br/jornal /suplem/agri/ 97/12/10/agri002.html (15 mar. 2003)
} 
$(17,7 \%)$ e feijão (8,8\%), conforme a figura 43. No ciclo agrícola 2001/02, o total de prêmios arrecadados chegou perto dos R 16 milhões.

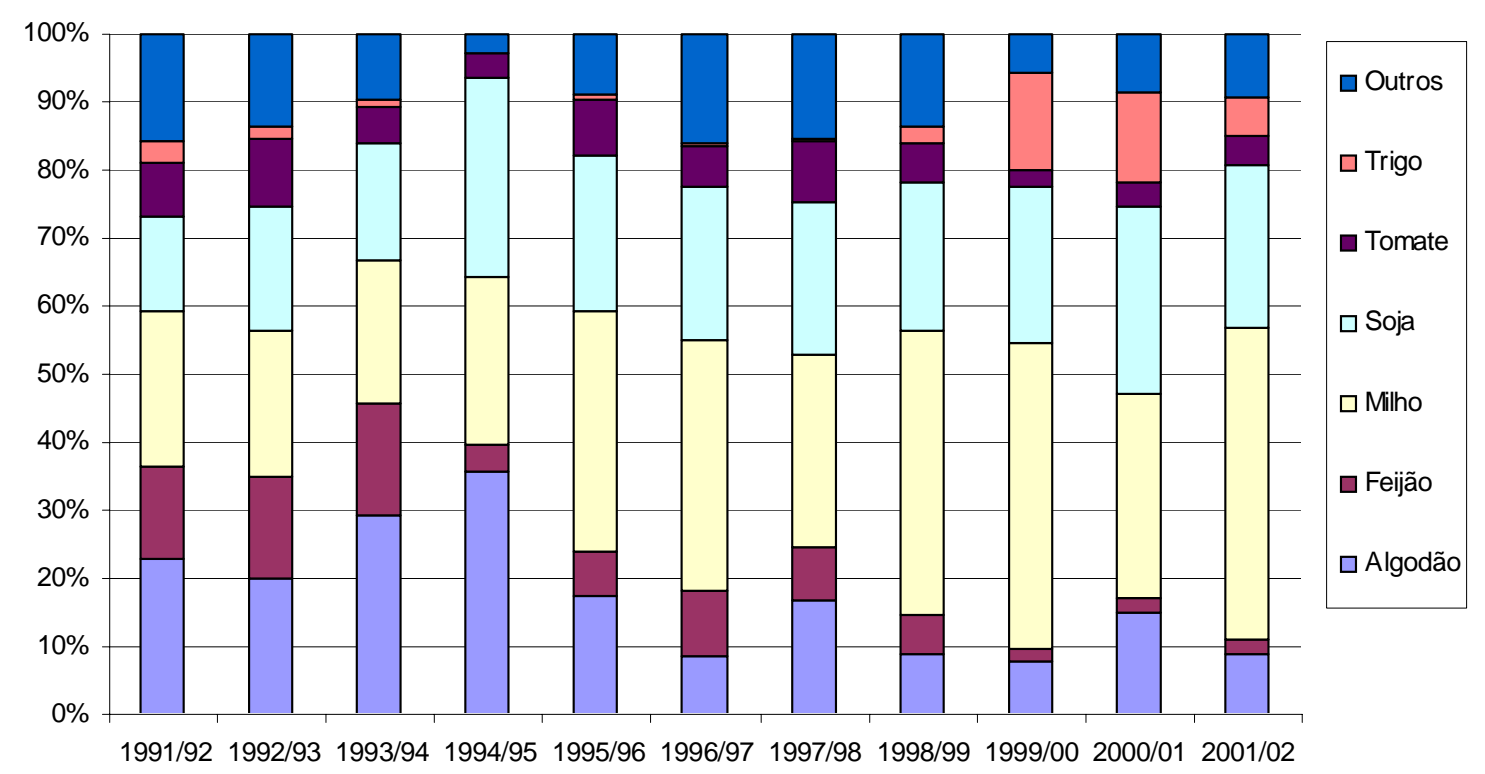

Figura 43 - Percentual de prêmio arrecadado, por modalidade, no período 1991/92 a 2001/02

Fonte: Cosesp (2002)

O número de sinistros aumentou no ciclo 1999/2000 devido à ocorrência de seca e geada que afetaram as culturas de inverno, principalmente no Estado do Paraná (figura 44). Neste período, cerca de 20 mil produtores tiveram suas lavouras afetadas.

A companhia passou por graves problemas de ressarcimento dos prejuízos nessa safra. O pagamento das indenizações foi atrasado, pois o Governo Federal remanejou os recursos do fundo para outras áreas econômicas.

Como medida assistencial, no final de 2000, aproximadamente R\$ 70 milhões foram repassados pelo Governo Federal ao fundo. Até maio de 2001, apenas 12 mil apólices tinham sido indenizadas, o restante aguardava a liberação de recursos. 


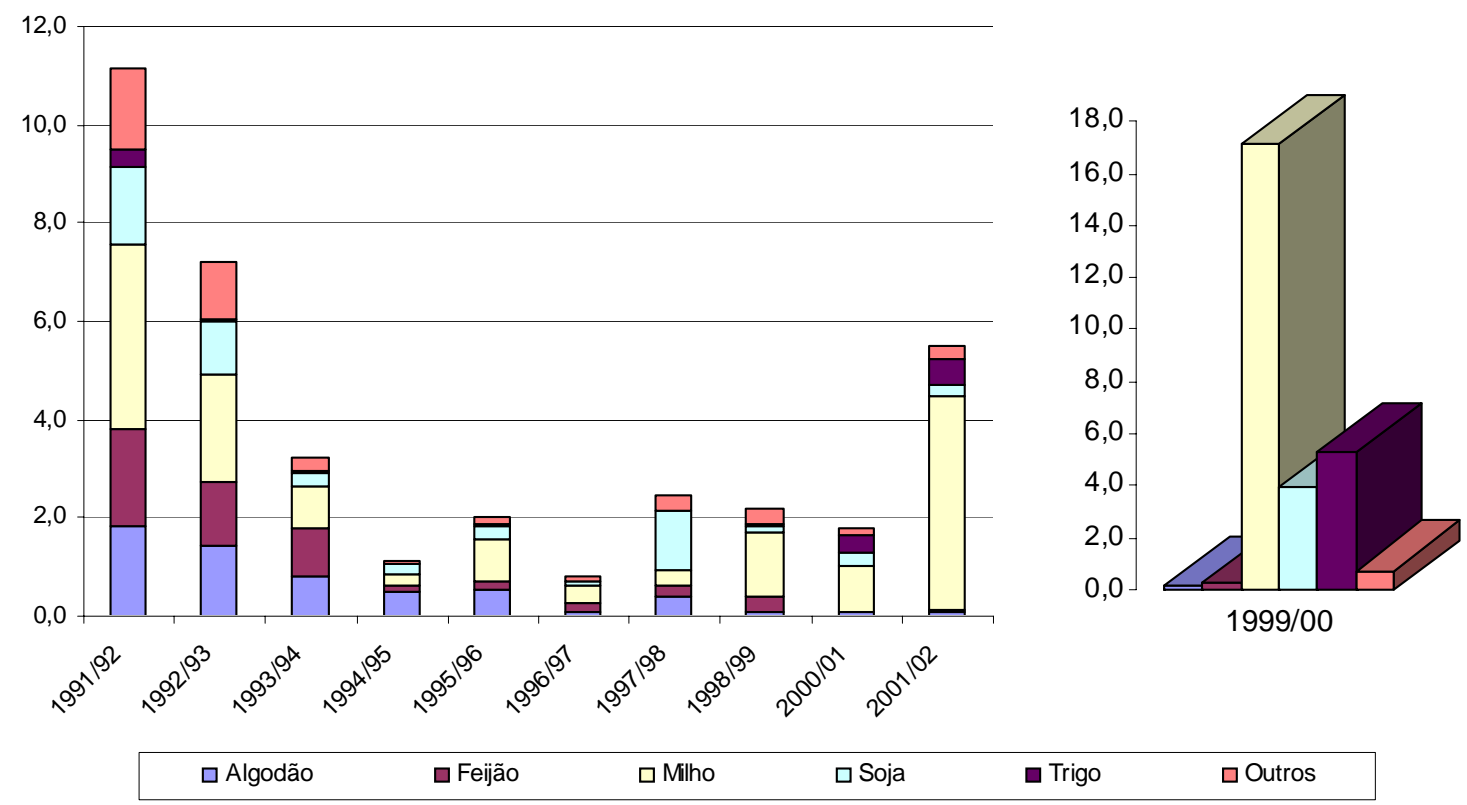

Figura 44 - Evolução do número de sinistros pagos (mil), por modalidade, no período 1991/92 a 2001/02

Fonte: Cosesp (2002)

Em relação à área segurada nota-se que, de modo geral, entre os ciclos 1991/92 e 1994/95, a área sofreu uma significativa redução. Posteriormente, seguiu-se uma tendência de aumento para o milho e soja, após a companhia ter expandido suas atividades para o Paraná, atingindo o máximo no ciclo 1999/00, que foi, respectivamente para o milho e para a soja, de aproximadamente 669 mil e 570 mil hectares (Figura 45).

Após a ocorrência do evento catastrófico ocorrido em 1999, a área segurada sofreu uma drástica redução, voltando a patamares verificados no início da década. 


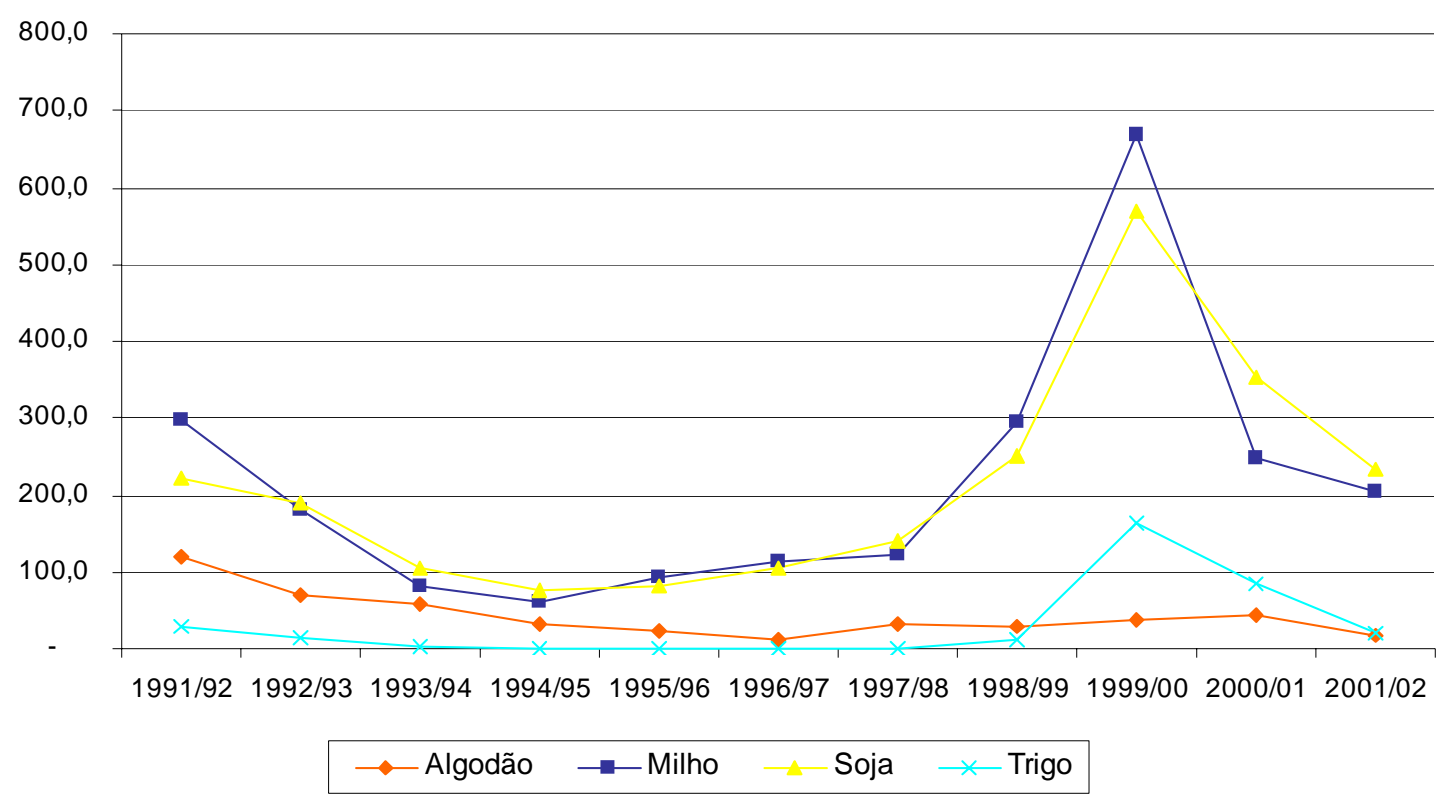

Figura 45 - Evolução da área segurada, por principais modalidades, em mil hectares, no período 1991/92 a 2001/02

Fonte: Cosesp (2002)

Em 1999/00, mais de 90\% da área segurada de milho e trigo foram sinistradas, totalizando pouco mais de R 108 milhões e R $\$ 30$ milhões em indenizações e correspondendo a 53\% e 65\% da importância segurada, respectivamente (Figura 46). 


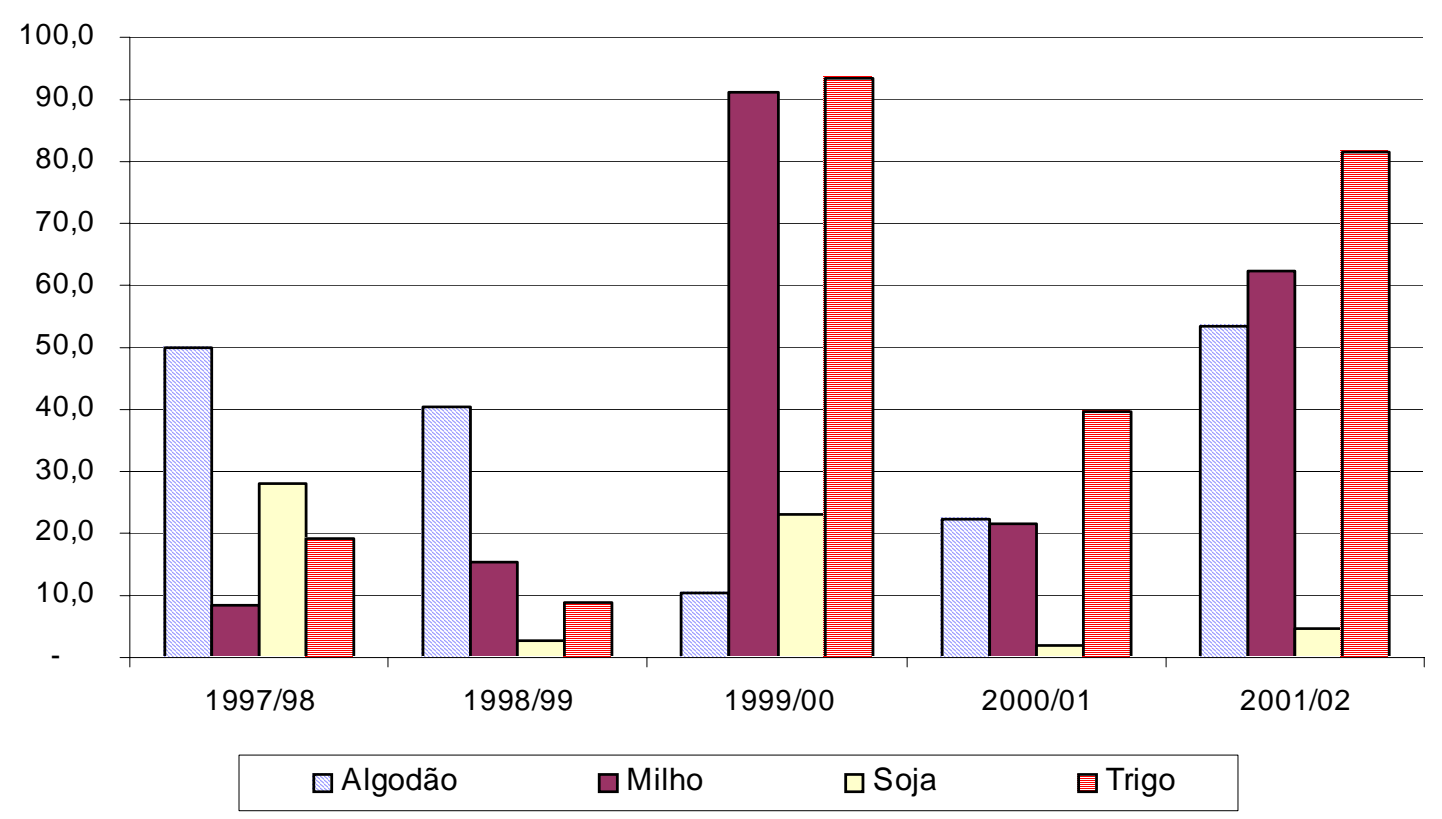

Figura 46 - Percentual da área sinistrada em relação à área segurada das respectivas culturas nos ciclos agrícolas de 1997/98 a 2001/02

Fonte: Cosesp (2002)

No período entre 1991/92 e 2001/02, o índice de sinistralidade foi menor do que a unidade em 6 dos 11 ciclos agrícolas, apresentando um valor médio de 1,44. No ciclo 1999/00 o índice apresentou um valor elevado $(4,9)$ em função da ocorrência do evento catastrófico (Figura 47). 


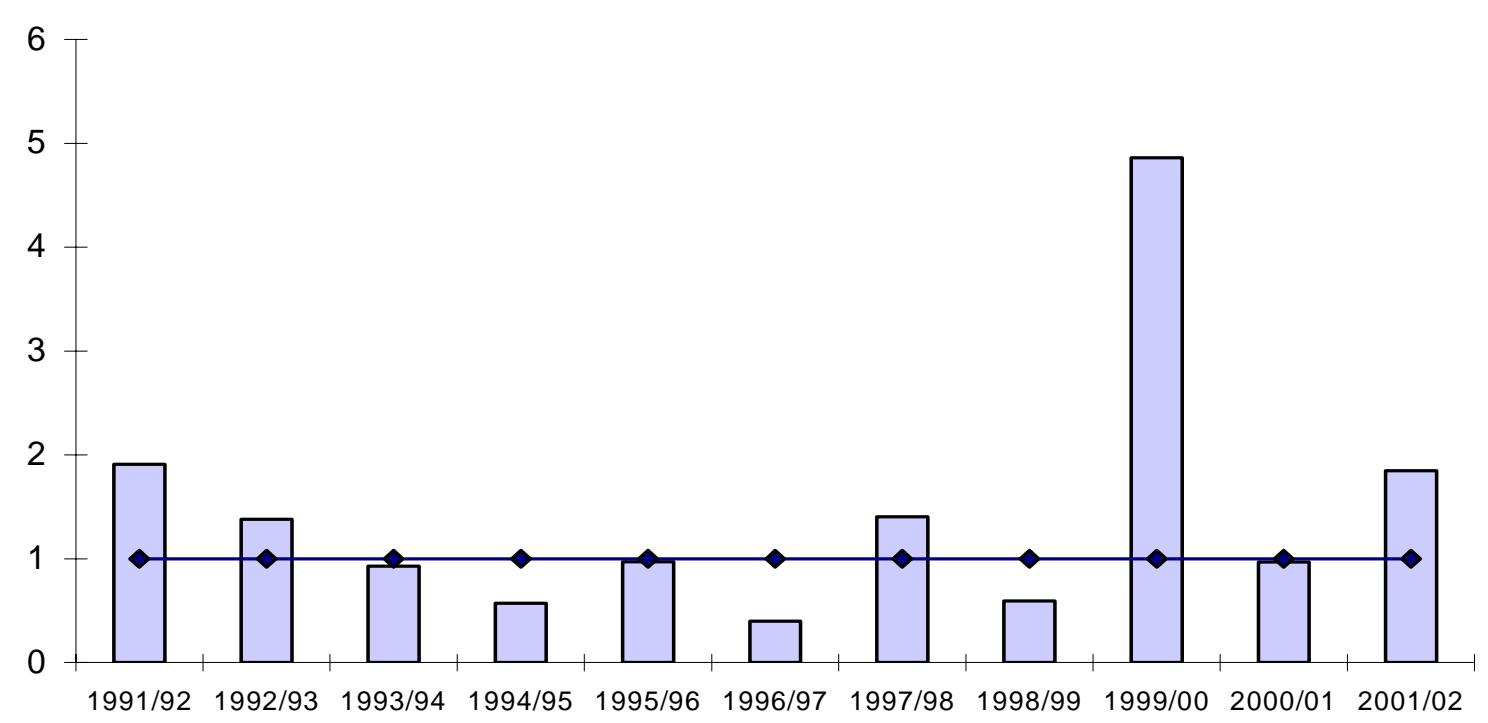

Figura 47 - Evolução do índice de sinistralidade da carteira agrícola da Cosesp no período 1991/92 a 2001/02

Fonte: Cosesp (2002)

Atualmente, a Cosesp oferece seus serviços a todos os produtores pertencentes ou não ao Sistema Nacional de Crédito Rural cobrindo, neste último caso, as operações de custeio e das parcelas de recursos próprios ou financiados.

A carteira de seguro rural da companhia compreende as seguintes modalidades: seguro agrícola (que pode ser vinculado ao crédito ou facultativo), seguro de animais, seguro de florestas, seguro facultativo porteira fechada e penhor rural, vinculado ao crédito, além do seguro de auto, vida e moradia rural.

O seguro agrícola cobre os seguintes riscos (compreensivos), do plantio à colheita: chuvas excessivas, geada, granizo, incêndio e raio, seca, tromba d’água, variação excessiva de temperatura e ventos fortes e frios.

Pode-se requerer o seguro para cobrir especificamente o granizo (GR) ou granizo e geada (GRG) ou granizo, geada e chuvas excessivas (GRGCE). Na figura 48, abaixo, verifica-se as culturas seguradas e os riscos cobertos, para o ciclo agrícola 2002/03. 


\begin{tabular}{|c|c|c|c|c|c|c|c|c|c|}
\hline Culturas & $\begin{array}{c}\text { Com- } \\
\text { preensiva }\end{array}$ & GR & GRG & GRGCE & Culturas & $\begin{array}{c}\text { Com- } \\
\text { preensiva }\end{array}$ & GR & GRG & GRGCE \\
\hline Abacaxi & $\mathrm{x}$ & & & & Goiaba & & $\mathrm{x}$ & $\mathrm{x}$ & \\
\hline Alface & & & & $\mathrm{x}$ & \begin{tabular}{|l|} 
Laranja \\
\end{tabular} & & $\mathrm{x}$ & $\mathrm{x}$ & \\
\hline Algodão & $X$ & & & & Maçã & & $\mathrm{x}$ & $\mathrm{x}$ & \\
\hline Alho & & & & $\mathrm{x}$ & Mandioca & $\mathrm{x}$ & & & \\
\hline Ameixa & & $\mathrm{x}$ & $\mathrm{x}$ & & Manga & & $\mathrm{x}$ & $\mathrm{x}$ & \\
\hline Amendoim & $\mathrm{x}$ & & & & Maracujá & & $\mathrm{x}$ & $\mathrm{x}$ & \\
\hline Arroz irrigado & $\mathrm{x}$ & & & & Milho & $\mathrm{x}$ & & & \\
\hline Batata & $\mathrm{x}$ & & & $\mathrm{x}$ & Morango & & & & $\mathrm{x}$ \\
\hline Batata-doce & & & & $\mathrm{x}$ & Nectarina & & $\mathrm{x}$ & $\mathrm{x}$ & \\
\hline Berinjela & & & & $\mathrm{x}$ & \begin{tabular}{|l|} 
Pepino \\
\end{tabular} & & & & $\mathrm{x}$ \\
\hline Beterraba & & & & $\mathrm{x}$ & Pêssego & & $\mathrm{x}$ & $\mathrm{x}$ & \\
\hline Café & & $\mathrm{x}$ & $\mathrm{x}$ & & Pimentão & & & & $\mathrm{x}$ \\
\hline Cana-de-açúcar & $\mathrm{x}$ & & & & Repolho & & & & $\mathrm{x}$ \\
\hline Caqui & & $\mathrm{x}$ & $\mathrm{x}$ & & Soja & $\mathrm{x}$ & & & \\
\hline Cebola & & & & $\mathrm{x}$ & Tomate & & & & $\mathrm{x}$ \\
\hline Cenoura & & $\mathrm{x}$ & $\mathrm{x}$ & $\mathrm{x}$ & Trigo & $\mathrm{x}$ & & & \\
\hline Couve-flor & & & & $\mathrm{x}$ & Uva & & $\mathrm{x}$ & & \\
\hline Feijão & $\mathrm{x}$ & & & & \begin{tabular}{|l|} 
Vagem \\
\end{tabular} & $\mathrm{x}$ & & & $x$ \\
\hline
\end{tabular}

Figura 48 - Culturas seguradas e riscos cobertos

Fonte: Cosesp (2002)

Quando um produtor contrata um seguro, a inspeção de risco é realizada, obrigatoriamente, somente no caso em que a cultura já estiver implantada. Nesta situação, o valor do prêmio será acrescido de $0,7 \%$ à taxa básica.

$\mathrm{Na}$ ocorrência do sinistro, o segurado deve comunicar a seguradora imediatamente. $\mathrm{O}$ aviso de sinistro deve conter todas as informações necessárias para caracterizar e estimar os prejuízos. Posteriormente, o segurado ou seu preposto ${ }^{87}$ deve acompanhar a inspeção de danos pelo perito com o objetivo de realizar o levantamento dos prejuízos e assinar o laudo de inspeção de danos conjuntamente com os peritos. Baseado no laudo, a seguradora providenciará a liquidação dos sinistros.

\footnotetext{
${ }^{87}$ Pessoa física ou jurídica indicada pelo segurado que acompanha o perito nas inspeções e assina os laudos.
} 
No caso de sinistro com perda total, seja na área total ou parcial, é realizado apenas um único laudo de ocorrência. Quando ocorre sinistro com perda parcial são realizados dois laudos de ocorrência. O primeiro, na época da ocorrência do sinistro, constando a estimativa dos prejuízos, e o segundo, antes da colheita.

No caso de perda total, no todo ou em parte da área, o percentual de cobertura pode atingir até a totalidade do financiamento ou valor de custeio, de acordo com estágio de desenvolvimento da cultura.

Se houver perda parcial na colheita, após a inspeção e o laudo técnico aprovado, a indenização é calculada multiplicando-se o valor segurado pela perda parcial deduzido o percentual correspondente à franquia, que varia em função do nível de tecnologia utilizado pelo segurado.

Dessa maneira, aqueles que empregam o nível de tecnologia A estão sujeitos a uma franquia de 6\%, para o nível B, 8\% e, para o C, $10 \%$.

No processo de indenização de sinistros agrícolas, as vistorias são realizadas na presença do produtor ou segurado e os laudos são feitos gratuitamente pela companhia, sendo o pagamento da indenização realizado no máximo em 30 dias (Rodrigues, 1998).

Existe um sistema de bonificação para os Estados de São Paulo e Paraná, para as culturas de milho e soja. Caso, para a mesma cultura, o segurado não tenha sido indenizado no ciclo anterior, haverá um desconto de 10\% para seguros contratados em tecnologia A, 5\% para seguros contratados em tecnologia B e C.

A tabela 6, abaixo, mostra os percentuais retidos, ressegurados no IRB e cossegurados para os diferentes ramos pela Cosesp. 
Tabela 6. Resseguros e cosseguros retidos

\begin{tabular}{|c|c|c|c|}
\hline \multirow{2}{*}{ Ramos } & Cosesp (retenção) & IRB Resseguros & Cosseguro \\
\hline & \multicolumn{3}{|c|}{$\%$} \\
\hline Agrícola & 54 & 30 & 16 \\
\hline Penhor Rural & 64 & 20 & 16 \\
\hline Porteira Fechada & 64 & 20 & 16 \\
\hline Florestas & 64 & 20 & 16 \\
\hline Animais & 64 & 20 & 16 \\
\hline
\end{tabular}

Fonte: Rodrigues (1998)

O seguro floresta garante uma indenização ao proprietário pelos prejuízos causados às florestas inscritas e caracterizadas nas condições gerais da apólice.

O contrato cobre espécies florestais introduzidas e adaptadas ao Brasil (como Pinus e Eucaliptus), espécies nativas do Brasil (implantadas para exploração) e matas naturais de preservação.

Existe uma classificação por três tipos categorias: A, compreende a área ou subdivisões internas de até 25 hectares; categoria B, com área entre 25 hectares a 50 hectares, e C, com área maior do que 50 hectares.

O segurado é isento de Imposto (IOF) e pode beneficiar-se de taxas reduzidas variando de $0,80 \%$ a 2,80 \%, podendo ainda ser concedido desconto de até 30\% sobre a taxa básica.

O seguro de animais cobre as seguintes espécies: bovinos, bubalinos, eqüinos, asininos, ovinos e caprinos. Ele tem por objetivo garantir o pagamento de uma indenização em caso de morte do animal segurado. Além disto, o seguro oferece cobertura para transporte, extensão da cobertura a território estrangeiro, premunição, coleta de sêmen, salto e adestramento, provas funcionais, hipismo rural, pólo, trote, vaquejada, reprodução e crias em geral.

Também são oferecidas coberturas especiais como transporte, exposição, mostra e leilão, importação com extensão de vida em território nacional.

Os riscos cobertos e excluídos são apresentados na figura 49, abaixo: 


\begin{tabular}{|c|c|}
\hline Cobertos & Excluídos \\
\hline Incêndio & Inundação e/ou alagamento \\
\hline Chuvas excessivas e tromba d'água & Formigas e cupins \\
\hline Ventos frios acima de $45 \mathrm{~km} / \mathrm{h}$ & Ensaios ou experimentos de qualquer natureza \\
\hline Granizo e geada & \multirow{2}{*}{$\begin{array}{l}\text { Atos ilícitos, negligência, culpa ou dolo do segurado } \\
\text { e seus pressupostos }\end{array}$} \\
\hline Seca & \\
\hline Raio & Frustração de safra \\
\hline Doenças sem método de combate & \multirow{2}{*}{$\begin{array}{l}\text { Incêndio resultante de queimadas propositadas para } \\
\text { limpeza de terreno pelo segurado }\end{array}$} \\
\hline $\begin{array}{l}\text { Infestação generalizada de pragas, desde que } \\
\text { não decorrentes de falta de práticas adequadas } \\
\text { de combate }\end{array}$ & \\
\hline
\end{tabular}

Figura 49 - Riscos cobertos e excluídos

Fonte: Rodrigues (1998)

Os riscos cobertos e não cobertos pelo seguro estão na figura 50:

\begin{tabular}{|l|l|}
\hline Riscos cobertos & Riscos excluídos \\
\hline Moléstia de caráter não epidêmico & Fuga, roubo, furto ou desaparecimento \\
\hline Acidente, raio, insolação & Maus-tratos \\
\hline $\begin{array}{l}\text { Envenenamento, intoxicação e ingestão de corpos } \\
\text { acidentais }\end{array}$ & $\begin{array}{l}\text { Acidente, quando o animal se encontrar solto ou } \\
\text { abandonado em estrada de ferro ou rodagem }\end{array}$ \\
\hline Eletrocussão & Não-cumprimento das normas zootécnicas \\
\hline Asfixia por sufocamento ou submersão & Riscos catastróficos e congêneres \\
\hline Luta, ataque, mordedura de animais & Perda de função do animal \\
\cline { 1 - 2 } $\begin{array}{l}\text { Parto, abortamento (exceto para fêmeas doadoras de } \\
\text { embriões e/ou em premunição) }\end{array}$ & Ensaios ou experiências de qualquer natureza \\
\cline { 1 - 2 } $\begin{array}{l}\text { Inoculações vacinais e outras medidas de ordem } \\
\text { profilática, necessárias à salvaguarda da saúde do } \\
\text { animal }\end{array}$ & \\
\cline { 1 - 2 } $\begin{array}{l}\text { Babesiose e anaplasmose, quando se tratar de bovinos } \\
\text { nascidos no País e nos casos de animais importados, } \\
\text { desde que tenham sido submetidos à premunição e } \\
\text { contratado cobertura adicional para esta finalidade }\end{array}$ & \\
\hline
\end{tabular}

Figura 50 - Riscos cobertos e excluídos

Fonte: Rodrigues (1998) 
A modalidade de seguro penhor rural, atrelado ao crédito, garante a proteção dos seguintes bens: benfeitorias, produtos agropecuários, máquinas e implementos agrícolas, veículos rurais, sacarias e embalagens.

O seguro facultativo porteira fechada de bens, benfeitorias e produtos agropecuários não vinculados ao financiamento segura os seguintes objetos, com as respectivas taxas anuais (Figura 51).

\begin{tabular}{|l|c|}
\hline \multicolumn{1}{|c|}{ Objetos Segurados } & $\begin{array}{c}\text { Taxa anual } \\
\%\end{array}$ \\
\hline Objetos agropecuários colhidos ou abatidos, beneficiados, transformados ou não & 0,35 \\
\hline Benfeitorias - (obs: cobre somente a construção) & 0,50 \\
\hline Galpões de granja (classificação: benfeitoria) & 1,00 \\
\hline $\begin{array}{l}\text { Conteúdo de granja (máquinas e implementos) Ex: bebedouros, campânulas, } \\
\text { comedouros }\end{array}$ & 1,00 \\
\hline Estufas (considerado como benfeitoria) & 1,00 \\
\hline Sacarias (considerado como benfeitoria) & 0,35 \\
\hline Mudas e sementes, corretivos, fertilizantes, defensivos, rações & 0,35 \\
\hline Máquinas e implementos agrícolas & 1,00 \\
\hline Veículos rurais de carga até 7 toneladas & 3,00 \\
\hline Veículos rurais de carga de mais de 7 toneladas & 4,00 \\
\hline Veículos rurais mistos & 10,00 \\
\hline
\end{tabular}

Figura 51 - Bens segurados e taxas anuais (\%) do seguro porteira fechada Fonte: Rodrigues (1998)

A cobertura se estende aos seguintes casos: incêndio, explosão, raio e suas conseqüências, vendaval, desmoronamento total ou parcial de construção, tremores de terra e granizo. No caso de veículos rurais, colisão, capotagem, defeitos mecânicos ou elétricos, desgaste pelo uso, roubo ou furto total.

Para os produtos agropecuários incluem-se, ainda, perdas e danos causados por acidentes com o veículo transportador, em que o seguro cobre as despesas 
com buscas para localização e recuperação do bem segurado. Também cobre o socorro e transporte do veículo do local do acidente para a oficina mecânica.

O seguro de auto-rural: destinado aos produtores rurais, engenheiros agrônomos, médicos veterinários e demais técnicos ligados ao setor agropecuário. Envolve cobertura para automóveis de passeio e veículos com capacidade de carga de até uma tonelada.

O seguro de vida rural oferece cobertura para morte por qualquer causa, indenização especial por acidente, indenização permanente, total ou parcial por acidente, invalidez total por doença, inclusão de cônjuge na forma automática, auxílio cesta-básica e auxílio-educação.

O seguro moradia rural abrange as seguintes coberturas: incêndio, vendaval, responsabilidade civil, danos elétricos, roubo e furto qualificado.

Para a safra 2003/04, o governo estadual iniciou um programa de incentivo à participação no seguro agrícola, o Projeto Estadual de Subvenção do Prêmio do Seguro Rural.

O projeto subsidia 50\% do prêmio pago pelo produtor e é ofertado por seguradoras devidamente credenciadas no programa. Inicialmente, o projeto cobria cinco culturas: laranja, banana, feijão, uva e milho em 219 municípios do Estado.

Para o ciclo 2004/05, 14 novas culturas foram incorporadas ao programa: algodão, amendoim, arroz irrigado, mandioca, soja, sorgo, trigo, abacaxi, ameixa, caqui, goiaba, maracujá, pêssego e repolho.

A extensão territorial também aumentou. Os municípios abrangidos atualmente chegam a 534. O valor dos recursos destinados à subvenção também cresceram, passando de $\mathrm{R}$ \$ 10 para R $\$ 20$ milhões. 


\subsubsection{O seguro rural estatal em outros Estados}

\subsection{A experiência de Minas Gerais}

Além do Estado de São Paulo, que iniciou suas atividades no ramo de seguro rural em 1938, o seguro rural operado por seguradoras estatais foi exercido em Minas Gerais, Rio de Janeiro e Rio Grande do Sul.

No Estado de Minas Gerais, o Decreto n¹3.860, de 31 de agosto de 1971, estabeleceu que as operações de seguro agrícola no Estado de Minas Gerais seriam conduzidas pela Companhia de Seguros de Minas Gerais (Cosemig), e que, posteriormente, foram submetidas ao CNSP.

No ano seguinte, pela Resolução $\mathrm{n}^{0}$ 5, de 27 de junho de 1972, foram regulamentadas as operações de seguro agrícola no Estado. No ano de 1974, a companhia passou a denominar-se Bemge - Companhia de Seguros de Minas Gerais.

As apólices emitidas nos anos de 1974/75 foram aplicadas às culturas de algodão, amendoim, arroz, feijão, milho, soja, sorgo e trigo por meio do Banco de Desenvolvimento de Minas Gerais (BDMG).

O seguro teve caráter obrigatório e funcionou conjuntamente com a aplicação do crédito rural integrado em regiões pré-estabelecidas, sendo a forma facultativa permitida após estudos referentes à técnica de plantio.

O suporte técnico foi designado à Associação de Crédito e Assistência Rural, que cobriu aproximadamente 94\% dos municípios do Estado, posteriormente, transformou-se na Empresa de Assistência Técnica e Extensão Rural do Estado de Minas Gerais (Emater-MG).

A tabela 7 fornece algumas estatísticas sobre a operação de seguro agrícola realizado pelo BDMG nos anos de 1974/75. Nota-se, neste período, que o índice de sinistralidade I/P foi muito elevado, ou seja, houve uma disparidade muito grande entre as indenizações pagas e os prêmios arrecadados (Caffagni, 1998; Formiga, 1983). 
Tabela 7. Dados estatísticos referentes aos seguros oferecidos pela Cosemig, no período de $1974 / 75$

\begin{tabular}{lr}
\hline Área segurada, em hectares & 17.698 \\
Área sinistrada, em hectares & 4.169 \\
Prêmios arrecadados (P), em cruzeiros (Cr\$) & 497.000 \\
Indenizações pagas (I), em cruzeiros (Cr\$) & 3.185 .000 \\
Índice de sinistralidade (I/P) & 6,41 \\
\hline
\end{tabular}

Fonte: IRB, extraído de Formiga (1983), adaptado pelo autor

Segundo Soma Jr. (1992), na safra agrícola 1991/92 a Bemge realizou aproximadamente mil contratos cobrindo uma área de 120 mil hectares de cereais, algodão e olerícolas nas regiões do Triângulo Mineiro e Alto do Paraíba, no oeste de Minas. Neste ano, as indenizações foram elevadas com um índice de sinistralidade próximo de 3.

\subsection{Rio de Janeiro}

A Resolução $\mathrm{n}^{0}$ 15, de 28 de junho de 1976, do Conselho Nacional de Seguros Privados (CNSP), estabeleceu as diretrizes básicas para a operacionalização do seguro rural no Estado do Rio de Janeiro. Mas foi apenas em 1989 que o seguro rural, por meio da carteira rural do Banco Estadual do Rio de Janeiro, Banerj Seguros, foi realizado.

O descontentamento dos produtores deste Estado com o Proagro, incentivou a criação de um seguro rural pelo banco. Conjuntamente com a Emater-RJ era realizada uma vistoria que averiguava as condições na propriedade do requerente, tais como condições da cultura, nível tecnológico, qualidade da terra e a adequação do produto à região onde está sendo cultivado. 
O seguro cobria prejuízos decorrentes de incêndio, explosão, raio e suas conseqüências, vendaval (ventos com velocidade superior ou igual a $54 \mathrm{~km} / \mathrm{h}$ ), granizo, tremores de terra, máquinas e implementos agrícolas, veículos rurais mistos ou de carga, inundação, alagamento ou qualquer dano causado por água, doenças, pragas, variação excessiva da temperatura, geada e seca.

A carteira abrangia 25 culturas, entre olerícolas e cereais. As taxas do seguro variavam de $1,5 \%$ a $10 \%$, conforme a cultura e, em caso de sinistro, era cobrada uma franquia de $10 \%$ sobre o valor da importância segurada, sendo que, quando ocorria perda total, o segurado ficava isento de seu pagamento (Clapp, 1989; Souza, 1990).

\subsection{Rio Grande do Sul}

O seguro rural no Estado do Rio Grande do Sul foi implementado em caráter experimental por meio da resolução nº 10, de 14 de maio de 1978, do CNSP. Até o ano de 1997, o seguro no Estado era explorado pela Companhia União de Seguros Gerais, que tinha autorização da Susep para realizá-lo.

A companhia foi privatizada em 1997, encerrando suas atividades nesse ramo de seguro. Dois anos mais tarde, em 1999, por meio da Lei $\mathrm{n}^{0} 11.352$, foi regulamentado o Sistema Estadual de Seguro Agrícola e o Fundo Estadual de Seguro Agrícola (Fesag). Foram disponibilizados R\$ 9,4 milhões para a implementação do seguro em 2000.

O programa contará com recursos do Fundo Rotativo de Emergência, contribuição dos prêmios dos agricultores, recursos orçamentários, recursos do Governo Federal e de fontes internacionais (Baldi, 2001) ${ }^{88}$.

O programa é subsidiado e operacionalizado por meio do Banco de Estado do Rio Grande do Sul S.A. (Banrisul), seguradoras, prefeituras e entidades

\footnotetext{
${ }^{88}$ BALDI, N. Força sindical aposta em fundo de pensão. http://www.gazetamercantil.com.br (12 mar. 2003b)
} 
ligadas aos produtores rurais, sob coordenação da Secretaria de Agricultura e Abastecimento.

O Conselho de Administração do Seguro ${ }^{89}$ estabelece as diretrizes do programa, que tem o principal objetivo de proteção à renda dos produtores familiares, devido à ocorrência excesso de chuvas, secas, geadas, nevascas, ventos e raios.

O programa opera com três tipos de seguro, que varia de acordo com o público-alvo e o montante de subsídio: o seguro agrícola básico (SAB); o seguro agrícola solidário (SAS), operado por entidades de produtores, como por exemplo, sindicatos, cooperativas e associações, subsidiados em 50\% do custo pelo governo; e, o seguro comercial.

O primeiro é voltado para o produtor de milho que opera com o Programa Troca-Troca de Sementes ${ }^{90}$, com custo subsidiado em $90 \%$ pelo governo estadual e cobrindo todas as regiões do Estado.

A contratação do seguro é realizada no momento em que o produtor adquire a semente no sindicato ou na prefeitura sendo o pagamento posterior à colheita, tendo como referência sacas de milho.

O valor segurado máximo é de R\$ 1 mil para quem obtém sementes variedade e R\$ 800 para aqueles que optam por híbridos, variando de acordo com a quantidade adquirida.

O segundo tipo oferece subsídio de $50 \%$ aos produtores com até 10 hectares cultivados de milho e 2 hectares de uva. Dentro destas condições existem 370 mil propriedades no Estado, mas apenas 25 mil participaram do programa em 2001.

Para a cultura do milho, o limite do subsídio é de R\$ 25 por hectare e R\$ 250 por produtor. Aqueles que possuírem área cultivada maior que 10 hectares podem segurar a área adicional, mas sem subsídio. Para a cultura da uva, o limite é de R\$ 250

\footnotetext{
89 Formado por representantes da Secretaria da Agricultura, Secretaria da Fazenda, Empresa de Assistência Técnica e Extensão Rural (Emater), Banrisul, Federação da Agricultura do Estado do Rio Grande do sul (Farsul), Federação das Cooperativas Agrícolas de Santa Catarina (Fecoagro), Cooperativa Central dos Assentamentos do Rio Grande do Sul (Coceargs), Federação dos Trabalhadores na Agricultura (Fetag), Central Única dos Trabalhadores (CUT) e Associação Riograndense de Pequenos Agricultores.

90 O Programa Troca-Troca de Sementes, criado em 1988, possibilitou a aquisição de sementes fiscalizadas e a captação de recursos para o custeio, com prazo de pagamento após a colheita e subsídios pelos pequenos produtores, assentamentos de reforma agrária e povos indígenas.
} 
por agricultor e a área excedente, como no caso do milho, pode ser segurada, sem subsídio.

Em ambos os casos o mecanismo de compensação é calculada por meio da diferença entre a média da produção do município onde a propriedade está segurada e a média de prejuízo local.

O terceiro e último tipo é o seguro comercial, em que o subsídio é indireto, por meio de ações de promoção, por parte do governo, e incentivo aos produtores para efetuarem o contrato. Neste mercado operam as seguradoras privadas.

Em 2001, 25.070 produtores contrataram o seguro agrícola, em 227 municípios do Rio Grande do Sul (Tabela 8).

Tabela 8. Resultado seguro agrícola estadual, no período de janeiro a novembro de 2001, em R\$

\begin{tabular}{lccc}
\hline \multicolumn{1}{c}{ Região } & $\mathrm{N}^{\circ}$ de Contratos & Importância Assegurada & Desembolso do Estado \\
\hline Alto Jacuí & 263 & 196.100 & 29.878 \\
Campanha & 55 & 38.200 & 6.131 \\
Central & 1.232 & 875.700 & 103.741 \\
Centro-Sul & 66 & 41.000 & 4.274 \\
Fronteira Noroeste & 5.150 & 3.540 .740 & 315.570 \\
Fronteira Oeste & 1 & 800 & 76 \\
Hortências & 128 & 79.800 & 8.922 \\
Litoral & 3 & 885 & 58 \\
Médio Alto Uruguai & 1.915 & 1.465 .200 & 158.570 \\
Missões & 4.081 & 2.918 .360 & 301.243 \\
Norteste & 1.588 & 1.117 .200 & 129.333 \\
Noroeste Colonial & 3.546 & 2.503 .800 & 321.168 \\
Norte & 3.659 & 2.749 .300 & 317.816 \\
Paranhana-Encosta da Serra & 6 & 4.200 & 236 \\
Produção & 974 & 709.000 & 79.868 \\
Serra & 112 & 59.200 & 5.064 \\
Sul & 560 & 395.100 & 50.431 \\
Vale do Caí & 29 & 17.700 & 1.762 \\
Vale do Rio Pardo & 1.186 & 795.500 & 67.293 \\
Vale do Taquari & 516 & 329.000 & 26.878 \\
Total & 25.070 & 17.836 .785 & 1.928 .312 \\
\hline
\end{tabular}

Fonte: Rio Grande do Sul (2002, p.110) 
O governo do Estado subsidiou a contratação do seguro pelos agricultores com um montante de R \$ 1,9 milhão, acrescentando-se o custo para apoio a calamidades, chegando-se a um total de $\mathrm{R}$ \$ 2,9 milhões. Isto possibilitou que os agricultores pudessem proteger suas lavouras pagando uma taxa de prêmio equivalente a um saco de milho, ou R\$ 7,43.

As indenizações pagas em 2002 para 17.279 famílias de agricultores (69\% do total), de 133 municípios, que tiveram prejuízos em suas lavouras devido a problemas climáticos, principalmente perdas com a estiagem nas lavouras de milho somam R \$ 4,2 milhões, o que representa um valor médio de R\$ 243 por segurado, sendo o mínimo equivalente a $\mathrm{R} \$ 40$ e o máximo de $\mathrm{R} \$ 700$. O montante investido pelos produtores foi aproximadamente R $\$ 200$ mil nas apólices de seguro.

As regiões que apresentaram maior número de contratos efetivados e volume de importância segurada foram Fronteira Noroeste, Missões, Noroeste Colonial e Norte. Juntas, elas representaram aproximadamente 65\% do número de contratos e do volume segurado.

A região das Missões envolve 15 municípios, nos quais foram indenizadas 2.398 famílias de produtores, no montante de R\$ 511 mil.

A região Noroeste Colonial, que compreende 20 municípios, recebeu R\$ 860 mil em recursos para as indenizações.

Para ter acesso à quantia a ser indenizada, o produtor recebe uma carta nominal informando o pagamento disponível para cada um e o cálculo que foi feito para determinar o valor da indenização (Rio Grande do Sul, 2002).

De acordo com o artigo Lá ...(1999), o processo de privatização de alguns bancos estaduais como o Banerj e o Bemge, que foram comprados pelo Banco Itaú, e da Companhia União de Seguros Gerais, adquirida pelo Bradesco durante a década de 90, privou o mercado de três das poucas seguradoras que mantinham uma carteira rural ativa. 


\subsubsection{Seguro Mútuo}

Ao longo de sua história, a humanidade desenvolveu medidas de autoproteção para se precaver diante de eventuais desastres que causassem alguma forma de prejuízo econômico.

O seguro mútuo é a forma mais antiga de proteção ao risco. A partir de um contrato, vários indivíduos se unem por meio de estatutos para dividir danos ou perdas que, eventualmente, cada um poderia ter, em razão de certo sinistro. Haja vista que, em lugar do prêmio, os segurados contribuirão com cotas necessárias para cobrir as despesas de administração e aos prejuízos verificados. A responsabilidade pelo risco será compartilhada por todos os segurados.

Desse modo, as operações de seguro, do ponto-de-vista técnico, só se estruturam quando coletivamente organizadas, Já no aspecto jurídico, tal operação se manifesta por meio de um acordo de vontades sendo, portanto, um negócio jurídico bilateral ${ }^{91}$ (FUNENSEG, 1996a).

Segundo Caffagni e Marques (1999), uma das características positivas desse mecanismo é a redução do risco de fraudes, pois como os indivíduos participantes rateiam os eventuais prejuízos, os segurados se fiscalizam uns aos outros.

No Brasil, essa modalidade de seguro vem sendo adotada por algumas cooperativas e associações de produtores, em boa parte, na região Sul do Brasil.

De um modo geral, tem sido superavitário devido à cobertura de riscos limitados e específicos e ao eficiente controle do risco moral a baixos custos.

Um problema potencial nesse mecanismo é a falta de algum tipo de resseguro, reservas ou fundos, pois o seguro não é elegível para a cobertura do Fundo de Estabilidade do Seguro Rural (Azevedo-Filho, 2000).

Como exemplos de seguro mútuo, podem ser citados a Cooperativa Agropecuária Batavo Ltda, a Cooperativa Agrária Mista Entre Rios Ltda e a Associação dos Fumicultores do Brasil (Afubra).

\footnotetext{
${ }^{91} \mathrm{O}$ contrato de seguros é bilateral, pois gera obrigações para ambos os participantes, o segurado e o segurador. O descumprimento da obrigação por uma das partes automaticamente desobriga a outra.
} 


\subsubsection{Cooperativa Agropecuária Batavo Ltda.}

A experiência de seguro mútuo da Cooperativa Agropecuária Batavo é uma das mais antigas e bem-sucedidas no Brasil. Localizada no município de Carambeí (PR), ela criou, em 1985, o Fundo Mútuo Agrícola (FMA), protegendo os seus cooperados da redução da receita decorrentes de doenças, granizo, pragas e seca, desde que não existam métodos conhecidos ou economicamente viáveis de profilaxia e controle. Abrange a cultura da soja e milho.

Uma das razões da criação do FMA foi o descontentamento dos cooperados em relação ao Proagro, que apresentava demoras excessivas no pagamento das indenizações. O custo final elevado, em função do processo de acompanhamento da safra, e a baixa confiabilidade no sistema também foram apontados como pontos fracos.

Até o ano de 1994, cada produtor contribuía com uma tarifa de 7\% para soja e $10 \%$ para o milho. A taxa de participação ou prêmio era calculada multiplicandose a tarifa pelo custo médio de produção Batavo, calculado pelo de Departamento Assistência Técnica (DAT).

O importante a ressaltar é que a taxa era depositada na cooperativa somente após a colheita. Caso não houvesse a comunicação de nenhum sinistro, o cooperado ficaria isento do depósito.

A cobertura era realizada sobre a diferença entre a venda da produção restante e o custo de produção. Caso o volume de indenização fosse maior que o da taxa de participação, procedia-se a um rateio proporcional aos valores a indenizar. Caso contrário, o saldo excedente era devolvido proporcionalmente a cada segurado.

Para participar do seguro, o cooperado deveria preencher certos requisitos, isto é, o produtor deveria ter uma produtividade média acima de 2.000 quilos/hectare para a soja e de 4.500 quilos/hectare para o milho, nas últimas três safras, utilizar boa tecnologia, programar corretamente o plantio e aceitar as recomendações do 
DAT. Além disto, deveria entregar toda a produção e adquirir os insumos da cooperativa.

Recentemente ocorreram algumas mudanças no seguro. A taxa de participação não é mais cobrada, as indenizações totais são rateadas entre os cooperados após a colheita e o risco máximo de cada um é de 7\% do custo individual de produção (Caffagni, 1998).

\subsubsection{Cooperativa Agrária Mista Entre Rios Ltda.}

A Cooperativa Agrária Mista Entre Rios encontra-se no distrito de Guarapuava (PR). Fundada em 1951, conta com 400 cooperados e aproximadamente 90 mil hectares de área plantada.

Em 1996, a cooperativa implantou o plano privado de cobertura complementar dos prejuízos causados por granizo, criado com o principal objetivo de indenizar com mais rapidez os prejuízos causados pelo fenômeno, a custos menores que os do Proagro.

As culturas cobertas são soja e milho (verão) e trigo, cevada e aveia (inverno). O seguro indeniza os custos dos insumos e operações agrícolas efetivadas na lavoura, baseados em orçamentos levantados pela Divisão de Assistência Técnica, que organiza uma planilha de custos com o custo médio da cooperativa e gastos de cada produtor.

Para o cálculo da indenização, consideram-se os custos dos insumos e das operações agrícolas, deduzindo o valor da produção colhida na mesma área e utilizando o preço de mercado coletado em data específica.

A receita do plano, equivalente a um prêmio, é obtida adicionando-se à diferença descrita anteriormente o valor do custo da vistoria. Divide-se este montante pelo total da área inscrita, determinando um índice indenizatório por hectare. Este índice multiplicado pela totalidade da área inscrita por cooperado define o valor a ratear. 
A adesão ao plano é facultativa, sendo obrigatória somente quando a cooperativa apresenta algum envolvimento com o produtor. Os gastos da vistoria pelos técnicos/peritos serão rateados também no final do plano, entre todos os participantes.

Além de cumprir todas as determinações estatutárias, comprar todos os insumos na cooperativa e vender toda sua produção por intermédio da mesma, é necessário que o cooperado utilize o nível de tecnologia adequado.

Na safra 1996/97, ocorreram sinistros para a cultura da aveia e soja. Em trigo, cevada e milho não houve indenizações. O histórico de indenizações, em mais de dez anos de operação, tem mostrado viabilidade do programa (Sattler, 1998).

Em milho, por exemplo, nunca houve indenização devido à ocorrência de granizo, pois mesmo áreas atingidas pelo fenômeno climático dificilmente produzem menos do que 3.500 quilos/hectare. A produtividade média para o milho, na região, é de 8.100 quilos/hectare.

No período 1996/97 foram indenizados para aveia pouco mais de $\mathrm{R} \$ 2$ mil, em 43 hectares (de um total de 7 mil hectares). Para a soja, quase R\$ 16 mil, em 242 hectares (de um total de 55 mil hectares).

\subsubsection{Associação dos Fumicultores do Brasil (Afubra)}

A Associação dos Fumicultores do Brasil (Afubra), localizada em Santa Cruz do Sul, é uma entidade que representa produtores de tabaco dos Estados do Rio Grande do Sul, Santa Catarina e Paraná.

Fundada em 1955, com 103 associados, seu principal objetivo foi criar um seguro mútuo que protegesse as lavouras das chuvas de granizo. Atualmente, a Afubra é formada por 116.787 famílias provenientes de 660 municípios da região Sul do Brasil.

A entidade resolveu idealizar um plano próprio baseado no mutualismo, criando o Departamento de Mutualidade em novembro de 1956. 
Na safra 1956/57, 103 cooperados realizaram o seguro mútuo e aproximadamente 23 tiveram suas propriedades atingidas. Nas safras 1957/58 e 1959/60 o número de segurados aumentou, respectivamente, para 861 e 5.332. Na safra 1994/95 pouco mais de 100 mil lavouras estavam cobertas pelo seguro.

Eventuais sobras de um determinado ano são contabilizadas como reserva para cobrir déficits em períodos futuros. Além da cobertura contra granizo, desde julho de 1962 a associação oferece o auxílio-reconstrução de estufa danificada por incêndio, decorrente da cura do tabaco.

Havendo o sinistro, o segurado comunica imediatamente a Afubra, que após a vistoria efetua o pagamento do auxílio no prazo máximo de cinco dias.

A associação também oferece o auxílio-funeral, aprovado em assembléia geral feita em julho de 1966. Este benefício equivale a 600 quilos de fumo de estufa de maior valor pago somente no caso de morte do associado, esposa ou filho solteiro, devidamente inscritos, e mediante apresentação de atestado de óbito. A contribuição anual é de três quilos de fumo da mesma classe.

No seguro mútuo são indenizados somente danos causados por granizo verificados em lavouras de fumo e danos por vendavais fortes não acompanhados de granizo. A lavoura deve apresentar, obrigatoriamente, no mínimo uma das três características: pés quebrados, talos partidos ou nervuras de folhas rompidas.

O auxílio de reconstrução de estufas somente será concedido se o incêndio ocorrer durante secagem de fumo, de modo que todas as estufas existentes na propriedade estejam inscritas, exceto as mistas. Para estufas geminadas, o benefício é de $75 \%$ por unidade sinistrada.

Varandas e paióis não estão cobertos, assim como danos causados nos fumais por ventos frios constantes, uso inadequado de antibrotante, pragas, doenças, geadas, enchentes, enxurradas e por seca. Também não são indenizadas estufas destruídas/avariadas por tempestade.

No caso de prejuízo total, a lavoura não deve ser eliminada antes da vistoria. Somente caberá indenização integral se o prejuízo for completo, desde que não 
existam mais folhas aproveitáveis por ocasião do evento e que o fumo esteja totalmente desenvolvido.

Quando ocorre o sinistro, o associado deve informar a Afubra, que destaca uma equipe de avaliadores para apurar os prejuízos. Na safra 1993/94, 108 pessoas, entre inspetores, coordenadores e avaliadores, atenderam 114 mil associados.

O valor da taxa para granizo foi estabelecido em 5,5 \%. Também foram determinadas redução de 10 \% para quem se inscreveu nas últimas quatro a sete safras seguidas e de $20 \%$, no caso de não ter sido atingido nas últimas oito safras seguidas ou mais (Cunha, 2003).

Segundo Seffrin (1995), outro fator que reduz o custo do seguro é:

“... a colaboração das empresas fumageiras que, através de suas equipes de assistência técnica, inscrevem os fumicultores no Departamento de Mutualidade, sem o que o trabalho de agenciamento seria onerado. É evidente que as empresas não prestam esse serviço a AFUBRA, mas aos fumicultores, pois além de acolherem as inscrições no seguro, elas fazem o cadastro e contrato de financiamento bancário dos insumos agrícolas.”

\subsubsection{Instituto Riograndense do Arroz (Irga)}

O esquema de seguro do Instituto Riograndense do Arroz (Irga) data de fins da década de 40. A Lei $n^{0}$ 533, de 31 de dezembro de 1948, estabeleceu que todo orizicultor, com lavouras no território do Estado e inscrito no Irga, poderia receber uma indenização decorrente de prejuízos causados por queda de granizo.

A Lei $n^{\circ} 533 / 48$ foi regulamentada, anos mais tarde, pelos Decretos 25.665, de 11 de junho de 1977 e 35.372, de 5 de julho de 1994.

Os recursos para o programa são provenientes da comercialização da commodity no Estado, ou seja, um certo percentual do valor de cada saca de arroz é 
recolhido e destinado ao Irga, constituindo um fundo a ser utilizado pelo instituto para cobrir eventuais prejuízos causados pelo evento climático (Azevedo, 1998).

Para requerer o valor a ser indenizado, o produtor deverá encaminhar-se ao Irga e solicitar a vistoria de sua propriedade, acompanhado pelo assistente indicado pelo solicitante por meio de uma requisição.

O segurado terá um prazo máximo de três dias úteis após a ocorrência do evento para realizar a solicitação. Após a comunicação do sinistro e o acompanhamento das peritagens do levantamento dos prejuízos é feito o laudo de inspeção de danos da área do produtor segurado atingido pelo granizo.

Para que haja a efetivação da liquidação do sinistro, o evento deve ter ocorrido até 30 de abril de cada ano. Além disso, a documentação necessária deverá estar encaminhada ao Irga até 31 de maio. Nota-se que qualquer importância recebida pelo segurado proveniente de outro programa de seguro rural, instituído pelo Governo Federal, deverá ser descontada do cálculo da indenização.

Na safra de 1996, o Irga arcou com um total indenizado de aproximadamente $\mathrm{R} \$$ 1.250.000, devido à ocorrência de granizo em lavouras de arroz.

\subsubsection{Novas iniciativas privadas}

Desde meados do final da década de 60, após o surgimento da Cosesp, diversas seguradoras tentaram operar no ramo agrícola. A figura 52, abaixo, ilustra as principais seguradoras que operam (em azul) ou que já operaram (em preto) o seguro agrícola, bem como o início e o final das atividades. 


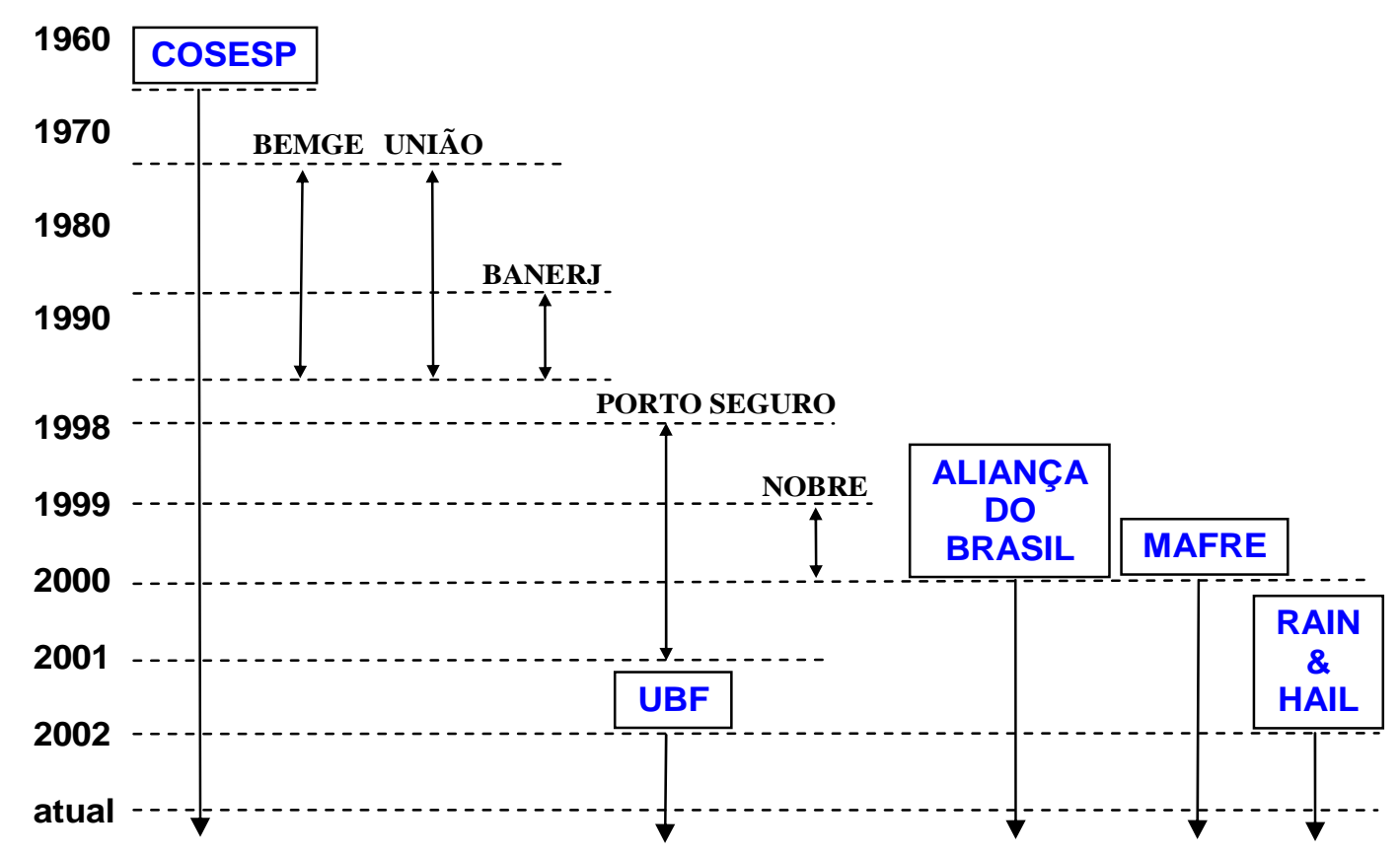

Figura 52 - Principais seguradoras que operam ou já operaram o seguro rural Fonte: Andrade Junior (2002)

A Vera Cruz Seguradora, controlada pelo grupo espanhol Mapfre, começou a operar no ramo rural em 2000, oferecendo cobertura para granizo nas safras de verão e inverno, seguro para danos materiais, paralisação de atividades e acidentes pessoais no campo para as culturas da soja, milho, arroz, feijão, trigo, cevada, aveia, sorgo, girassol, centeio e triticale, arrecadando um total de R\$ 3,3 milhões em prêmios, de acordo com Cresce ... (2003) ${ }^{92}$.

A seguradora, em parceria com a Cooperativa Agropecuária Mourãoense Ltda (Coamo), na safra de inverno de 2002 ofertou mais de 200 apólices para os cooperados na região da cooperativa.

\footnotetext{
${ }^{92}$ CRESCE a procura por seguro rural. http://www.gazetamercantil.com.br (14 mar. 2003)
} 
A Vera Cruz oferece cobertura contra granizo para a soja e o milho, por talhão da propriedade e não pela área total da lavoura e a possibilidade de segurar a lavoura pelas médias de produtividade (Vera ... , 2002) ${ }^{93}$.

A seguradora Porto Seguro começou a operar no ramo agrícola em 1998, pela carteira de seguros denominada Porto Seguro Agrícola. As operações com seguro agrícola funcionaram por quatro anos, sendo desativadas em 2001, permanecendo a companhia apenas com o seguro de animais (Porto ... , 2002) ${ }^{94}$.

Durante esses quatro anos, a seguradora desenvolveu contratos para cobertura de prejuízos causados por granizo nas culturas de maçã, uva, ameixa, nectarina, pêssego, caqui, figo, goiaba e pêra, que podiam ser contratados nos Estados de São Paulo, Paraná, Santa Catarina, Rio Grande do Sul (exceto uva) e Minas Gerais.

O seguro cobria a produção e não o valor do custeio, sendo que o valor segurado era obtido com a multiplicação do preço médio de venda do quilo da fruta pelo rendimento médio esperado.

A seguradora Aliança do Brasil, que tem o Banco do Brasil como acionista minoritário, iniciou suas operações no ramo agrícola na safra 2000/01, quando foram cobertas as culturas de milho e soja no Distrito Federal, Goiás, Mato Grosso do Sul, Minas Gerais, Paraná e São Paulo e a cultura de arroz irrigado em Santa Catarina e Rio Grande do Sul.

Apenas os clientes do Banco do Brasil que receberam crédito rural e os produtores de culturas implantadas e conduzidas tecnicamente de acordo com o zoneamento agrícola tiveram acesso, nessa fase, ao mecanismo de proteção contra perdas de safras decorrentes de incêndios, raios, ventos frios, ventos fortes, granizo, chuva excessiva, tromba d'água, seca, geada ou variação excessiva de temperatura.

O seguro é proporcional às perdas, levando em conta as despesas totais para custeio da lavoura, inclusive o capital próprio investido pelo produtor rural. $\mathrm{O}$

\footnotetext{
${ }^{93}$ VERA Cruz opera seguro rural na região. http://www.coamo.com.br/jornalcoamo/nov02/index3.html (20 mar. 2003)

94 PORTO Seguro estima crescer 10\% em 2003 e faturar R\$ 2,2 bilhões. http://www. gazetamercantil.com.br (20 mar. 2003)
} 
segurado fica isento do pagamento do IOF e outros impostos estaduais e federais (Ferreira, 2003) ${ }^{95}$.

As taxas de prêmio foram de 3,5\% para soja e milho irrigados, 4,5\% para soja e milho, $5 \%$ para o milho safrinha irrigado, $7 \%$ para o milho safrinha e 3,5\% para o arroz irrigado.

A indenização é devida, por ocorrência de sinistro, quando a produtividade individual efetiva for inferior ao maior valor entre $70 \%$ da produtividade esperada, indicada na proposta de seguro, e a produtividade de equilíbrio, que representa a produtividade mínima a fim de cobrir o custeio da lavoura (Seguro ..., 2003) ${ }^{96}$.

O mecanismo de compensação, no caso de perda parcial, é dado por $I=V\left(1-P_{O} / P_{E}\right)(1-F)$, onde $I$ é a indenização devida, $V$ o valor segurado que tem o mínimo igual ao valor do financiamento e o máximo igual ao valor total do orçamento do custeio da lavoura, $P_{O}$ a produtividade observada, $P_{E}$ o maior valor entre os $70 \%$ da produtividade esperada e a produtividade de equilíbrio e $F$ a franquia igual a 5\% somente no caso de perda parcial.

Em caso de sinistro total, em área total ou parcial, o segurado recebe o pagamento da indenização imediatamente, além disso, pode-se repor a cultura com a garantia de continuidade da produção. No caso de perda total, a indenização é realizada por meio de percentuais do valor segurado, variando de acordo com o estágio da cultura.

As taxas de prêmio para a safra 2001/02 foram de 4,5\% para milho e soja, 3,5\% para soja irrigada e 3,5\% para arroz irrigado, acrescidos de R\$ 10 por apólice. Nota-se que o prêmio pode ser financiado pelo Banco do Brasil e o segurado permanece isento do pagamento do imposto sobre operações financeiras e do custo da inspeção.

Em 2001 foram realizados 6,5 mil contratos, não mais sendo obrigatório ao produtor que quisesse adquirir o seguro realizasse financiamentos junto ao banco, bastando ser correntista.

\footnotetext{
${ }^{95}$ FERREIRA, V. Aliança do Brasil lança seguro agrícola para safra 2000/2001. http://www.Estado. estadao.com.br/editorias/2000/06/30/eco897.html (22 mar. 2003)

${ }^{96}$ SEGURO Ouro agrícola safra 2001/02. http://www.faep.com.br/meiorural/seguro/aliança2.asp (22 mar. 2003)
} 
Na safra 2002/03 a seguradora ampliou a carteira agrícola, incluindo como culturas beneficiadas o algodão e arroz irrigado, além do milho e soja nos Estados da Bahia, Distrito Federal, Goiás, Maranhão, Minas Gerais, Mato Grosso, Mato Grosso do Sul, Paraná, Piauí, Rio Grande do Sul, Santa Catarina, São Paulo e Tocantins.

As taxas foram fixadas em 3\% nas culturas de arroz irrigado nos Estados de Santa Catarina, Rio Grande do Sul, São Paulo, 3,5\% na soja e de 2,5\% na cultura de soja irrigada no Mato Grosso (BB ..., 2002) ${ }^{97}$.

A seguradora adotou um procedimento de cobrança de taxas de forma regionalizada, em função do risco de sinistros em cada região, e passou a cobrir reduções na produtividade individual do produtor de acordo com o nível de tecnologia empregado.

No Paraná, por exemplo, o estudo para a regionalização das taxas já foi totalmente concluído (Seguros ... , 2003) ${ }^{98}$. Como resultado, as lavouras que empregam maior tecnologia ou que tenham o solo ou o clima mais adequado ao plantio passaram a ter taxas mais baixas.

\footnotetext{
${ }^{97}$ BB lança seguro agrícola para a safra 2002/2003. http://www.fenaseg.org.br (20 mar. 2003)

98 SEGUROS rurais têm novidades para a safra 2003/2004. http://www.diariodoscampos.com.br/ 20030703/economia/agri.htm (5 jul. 2003)
} 
Na safra 2003/04, a cobertura para a cultura do arroz foi estendida para o Estado de Tocantins e, do milho, para o Rio Grande do Sul e Santa Catarina. A figura 53, resume as informações descritas anteriormente:

\begin{tabular}{|c|c|c|c|c|c|c|c|c|c|c|c|c|c|}
\hline Culturas & & & & & & ES & $\operatorname{ado}$ & & & & & & \\
\hline & $\mathrm{BA}$ & $\mathrm{DF}$ & GO & $\mathrm{MA}$ & $M G$ & MS & $\mathrm{MT}$ & PR & $\mathrm{PI}$ & RS & $\mathrm{SC}$ & SP & $\mathrm{TO}$ \\
\hline Algodão & $x$ & - & $x$ & - & $x$ & $x$ & $x$ & $x$ & - & - & - & $x$ & - \\
\hline Arroz Irrigado & - & - & - & - & - & - & - & - & - & $x$ & $x$ & $x$ & $x$ \\
\hline Feijão Irrigado & $x$ & $x$ & $x$ & - & $x$ & - & - & $x$ & - & - & - & $x$ & - \\
\hline Milho & $x$ & $x$ & $x$ & $x$ & $x$ & $x$ & $x$ & $x$ & $x$ & $x$ & $x$ & $x$ & $x$ \\
\hline Soja & $x$ & $x$ & $x$ & $x$ & $x$ & $x$ & $x$ & $x$ & $x$ & $x$ & $x$ & $x$ & $x$ \\
\hline Sorgo & - & $x$ & $x$ & - & $x$ & $x$ & - & $x$ & - & - & - & $x$ & - \\
\hline Trigo & - & $x$ & $x$ & - & $x$ & $x$ & - & $x$ & - & $x$ & $x$ & $x$ & - \\
\hline
\end{tabular}

Figura 53 - Principais culturas e abrangência territorial do Seguro Agrícola da Aliança do Brasil, no ano-safra 2003/04

Fonte: Aliança do Brasil (2003) ${ }^{99}$

A seguradora Rain and Hail Insurance Service International Inc., uma das principais no ramo agrícola nos EUA, tem interesse em operar o seguro agrícola no Brasil, em um primeiro momento nos Estados do Rio Grande do Sul, Paraná, São Paulo, Goiás, Minas Gerais, Mato Grosso e Mato Grosso do Sul. O objetivo é cobrir as culturas de soja, milho e algodão. As apólices serão emitidas pela Ace Seguradora, por meio de sua carteira agrícola (Empresa ... , 2001) ${ }^{100}$.

O contrato protegeria o produtor de eventuais quedas na produção contra perdas por problemas climáticos, nos moldes do seguro MPCI (visto anteriormente) e, posteriormente, um seguro contra a perda de renda. As taxas de prêmio serão fixadas para cada microrregião. O resseguro das operações será realizada pela Münchener do Brasil.

\footnotetext{
${ }^{99}$ ALIANÇA DO BRASIL. http://www.aliancadobrasil.com.br/ (15 jul. 2003)

${ }^{100}$ Empresa americana oferece seguro rural. Gazeta Mercantil. São Paulo, 17 maio 2001. p.B16.
} 
No ano de 2002, um projeto-piloto de seguro agrícola foi desenvolvido na região de Passo Fundo por duas resseguradoras e duas seguradoras, aguardando apenas a aprovação da Susep (Ucha, 2003) ${ }^{101}$.

O projeto conta com a maior resseguradora do mundo, a alemã Munich Re, o Instituto de Resseguros do Brasil (IRB), a seguradora mexicana Protección Agropecuária e a seguradora Previdência do Sul, em parceria com a Cooperativa do município de Não-Me-Toque, a Cotrijal.

A seguradora Sul América oferece seguro agrícola que cobre prejuízos causados por granizo nas culturas de café no sul de Minas e norte de São Paulo (Cresce $\ldots, 2001)^{102}$.

\subsubsection{Seguro-Safra}

O Seguro-Safra é um programa de seguro governamental criado pela Lei $\mathrm{n}^{\mathrm{o}}$ 10.420, de 10 de Abril de 2002, e regulamentado pelo Decreto $\mathrm{n}^{\circ}$ 4.363, de 6 de setembro de 2002.

O documento estabelece a criação de um fundo, denominado Fundo Seguro-Safra e institui o benefício Seguro-Safra para garantir uma renda mínima aos agricultores familiares da região Nordeste, do semi-árido do Estado de Minas Gerais (norte de Minas Gerais e Vale do Jequitinhonha), da região norte do Espírito Santo e nos municípios sujeitos a estado de calamidade ou situação de emergência em razão do fenômeno da estiagem (Brasil, 2002).

O Ministério do Desenvolvimento Agrário é o gestor do fundo que tem como fontes de recursos:

i) A contribuição individual e voluntária do agricultor familiar, no valor de $\mathrm{R} \$ 6$;

\footnotetext{
${ }^{101}$ UCHA, D. Enfim, um seguro agrícola. http://jcrs.uol.com.br (30 mar. 2003)

${ }^{102}$ Cresce a procura por seguro rural. Gazeta Mercantil. São Paulo, 22 março 2001.
} 
ii) Contribuições anuais dos municípios equivalentes a 3\% do valor dos benefícios previstos, conforme acordado entre o Estado e o município que aderir ao programa;

iii) A contribuição anual do Estado, adicionada às contribuições dos agricultores e dos municípios, deve ser suficiente para complementar a contribuição de $10 \%$ do valor da previsão dos benefícios anuais para o respectivo Estado;

iv) Os recursos da União equivalentes ao montante anual de até $90 \%$ dos benefícios previstos para o Estado; ,

v) O resultado das aplicações financeiras de seus recursos.

O benefício é voltado aos agricultores familiares que perderem pelo menos $60 \%$ da produção de algodão, milho, feijão e arroz, devido à ocorrência de estiagem devidamente comprovada.

Além disso, os beneficiados devem possuir uma renda inferior a um salário mínimo e meio, área plantada de até dez hectares e não poderão explorar área superior a quatro módulos fiscais, independentemente do tipo de posse de terra.

A adesão ao programa é vedada ao agricultor cuja produção seja irrigada, deve ter o trabalho familiar como base na exploração do estabelecimento e possuir, antes da adesão, o Número de Identificação Social (NIS), documento emitido pela Caixa Econômica Federal a partir do Cadastro Único do Governo Federal.

Os agricultores familiares tem direito ao benefício de até $\mathrm{R} \$ 600$ por família, realizado em até seis parcelas mensais, desde que, a partir de sua adesão, participassem de programas de educação e capacitação rural.

O Decreto $n^{\circ} 4.363 / 02$ criou o Comitê Gestor ${ }^{103}$, ao qual ficou atribuída competência, dentre outras, para definir e assegurar as ações interinstitucionais, visando ao gerenciamento integrado da concessão do benefício Seguro-Safra e propor diretrizes

103 Composto por representantes dos ministérios do Desenvolvimento Agrário, do Planejamento, Orçamento e Gestão, da Fazenda, da Agricultura, Pecuária e Abastecimento, da Integração Nacional, da Justiça, do Desenvolvimento Agrário, da Casa Civil da Presidência da República, da Secretaria de Agricultura Familiar, da Secretaria da Reforma Agrária, da Agência de Desenvolvimento do Nordeste (Adene), da Empresa Brasileira de Pesquisa Agropecuária (Embrapa), da instituição financeira responsável pela gestão financeira do fundo, da instituição nacional de representação dos trabalhadores rurais e dos agricultores familiares e um representante de cada Estado que formalizar sua adesão ao fundo Seguro-Safra. 
gerais e setoriais e as metas a serem atingidas pelo fundo, assim como normas e medidas que permitam melhor atendimento do publico-alvo do beneficio.

$\mathrm{Na}$ safra 2003/04 aderiram ao programa seis Estados: Alagoas (4 municípios), Ceará (163), Paraíba (58), Pernambuco (58), Piauí (77) e Sergipe (26).

Inicialmente, o Seguro-Safra vai garantir renda mínima de até R\$ 475, parcelados em seis meses, aos produtores que perderem entre $50 \%$ e $100 \%$ da safra de milho, arroz, feijão, mandioca e algodão. O Governo Federal destinou aproximadamente R\$ 52 milhões para o programa (Seguro safra ... , 2003) ${ }^{104}$.

\subsubsection{Projetos de Lei}

Diversos projetos de lei relacionados ao tema do seguro rural tramitam no Congresso, frente à crescente demanda pelo mercado por este tipo de seguro (Relatório ... , 2001) ${ }^{105}$. Alguns dos projetos estão apresentados abaixo:

1. Projeto de Lei do Senado $n^{\circ} 156 / 00^{106}$, que institui o Sistema de Apoio ao Seguro Rural, de acordo com o disposto nos incisos II e IV, do artigo 192, da Constituição Federal, com participação dos governos federal, estadual e municipal, sociedades por ações, cooperativas, associações e sociedades de produtores rurais. São previstas quatro modalidades de seguro: agrícola, pecuário, de bens, equipamentos, benfeitorias e produtos agropecuários e o seguro temporário de vida dos produtores rurais. O documento prevê que o seguro será operado pelas empresas seguradoras públicas e privadas, o sistema será obrigatório nos contratos de crédito rural de custeio e de investimento e,

\footnotetext{
${ }^{104}$ SEGURO safra. http://www.radiobras.gov.br/seguro\%20safra/safra.htm (13 mar. 2003)

105 RELATÓRIO de atividades 2001. http://www.cna.org.br/Relatorio01/PlanoAgricolaPecuario.htm (12 mar. 2003)

${ }^{106}$ Do senador Edison Lobão. O projeto está na Comissão de Finanças e Tributação, aguardando o parecer do relator Fetter Junior. Depois, vai à Comissão de Constituição e Justiça e de Redação para apreciação.
} 
facultativo nas lavouras conduzidas pelo agricultor com recursos próprios (Diário $\ldots, 2003)^{107}$;

2. Projeto de Lei Complementar $n^{\circ} 27 / 99^{108}$, que cria o seguro de renda para pequenos agricultores de base familiar sinistrados por eventos climáticos. A participação no programa será por livre adesão, mediante pagamento de prêmio de seguro, que variará de acordo com o risco a que estiver sujeita a lavoura, a tecnologia utilizada e a região. Descontos são previstos, de acordo com as medidas preventivas adotadas pelo agricultor no sentido de reduzir o risco e proteger o meio ambiente. O valor do prêmio não excederá $10 \%$ do valor da indenização (Pinheiro, 2003) ${ }^{109}$;

3. Projeto de Lei $n^{\circ} 4214 / 01^{110}$, que altera os artigos 15 e 17 do Decreto-Lei $n^{\circ}$ 73/66, que dispõe sobre o Sistema Nacional de Seguros Privados e regula as operações de seguros e resseguros (Queiroz, 2003) ${ }^{111}$. O artigo $1^{\circ}$ da proposição acrescenta ao “caput” do artigo 15, o qual permite ao Governo Federal assumir riscos catastróficos e excepcionais, a critério do Conselho Nacional de Seguros Privados (CNSP), desde que interessem à economia e à segurança do País, a expressão "...especialmente no caso do Seguro Rural.".

\footnotetext{
107 DIÁRIO da câmara dos deputados. http://imagem.camara.gov.br/dc20.asp?selCodColecaoCsv=D\& Datain $=27 / 10 / 2000 \&$ txpagina $=53144 \&$ altura $=700 \&$ largura $=800$ (15 jul. 2003)

${ }^{108}$ Do deputado Geddel Vieira Lima.

109 PINHEIRO, L.C. Seguro rural é alvo de projetos. http://www.camara.gov.br/internet/agencia/ materias.asp ? pk =22019 (11 mar. 2003)

${ }^{110}$ Do senador Arlindo Porto. Aprovado na Comissão de Agricultura e Política Rural (CAPR) e Comissão de Finanças e Tributação (CFR) e encaminhado à Comissão de Constituição e Justiça e de Redação (CCJR).

111 QUEIROZ, C. Comissão aprova mudança no seguro rural. http://www.camara.gov.br/internet/ agencia/materias.asp?pk=9062 (11 mar. 2003)
} 
No artigo 2, propõe nova redação para a alínea "c" do artigo 17, o qual estabelece dotações orçamentárias anuais para a constituição do Fundo de Estabilidade do Seguro Rural, pelo período de dez anos a partir da vigência do Decreto-Lei $\mathrm{n}^{\circ} 73 / 66$, de forma que as dotações anuais sejam determinadas pelo CNSP e Ministério da Fazenda, de forma permanente. Prevê, no artigo 3, que a lei entrará em vigor no exercício financeiro subseqüente ao de sua publicação. A critério do Conselho Nacional de Seguros Privados (CNSP), o Governo Federal, por intermédio do Instituto de Resseguros do Brasil (IRB) poderia assumir riscos excepcionais no caso de seguro rural. Além disto, estende o seguro para áreas agrícolas afetadas por fenômenos naturais que causem prejuízos econômicos, comprometendo toda uma cultura plantada;

4. Projeto de Lei $n^{\circ} 1005 / 99^{112}$, que dispõe sobre a criação do Sistema Nacional de Seguro Rural e institui, em caráter facultativo, o seguro para empresas agropecuárias privadas e públicas. Pela proposta, o SNSR será regido pela mesma estrutura administrativa do Sistema Nacional de Seguros Privados. O projeto estabelece coberturas decorrentes de incêndios, furtos e roubos, acidentes de trabalho, acidentes ou doenças com animais e plantas, pragas e pestes e problemas decorrentes de acidentes climáticos. Os meios de produção agrícola também ficarão cobertos equipamentos, veículos, instalações, imóveis, animais, lavouras, florestas cultivadas, produtos agrícolas estocados, sêmen e embriões, insumos, recursos de custeio e obras, inclusive as destinadas à captação de água e ao combate à erosão. Estão fora da cobertura os sinistros decorrentes de atos do Poder Público (como confisco ou indisponibilidade de bens), guerras, greves, experimentos, uso inadequado de tecnologia ou negligência.

\footnotetext{
${ }^{112}$ Do deputado Geddel Vieira Lima. O documento foi aprovado na Comissão de Agricultura e Política Rural. Na Comissão de Finanças e Tributação, o parecer do relator, deputado Coriolano Sales, foi pela inadequação financeira e orçamentária do projeto e pela adequação financeira e orçamentária da emenda adotada pela Comissão de Agricultura e Política Rural. O projeto ainda tem de ser analisado, em caráter conclusivo, pela comissão de Constituição e Justiça e de Redação.
} 
Em relação ao funcionamento do Seguro Rural, o projeto de lei diferencia o risco em duas possibilidades: riscos localizados e eventos generalizados. Caracterizam-se estes quando os sinistros ocorridos em determinado município atingir o correspondente a $20 \%$ da área municipal ou $40 \%$ dos estabelecimentos agropecuários do município. Neste caso, o pagamento das indenizações exigirá a participação de recursos do município, do Estado e da União, de forma a garantir uma cobertura de $70 \%$ do custo de reposição dos bens sinistrados. A responsabilidade do município será de $15 \%$ da indenização assumida pelo Poder Público, a do Estado será de no mínimo 35\% e o restante, caberá à União. No caso de eventos catastróficos generalizados, são obrigatórios o resseguro e a retrocessão. A responsabilidade pela indenização será integralmente das seguradoras se as perdas ocorridas não ultrapassarem $20 \%$ do total dos bens segurados, mesmo no caso de sinistro generalizado. Além disto, limita o aporte de recursos do governo destinados à cobertura de eventos catastróficos, cria um sistema de arbitragem e resolução de conflitos em âmbito local, a introdução da figura do corretor de seguro rural e de mecanismos que incentivam práticas e tecnologias que permitem reduzir o risco (Morais, 2003) ${ }^{113}$;

5. Projeto de Lei $n^{\circ} 7214 / 02^{114}$, que dispõe sobre a subvenção econômica ao prêmio do Seguro Rural e dá outras providências. Para obter tal benefício, o proponente deverá estar adimplente com a União. A subvenção poderá ser diferenciada segundo a modalidade do seguro rural, tipos de culturas e espécies animais, categorias de produtores, regiões de produção e condições contratuais, priorizando aquelas consideradas redutoras de risco ou indutoras de tecnologia. $\mathrm{O}$ projeto cria o Conselho Interministerial do Seguro Rural, o qual apresentará anualmente uma proposta de subvenção econômica com valores estimados para constar no Orçamento Geral da União relativo ao ano fiscal subseqüente. O

\footnotetext{
${ }^{113}$ MORAIS, C. Programa de Seguro Agrícola é aprovado em Comissão. http://www.camara.gov.br (10 mar. 2003)

${ }^{114}$ Elaborado pelo Poder Executivo. Este projeto de lei foi transformado na Lei ${ }^{\circ} 10.823$, de dezembro de 2003.
} 
conselho, ligado ao Ministério da Agricultura, Pecuária e Abastecimento, que o coordenará, poderá criar Comissões Consultivas, cuja organização, composição e o funcionamento serão regulados pelo próprio conselho com a possibilidade de participação de representantes do setor privado (Projeto ... , 2003) ${ }^{115}$;

6. Projeto de Lei Complementar $n^{\circ} 215 / 2001^{116}$, que institui o Programa de Garantia de Renda Agrícola e o Fundo de Sustentação da Renda Agrícola, propondo mecanismos de compensação às eventuais reduções de renda decorrentes da comercialização dos produtos agrícolas não sendo objeto de cobertura os sinistros decorrentes de problemas climáticos ou de ataque de pragas e doenças, bem como deficiências de renda originadas de redução da produção ou da produtividade, altera dispositivo da Lei $\mathrm{n}^{\circ}$ 8427, de 27 de maio de 1992, e dá outras providências. ...”Com a finalidade de garantir o pagamento de indenização correspondente à diferença entre o Preço de Garantia de Renda (PGR) e o Preço Médio de Mercado (PMM), cria o Fundo de Estabilização do Seguro de Renda que seria constituído pelos valores da taxa de adesão recolhida dos produtores rurais que aderirem ao Programa, por dotações orçamentárias da União, dos Estados e dos Municípios, por retornos e resultados das aplicações financeiras do Fundo e por outros recursos” (Projeto ... , 2003) ${ }^{117}$;

7. Projeto de Lei $3031 / 00^{118}$, que institui o Programa de Seguro Agrícola. O projeto desobriga o produtor de liquidar suas operações de crédito quando ocorrerem fenômenos naturais que prejudiquem as lavouras. A obrigação será cumprida por uma companhia de seguros pública, a ser constituída pelo Poder Executivo, que

\footnotetext{
115 PROJETO de Lei. http://www.camara.gov.br/Internet/sileg/integras/97588.htm (20 jul. 2003)

${ }^{116}$ Deputado Luís Carlos Heinze. Aprovado em 12 de dezembro pela Comissão da Agricultura e Política Rural da Câmara. A última ação ocorreu em 31 de janeiro de 2003, sendo arquivado nos termos do artigo 105 do Regimento Interno.

${ }^{117}$ PROJETO de lei complementar $n^{\circ}$ 215, de 2001. http://www.camara.gov.br/Internet/sileg/integras/ 106484.htm (23 jul. 2003)

${ }^{118}$ Do deputado Pompeo de Mattos. O Projeto de Lei foi aprovado na Comissão de Agricultura e Política Rural, em 26 de março de 2002, mas a comissão de Finanças e Tributação concluiu pela inadequação financeira e orçamentária do PL, nos termos do parecer do relator, deputado José Carlos Fonseca Jr.
} 
contará com um conselho consultivo composto por integrantes dos ministérios da Agricultura e da Fazenda, bem como por entidades não-governamentais representativas do setor agrícola. As fontes de financiamento do Programa de Seguro Agrícola são as contribuições sobre as operações de crédito para custeio da atividade agrícola, concedidas por instituições financeiras em funcionamento no País, e os recursos a serem definidos pelo Poder Executivo em dotação orçamentária específica para o programa têm como objetivo a transferência do ônus do subsídio aos bancos (Diário ... , 2003 ${ }^{119}$; Morais, $2003^{120}$ );

8. Projeto de Lei $186 / 01^{121}$, que cria o Seguro de Renda Agrícola para os trabalhadores assentados, pequenos e médios agricultores, institui o Fundo de Estabilização do Seguro de Renda Agrícola e dá outras providências. O seguro será uma cobertura financeira dos riscos de preços, incluindo adversidades climáticas, de modo a garantir renda mínima da produtividade, com limites de área de cobertura entre $100 \%$ a $60 \%$, de acordo com a renda do agricultor. O projeto prevê a criação de um fundo, proveniente de recursos do prêmio pago pelos produtores e de dotações orçamentárias do governo. Desta forma, no caso de, durante a colheita, o preço do produto no mercado ser inferior ao mínimo, este fundo pagaria a diferença (Baldi, 2003) ${ }^{122}$.

\subsubsection{Fundo de Estabilidade do Seguro Rural (FESR)}

O Fundo de Estabilidade do Seguro Rural (FESR) foi criado pelo Decreto-Lei $\mathrm{n}^{\circ}$ 73/66, artigo 16, e tinha como objetivo garantir a estabilidade das operações e atender à cobertura suplementar dos riscos catastróficos. O fundo, segundo

\footnotetext{
119 CÂMARA dos Deputados. http://imagem.camara.gov.br/dc20.asp?SelCodColeçãoCsv=D\&Datain= 5/12/2002\&txpagina=52810\&altura=700\&largura=800 (13 jul. 2003)

120 MORAIS, C. Agricultura aprova sistema de seguro rural. http://www.camara.gov.br/internet/ agencia/materias.asp?pk=10838 (12 mar. 2003)

${ }^{121}$ Da deputada Luci Choinacki.

${ }^{122}$ BALDI, N. Projeto pioneiro de seguro rural. http://www.agroclubes.com.br (13 mar. 2003)
} 
o documento, seria administrado pelo IRB e seus recursos aplicados de acordo com o CNSP. De acordo com o artigo 17, o fundo teria como receitas:

i) Excedentes do máximo admissível tecnicamente como lucro nas operações de seguros de crédito rural, incluindo seus resseguros e suas retrocessões, com os limites fixados pelo CNSP;

ii) Dotações orçamentárias anuais, mediante o crédito especial necessário para cobrir a deficiência operacional do exercício anterior, durante dez anos.

Além disso, o artigo 23 determinava que os seguros dos bens, direitos, créditos e serviços dos órgãos do Poder Público seriam contratados mediante sorteio realizado pelo IRB, que também determinava anualmente as faixas de cobertura de mercado nacional para cada ramo ou modalidade de seguro. As comissões de corretagem destes seguros, admitidas pelo CNSP, seriam creditadas no Fundo de Estabilidade do Seguro Rural.

Já o artigo 142 incorporava ao Fundo de Estabilidade do Seguro Rural o Fundo de Estabilidade do Seguro Agrário a que se refere o artigo 8 da Lei 2.168/54 e o Fundo de Estabilização previsto no artigo 27 da referida lei, que foram transferidos para o IRB na conta do Fundo de Estabilidade do Seguro Rural, via Banco do Brasil.

A Lei $n^{\circ} 8171 / 91$ considerou como fontes de recursos para o FESR:

i) Os recursos provenientes da participação dos produtores rurais, pessoa física e jurídica, de suas cooperativas e associações;

ii) Multas aplicadas às instituições seguradoras pelo descumprimento de leis e normas do seguro rural;

iii) Dotações orçamentárias e outros recursos alocados pela União.

Segundo Barros (1998), até setembro de 1995, a principal fonte de recursos do FESR vinha das comissões de corretagem. O cenário mudou depois da Lei 
$\mathrm{n}^{\text {o }}$ 8.666, de 21 de junho 1993, que regulamentou a forma de contratação de serviços por meio do processo licitatório.

Desse modo, a entrada de recursos ficou limitada ao excedente do máximo admissível tecnicamente como lucro, ou seja, ao FESR é depositado 50\% dos lucros, sendo cobertos $100 \%$ dos prejuízos ao final de cada exercício.

No caso do seguro agrícola, quando ocorre um evento catastrófico, ou seja, com prejuízos superiores a R\$ 470 mil, decorrentes de um ou vários sinistros causados por um mesmo evento, a seguradora poderá imediatamente recuperar a diferença.

Dentre todos as modalidades do seguro rural, o ramo que mais contribuiu para o aumento do FESR foi a modalidade de penhor rural do Banco do Brasil. Por outro lado, a modalidade de seguro agrícola foi a que mais se beneficiou dos recursos provenientes do fundo para cobrir eventuais déficits.

Com relação à possibilidade de repasse de recursos da União ao fundo, o saldo foi suficiente para cobrir eventuais déficits do mercado segurador até 2001, quando foi solicitada pela Lei $n^{0} 10.253$, de 4 de julho de 2001, suplementação orçamentária para atender ao FESR.

Nesse mesmo ano, a Resolução $\mathrm{n}^{\circ}$ 46, de 12 de fevereiro de 2001, do CNSP, reestruturou as diversas modalidades do seguro rural. Segundo os artigos 2 e 3, "seguro rural constitui o ramo de seguro destinado à cobertura dos riscos peculiares às atividades agrícola, pecuária, aqüícola e florestal”, abrangendo as seguintes modalidades:

i) Seguro agrícola, seguro pecuário, seguro aqüícola, seguro de florestas;

ii) Seguro de penhor rural operacionalizado por instituições financeiras públicas;

iii) Seguro de penhor rural operacionalizado por instituições financeiras privadas;

iv) Seguro de benfeitorias e produtos agropecuários (Brasil, 2001). 
Além disso, prevê que as seguradoras contribuam ao FESR determinado percentual do lucro em cada exercício nas modalidades garantidas pelo fundo, de acordo com os seguintes percentuais:

i) 30\% para seguros agrícola, pecuário, aqüícola e de florestas;

ii) $50 \%$ para seguro de penhor rural - instituições financeiras públicas e instituições financeiras privadas.

O documento também limitou os prejuízos recuperáveis às perdas correspondentes a um índice de sinistralidade de até 150\% e, em casos de catástrofe, superiores a $250 \%$.

Ao fundo ficou autorizado o repasse de crédito especial pelo CNSP, via Ministério da Fazenda, no caso de insuficiência de recursos.

A resolução ainda condicionou a aprovação das notas técnicas encaminhadas pelas seguradoras à apresentação da cobertura de resseguro e determinou que somente teriam acesso aos recursos do FESR as empresas que obtivessem aprovação da Susep para as condições contratuais, a cada ano.

As comissões de corretagem, que antes eram fixadas em 5\%, foram liberadas, ficando as seguradoras obrigadas a informar o limite mínimo e máximo do percentual de comissão.

A Resolução do CNSP $n^{0}$ 50, de 3 de setembro de 2001, dispõe sobre a participação do IRB-Brasil Resseguros S.A. na garantia de que trata o Capítulo 4 da Resolução CNSP nº 46, de 12 de fevereiro de 2001, e dá outras providências.

O documento assegura que o IRB-Brasil Resseguros efetuará contribuições e recuperações ao FESR em função de seu resultado, nas mesmas bases estabelecidas para as sociedades seguradoras na Seção 2 do Capítulo 4 da Resolução CNSP $n^{\circ} 46 / 01$, exclusivamente, para o resseguro proporcional, quota parte e/ou excedente de responsabilidade, das operações de seguro habilitadas à garantia do FESR.

Também restringe a cobertura do fundo ao seguro agrícola de custeio, ou seja, aquela em que cobre exclusivamente as despesas de orçamento de custeio direto de 
culturas periódicas e o orçamento das despesas anuais de manutenção das culturas permanentes (Brasil, 2001b).

A Resolução do CNSP nº 95, de 30 de setembro de 2002, altera o artigo 3 da Resolução CNSP n 46/02, incluindo no seguro rural as modalidades seguro de vida destinado ao produtor rural, devedor de crédito rural, e terá sua vigência limitada ao período de financiamento, sendo que o beneficiário será o agente financiador e seguro de cédula de produto rural (CPR), modalidade do Seguro Rural que dependerá de regulamentação da Susep (Brasil, 2002).

\subsubsection{Instituto de Resseguros do Brasil (IRB)}

O Instituto de Resseguros do Brasil (IRB) foi criado pelo Decreto-Lei $\mathrm{n}^{\circ}$ 1.186, de 3 de abril de 1939, constituído pelo Decreto-Lei $n^{\circ}$ 73/66, com a redação dada pela Lei $\mathrm{n}^{\circ}$ 9.482, de 13 de agosto de 1997, passando a se denominar IRB-Brasil Resseguros S.A., sociedade anônima de economia mista.

O IRB-Brasil Re tem como finalidade efetuar e regular operações de resseguro, cosseguro e retrocessão, além de elaborar as condições de seguro e taxação para novas culturas e riscos no País.

O resseguro é um método utilizado pelas seguradoras para pulverizar as responsabilidades. Uma ou mais seguradoras transferem a resseguradora o excesso de responsabilidade que ultrapassa o limite técnico de cada firma seguradora fixado pela Susep.

Por outro lado, o ressegurador pode realizar uma operação denominada retrocessão, ou seja, quando ocorre cessão ou um repasse de parte de suas responsabilidade recebida ao mercado segurador nacional.

Outro procedimento utilizado pelas seguradoras para pulverizarem as responsabilidades é o cosseguro. A técnica consiste na distribuição da responsabilidade assumida em um contrato de seguro entre duas ou mais seguradoras, denominadas seguradoras cotizantes ou cosseguradoras. 
Nesse processo, existe a emissão de apenas uma apólice pela seguradora líder, que tem a função de receber a proposta, emitir a apólice, arrecadar e distribuir o prêmio e indenizar o segurado.

O contrato deve estipular a quota de participação de cada seguradora sobre a responsabilidade total, sendo o prêmio equivalente a uma taxa sobre o valor segurado de cada seguradora e a indenização correspondente à quota de cada firma sobre o valor da indenização a ser paga.

O resseguro pode ser realizado de três formas distintas:

i) Resseguro de excedente de responsabilidade: é um contrato de resseguro proporcional $^{123}$, na qual a seguradora cedente ou retrocedente ${ }^{124}$ repassa a resseguradora aceitante parte ou totalidade do que exceder o seu limite de retenção, ou pleno, ou seja, a responsabilidade máxima que a seguradora mantém em cada risco isolado;

ii) Resseguro quota-parte: um percentual de cessão é estabelecido sobre a responsabilidade assumida pela seguradora, sendo o prêmio e a recuperação ${ }^{125}$ realizados na mesma proporção. Atualmente, o percentual de participação por quota do IRB-Brasil Re é de 20\%, com exceção do ramo penhor rural do Banco do Brasil, com quota de $50 \%$, e da Cosesp, com $30 \%$;

iii) Resseguro de excesso de danos: É um tipo de resseguro não proporcional ${ }^{126}$. Neste caso, não há a divisão da responsabilidade. A seguradora estabelece um contrato de resseguro que consta o "limite de sinistro", “máximo de conservação de danos" ou "prioridade", que é o valor-limite, pela qual a seguradora se responsabiliza pela cobertura do prejuízo. Além deste limite ocorre a recuperação, dada pela diferença

\footnotetext{
${ }^{123}$ Quando o ressegurador responde por parte proporcional, previamente definida, em relação ao risco integral.

${ }^{124}$ Seguradora cedente é aquela que transfere parte ou a totalidade das responsabilidades diretamente aceitas. Retrocedente é o ressegurador que repassa a outro ou outros resseguradores a totalidade ou os excessos das responsabilidades por ele aceitas em resseguro.

${ }^{125}$ Recuperação ou sinistro recuperado é a parte da indenização sob responsabilidade do ressegurador (FUNENSEG, 1996).

${ }^{126}$ Quando o ressegurador responde pela totalidade da carteira ou pela sinistralidade globalmente considerada, responsabilizando-se pela parte que exceder o "limite de sinistro" da seguradora cedente.
} 
entre o excedente e o limite de sinistro. Quando o "limite de sinistro" não é atingido,o segurador arca com a totalidade das indenizações;

A tabela 9, abaixo, mostra o resseguro automático, isto é, quando a responsabilidade do ressegurador e da seguradora iniciam concomitantemente e a retenção, ou seja, a parte da responsabilidade atribuída ao IRB-Brasil Re diretamente, sem retroceder.

Tabela 9. Resseguro automático e retenção do IRB-Brasil Re, em R\$, no ramo rural

\begin{tabular}{lcc}
\hline \multicolumn{1}{c}{ Ramo de seguro } & Resseguro automático & Retenção do IRB \\
\hline Riscos Rurais (Agrícola) & 170.000 & 470.000 \\
Florestas & 170.000 & 470.000 \\
Penhor Rural Banco do Brasil & 4.560 .000 & 4.560 .000 \\
Penhor Rural bancos privados & 530.000 & 530.000 \\
Animais: Individual & 10.000 & 70.000 \\
Animais: Rebanho & 35.000 & 70.000 \\
\hline
\end{tabular}

Fonte: Barros (1998)

No final de 1999 foi sancionada a Lei $n^{\circ}$ 9.932, de 20 de dezembro de 1999, que dispõe sobre a transferência de atribuições da IRB-Brasil Resseguros S.A. IRB-BRASIL Re para a Superintendência de Seguros Privados (Susep).

Entre outras atribuições, a lei transferiu as funções de regulação e fiscalização do mercado de resseguros que pertencia ao IRB Brasil Re para a Susep. Esta era uma questão primordial para o andamento da privatização do IRB, iniciada em dezembro de 1997, quando a estatal foi incluída no Programa Nacional de Desestatização (PND) ${ }^{127}$.

Recentemente, o Superior Tribunal de Justiça (STJ) resolveu arquivar a Ação Direta de Inconstitucionalidade (Adin) que suspendia o processo de privatização do IRB-Brasil Re. Existe uma grande movimentação e interesse por parte de partidos

\footnotetext{
${ }^{127}$ ROCHA, J. Estrangeiros buscam nicho de atuação. http://www.factor.com.br/site/NEWSdetalhes .asp?cod=295483 (14 out. 2004)
} 
políticos e agentes do mercado segurador e ressegurador internacional no processo de privatização do $\operatorname{IRB}^{128}$.

${ }^{128}$ Além dos interesses econômicos no âmbito da Organização Mundial do Comércio (OMC), a abertura do mercado ressegurador brasileiro é moeda de troca pela redução das barreiras aos produtos agrícolas brasileiros no mercado europeu. 


\section{REVISÃO TEÓRICA E METODOLÓGICA}

\subsection{Aspectos microeconômicos do seguro}

Nesta seção serão abordados, de maneira simplificada, os fundamentos econômicos do seguro. A primeira subseção apresenta a teoria dos mercados contingentes e, posteriormente, a teoria econômica do seguro. Nota-se que a primeira teoria está diretamente relacionada com a segunda. Na verdade considera-se o mercado de seguros como uma aplicação natural da teoria das commodities contingentes.

\subsubsection{A teoria dos mercados contingentes ${ }^{129}$}

A abordagem preferências de estado ${ }^{130}$ foi introduzida na teoria econômica por Arrow (1953) e, posteriormente detalhada por Debreu (1959).

A idéia básica por trás da abordagem preferências de estado se refere ao fato de um contrato especificar, para a transferência (recebimento ou entrega) de uma determinada commodity, não somente suas características físicas, seu local e sua data, mas também um determinado "evento ou estado", na qual a transferência está condicionada.

\footnotetext{
${ }^{129} \mathrm{Na}$ literatura é encontrada como "State-Contingent Markets", "Contingent Commodities" ou "Theory of Contingent Markets".

${ }^{130}$ Do termo em inglês "State-Preference Approach".
} 
Por exemplo, a commodity guarda-chuva quando está chovendo e a commodity guarda-chuva quando está sol são tratadas de maneira diferente pelos agentes econômicos e, conseqüentemente, precificadas de maneira apropriada. Outro exemplo é a commodity agrícola soja, que tem sua disponibilidade em local e data préestabelecidos claramente dependente das condições climáticas adequadas desde sua semeadura até a colheita, como por exemplo, a quantidade de chuva. Assim, uma commodity contingente é uma commodity cuja disponibilidade é dependente do acontecimento de certo evento ou estado da natureza.

A especificação e desenvolvimento do modelo com commodities contingentes é similar ao modelo tradicional de equilíbrio geral. Nota-se que o equilíbrio e alocação ótima do compartilhamento do risco, quando atingidos, são ótimos de Pareto.

No caso da análise sobre condições de certeza, as preferências de cada um são baseadas nas cestas de bens, que são os objetos de escolha destes indivíduos. Em condições de incerteza, os conjuntos do consumo, produção e recursos são dependentes da aleatoriedade dos estados da natureza. Desta maneira é necessário especificar para cada estado uma cesta de bens.

Seja $\boldsymbol{S}=\{1,2, \ldots, \mathrm{S}\}$ o conjunto dos estados da natureza, indexado pela letra $\mathrm{s}$, tal que os eventos são mutuamente exclusivos e coletivamente exaustivos. No exemplo anterior tem-se que $\boldsymbol{S}=\{$ chuva, sol $\}$.

Denotando o conjunto $C=\{1,2, \ldots, C\}$, indexado pela letra c, como formado por diferentes commodities, então haverá CS commodities e CS preços. Seja $\mathrm{x}$ a quantidade da commodity c recebida (entregue) se o estado s ocorrer e definida como uma commodity contingente. $\mathrm{O}$ espaço da commodity contingente, $\boldsymbol{X}$, é um subconjunto de $\mathfrak{R}^{\mathrm{CS}}$.

Os conjuntos da produção e consumo são subconjuntos de um espaçoEuclideano com dimensão CS. O comportamento da firma e do consumidor segue as tradicionais regras de decisão de maximização do lucro e da utilidade, respectivamente.

A figura 54 mostra as combinações de bens e estados da natureza das quantidades $\mathrm{x}_{\mathrm{cs}}$ : 


\begin{tabular}{|c|c|c|c|c|c|c|c|}
\hline \multirow{8}{*}{ 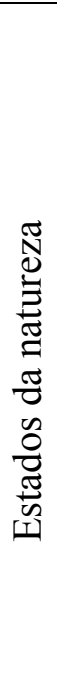 } & \multicolumn{7}{|c|}{ Bens } \\
\hline & $\mathrm{x}_{11}$ & $\mathrm{x}_{21}$ & $\mathrm{X}_{31}$ & $\ldots$ & $\mathrm{X}_{\mathrm{n} 1}$ & $\ldots$ & $\mathrm{X}_{\mathrm{C} 1}$ \\
\hline & $\mathrm{x}_{12}$ & $\mathrm{X}_{22}$ & $\mathrm{x}_{32}$ & $\ldots$ & $\mathrm{x}_{\mathrm{n} 2}$ & $\ldots$ & $\mathrm{X}_{\mathrm{C} 2}$ \\
\hline & $\mathrm{X}_{13}$ & $\mathrm{X}_{23}$ & $\mathrm{x}_{33}$ & $\ldots$ & $\mathrm{X}_{\mathrm{n} 3}$ & $\ldots$ & $\mathrm{X}_{\mathrm{C} 3}$ \\
\hline & $\vdots$ & $\vdots$ & $\vdots$ & & $\vdots$ & & $\vdots$ \\
\hline & $\mathrm{X}_{1 \mathrm{i}}$ & $\mathrm{X}_{2 \mathrm{i}}$ & $\mathrm{X}_{3 \mathrm{i}}$ & $\ldots$ & $\mathrm{X}_{\mathrm{ni}}$ & $\cdots$ & $\mathrm{X}_{\mathrm{Ci}}$ \\
\hline & $\vdots$ & $\vdots$ & $\vdots$ & & $\vdots$ & & $\vdots$ \\
\hline & $\mathrm{X}_{1 \mathrm{~S}}$ & $\mathrm{X}_{2 \mathrm{~S}}$ & $\mathrm{X}_{3 \mathrm{~S}}$ & $\ldots$ & $\mathrm{X}_{\mathrm{nS}}$ & $\ldots$ & $\mathrm{x}_{\mathrm{CS}}$ \\
\hline
\end{tabular}

Figura 54 - O mercado de commodities contingentes

$\mathrm{Na}$ figura 54, a i-ésima linha denota a cesta de bens recebida em um particular estado da natureza. Para qualquer estado da natureza $\mathrm{s} \in \boldsymbol{S}$, pode-se definir um vetor de quantidades $\mathrm{x}_{\mathrm{s}}=\left[\mathrm{x}_{1 \mathrm{~s}}, \mathrm{x}_{2 \mathrm{~s}}, \mathrm{x}_{3 \mathrm{~s}}, \ldots, \mathrm{x}_{\mathrm{Cs}}\right]$, tal que $\mathrm{x}_{\mathrm{s}}$ são todas as commodities recebidas no estado s. Pode-se definir também, um vetor de preços contingente, ou seja, o preço da commodity correspondente a sua transferência no estado s, representado por $\mathrm{p}_{\mathrm{s}}=\left[\mathrm{p}_{1 \mathrm{~s}}, \mathrm{p}_{2 \mathrm{~s}}, \mathrm{p}_{3 \mathrm{~s}}, \ldots, \mathrm{p}_{\mathrm{Cs}}\right]$.

Do mesmo modo, a n-ésima coluna representa uma particular commodity recebida em diferentes estados. Para qualquer $\mathrm{c} \in \boldsymbol{C}$, pode-se definir o vetor $\mathrm{x}_{\mathrm{c}}=\left[\mathrm{x}_{\mathrm{c} 1}\right.$, $\left.\mathrm{x}_{\mathrm{c} 2}, \mathrm{x}_{\mathrm{c} 3}, \ldots, \mathrm{x}_{\mathrm{cS}}\right]^{\prime} \mathrm{e} \mathrm{p}_{\mathrm{c}}=\left[\mathrm{p}_{\mathrm{c} 1}, \mathrm{p}_{\mathrm{c} 2}, \mathrm{p}_{\mathrm{c} 3}, \ldots, \mathrm{p}_{\mathrm{cS}}\right]$ ' como, respectivamente, as quantidades $\mathrm{e}$ preços em diferentes estados da natureza.

Representa-se, então uma cesta de commodities específica, $\mathrm{x}$, como um conjunto de vetores de commodities contingentes, $\mathrm{x}=\left[\mathrm{x}_{\mathrm{S}}\right]=\left[\mathrm{x}_{1}, \mathrm{x}_{2}, \ldots, \mathrm{x}_{\mathrm{S}}\right]=\left[\mathrm{x}_{11}, \ldots, \mathrm{x}_{\mathrm{C} 1}\right.$; $\left.\mathrm{x}_{12}, \ldots, \mathrm{x}_{\mathrm{C} 2} ; \ldots ; \mathrm{x}_{1 \mathrm{~S}}, \ldots, \mathrm{x}_{\mathrm{CS}}\right] \mathrm{e}$ os preços como um conjunto de vetores de preços contingentes, $\mathrm{p}=\left[\mathrm{p}_{\mathrm{s}}\right]=\left[\mathrm{p}_{1}, \mathrm{p}_{2}, \ldots, \mathrm{p}_{\mathrm{S}}\right]=\left[\mathrm{p}_{11}, \ldots, \mathrm{p}_{\mathrm{C} 1} ; \mathrm{p}_{12}, \ldots, \mathrm{p}_{\mathrm{C} 2} ; \ldots ; \mathrm{p}_{1 \mathrm{~S}}, \ldots, \mathrm{p}_{\mathrm{CS}}\right]$ 
Neste mercado, assume-se que os acordos são realizados antes do acontecimento do evento. Deste modo, o pagamento pela quantidade do bem $\mathrm{x}_{\mathrm{cs}}$ ocorre antes e seu recebimento ou sua entrega fica condicionada ao acontecimento do estado.

Assim, o custo de uma determinada cesta $\mathrm{x}$ seria obtido pela multiplicação de todas as commodities, $\mathrm{x}_{\mathrm{cs}}$, em todos os estados do mundo pelo respectivo preço contingente de estados.

Neste modelo nota-se dois aspectos interessantes. O primeiro é que as probabilidades não entram explicitamente no modelo e a segunda é a importância da atitude dos agentes diante do risco.

$\mathrm{Na}$ abordagem das preferências de estado o conjunto dos bens $\mathrm{X} \subset \mathfrak{R}^{\mathrm{CS}}$, as relações de preferência dos indivíduos refletem não somente seus gostos, mas também suas crenças subjetivas a respeito da ocorrência de determinado evento da natureza e suas atitudes diante do risco.

Supondo racionalidade ${ }^{131}$, então a relação de preferência sobre cestas de bens é completa e transitiva e sobre certas condições de regularidade, pode-se demonstrar que uma função de utilidade contínua $\mathrm{U}(\mathrm{x})$ pode representar tais relações de preferência.

A convexidade das relações de preferência ou, equivalentemente, a quasiconcavidade da função de utilidade, tal que $\mathrm{U}: \boldsymbol{X} \rightarrow \mathfrak{R}$, pode ser interpretada como aversão ao risco, enquanto que a maximização do lucro pela firma pode ser vista como neutralidade ao risco.

Complementarmente a esta análise, Savage (1954) desenvolve diversos postulados que possibilitam expressar a função de utilidade em utilidades esperadas subjetivas. Assumindo a existência de funções de utilidade independentes de estado, tal que V: $\boldsymbol{C} \rightarrow \mathfrak{R}$, então as relações de preferência da commodities contingentes podem ser representadas por:

$$
\mathrm{U}(\mathrm{x})=\sum_{\mathrm{s} \in \mathrm{S}} \pi_{\mathrm{s}} \mathrm{V}\left(\mathrm{x}_{\mathrm{s}}\right)=\sum_{\mathrm{s} \in \mathrm{S}} \pi_{\mathrm{s}} \mathrm{V}\left(\mathrm{x}_{1 \mathrm{~s}}, \mathrm{x}_{2 \mathrm{~s}}, \mathrm{x}_{3 \mathrm{~s}}, \ldots, \mathrm{x}_{\mathrm{Cs}}\right)
$$

${ }^{131}$ Ver Mas-Colell et al. (1995), cap. 1, 2 e 3. 
A eq. (1) mostra que a utilidade de uma cesta de commodities, $x$, pode ser expressa como a soma de funções de utilidade independentes de estado, ponderado pelas probabilidades subjetivas ${ }^{132} \pi$, correspondentes a cada estado, tal que $\Sigma_{\mathrm{s}} \pi_{\mathrm{s}}=1$. Nota-se que $\pi_{\mathrm{s}}$ representa a probabilidade associada por certo indivíduo a ocorrência de um determinado evento.

Neste ponto vale ressaltar que a análise poderia ser levada adiante sem a pressuposição das preferências serem independentes de estado e sem os postulados colocados por Savage.

A dependência de estado pode ser introduzida formalmente no modelo inserindo o estado da natureza como um argumento adicional na cesta de bens. Neste caso, a análise de uma commodity por um indivíduo em um estado é melhor avaliada do que em outro estado considerando a mesma commodity, independentemente da probabilidade associada aos estados. Neste caso, representa-se U(x) como:

$$
\mathrm{U}(\mathrm{x})=\sum_{\mathrm{s} \in \mathrm{S}} \pi_{\mathrm{s}} \mathrm{V}_{\mathrm{s}}\left(\mathrm{x}_{\mathrm{s}}\right)=\sum_{\mathrm{s} \in \mathrm{S}} \pi_{\mathrm{s}} \mathrm{V}_{\mathrm{s}}\left(\mathrm{x}_{1 \mathrm{~s}}, \mathrm{x}_{2 \mathrm{~s}}, \mathrm{x}_{3 \mathrm{~s}}, \ldots, \mathrm{x}_{\mathrm{Cs}}\right)
$$

Considerando o caso em que as preferências são independentes de estado, o problema do indivíduo é:

$$
\begin{aligned}
& \operatorname{Max} \sum_{\mathrm{s} \in \mathrm{S}} \pi_{\mathrm{s}} \mathrm{V}\left(\mathrm{x}_{\mathrm{s}}\right) \\
& \text { Sj. a } \sum_{\mathrm{s} \in \mathrm{S}} \mathrm{p}_{\mathrm{s}} \mathrm{x}_{\mathrm{s}} \leq \sum_{\mathrm{s} \in \mathrm{S}} \mathrm{p}_{\mathrm{s}} 1_{\mathrm{s}}
\end{aligned}
$$

\footnotetext{
132 “As probabilidades subjetivas de um estatístico representam numericamente suas crenças e informações. Suas utilidades são representações numéricas de suas preferências.” DeGroot (1970). “...tendo em vista seu uso freqüente em uma ampla variedade de contextos, não é de surpreender que a palavra "probabilidade" tenha adquirido vários significados que são dificilmente distinguíveis uns dos outros. Em discurso ordinário não importa que significado a palavra tem, desde que o sentido particularmente utilizado seja claro no contexto em que é usado. Entretanto "probabilidade" é também uma palavra técnica, aparecendo na ciência e na matemática; quando utilizada de forma técnica, deveria possuir um significado claro e definitivo para o contexto em que é utilizada. O mesmo é verdadeiro para seus usos filosóficos. Várias propostas foram feitas a esse respeito; a teoria de probabilidade subjetivista é uma delas.” Kyburg e Smockler (1980) traduzido por Migon e Lopes (2002).
} 
onde $1_{\mathrm{s}}=\left[1_{1 \mathrm{~s}}, 1_{2 \mathrm{~s}}, 1_{3 \mathrm{~s}}, \ldots, 1_{\mathrm{Cs}}\right]$ corresponde ao vetor de dotações em cada estado $\mathrm{s}$.

Através do método de Lagrange obtêm-se as condições de primeira ordem diferenciando-se em relação a cada commodity contingente $\mathrm{x}_{\mathrm{cs}}$. Além disso, admitindo apenas soluções interiores, então:

$$
\frac{\pi_{1} \mathrm{~V}^{\prime}\left(\mathrm{x}_{\mathrm{c} 1}\right)}{\mathrm{p}_{\mathrm{c} 1}}=\frac{\pi_{2} \mathrm{~V}^{\prime}\left(\mathrm{x}_{\mathrm{c} 2}\right)}{\mathrm{p}_{\mathrm{c} 2}}=\frac{\pi_{3} \mathrm{~V}^{\prime}\left(\mathrm{x}_{\mathrm{c} 3}\right)}{\mathrm{p}_{\mathrm{c} 3}}=\ldots=\frac{\pi_{\mathrm{S}} \mathrm{V}^{\prime}\left(\mathrm{x}_{\mathrm{cS}}\right)}{\mathrm{p}_{\mathrm{cS}}}
$$

A eq. (4) mostra que a relação entre a utilidade marginal esperada de $\mathrm{x}_{\mathrm{cs}} \mathrm{e}$ seu preço será a mesma para todos os estados a natureza ${ }^{133}$. Através da figura 55 , abaixo ilustra-se a escolha ótima do indivíduo. Na situação ilustrada considera-se apenas uma commodity (renda ou riqueza, por exemplo) e dois estados da natureza, tal que $\mathrm{C}=1$ e $\mathrm{S}$ $=2$.

${ }^{133}$ Caso o problema da maximização levasse em conta as preferências dependentes de estado, então a solução ótima seria: $\pi_{1} \mathrm{~V}_{\mathrm{l}}{ }^{\prime}\left(\mathrm{x}_{\mathrm{cl}}\right) / \mathrm{p}_{\mathrm{cl}}=\ldots=\pi_{\mathrm{S}} \mathrm{V}_{\mathrm{S}}{ }^{\prime}\left(\mathrm{x}_{\mathrm{cs}}\right) / \mathrm{p}_{\mathrm{cs}}$. 


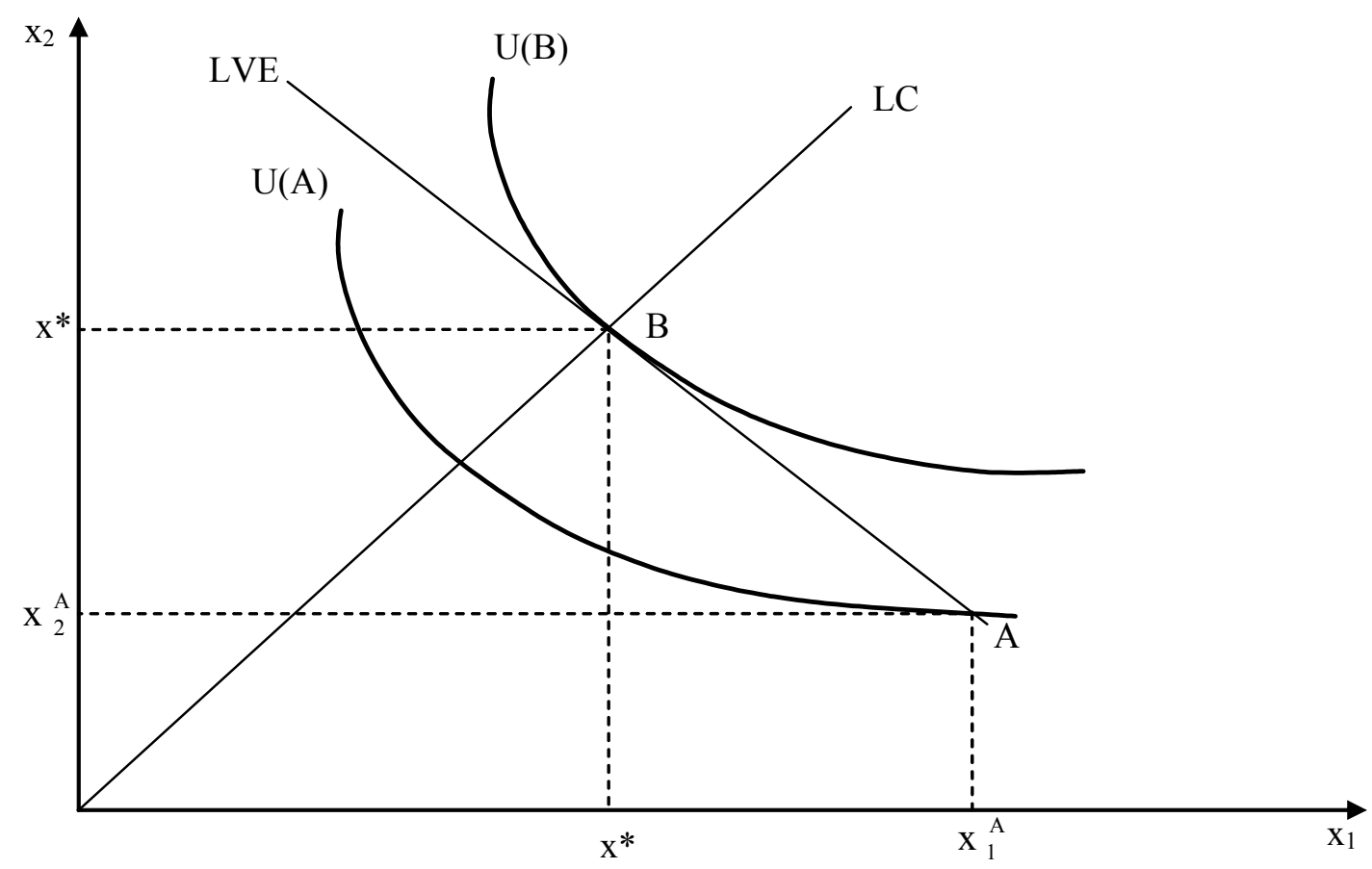

Figura 55 - Escolha ótima individual

$\mathrm{O}$ espaço da commodity contingente neste caso será $\boldsymbol{X} \subset \mathfrak{R}^{2}$. Deste modo, a cesta de bens é representada por $\mathrm{x}=\left\{\mathrm{x}_{1}, \mathrm{x}_{2}\right\}$. O bem contingente $\mathrm{x}_{1}$ é transferido caso o estado 1 aconteça e $x_{2}$, caso o estado 2 ocorra. Supondo que exista uma função de utilidade, $\mathrm{U}: \boldsymbol{X} \rightarrow \mathfrak{R}$ representando as preferências sobre $\boldsymbol{X}$ e que seja expressa de acordo com a eq. (1). Neste caso, a função de utilidade esperada será dada por:

$$
\mathrm{U}(\mathrm{x})=\pi_{1} \mathrm{~V}\left(\mathrm{x}_{1}\right)+\pi_{2} \mathrm{~V}\left(\mathrm{x}_{2}\right)
$$

onde $\pi_{1}$ e $\pi_{2}$ são as probabilidades subjetivas dos estados 1 e 2 . 
Lembrando que a função de utilidade $U$ é quasi-côncava, então a inclinação das curvas de indiferença será:

$$
\frac{\partial \mathrm{x}_{2}}{\partial \mathrm{x}_{1}}=-\frac{\pi_{1}}{\pi_{2}} \frac{\mathrm{V}^{\prime}\left(\mathrm{x}_{1}\right)}{\mathrm{V}^{\prime}\left(\mathrm{x}_{2}\right)}
$$

Nota-se que quando $\mathrm{x}_{1}=\mathrm{x}_{2}=\mathrm{x}^{*}$, ponto $\mathrm{B}$, na figura 55, acima, então $\mathrm{V}^{\prime}\left(\mathrm{x}_{1}\right)=\mathrm{V}^{\prime}\left(\mathrm{x}_{2}\right)$ e a inclinação da curva de indiferença neste ponto será $-\left(\pi_{1} / \pi_{2}\right)$. A reta LC representa a "linha da certeza" e tem inclinação igual a 1. Ao longo de LC a inclinação da cada curva de indiferença será $-\left(\pi_{1} / \pi_{2}\right)$.

O indivíduo é provido de uma dotação inicial representada pela cesta de commodity contingente $\mathrm{A}=\left(\mathrm{x}_{1}^{\mathrm{A}}, \mathrm{x}_{2}^{\mathrm{A}}\right)$. Neste ponto o indivíduo possui mais do bem no estado 1 do que no estado 2. Além disso, percebe-se que a curva de indiferença associada a esta cesta é menor do que a curva que é tangente a "linha do valor esperado" LVE quando intercepta a LC, no ponto B.

Assumindo que exista um mercado onde bens contingentes são transacionados e que seus preços sejam conhecidos antes da transação ocorrer. Deste modo $\mathrm{p}_{1}$ será o preço da commodity no estado 1 e $\mathrm{p}_{2}$, seu preço no estado 2 . O indivíduo está sujeito agora, a uma restrição dada pela reta $\mathrm{R}$ com inclinação - $\mathrm{p}_{1} / \mathrm{p}_{2}$, na figura 56 , abaixo.

O problema deste indivíduo será:

$$
\begin{aligned}
& \operatorname{Max} U=\pi_{1} V\left(x_{1}\right)+\pi_{2} V\left(x_{2}\right) \\
& \text { Sj. a } p_{1} x_{1}+p_{2} x_{2}=\pi_{1} x_{1}+\pi_{2} x_{2}
\end{aligned}
$$

A condição de primeira ordem que satisfaz (7) será:

$$
-\frac{\pi_{1}}{\pi_{2}} \frac{\mathrm{V}^{\prime}\left(\mathrm{x}_{1}\right)}{\mathrm{V}^{\prime}\left(\mathrm{x}_{2}\right)}=-\frac{\mathrm{p}_{1}}{\mathrm{p}_{2}}
$$


A eq. (8) mostra que no ponto ótimo, como já mostrado anteriormente, a utilidade marginal esperada por unidade monetária será igual nos dois estados. Na figura 56, abaixo, nota-se que, dado o nível de preços nos dois estados, a quantidade no estado 1 difere da quantidade no estado 2 , no ponto $\mathrm{C}=\left(\mathrm{x}_{1}^{\mathrm{C}}, \mathrm{x}_{2}^{\mathrm{C}}\right)$.

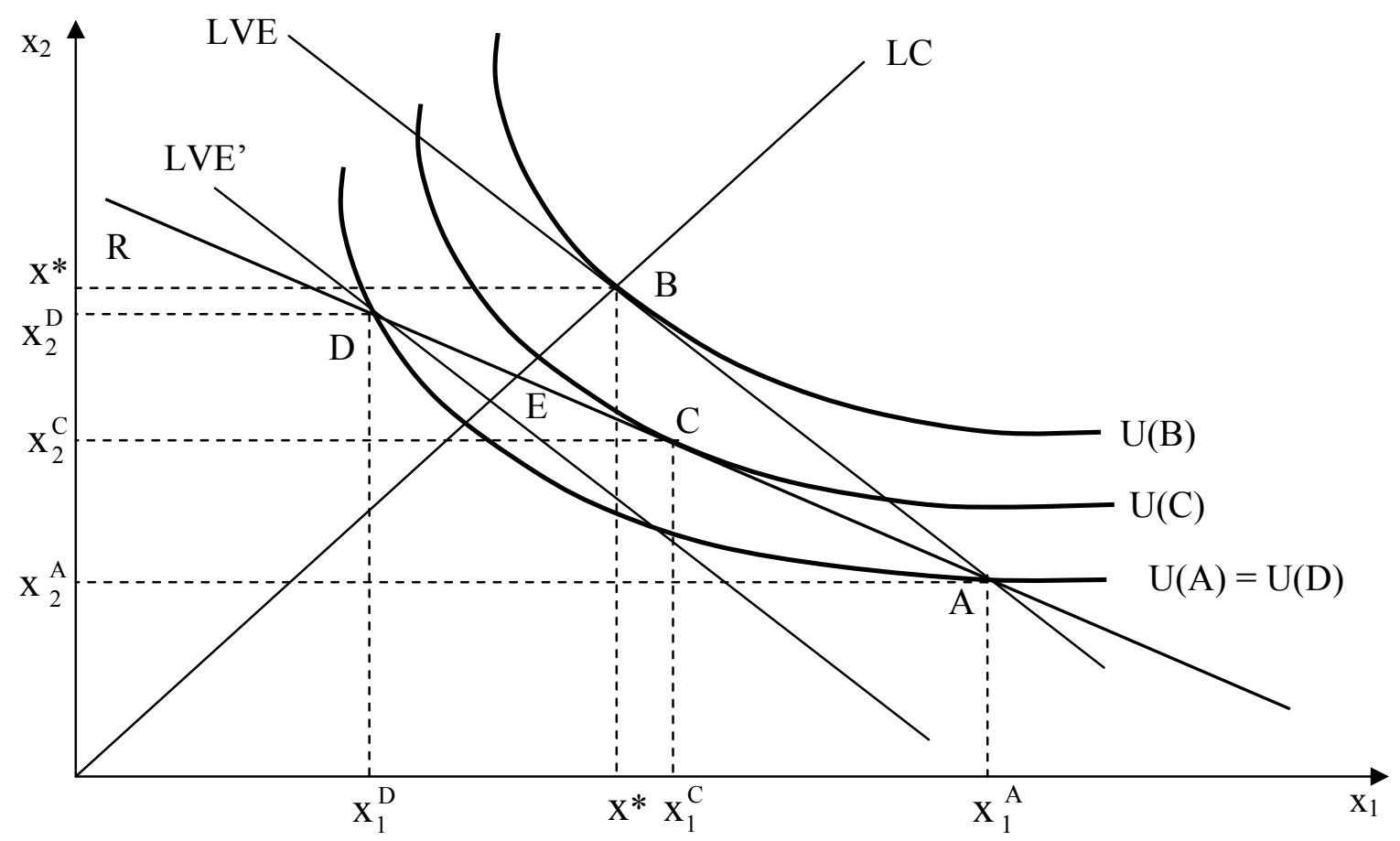

Figura 56 - Preços justos e não justos e a escolha do consumidor

Isto ocorre, pois de acordo com (6) a relação $\pi_{1} / \pi_{2}>\mathrm{p}_{1} / \mathrm{p}_{2}$, ou seja, a relação dos preços nos dois estados não é a mesma que a relação entre as probabilidades subjetivas nos respectivos estados.

Quando isto ocorre, diz-se que os preços não são "atuarialmente justos". Se os preços fossem atuarialmente justos então a linha $R$ coincidiria com a LVE e o indivíduo optaria pelo ponto $\mathrm{B}$, atingindo um nível de utilidade maior neste caso. 
Mas existem situações em que o preço justo pode não ser preferível pelo indivíduo. Por exemplo, na fig. 56, se o indivíduo estivesse inicialmente com a dotação inicial $\mathrm{D}=\left(\mathrm{x}_{1}^{\mathrm{D}}, \mathrm{x}_{2}^{\mathrm{D}}\right)$, com o nível de utilidade $\mathrm{U}(\mathrm{A})=\mathrm{U}(\mathrm{D})$ e se defrontasse com preços não justos $\left(\mathrm{p}_{1} / \mathrm{p}_{2} \neq \pi_{1} / \pi_{2}\right)$, dado que a relação de possibilidades subjetivas permaneça inalterada, então o indivíduo optaria pelo ponto $\mathrm{C}$, a um nível de utilidade maior.

Neste caso, o mesmo possui inicialmente mais do bem no estado 2 do que no estado 1 e o preço de mercado para o bem no estado 2 é maior que a probabilidade subjetiva de ocorrência neste estado. Nesta situação o indivíduo claramente se beneficiaria de preços não justos.

Por outro lado, se os preços fossem atuarialmente justos, então a inclinação de R seria a mesma de LVE'. Partindo do ponto D, novamente, percebe-se que a curva de indiferença U(D) tangenciaria LVE' no ponto $\mathrm{E}$ a um nível de utilidade menor que na situação anterior (ponto $C$, ao nível de utilidade $U(C)$ ).

Deste modo, se o indivíduo estiver em uma posição inicial como nos pontos A ou D, então optará por combinações de bens ao longo de LC, se os preços forem justos.

De outra maneira, se o mesmo estiver inicialmente em uma posição sobre LC e se for confrontado com preços justos, então irá permanecer sobre a LC, pois neste caso o maior nível de utilidade é atingido e as quantidades do bem nos dois estados são igualados.

\subsubsection{A economia do seguro ${ }^{134}$}

O seguro é uma das instituições mais antigas idealizadas pelo homem para lhe dar com eventos incontroláveis, de maneira a reduzir a incerteza ou risco presente no mundo real.

\footnotetext{
${ }^{134}$ Subseção baseada em trabalhos de Akerlof (1970); Arrow (1971); Coles e Malcomson (1989); Holmströn (1979); Hoy (1982); Mas-Colell et al. (1995); Pauly (1968); Rees (1989); Rothchild e Stiglitz (1976); Shavell (1979a); Shavell (1979b); Siberberg (1995).
} 
A grande maioria dos riscos apresenta conseqüências econômicas, e são estes riscos e estas conseqüências que interessam ao mercado segurador.

Diversos mecanismos criados pelo homem surgiram com o objetivo de redução do risco, como por exemplo, diversificação, auto-seguro, reservas de crédito, investimentos em redução da perda ou mecanismos baseados na pulverização do risco pelo mercado.

Entretanto, permanecem muitas formas de perdas econômicas que não podem ser prevenidas. Existem limites, na qual a probabilidade de perda ou dano não pode ser reduzida. Tendo em vista este problema, o seguro é a forma mais eficiente de transferência do risco.

Nota-se, que nem todos os tipos de riscos são seguráveis. Os critérios básicos para a segurabilidade são apontados, a seguir (Booth et al., 1999; Hart et al., 1996; Redja, 1995; Skees e Barnett, 1999; Trowbridge, 1989):

- A perda esperada deve ser calculável. Para calcular o prêmio, a seguradora deve ser capaz de estimar a severidade e a freqüência média da perda, levando-se em conta a seleção adversa;

- As circunstâncias de uma perda devem ser possíveis de definição, além disso, devem ser não intencionais e acidentais. Uma atenção especial deve ser dada ao risco moral;

- Deve haver um grande número de unidades expostas, homogêneas e independentes ${ }^{135}$

para que se possa obter uma previsão com certo nível de exatidão das perdas médias futuras;

\footnotetext{
${ }^{135}$ Seja X uma variável aleatória representando a indenização recebida por um grupo de $\mathrm{n}$ indivíduos independentes e idênticos. Assim, $X_{i}$ será uma amostra de variáveis aleatórias independentes e identicamente distribuídas. Seja $\mathrm{E}\left(\mathrm{X}_{\mathrm{i}}\right)=\mu \mathrm{e} \mathrm{V}\left(\mathrm{X}_{\mathrm{i}}\right)=\sigma^{2}$, para $\mathrm{i}=1,2, \ldots, \mathrm{n}$. O coeficiente de variação é uma medida de incerteza associado com a variável aleatória, relativo ao tamanho esperado do risco e dado por $\mathrm{CV}_{\mathrm{X}}=\sigma / \mu$. Definido $\mathrm{S}=\Sigma \mathrm{X}_{\mathrm{i}}$, então $\mathrm{E}(\mathrm{S})=n \mu \mathrm{e} \mathrm{V}(\mathrm{S})=\mathrm{n} \sigma^{2}$. O coeficiente de variação será $\mathrm{CV}_{\mathrm{S}}=\sigma$ $/ \mu(\mathrm{n})^{1 / 2}$. Assim, quando $\mathrm{n} \rightarrow \infty, \mathrm{CV}_{\mathrm{S}} \rightarrow 0$. Este resultado é uma conseqüência da Lei dos Grandes Números.
} 
- O prêmio deve ser economicamente viável. Quando um risco tem alta freqüência e baixa severidade, o custo de transação é elevado a ponto do prêmio não ser economicamente viável;

- Não haja perda catastrófica. Se os riscos forem sistêmicos, ou positivamente correlacionadas entre unidades seguradas, a Lei dos Grandes Números não se aplica;

- O seguro não deve ameaçar o interesse público como, por exemplo, encorajar atos ilícitos;

Se um indivíduo adquire um contrato de seguro, uma taxa ou um prêmio é pago à firma seguradora em troca de um pagamento ou indenização futura, caso um evento incerto especificado a priori ocorra.

Os trabalhos realizados por Arrow (1971) e Borch (1968) foram pioneiros na formalização dos conceitos de seguro dentro do arcabouço econômico.

Dentro deste contexto, a informação tem um papel relevante para a alocação de recursos de forma eficiente. Embora a importância do valor da informação tenha sido reconhecida a um longo tempo, sua caracterização econômica formal e suas implicações na alocação de recursos foram inicialmente analisadas por Stigler (1961).

Nota-se que uma característica inerente à informação é a dificuldade de sua definição. Por exemplo, a informação pode ser considerada, em alguns casos como um bem público, ou seja, é um bem não rival, pois outros poderão utilizá-lo a um custo zero e, também um bem não exclusivo, no sentido de que alguns indivíduos não poderão proibir outros de usufruir da informação.

Por outro lado, podem existir custos associados à geração, transferência e utilização da informação. Na ausência de informação perfeita, os indivíduos serão incapazes de saber, com certeza, quais as conseqüências de determinadas decisões tomadas em certa situação. 
Segundo os dois teoremas fundamentais da economia do bem estar, sob certas pressuposições, a alocação no equilíbrio competitivo é ótimo de Pareto $^{136}$ e qualquer alocação eficiente de Pareto será uma alocação no equilíbrio competitivo após algumas redistribuições adequadas das dotações iniciais.

O primeiro teorema assume que todos os indivíduos em uma economia possuem a mesma informação a respeito de todas as variáveis econômicas. Nota-se que pode existir incerteza, mas esta é compartilhada por todos em um mesmo nível.

Caso a suposição de simetria de informação seja violada, então os resultados obtidos em equilíbrio competitivo não serão Pareto ótimo. Neste caso, os consumidores terão maior conhecimento de seus gostos e preferências do que as firmas, as firmas saberão mais de seus custos do que o governo, e todos os agentes tomarão decisões que são, no mínimo parcialmente não observáveis.

$\mathrm{Na}$ busca de um novo paradigma na análise do equilíbrio competitivo, Stiglitz (1985) considera a influência da informação imperfeita em diversas áreas da economia. Tal imperfeição faz com que surjam dois problemas que incidem sobre as relações econômicas dos indivíduos. O problema das ações ocultas e das informações ocultas.

O fenômeno da ação oculta acontece quando, em uma transação, uma das partes, o Agente, toma iniciativas que não podem ser monitoradas ou fiscalizadas com exatidão pela outra parte ou quando o Agente recebe informações relevantes após o contrato ser estabelecido.

Dentro de um contexto mais amplo, o modelo Agente-Principal é utilizado para determinar a eficiência econômica na presença da assimetria de informação (Arrow, 1991).

Neste modelo, o Principal é aquele que propõe o contrato e realiza o pagamento e o Agente é a parte que aceita ou rejeita este contrato, decide sobre determinada ação e recebe a compensação, de acordo com o especificado no contrato.

\footnotetext{
${ }^{136}$ Em um modelo com dois indivíduos ou duas firmas e dois produtos, a taxa marginal de substituição e a taxa marginal de transformação devem igualar a razão entre os preços. Desde que todos os agentes considerem os preços como constantes, então todas as taxas marginais serão constantes no equilíbrio.
} 
Ambos poderiam ser representados por indivíduos, empresas, organizações ou instituições.

O objetivo do Principal é desenhar um contrato, ou um mecanismo de compensação, que proporcione o correto incentivo para que o Agente atue de acordo com o seu interesse.

Considere, por exemplo, um proprietário de terra, o Principal e um arrendatário, o Agente. Percebe-se que pode não ser uma tarefa fácil monitorar as ações do arrendatário. Neste caso, se tais ações são não observáveis, a compensação não poderá ser baseada nas mesmas.

Mas, caso as ações não sejam diretamente observáveis e supondo que a produção seja uma função apenas do esforço ${ }^{137}$ do indivíduo e, além disso, se a relação entre o esforço e a produção for completamente especificado, então se a produção for observada, inferências a respeito da ação poderão ser realizadas com exatidão.

Dentro deste contexto, a questão central do problema Agente-Principal são os incentivos econômicos onde as ações não são observadas e não podem ser inferidas através de outra variável observável. Deste modo, uma suposição bastante comum neste problema é que o produto seja uma função do esforço do Agente ${ }^{138}$.

O contrato especifica a compensação ou pagamento do Principal para o Agente como uma função do resultado ou produção, observável para ambos. O resultado está sobre a influência da ação do Agente, mas a ação não é observável. Assim, as características do contrato apenas refletirão em parte tais ações.

Para a formulação do problema define-se uma ação $a$, tal que $a \in A$, o conjunto de todas as possíveis ações, $\mathrm{O}=\left\{\mathrm{o}_{J}\right\}=\left\{\mathrm{o}_{1}, \mathrm{o}_{2}, \ldots, \mathrm{o}_{\mathrm{N}}\right\}$, tal que, $\mathrm{O}=\delta(a)$, o conjunto de todos os resultados e $\pi_{J}(a)$, a probabilidade de que o resultado $j$ ocorra, dado que a ação $a$ foi tomada pelo Agente.

Além disso, seja o mecanismo de compensação, $\mathrm{M}=\left\{\mathrm{m}_{J}\right\}=\left\{\mathrm{m}_{1}, \mathrm{~m}_{2}, \ldots\right.$, $\left.\mathrm{m}_{\mathrm{N}}\right\}$, ou seja, o pagamento feito ao Agente se determinado resultado ocorrer, tal que, $\mathrm{M}$

\footnotetext{
${ }^{137}$ Esforço, neste contexto, pode ser entendido também como gasto em unidades monetárias, como será visto em seção posterior.

${ }^{138}$ A suposição pode ser estendida para o caso em que o produto é função do esforço e de uma variável aleatória observável para o Agente, como por exemplo, o clima.
} 
$=\gamma(\mathrm{O})$. A utilidade esperada do Principal será denotada por, $\mathrm{U}(\cdot)$, e a utilidade esperada do Agente, $\mathrm{V}(\cdot)$, de modo que:

$$
\begin{aligned}
& \mathrm{U}(\gamma(\mathrm{O}), \mathrm{O}, a)=\sum_{\mathrm{J}} \pi_{\mathrm{J}}(a) \mathrm{U}\left(\mathrm{o}_{\mathrm{J}}-\mathrm{m}_{\mathrm{J}}\right) \\
& \mathrm{V}(\mathrm{M}, a)=\sum_{\mathrm{J}} \pi_{\mathrm{J}}(a) \mathrm{V}\left(\mathrm{m}_{\mathrm{J}}, a\right)
\end{aligned}
$$

O problema será determinar $\gamma$ que maximize a utilidade esperada do Principal, $\mathrm{U}(\cdot)$, dado que o Agente escolherá a ação $a$ que maximize sua utilidade esperada, $\mathrm{V}(\cdot)$, dado o contrato:

$$
\begin{aligned}
& \underset{\mathrm{P}, a}{\operatorname{Max}} \mathrm{EU} \\
& \text { Suj. a } \mathrm{EV} \geq \widetilde{\mathrm{V}} \\
& a \in \operatorname{argmax} \mathrm{V}\left(\mathrm{M}, a^{*}\right), a^{*} \in A
\end{aligned}
$$

Percebe-se que o problema será a maximização de $\mathrm{U}(\cdot)$, sujeito à restrição de que a utilidade esperada do Agente deverá ser no mínimo $\widetilde{\mathrm{V}}$, denominada "utilidade de reserva". Isto é, qualquer contrato proposto pelo Principal será aceito pelo Agente se garantir no mínimo a utilidade de reserva.

A outra parte da restrição é denominada "restrição de compatibilidade de incentivos" (RCI) e mostra que o valor de a que soluciona o problema do Principal também deverá solucionar o problema de maximização da utilidade esperada do Agente, dado o contrato M. Outra maneira de colocar a RCI é $\operatorname{EV}\left(\mathrm{M}^{*}, a^{*}\right)>\operatorname{EV}(\mathrm{O}(a), a)$, tal que, $\mathrm{M}^{*}=\gamma\left(\mathrm{O}\left(a^{*}\right)\right)$. (Arrow, 1991; Luenberger, 1995; Macho-Stadler e Peres-Castrillo, 1997; Ross, 1973; Salanié, 1997; Stiglitz, 1987).

$\mathrm{Na}$ literatura de seguro, o termo ação oculta é conhecido como risco moral. Na presença de risco moral, caso a seguradora consiga monitorar perfeitamente 
as ações do segurado, então o prêmio pelo seguro é atuarialmente justo e seguro é total ou completo.

Caso contrário, se a seguradora monitora imperfeitamente as ações do indivíduo, o seguro é oferecido a um nível de cobertura parcial, de modo que, o indivíduo se responsabilize pelo risco remanescente.

Diversos mecanismos foram desenvolvidos com o objetivo de reduzir o risco moral, na qual os mais importantes são a dedutibilidade e o cosseguro. A dedutibilidade é o montante reduzido, em percentagem, do nível de cobertura. $\mathrm{O}$ cosseguro é o esquema pela qual o segurado paga uma fração do custo (Arrow, 1968; Milgrom e Roberts, 1992; Pauly, 1974; Spence e Zeckhauser, 1971).

O problema da informação oculta ou seleção adversa ocorre quando, as características do agente são imperfeitamente observadas pelo principal.

Em um artigo analisando o mercado de carros usados, Akerlof (1970) argumenta que em um mercado onde os vendedores estão mais bem informados da qualidade do carro do que os compradores, então apenas os carros ruins permanecem no mercado.

Nota-se que, em média, a qualidade recebida será inferior ao preço pago e no limite não existirá mercado para carros usados devido ao problema da assimetria de informação.

Análogo ao mercado analisado, o mercado de seguro médico também é afetado pela seleção adversa. À medida que o prêmio se eleva, apenas as pessoas que realmente necessitam do seguro adquirem o contrato, selecionando deste modo, somente aqueles indivíduos mais propensos a receber a indenização.

Um modelo altamente estilizado e bastante geral de um mercado de seguros competitivo foi analisado por Rothschild e Stiglitz (1976).

Neste mercado a natureza da informação imperfeita está no fato da firma seguradora não ser capaz de diferenciar seus consumidores. Deste modo, os autores afirmam que em um mercado de seguro competitivo o equilíbrio não pode ser atingido. 
Possíveis soluções "segundo melhor"139 seriam desejáveis para a viabilidade do mercado. Dentre elas destacam-se a implementação de contratos de seguro "auto-seletivos", na qual satisfazendo a condição de lucro zero pela firma os segurados revelariam

à seguradora sua estrutura de riscos.

Assim, seriam oferecidos aos indivíduos contratos que poderiam ser escolhidos voluntariamente, de modo que aos indivíduos de baixo risco contratos com cobertura parcial a um prêmio proporcional seriam ofertados, para que não houvesse incentivos por parte do grupo de alto risco de adquirir tal contrato.

O mecanismo de auto-seleção foi demonstrado ser Pareto improvement se um determinado indivíduo pode ser categorizado segundo sinais que sejam correlacionados com seu risco.

Outra solução "segundo melhor" seria formular o contrato de acordo com a informação disponível. Se o monitoramento ocorrer, mesmo imperfeitamente, então uma situação Pareto improvement pode ser atingido.

A teoria dos mercados contingentes está diretamente relacionada com a teoria da economia do seguro. Na verdade o mercado de seguro é uma aplicação natural da teoria das commodities contingentes.

A transferência de uma commodity, neste caso, um pagamento monetário ou indenização, pela seguradora, está diretamente relacionada à ocorrência de um evento especificado no contrato.

A seguir será formalizado um modelo em competição perfeita do mercado de seguro que, apesar de estilizado e bastante geral, apresenta resultados interessantes e proporciona alguns insights sobre os contratos de seguro transacionados no mercado pelas firmas seguradoras.

Quando a pressuposição de informação perfeita é retirada do modelo, então problemas relacionados à assimetria de informação ocorrem impedindo o mercado de alocar eficientemente os recursos sobre condições de incerteza.

\footnotetext{
139 Segundo Lipsey e Lancaster (1956/57) a teoria do segundo melhor é aplicada quando uma situação Pareto ótimo não pode ser atingido e não existe condições suficientes simples e gerais para melhorar a eficiência.
} 


\subsection{A escolha individual}

Seja um indivíduo que tenha inicialmente uma dotação contingente representada pela sua renda, $\mathrm{W}$, e condicionada à ocorrência de um evento natural. Assim, na ocorrência de um acidente sua renda será de $\mathrm{W}_{2}=\mathrm{W}_{1}-d$, na qual $d$ é o prejuízo causado pelo acidente e $\mathrm{W}_{1}$, caso contrário.

No modelo supõe-se que existam dois estados da natureza, $\mathrm{S}=2$ e uma commodity transacionada, então $\mathrm{C}=1$. No estado 1 não ocorre acidente com probabilidade $(1-\pi)$ e sua renda inicial será $\mathrm{W}_{1}^{0}$. No estado 2 ocorre acidente com probabilidade $\pi$ e $\mathrm{W}_{2}^{0}$ será sua renda neste estado.

O valor esperado da renda deste indivíduo na situação inicial será:

$$
\overline{\mathrm{W}}^{0}=(1-\pi) \mathrm{W}_{1}^{0}+\pi \mathrm{W}_{2}^{0}=\mathrm{W}_{1}^{0}-\pi d
$$

A utilidade esperada será representada por:

$$
\mathrm{U}(\mathrm{W})=(1-\pi) \mathrm{U}\left(\mathrm{W}_{1}^{0}\right)+\pi \mathrm{U}\left(\mathrm{W}_{2}^{0}\right)
$$

onde $\mathrm{U}(\cdot)$ é função de utilidade esperada de von Neumann-Morgenstern (vN-M) ou função de utilidade de Bernoulli ${ }^{140}$.

Através da aquisição de um contrato de seguro, o indivíduo poderá atingir outra distribuição de renda diferente da inicial. Neste caso, suponha que uma firma seguradora ofereça um contrato de seguro, $q$, totalmente especificado pela dupla,

\footnotetext{
${ }^{140}$ A função de utilidade esperada foi inicialmente investigada por Bernoulli (1954), através de um famoso e interessante paradoxo, o paradoxo de Saint Petersburg, que ilustra a dificuldade na época de dissociar o valor do dinheiro de sua utilidade.
} 
prêmio, $P$, e indenização ou compensação, $I$, de modo que $q=(P, I)$. A tabela 10 , abaixo mostra as afirmações até agora realizadas.

Tabela 10. Situação do indivíduo com e sem seguro nos estados 1 e 2.

\begin{tabular}{ccc}
\hline Situação & Renda & Estado \\
\hline Sem seguro & $\left\{\begin{array}{cc}\mathrm{W}_{1}^{0} & 1 \\
\mathrm{~W}_{1}^{0}-d=\mathrm{W}_{2}^{0} & 2 \\
\mathrm{~W}_{1}^{0}-P & 1 \\
\mathrm{~W}_{1}^{0}-P-d+I & 2 \\
\hline\end{array}\right.$ & $\left\{\begin{array}{c}\text { Com seguro } \\
\hline\end{array}\right.$
\end{tabular}

Com a aquisição de seguro, o valor esperado da sua renda será:

$$
\begin{aligned}
& \overline{\mathrm{W}}_{\mathrm{q}}=(1-\pi)\left(\mathrm{W}_{1}^{0}-P\right)+\pi\left(\mathrm{W}_{2}^{0}-P+I\right) \\
& \overline{\mathrm{W}}_{\mathrm{q}}=\mathrm{W}_{1}^{0}+\pi(d-I)-P
\end{aligned}
$$

A utilidade esperada será:

$$
\mathrm{U}_{q}(\mathrm{~W})=(1-\pi) \mathrm{U}\left(\mathrm{W}_{1}^{0}-P\right)+\pi \mathrm{U}\left(\mathrm{W}_{2}^{0}-P+I\right)
$$

O critério de decisão utilizada pelo indivíduo para adquirir o contrato será aquela, na qual a utilidade esperada na situação com seguro será maior ou igual a utilidade esperada na situação sem seguro:

$$
\mathrm{U}_{q} \geq \mathrm{U}
$$

Sendo o lucro esperado da firma igual a $(1-\pi) P-\pi(I-P)$, definindo a indenização líquida como $I_{\mathrm{L}}$, tal que $I_{\mathrm{L}}=I-P$, e assumindo que o lucro da firma 
seguradora é zero, dada a pressuposição de competição perfeita, então $(1-\pi) P-\pi(I-$ $P)=0$.

Denotando o prêmio como um percentual, $\phi$, tal que $\phi \in[0,1]$, da importância segurada ou valor máximo da indenização, de modo que $P=\phi I$, então têmse que, rearranjando os termos, $\pi /(1-\pi)=P / I_{\mathrm{L}}=\phi /(1-\phi)$, que implica que $\pi=\phi$, ou do mesmo modo, $P=\pi I$.

O prêmio é considerado atuarialmente justo, ou somente "prêmio justo" quando a probabilidade de um acidente ocorrer é igual ao prêmio por unidade de compensação ou quando o prêmio for igual a indenização esperada.

O problema do indivíduo será:

$\operatorname{Max}_{I}\left[(1-\pi) \mathrm{U}\left(\mathrm{W}_{1}^{0}-P\right)+\pi \mathrm{U}\left(\mathrm{W}_{1}^{0}-P-\mathrm{d}+I\right)\right]$

Sj. a $P-\phi I=0$

Das condições de primeira ordem resulta que:

$$
\frac{\mathrm{U}^{\prime}\left(\mathrm{W}_{1}^{0}-\phi I\right)}{\mathrm{U}^{\prime}\left(\mathrm{W}_{2}^{0}+I-\phi I\right)}=\frac{\pi}{(1-\pi)} \frac{(1-\phi)}{\phi}
$$

Retomando a eq. (18), quando o prêmio é justo, então $\mathrm{U}^{\prime}\left(\mathrm{W}_{1}^{0}-\phi I\right)=\mathrm{U}^{\prime}\left(\mathrm{W}_{2}^{0}+I-\phi I\right)$, se e somente se, $\mathrm{W}_{1}^{0}=\mathrm{W}_{2}^{0}+I$, ou $I=d$, ou seja, quando toda a perda é indenizada. Nesta situação, o seguro é dito ser um "seguro completo".

Definindo, deste modo, o contrato de seguro justo e completo como aquele em que $q=(\pi d, d)$, ou seja, o prêmio justo é igual a perda esperada, mas como toda a perda é indenizada, $d=I$, então diz-se que o prêmio justo é igual a indenização esperada.

O ponto ótimo de compensação escolhido pelo indivíduo maximizador de sua utilidade na figura 57 , abaixo será o ponto $\bar{W}\left(\mathrm{~W}_{1}^{0}-\pi d, \mathrm{~W}_{2}^{0}+(1-\pi) d\right)$. 


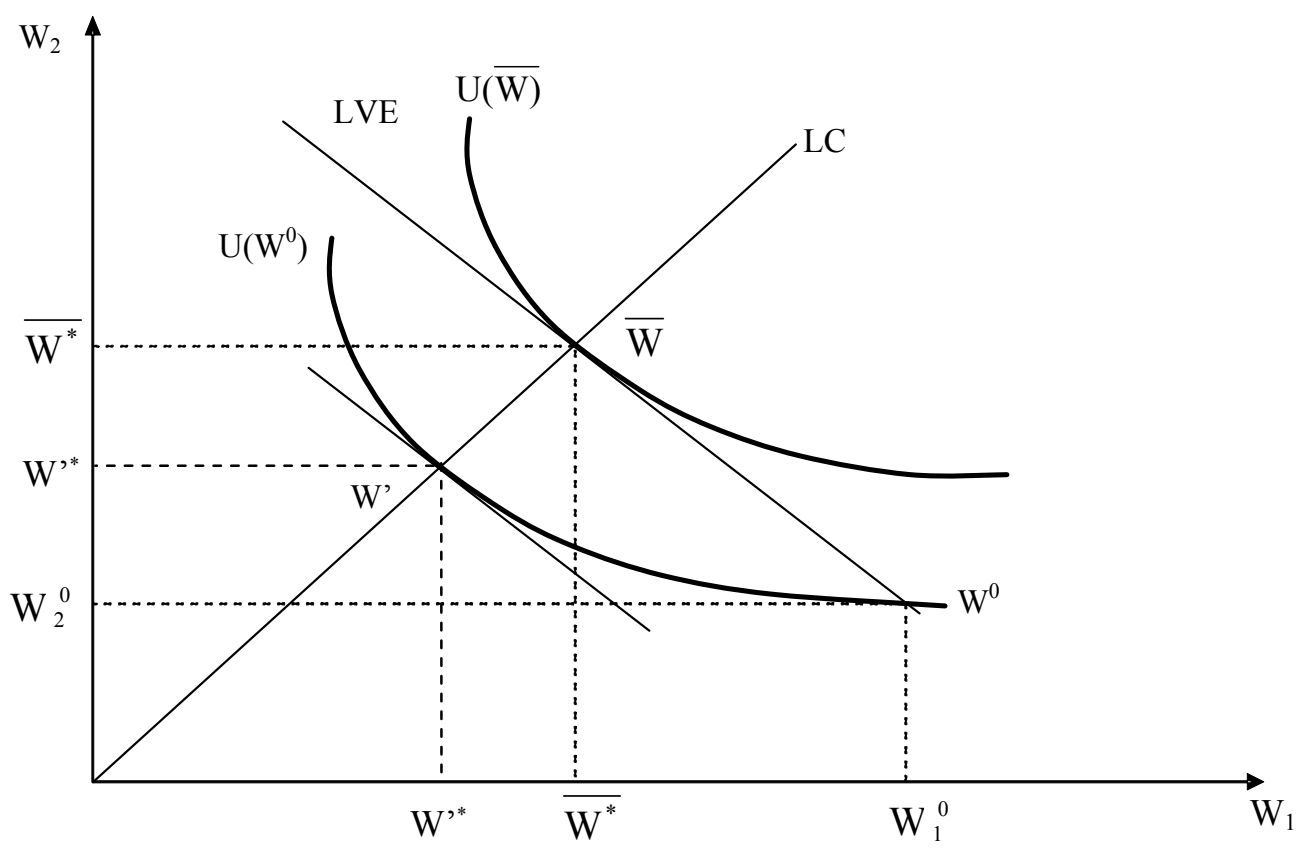

Figura 57 - Ótimo individual

Nesta situação o valor esperado da renda será:

$$
\overline{\mathrm{W}}_{\mathrm{q}}^{\mathrm{c}}=(1-\pi)\left(\mathrm{W}_{1}^{0}-P\right)+\pi\left(\mathrm{W}_{2}^{0}+I-P\right)=\mathrm{W}_{1}^{0}-\pi d
$$

A eq. (19) mostra que, o valor esperado da renda na situação com contrato de seguro completo e justo será igual ao valor esperado na situação inicial, ou seja, $\overline{\mathrm{W}}_{\mathrm{q}}^{\mathrm{c}}=\overline{\mathrm{W}}^{0}$.

Além disso, sobre a pressuposição de que o indivíduo tem aversão ao risco $^{141}$, pode-se perceber pela figura 57 que o contrato de seguro justo e completo é

${ }^{141} \frac{\partial \mathrm{U}}{\partial \mathrm{W}_{\mathrm{i}}}=\mathrm{U}^{\prime}\left(\mathrm{W}_{\mathrm{i}}\right)>0$ e $\frac{\partial^{2} \mathrm{U}}{\partial \mathrm{W}_{\mathrm{i}}^{2}}=\mathrm{U}^{\prime \prime}\left(\mathrm{W}_{\mathrm{i}}\right)<0$, para $\mathrm{i}=1,2$. 
preferível à situação sem seguro, isto é, $\mathrm{U}(\overline{\mathrm{W}})>\mathrm{U}\left(\mathrm{W}^{0}\right)$. Nota-se também que, este contrato permite ao indivíduo trocar a distribuição da renda incerta $\left(\mathrm{W}_{1}^{0}, \mathrm{~W}_{2}^{0}\right)$ pela renda certa $\overline{\mathrm{W}}$.

Da mesma forma que na seção anterior, LC é a "linha da certeza" com inclinação igual a 1 e mostra todos os pares $\left(\mathrm{W}_{1}, \mathrm{~W}_{2}\right)$, tal que $\mathrm{W}_{1}=\mathrm{W}_{2}$.

A reta negativamente inclinada, LVE, representa a "linha do valor esperado" e mostra todos os pares de renda nos dois estados que satisfazem:

$$
\overline{\mathrm{W}}^{*}=(1-\pi) \mathrm{W}_{1}+\pi \mathrm{W}_{2}
$$

A inclinação de LVE será dada por $-(1-\pi) / \pi$ e percebe-se que saindo do ponto $\mathrm{W}^{0}$ em direção a $\overline{\mathrm{W}}$ ocorre redução da dispersão em torno do valor esperado $\overline{\mathrm{W}}^{*}$ nos eixos da abscissa e ordenada. Além disso, ao longo de LVE, o indivíduo opta por trocar renda no estado 1 por renda no estado 2 .

Se ao indivíduo for permitido escolher o nível de indenização, $I$, através do nível de cobertura, em contrapartida, pagar o prêmio justo equivalente, $\pi I$, então todos os pontos na LVE estarão sendo ofertados ao mesmo. Deste modo, a LVE representa a restrição de lucro zero pela seguradora, pois para qualquer nível de indenização, tem-se que $P-\pi I=0$.

Dada a pressuposição de aversão ao risco do indivíduo, então sua função de utilidade será estritamente côncava. Supondo que tais funções sejam separáveis, então a soma de funções côncavas ponderadas pelas probabilidades, que é a representação da função de utilidade esperada, será também estritamente côncava, gerando contornos ou curvas de indiferenças convexas em relação à origem ${ }^{142}$.

\footnotetext{
${ }^{142}$ Para se obter curvas de indiferença negativamente inclinadas e convexas em relação à origem basta admitir uma função de utilidade quasi-côncava. A concavidade estrita da função não é, portanto, uma condição necessária para a obtenção destes tipos de curvas. Por outro lado, a pressuposição de aversão ao risco implica em concavidade estrita da função.
} 
Nota-se que, ao longo da curva de indiferença, a utilidade esperada é constante. Para verificar tal propriedade das curvas de indiferença, considere a curva de indiferença dada por:

$$
\mathrm{U} \equiv(1-\pi) \mathrm{U}\left(\mathrm{W}_{1}\right)+\pi \mathrm{U}\left[\mathrm{W}_{2}\left(\mathrm{~W}_{1}\right)\right]
$$

A inclinação da curva de indiferença ou a taxa marginal de substituição será em função da razão entre as probabilidades e a razão entre as utilidades marginais nos dois estados, como pode ser observado abaixo:

$$
\frac{\partial \mathrm{W}_{2}}{\partial \mathrm{W}_{1}}=-\frac{(1-\pi)}{\pi} \frac{\mathrm{U}^{\prime}\left(\mathrm{W}_{1}\right)}{\mathrm{U}^{\prime}\left(\mathrm{W}_{2}\right)}
$$

A derivada segunda será dada por:

$$
\begin{aligned}
& \frac{\partial^{2} \mathrm{~W}_{2}}{\partial \mathrm{W}_{1}^{2}}=\frac{(1-\pi) \pi \mathrm{U}^{\prime \prime}\left(\mathrm{W}_{1}\right) \mathrm{U}^{\prime}\left(\mathrm{W}_{2}\right)-(1-\pi) \pi \mathrm{U}^{\prime}\left(\mathrm{W}_{1}\right) \mathrm{U}^{\prime \prime}\left(\mathrm{W}_{2}\right)\left(\mathrm{dW}_{2} / \mathrm{dW}_{1}\right)}{\pi^{2} \mathrm{U}^{\prime}\left(\mathrm{W}_{2}\right)^{2}} \\
& \frac{\partial^{2} \mathrm{~W}_{2}}{\partial \mathrm{W}_{1}^{2}}=-\frac{\mathrm{U}^{\prime \prime}\left(\mathrm{W}_{1}\right)(1-\pi)\left[\pi \mathrm{U}^{\prime}\left(\mathrm{W}_{2}\right)\right]^{2}+\pi \mathrm{U}^{\prime \prime}\left(\mathrm{W}_{2}\right)\left[(1-\pi) \mathrm{U}^{\prime}\left(\mathrm{W}_{1}\right)\right]^{2}}{\left[\pi \mathrm{U}^{\prime}\left(\mathrm{W}_{2}\right)\right]^{3}}
\end{aligned}
$$

$\mathrm{Na}$ eq. (23), o primeiro e segundo termos do lado direito são negativos, conseqüentemente, $\partial^{2} \mathrm{~W}_{2} / \partial \mathrm{W}_{1}{ }^{2}>0$. Através da eq. (22), nota-se que $\partial \mathrm{W}_{2} / \partial \mathrm{W}_{1}<0$. Deste modo, as curvas de indiferença serão negativamente inclinadas e convexas em relação à origem.

Outro ponto interessante é a relação entre a convexidade da curva de indiferença e a coeficiente de aversão ao risco absoluto. Utilizando a eq. (23) e igualando as rendas nos dois estados, de tal forma que $\mathrm{W}_{1}=\mathrm{W}_{2}=\mathrm{W}$, então:

$$
\frac{\partial^{2} \mathrm{~W}_{2}}{\partial \mathrm{W}_{1}^{2}}=-\frac{\mathrm{U}^{\prime}(\mathrm{W})^{2} \mathrm{U}^{\prime \prime}(\mathrm{W}) \pi(1-\pi)}{\left[\pi \mathrm{U}^{\prime}(\mathrm{W})\right]^{3}}=-\frac{(1-\pi) \mathrm{U}^{\prime \prime}(\mathrm{W})}{\pi^{2} \mathrm{U}^{\prime}(\mathrm{W})}=\frac{(1-\pi)}{\pi^{2}} \mathrm{R}
$$


onde $\mathrm{R}=-\mathrm{U}$ '’(W) / U'(W) é o coeficiente de aversão ao risco absoluto de ArrowPratt $^{143}$.

Ao longo da LC o grau de convexidade da curva de indiferença é proporcional a R. A medida de aversão ao risco absoluto tem implicações na disposição do indivíduo em aceitar o risco.

Pela fig. 57, quando o indivíduo adquire o seguro justo e completo, $(\pi d$, d), então, a renda no estado 1 se iguala a renda no estado 2 , conseqüentemente, $U^{\prime}\left(\mathrm{W}_{1}\right)$ $=\mathrm{U}$ '( $\left(\mathrm{W}_{2}\right)$. Nesta situação, a curva de indiferença intercepta a LC e sua inclinação será a mesma que LVE, ou seja, a razão das probabilidades, $-(1-\pi) / \pi$.

Todas as rendas ao longo da linha da certeza serão rendas garantidas com certeza. Assim, o ponto $\mathrm{W}^{\prime}$, na qual $\mathrm{U}\left(\mathrm{W}^{\prime}\right)=\mathrm{U}\left(\mathrm{W}^{0}\right)$, é chamado de "equivalente certeza", pois o nível de utilidade neste ponto, onde as rendas nos dois estados são as mesmas será igual a utilidade considerando as rendas iniciais.

O prêmio do seguro, $\pi I, \forall I \in(0, d)$, é dada na fig. 57 pela dispersão em torno do valor médio $\overline{\mathrm{W}}^{*}$. Deste modo, quando o prêmio é justo, $P=W_{1}^{0}-\overline{\mathrm{W}}^{*}=\pi d$, a indenização atinge seu limite superior, ou seja, o seguro é completo.

O prêmio dado por $P_{\mathrm{r}}=\overline{\mathrm{W}}^{*}-\mathrm{W}^{*}$ é denominado "prêmio de risco individual", e corresponde ao excesso máximo sobre o prêmio justo.

A diferença entre $\mathrm{W}_{1}^{0}$ e $\mathrm{W}^{\text {'* }}$ corresponde ao prêmio máximo que o indivíduo estaria disposto à pagar para trocar a distribuição de renda de risco pela distribuição com garantia de renda certa W'.

$\mathrm{O}$ fato de $q_{\mathrm{r}}$ ser maior que zero é devido à convexidade da curva de indiferença, deste modo, quanto maior aversão ao risco terá o indivíduo, maior o grau de

${ }^{143}$ Arrow (1971) e Pratt (1964) 
convexidade da curva de indiferença. Percebe-se, então que o prêmio de risco individual pode ser considerado como uma medida de aversão ao risco ${ }^{144}$.

Até agora a pressuposição de lucro zero foi considerada. Na prática, os custos não são nulos, o que implica em um prêmio maior do que o atuarialmente justo.

Se tal pressuposição for relaxada, então o contrato eficiente não será atingido, isto é, o seguro não será completo. Deste modo, $\phi>\pi$, ou seja, o prêmio por unidade de compensação será maior que a probabilidade de ocorrência de um acidente. Conseqüentemente, $(1-\pi) / \pi>(1-\phi) / \phi$, ou seja, a inclinação da LVE reduzirá. (figura 58, abaixo).

Além disso, a utilidade marginal no estado 1 será menor que a utilidade marginal no estado 2 (eq. 25 , como resultado, a renda no estado 1 será maior que a renda no estado 2:

$$
\frac{\mathrm{U}^{\prime}\left(\mathrm{W}_{1}^{0}-\phi I\right)}{\mathrm{U}^{\prime}\left(\mathrm{W}_{2}^{0}+I-\phi I\right)}=\frac{\pi}{(1-\pi)} \frac{(1-\phi)}{\phi}<1
$$

\footnotetext{
${ }^{144}$ Yaari (1969) propõe uma medida alternativa de aversão ao risco. Se, dadas duas curvas de indiferença $\mathrm{U}$ e $\mathrm{V}$, partindo do mesmo ponto, o conjunto de todas as alocações de risco aceitáveis para $\mathrm{U}$ for um subconjunto do conjunto de todas as alocações de risco aceitáveis para $\mathrm{V}$, então U terá maior aversão ao risco do que $\mathrm{V}$.
} 


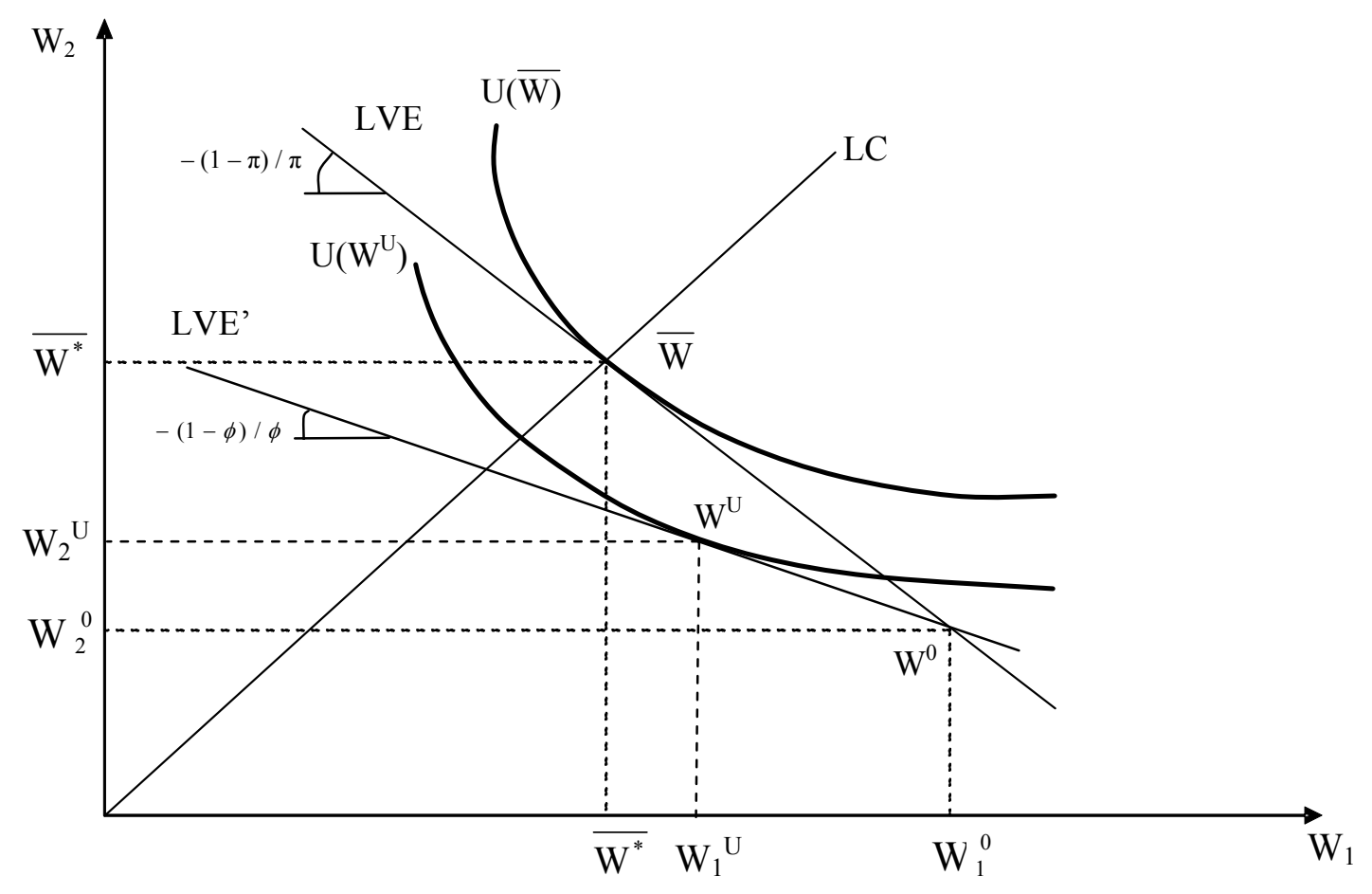

Figura 58 - Custos incidentes

$\mathrm{O}$ fato de $\mathrm{W}_{1}{ }^{\mathrm{U}}>\mathrm{W}_{2}{ }^{\mathrm{U}}$ significa que, caso haja um acidente, o indivíduo não estará totalmente coberto pelo seguro. O ponto não ótimo $\mathrm{W}^{\mathrm{U}}$ situa-se abaixo da $\mathrm{LC}$.

\subsection{O problema da seleção adversa}

A suposição de que existem agentes idênticos no mercado será agora revisada. A situação se torna mais complicada quando existem diversos agentes que possuem diferentes probabilidades de acidentes.

Considerando-se, agora as diferenças intrínsecas ao indivíduo e que estão fora de seu controle, supõe-se que existam dois tipos de indivíduos na sociedade. Um 
grupo de alto risco, com probabilidade de ocorrência do evento, $\pi_{\mathrm{A}}$, e um grupo de baixo risco, com probabilidade, $\pi_{\mathrm{B} .}\left(\pi_{\mathrm{A}}>\pi_{\mathrm{B}}\right)$

Em todos os outros aspectos os indivíduos são idênticos. A proporção de indivíduos de baixo risco será dado por $\delta$. A probabilidade média de ocorrência do evento será $\pi_{\mathrm{M}}$, tal que:

$$
\pi_{\mathrm{M}}=\delta \pi_{\mathrm{B}}+(1-\delta) \pi_{\mathrm{A}}
$$

Caso a firma seguradora possa verificar com exatidão os dois tipos de indivíduos no mercado, então dois contratos serão ofertados, ao prêmio justo, respectivamente, para os indivíduos de baixo e alto risco, $\mathrm{P}_{\mathrm{B}}=\pi_{\mathrm{B}} d$ e $\mathrm{P}_{\mathrm{A}}=\pi_{\mathrm{A}} d$. No equilíbrio cada indivíduo adquire o seguro completo a um prêmio justo, apropriado para seu grupo.

\subsection{O equilíbrio conjunto}

Por outro lado, se existir assimetria de informação no mercado, a seguradora não consegue observar, ex ante, a qual grupo os indivíduos pertencem. Mas os agentes conhecem suas probabilidades de ocorrência do evento.

O equilíbrio anterior não poderia existir, pois os indivíduos pertencentes ao grupo de alto risco sentiriam atraídos pelo contrato ofertado ao grupo de baixo risco, devido ao prêmio mais baixo.

Mesmo nesta situação, se a seguradora ofertar o contrato ao prêmio voltado ao grupo de baixo risco, $\pi_{\mathrm{B}} d$, então na média haverá prejuízos, L, pois o valor esperado das indenizações por contrato será $\pi_{\mathrm{M}} d$ :

$$
\mathrm{L}=\pi_{\mathrm{M}} d-\pi_{\mathrm{B}} d=(1-\delta)\left(\pi_{\mathrm{A}}-\pi_{\mathrm{B}}\right) d
$$

O prejuízo médio, de acordo com a eq. (27), será tanto maior, quanto: 
- Maior a proporção de indivíduos de alto risco na sociedade;

- Maior a diferença entre as probabilidades de ocorrência do evento nos dois grupos de risco e;

- $\quad$ Maior a perda;

Percebe-se, deste modo, que a firma seguradora não ofertaria um contrato com seguro completo e prêmio justo voltado aos indivíduos de baixo risco.

Por outro lado, a seguradora poderia ofertar um contrato em que na média haveria lucro zero. $\mathrm{O}$ contrato seria ofertado ao prêmio justo, fixado de acordo com a probabilidade média, $\pi_{\mathrm{M}} d$, e seguro completo aos dois grupos simultaneamente. Esta situação caracteriza o equilíbrio conjunto (ponto E).

$\mathrm{Na}$ figura 59, abaixo $\mathrm{U}^{\mathrm{B}}$ é a curva de indiferença associada ao grupo de baixo risco, tangente a $\mathrm{LVE}^{\mathrm{B}}$, com inclinação $-\left(1-\pi_{\mathrm{B}}\right) / \pi_{\mathrm{B}}$ e $\mathrm{U}^{\mathrm{A}}$, associada ao grupo de alto risco, tangente a $\mathrm{LVE}^{\mathrm{A}}$, com inclinação $-\left(1-\pi_{\mathrm{A}}\right) / \pi_{\mathrm{A}}$. 


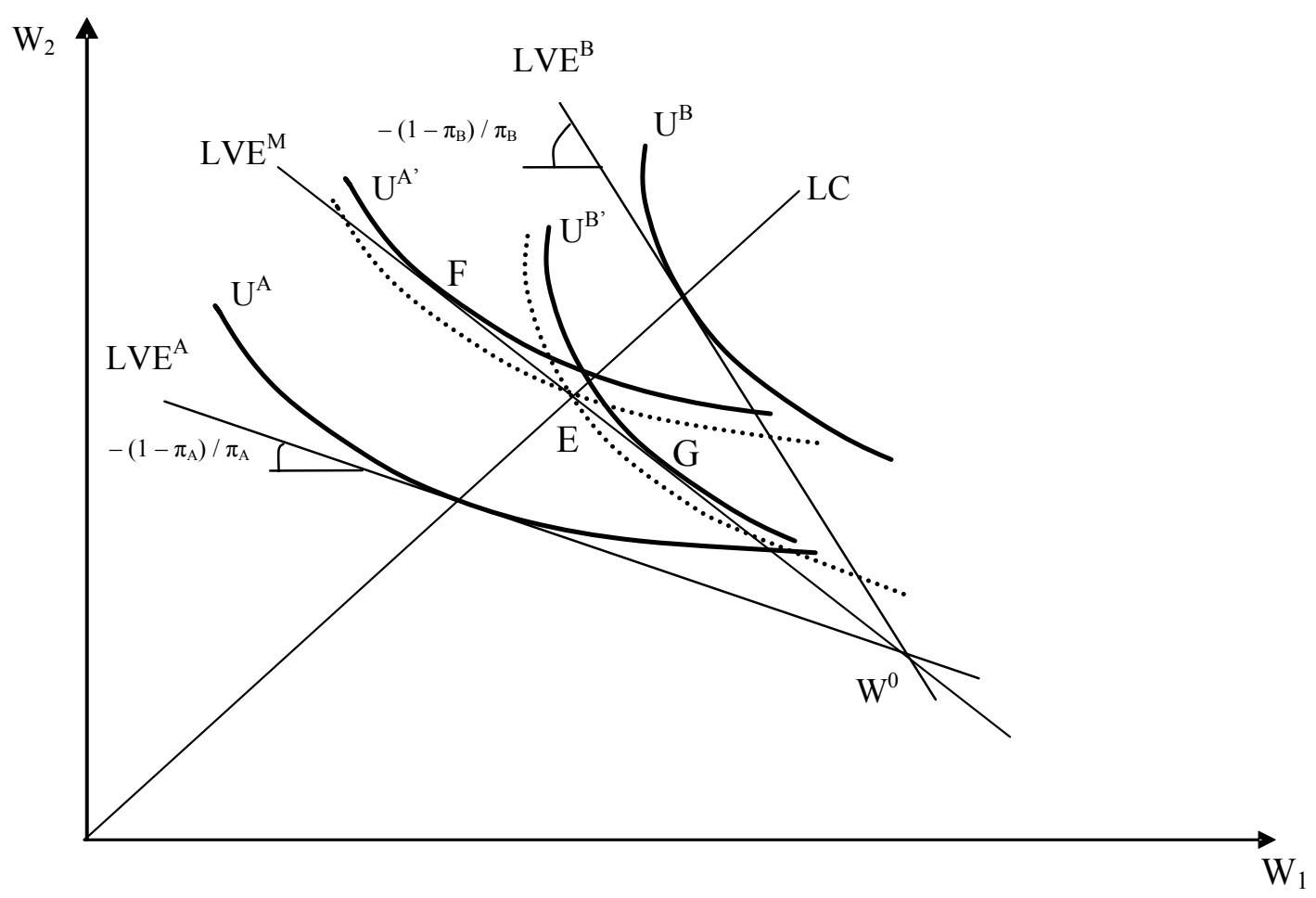

Figura 59 - O contrato ofertado para ambos os grupos ao prêmio justo

Nota-se que nenhum dos dois grupos está adquirindo a quantidade de seguro, ou a compensação desejada. No ponto $E$ onde $L_{V E}{ }^{M}$, com inclinação $-\left(1-\pi_{M}\right)$ $/ \pi_{\mathrm{M}}$, cruza com a LC não existe tangência das curvas de indiferença de nenhum dos grupos com a $\mathrm{LVE}^{\mathrm{M}}$.

Os indivíduos de baixo risco desejarão adquirir menos do que o seguro completo, com a quantidade ótima no ponto $\mathrm{G}$, enquanto que os indivíduos do outro grupo desejarão adquirir mais, ponto F.

Caso a firma seguradora permita que o segurado escolha o nível de indenização, de modo que $I_{\mathrm{A}}<\mathrm{d}<I_{\mathrm{B}}$, então ambos os grupos poderão demandar a quantidade ótima.

$\mathrm{O}$ prêmio do seguro para os indivíduos de alto risco será $P_{\mathrm{A}}=\pi_{\mathrm{M}} I_{\mathrm{A}}$, enquanto que o prêmio voltado para os de baixo risco, $P_{\mathrm{B}}=\pi_{\mathrm{M}} I_{\mathrm{B}}$. Neste caso, 
novamente a seguradora incorrerá em prejuízo médio dado pela diferença entre o pagamento de indenizações e o total arrecadado de prêmios:

$$
\mathrm{L}=\left[\delta \pi_{\mathrm{B}} I_{\mathrm{B}}+(1-\delta) \pi_{\mathrm{A}} I_{\mathrm{A}}\right]-\left[\delta \pi_{\mathrm{M}} I_{\mathrm{B}}+(1-\delta) \pi_{\mathrm{M}} I_{\mathrm{A}}\right]
$$

Portanto, a diferença relacionada na eq. (28) será igual a:

$$
\mathrm{L}=\delta(1-\delta)\left(\pi_{\mathrm{A}}-\pi_{\mathrm{B}}\right)\left(I_{\mathrm{A}}-I_{\mathrm{B}}\right)
$$

No exercício da atividade, a firma seguradora arcará com prejuízos médios, visto que, $\pi_{\mathrm{A}}>\pi_{\mathrm{B}}$ e $I_{\mathrm{A}}>I_{\mathrm{B}}$, caso permita que os indivíduos de ambos os grupos escolham o nível de indenização.

Assim, a seguradora deve fixar o nível de indenização, de modo que $I_{\mathrm{A}}=$ $I_{\mathrm{B}}=d$, e ofertar o seguro ao prêmio $\pi_{\mathrm{M}} d$, para que não haja prejuízo médio final e a restrição de lucro zero seja atingida. Mas como verificado anteriormente, ambos os grupos de risco não adquirem o contrato de seguro desejável nesta situação.

Supondo que houvesse uma firma que ofertasse um contrato de seguro que seria preferido ao contrato representado pelo ponto $\mathrm{E}$, pelos indivíduos de baixo risco e que não fosse preferido pelo grupo de maior risco e não resultasse em prejuízo para a firma seguradora.

Percebe-se pela figura 60 , abaixo que qualquer ponto sobre a $\mathrm{LVE}^{\mathrm{B}}$, no trecho HI preencheria as suposições acima, pois tais contratos seriam preferidos pelos indivíduos de baixo risco e não seriam preferidos pelos indivíduos pertencentes ao grupo de alto risco, pois sua curva de indiferença está acima do conjunto dos pontos no trecho HI. 


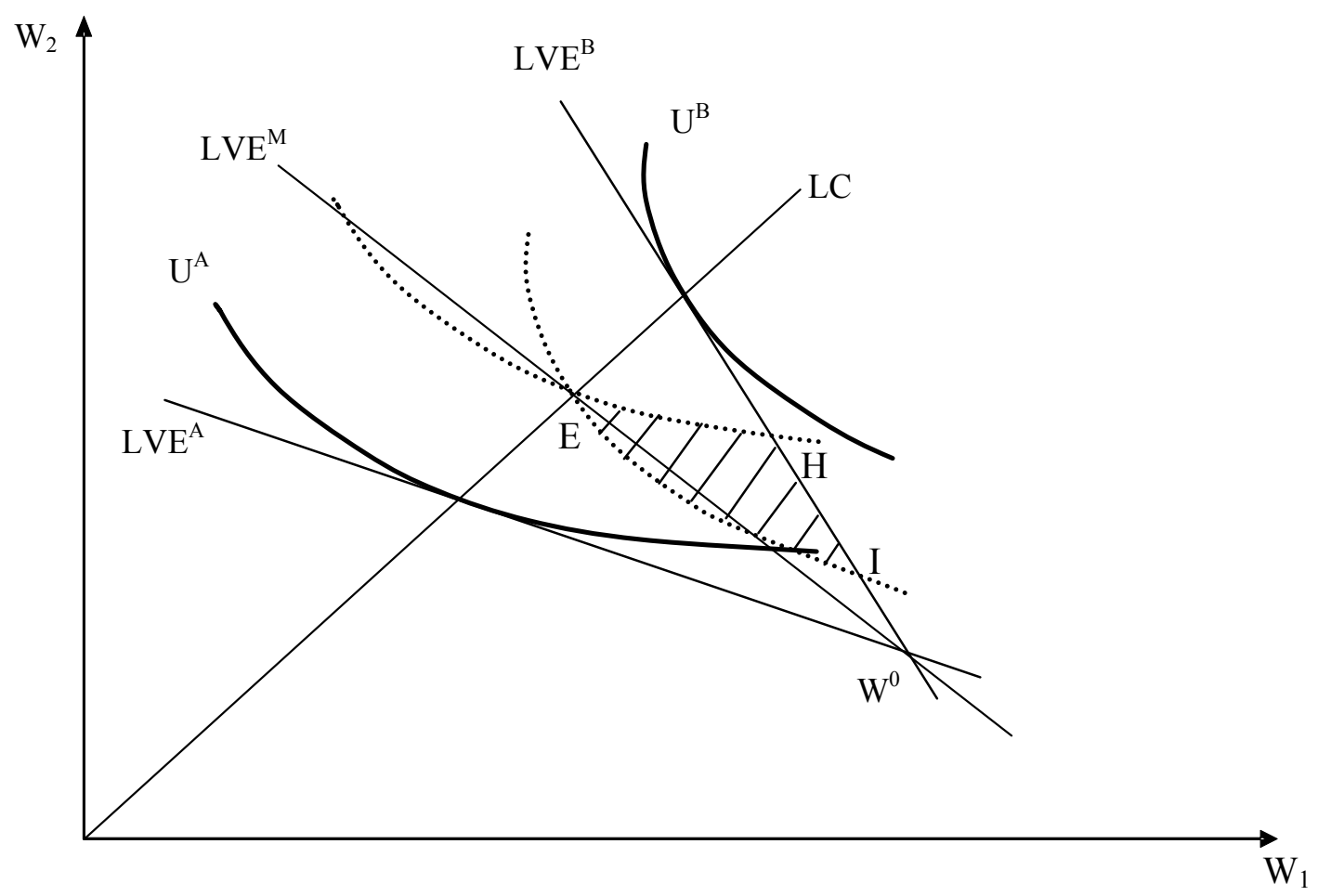

Figura 60 - Contratos ofertados aos indivíduos de baixo risco

Para pontos abaixo de $\mathrm{LVE}^{\mathrm{B}}$, na área hachurada, EHI, a firma teria lucro esperado positivo, pois a indenização é menor do que a completa.

Percebe-se que, de um lado, em um mercado competitivo perfeito, as firmas seguradoras optariam pela oferta do contrato mais lucrativo, ou seja, o contrato parcial voltado somente ao grupo de baixo risco, ao invés do contrato conjunto E.

Por outro lado, os indivíduos de baixo risco estariam dispostos a aceitar um nível de cobertura mais baixo em troca de um prêmio proporcionalmente mais baixo.

$\mathrm{O}$ contrato de seguro ofertado com prêmio baseado na probabilidade média dos dois grupos não será sustentável ao longo do tempo pela firma, pois haverá prejuízo. 


\subsection{O equilíbrio separado}

Se a firma tentar, por outro lado, oferecer um contrato, separadamente para cada grupo, o resultado final dependerá da proporção de indivíduos de baixo risco nesta sociedade.

Nesta situação, algumas pressuposições deverão ser satisfeitas. Os indivíduos de alto risco deverão preferir seu contrato aquele ofertado ao grupo de baixo risco e, vice-versa.

A restrição de lucro zero deverá ser satisfeita, de modo que o contrato para cada grupo será ofertado ao prêmio justo. As firmas seguradoras não poderão formular um novo contrato, que seja preferido pelo menos a um grupo.

Deste modo, sejam os contratos $\mathrm{E}^{\mathrm{B}}$ e $\mathrm{E}^{\mathrm{A}}$ oferecidos, respectivamente, para o grupo de baixo risco e alto risco, na figura 61 , abaixo. $\mathrm{O}$ contrato $\mathrm{E}^{\mathrm{B}}$ é ofertado com cobertura parcial e prêmio menor, $\pi_{\mathrm{B}} I^{*}$, tal que $I^{*}<d$, e o contrato $\mathrm{E}^{\mathrm{A}}$, com cobertura completa e prêmio justo, $\pi_{\mathrm{A}} d$.

Supõe-se que aqueles de alto risco são indiferentes entre adquirir $\mathrm{E}^{\mathrm{A}}$ ou $\mathrm{E}^{\mathrm{B}}$, mais do que isso, optam pelo contrato com cobertura completa ${ }^{145}$. Nesta situação os contratos atingem a condição de lucro zero, pois cada um está sobre as respectivas LVEs.

\footnotetext{
${ }^{145} \mathrm{Na}$ verdade, o contrato $\mathrm{E}^{\mathrm{A}}$ será preferido aos indivíduos de alto risco se o contrato ofertado ao grupo de baixo risco se localizar um pouco abaixo de $\mathrm{E}^{\mathrm{B}}$.
} 


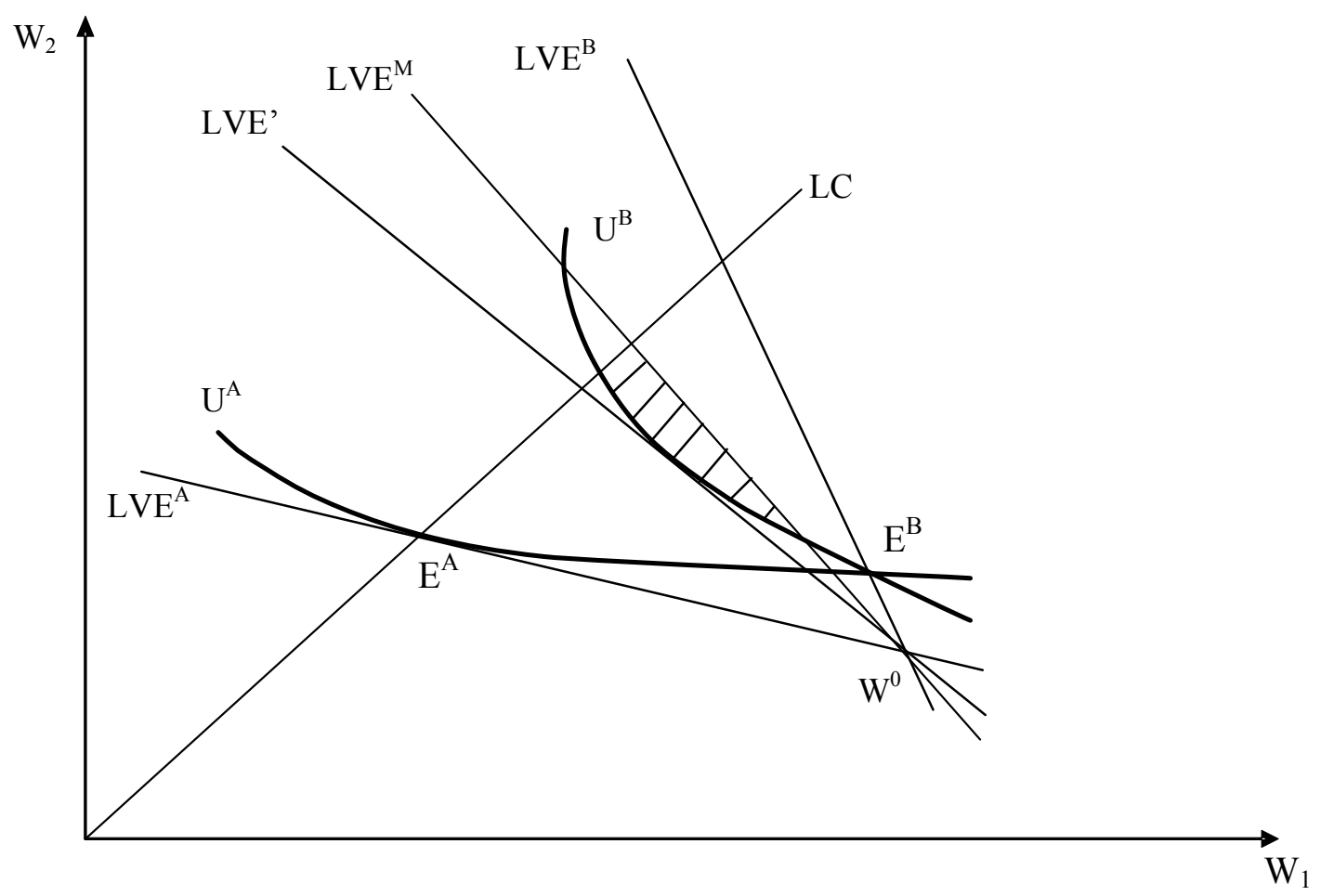

Figura 61 - Contratos ofertados separadamente para cada grupo

$\mathrm{O}$ equilíbrio, neste caso, ocorrerá em função de $\delta$. Para verificar tal afirmação, considere a $L V E^{M}$ com inclinação - $\left(1-\pi_{M}\right) / \pi_{M}$, na figura 61. Substituindo a eq. (28) na anterior verifica-se que:

$$
\frac{1-\pi_{\mathrm{M}}}{\pi_{\mathrm{M}}}=\frac{1-\pi_{\mathrm{A}}+\delta\left(\pi_{\mathrm{A}}-\pi_{\mathrm{B}}\right)}{\pi_{\mathrm{A}}-\delta\left(\pi_{\mathrm{A}}-\pi_{\mathrm{B}}\right)}
$$

Pela eq. (30), nota-se que a inclinação de $\operatorname{LVE}^{\mathrm{M}}$ depende de $\delta$, pois $\pi_{\mathrm{A}}>$ $\pi_{\mathrm{B}}$. Assim, quanto maior a proporção de indivíduos de baixo risco, maior a inclinação de $\mathrm{LVE}^{\mathrm{M}}$.

Supondo que o valor de $\delta$ corresponda à inclinação da $\mathrm{LVE}^{\mathrm{M}}$, na figura 61, então as seguradoras poderiam ofertar um contrato pertencente a área hachurada, na qual no mínimo geraria lucros positivos e seria preferida por ambos os grupos. 
Tal contrato substituiria os contratos ofertados separadamente para cada grupo, $\mathrm{E}^{\mathrm{B}}$ e $\mathrm{E}^{\mathrm{A}}$. Deste modo, não haveria o equilíbrio separado.

Se por outro lado, o valor de $\delta$ seja reduzido o bastante, tal que, a $\mathrm{LVE}^{\mathrm{M}}$ tenha inclinação menor ou igual a LVE', então nesta situação, não existirá nenhum contrato que satisfaça a condição de lucro zero e seja preferido pelos indivíduos de baixo e alto risco, concomitantemente. Desta forma, o equilíbrio ocorre de forma separada, para determinados valores de $\delta$.

\subsection{O problema do risco moral}

O problema do risco moral é comum na prática e bastante conhecido pelas firmas seguradoras. O problema ocorre porque o segurado pode optar por decisões que afetam sua probabilidade de perda e não podem ser observadas pela firma seguradora.

Como um exemplo, considere um produtor rural que adquire um contrato de seguro, que especifica os riscos cobertos, duração do contrato, indenização por unidade de área em caso da ocorrência do evento e o prêmio.

Suponha que em um determinado mês, após a contratação do seguro, ocorra o sinistro e dois terços da área são afetados, com prejuízos totais. Por possuir o contrato de seguro, o produtor pode não ter incentivos para levar adiante a produção restante acarretando em uma perda ainda maior.

Se a seguradora não for capaz de identificar que o prejuízo adicional foi devido à decisão inadequada do produtor, então arcará com o pagamento de uma indenização ainda maior, que terá como conseqüência, o repasse deste custo adicional ao segurado através do aumento do custo da cobertura.

Pode-se verificar que o problema do risco moral pode ser suprimido, através de uma solução "segundo melhor". Esta solução seria oferecer ao segurado um contrato com cobertura parcial ou incompleta, através de uma dedução do montante de indenização. Esse montante subtraído da compensação é denominado “dedutibilidade”. 
Essa prática cria o incentivo necessário para que o segurado incorra em gastos para sua "auto-proteção"146, conseqüentemente, reduzindo a sua probabilidade de perda, pois transfere para o segurado parte do risco.

Para formalizar o problema do risco moral, considere um indivíduo maximizador da esperança da utilidade da riqueza ou renda, que possui aversão ao risco e pode afetar sua probabilidade de perda através de mecanismos de prevenção, ou simplesmente tomando cuidado.

Tais mecanismos serão representados por gastos expressos em unidades monetárias e denotadas por $g$, tal que $g \geq 0$. Deste modo, $\pi(g)$, a probabilidade da perda será uma função dos gastos com algum tipo de mecanismo de auto-proteção. Suponha que tal probabilidade se reduza com o aumento dos gastos, então $\pi^{\prime}(g)<0$.

O problema pode ser analisado quando os gastos não são observados pela firma seguradora e quando são observados. No segundo caso, a observação poderá ser realizada com perfeita ou com imperfeita exatidão.

Considerando inicialmente a situação ilustrada na figura 62, abaixo em que a seguradora observa se o segurado incorreu em gastos ou não, o ponto $\mathrm{W}^{0}$ corresponde a situação inicial com rendas nos dois estados de $\mathrm{W}_{1}^{0} \mathrm{e} \mathrm{W}_{2}^{0}$. A linha do valor esperado será LVE e sua inclinação será - $(1-\pi(0)) / \pi(0)$.

\footnotetext{
${ }^{146}$ Neste ponto é interessante perceber a diferença entre auto-proteção e auto-seguro. A auto-proteção reduz a probabilidade de perda sem afetar a magnitude da perda, por exemplo, alarme e travas contra roubo de carro. O auto-seguro é um mecanismo que tem o efeito de reduzir a magnitude da perda sem afetar a probabilidade da perda, por exemplo, uma poupança voltada para eventuais acidentes. Nesta subseção apenas a auto-proteção será relevante.
} 


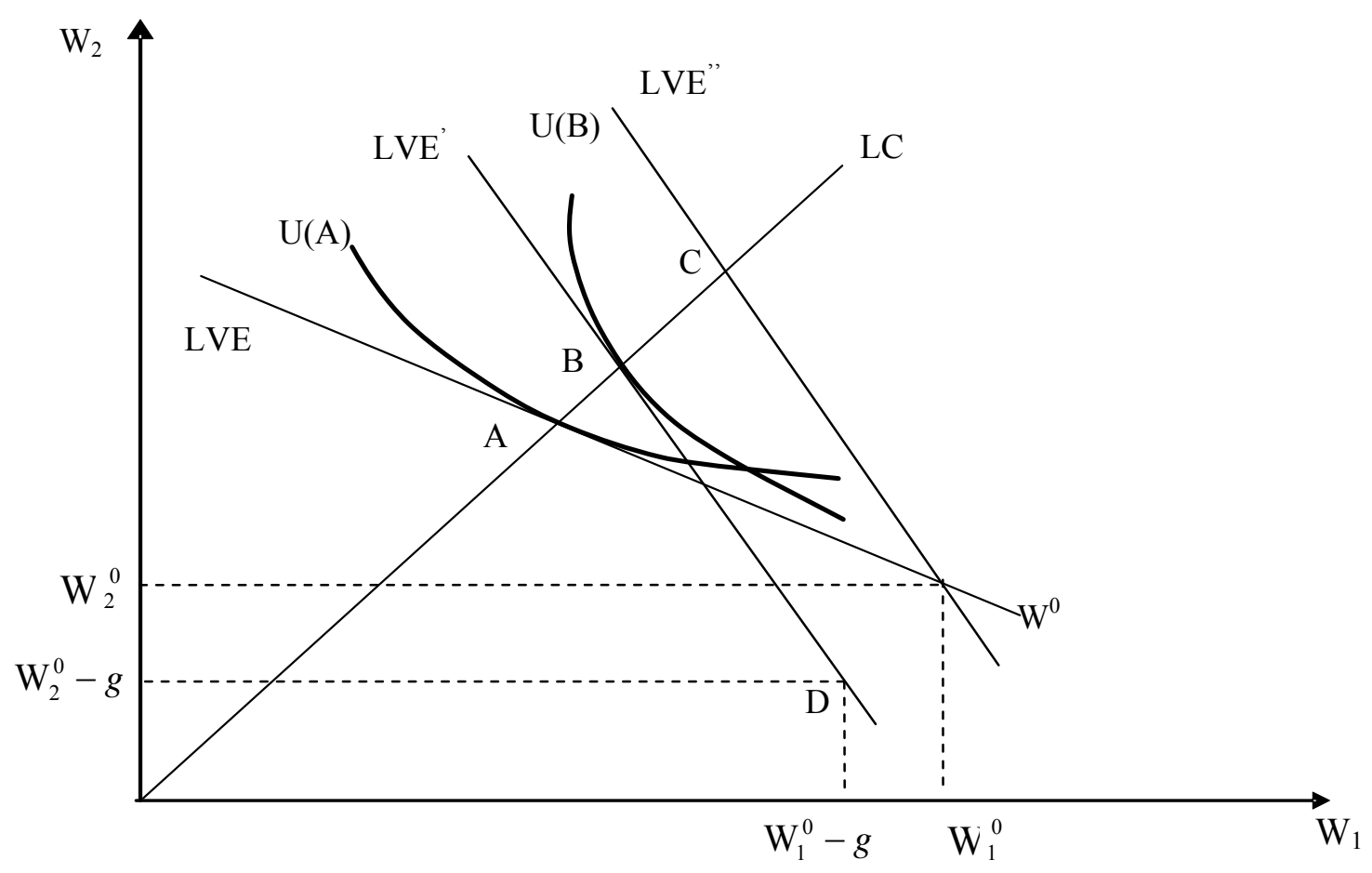

Figura 62 - O risco moral

Caso o indivíduo decida realizar gastos, $\mathrm{x}$, então sua nova dotação inicial passará a ser o ponto $\mathrm{D}=\left(\mathrm{W}_{1}^{0}-\mathrm{g}, \mathrm{W}_{2}^{0}-g\right)$, com a respectiva LVE' de inclinação igual a $-(1-\pi(g)) / \pi(g), \pi(g)<\pi(0)$. Assim, nota-se que LVE' será mais inclinada que LVE.

Como a firma seguradora percebe perfeitamente o valor de $g$, então poderá ofertar dois contratos.

Um correspondente ao caso em que $g$ é gasto, com prêmio justo igual a $\mathrm{P}_{g}$ $=\pi(g) d$, seguro completo e equilíbrio ocorrendo no ponto B.

Outro, quando não ocorre gastos, com prêmio justo $\mathrm{P}_{0}>\mathrm{P}_{g}$, tal que, $\mathrm{P}_{0}=$ $\pi(0) d$, seguro completo e equilíbrio no ponto A. 
Como as rendas representadas pelo ponto $\mathrm{B}$ estão à direita de $\mathrm{A}$ na $\mathrm{LC}$, então este ponto será preferido pelo indivíduo ${ }^{147}$.

Como a firma seguradora consegue monitorar o valor de $g$, então fixará um prêmio de acordo com o montante gasto. O problema do indivíduo será escolher um valor de g que maximize sua utilidade esperada:

$$
\operatorname{Max}_{(g, I)}\left[(1-\pi(g)) \mathrm{U}\left(\mathrm{W}_{1}^{0}-g-\pi(g) I\right)+\pi(g) \mathrm{U}\left(\mathrm{W}_{2}^{0}-g+I-\pi(g) I\right)\right]
$$

As condições de primeira ordem com respeito à variável $g$ e a $I$, respectivamente, são:

$$
\begin{aligned}
& \pi^{\prime}(g)\left[\mathrm{U}\left(\mathrm{W}_{2}^{0}-g+I-\pi(g) I\right)-\mathrm{U}\left(\mathrm{W}_{1}^{0}-g-\pi(g) I\right)\right]-(1-\pi(g))\left(1+\pi^{\prime}(g) I\right) \\
& \left.\mathrm{U}^{\prime}\left(\mathrm{W}_{1}^{0}-g-\pi(g) I\right)-\pi(g)\left(1+\pi^{\prime}(g) I\right) \mathrm{U}^{\prime}\left(\mathrm{W}_{2}^{0}-g+I-\pi(g) I\right)\right]=0 \\
& (1-\pi(g)) \pi(g) \mathrm{U}^{\prime}\left(\mathrm{W}_{1}^{0}-g-\pi(g) I\right)-(1-\pi(g)) \pi(g) \mathrm{U}^{\prime}\left(\mathrm{W}_{2}^{0}-g+I-\pi(g) I\right) \\
& =0
\end{aligned}
$$

A eq. (33) implica que $\mathrm{U}^{\prime}\left(\mathrm{W}_{1}^{0}-g-\pi(g) I\right)=\mathrm{U}^{\prime}\left(\mathrm{W}_{2}^{0}-g+I-\pi(g) I\right)$, se e somente se, o seguro for completo. Deste modo, ao nível ótimo de gasto, $g^{*}$, o seguro será ofertado ao prêmio justo, $\mathrm{P}_{\mathrm{g}^{*}}=\pi\left(g^{*}\right) d$ e seguro completo, correspondente ao ponto B da figura 62.

A condição (32), supondo seguro justo e completo, implica que $\mathrm{U}^{\prime}\left(\mathrm{W}_{1}^{0}-g^{*}-\pi\left(g^{*}\right) d\right)=0$, ou $1+\pi^{\prime}\left(g^{*}\right) d=0$, que é igual a $-\pi^{\prime}\left(g^{*}\right) d=1$, isto é, o benefício marginal de realizar gastos com auto-proteção é igual ao custo marginal.

\footnotetext{
${ }^{147}$ Supõe-se que o ponto B esteja à direita do ponto A. Caso contrário, não valeria a pena gastar $g$. O indivíduo realizará o gasto $g$ se o valor esperado da renda com o gasto for no mínimo igual ao valor esperado da renda sem o gasto. Assim, tem-se que $(1-\pi(g))\left(\mathrm{W}_{1}^{0}-g\right)+\pi(g)\left(\mathrm{W}_{2}^{0}-g\right) \geq(1-\pi(0))$ $\left(\mathrm{W}_{1}^{0}\right)+\pi(0)\left(\mathrm{W}_{2}^{0}\right)$. Portanto $\mathrm{P}_{0} \geq \mathrm{P}_{g}+g$.
} 
Caso a seguradora seja incapaz de perceber se o segurado realizou ou não os gastos, então os termos em que o contrato será ofertado não poderá depender de $g$.

O problema do indivíduo será escolher um valor de $g$ que maximize sua utilidade esperada, dado que o contrato $q=(P, I)$ foi adquirido pelo segurado. Assumese que o $g$ escolhido é único.

$$
\operatorname{Max}_{(g, I)}\left[(1-\pi(g)) \mathrm{U}\left(\mathrm{W}_{1}^{0}-g-\phi I\right)+\pi(g) \mathrm{U}\left(\mathrm{W}_{2}^{0}-g+I-\phi I\right)\right]
$$

As condições de primeira ordem com respeito a $g$ e a $I$, respectivamente, são:

$$
\begin{aligned}
& \pi^{\prime}(g)\left[\mathrm{U}\left(\mathrm{W}_{2}^{0}-g+I-\phi I\right)-\mathrm{U}\left(\mathrm{W}_{1}^{0}-g-\phi I\right)\right]-\pi(g) \mathrm{U}^{\prime}\left(\mathrm{W}_{2}^{0}-g+I-\phi I\right) \\
& -(1-\pi(g)) \mathrm{U}^{\prime}\left(\mathrm{W}_{1}^{0}-g-\phi I\right)=0 \\
& \mathrm{U}^{\prime}\left(\mathrm{W}_{2}^{0}-g+I-\phi I\right) \pi(g)(1-\phi)-\mathrm{U}^{\prime}\left(\mathrm{W}_{1}^{0}-g-\phi I\right)(1-\pi(g)) \phi=0
\end{aligned}
$$

A condição de lucro zero da firma seguradora requer que $\pi\left(g^{*}\right)=\phi$, para o nível ótimo de gastos $g^{*}$. A eq. (36), portanto implica que $\mathrm{U}^{\prime}\left(\mathrm{W}_{2}^{0}-g^{*}+I-\phi I\right)=$ $\mathrm{U}^{\prime}\left(\mathrm{W}_{1}^{0}-g^{*}-\phi I\right)$, se e somente se, o seguro for completo. Deste modo, a eq. (35) pode ser reescrita como:

$$
\begin{aligned}
& \mathrm{U}^{\prime}\left(\mathrm{W}_{1}^{0}-g^{*}-\phi I\right)=0, \text { se } g^{*}>0 \mathrm{e} \\
& \mathrm{U}^{\prime}\left(\mathrm{W}_{1}^{0}-\phi I\right)>0, \text { se } g^{*}=0
\end{aligned}
$$

Se tal contrato fosse ofertado pela seguradora os indivíduos comprariam o contrato ao prêmio $\pi(g) d$, mas não iriam realizar os gastos, conseqüentemente, atingiriam o ponto $\mathrm{C}$, na fig. 62 e a seguradora arcaria com prejuízos. 
Deste modo, a firma seguradora deve desenhar um contrato, na qual o valor da probabilidade ou da taxa deve refletir o valor do gasto $g$ realizado, dado que o indivíduo adquire o contrato $q$. Além disso, o contrato deve satisfazer a condição de lucro zero.

Uma possível solução para o problema do risco moral seria restringir o montante de compensação, tal que $I<d$. A figura 63, abaixo ilustra a situação. Caso a seguradora oferte um contrato com cobertura parcial, $I_{\mathrm{p}}$, a um prêmio $\pi(g) I_{\mathrm{p}}$, então a curva de indiferença $\mathrm{U}(\mathrm{F})$ com o indivíduo realizando o gasto $g$ intercepta o ponto $\mathrm{F}$ e, $\mathrm{U}(\mathrm{G})$ atingindo o ponto $\mathrm{G}$, quando não realiza o gasto.

Percebe-se que, se o indivíduo for indiferente aos pontos E e F e E e G, então será indiferente aos pontos F e G. Deste modo, possuem o mesmo equivalente certeza, visto que o ponto E está sobre $\mathrm{LC}$ e $\mathrm{U}(\mathrm{F})=\mathrm{U}(\mathrm{G})$.

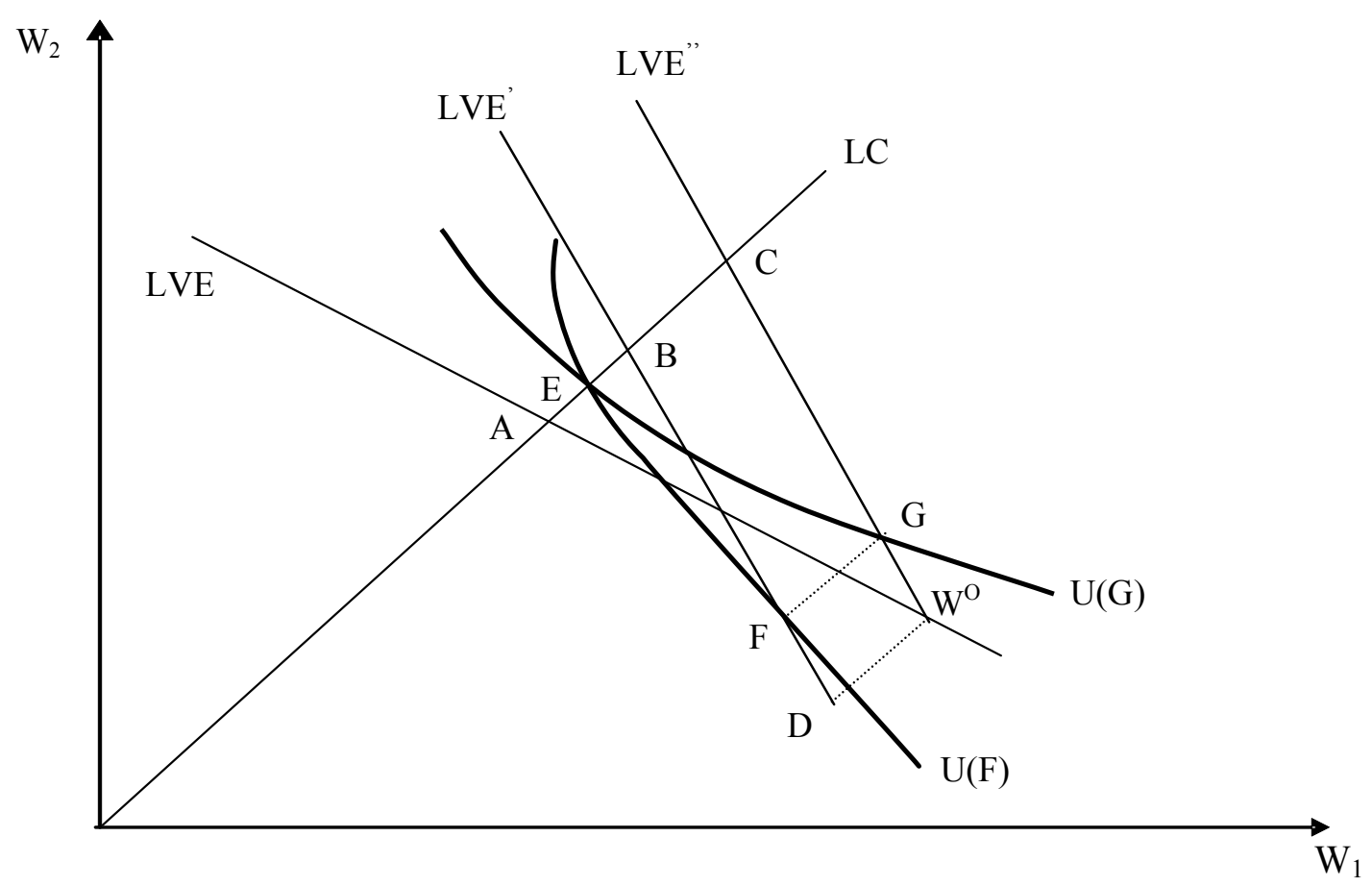

Figura 63 - Contrato com cobertura parcial 
As utilidades esperadas nos pontos F, G e A serão representados, por:

$$
\begin{aligned}
& \mathrm{U}(\mathrm{F})=(1-\pi(g)) \mathrm{U}\left(\mathrm{W}_{1}^{0}-g-\pi(g) I\right)+\pi(g) \mathrm{U}\left(\mathrm{W}_{2}^{0}-g+I-\pi(g) I\right) \\
& \mathrm{U}(\mathrm{G})=(1-\pi(0)) \mathrm{U}\left(\mathrm{W}_{1}^{0}-\pi(g) I\right)+\pi(0) \mathrm{U}\left(\mathrm{W}_{2}^{0}+I-\pi(g) I\right) \\
& \mathrm{U}(\mathrm{A})=\mathrm{U}\left(\mathrm{W}_{1}^{0}-\pi(0) d\right)
\end{aligned}
$$

Quando $I<d$, surge a seguinte situação: quanto maior o nível de indenização, maior será o nível de utilidade atingido pelo indivíduo, pois:

$$
\begin{aligned}
& \mathrm{dU}(\mathrm{F}) / \mathrm{d} I=\pi(g)(1-\pi(g))\left[\mathrm{U}^{\prime}\left(\mathrm{W}_{2}^{0}-g+I-\pi(g) I\right)-\mathrm{U}\left(\mathrm{W}_{1}^{0}-g-\right.\right. \\
& \pi(g) I)]>0,
\end{aligned}
$$

Como pode ser visto na figura 63, a indenização pode variar de 0 a $d$ na LVE', ou seja, partindo do ponto D e chegando ao ponto B ou na LVE", se deslocando de $\mathrm{W}^{0}$ para $\mathrm{C}$.

O ponto E será preferível ao ponto A, pois neste ponto curvas maiores são atingidas. Nota-se que, neste caso, o contrato oferecendo cobertura parcial será preferível ao contrato com cobertura completa.

Quando $I=d$, então:

$$
\mathrm{U}(\mathrm{F})=\mathrm{U}\left(\mathrm{W}_{1}^{0}-g-\pi(g) d\right) \text { e } \mathrm{U}(\mathrm{G})=\mathrm{U}\left(\mathrm{W}_{1}^{0}-\pi(g) d\right)
$$

portanto, $\mathrm{U}(\mathrm{F})<\mathrm{U}(\mathrm{G})$. Esta inequação reflete o problema do risco moral. Quando $I=0$, duas situações ocorrem: $\mathrm{U}(\mathrm{F})>\mathrm{U}(\mathrm{G})$ ou $\mathrm{U}(\mathrm{F}) \leq \mathrm{U}(\mathrm{G})$.

No primeiro caso, supõe-se que possa existir apenas um ponto, $I^{*}$, na qual antes deste ponto, $\mathrm{U}(\mathrm{F})>\mathrm{U}(\mathrm{G})$, que é a condição pela qual o segurado irá realizar o 
gasto. Assim, o contrato $q=\left(\pi(g) I^{*}, I^{*}\right)$, desde que preferível ao contrato $q=(\pi(0) d, d)$, está em equilíbrio.

Este contrato soluciona o problema, desde que o segurado prefira F a G. Devido ao fato de parte do risco ser transferido ao indivíduo, isto cria o incentivo necessário para a realização do gasto com mecanismos de auto-proteção, que reduzirá a probabilidade de perda a um nível compatível com o montante gasto.

No segundo caso, $\mathrm{U}(\mathrm{F}) \leq \mathrm{U}(\mathrm{G})$, poderá ou não existir um valor $I^{*}$, pela qual $\mathrm{U}(\mathrm{F})>\mathrm{U}(\mathrm{G})$ antes deste valor. Caso exista, o contrato $\left(\pi(g) I^{*}, I^{*}\right)$ soluciona o problema do risco moral. Mas para estar em equilíbrio deverá satisfazer a restrição U(F) $>\mathrm{U}(\mathrm{A})$.

Percebe-se, desta forma, que alguns resultados interessantes emergem quando considera-se o problema da assimetria de informação no mercado de seguros. No caso da seleção adversa, uma possível solução seria ofertar aos indivíduos de baixo risco contratos com cobertura parcial, para que tornasse o contrato não atrativo para o grupo de alto risco.

A cobertura parcial também pode ser vista como uma possível resposta para o problema do risco moral. Neste caso, em virtude do contrato não cobrir totalmente o segurado, incentivaria o mesmo a investir em ações que reduzissem sua probabilidade de perda. 


\subsection{O seguro agrícola}

O seguro agrícola é um mecanismo alternativo de administração do risco, que transfere, total ou parcialmente, o risco para outros agentes econômicos.

Experiências privadas tem tido relativo sucesso com seguros cobrindo riscos específicos e bem definidos como, por exemplo, o granizo. A ocorrência de granizo, em um extremo, pode ser caracterizada como um evento que ocorre de maneira "independente", enquanto o risco de preço, no outro extremo é classificado como "sistêmico" ou correlacionado Barnett e Coble (1999).

Neste contexto, o mercado de seguros é utilizado largamente por diversos agentes econômicos na proteção contra riscos independentes, enquanto o mercado de opções e futuros é eficiente na cobertura de riscos correlacionados.

Por outro lado, mecanismos de seguro cobrindo riscos mais amplos não tem apresentado resultados satisfatórios, em diversos países. Alguns motivos são apontados como empecilhos para a adequada operacionalização do seguro agrícola ${ }^{148}$ :

i) Risco moral e fraude: situação na qual o segurado decide por tomar certas decisões, cuja firma seguradora é incapaz de monitorar, acarretando no aumento do volume das indenizações pagas. Tais decisões não seriam tomadas se o contrato oferecesse o incentivo compatível. Na prática, este problema é bastante relevante para a seguradora. Diversos casos de fraude foram relatados por Kilman $(2003)^{149}$ :

“... o triticultor recebeu fraudulentamente pelo menos US\$ 4 milhões de um programa de seguro agrícola financiado pelo governo, de acordo com promotores federais dos Estados Unidos... Um dos esquemas usados pelo agricultor, como descreveram os promotores, era simples: ele registrava

\footnotetext{
${ }^{148}$ Uma ampla revisão da literatura é encontrada em Coble e Knight (2002). Os autores apresentam e comentam diversos artigos relacionados ao seguro agrícola, desde os aspectos da demanda de seguro, risco moral, seleção adversa até contratos alternativos criados recentemente.

${ }^{149}$ KILMAN, S. Fraudar seguro rende mais que plantio para alguns agricultores nos EUA. Estado de São Paulo. Wall Street Journal Americas. São Paulo, 5 maio 2003. p.B-8.
} 
parte da produção da lavoura A como sendo da lavoura B, de forma que a lavoura A parecia ter quebrado, passando a se qualificar para uma indenização do seguro. O caso, embora extremo, não é isolado. Não muito longe daqui, o administrador de um silo foi condenado em fevereiro por ter ajudado triticultores a receber US\$ 650.000 do programa de seguro com documentos falsos. ...um agricultor e sua mãe foram considerados culpados por uma trapaça que envolvia uma lavoura de feijão."

ii) Segundo o mesmo, a Agência de Gerenciamento do Risco (RMA) possui apenas 100 pessoas responsáveis pela fiscalização de uma área de aproximadamente 81 milhões de hectares e quase 100 tipos diferentes de commodities. Nota-se, deste modo que, o aumento da infra-estrutura necessária para a fiscalização adequada poderia aumentar substancialmente o custo administrativo podendo inviabilizar o desenvolvimento do mercado de seguros.

iii) Seleção adversa ou anti-seleção: ocorre quando a seguradora não consegue distinguir entre os diferentes grupos de risco. Neste caso, as diferenças são intrínsecas aos indivíduos e estão fora de seu controle. Por exemplo, por razões genéticas, um indivíduo tem certa predisposição a uma determinada doença. Uma conseqüência direta para a seguradora é a possível seletividade dos indivíduos de alto risco na sociedade, que pode ser agravado se o prêmio for calculado através de observações médias;

iv) Falta de métodos atuariais adequados e escassez de dados relevantes: a falta de uma série temporal relativamente longa e confiável de produtividade agrícola ao nível do produtor ${ }^{150}$ e métodos atuariais adequados tem implicações diretas na fixação de taxas de prêmio imprecisas por parte das seguradoras;

\footnotetext{
${ }^{150}$ Além de outras informações que pudessem revelar o perfil de risco de cada segurado.
} 
v) Eventos catastróficos ou generalizados: um determinado evento climático ocorrido em certo período de tempo que cause danos a uma certa cultura atinge não apenas um produtor, mas toda uma vasta extensão de terra e muitos produtores, de modo que a pressuposição básica para a segurabilidade, que é a independência entre os eventos é violada. Este tipo de risco é chamado "sistêmico". Para a seguradora a existência do risco sistêmico pode acarretar no descumprimento de parte de suas obrigações perante o segurado, de acordo com o especificado no contrato, caso não haja auxílio governamental ou nenhum mecanismo de transferência do risco pela seguradora, através de outras seguradoras, resseguradoras ou mesmo para o mercado financeiro;

Estes problemas podem inibir o desenvolvimento de um mercado de seguro agrícola, pois de um lado, contribuem para aumentar a taxa de prêmio devido ao risco peculiar da atividade agrícola e, por outro lado, os produtores podem não estar dispostos a pagar pelo contrato de seguro agrícola, dado que utilizam outros mecanismos de administração do risco. (Azevedo-Filho, 2001)

Além disso, os programas, em geral, são altamente dependentes de aporte governamental, no sentido de oferecer subsídio ao prêmio, arcar com uma parte ou a totalidade do custo administrativo, assumir a responsabilidade nos contratos de maior risco e dar apoio ao resseguro de riscos catastróficos.

Neste sentido, a formulação de um mecanismo alternativo de seguro agrícola que não seja baseada na produtividade individual e que amenize os problemas citados anteriormente é desejável como, por exemplo, um seguro baseado em um índice de produtividade regional ou em um indicador climático.

\subsubsection{Alguma considerações teóricas}

A fundamentação econômica do seguro tiveram suas origens em fins da década de 60 e início de 70, por Borch e Arrow, como visto anteriormente. No que se refere ao ramo do seguro responsável por cobrir os riscos agrícolas, a fundamentação teórica 
ocorreu apenas no início da década de 80 , como uma adaptação da teoria já existente ao ramo agrícola.

Desta forma, Ahsan et al. (1982) analisam um modelo simples de competição perfeita, aplicado ao mercado de seguro agrícola. Neste modelo, assume-se que o produtor aloca sua dotação orçamentária inicial em duas atividades, uma de risco, representada pela produção agrícola e outra, com uma taxa de retorno constante e sem risco.

A função de produção, que possui produtividade marginal decrescente, é função de apenas um fator de produção e o indivíduo é avesso ao risco. Sendo assim, através da maximização da utilidade esperada sujeita aos lucros normais pela firma seguradora, o equilíbrio competitivo é alcançado com o produtor optando pela cobertura total ou seguro total (situação onde todo o prejuízo é indenizado), ao prêmio justo, ou seja, quando o prêmio se iguala a perda esperada do produto.

Além disso, a escolha ótima dos recursos destinados para a atividade de risco requer que a produtividade marginal esperada se iguale ao seu custo de oportunidade, ou a taxa de retorno do investimento sem risco.

Nota-se ainda que, na situação com seguro, cobertura total, o produtor aloca maiores quantidades do recurso para a atividade de risco do que na situação sem a aquisição do contrato de seguro, conseqüentemente, aumentando o produto total e também o bem estar social esperado.

Relaxando a pressuposição de informação perfeita e incorporando o problema da assimetria de informação no modelo, determinou-se que não é possível a existência de um mercado de seguro em moldes puramente privados, cabendo ao governo subsidiar as operações de seguro.

Posteriormente, o artigo de Nelson e Loehman (1987) ampliou o modelo anterior, no sentido de considerar uma função de produção estocástica, com múltiplos insumos e produtos. 
Considerou-se para efeito de análise da utilização do fator de produção para um produto, a atitude do produtor frente ao risco, se neutro ou avesso, e o tipo de insumo, se marginalmente de risco crescente ou de risco decrescente ${ }^{151}$.

Se o insumo for marginalmente de risco crescente, então o indivíduo neutro ao risco demandará mais por este tipo de insumo, do que o indivíduo que tem aversão ao risco, implicando em um produto maior. Caso contrário, se o insumo for marginalmente de risco decrescente, o indivíduo avesso ao risco demandará maior quantidade deste insumo, resultando em uma maior produção.

Para o caso de um insumo utilizado para produzir dois tipos de produtos diferentes, suponha que o fator de produção seja risco decrescente para o produto 1 e risco crescente para o produto 2. Neste caso, o indivíduo avesso ao risco irá produzir mais do produto 1, pelo fato do insumo ser risco decrescente, do que o produto 2 .

Os autores ressaltam que nem sempre a aquisição de um contrato de seguro "completo" aumenta a produção quando o insumo é risco crescente, podendo ser reduzida dependendo da atitude do produtor diante do risco e do tipo de insumo.

Posteriormente, a pressuposição de informação perfeita é descartada do modelo surgindo, assim, o problema da assimetria de informação, especificamente o risco moral e a seleção adversa.

O risco moral se refere ao fato de que a decisão ótima do segurado pode mudar em função da aquisição do seguro. A seleção adversa é a situação onde pessoas mais prováveis em sofrer determinado dano coberto pelo seguro são mais propensas a demandar por este contrato (Quiggin et al., 1994).

O problema do risco moral ocorre, de maneira geral, no seguro agrícola, se a firma seguradora é incapaz de observar se o produtor utilizou ou não determinado fator de produção. Deste modo, os autores demonstraram que o produtor maximizador de sua utilidade esperada, de fato, utilizará uma quantidade menor do insumo, dado que a firma seguradora é incapaz de perceber as ações tomadas pelo produtor em relação ao fator de produção.

\footnotetext{
${ }^{151}$ Segundo Pope e Kramer (1979), um insumo será marginalmente risco decrescente (crescente) se uma firma avessa ao risco utilizar uma quantidade maior (menor) de insumo do que a firma, neutra ao risco, correspondente.
} 
Este fato pode ser comprovado através de um estudo empírico que gastavam, em média, US\$ 4,23/acre a menos em fertilizantes e defensivos do que aqueles que não estavam cobertos por nenhum tipo de seguro agrícola (Smith e Goodwin, 1996).

Devido ao fato da firma seguradora possuir informações apenas em relação ao risco agregado faz com que ocorra o problema da seleção adversa. Dispondo de tais informações a firma formulará o contrato e realizará o cálculo do prêmio, tendo em vista este problema.

Se o prêmio for considerado pelo indivíduo maior que sua perda esperada, então este não irá adquirir o contrato, caso contrário, se o indivíduo considera que sua perda esperada é maior que o prêmio então adquirirá o seguro (Skees e Reed, 1986).

Esta situação irá resultar em prejuízo econômico para a firma seguradora devido à alta seletividade por indivíduos de alto risco em sua carteira. Os autores concluem que um contrato de seguro Pareto ótimo deveria ser ofertado a um nível de cobertura total e individualizado.

Analisando o problema da seleção adversa, Goodwin (1993) mostra que quanto maior o perfil de risco do produtor, menos elásticas serão as respostas às mudanças de prêmio, ou seja, embora a demanda por seguro seja negativamente relacionada com a taxa de prêmio, produtores com maior risco tendem a serem menos sensíveis a aumentos do prêmio do que produtores com menor nível de risco.

O problema da assimetria de informação é captado por Goodwin (2001) na análise de um conjunto de dados de produtores de trigo em Kansas. A análise indicou que os produtores considerados mais arriscados na amostra tendem a apresentar uma menor elasticidade da demanda à variação do prêmio, mostrando que os indivíduos de alto risco são pouco sensíveis à elevação do prêmio para a aquisição do seguro, comprovando a existência da seleção adversa.

Além da seleção adversa, o problema do risco moral é abordado através da utilização de insumos, especificamente, fertilizantes. Os resultados mostraram que produtores que adquirem seguro agrícola utilizam menor quantidade de fertilizantes, comparativamente a situação onde não estão segurados. 
Segundo Chambers (1989), na presença de custos relacionados a atividade seguradora, um contrato ofertado com cobertura total não é Pareto ótimo. O autor amplia o modelo de Nelson e Loehman incorporando não apenas um vetor de fatores aleatórios, responsáveis pelo risco de produção, como também um vetor aleatório de preços e uma variável de custo ${ }^{152}$ e se baseia não mais no seguro de produtividade, mas no seguro da renda do produtor.

$\mathrm{O}$ autor argumenta que, devido ao fato da atividade agrícola possuir um risco altamente correlacionado e os sinistros ocorrerem com relativa freqüência, existe a possibilidade da firma seguradora não conseguir arcar com o pagamento de todos os contratos realizados, seja pelo rápido esgotamento do seu fundo ou pela limitação da captação de recursos. Uma possível saída para este problema seria a diversificação do risco da firma em abranger outras formas de risco menos correlacionadas.

\subsubsection{O seguro agrícola baseado em índices regionais}

Nesta subseção, apresentar-se-á a revisão de literatura pertinente ao seguro agrícola baseado em indicadores de produtividade regional e de indicadores climáticos, tendo em vista aspectos teóricos, metodológicos e experiências práticas.

\footnotetext{
${ }^{152}$ No artigo, Chambers considera apenas o custo de administração e o custo relacionado ao levantamento de fundos para pagamento das indenizações.
} 


\subsubsection{O seguro agrícola de produtividade regional}

Um dos artigos pioneiros na análise do seguro agrícola baseado em índices regionais foi publicado por Halcrow em 1949. O mesmo define três formas de seguro voluntário $^{153}$ : o seguro agrícola múltiplos riscos ou multi-risco; seguro baseado em um indicador de produtividade regional; e, o seguro baseado em um índice climático, que será abordado com maior nível de detalhamento na próxima subseção.

No seguro agrícola multi-risco seria estabelecido como produtividade base a produtividade média do produtor em um período de 10 anos. O nível de cobertura poderia variar entre 50 e $75 \%$ da produtividade base.

$\mathrm{O}$ valor a ser indenizado seria igual a diferença entre a produtividade base levando em conta o nível de cobertura e a produtividade atual. O prêmio é o mesmo para uma determinada área e calculada a partir de uma estimativa da indenização média em um determinado período de anos.

O maior problema apontado pelo autor e de difícil resolução neste tipo de seguro é a seleção adversa ${ }^{154}$. Além disso, o programa, para apresentar resultados satisfatórios, deveria ser operacionalizado de maneira que as informações deveriam ter um tal nível de detalhamento que os custos para obtenção tornariam o programa inviável.

O seguro de produtividade regional teria o prêmio e a indenização baseados na produtividade de determinada região. A indenização seria paga quando a produtividade

\footnotetext{
${ }^{153}$ No artigo, o autor afirma que o seguro voluntário seria preferido ao seguro de forma obrigatória e o seguro subsidiado. A obrigatoriedade do seguro seria desvantajosa para os produtores, pois o valor descontado do prêmio no tempo seria maior que o valor da indenização recebida e o seguro subsidiado resultaria em uma alocação ineficiente dos recursos, no sentido de se utilizar áreas, que não seriam utilizadas na ausência do seguro.

Por outro lado, o custo do subsídio seria menor do que outros tipos de programas, como por exemplo, pagamentos realizados decorrentes de eventos catastróficos.

${ }^{154}$ McCarty (1941) analisando o seguro agrícola para o trigo nos EUA afirma que produtores poderiam prever, com uma certa confiabilidade, a produtividade de acordo com pluviosidade ocorrida alguns meses antes do início do plantio e a umidade do solo amostrada anteriormente à semeadura. Este tipo de procedimento levaria a um aumento da demanda por seguro em épocas em que as condições climáticas não fossem favoráveis, havendo o problema da seleção adversa. O autor propõe alternativas para reduzir o problema, que são a aquisição do contrato até uma data limite, supostamente um ano antes da época de plantio e o contrato contínuo, prevalecendo por um período de três anos, por exemplo. Halcrow afirma que tais alternativas não eliminam totalmente o problema.
} 
média da região fosse menor que um percentual da produtividade normal ou esperada para a região.

A produtividade normal seria uma média ponderada da produtividade da região em um determinado período de tempo, que levaria em conta as mudanças econômicas e tecnológicas, que poderiam influenciar na variação da produtividade.

Alguns aspectos importantes para o desenvolvimento do seguro foram destacados, entre eles estão o limite geográfico da área, sua uniformidade e homogeneidade e a correlação entre a produtividade ao nível do produtor e da área considerada.

Dois problemas são apontados pelo autor para o cálculo do índice regional. O primeiro é a ponderação utilizada em uma determinada área para se determinar a média desta área e o segundo, a mensuração da produtividade em diversos pontos da área para se calcular o indicador, ou seja, um problema de amostragem.

O mesmo sugere que este cálculo poderia ser realizado através da seleção de 15 a 20 propriedades e o resultado estendido para compreender toda a área. A vantagem deste tipo de seguro em relação ao multi-risco está na forma com que o contrato é estabelecido, isto é, no processo de cálculo atuarial, que poderia prevenir o problema da seleção adversa.

De acordo com Halcrow, no seguro baseado em um índice climático, o contrato seria especificado de acordo com uma medida climática correlacionada com a produtividade. O cálculo da produtividade poderia ser realizado através de uma regressão múltipla, relacionando esta variável com os fatores climáticos que a afetam, tais como a temperatura, evapotranspiração, pluviosidade durante a fase de emergência e desenvolvimento e umidade do solo na semeadura.

Posteriormente, no ano de 1991, Miranda publica um artigo, na qual reconsidera o trabalho de Halcrow (1949) sobre seguro agrícola baseado em indicadores regionais de produtividade.

No trabalho é demonstrado, de uma forma clara e elegante o motivo pela qual o seguro baseado em um índice de produtividade regional elimina total ou 
parcialmente o problema da assimetria de informação ${ }^{155}$ e reduz os altos custos associados a fiscalização e a verificação do sinistro, principalmente quando o evento causador do prejuízo atinge uma área relativamente extensa.

Em um artigo, na qual são analisados e comparados cinco tipos de contratos distintos, Smith et al. (1994) complementam o trabalho de Miranda.

No primeiro contrato analisado, AYC3, denominado contrato "ideal", o segurado poderia escolher o nível de cobertura e a produtividade crítica ${ }^{156}$. Dois fenômenos interessantes ocorrem sob este tipo de contrato.

O primeiro deles é que o indivíduo poderá ser indenizado quando a sua produtividade observada é maior do que a produtividade média, $\mu$, sempre que $\alpha_{\mathrm{i}}>1$. O segundo ponto levantado é que, eventualmente, o segurado poderá receber um valor de indenização maior do que a diferença entre a produtividade crítica e a produtividade observada, quando o nível de cobertura $\phi_{i}>1$.

O segundo contrato, AYC1, é baseado no programa piloto americano de seguro agrícola baseado em um indicador de produtividade regional, denominado Group Risk Plan (GRP).

Neste seguro, o nível de cobertura e o valor da produtividade crítica, através do $\alpha_{i}$, estão limitados a valores máximos, respectivamente, 1,5 e 0,9. O cálculo da indenização, para o indivíduo $i$ neste seguro, será paga sempre que a produtividade regional $\tilde{y}$ for menor do que a produtividade crítica $y_{c}$, dado por:

$$
I_{i}=\phi_{i} \max \left[\left(y_{c}-\tilde{y}\right) / \alpha_{\mathrm{i}}, 0\right]
$$

\footnotetext{
155 Teoricamente, o risco moral ex ante é eliminado, pois o segurado não pode alterar a sua probabilidade de perda, visando o recebimento da indenização, pois o mecanismo de compensação está baseado na produtividade regional. O risco moral ex post, que consiste na percepção incorreta pela firma seguradora da produtividade ao nível do produtor é reduzida. A maior facilidade de aquisição e exatidão das informações sobre a distribuição da produtividade da área possibilitam a redução significativa do problema da seleção adversa.

${ }^{156}$ A produtividade crítica é calculada pela fórmula, $\mathrm{y}_{\mathrm{c}}=\alpha_{\mathrm{i}} \mu$, de tal forma que o segurado poderia escolher um valor não negativo de $\alpha_{\mathrm{i}}$, tal que, $\alpha_{\mathrm{i}}=(1-$ dedutibilidade $)$, multiplicado pela média a longo prazo ou a produtividade regional esperada, $\mu$.
} 
O terceiro contrato, AYC2, denominado "quase ideal" é mais simples, pois permite que o produtor escolha apenas o valor de $\alpha_{\mathrm{i}}$, fixando $\phi_{i}$ em um valor unitário.

O quarto, IYC1, e o quinto, IYC2, contratos são baseados nas produtividades individuais, diferenciando-se no percentual, $\alpha_{i}$, incidente sobre a produtividade média, respectivamente de $75 \%$ e $90 \%{ }^{157}$.

Os autores realizaram, posteriormente, uma análise empírica dos contratos a um conjunto de dados de produtividades individuais de trigo na região de Montana.

Os resultados demonstraram que o contrato AYC2 provê os produtores de uma significativa redução do risco em relação ao $\mathrm{AYC1}$, e uma redução um pouco menor do que o AYC3, embora o prêmio seja inversamente proporcional a redução do risco da variação da produtividade.

Levando-se em conta todos os produtores, a produtividade crítica média para os contratos AYC2 e AYC3, é igual a $1,246 \mu$ e os níveis de cobertura médio para os mesmos contratos são, respectivamente, igual a 1 e 1,074 .

Os seguros de produtividade individual, IYC1 e IYC2, possibilitam, na ausência do risco moral e seleção adversa, uma redução do risco equivalente aos seguros de produtividade regional a um prêmio significativamente menor.

Tomando como base o artigo de Miranda, Mahul (1999) generaliza o modelo em um contexto, na qual um indivíduo avesso ao risco maximiza a utilidade esperada da produtividade líquida, sujeito a uma função de indenização não negativa e o prêmio como uma função da indenização esperada ${ }^{158}$.

Nesse contexto, define-se o contrato ótimo como sendo a indenização $(I)$ e o prêmio $(P)$ que maximizam a utilidade esperada, dada as restrições. Deste modo,

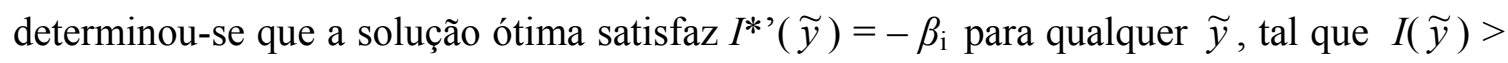
0 , onde $\beta_{\mathrm{i}}$ representa a sensibilidade da produtividade individual aos fatores sistêmicos.

\footnotetext{
${ }^{157}$ Uma das diferenças do contrato baseado na produtividade individual consiste na determinação de $\mathrm{y}_{\mathrm{c}}$, através da multiplicação da produtividade média, que é baseada na produtividade histórica da unidade de produção por $\alpha_{\mathrm{i}}$.

${ }^{158}$ A função de indenização é dada por $I(y) \forall y \in\left[0, y_{\max }\right]$ e o prêmio, $P=\mathrm{c}[\mathrm{E} I(y)]$. Nota-se que $\mathrm{c}(0)=0 \mathrm{e}$ $\mathrm{c}^{\prime}(I) \geq 0 \forall I(y) \geq 0$. Caso $\mathrm{c}^{\prime}(I)=1$, então define-se o seguro como atuarialmente justo, isto é, a firma seguradora tem como único componente de sua estrutura de custos aqueles destinados ao pagamento da indenização.
} 
Percebe-se, que se $\beta_{\mathrm{i}}>0$, então o indivíduo será indenizado toda vez que a produtividade regional $(\tilde{y})$ for menor que a produtividade crítica $\left(y_{\mathrm{c}}\right), y_{\mathrm{c}} \in\left[0, y_{\max }\right]$, tal que:

$$
I^{*}(\tilde{y})=\beta_{\mathrm{i}} \max \left(y_{\mathrm{c}}-\tilde{y}, 0\right)^{159}
$$

Neste caso, o seguro assemelha-se a um contrato de opção de venda, ou seja, o pagamento equivalente a indenização é recebida pelo portador do contrato, sempre que a produtividade regional for menor que a produtividade crítica.

Caso o produtor possa escolher o nível de cobertura $\left(\phi_{i}\right)$ e a produtividade crítica, então a maximização da utilidade esperada incorporando a nova variável resulta que $\phi_{i}^{*}=\beta_{\mathrm{i}}$ e a produtividade crítica ótima se iguala a produtividade regional máxima, $y_{\mathrm{c}}{ }^{*}=y_{\max }$, se $\mathrm{c}^{\prime}(I)=1$, para qualquer $I(\tilde{y}) \geq 0$. Caso c' $(I)>1$, então $y_{\mathrm{c}} *<y_{\max }$.

Se a firma seguradora, por outro lado, fixar o nível de cobertura e supondo que o prêmio seja justo e aversão ao risco absoluto constante (CARA), então a produtividade crítica se reduz com o aumento do nível de cobertura.

Uma possível explicação é que, se o nível de cobertura, fixado a priori, é maior que seu valor ótimo, $\beta_{\mathrm{i}}$, então o produtor compensa seu alto valor reduzindo a sua produtividade crítica abaixo do seu nível ótimo, $y_{\max }$.

Nota-se que os resultados apresentados por Mahul, se aplicam ao tipo de seguro "ideal", definido anteriormente como aquele em que o nível de cobertura e a produtividade crítica poderiam variar. Tais resultados foram aplicados ao conjunto de dados utilizados por Miranda sugerindo que o prêmio médio sob este tipo de seguro, \$ 7,68 por acre, é mais do que três vezes o valor encontrado por Miranda, em um contrato em que $\phi$ varia e $y_{\mathrm{c}}$ é igual a $95 \%$ da produtividade normal.

Comparativamente ao trabalho de Smith et al., o autor sugere que o nível ótimo de cobertura deveria ser 1 ao invés de 1,074, pois a média ponderada dos $\beta_{\mathrm{i}}$ 's é igual

\footnotetext{
${ }^{159} \mathrm{O}$ caso em que $\beta_{\mathrm{i}}<0$, situação em que o indivíduo é indenizado quando a produtividade regional $(y)$ for maior que a produtividade crítica $\left(y_{\mathrm{c}}\right)$, não foi considerado, pois tal situação é bastante incomum na prática.
} 
a um e no nível ótimo, $\phi_{i}^{*}=\beta_{\mathrm{i}}$. Deste modo, os contratos, AYC2 e AYC3, seriam iguais, ou seja, teriam o mesmo valor de $\phi$ e $y_{\mathrm{c}}$.

Conseqüentemente, ambos os contratos apresentariam, em média, a mesma redução no risco e, também o mesmo prêmio, dada a pressuposição de que o prêmio é igual a indenização esperada.

Miranda e Mahul consideraram que a relação entre a produtividade individual $\tilde{y}_{i}$ e a produtividade regional $\tilde{y}$ segue um modelo linear aditivo (MLA), ou seja, o modelo pode ser entendido como uma regressão linear onde a variável dependente é representada pela produtividade individual e a independente, pela produtividade regional. Além disso, os riscos sistêmico e não-sistêmico são aditivos no modelo.

Mas problemas podem aparecer se a relação entre as produtividades não for do tipo MLA e os resultados encontrados pelos autores podem não ser mais válidos. Neste contexto, Ramaswami e Roe (2004), verificam teoricamente se outros tipos de modelos estruturais podem ser expressos na forma MLA.

Três modelos estruturais foram verificados pelos autores. O primeiro denominado modelo de riscos aditivos e componentes aditivos (RACA), expresso por $\tilde{y}_{i}=$ $\mu_{i}+\vartheta_{i}+\imath^{160}$. O segundo modelo chamado Just-Pope com componentes aditivos, dado por $\tilde{y}_{i}=\mu_{i}+\sigma_{i}\left(\vartheta_{i}+\imath\right)$ e o terceiro modelo de riscos multiplicativos e de componentes multiplicativos, $\tilde{y}_{i}=\mu_{i} \vartheta_{i} l$.

A partir de um modelo estrutural geral, os autores derivaram as condições necessárias em que este modelo pode implicar em um modelo MLA, supondo que existam um grande número de produtores ${ }^{161}$. A partir destas condições, considerou-se que o primeiro e segundo modelo são consistentes com o MLA, mas o último modelo é inconsistente.

\footnotetext{
${ }^{160}$ Onde $\vartheta_{i}$ representa um choque específico ao produtor i e $l$ é o choque comum a todos os produtores em uma certa região.

${ }^{161}$ Se a Lei dos Grandes Números pode ser aplicada, então a covariância amostral irá convergir para a covariância populacional, em probabilidade. Esta suposição faz com que a produtividade regional seja considerada aleatória, somente pela choque comum a todos os produtores em certa área $\boldsymbol{l}$.(pg. 423)
} 
Outro resultado interessante obtido por Ramaswami e Roe se refere ao nível de agregação dos produtores. Quanto maior o nível de agregação, maior a redução do risco sistêmico e maior será o aumento do risco não-sistêmico.

Caso a suposição da existência de um grande número de produtores for relaxada, de modo que, se possa considerar um pequeno número de produtores no universo de agregação, então os resultados encontrados usando-se o MLA e a relação linear entre a produtividade individual e regional continuam os mesmos. A diferença é que neste caso, os estimadores de $\beta_{\mathrm{i}}$ obtidos por mínimos quadrados serão inconsistentes.

Baseados no trabalho de Halcrow e Miranda, Skees et al. (1997) realizaram um estudo detalhado objetivando a formulação, precificação e implementação de um contrato de seguro baseado em um indicador regional de produtividade.

Neste trabalho, foram enfocados quatro pontos principais: a seleção e delimitação da área a ser abrangida pelo seguro, de modo que a área escolhida deve apresentar características de solo e clima semelhantes; método empírico de previsão da tendência central nas produtividades regionais ${ }^{162}$; as regras de pagamento da indenização, levando em conta o percentual de dedutibilidade, que poderia variar de 10 a $30 \%$, em múltiplos de 5 ; o nível de cobertura ${ }^{163}$, com máximo de $150 \%$ e mínimo equivalente a seis décimos do máximo correspondente, neste caso, 90\%; e, por último, a precificação ou o cálculo da taxa de prêmio utilizando as informações de áreas adjacentes, devido a correlação espacial $^{164}$ existente entre as produtividades das diversas áreas próximas umas as outras.

\footnotetext{
${ }^{162}$ Segundo os autores, a produtividade pode ser dividida em dois componentes: a tendência central e o desvio em relação à tendência central. A primeira pode ser vista como uma função da administração, manejo, tecnologia e recursos disponíveis, e a segunda como função de eventos aleatórios causados pela natureza e que não estão sob controle do produtor.

${ }^{163}$ No artigo os autores se referem ao de nível de cobertura como nível de proteção ou escala, obedecendo a notação utilizada pela Federal Crop Insurance Corporation (FCIC).

${ }^{164}$ Analisando a correlação espacial da produtividade do milho nos três maiores estados produtores nos EUA, Goodwin (2001) argumenta que, em uma primeira situação, na qual são analisados anos de produtividade normal, a medida de correlação se reduz mais rapidamente com o aumento da distância, estabilizando-se no valor de 0.10 quando a distância entre as áreas consideradas é de aproximadamente 200 milhas. Em outra situação, considerando anos em que secas ocorreram, a medida de correlação decresceu mais vagarosamente, atingindo o mesmo nível de 0.10 a uma distância de 400 milhas. Percebe-se, deste modo que, em anos de ocorrência de eventos generalizados o problema do risco sistêmico é mais acentuado do que em anos normais.
} 
No trabalho, ressalta-se que a eficácia do seguro está relacionada à presença do risco sistêmico, e também que, a magnitude do risco de base está atrelada aos quatro objetivos descritos anteriormente.

Além disso, os autores sugerem que a redução do risco de base poderia ser maximizada se houvesse a conjugação entre contratos de seguro com cobertura de riscos individuais ofertados por seguradoras privadas e contratos de seguro baseados em um índice regional de produtividade ofertados pelo governo. A vantagem deste esquema estaria na maior proteção oferecida ao produtor, dado que o risco sistêmico e os riscos individuais estariam sendo cobertos.

Embora o problema da assimetria de informação tenha recebido maior atenção na literatura econômica do seguro, o risco sistêmico representa, segundo Miranda e Glauber (1997), a principal causa do fracasso na emergência de um mercado privado de seguro agrícola.

Uma análise empírica baseada na estimativa do risco da carteira das dez maiores firmas seguradoras no ramo agrícola, representada pelo coeficiente de variação das indenizações totais pagas em um determinado período de tempo, mostrou que a variação percentual desta estimativa, com riscos correlacionados, pode chegar ao mínimo de $67 \%$ e ao máximo de $130 \%$, enquanto que a variação seria de $1 \%$ a $4 \%$, caso as indenizações fossem tratadas como eventos independentes.

Se comparativamente aos ramos tradicionais de seguro, como por exemplo, automóveis e incêndio, que teoricamente, apresentam riscos não correlacionados, o risco da carteira de seguro agrícola é aproximadamente dez vezes maior.

Para atenuar este problema, os autores sugerem alternativas que possam reduzir a variação do pagamento das indenizações pelas firmas seguradoras e que haja a possibilidade de transferência do risco sistêmico, parcialmente ou em sua totalidade, para o mercado ressegurador, através de contratos de resseguro e contratos de opções, ambos baseados em indicadores de produtividade regionais, os mesmos utilizados para a operacionalização do seguro direto.

Tanto o contrato de resseguro, quanto o contrato de opções indenizariam o portador caso houvesse qualquer redução na produtividade regional estabelecido no 
contrato. A diferença está na definição do prêmio e em quem escreve o contrato, seja pelo governo ou por aqueles que participam do mercado de opções e futuros.

\subsubsection{O Seguro de índices climáticos}

De acordo com Halcrow, no seguro baseado em um índice climático, o contrato seria especificado de acordo com uma medida climática correlacionada com a produtividade.

O cálculo da produtividade poderia ser realizado através de uma regressão múltipla, relacionando esta variável com os fatores climáticos que a afetam, tais como a temperatura, evapotranspiração, pluviosidade durante a fase de emergência e desenvolvimento e umidade do solo na semeadura.

Percebe-se que quanto maior a correlação entre a produtividade e o indicador climático, maior proteção terá o produtor que adquirir este tipo de seguro. $\mathrm{O}$ autor ressalta, ainda que, o seguro seria adaptado mais facilmente àquelas áreas semi-áridas em que a produtividade estaria sendo fortemente limitada por uma ou duas variáveis climáticas, como por exemplo, temperatura e/ou pluviosidade.

O seguro baseado em índices climatológicos apresentaria diversas vantagens em relação ao multi-risco, entre elas estariam a eliminação do risco moral e da seleção adversa, a substituição de uma série histórica de dados da produtividade individual pela utilização de dados climatológicos, possibilitando a redução dos custos administrativos e a cobertura total do risco, existindo a opção de reduzir o nível de cobertura com a respectiva redução do prêmio Sanderson (1943).

A principal desvantagem estaria atrelada à reduzida capacidade de proteção oferecida pelo seguro, caso a correlação entre o índice e a produtividade seja baixa.

Neste sentido, Lee (1953) analisa o seguro agrícola contra geada, baseado em medidas de temperatura aplicados em pomares de citrus na Califórnia.

O seguro se diferencia do modelo proposto por Sanderson e Halcrow, em relação ao prêmio e a indenização que estão diretamente relacionadas à medida de 
temperatura ao invés da perda calculada a partir da relação entre a produtividade e as variáveis climatológicas.

De modo geral, a indenização seria baseada na duração da temperatura crítica em uma determinada estação meteorológica multiplicada por um valor prédeterminado no contrato, que varia inversamente com a redução da temperatura.

A taxa de prêmio seria calculada, a partir de uma série de tempo de duração da temperatura em cada estação. A análise mostra que em uma série de 23 anos, o total de indenização se iguala ao total do prêmio recolhido, sem a inclusão de custos administrativos.

Uma das desvantagens que o autor ressalta é que existe a possibilidade do segurado, neste sistema de seguro, estar sujeito a realizar grandes prejuízos, mas receber nenhum ou um reduzido valor de indenização ou receber um alto valor de indenização sem ter tido prejuízos econômicos.

Analisando um modelo de oferta e demanda de seguro agrícola, cujo contrato é baseado em observações meteorológicas ao invés de variações na produtividade, Bardsley et al. (1984) afirmam que a eficiência deste contrato é em função de variáveis relacionadas com a correlação entre o risco dos produtores e o retorno do contrato de seguro $(\mathrm{RC}>0)$, custo administrativo $(\mathrm{CA})$ e a correlação espacial do risco ${ }^{165}$.

Os autores defendem a hipótese de que o seguro agrícola não é viável em moldes puramente privados, sem subsídio governamental, mesmo quando o custo administrativo é nulo.

De fato, quando aplicam este tipo de seguro em um conjunto de dados de produtores de trigo na Austrália verificam, que ocorre uma reduzida contribuição no gerenciamento do risco agrícola através do seguro agrícola, devido à alta correlação do risco entre as diversas áreas consideradas, que implica na elevação considerável do prêmio do seguro tornando sua aquisição inviável pelo produtor.

\footnotetext{
${ }^{165}$ No artigo quando $\mathrm{RC}=1$, então os retornos do contrato cobrem as flutuações da renda exatamente quando são requeridos. Por outro lado, quando $\mathrm{RC}=0$, esta cobertura está completamente não relacionada a necessidade. O parâmetro CA foi permitido variar em $0,2,5,10,20 \%$. A correlação espacial do risco quando perfeitamente correlacionada mostra que é impossível a pulverização do risco e quando igual a zero, então uma considerável redução do risco pode ser atingida.
} 
Tomando como base o modelo de Bardsley et al., Quiggin (1986) argumenta que algumas especificações incorretas no modelo levaram os autores a concluírem, de maneira errônea, que o seguro agrícola privado seria inviável.

Realizando as devidas correções, no referente ao custo administrativo e na situação da seguradora quando um novo ativo de risco é incorporado a uma determinada carteira pré-existente ${ }^{166}$, o mesmo mostra, utilizando o mesmo conjunto de dados, que o seguro poderia resultar em significativa redução do custo de administração do risco.

Apesar disso, Quiggin aponta outros motivos que impossibilitam a emergência de um mercado de seguro agrícola: a inexistência de firmas seguradoras possuindo uma carteira relativamente grande de ativos e com larga experiência em gerenciamento de risco na Austrália; a existência de políticas governamentais de auxílio direto em casos catastróficos que competem com mecanismos tradicionais de pulverização do risco como o seguro; e, problemas relacionados ao correto incentivo que os contratos deveriam proporcionar.

Nos moldes dos trabalhos de Sanderson e Lee, Turvey (2001) analisa a precificação e implementação de um seguro fundamentado em índices climatológicos (temperatura e pluviosidade), correlacionados com a variação da produtividade agrícola. Três critérios importantes devem ser levados em conta para a formulação do contrato, segundo o autor:

i) O evento segurado;

ii) A duração do contrato; e,

iii) O local na qual o evento é mensurado.

A vantagem deste tipo de seguro em relação ao seguro múltiplos riscos baseado na produtividade local do produtor e no seguro baseado na produtividade regional é que o mecanismo de compensação é em função da ocorrência de um evento específico independente da variação da produtividade local ou regional.

\footnotetext{
${ }^{166}$ Caso o novo ativo seja não correlacionado com a carteira existente, então para pequenas quantidades deste ativo, a firma seguradora é neutra ao risco.
} 
Neste caso, o problema da assimetria de informação é reduzido drasticamente, como no caso do seguro de produtividade regional, pois o segurado não tem controle sobre o evento especificado no contrato.

Além disso, o seguro poderia ser adquirido por qualquer agente que queira reduzir o risco proveniente de eventos climáticos que causassem prejuízos a sua atividade econômica, não se limitando apenas aos produtores agrícolas.

Em princípio, o seguro climático pode ser atrativo onde outros tipos de seguro não alcançaram a receptividade desejada ou devido a problemas de informação e incentivo adequado, onde outros seguros apresentaram-se ineficientes.

O custo administrativo também é reduzido, como no contrato baseado na produtividade regional, pois não existe necessidade da averiguação do sinistro por um agrônomo ou técnico. A indenização é efetivada de acordo com a variação do índice climático.

Outro ponto positivo se refere a obtenção de uma série temporal, por exemplo, de índices pluviométricos ou temperaturas, relativamente longa e confiável, o que permite o cálculo mais preciso do prêmio.

Alguns problemas também incidem sobre este tipo de seguro. Como no caso do seguro regional, a variável climática apresenta seu componente sistêmico, ou seja, a queda da temperatura atinge uma vasta área geográfica, atingindo diversos indivíduos ao mesmo tempo.

Uma firma seguradora pode optar pela diversificação espacial de seu portfólio, mas esta alternativa é limitada pela extensão territorial do país. A operação de resseguro é outra opção pela qual a seguradora pode lhe dar com o risco sistêmico.

O problema neste caso é que as resseguradoras operam em grande escala e com produtos de alta sofisticação, portanto a seguradora deve iniciar as operações abrangendo diversos estados ou mesmo o país todo para obter a cobertura do resseguro.

Outro entrave ao seguro climático é o risco de base. Para uma mesma região, podem existir diversos microclimas, que podem afetar a distribuição da chuva nesta área, afetando com isso a correlação entre a renda e chuva de maneira indesejada. 
Além disso, se a estação meteorológica que afere o índice climático na região estiver muito distante, os dados não refletirão o que de fato ocorreu na área.

Neste caso, uma possível solução seria a implantação de mais pontos medidores dentro da área desejada, que se tornariam úteis à medida que mais dados fossem se acumulando com o passar do tempo.

O mesmo define risco de evento específico aquele evento na qual o resultado é sabido como certo ${ }^{167}$. O interessante neste caso é que a causa ou evento é segurado e não o efeito ou conseqüência.

Alguns exemplos de risco de evento específico são: geada anterior a uma data específica, granizo no período que antecede a colheita e chuva excessiva na época após a maturação, que cause danos ao produto ou que impossibilite sua colheita.

No trabalho, o autor estima os efeitos da chuva e da temperatura na produtividade agrícola de três culturas na região de Ontário, Canadá, analisa a exatidão das estimativas e a sensibilidade da produtividade de cada cultura de acordo com a variabilidade do clima.

Nota-se que o seguro, de modo geral, funciona como um derivativo agrícola, particularmente se assemelha no mecanismo de compensação a opção de venda e a opção de compra.

No primeiro caso, o indivíduo recebe uma indenização quando a temperatura ou índice pluviométrico for menor do que um nível crítico e no segundo caso, quando os índices excederem um nível crítico.

Para cada unidade de variação um pagamento fixo por unidade é realizado. O valor do prêmio é calculado levando-se em conta a distribuição de probabilidade do evento climático, a variabilidade do índice em torno de um nível crítico e o pagamento fixo por unidade.

Uma importante consideração para que o seguro funcione de maneira eficiente se refere ao local que está sendo segurado e o local de mensuração do índice climatológico. Em muitos casos os locais podem não ser os mesmos.

\footnotetext{
${ }^{167}$ Por exemplo, seja a proposição: caso ocorra uma seca, haverá com certeza frustração de safra. O evento específico neste caso é a seca, implicando que haverá certeza de frustração de safra.
} 
A utilização de dados climáticos locais, que sejam correlacionados com a variabilidade da produtividade da cultura é de elevada importância, dada a grande variabilidade que certo fenômeno climático pode exercer em uma determinada região. Além disso, contratos diferenciados quanto ao prêmio e a indenização deverão ser adaptados para cada região.

A possibilidade de implantação e operacionalização do seguro baseado em um índice pluviométrico é analisada por Hazell et al. (2003) e Skees et al. (2002) em países em que boa parte da população vive na área rural e tem sua renda baseada, em grande parte, na produção agrícola.

Nestes países esta atividade econômica é altamente dependente da pluviosidade e de outras variáveis climáticas. O nível tecnológico adotado pelos produtores é extremamente baixo e há grande variabilidade da produção devido à ocorrência destes eventos, que causam grandes perdas econômicas e muitas vezes impossibilitam o produtor de continuar exercendo sua atividade. 


\subsection{Modelagem da produtividade agrícola: implicações para a precificação de contratos de seguro agrícola}

Para caracterizar acuradamente o risco intrínseco de cada produtor, o contrato de seguro agrícola deve levar em conta não somente o tipo de cultura, solo, clima e o tipo de manejo, mas também metodologias atuariais adequadas para a modelagem dos dados de produtividade agrícola.

A determinação da taxa atuarial “justa” ou "pura” do prêmio, ou do mesmo modo, a indenização esperada, é um fator importante que deve ser levado em conta para que um contrato de seguro agrícola seja economicamente viável. Por exemplo, um produtor com histórico de produtividade média maior do que a média dos produtores de sua região ou município, possivelmente não seria atraído por um seguro pagando um prêmio igual a outros produtores da região. Melhor seria determinar uma taxa de prêmio individual que refletisse a estrutura de risco de cada produtor.

Para tanto seria necessário uma quantidade de dados para captar precisamente o risco de cada produtor. Na prática isto é inviável devido à inexistência de uma longa série de dados de produtividade individual.

Outro aspecto importante deve ser levado em conta no cálculo da taxa de prêmio. Os métodos comumente empregados não levam em conta a incerteza relacionada ao cálculo da taxa, ou seja, a forma da distribuição de probabilidade da variável aleatória representada pela produtividade agrícola.

Durante vários anos, este tem sido um ponto bastante controverso na precificação do contrato de seguro agrícola. Diversas abordagens foram utilizadas por diversos autores na busca da distribuição de probabilidade que melhor se ajustasse à produtividade agrícola. Exemplos: a abordagem paramétrica, não-paramétrica e Bayesiana.

Dentro da abordagem paramétrica, existem constatações de que a produtividade agrícola segue uma distribuição Normal, Beta, Gama ou Lognormal, por exemplo. O universo de discussão em torno deste ponto vem de longa data, além de ser bastante vasto. 
Um dos primeiros trabalhos sobre precificação de contratos de seguro agrícola é o de Botts \& Boles (1958). Este trabalho deriva a fórmula da taxa de prêmio puro (P) por unidade de área (acre), em unidades físicas, utilizada pelo FCIC em fins da década de $50^{168}$.

Um problema abordado foi a utilização de dados agregados de produtividade no cálculo da taxa de prêmio, quando as indenizações eram baseadas em produtividades individuais.

Para solucionar este problema, pelo menos parcialmente, dois tipos de contratos foram estudados. O primeiro deles tinha o mecanismo de compensação baseado na produtividade individual e regional e o segundo, somente na produtividade regional ${ }^{169}$.

Os dois contratos, assumem que a produtividade segue uma distribuição Normal com média $\mu_{i}$ e desvio-padrão $\sigma$. Assim, para o primeiro contrato ${ }^{170}$, a taxa média de prêmio $P$ é calculada através da eq. (42):

$$
P=A\left(y_{c}-\mu_{i}\right)+o \sigma_{i}
$$

Em que:

$A$ representa a relação entre a área onde ocorreu o sinistro e a área total utilizada para o cálculo da produtividade regional;

$y_{c}$ é a cobertura ou a produtividade garantida (assume-se igual a $0,6 \mu$ );

\footnotetext{
168 Neste período, a produtividade garantida (também denominada limite do gatilho de compensação ou produtividade crítica, na notação utilizada no estudo) e o prêmio eram estabelecidos em bases regionais, não levando em conta as especificidades de cada propriedade.

${ }^{169}$ No primeiro caso, a produtividade observada era baseada nas produtividades individuais e a indenização era paga toda vez que a produtividade observada na propriedade segurada fosse menor que a produtividade crítica calculada com base na produtividade regional. No segundo, a produtividade observada e crítica eram baseadas na produtividade regional.

${ }^{170}$ Os autores ainda destacam três pontos em relação as variáveis mencionadas. O primeiro deles se refere ao valor fixo do nível de cobertura igual a 60\% da produtividade regional média de uma série histórica. Havia a possibilidade do produtor substituir este valor por outro igual a divisão entre o custo de investimento e o preço garantido, na qual a produção era avaliada, toda vez que o valor de $60 \%$ excedesse o custo de investimento. O segundo e o terceiro pontos estão relacionados aos valores fixos da taxa mínima 0,01152 e do desvio padrão 0,25, fixados com base na "experiência”. O terceiro ponto supõe que a variância da produtividade é constante ao longo do tempo, o que parece ser uma pressuposição bastante rígida se levado em conta que a variância da produtividade individual é maior em anos em que a produtividade regional é alta.
} 
$\mu_{i}$ é a produtividade média individual;

$\mu$ é a produtividade regional média;

$o$ é a altura da ordenada no ponto C na distribuição Normal;

$\sigma_{i}$ é o desvio padrão da produtividade individual (assume-se igual a 0,25 $\mu$ );

Esta equação indica que quanto o valor do prêmio é inversamente proporcional à produtividade individual média $\left(\mu_{i}\right)$ e diretamente proporcional à cobertura $\left(y_{c}\right)$. Além disso, havia uma taxa mínima igual a $0,01152 \mu$ que era aplicada toda vez que taxa calculada fosse menor que este valor.

O segundo tipo de contrato era baseado apenas nas produtividades regionais, de modo que o valor da indenização não seria mais dependente da produtividade individual. Neste caso, a indenização $(I)$ seria calculada multiplicando-se a cobertura ${ }^{171}$ pelo percentual de dano, através de: $I=0,5 \mu\left[1-\left(\mu_{i} / \mu\right)\right]$.

Neste esquema, todos ou ninguém recebe a indenização. Além disso, havia uma cláusula de perda mínima. Ou seja, não haveria indenização se o percentual de dano em determinada área fosse menor ou igual a $30 \%{ }^{172}$.

A taxa por unidade de área (acre) para determinado ano será igual a indenização esperada, ou seja, 0,5 $\left(\mu-\mu_{i}\right)$. Assim, o produtor recebe metade da diferença entre a produtividade garantida e a produtividade observada, contanto que a última seja menor do que $70 \%$ da primeira.

A taxa média de prêmio $P$, neste caso será igual $\mathrm{a}^{173}$ :

$$
P=0,5 D(\mu-R)=0,5 \text { o } \sigma_{i}
$$

Em que:

\footnotetext{
${ }^{171}$ Igual a $0,5 \mu$ multiplicada por um preço predeterminado $p$.

${ }^{172}$ Da mesma forma, não há indenização se $\mu_{i} \geq 0,7 \mu$.

${ }^{173}$ A igualdade é válida, pois $\frac{\mu-R}{\sigma}=\frac{o}{D}$ ( Botts e Boles, pg. 739)
} 
$D$ representa a relação entre o número de anos em que houve indenização e o número de total de anos;

$R$ é a produtividade média nos anos em que houveram indenizações $Y \geq 0,7 \bar{Y}$; e, $o$ representa a mesma variável do contrato anterior e $\sigma$ o desvio-padrão obtido através dos dados.

A taxa de prêmio por acre, em unidades monetárias, é obtida multiplicandose $P$, equação (43) pelo preço de garantia $p$, sendo aplicável a todos os produtores em determinada área.

Até fins da década de 70, era desta maneira que a Companhia Federal de Seguro Agrícola (FCIC) estipulava as taxas e o nível de proteção baseados nos valores de produtividade regional. A partir de 1980, a Companhia realizou importantes modificações, nos níveis de proteção e processo de formulação das taxas de prêmio, agora, baseados nos níveis de produtividade individual ${ }^{174}$.

Estas modificações foram justificadas, devido ao fato de que os contratos possuiam níveis de proteção e taxas de prêmio, baseados na produtividade regional. Isto reforçava o problema da seleção adversa, pois produtores cuja produtividade esperada era acima da média regional, teriam menor proteção do que produtores com produtividade esperada abaixo desta média, incentivando, desta forma, apenas aqueles produtores com menor valor de produtividade.

Além disso, como o prêmio cobrado pelo seguro era o mesmo para todos os produtores aqueles com produtividade esperada maior têm menor risco relativo ${ }^{175} \mathrm{em}$ termos percentuais. Por outro lado eles recebem um nível de proteção menor do que aqueles de menor produtividade esperada e maior risco relativo (considerando que os desvios padrões da produtividade sejam similares).

\footnotetext{
${ }^{174}$ Inicialmente, denominado IYC - Individual Yield Coverage e, posteriormente, APH - Actual Production History.

${ }^{175}$ Risco relativo é definido no trabalho como sendo igual ao coeficiente de variação (CV), ou seja, o quociente entre o desvio padrão e a produtividade esperada por unidade de área. Os autores ressaltam que alguns pontos devem ser analisados pelos produtores no referente à demanda pelo seguro, ou seja, devem ser capazes de avaliar suas produtividades esperadas, desvio padrão, disponibilidade em aceitar risco e acreditar que os benefícios oriundos do seguro são maiores que seu custo.
} 
Se os indivíduos fossem capazes de identificar tais riscos (e levando em conta o menor nível de proteção dado aos produtores com produtividade esperada maior), o seguro agrícola atrairia apenas aqueles com maior risco relativo, desencorajando os de menor risco a participarem do programa ${ }^{176}$.

O trabalho ressalta ainda, a importância da relação entre a produtividade esperada e as taxas teóricas ${ }^{177}$. Ceteris paribus, o aumento na produtividade tende a reduzir a perda esperada e, conseqüentemente, reduzir a taxa teórica. Além disso, destaca a necessidade de se ajustar a série de produtividade, em relação à tendência. O método de cálculo da produtividade APH utilizada pelo FCIC até então, utilizava a média aritmética entre os valores máximo e mínimo para obter a produtividade $\mathrm{APH}^{178}$.

Se a tendência não for levada em conta no cálculo da produtividade APH, a perda esperada calculada será menor do que se a produtividade fosse calculada levando-se em conta tal tendência. Uma implicação direta deste fato é a cobrança de taxas teóricas subestimadas.

Outros pontos são ressaltados no trabalho: verificar se a produtividade esperada individual e o desvio padrão são independentes e se a produtividade individual segue uma distribuição Normal.

No referido trabalho ${ }^{179}$, os resultados empíricos revelam que a hipótese de que a tendência é a mesma em todas as propriedades não foi rejeitada a um nível de significância de 5\%. Desta forma, pode-se considerar que existe uma tendência de produtividade comum a todas as propriedades, em determinada região ${ }^{180}$.

\footnotetext{
${ }^{176}$ Assim, um contrato de seguro com um nível de cobertura e prêmio fixos ofertado a produtores com níveis de dispersão da produtividade semelhantes, mas produtividades esperadas diferentes, acentuaria o problema da seleção adversa.

177 Definida como (EL/yc)x100, onde EL é a perda esperada e $\mathrm{y}_{\mathrm{c}}$ é a produtividade garantida ou crítica (produtividade APH multiplicada pelo percentual do nível de cobertura). Equação (6) pg.654.

${ }^{178}$ Neste caso, se existir uma tendência significativa na série histórica, então a produtividade esperada será maior do que a produtividade APH, calculada pelo FCIC. Assim, como a proteção está associada à produtividade APH, o produtor que possui uma tendência positiva não terá o nível de proteção adequado, ou seja, aquele que reflete de fato a produtividade esperada, e sim aquele que equivale à média da produtividade APH.

179 Realizados a partir de dados de produtividade, por propriedades rurais, nos estados de Illinois (54 propriedades), no período de 12 anos, para milho e soja e Kentucky (65 propriedades para milho e 48 propriedades para soja), no período de 12 a 22 anos.

${ }^{180}$ Consequentemente, ajustou-se a série de todas as propriedades para o nível de tecnologia de 1983.
} 
No referente à relação de dependência entre a produtividade esperada e o desvio padrão, comprovou-se estatisticamente que a hipótese de que o desvio padrão é independente da produtividade esperada não pode ser rejeitada a um nível de significância de $5 \%$.

Por outro lado, rejeitou-se a hipótese de que a série de produtividade individual segue a distribuição Normal.

A relação entre a produtividade esperada e a taxa teórica foi analisada em 4 possíveis situações: (1) a série de produtividade ajustada para a tendência segue uma distribuição Normal; (2) a série de produtividade não ajustada (utilizando os procedimentos de cálculo da média do máximo e mínimo da produtividade APH) e normalidade; (3) a série de produtividade ajustada sem a suposição de normalidade ${ }^{181}$; e, (4) a série de produtividade não ajustada sem a suposição de normalidade.

Observou-se que, em todas as situações, a produtividade esperada e a taxa teórica são inversamente relacionadas. Além disso, quando os ajustamentos foram realizados, as taxas foram superiores à situação em que o não houve ajuste, para o mesmo nível de produtividade. Quando a pressuposição de normalidade foi relaxada, as taxas encontradas foram maiores nos dois casos, ou seja, com ajuste e sem ajuste para a tendência.

Concluem os autores que a seleção adversa é acentuada e a participação no programa é reduzida quando o valor garantido está atrelado a alguma medida de produtividade esperada, pois aqueles com alta produtividade esperada esperam baixo valor de indenização e baixa freqüência de recebimento.

Os mesmos sugerem que os níveis de garantia deveriam estar atrelados a alguma medida de variabilidade, como por exemplo, o desvio padrão da produtividade e não em uma medida baseada no valor esperado.

A forma da distribuição de probabilidade da produtividade tem merecido relativo destaque dentro do meio especializado. Este assunto tem sido estudado por

\footnotetext{
${ }^{181}$ Utilizou-se como método para relaxar a pressuposição de normalidade a seguinte equação para a perda esperada: $E L=\sum_{i}\left(y_{c}-\tilde{y}_{i}\right) / n$, para $\tilde{y}_{i}<y_{c}$ e $\mathrm{i}=1, \ldots, n$.
} 
diversos especialistas e por longa data, mas ainda não se chegou a nenhum consenso sobre a maneira mais adequada para representar a distribuição.

Nota-se que, se a produtividade possuir determinada distribuição paramétrica, por exemplo, uma distribuição que possua assimetria positiva e for suposto erroneamente que, a distribuição é simétrica, então poder-se-ia chegar a conclusões completamente distorcidas.

Neste caso, especificamente, a probabilidade de se obter valores abaixo da produtividade esperada estará sendo subestimada. Este fato tem impacto direto na correta percepção de risco da seguradora em relação aos produtores e, também, em cobrar uma taxa de prêmio que reflita, de fato, o perfil de risco do produtor.

Um dos primeiros trabalhos relacionados à forma da distribuição de probabilidade da produtividade foi realizado por Day (1965). Utilizando uma série de dados experimentais, de algodão e milho (37 observações) e aveia (33 observações), para 7 níveis de aplicação de nitrogênio, o autor aponta que as distribuições apresentam, em geral, assimetrias e curtoses não-normais.

A hipótese era de que a produtividade tinha assimetria positiva, pois pequenas variações climáticas durante as fases mais sensíveis da cultura poderiam reduzir drasticamente sua produtividade esperada. Desta forma, produtividades menores do que a média seriam mais prováveis do que acima da média.

Inicialmente, foi realizado o teste de aleatoriedade da amostra ${ }^{182}$. Após realizar o teste o autor argumenta, que pode se proceder à análise considerando que cada série (21 ao todo) representa uma amostra aleatória.

Quanto ao teste de normalidade, optou-se por utilizar o teste de Egon Pearson para assimetria e o teste de Geary para curtose ${ }^{183}$. Ambos os testes podem ser utilizados para no mínimo 11 observações.

O teste de Pearson revela que, para todos os níveis de nitrogênio, pode se rejeitar a hipótese nula de simetria Normal, havendo assimetria positiva, para o algodão e

\footnotetext{
${ }^{182}$ Utilizando os testes não-paramétricos da seqüência de sinais de Wald-Wolfowitz e Wallis-Moore.

${ }^{183}$ A hipótese nula para o teste de simetria é que o coeficiente $\left(B_{1}\right)^{1 / 2}$, que é uma função do segundo e terceiro momentos da distribuição, seja igual a zero. Para o teste de curtose, a hipótese é de que a distribuição apresenta curtose normal, ou seja, coeficiente $\mathrm{B}_{2}=3$.
} 
assimetria negativa para três das sete séries da aveia. Quanto a série de milho não se pode rejeitar a hipótese de normalidade.

O teste de Geary sugere que pode se rejeitar todas as séries de algodão, em relação à hipótese de curtose Normal, apenas uma série para milho e duas séries para aveia. Os resultados parecem indicar que existe uma relativa mudança da distribuição, em relação à Normal, sendo mais achatada e larga para o milho e mais alongada e estreita para a aveia.

Mais recentemente, Gallagher (1987) estudou-se evidências a respeito da assimetria da distribuição da produtividade média nacional da soja nos Estados Unidos, levando-se em conta o limite superior de produção ${ }^{184}$, as razões pela qual ocorrem os desvios em relação à capacidade e as diversas distribuições de probabilidade induzidas pelas variações do clima na produtividade ${ }^{185}$.

O autor considerou a capacidade de produtividade como uma função das variáveis técnico-econômicas, que determinam a tendência e um termo aleatório que mede a influência do meio ambiente na produtividade. O termo aleatório foi suposto seguir uma distribuição não Normal, especificamente, a distribuição Gama, pois diversos graus de variância e assimetria podem ser obtidos com um número relativamente pequeno de parâmetros.

Sendo assim, uma série de 34 observações de produtividade de soja, agregadas a nível nacional, foram utilizadas no estudo empírico. Correções quanto à variabilidade da série (heteroscedasticia), em razão das mudanças no nível de tecnologia foram realizadas. Os resultados mostraram uma assimetria negativa moderada e, que a variabilidade, de fato aumentou, sendo $20 \%$ maior na metade da década de 80 do que em 1972.

Na mesma linha de raciocínio, Moss \& Shonkwiler (1993) elaboraram um modelo que incorpora na análise o modo pela qual a produtividade do milho nacional, no

\footnotetext{
${ }^{184} \mathrm{O}$ autor define limite superior da produção como capacidade de produtividade, que é “....a produtividade que ocorreria com uso eficiente de dada tecnologia para insumos controláveis e clima ideal.”

185 Os parâmetros foram estimados supondo que os efeitos do meio ambiente sobre a produtividade fossem incluídos no termo aleatório no modelo estatístico.
} 
período de 1930 a 1990, varia com o tempo e mostram como esta variação afeta a estimação e os resultados. ${ }^{186}$

Sendo assim, propôs-se que a não estacionariedade dos dados e erros não normais pudessem ser inseridos no modelo. Para isso, optou-se por se construir um modelo de tendência estocástica, juntamente com a possibilidade de se transformar os dados para reduzir o efeito de outliers na série de dados e induzir normalidade.

Tal modelo foi construído inicialmente, a partir da suposição de que a produtividade evolui no tempo ao longo de uma média constante. Relaxando tal pressuposição, considerou-se que a produtividade média avançasse de acordo com uma componente de tendência determinística, em função de mudanças técnico-econômicas.

O modelo proposto pode ser considerado como uma generalização do modelo anterior, permitindo que a produtividade média crescesse, mas de modo aleatório.

Após a estimativa dos parâmetros procedeu-se na análise dos resíduos para testar a normalidade. Utilizando dois testes, um paramétrico (Bera-Jarque) e outro nãoparamétrico (Kolmogorov-Smirnov), concluiu-se, que os erros são não-normais.

Para estimar os parâmetros do modelo de tendência estocástica com resíduos não-normais, utilizou-se a transformação seno hiperbólica inversa para converter uma distribuição não-Normal em uma distribuição Normal padrão.

Após a estimativa dos parâmetros, procedeu-se na aplicação dos mesmos dois testes, paramétrico e não-paramétrico, para verificação da normalidade nos resíduos transformados. Observou-se que, não se rejeitou a hipótese de normalidade dos resíduos transformados em ambos os testes.

Os resultados do modelo de tendência estocástica, utilizando a transformação seno hiperbólica inversa, sugerem que a produtividade do milho não segue uma distribuição Normal apresentando, particularmente, assimetria negativa.

Outra abordagem de determinação empírica da função de densidade da probabilidade multivariada não Normal foi proposta por Taylor (1990), a partir de dados de pequenas amostras.

\footnotetext{
${ }^{186}$ Segundo os autores, a presença de outliers podem exercer forte influência na estimação dos parâmetros. Além disso, resíduos que apresentam distribuição não normal podem distorcer os procedimentos usuais de inferência.
} 
O autor propõe dois métodos de ajuste empírico. O primeiro deles, denominado método da transformação Normal, ajusta empiricamente distribuições marginais, que são transformadas, posteriormente, em observações normais univariadas. $\mathrm{O}$ conjunto das variáveis transformadas é suposto ter uma distribuição Normal multivariada.

O segundo método, chamado de método da distribuição condicional, se baseia no fato da distribuição conjunta ser igual a distribuição condicional multiplicada pela distribuição marginal. Ambas as distribuições, condicional e marginal, são individualmente ajustadas neste método ${ }^{187}$.

Utilizando os dados produtividade de milho, soja e trigo, corrigidos em relação à componente de tendência, para os anos de 1945 a 1987, o autor verificou ${ }^{188}$ que ocorreu assimetria e curtose para todas as culturas, tanto para os testes univariados, quanto para o teste multivariado. Para o primeiro caso, particularmente, observou-se assimetria negativa para milho e soja e assimetria positiva no caso do trigo.

Uma análise alternativa é mostrada em Nelson \& Preckel (1989). No modelo os autores assumem que a distribuição de probabilidade do produto é conhecida a priori ${ }^{189}$. Desta forma, modelam à produtividade agrícola de acordo com a distribuição Beta, permitindo que os parâmetros de tal distribuição $\left(b_{1}, b_{2}\right)$ pudessem ser condicionadas a um vetor de insumos $x$.

A escolha da distribuição Beta foi justificada tendo em vista dois argumentos. O primeiro deles é em relação ao intervalo de variação da produtividade agrícola, que varia do zero a um limite superior máximo, $\mathrm{y}^{\mathrm{u}}$. Assim, tal variável aleatória é definida no intervalo $\left(0, \mathrm{y}^{\mathrm{u}}\right)$. O outro argumento está relacionado à flexibilidade da distribuição, ou seja, a possibilidade da distribuição da produtividade ser tanto assimétrica à direita, quanto à esquerda.

\footnotetext{
${ }^{187}$ Nota-se que, antes de ajustar os dados de acordo com os métodos descritos acima, testou-se os dados para verificar se os mesmos poderiam ter sido gerados por uma distribuição teórica comum.

${ }^{188}$ Através dos testes de assimetria e curtose de Pearson, teste de curtose de Geary e Shapiro-Wilks aplicados sobre os resíduos dos dados.

${ }^{189}$ Os autores apontam como principais vantagens deste modelo a possibilidade de se obter uma quantidade maior de informação, à respeito da distribuição do produto do que a abordagem não-paramétrica. Além disso, esta abordagem resultará em estimativas dos parâmetros mais eficientes, se a distribuição estiver corretamente especificada.
} 
Em um primeiro momento, os parâmetros do modelo, $b_{1}, b_{2}$ e $y^{u}$, foram estimados através do método da máxima verossimilhança ${ }^{190}$. Posteriormente, os parâmetros $b_{1}$ e $b_{2}$ foram expressos como uma função de $x^{191}$, considerando $\mathrm{y}^{\mathrm{u}}$ como fixo e igual a estimativa da distribuição não-condicionada.

Diversos resultados ${ }^{192}$, relacionados ao primeiro e segundo momentos foram discutidos pelos autores, mas será focalizado apenas à discussão em torno da assimetria da distribuição. Desta forma, as estimativas mostraram que em todos os municípios a distribuição apresentou assimetria negativa.

Além disso, estimou-se a elasticidade da assimetria da produtividade, ou seja, a influência dos insumos na assimetria. Observou-se que, o uso de nitrogênio e o potássio reduzem a assimetria em dois e três dos cinco municípios, respectivamente, e o fósforo aumenta a assimetria em todos os municípios.

De acordo com a exposição acima, percebe-se que diferentes métodos podem ser empregados para determinar a distribuição de probabilidade da produtividade. Embora os resultados mostrem que a distribuição pode apresentar tanto assimetria negativa quanto positiva, as evidências não comprovam que, de fato, a produtividade não segue uma distribuição não Normal.

Argumentando a favor da normalidade, Just \& Weninger (1999) identificaram três problemas metodológicos nos trabalhos vistos anteriormente, que podem de alguma forma, introduzir a não normalidade na série ou fazer com que os resultados estatísticos sejam mal interpretados. São eles:

1. Dados agregados

\footnotetext{
${ }^{190}$ Neste método de estimação, as estimativas são eficientes, consistentes e assintoticamente normais, se $b_{2}>$ 2. Além disso, para a distribuição ser unimodal é necessário que $b_{1}$ e $b_{2}$ sejam maiores do que um. (pg. 371)

191 Através da forma funcional log-linear e estimados pelo mesmo método.

${ }^{192}$ A análise empírica foi realizada através de dados de produtividade de milho, a nível de propriedade, para cinco municípios, no período de 1961 a 1970, coletados pela Iowa Agricultural Experiment Station. Além da produtividade, os autores coletaram dados de outras variáveis, tais como, quantidade de nitrogênio, fósforo e potássio aplicados, inclinação e percentual de argila no solo.
} 
A utilização de dados agregados ${ }^{193}$ pode não refletir de maneira verdadeira a aleatoriedade da produtividade a nível individual. Os autores observaram que a série de produtividade agregada apresenta uma variabilidade menor que a série de produtividade individual $^{194}$, tendo implicações na estimação das taxas de prêmio do seguro.

2. Especificação incorreta da componente determinística da produtividade

A maioria dos trabalhos assume que a componente determinística pode ser aproximada por uma função de tendência polinomial. Os autores mostram que os métodos usuais de remoção da tendência podem ter introduzido de maneira inapropriada a assimetria e curtose não normais.

Supondo que, inicialmente, as variações tecnológicas sejam ignoradas, de modo que a produtividade varie no tempo de modo constante. Assim, se for ajustado uma reta aos dados, a distribuição dos desvios em relação ao ajuste pode apresentar uma calda relativamente mais alongada para esquerda ou para a direita, implicando em assimetria negativa ou positiva, respectivamente.

Em vista disso foi mostrado que pode se obter assimetria e curtose não normais, como conseqüência da especificação incorreta do grau do polinômio ${ }^{195}$. Além disso, a utilização de dados agregados pode elevar sobremaneira o viés de não normalidade.

\footnotetext{
${ }^{193}$ Como por exemplo, a média municipal ou estadual da produtividade.

194 A variabilidade da produtividade individual de milho encontrada por Nelson e Preckel (1989) foi no mínimo de 177 e no máximo de 770. Utilizando dados agregados de produtividade do milho, Moss e Shonkwiler (1993) obtiveram variâncias igual a 70 e 85, como valores mínimo e máximo, respectivamente.

${ }^{195}$ A direção e a magnitude do erro dependem da curvatura da verdadeira tendência em relação à tendência aproximada. Além disso, mostrou-se que ignorando a heteroscedasticia presente nos dados, o resultado é um excesso de curtose, indicando de maneira incorreta a não normalidade, como ocorre em Gallagher (1987), Moss e Shonkwiler(1993) e Nelson e Preckel (1989).
} 
3. Especificação incorreta do nível de significância estatística.

Segundo Just \& Weninger, o fato de publicações anteriores ${ }^{196}$ testarem múltiplas séries temporais e utilizarem múltiplos testes estatísticos, ${ }^{197}$ separadamente, pode resultar em uma interpretação incorreta do nível de significância.

Os testes de múltiplas séries de produtividade, como por exemplo, múltiplas culturas ou diversos tratamentos da mesma cultura, devem levar em conta a correlação existente entre as séries no momento de se verificar a significância estatística. É muito comum que diversas culturas sejam afetadas simultaneamente por variáveis regionais, como o clima e o solo, por exemplo.

O problema surge quando os testes são realizados para cada série separadamente e as inferências são extrapoladas para toda a amostra.

No trabalho, os autores ressaltaram também o fato de se utilizar múltiplos testes na mesma série temporal. Isto pode gerar uma interpretação incorreta do nível de significância quando todas as estatísticas não são explicitamente combinadas em um teste de normalidade geral ${ }^{198}$.

Tendo isto em vista, os autores sugerem testes que combinassem o terceiro e quarto momentos. Desta forma, procedeu-se às estimações empíricas utilizando dados agregados e dados específicos, a nível de propriedade rural.

No primeiro caso, para verificar a hipótese de normalidade, foram utilizados dados de produtividade de alfafa (período de 1960-1993), milho (1941-1994), sorgo (19801994), soja (1969-1994 para Ford e Hodgeman e 1965-1994 para Finney e Gray) e trigo (1926-1994), para os municípios de Ford, Hodgeman, Finney e Gray pertencentes ao estado de Kansas.

\footnotetext{
${ }^{196}$ Day (1965) e Taylor(1990).

${ }^{197}$ Diversos testes estatísticos são empregados na literatura para verificar normalidade dos dados como, por exemplo, teste de qui-quadrado, teste do terceiro e quarto momentos e combinações destes, teste da função de distribuição empírica e teste de regressão.

198 Por exemplo, quando a significância da assimetria, curtose ou outros momentos for analisada separadamente, pode-se optar pela não normalidade, caso um dos testes rejeite a normalidade. Mas esta decisão se torna um tanto quanto confusa quando um dos testes, por exemplo, assimetria, rejeita a normalidade, enquanto outro teste, curtose, não rejeita a normalidade.
} 
Os resultados encontrados pelos autores mostraram que os dados ajustados para a tendência não apresentaram evidência de assimetria ou curtose não Normal, ao nível de significância de 5\%. Desta forma, percebe-se que a normalidade não é rejeitada para nenhuma das 20 amostras ao nível de 5\%, quando a análise estatística é realizada com os dados agregados, a nível municipal.

No segundo caso, quando a análise é feita com dados de produtividade individuais de 106 produtores no estado de Kansas, para a cultura da trigo irrigado e sequeiro, milho irrigado, sorgo irrigado e sequeiro, soja irrigada e alfafa irrigada, no período de 1973 a 1987, comprovou-se, como já tinha sido observado, que a variância da produtividade individual é bem superior à variância da produtividade agregada ${ }^{199}$.

A assimetria Normal não é rejeitada para nenhuma das sete amostras. A curtose Normal, ao nível de 5\%, é rejeitada somente para trigo irrigado. No teste conjunto, ao nível de 5\%, nenhuma série é rejeitada. Ao nível de 10\%, rejeita-se apenas o trigo irrigado.

\footnotetext{
199 Por exemplo, a variância para o milho, no segundo caso foi de, aproximadamente, 431 enquanto que, no primeiro caso a variância máxima, no município de Hodgeman atingiu pouco mais de 202, ou seja, subestimou-se a variabilidade individual em $55 \%$, neste caso.
} 


\section{METODOLOGIA}

Neste capítulo serão apresentado as metodologias utilizadas para a determinação das taxas de prêmio atuarialmente justas. $\mathrm{Na}$ subseção 4.1, serão mostrados os métodos paramétrico e não-paramétrico.

Posteriormente, na subseção 4.2 será detalhada a metodologia de modelos hirerárquicos Bayesianos, levando-se em conta os aspectos temporais, espaciais e a interação destes dois componentes resultando em modelos espaço-temporais.

Além disso, na subseção 4.3 serão descritos os métodos de quantificação: da redução do risco sistêmico proveniente da aquisição de um contrato de seguro agrícola; do impacto da escolha do nível de agregação da produtividade na redução do risco; da correlação entre a produtividade regional e a individual e da correlação espacial.

\subsection{Análise paramétrica e não-paramétrica na determinação das taxas de prêmio de um contrato de seguro agrícola}

Esta subseção apresenta a metodologia empregada para a estimação da densidade da produtividade condicional, necessária para determinar a probabilidade de perda e para o cálculo da taxa atuarial justa. Os respectivos resultados serão apresentados e discutidos na subseção 5.1. 


\subsubsection{Peculiaridades na modelagem de dados de produtividade agrícola}

A determinação da taxa atuarial "justa" ou "pura" do prêmio, ou em outras palavras, a indenização esperada, é um fator importante que deve ser levado em conta para que um contrato de seguro agrícola seja viável economicamente.

Outro aspecto importante se refere ao fato dos métodos comumente empregados não levarem em conta a incerteza relacionada ao cálculo da taxa, ou seja, a forma da distribuição de probabilidade que deve ser ajustada a variável aleatória em questão representada pela produtividade agrícola.

Durante vários anos, este tem sido um ponto bastante controverso na problemática da precificação do contrato de seguro agrícola. Diversas abordagens foram utilizadas por diversos autores na busca de distribuição de probabilidade que melhor se ajustasse à produtividade agrícola, como por exemplo, a abordagem paramétrica, semiparamétrica (Ker e Coble, 2003), não-paramétrica (Goodwin e Ker, 1998; Turvey e Zhao, 1999) e a abordagem Bayes empírico não-paramétrico (Ker e Goodwin, 2000).

Dentro da abordagem paramétrica, diversos autores concluem que a produtividade agrícola segue uma distribuição normal (Just e Weninger, 1999). Entretanto, outros pesquisadores como Day (1965), Taylor (1990), Ramirez (1997), Ramirez et al. (2003), encontraram evidências contra a normalidade.

Outras sugestões incluem o uso da distribuição Beta (Nelson e Preckel, 1989), transformações seno hiperbólico inversa (Moss e Shonkwiler, 1993), Gama (Gallagher, 1987). Sherrick et al. (2004) ajustaram a dados de produtividade individuais diversas distribuições paramétricas, como por exemplo, a Normal, Lognormal, Beta, Weibull e Logística.

Goodwin e Mahul (2004), apontaram que a distribuição Lognormal impõe assimetria positiva à distribuição, característica que pode ou não estar presentes nos dados.

Neste ponto, ressalta-se que o pequeno número de observações de produtividade, em nível agregado e menor ainda a nível individual, existentes em todos 
os países dificulta sobremaneira qualquer tipo de análise estatística deste conjunto de dados.

Este fato pode ser considerado como um dos maiores entraves na modelagem empírica da densidade da produtividade condicional. A escassez de uma série temporal relativamente longa impossibilita ao analista detectar variações estruturais na produtividade e, consequentemente, verificar a ocorrência de eventos catastróficos no decorrer da série.

Em alguns países, como por exemplo, os EUA, a série de produtividade agrícola regional gerada pelo órgão responsável (National Agricultural Statistics Service -NASS) abrange o périodo de 1962 - 2002, para a maioria das culturas. Ao nível de fazenda, a série de dados pode ser bem menor, podendo ir de 10 a 15 observações, dependendo do tipo de cultura e região.

Apesar de alguns métodos terem sido sugeridos para tentar superar tal problema, tais como, combinar dados de produtividade individuais e regionais ou utilizar dados agregados como proxies para os dados a nível de fazenda, ainda assim, isto dificulta sobremaneira o trabalho de modelar a estrutura de risco do produtor de maneira acurada.

No Brasil, a série de dados agregados existente é ainda menor que a utilizada para o cálculo atuarial nos EUA. Os dados de produtividade, em kilogramas por hectare, são liberados pelo Instituto Brasileiro de Geografia e Estatística (IBGE) e correspondem ao período de 1990 a 2002.

Para exemplificar os métodos discutidos nesta subseção, utilizou-se dados de produtividade municipal para as culturas da soja, milho e trigo, com no mínimo 10 anos de observações, resultando em 267, 366 e 266 municípios do estado do Paraná, respectivamente.

A seguir, na figura 64, abaixo, serão mostradas as produtividades agrícolas para todos os municípios no Estado do Paraná, para a soja, milho e trigo, nos anos de 1990, 1996 e 2002. 
MILHO

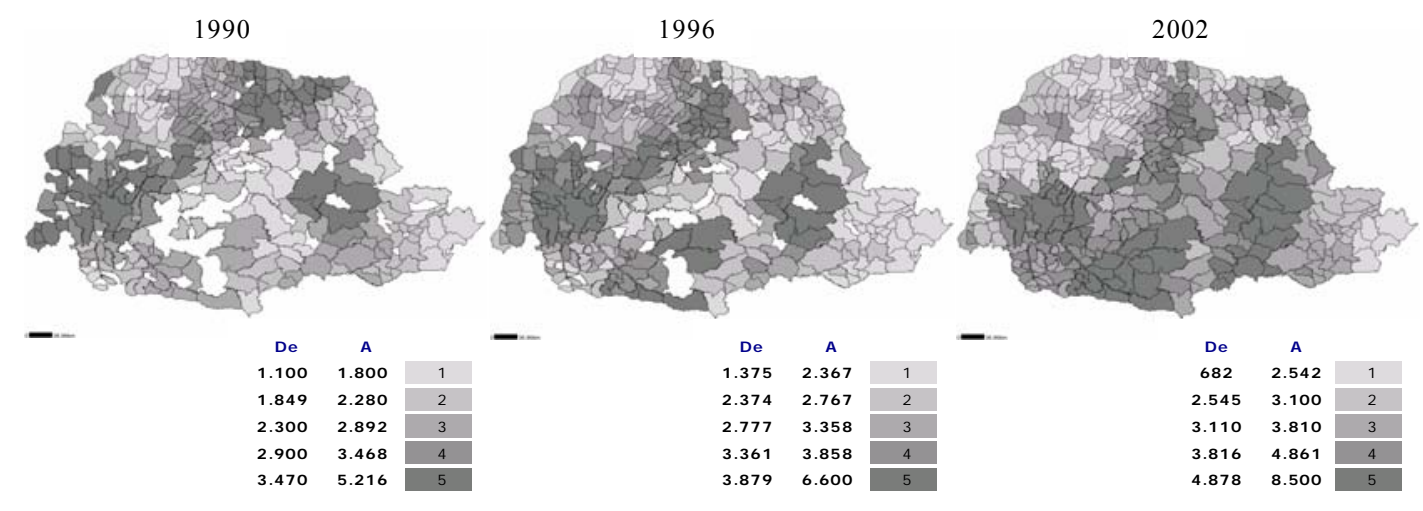

SOJA
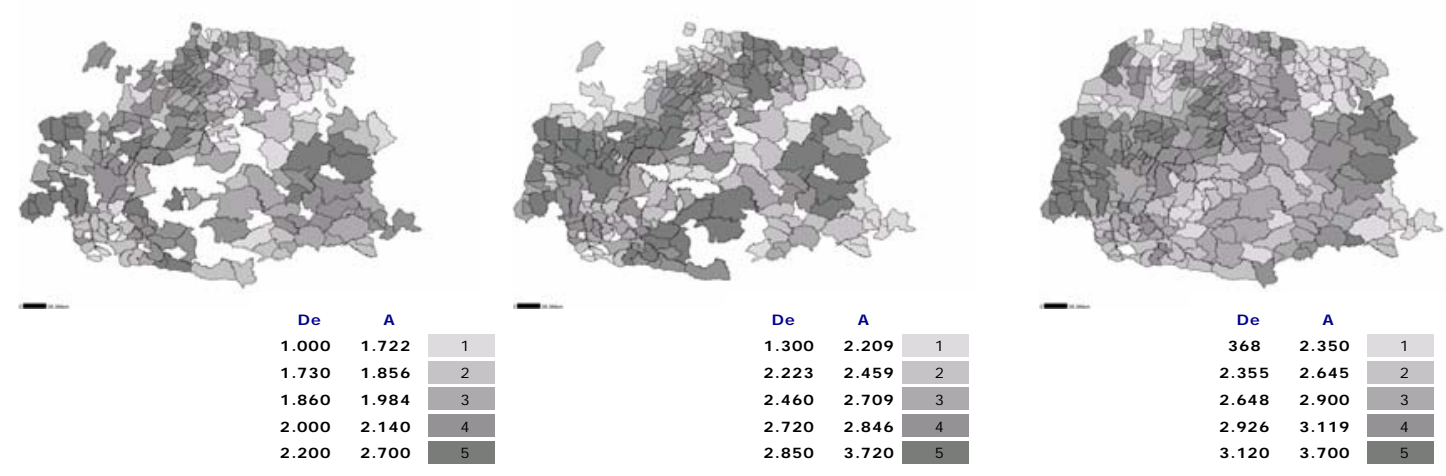

TRIGO
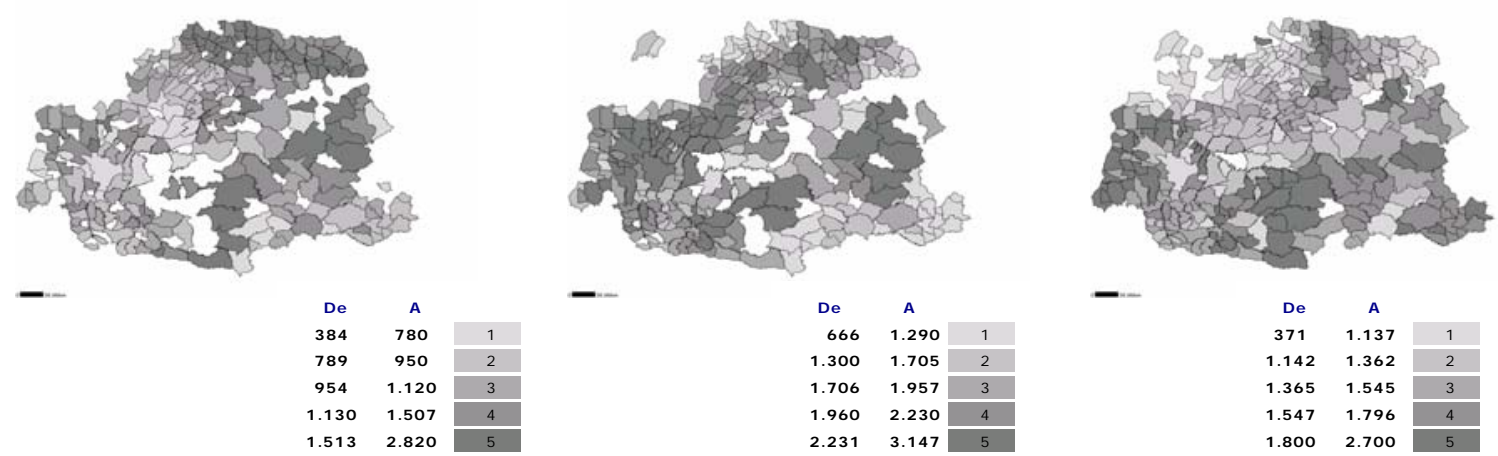

Figura 64 - Evolução da produtividade do milho, soja e trigo, nos municípios do Estado do Paraná, em 1990, 1996 e 2002, em kg/ha

Fonte: IBGE (2004) 


\subsubsection{Análise paramétrica}

Em virtude dos dados corresponderem a um período de apenas 13 anos, método da taxa empírica, ou seja, a taxa é calculada baseada na relação da perda média sobre a responsabilidade, apresenta desvantagens em relação aos métodos paramétricos, pois não há nenhum "alisamento" (smoothing) realizado na série. Sendo assim, há necessidade de um grande número de observações para refletir de maneira precisa a distrbuição de probabilidade.

Dentro da abordagem paramétrica, diversos autores concluem que a produtividade agrícola segue uma distribuição normal. Outros sugerem que a produtividade segue uma distribuição Beta, Gama ou Lognormal, por exemplo.

Sendo assim, tendo como base a literatura já discutida, inicialmente, modelou-se a densidade da produtividade condicional parametricamente, ou seja, ajustando-se uma determinada distribuição de probabilidade aos dados, como por exemplo, a distribuição Normal, com os parâmetros estimados pelo método da máxima verossimilhança.

Apesar das estimativas da média de uma série de observações independentes e identicamente distribuídas seguirem a distribuição Normal, de acordo com o Teorema do Limite Central, no caso das observações médias de produtividade municipais, este comportamento pode ser questionado, pois as observações são correlacionadas espacialmente.

Embora existam versões alternativas do TLC, para processos espaciais ${ }^{200}$ que suportam a normalidade, a correlação em determinada região pode não diminuir a uma taxa relativamente acelerada para assegurar que a produtividade média segue uma distribuição Normal, conforme apontam Goodwin e Ker (2002).

Analisando a correlação espacial da produtividade do milho nos três maiores estados produtores nos EUA, Goodwin (2001) argumenta que, em uma primeira situação, na qual são analisados anos de produtividade regular, a medida de correlação

\footnotetext{
${ }^{200}$ Para os processos espaciais dependentes, o TLC garante a suposição de normalidade, caso a dependência diminua a uma taxa acelerada com o aumento da distância, sob certas condições de regularidade (Guyon, 1995).
} 
se reduz mais rapidamente com o aumento da distância, estabilizando-se no valor de 0,10 quando a distância entre as áreas consideradas é de aproximadamente 200 milhas.

Em outra situação, considerando anos em que secas ocorreram, a medida de correlação decresceu mais vagarosamente, atingindo o mesmo nível de 0,10 a uma distância de 400 milhas. Percebe-se, deste modo que, em anos de ocorrência de eventos generalizados o problema do risco sistêmico é mais acentuado do que em anos normais.

Argumentando de maneira contrária, Wang e Zhang (2003), utilizando correlogramas para a determinação da estrutura de dependência espacial para milho, soja e trigo no período de 26 anos para, respectivamente, 2591, 2000 e 2641 municípios nos EUA, concluem que a correlação diminui mais rapidamente com o aumento da distância. A distância máxima estimada para a correlação positiva foi de 570 milhas.

Uma distribuição alternativa frequentemente ajustada na literatura é a distribuição Beta. Uma vantagem associada a esta família de distribuição está no fato de ser flexível, ou seja, assumir diversas formas em função dos valores dos parâmetros ( $b_{1}$, $\left.b_{2}\right)$, como por exemplo, ser estritamente crescente $\left(b_{1}>1, b_{2}=1\right)$, estritamente decrescente $\left(b_{1}=1, b_{2}>1\right)$, forma de $U\left(b_{1}<1, b_{2}<1\right)$ ou unimodal $\left(b_{1}>1, b_{2}>1\right)$ (Casella e Berger, 1990). Desta forma, pode-se acomodar tanto assimetrias negativas quanto positivas. Desvantagens associadas a esta distribuição residem no fato de que não é possível captar a bimodalidade ou a multimodalidade.

\subsubsection{Análise não-paramétrica}

Outra abordagem explorada na literatura é a análise não-paramétrica dos dados de produtividade. Neste caso, nenhuma especificação à priori é definida para a distribuição, ou seja, deixa-se que os dados revelem a forma da densidade.

Por razões atuariais, as informações necessárias para se precificar um contrato de seguro agrícola são a perda esperada e a probabilidade da perda, ou seja, a probabilidade da produtividade ser menor do que determinado valor igual a produtividade garantida. 
$\mathrm{Na}$ análise não-paramétrica, certas características da distribuição podem ser captadas, tais como, assimetrias positivas e negativas e a bimodalidade. Além disso, este método não atribui a priori uma determinada distribuição de probabilidade aos dados observados. Ao contrário, deixa que as observações revelem a forma da densidade.

Dentre os diversos tipos de estimadores da densidade, o histograma é sem dúvida o mais conhecido e utilizado. Dois aspectos merecem destaque na estimação dos histogramas: a origem e a largura das classes $h$ ou "janelas".

Em função da escolha da origem, diferentes histogramas podem ser construídos e, consequentemente, diferentes interpretações podem surgir. O outro aspecto, a largura das classes determinam o quão alisada (smooth) será a série.

Apesar de sua simplicidade, este estimador apresenta desvantagens em relação a outros estimadores, como por exemplo, o estimador Kernel. O histograma é útil para realizar uma primeira análise exploratória dos dados.

Analisando apenas em uma dimensão, o histograma não apresenta dificuldades de ser estimado, apesar do escolha da origem e do fator de alisamento, mas em um espaço $m$-dimensional a estimação pode se tornar um trabalho árduo e bastante complicado.

No contexto de precificação de contratos de seguro agrícola, Goodwin e Ker (1998) $)^{201}$ e Turvey e Zhao (1999) utilizaram o estimador Kernel para determinar a forma da densidade da produtividade condicional.

Conforme apontam Goodwin e Ker (2002), o estimador kernel da densidade $f(y)$ pode ser representada como uma convolução da distribuição amostral, utilizando-se uma função kernel $K$, representada pela equação 44 , tal que:

$$
\hat{f}(y)=\int K_{h}(y-v) d F_{n}(v)
$$

\footnotetext{
${ }^{201}$ De acordo com os autores, o fato dos dados de produtividade agrícola apresentarem certo grau de correlação espacial entre municípios vizinhos, implica em estimativas das densidades não-paramétricas que podem ser viesadas (embora consistente), em amostras finitas. O esquema de pesos adotado nesta pesquisa (detalhes na subseção 5.1.1) para compor a série de dados tende a reduzir a dependência espacial entre estes municípios.
} 
onde $\mathrm{K}_{h}(v)=1 / h K(v / h)$ e $F_{n}(v)$ é a função de distribuição amostral.

O estimador kernel é a soma de "saltos" (bumps) localizados em cada observação, de modo que a função kernel determina a forma destes saltos e a janela sua largura.

Quanto maior o valor da janela, a série terá um alisamento maior e os detalhes tendem a desaparecer. Caso contrário, quanto mais próxima de zero, os saltos terão uma forma de pico, tornando mais pronunciado os detalhes na densidade.

Algumas suposições devem ser feitas à respeito de $K$. A função kernel será não negativa, simétrica e constituirá uma função de densidade, tal que $\int K(v) d v=1$. Além disso:

$$
\int v K(v) d v=0 \text { e } \int v^{2} K(v) d v=\theta_{2} \neq 0
$$

Caso a função kernel seja representada pela densidade Normal, então $\theta_{2}$ será a variância da distribuição.

Como uma medida de discrepância do estimador da densidade $\hat{f}$ em relação a verdadeira densidade $f$, Silverman (1986) adota o erro quadrático integrado médio (MISE) dado por:

$$
\int E[\hat{f}(y)-f(y)]^{2} d y
$$

que pode ser decomposta em dois componentes, o viés quadrático integrado e a variância integrada. Sob certas pressuposições, o viés pode ser aproximado por:

$$
\frac{1}{4} h^{4} \theta_{2} \int f^{\prime \prime}(y)^{2} d y \mathrm{e},
$$


a variância por $(n h)^{-1} \int k(v)^{2} d v$.

Conforme aponta o autor, se para minimizar o MISE escolhe-se um alto valor para o parâmetro de alisamento, reduz-se a variação aleatória (variância) levando ao aumento do erro sistemático (viés). Caso contrário, um baixo valor do parâmetro resulta em aumento da variância integrada e diminuição do viés quadrático integrado.

Na busca pelo parâmetro de alisamento ótimo e o kernel que minimize o MISE, o autor mostra que, se o $h$ for ótimo:

$$
h_{o p t}=\theta_{2}^{-2 / 5}\left(\int K(v)^{2} d v\right)^{1 / 5}\left(\int f^{\prime \prime}(y)^{2} d y\right)^{-1 / 5} n^{-1 / 5},
$$

então o valor aproximado para o erro quadrático integrado médio será dado por:

$$
\frac{5}{4} W(K)\left(\int f^{\prime \prime}(y)^{2} d y\right)^{1 / 5} n^{-4 / 5}, \text { onde } W(K)=\theta_{2}^{2 / 5}\left(\int K(v)^{2} d v\right)^{4 / 5}
$$

O problema de minimizar o MISE torna-se um problema de escolher o mínimo $W(K)$, dado o parâmetro de alisamento. Seguindo certas restrições, se a função kernel escolhida for o kernel de Epanechnikov $W\left(K_{e}\right)$, então o MISE será minimizado.

Para comparar outros kernel simétricos, procedeu-se na elaboração de um índice de eficiência igual a $\left[W\left(K_{e}\right) / W(K)\right]^{5 / 4}$. Utilizando as densidades Biweight, Triangular, Gaussiana e Retangular, observou-se que todos os kernel apresentaram eficiência próximas de um. Desta forma, a escolha do kernel resulta em pouca influência no resultado final sob o critério escolhido.

A escolha do parâmetro de alisamento ótimo, no caso da distribuição Gaussiana, será igual a $1.06 \sigma n^{-1 / 5}$, onde $\sigma$ é o desvio padrão da produtividade. Silverman, sugere que para levar em conta desvios da normalidade, a seguinte estimativa deve ser utilizada $\sigma=\min ($ desvio padrão, amplitude interquartílica/1.34). Além disso, se for reduzido o fator 1.06 para 0.9 , resulta em melhores resultados empíricos. Desta 
forma, esta estimativa foi adotada, nesta subseção, para determinação do parâmetro de alisamento ótimo.

\subsubsection{Heteroscedasticia e tendência}

A tendência e a heteroscedasticidade são dois aspectos que devem ser levados em conta no momento de analisar dados de produtividade agrícola. O processo gerador dos dados de produtividade não é constante, mas varia de acordo com o tempo.

A incorporação de novas tecnologias e métodos mais adequados de manejo permitiram ao produtor elevar sua produtividade com o passar do tempo. Assim, a produtividade observada em meados de 1980 não pode ser comparada com a produtividade em 2004, por exemplo. Para que tais produtividades sejam comparáveis é preciso que a componente de tendência e sazonalidade sejam retiradas da série e assim trabalhar com a série sem tendência e desazonalizada.

Diversos métodos tem sido utilizados na literatura para remover a tendência, podendo ser caracterizados como lineares ou não-lineares. Exemplos: modelos autoregressivos-média móvel, alisamento não-paramétrica local e splines.

Mas devido a série utilizada neste artigo ser realtivamente curta, preocupar-se-á apenas com a componente de tendência, pois não é possível captar de maneira precisa, com apenas 13 observações, a componente sazonal. Desta forma, para retirar a tendência da série optou-se por um modelo de tendência determinística de primeira ordem em $t$, de acordo com a equação:

$$
y_{t}=\Lambda_{0}+\Lambda_{1} t+u_{t}, u_{t} \sim \mathrm{N}\left(0, \sigma^{2}\right)
$$

Apenas aquelas séries em que o coeficiente de inclinação foi significativo ao nível de 5\%, procedeu-se na retirada do componente de tendência, de modo que a produtividade sem tendência será igual a $u_{t}$. 
O outro aspecto citado, a heteroscedasticia, ou seja, situação em que a variabilidade da produtividade aumenta com o tempo, deve ser corretamente diagnosticada e corrigida. Goodwin e Ker (1998), utilizaram testes paramétricos (Goldfeld-Quandt) e não-paramétricos para o diagnóstico da heteroscedasticia.

Segundo os autores, caso a heteroscedasticia seja percebida como sendo desvios da tendência em relação ao nível da produtividade, e assim a hipótese de que o coeficiente de variação constante possa ser suportada, então resíduos proporcionais calculados dividindo-se o erro $u_{t}$ pelo respectivo valor predito serão homocesdásticos.

Para normalizar tal resíduo, multiplica-se $(1+$ erros proporcionais $)$ pela produtividade em 2004 de modo que produtividade seja expressa em termos da tecnologia em 2004 (Goodwin e Mahul, 2004).

De outro modo, se o valor dos erros não forem proporcionais ao nível da produtividade, então os resíduos normalizados serão calculados adicionando-se ao erro a produtividade observada em 2004.

Calcular-se-á a produtividade normalizada pelos dois métodos descritos anteriormente, ou seja, de forma aditiva e multiplicativa, de modo que se verificará, posteriormente, se grandes diferenças podem ser observadas na taxa de prêmio. Além disso, como a última observação corresponde ao ano de 2002, então todos os resíduos normalizados foram calculados para o ano de 2002.

\subsection{Modelagem espaço-temporal de dados de produtividade agrícola aplicados à precificação de contratos de seguro agrícola}

Esta subseção se concentra na análise espaço-temporal, baseados em modelos hierárquicos Bayesianos. Na recuperação do processo gerador destes dados, considerou-se os efeitos temporal, espacial e a interação destes dois efeitos tendo em vista a predição e a precificação de contratos de seguro baseados em um índice de produtividade regional. No item 5.2, serão apresentados e discutidos os resultados. 


\subsubsection{Modelagem estatística}

A escolha de um modelo estatístico que melhor reflita a densidade da produtividade condicional é um fator importante no cálculo atuarial da taxa de prêmio. Para isso, deve-se destacar o processo gerador dos dados no momento de se modelar a produtividade agrícola.

Em diversos trabalhos empíricos, a única informação conhecida no momento $t$ é o próprio tempo. Desta forma, nestas análises, a densidade condicional é baseada apenas no processo temporal gerador dos dados.

Nesta subseção incorporou-se o aspecto temporal do processo gerador dos dados e também o aspecto espacial na análise, levando-se em conta os municípios vizinhos. Além disso, os dois aspectos espacial e temporal são combinados de modo a construir um modelo espaço-temporal.

Devido ao fato da série temporal estudada neste trabalho não ser relativamente longa criou dificuldades adicionais no tocante à predição ou previsão ${ }^{202} \mathrm{da}$ produtividade agrícola nos anos subsequentes.

De acordo com a seção 4.1.1, a última observação liberada pelo IBGE foi relativo ao ano 2002. Desta forma, tentou-se ajustar um modelo que pudesse refletir de maneira mais acurada a predição dos próximos dois anos, baseado no critério da soma dos erros preditos.

Para atingir tal objetivo, optou-se por modelar a estrutura de média e deixar que a precisão permanecesse constante, ao longo da análise. Gelfand et al. (1998), apontam que modelar o componente de média para problemas de previsão resulta em maior efetividade.

Deste modo, considerando a média $\mu_{i t}$ como sendo idêntica a $\mathrm{E}\left(Y_{i t}\right)$, onde $i$ representa o indexador da variável espacial e $t$ a variável temporal, tal que $i=1,2, \ldots$ $, S, t=1,2, \ldots, T$ e $Y_{i t}$ representa a produtividade no município $i$ no tempo $t$. O objetivo

\footnotetext{
${ }^{202}$ Neste trabalho, utilizou-se os termos predição e previsão e densidade e distribuição de maneira permutável.
} 
desta subseção será modelar a média, de tal forma que $\mu_{i t}$ reflita, de forma geral, as covariáveis, o efeito temporal, a variação espacial da produtividade agrícola além do efeito espaço-temporal.

Os modelos estatísticos podem envolver um grande número de parâmetros. Quando isso ocorre, a maneira mais natural de se modelar tais parâmetros é através de modelos hierárquicos.

Nestes modelos, a estrutura de dependência entre os parâmetros pode ser captada através da distribuição de probabilidade conjunta. Consequentemente, pode-se definir uma distribuição à priori para estes parâmetros assumindo que podem ser considerados como uma amostra provenientes de uma distribuição populacional comum.

Na notação usual, os modelos hierárquicos são determinados por estágios. Deste modo, se o modelo tiver $k$ estágios, a distribuição conjunta da variável observada $y$ e parâmetros $\theta^{\prime} s$, pode ser expressa de forma multiplicativa como :

$$
f\left(y \mid \theta_{1}\right) f\left(\theta_{1} \mid \theta_{2}\right) f\left(\theta_{2} \mid \theta_{3}\right) \ldots f\left(\theta_{\mathrm{k}-1} \mid \theta_{\mathrm{k}}\right) f\left(\theta_{\mathrm{k}}\right)
$$

Se $y_{i t}$ for considerado como condicionalmente independente em relação a $\mu_{i t}$, então os parâmetros adicionados a $\mu_{i t}$ serão aletórios. Sendo assim, se um efeito aleatório indexado por $t$ for adicionado a $\mu_{i t}$, então, marginalmente, $y_{i t}$ refletirá a dependência temporal no decorrer de certo ano.

O mesmo ocorre com um efeito indexado por $i$, ou seja, marginalmente, $y_{i t}$ refletirá a dependência espacial dentro de certa localidade, ou em outras palavras, quando um efeito espacial é inserido, induz-se a dependência espacial entre as variáveis observadas $y_{i t}$. 
A possibilidade de se modelar a estrutura de dependência através de modelos hierárquicos é bastante intuitiva e facilita a visualização de cada componente na análise ao invés de modelar tal estrutura diretamente através de $y_{i t}{ }^{203}$.

Em muitas aplicações, a variável observada é modelada condicional a certos parâmetros, que recebem uma distribuição de probabilidade, que por sua vez são atribuídos outros parâmetros, denominados hiper-parâmetros, que são atreladas distribuições, chamadas hiper-prioris. Se, pouco se sabe à respeito dos hiper-parâmetros, pode-se atribuir distribuições a priori difusas para tais parâmetros.

Um fato, porém, deve ser levado em conta. Quando se atribui distribuições a priori impróprias, a distribuição à posteriori resultante pode não ser própria.

Neste contexto, Hobert e Casella (1996), estimando os parâmetros de um modelo linear hierárquico misto (hierarchical linear mixed model) usando o amostrador de Gibbs, advertem quanto ao uso de distribuições a priori não informativas, que podem resultar em distribuições a posteriores impróprias.

Considere, por exemplo, a seguinte distribuição a priori para o parâmetro $\theta \sim \mathrm{N}\left(\mu, \sigma^{2}\right)$. Se for atribuído uma distribuição hiper-priori para $\sigma^{2}$, de modo que, $f(\sigma)=1 /\left(\sigma^{2}\right)^{a}$, onde $a=0,0,5,1$, pode ser o caso, da distribuição a posteriori conjunta ser imprópria, embora os resultados encontrados parecerem razoáveis e o problema não ser captado pelo analista, ou em outras palavras, realiza-se inferências à respeito de uma distribuição a posteriori inexistente.

Na prática, como mostrado em Gelfand e Smith (1990), este problema pode ser evitado considerando distribuições a priori próprias, que assegurem que o amostrador de Gibbs será bem comportado, na qual o estado de ignorância pode ser expresso como valores próximos a zero para o parâmetro de precisão. Entretanto, mesmo nestes casos Gelman (2004) aponta algumas questões numéricas.

\footnotetext{
${ }^{203}$ Para esta versão alternativa, Anselin(1988) descreve diversos modelos espaciais e espaço-temporais que modelam a estrutura de dependência através do termo de erro epsilon $[\mathrm{i}, \mathrm{t}]$, onde $\mathrm{y}[\mathrm{i}, \mathrm{t}]=\mathrm{x}[\mathrm{i}, \mathrm{t}]^{*} \beta[\mathrm{i}, \mathrm{t}]+$ $\varepsilon[i, t]$. Como por exemplo, nos modelos SUR (seemingly unrelated regression), onde o coeficiente beta pode variar em uma das duas dimensões e o termo de erro correlacionado na outra dimensão.
} 
Inicialmente, extendendo o trabalho de Ker e Goodwin (2000), modelouse $\mu_{i t}^{204}$ como proveniente de duas subpopulações ou grupos, um grupo catastrófico e outro não-catastrófico. Entende-se por catastrófico o evento climático que venha a ocorrer em determinado ano, tal como seca, excesso de chuva, granizo, etc.

Desta forma, caso venha a ocorrer um evento climático adverso, a produtividade agrícola será considerada proveniente do grupo catastrófico. Caso contrário, considera-se a produtividade como do grupo não-catastrófico. Assim, como destacam os autores, a produtidade pode ser pensada como uma mistura finita de duas distribuições.

Particularmente, nesta subseção, utilizou-se uma mistura de duas gaussianas, onde a densidade do primeiro grupo se aloja na calda inferior do segundo grupo, pois eventos catastróficos podem ser considerados muito menos frequentes e a produtividade observada, nestes anos ser muito inferior a de anos regulares.

Sendo assim, espera-se que o primeiro grupo tenha massa menor comparado ao segundo grupo e tal concentração se situe na calda inferior da primeira.

O modelo misto geral pode ser descrito como:

$$
f\left(x / \theta_{j}, \gamma_{j}\right)=\sum_{j} \gamma_{j} f\left(x / \theta_{j}\right)
$$

Onde $\theta_{j}$ é o vetor de parâmetros, $j$ é o número de componentes, tal que $j$ $=1,2, \ldots, J$ e e $\gamma_{j}$ o parâmetro representando a proporção da população atribuída ao componente $j$. Onde $\sum_{j} \gamma_{j}=1$ e $\gamma_{j} \geq 0$.

No caso em que $f\left(y \mid \theta_{j}, \gamma_{j}\right)$ representa uma distribuição gaussiana, temse que $\theta_{j}=\left(\mu_{j}, \sigma_{j}^{2}\right)$. Desta forma, a eq(1) pode ser escrita como:

\footnotetext{
${ }^{204}$ Neste caso, como os subgrupos não serão considerados na análise a análise será levada adiante sem subscrito $s$.
} 


$$
f\left(x / \mu_{j}, \sigma_{j}^{2}, \gamma_{j}\right)=\sum_{j} \gamma_{j} N\left(x / \mu_{j}, \sigma_{j}^{2}\right)
$$

O modelo anterior pode ser alternativamente especificado se for introduzido uma variável indicadora não observada que identifica a qual componente cada observação é designada.

Esta variável indicadora $I$ recebe valores iguais a $i$ quando $y$ é sorteada do j-ésimo componente. Deste modo, equivalentemente, o modelo misto em (66) pode ser representado como:

$$
\begin{aligned}
& y \mid I, \theta \sim \mathrm{f}\left(y \mid \theta_{I}\right) \\
& I \mid \underline{\gamma} \sim \operatorname{DCat}(\gamma),
\end{aligned}
$$

onde $\left(\theta_{I}\right)=(\underline{\theta}, \underline{\gamma}, \underline{I})$, DCat ( ) é a distribuição categórica e $\mathrm{P}[I=j]=\gamma_{j}, j=1, \ldots, J$.

Procedendo-se a análise, atribui-se a esta variável uma determinada distribuição, como por exemplo, uma distribuição categórica ou uma distribuição multinomial. Assume-se que não se sabe, inicialmente, a que componente é atribuída cada observação.

Neste caso, se for considerado que os parâmetros $\theta$ e $\gamma$ são independentes, então a distribuição a priori pode ser considerada como o produto das duas distribuições.

Desta forma, se for atribuído uma distribuição à priori Categórica para $I$, então a priori conjugada será a distribuição Dirichlet, com hiper-parâmetro $\alpha^{D}$, representada pela eq. 68, abaixo (Spiegelhalter, 2003):

$$
f(\gamma)=\frac{\Gamma\left(\sum_{j} \alpha_{j}^{D}\right)}{\Pi_{j} \Gamma\left(\alpha_{j}^{D}\right)} \Pi_{j} q_{j}^{\alpha_{j}^{D}-1}
$$


onde $0<q_{j}<1$ e $\sum_{j} q_{j}=1, \alpha_{j}^{D}>0, j=1, \ldots J$.

Para assegurar que a distribuição a posteriori seja própria, Gelman et al. (2003) sugerem que a razão entre as duas variâncias seja fixa ou seja atribuída uma distribuição a priori própria, como por exemplo, uma distribuição Gama Inversa $(a, b)$, como utilizada neste trabalho.

\subsubsection{Modelagem temporal}

Como parte integrante de $\mu_{i t}$, a componente temporal $\Psi_{t}$ será modelada considerando-se inicialmente, um modelo onde $\Psi_{t}=\zeta+e_{t}$, ou seja, é igual a uma média constante para todos os municípios mais um termo de erro, tal que $e_{t} \sim \mathrm{iid} \sim\left(0, \sigma^{2}\right)$.

Este modelo inicial, longe de ser realístico será expandido, posteriormente, para que no modelo seguinte possa se incorporar o tempo como uma covariável na análise, denominado modelo de tendência determinística, de acordo com:

$$
\Psi_{t}=\sum_{l=1}^{p} \zeta_{l} t^{l}+e_{t}
$$

polinomial em $t$.

Para este tipo de tendência determinística optou-se por trabalhar com a variável $t$ centrada para que os algoritmos MCMC atingissem convergência mais acelerada. Desta forma, centrando $t$, têm-se que $t^{*}=\left(t-(\mathrm{N}+1)^{*} 0.5\right)$. Considerou-se $\mathrm{p}=$ 1, 2 no ajuste dos modelos.

Como distribuições a priori para os parâmetros dos modelos determinísticos utilizou-se a distribuição Normal para os parâmetros de intercepto e para os parâmetros de tendência. 
Como uma forma inicial de exploração dos dados, utilizou-se gráficos empíricos para estudar o tipo de tendência que possivelmente poderiam estar presentes nos dados. Por exemplo, pode-se plotar $y_{i t}$ versus $t$ para cada $i$ para estudar a tendência. Nosso estudo mostra que não há necessidade de se considerar além da tendência quadrática.

Além dos modelos de tendência determinística, analisou-se de forma complementar modelos de tendência estocástica e interações entre modelos estocásticos e determinísticos.

Sendo assim, modelou-se a componente de tendência estocástica através de um modelo auto-regressivo de primeira ordem $\operatorname{AR}(1)^{205}$ e um modelo de caminho aleatório, de forma que $\Psi_{t}=\rho \mathrm{y}_{t-1}+e_{t}$, onde $-1 \leq \rho \leq 1$. O segundo como sendo o caso particular do primeiro.

Algumas considerações quanto aos modelos de tendência estocástica devem ser colocadas. Primeiro, o parâmetro de correlação $\rho$ foi permitido variar de acordo com a área e segundo ${ }^{206}$, uma priori permutável com distribuição Normal foi atribuída ao parâmetro $\rho$, com hiper-distribuições Normal e Inversa Gama para os parâmetros de média e variância, repectivamente.

A interação entre a tendência determinística e estocástica foi analisada, inicialmente, considerando uma função polinomial de primeira ordem em $t$ adicionada à componente estocástica. Posteriormente, incorporou-se a funcão de segunda ordem, de acordo com a equação:

\footnotetext{
${ }^{205}$ Devido ao fato da série de tempo ser muito curta, não foi permitido utilizar modelos temporais mais sofisticados. Como exemplo, Ker e Goodwin (2000 p. 465) utilizaram um processo $\operatorname{IMA}(1,1)$, representado por $\mathrm{y}_{t}=\mathrm{y}_{t-1}+\theta_{0}+\theta \mathrm{e}_{t-1}+$ et Devido ao fato da série utilizada pelos autores ser também pequena, embora maior que a utilizada neste trabalho, modelar um processo $\operatorname{IMA}(1,1)$ pode ser um trabalho árduo quanto atingir estabilidade e convergência dos parâmetros. Desta forma, como um processo MA(1) pode ser representado como $\mathrm{AR}(\infty)$ os autores modelaram o processo temporal como um $\mathrm{AR}(4)$, de forma que: $\mathrm{y}_{t}=\mathrm{y}_{t-1}+\zeta_{0}+\zeta_{1}\left(\mathrm{y}_{t-1}-\mathrm{y}_{t-2}\right)+\zeta_{2}\left(\mathrm{y}_{t-2}-\mathrm{y}_{t-3}\right)+\zeta_{3}\left(\mathrm{y}_{t-3}-\mathrm{y}_{t-4}\right)+\zeta_{4}\left(\mathrm{y}_{t-4}-\mathrm{y}_{t-5}\right)+e_{t}$.

${ }^{206}$ Uma outra opção seria repametrizar o parâmetro para que fosse possível atribuir uma distribuição a priori para $\rho$, de tal forma que, $\rho=2 \eta-1,0 \leq \eta \leq 1$. Naturalmente, utilizou-se a distribuição Beta $\left(\mathrm{b}_{1}\right.$, $\mathrm{b}_{2}$ ), onde $\mathrm{b}_{1}=\xi \psi$ e $\mathrm{b}_{2}=(1-\xi) \psi, 0<\xi<1, \psi>0$, como priori para o parâmetro $\eta$ e distribuições hiper-priori para $\xi$ e $\psi$.
} 


$$
\Psi_{t}=\rho \mathrm{y}_{t-1}+\zeta_{0}+\zeta_{1} t^{*}+\zeta_{2} t^{2}+e_{t}
$$

Do mesmo modo que no caso anterior, o coeficiente de correlação foi reparametrizado. Distribuições a priori não-informativas foram designadas para $\zeta_{0}, \zeta_{1}$ e $\zeta_{2}$ considerando uma distribuição Normal com o parâmetro de precisão $\tau \rightarrow 0$.

Se considerarmos um modelo de efeitos aleatórios então todos os parâmetros $\zeta$ 's serão permutáveis, de modo que seria conveniente e razoável supor que embora os parâmetros possam ser diferentes um do outro, são provenientes da mesma distribuição populacional.

Desta forma, pode-se considerar o modelo acima como um modelo permutável da forma $\zeta \sim \mathrm{N}_{\mathrm{n}}(z, \Sigma)$, onde as distribuições hiper-prioris para o vetor b e a matriz $\Sigma$ são, respectivamente, $z \sim \mathrm{N}_{\mathrm{n}}\left(\mu_{z}, \Sigma_{z}\right)$, onde $\mu_{z}=0$ e $\Sigma_{z}$ é a matriz de covariância diagonal, onde os elementos da diagonal principal aproximam $\infty$ e $\Sigma \sim$ $\mathrm{W}(\mathrm{Q}, \mathrm{k})$, onde $\Sigma$ é uma matriz simétrica $\mathrm{p} \times \mathrm{p}$ positiva definida, com densidade proporcional a:

$$
|\mathrm{Q}|^{\mathrm{k} / 2}|\Sigma|^{(\mathrm{k}-\mathrm{p}-1) / 2} \exp [-1 / 2(\operatorname{Tr}(\mathrm{Q} \Sigma))]
$$

onde $\mathrm{k} \geq \mathrm{p}$, conhecida como distribuição Wishart (Anderson, 1984).

\subsubsection{Modelagem espacial}

Na literatura tradicional de modelos espaciais, a variável espacial $\Phi_{i}$ pode ser representada, em um primeiro instante, como covariáveis alocadas em um vetor $\Phi_{i}$ representando determinadas características de certa área, contribuindo um componente $g\left(\Phi_{i}\right)$, onde $g$ é uma função paramétrica específica.

$\mathrm{Na}$ ausência de covariáveis, efeitos aletórios $v_{i}$ são introduzidos de modo a captar a heterogeneidade entre certas regiões. Gelfand et al. (1998), na ausência de 
covariáveis utilizaram variáveis de efeito aletório como substitutos às covariáveis, para captar o efeito de heterogeneidade em um contexto em que se utilizou como fundamento econômico o modelo de preços hedônicos para prever o preço futuro de venda de casas.

Desta forma, no trabalho os autores utilizaram $v_{i}$ para captar tais características como, por exemplo, qualidade da construção, renda na subdivisão e variáveis socio-econômicas, tais como, raça e educação.

Além da variável de heterogeneidade, introduziu-se uma variável latente para captar o efeito espacial $\xi_{i}$ considerando a natureza geográfica de cada subdivisão e a importância de cada área em relação ao preço de venda das casas.

Assim, a variável espacial pode ser designada como $\Phi_{i}=\xi_{i}+v_{i}$, onde $v_{i}$ é denominada variável latente não-estruturada espacialmente (heterogeneidade) e $\xi_{i}$, variável latente estruturada ou correlacionada espacialmente (clustering).

A identificabilidade na verossimilhança, neste caso é verificada no modelo hierárquico atribuindo-se distribuições a priori condicionais auto-regressivas (CAR) para $\xi_{i}$ e permutáveis para $v_{i}$.

Retomando o trabalho de Besag (1974), Clayton e Kaldor (1987), utilizaram o conceito de dependência espacial aplicada ao mapeamento de doenças, particularmente cancer na Escócia. A correlação foi modelada tendo-se como base a proximidade geográfica de determinada região em relação a regiões adjacentes.

Na mesma linha de trabalho, Cressie e Chan (1989), apresentam modelos espaciais para modelar a síndrome da morte súbita infantil com dados de 1974-1984 nos municípios do Estado da Carolina do Norte.

Conforme salientam os autores, como ocorre em dados de séries temporais, onde se tenta captar como uma observação é influenciada pelo seus valores passados, em processos espaciais tenta se verficar como um particular valor é influenciado pelos seus valores "vizinhos".

Nestes trabalhos, a variável não-estruturada segue uma distribuição Normal, de modo que $v_{i} \sim \mathrm{N}\left(\mu_{v}, \sigma_{v}^{2}\right)$ e a variável estrutura espacialmente $\xi_{i}$ condicional 
a $\xi_{j}$, onde $j \neq i$, é modelada de modo que $\xi_{i} \sim \mathrm{N}\left(\bar{\xi}_{i}, \sigma_{\xi}^{2} / n_{i}\right)$, onde $\bar{\xi}_{i}$ é a média dos $\xi_{i}$ 's e $i$ pertence as áreas adjancentes.

Para os parâmetros de variância $\sigma_{v}^{2}$ e $\sigma_{\xi}^{2}$ foi atribuída a distriuição Inversa Gama como prioris. Nota-se que, estes termos determinam um processo espacial, de acordo com Besag et al. (1991).

Bernardinelli et al. (1995a) salientam que a escolha do parâmetro de dispersão deve ser vista com cautela. Realizando um estudo de simulação de um modelo Poisson aplicado a modelagem de mapeamento de doenças, os autores verificaram que o parâmetro de heterogeneidade apresentou desvio padrão da distribuição a priori aproximadamente igual a 0.7 vezes o desvio padrão do parâmetro de clustering, ou de outro modo, $\operatorname{var}\left(v_{i}\right) \approx 0,7 \operatorname{var}\left(\xi_{i}\right)$.

Thomas et al. (2002) sugerem que uma restrição seja imposta aos parâmetros de efeito aleatório, ou seja, que esses efeitos somem zero. Na prática, incluise um parâmetro de intercepto no modelo e atribui-se a este parâmetro uma distribuição (uniforme) a priori imprópria.

Gelfand et al. (1998), ressaltam que, se ambos os parâmetros forem colocados no modelo, então $\mathrm{E}\left(v_{i}\right)=0$. No mesmo sentido, caso os parâmetros $\Psi_{t}$ e $\xi_{i}$ estiverem no modelo e a $\Psi_{t}$ for atribuída uma priori nao-informativa, então $\Psi_{1}=0$ ou $\Sigma$ $\Psi_{t}=0$. Além disso, conforme apontam os autores, se $\xi_{i}$ e $v_{i}$ estiverem incluídos, a distribuição a priori terá um peso maior na posteriori.

Sendo assim, caso seja permitido que $v_{i}$ se situe ao redor de zero com uma pequena variância, então a componente $\xi_{i}$ constituirá boa parte de $\Phi_{i}$.

Devido e questões de convergência no algoritmo MCMC, os autores sugerem que se escolha ou a variável não-estruturada espacialmente ou a variável estruturada, mas não ambos. Como o objetivo da análise era obter valores preditos, então os autores concluiram, de maneira geral, que o modelo incluindo $\xi_{i}$ apresentou melhores resultados. 


\subsubsection{Modelagem espaço-temporal}

Um dos artigos pioneiros relacionados a análise espaço-temporais utilizando um modelo log-linear Poisson no mapeamento de doenças foi elaborado por Bernardinelli et al. (1995b).

Neste trabalho, os autores, no contexto de modelos lineares generalizados, modelam o efeito espacial, que representa a variação da taxa de certa doença em determinada área, através de uma variável de efeito aleatório $v_{i}$, o efeito temporal, que é a variação da taxa no tempo, através de um coeficiente de tendência e a interação entre o efeito espacial e temporal captada pela covariável correlacionada espacialmente $\xi_{i}$. O modelo pode ser representado de modo geral como: $($ intercepto + área) $+($ tempo + área.tempo).

Para captar a dependência entre $v_{i}$ e $\xi_{i}$, ou de outra forma, entre intercepto e tendência, os autores consideraram $v_{i}$ como proveniente de uma distribuição Normal univariada e $\xi_{i}$ como uma distribuição Normal condicional a $v_{i}$.

Nesta mesma linha, Dreassi (2003), utiliza o modelo anterior para modelar o risco relativo para cada período e para cada município na Itália incorporando uma covariável ordinal que permitisse captar em que lag a doença, no caso, o cancer de pulmão é afetado por fatores socio-econômicos.

Outra forma de abordar a modelagem espaço-temporal foi proposta por Waller et al. (1997). Neste modelo, ao invés de captar a variação espaço-temporal de forma multiplicativa, os autores consideraram um modelo aninhado, onde o efeito espacial e o efeito de heterogeneidade foram deixados variar no tempo. O modelo geral foi considerado como:

$$
\mu_{i s t}=x_{s}^{T} \zeta+\lambda_{i}^{T} \omega+\xi_{i}^{(t)}+v_{i}^{(t)}
$$


onde $x_{s}^{T} \zeta$ é a covariável representando os efeitos para cada subgrupo, $\lambda_{i}^{T} \omega$ representa a covariável regional, $\xi_{i}^{(t)}$ é o efeito espacial para a i-ésima região no ano $t$ e $v_{i}^{(t)}$ é o efeito aleatório para a i-ésima região no ano $t$.

Utilizando-se do princípio da parsimônia, modelos mais simples foram considerados ao longo do trabalho.

Nota-se que, devido a permutabilidade condicional dado o tempo, a distribuição à priori resultante pode ser representada por $v_{i}^{(t)} \stackrel{\text { iid }}{\sim} \mathrm{N}\left(\mu_{v}^{(t)}, \sigma_{v}^{2(t)}\right)$. Considerou-se para o efeito espacial $\xi_{i}^{(t)}$ na i-ésima região no ano $t$ a priori CAR dado o tempo $t$. Assim:

$$
\xi_{i}^{(t)} \sim \mathrm{N}\left(\bar{\xi}_{i}^{(t)}, \sigma_{\xi}^{2(t)} / n_{i}\right)
$$

onde $\bar{\xi}_{i}^{(t)}$ é a média das j-ésimas áreas adjancentes a $i$. Distribuições Inversa Gama foram consideradas como hiper-prioris para $\sigma_{v}^{2(t)}$ e $\sigma_{\xi}^{2(t)}$.

Como nos modelos espaciais algumas restrições também devem ser impostas nos modelos espaço-temporais. A inclusão destes efeitos tornam o aparecimento de $v_{i}$ e $\xi_{i}$ desnecessários. Além disso, o modelo é incapaz de indentificar $\xi_{i}^{(t)}$ e $\Psi_{t}$ se ambos estiverem incluídos no modelo e a $\Psi_{t}$ for atribuída uma priori naoinformativa dado o tempo $t$. Se $v_{i}^{(t)} \mathrm{e} \xi_{i}^{(t)}$ forem inclúídos no modelo, então deve-se deixar que $\mu_{v}^{(t)}=0$.

Além dos modelos espaço-temporais vistos anteriormente, ajustou-se um modelo temporal, mas permitindo que os coeficientes $\zeta$ 's variassem no espaço e, desta forma, fosse captada a correlação espacial dado o tempo $t$. Para isso, atribui-se a cada parâmetro uma priori condicional autoregressiva. De forma geral, o modelo pode ser definido como: 


$$
\mu_{i t}=\zeta_{0}^{(i)}+\zeta_{1}^{(i)} t^{*}+\zeta_{2}^{(i)} t^{* 2}+e_{i t}
$$

Pode-se incorporar a componente de tendência estocástica, de maneira aditiva no modelo geral. Como na modelagem temporal, o parâmetro de correlação pode ser reparametrizado ou atribuido prioris permutáveis, com suas respectivas hyperdistribuições.

\subsubsection{Seleção de modelos e escolha}

Tendo em vista diversos modelos ajustados nesta subseção, uma questão fundamental é como selecionar o melhor modelo tendo em vista um dos objetivos desta subseção que é a predição da produtividade agrícola.

Os critérios tradicionais de seleção de modelos, como por exemplo, o fator de Bayes, em casos como estes, em que são utilizadas distribuições a priori nãoinformativas ou condicionais auto-regressivas (CAR) não são aplicáveis. Conforme salienta Carlin e Louis (2000 pg. 220), o uso de prioris impróprias resulta em distribuições preditivas condicionais impróprias, limitando sobremaneira o uso do fator de Bayes nestes casos.

Visto que, na situação mais simples onde ambos os modelos possuem a mesma parametrização e as hipóteses são simples, o fator de Bayes é a razão de verossimilhança entre os dois modelos.

A abordagem clássica de seleção de modelos também é de difícil aplicação nestes casos. Critérios de verossimilhança penalizada, baseados em eficiência assintótica requerem a determinação da dimensão do modelo ou número de parâmetros (Schwarz, 1978).

Nos modelos hirárquicos com efeitos aleatórios, como os utilizados na presente subseção, a dimensão é difícil de caracterizar. Além disso, em modelos sofisticados a dimensão do modelo aumenta com o tamanho da amostra, 
consequentemente, invalidando o uso de critérios de seleção de modelos mais conhecidos, tais como, AIC e BIC (Akaike, 1973).

Cita-se, como exemplo, “Akaike Information Criteria” (AIC), que em termos de mudança do modelo $1\left(\mathrm{M}_{1}\right)$ para o modelo $2\left(\mathrm{M}_{2}\right)$ é dado por:

$$
-2 \log \left(\sup _{\mathrm{M} 1} \mathrm{f}(y / \theta)\right)\left(\sup _{\mathrm{M} 2} \mathrm{f}(y / \theta)\right)^{-1}-2\left(\mathrm{p}_{2}-\mathrm{p}_{1}\right)
$$

onde $\mathrm{p}_{1}$ e $\mathrm{p}_{2}$ são o número de parâmetros, "Bayesian Information Criteria" (BIC), expresso por:

$$
-2 \log \left(\sup _{\mathrm{M} 1} \mathrm{f}(y / \theta)\right)\left(\sup _{\mathrm{M} 2} \mathrm{f}(y / \theta)\right)^{-1}-\left(\mathrm{p}_{2}-\mathrm{p}_{1}\right)(\log n)
$$

e "Deviance Information Criteria” (DIC), dado por:

$$
\left(E_{\theta \mid y}(D)-D\left(E_{\theta \mid y}(\theta)\right)\right)
$$

onde o primeiro termo é a esperança da deviance e o segundo termo a deviance estimada na esperança da posteriori.

Critérios baseados em validação cruzada também são de difícil aplicação para modelos mais sofisticados, devido, por exemplo, a inclusão de variáveis de heterogeneidade e clustering que são definidas somente pela priori (Waller, 1998).

Nesta subseção, optou-se por critérios baseados em densidades preditivas, como o desenvolvido por Laud e Ibrahim (1995). Conforme apontam os autores, estes critérios são de fácil interpretação, não são baseados em análise assintótica e permitem a incorporação de distribuições a priori.

Trabalhando no espaço de preditivas, a penalidade surge sem a necessidade de definições assintóticas. Intuitivamente, pode-se dizer que bons modelos devem realizar predições próximas ao que foi observado em experimentos idênticos.

Neste mesmo contexto, Gelfand e Ghosh (1998), formalizam o referido critério utilizando uma forma específica de função de perda. O objetivo é minimizar a 
perda preditiva a posteriori, denominada erro predito quadrático. A distribuição preditiva à posteriori, é mostrado abaixo:

$$
f\left(y_{\text {new }} \mid y_{\text {obs }}\right)=\int f\left(y_{\text {new }} \mid M\right) p\left(M \mid y_{\text {obs }}\right) d M
$$

onde $M$ representa o conjunto de todos os parâmetros em certo modelo e $y_{\text {new }}$ é a réplica do vetor de dados observados $y_{o b s}$.

O critério de seleção de modelos é baseada em uma função de discrepância $d\left(y_{\text {new }}, y_{o b s}\right)$, sendo que o objetivo é escolher aquele que minimiza a esperança da função de discrepância, condicional a $y_{o b s}$ e $M_{i}$, onde o subscrito $i$ representa todos os parâmetros em determinado modelo $i$. Para modelos Gaussianos, a função de discrepância é dada por $d\left(y_{\text {new }}, y_{\text {obs }}\right)=\left(y_{\text {new }}-y_{\text {obs }}\right)^{\mathrm{T}}\left(y_{\text {new }}-y_{\text {obs }}\right)$ e $D_{m}$ por:

$$
\begin{aligned}
& D_{M_{i}}=E\left[\left(y_{\text {new }}-y_{\text {obs }}\right)^{T}\left(y_{\text {new }}-y_{\text {obs }}\right) \mid y_{\text {obs }}, M_{i}\right] \\
& D_{M_{i}}=\sum_{n} E\left[\left(y_{n, o b s}-y_{n, \text { new }}\right)^{2} \mid y_{\text {obs }}, M_{i}\right]
\end{aligned}
$$

Os autores demostram que $D_{M_{i}}$ pode ser fatorada em dois termos aditivos $G_{M_{i}}$ e $P_{M_{i}}$. Onde o primeiro:

$$
G_{M_{i}}=\sum_{n}\left[y_{n, o b s}-E\left(y_{n, n e w} \mid y_{o b s}\right)\right]^{2}
$$

representa a soma de quadrado dos erros, ou seja, uma medida de qualidade de ajuste e o segundo:

$$
P_{M_{i}}=\sum_{n} \operatorname{var}\left(y_{n, n e w} \mid y_{o b s}\right)
$$

um termo de penalização. 
Em modelos superajustados ou subajustados, percebe-se que a variância predita tende a ser grande e, consequentemente, $P_{M_{i}}$. Desta forma a penalização é considerada na análise sem se considerar a dimensão do modelo.

Neste trabalho, uma versão levemente diferente será contemplada. Ao invés de utilizar o erro predito quadrático, optou-se por utilizar o erro predito quadrático médio relativo ao número de regiões utilizadas na análise. Percebe-se que, a inclusão de um denominador comum a todos os modelos não afeta o critério.

\subsection{Correlação e risco sistêmico}

Conforme destacado, anteriormente, por Halcrow, o limite geográfico da região ou, em outras palavras, o nível de agregação, sua uniformidade e homogeneidade e a correlação entre a produtividade ao nível do produtor e da região considerada são pontos que merecem destaque no design de um contrato de seguro agrícola regional. Estes pontos serão abordados nesta subseção e seus resultados discutidos, posteriormente, na subseção 5.3.

A fim de verificar a possibilidade do seguro baseado em um índice de produtividade regional na região de Castro, no Estado do Paraná, utilizou-se as séries de produtividade individuais para o milho e a soja, no período de 1994 a 2003.

A análise será realizada para dois níveis distintos de agregação. O primeiro deles, denominado nível de agregação "municipal”, considera que as observações representem a média da produtividade de todos os produtores no Estado do Paraná. Estes dados foram obtidos através do IBGE, para o milho e a soja, no perído de 1990 a 2002.

O segundo, nível de agregação "cluster", assume que a produtividade da região é a média da produtividade de alguns produtores nesta região. No trabalho, considerou-se a produtividade média de 26 e 40 produtores de milho e soja, respectivamente. 
Desta forma, a produtividade regional $\tilde{y}$ será igual a $\Sigma_{i} w_{i} \tilde{y}_{i}$, onde $w_{i}$ é a proporção da área cultivada pelo produtor $i$ na área cultivada total, $\Sigma_{i} w_{i}=1$ e $i=1, \ldots$, 26 e $1, \ldots, 40$, para a cultura do milho e soja, respectivamente. As séries de dados foram cedidas pela Cooperativa Castrolanda e pela Fundação $\mathrm{ABC}$, ambos situados no município de Castro, no Paraná.

$\mathrm{Na}$ amostra analisada dos produtores, todos se encontravam na área considerada boa a regular, dentro de uma escala que vai de boa (1) a desfavorável (10), tendo em vista o potencial agrícola, de acordo com a fertilidade, características físicas e morfológicas do solo e topografia (IBGE, 2004) ${ }^{207}$.

Retomando o trabalho de Miranda, a produtividade individual é decomposta em um componente sistêmico $^{208}$, que são os fatores que afetam os produtores em uma determinada área e um componente não sistêmico. Deste modo, a produtividade local do produtor $i, \widetilde{y}_{i}$, pode ser caracterizada, de acordo com a equação (53), abaixo:

$$
\tilde{y}_{i}=\mu_{i}+\beta_{i}(\tilde{y}-\mu)+\widetilde{\varepsilon}_{i}
$$

Em que:

$$
\begin{aligned}
& \beta_{i}=\operatorname{cov}\left(\widetilde{y}_{i}, \tilde{y}\right) / \operatorname{var}(\widetilde{y}) \\
& E\left(\widetilde{\varepsilon}_{i}\right)=0 \quad \operatorname{var}\left(\widetilde{\varepsilon}_{i}\right)=\sigma_{\widetilde{\varepsilon}_{i}}^{2} \quad \operatorname{cov}\left(\widetilde{y}, \widetilde{\varepsilon}_{i}\right)=0 \\
& E\left(\widetilde{y}_{i}\right)=\mu_{i} \quad \operatorname{var}\left(\widetilde{y}_{i}\right)=\sigma_{\widetilde{y}_{i}}^{2} \\
& E(\tilde{y})=\mu \quad \operatorname{var}(\tilde{y})=\sigma_{\widetilde{y}}^{2} \\
& \mu_{i} \text { é a produtividade média individual }
\end{aligned}
$$

\footnotetext{
${ }^{207} \mathrm{http}: / /$ www.ibge.gov.br (12 set. 2004)

${ }^{208} \mathrm{O}$ componente sistêmico ou não diversificável ocorre devido ao fato do prejuízo ao nível do produtor conter uma alta correlação espacial, ou seja, um evento climático extremo, como por exemplo, a geada afetaria uma grande quantidade de produtores em uma vasta extensão de território. Este evento generalizado se traduz na inexistência de independência entre os eventos, conseqüentemente, elevando o risco de uma seguradora administrar uma carteira agrícola. Tendo a seguradora que se responsabilizar pelo risco adicional, o aumento da taxa do prêmio é inevitável, caso não exista a possibilidade da transferência deste risco para um mercado ressegurador nacional ou internacional ou através do mercado financeiro.
} 
$\mu$ é a produtividade média regional e,

$\tilde{y}$ é a produtividade regional.

Neste modelo, o $\beta_{i}{ }^{209}$ representa a sensibilidade da produtividade individual aos fatores sistêmicos que afetam a produtividade regional, o termo $\beta_{i}(\tilde{y}-\mu)$ o risco sistêmico e, $\widetilde{\varepsilon}_{i}$ o risco não sistêmico.

Desta forma um contrato de seguro de produtividade regional, cobra um prêmio $P$, e paga uma indenização ${ }^{210}$ igual a $\left(y_{\mathrm{c}}-\tilde{y}\right)$, caso a produtividade regional $\tilde{y}$ seja menor que a produtividade crítica $y_{\mathrm{c}}$. O mecanismo de compensação será dado por (58):

$$
I=\phi \max \left(\mathrm{y}_{\mathrm{c}}-\tilde{y}, 0\right)
$$

Onde $I$ é a indenização ocorrida, em volume físico, como por exemplo, toneladas por hectare, quando o gatilho de compensação representada pela produtividade observada $(y)$ é menor que a produtividade crítica $\left(\mathrm{y}_{\mathrm{c}}\right)$, também denominada limite do gatilho de compensação, e $\phi$ é o nível de cobertura.

A produtividade líquida individual $\tilde{y}_{i}^{L}$ será dada por:

$$
\tilde{y}_{i}^{L}=\tilde{y}_{i}-P+I
$$

Isto é, o produtor terá uma produtividade líquida igual à produtividade obtida menos o prêmio pago pelo seguro mais o eventual pagamento da indenização.

Supondo que o prêmio seja justo, ou seja, $P=E(I)$, e que o risco de produtividade seja dado pela variância da produtividade líquida, então:

\footnotetext{
${ }^{209}$ Analogamente ao modelo Capital Asset Pricing Model (CAPM).

${ }^{210}$ A indenização e o prêmio são expressos em unidade físicas, neste modelo.
} 


$$
\operatorname{var}\left(\tilde{y}_{i}^{L}\right)=\operatorname{var}\left(\tilde{y}_{i}\right)+\operatorname{var}(I)+2 \operatorname{cov}\left(\tilde{y}_{i}, I\right)
$$

Pela aquisição do seguro, o produtor reduz seu risco de produtividade no montante equivalente à diferença entre a variância da produtividade local e a variância da produtividade líquida, dada por:

$$
\Delta_{i}=-\operatorname{var}(I)-2 \operatorname{cov}\left(\tilde{y}_{i}, I\right)
$$

Lembrando que $\operatorname{cov}\left(\tilde{y}, \widetilde{\varepsilon}_{i}\right)=0$ e que o componente não sistêmico não é correlacionada com a indenização, então $\operatorname{cov}\left(I, \widetilde{\varepsilon}_{i}\right)=0$. Assim de acordo com (53), temos que:

$$
\operatorname{cov}\left(\tilde{y}_{i}, I\right)=\beta_{i} \operatorname{cov}(\tilde{y}, I)
$$

Miranda define o "beta crítico", como:

$$
\beta_{c}=-\frac{\operatorname{var}(I)}{2 \operatorname{cov}(\tilde{y}, I)}
$$

Como a produtividade regional e a indenização são negativamente correlacionadas, então $\beta_{c}>0$. Pode-se verificar, levando em conta a equação (61), (62) e (63) que:

$$
\Delta_{i}=\operatorname{var}(I)\left(\frac{\beta_{i}}{\beta_{c}}-1\right)
$$


Nota-se que, $\beta_{c}$ e a variância da indenização serão determinados pela distribuição da produtividade regional e crítica sendo assim, invariantes entre os diversos produtores em uma determinada área.

Assim, $\Delta_{i}$ é determinado e positivamente relacionado ao $\beta_{i}$. Além disso, a redução do risco de produtividade do produtor ocorrerá somente quando o beta individual exceder o beta crítico.

Introduzindo $\rho_{i}=\operatorname{corr}\left(\tilde{y}_{i}, \tilde{y}\right)$, a correlação entre a produtividade individual e a produtividade regional, então a equação (42) poderá ser escrita como:

$$
\beta_{i}=\rho_{i} \sqrt{\frac{\operatorname{var}\left(\tilde{y}_{i}\right)}{\operatorname{var}(\tilde{y})}}
$$

Percebe-se pela equação acima que, ceteris paribus, quanto mais correlacionada a produtividade individual for da produtividade regional, maior será o valor de $\beta_{i}$ e, conseqüentemente, maior será a redução do risco propiciado pelo seguro de produtividade regional. Colocado de forma suplementar, quanto maior a correlação, menor o risco de base.

Além disso, a redução do risco de produtividade será tanto maior quanto mais elevado for o valor da variância da produtividade individual.

Pela análise até agora realizada, nota-se que a redução do risco é influenciado diretamente pelo beta individual. Para verificar a sensibilidade do $\Delta_{i}$ entre produtores em uma certa área é necessário verificar como o beta individual varia nesta área e como a produtividade crítica afeta o beta crítico.

Seja $w_{i}$ a proporção da área cultivada pelo produtor $i$ na área cultivada total, então:

$$
\begin{aligned}
& \Sigma_{i} w_{i}=1 \\
& \Sigma_{i} w_{i} \tilde{y}_{i}=\tilde{y}
\end{aligned}
$$


Sabendo que:

$\sum_{i} w_{i} \operatorname{cov}\left(\tilde{y}_{i}, \tilde{y}\right)=\operatorname{var}(\tilde{y})$

Então através de (68), verifica-se que $\Sigma_{i} w_{i} \beta_{i}=1$, ou seja, teoricamente, a média ponderada dos betas individuais deve ser igual a um.

O beta crítico é uma função crescente da produtividade crítica, de tal forma que:

$0 \leq \beta_{c} \leq 0,5$ e $\lim _{y_{c} \rightarrow 0} \beta_{c}=0$ e $\lim _{y_{c} \rightarrow \infty} \beta_{c}=0,5$

Através da eq. (64) e restrições (69), nota-se que o seguro terá um impacto redutor no risco sempre que $\beta_{i}>0,5$. Na média, o seguro será atrativo para os produtores, pois o $\beta_{i}$ médio dentro de uma determinada área é igual a um.

Toda vez que a produtividade individual for negativamente correlacionada com a produtividade regional, isto é, quando $\beta_{i} \leq 0$, então haverá um aumento do risco, caso o produtor adquira o contrato.

O nível de cobertura $(\phi)$ foi suposto não variar, até o momento, ou seja, foi fixado em $100 \%$. Caso o produtor possa escolher um valor de $\phi$, maior ou menor do que $100 \%$, então o nível de cobertura ótimo que maximiza a redução do risco será dado por:

$$
\phi_{i}^{*}=\frac{\beta_{i}}{2 \beta_{c}}
$$

O produtor deverá considerar a eq. (70) somente se seu $\beta_{i}>0$. Caso contrário, o seguro terá efeito de aumento do risco de produtividade. 
Nota-se que, como $\beta_{c}$ é positivamente relacionado com $y_{\mathrm{c}}$, o nível de cobertura se reduz com o aumento de $y_{\mathrm{c}} \mathrm{e}$, também, quando $\beta_{c}$ atinge seu valor máximo. Então, o nível de cobertura atingirá o valor mínimo, ao redor de $\beta_{i}$. Além disso, como o $\beta_{i}$ médio é igual a um, espera-se que o nível de cobertura ótimo tenha um valor maior do que $100 \%$ para grande parte dos produtores.

Utilizando o nível ótimo de cobertura, eq. (70), o produtor seria beneficiado pelo seguro, pois reduziria seu risco de produtividade em:

$$
\Delta_{i}^{*}=\rho^{2}\left(\beta_{i}^{2} \sigma_{\widetilde{y}}^{2}\right)
$$

onde $\rho=\operatorname{corr}(I, \tilde{y})$. Lembrando que a variância da produtividade individual é dada por:

$$
\operatorname{var}\left(\widetilde{y}_{i}\right)=\beta_{i}^{2} \sigma_{\widetilde{y}}^{2}+\sigma_{\widetilde{\varepsilon}_{i}}^{2}
$$

Percebe-se que a redução do risco, dada por (71), é uma proporção do componente sistêmico, $\beta_{i}^{2} \sigma_{\widetilde{y}}^{2}$.

O seguro baseado em um indicador de produtividade regional elimina uma parcela do risco sistêmico enfrentado pelo produtor, mas não elimina o risco não sistêmico.Além disso, nota-se que, quanto maior a correlação entre a produtividade individual e a regional, maior será o valor de $\beta_{i}$ e, consequentemente, maior a redução do risco proveniente da aquisição de um contrato de seguro agrícola regional.

Considerando que o nível de agregação é municipal, o $\beta_{i}$ foi calculado, de acordo, com a equação (65) e a correlação das séries de produtividade foi representada pelo coeficiente de correlação de Pearson, dada por:

$$
\rho_{i}=\left(\sum_{i}[\tilde{y}-\mu]\left[\tilde{y}_{i}-\mu_{i}\right]\right) /(n-1) \sigma_{\widetilde{y}} \sigma_{\widetilde{y}_{i}}
$$


Como pode ser visto, através da eq. 65 , o $\beta_{i}$ depende não somente de $\rho_{i}$, mas também da variância da série de produtividade individual. Desta forma, quanto maior $\rho_{i}$ e $\sigma_{\widetilde{y}_{i}}$, maior será o valor de $\beta_{i}$.

\subsection{Correlação espacial}

Nesta subseção serão abordados, aspectos metodológicos referentes à correlação espacial, tais como, estimação dos semivariogramas e parâmetros de alcance (“range"), ou seja, a máxima distância, na qual a correlação é igual a zero.

Seja $y_{\mathrm{i}}$ igual a determinado atributo, como por exemplo, a produtividade agrícola, medido no local $x_{\mathrm{i}}$. Define-se um processo espacial Gaussiano estacionário $^{211}\left\{\mathrm{Y}(x): x \in \mathfrak{R}^{2}\right\}$ como aquele em que $\mathrm{E}[\mathrm{Y}(x)]=\mu$, para $\forall \mathrm{x}, \operatorname{Var}[\mathrm{Y}(x)]=$ $\sigma^{2}$ e função de correlação:

$$
\rho^{e}(u)=\operatorname{Corr}\left[\mathrm{Y}\left(x_{i}\right), \mathrm{Y}\left(x_{j}\right)\right]
$$

para $\mathrm{i} \neq \mathrm{j}$, onde $u=\left\|x_{i}-x_{j}\right\|$ e corresponde a distância Euclideana entre $x_{i}$ e $x_{j}$. (Diggle e Ribeiro Jr., 2000)

De forma complementar, define-se a covariância como:

$$
\operatorname{Cov}\left[\mathrm{Y}\left(x_{i}\right), \mathrm{Y}\left(x_{j}\right)\right]=\gamma^{e}\left(x_{i}-x_{j}\right)
$$

\footnotetext{
${ }^{211}$ Pode-se definir dois tipos de processos estacionários: Processos intrinsicamente estacionários, onde $\mathrm{E}\left[\mathrm{Y}\left(x_{i}\right)-\mathrm{Y}\left(x_{j}\right)\right]=0$ e $\operatorname{Var}\left[\mathrm{Y}\left(x_{i}\right)-\mathrm{Y}\left(x_{j}\right)\right]=2 \gamma^{e}(u)$ e estacionários de segunda ordem, tal que $\mathrm{E}[\mathrm{Y}(x)]=\mu \mathrm{e}$ $\operatorname{Cov}\left[\mathrm{Y}\left(x_{i}\right), \mathrm{Y}\left(x_{j}\right)\right]=\gamma^{e}(u)$. Nota-se que a classe dos processos intrinsicamente estacionários contêm a classe dos processos estacionários de segunda ordem (Cressie, 1989).
} 
O processo será dito isotrópico ${ }^{212}$ se a covariância depender apenas da distância, ou seja:

$$
\gamma^{e}\left(x_{i}-x_{j}\right)=\gamma^{e}\left\|x_{i}-x_{j}\right\|
$$

Deste modo, se o processo for estacionário, então $\gamma^{e}(u)=\sigma^{2} \rho^{e}(u)$.

Se a variância puder ser expressa como:

$$
\operatorname{Var}\left[\mathrm{Y}\left(x_{i}\right)-\mathrm{Y}\left(x_{j}\right)\right]=2 V\left(x_{i}, x_{j}\right)
$$

então, $2 V(\cdot)$ será denominada variograma (Matheron, 1963) e $V(\cdot)$, semivariograma. Pode-se verificar que a primeira relação está intimamente relacionada com o conceito de covariância. Sendo assim:

$$
V\left(x_{i}, x_{j}\right)=\sigma^{2}\left(x_{i}\right)+\sigma^{2}\left(x_{j}\right)-2 \operatorname{Cov}\left(x_{i}, x_{j}\right)
$$

Se o processo for estacionário, então $V(u)=\sigma^{2}(x)\left[1-\rho^{e}(u)\right]$.

Retomando o fato de que $\operatorname{Var}\left[\mathrm{Y}\left(x_{i}\right)-\mathrm{Y}\left(x_{j}\right)\right]=2 V\left(x_{i}, x_{j}\right)$ e supondo que os dados seguem um processo intrinsicamente estacionário, então:

$$
\mathrm{E}\left(\mathrm{Y}\left(x_{i}\right)-\mathrm{Y}\left(x_{j}\right)\right)^{2}=2 V\left(x_{i}, x_{j}\right)
$$

Conforme aponta Cressie (1989), um estimador do variograma $2 V\left(x_{i}, x_{j}\right)$ que possa refletir a dependência espacial dos dados $\left\{\mathrm{Y}\left(x_{i}\right): i=1, \ldots, \mathrm{n}\right\}$ será dado por:

$$
\sum_{N(u)}\left[Y\left(x_{i}\right)-Y\left(x_{j}\right)\right]^{2} /|N(u)|
$$

conhecido como estimador empírico ou clássico.

\footnotetext{
${ }^{212}$ Diz-se que o comportamento de uma variável é isotrópico, se a variabilidade espacial dos valores é a mesma para todos os sentidos ou direções. Caso contrário, será denominado anisotrópico. Isto porque o semivariograma depende da direção em que é calculado. Neste estudo, estimou-se os semivariogramas para diferentes direções, ou seja, para $0^{\circ}, 45^{\circ}, 90^{\circ}$ e $135^{\circ}$. Todas os semivariogramas estimados apresentaram um comportamento isotrópico.
} 
O estimador empírico, conforme ressalta Diggle e Ribeiro (2000), é sensível a outliers. Em um estudo, simulando a presença de um valor outlier nos dados, os autores verificaram que devido ao fato do outlier se situar perto dos dados com baixos valores, isto resulta em um impacto substancial na parte inicial do variograma. Consequentemente, isto pode gerar conclusões erradas à respeito da existência de dependência espacial e sobre o valor do parâmetro "nugget".

Sendo assim optou-se por utilizar neste trabalho um estimador mais robusto, na presença de outliers, como por exemplo, o estimador proposto por Cressie e Hawkins (1980), dado por:

$$
\left\{(1 /|N(u)|) \sum_{N(u)}\left|Y\left(x_{i}\right)-Y\left(x_{j}\right)\right|^{1 / 2}\right\}^{4} /(0.457+0.494 /|N(u)|)
$$

Diversas funções de correlação paramétricas podem ser incorporadas ao modelo. Dentre elas, destacam-se a família esférica, representada por:

$$
1-3 / 2\left(u / \phi^{e}\right)+1 / 2\left(u / \phi^{e}\right)^{3}
$$

se $0 \leq u \leq \phi^{e}$ e 0 , se $u>\phi^{e}$, a família potência exponencial ${ }^{213}$ :

$$
\exp \left\{-\left(u / \phi^{e}\right)^{k}\right\}
$$

onde $\phi^{e}>0$ e $0<k \leq 2$ e a família Matérn:

$$
\left\{2^{k-1} \Gamma(k)\right\}^{-1}\left(u / \phi^{e}\right)^{k} K_{k}\left(u / \phi^{e}\right)
$$

\footnotetext{
${ }^{213}$ Quando $k=1$, tal função recebe o nome de função de correlação exponencial e quando $k=2$, função de correlação Gaussiana.
} 
Nestas funções, $k$ e $\phi^{e}$ são parâmetros, onde $k$ corresponde ao nível de alisamento do sinal $\mathrm{S}(x), \phi^{e}$ determina a taxa pela qual a correlação se aproxima de zero com o aumento da distância e $K_{k}(\cdot)$ representa a função Bessel do terceiro tipo de ordem $k$.

No trabalho, as séries de milho e soja foram analisadas no período de 1990 a 2002. Desta forma, estimou-se 26 semivariogramas empíricos, de acordo com o estimador robusto de Cressie e Hawkins, para todos os municípios do Estado do Paraná em que haviam dados nos respectivos anos.

Para estudar o comportamento da correlação espacial em cada um dos 26 anos, optou-se por analisar os semivariogramas, particularmente através das estimativas, obtidas através do método da máxima verossimilhança, do parâmetro "range" $\left(\phi^{e}\right)$.

Definindo o parâmetro $\phi^{e}$, de modo mais formal, de acordo com Cressie (1993), se o processo for estacionário, então o semivariograma será dado por $V(u)=\sigma^{2}$ $(x)\left[1-\rho^{e}(u)\right]$.

Pode-se reescrever a equação anterior, de modo que:

$$
V(u)=\sigma^{2}(x)-\sigma^{2}(x) \rho^{e}(u)
$$

Representando, de modo geral, a correlação $\rho^{e}(\cdot) \operatorname{como} \gamma^{e}(\cdot) / \gamma^{e}(0)$, então:

$$
V(u)=\gamma^{e}(0)-\gamma^{e}(u)
$$

Caso $\gamma^{e}(u) \rightarrow 0$, quando $u \rightarrow \infty$, então a quantidade $\gamma^{e}(0)$ será denominada "sill". A quantidade $\gamma^{e}(0)-\tau^{2}=\gamma_{p}^{e}$ será denominada "sill" parcial. Neste ponto, ressalta-se, que $V(u)$ já incorpora o efeito “nugget", pois $\gamma^{e}(0)=\gamma_{p}^{e}+\tau^{2}$.

O parâmetro $\phi^{e}$ será definido como o menor valor $\|r\|$, na qual $\gamma^{e}[r(1+$ $\epsilon)]=\gamma^{e}(0)$. Percebe-se, desta forma, que quando o semivariograma estabilizar em torno de $\gamma^{e}(0)$, a distância equivalente será igual a $\phi^{e}$. 
A análise exploratória dos dados espaciais foi realizada para checar a presença de tendência. Além disso, ajustou-se os dados com um modelo corrigido para a tendência, resultando em resíduos utilizados para a estimação do respectivo semivariograma e outro modelo não corrigido para a tendência.

Posteriormente, utilizou-se o critério "Bayesian Information Criteria" (BIC), que em termos de mudança do modelo $1\left(\mathrm{M}_{1}\right)$ para o modelo $2\left(\mathrm{M}_{2}\right)$ é dado por $2 \log \left(\sup _{\mathrm{M} 1} \mathrm{f}(y / \theta)\right)\left(\sup _{\mathrm{M} 2} \mathrm{f}(y / \theta)\right)^{-1}-\left(\mathrm{p}_{2}-\mathrm{p}_{1}\right)(\log n)$, para a escolha do melhor modelo. Em todos os casos, os modelos sem tendência apresentaram-se melhores, de acordo com o referido critério.

Através da distribuição empírica dos dados, observou-se que boa parte das séries de milho, apresentaram-se com um certo grau de assimentria. Segundo Diggle et al. (2003), quando $\mathrm{Y}_{i}, \mathrm{i}=1, \ldots, n$, é contínua mas o ajuste de um modelo Gaussiano não parecer razoável, então a inclusão de um parâmetro extra $\lambda^{e}$ permite atingir certo grau de flexibilidade, definindo desta forma, uma transformação Box-Cox. Assim, os dados $\mathrm{y}_{i}$ podem ser transformados, através de $y_{i}^{*}=\left(y_{i}^{\lambda^{e}}-1\right) / \lambda^{e}$, se $\lambda^{e} \neq 0$ e log $\mathrm{y}_{i}$, se $\lambda^{e}=$ 0 . Consequentemente, $y_{i}^{*}$ será a realização de um modelo Gaussiano.

O parâmetro lambda foi estimado através do método da verossimilhança perfilhada. Neste ponto ressalta-se que apenas três valores de lambda foram utilizados na transformação dos dados, de acordo com o intervalo de confiança a 95\%. São eles, lambda igual a zero (transformação logarítmica), 0,5 (raiz quadrada) e 1 (nenhuma transformação). 
A partir das metodologias consideradas no capítulo 4, neste capítulo serão apresentados os respectivos resultados e sua subsequente discussão.

\subsection{Resultados da análise paramétrica e não-paramétrica na determinação da taxa atuarialmente justa de prêmio}

Nesta subseção serão analisados os resultados provenientes do item 4.1, referente a análise paramétrica e não-paramétrica dos dados de produtividade, bem como a discussão dos resultados.

\subsubsection{Análise dos dados e precificação de um contrato de seguro agrícola}

Em razão da série de produtividade utilizada neste trabalho ser relativamente curta e tendo em vista a sensibilidade e a estabilidade dos métodos não paramétricos a pequenas amostras, utilizar-se-á as informações provenientes dos municípios vizinhos $^{214}$ para se tentar reduzir as diferenças existentes entre os municípios.

Desta forma, incorporou-se as observações dos $j$-ésimos municípios vizinhos em relação ao $i$-ésimo município central, a fim de aumentar o número de

\footnotetext{
${ }^{214}$ Considera-se como municípios vizinhos não apenas aqueles adjacentes ao município central $i$, mas todos aqueles em que se encontram a uma certa distância $d$ de $i$, ou em outras palavras, considerou-se a distância $d$ como igual ao raio de uma circunferência. Assim, todos aqueles municípios em que o centróide se localizar dentro da circunferência serão considerados vizinhos a $i$.
} 
observações utilizadas para se estimar a densidade da produtividade condicional. Assim, para um grupo de $m$ municípios vizinhos atribui-se os seguintes pesos ao município central e aos vizinhos, respectivamente, $(m+1) /(2 m+1)$ e $1 /(2 m+1)$.

$\mathrm{Na}$ análise serão considerados municípios situados a 30 e 40 milhas, aproximadamente, 48 e 64 kilômetros distantes a um determinado município central.

Possíveis diferenças na taxa de prêmio serão analisadas, posteriormente, tendo em vista a distância escolhida para a determinação dos municípios vizinhos.

A seguir serão analisadas as densidades dos municípios com maiores valores de produção média durante o período de 1998 a 2002, para as culturas do milho, soja e trigo no Estado do Paraná.

A figura 65, abaixo, mostra as densidades não-paramétricas para os municípios com maior representatividade no Estado do Paraná, em termos de produção, em toneladas. 
Milho $\mathrm{d}=30$ milhas

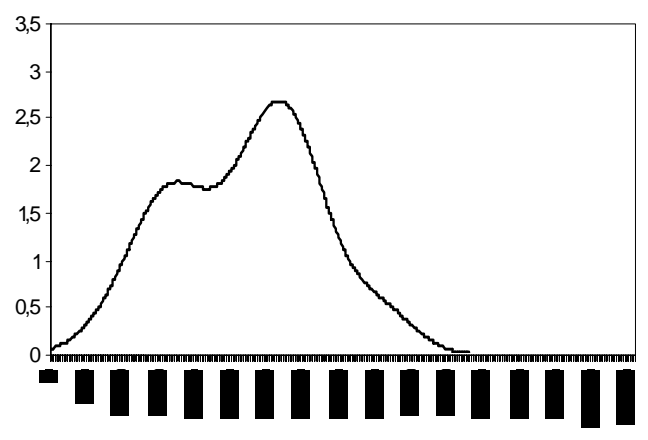

Soja d $=30$ milhas

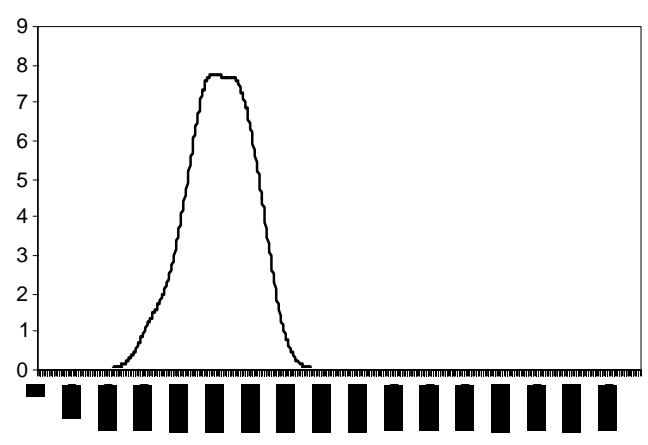

Trigo $\mathrm{d}=30$ milhas

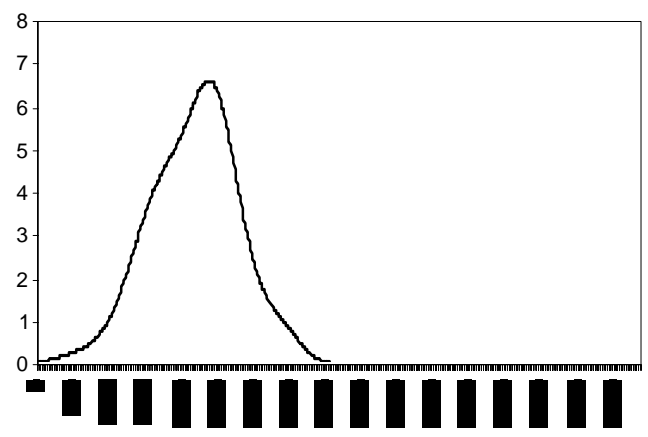

Milho $\mathrm{d}=40$ milhas

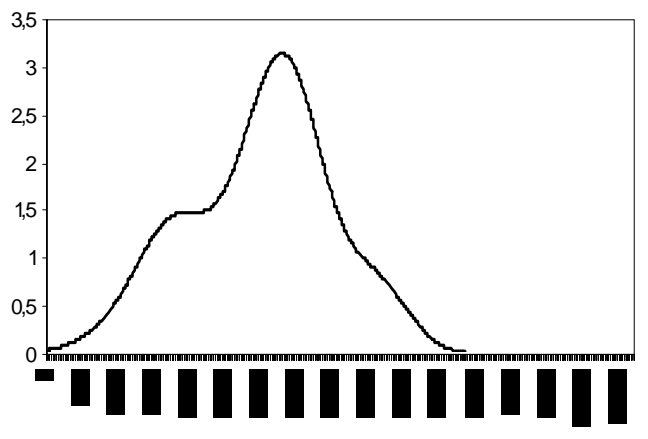

Soja $\mathrm{d}=40$ milhas

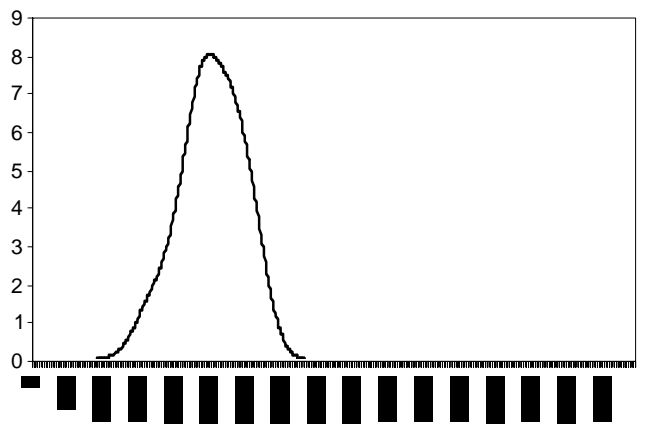

Trigo $\mathrm{d}=40$ milhas

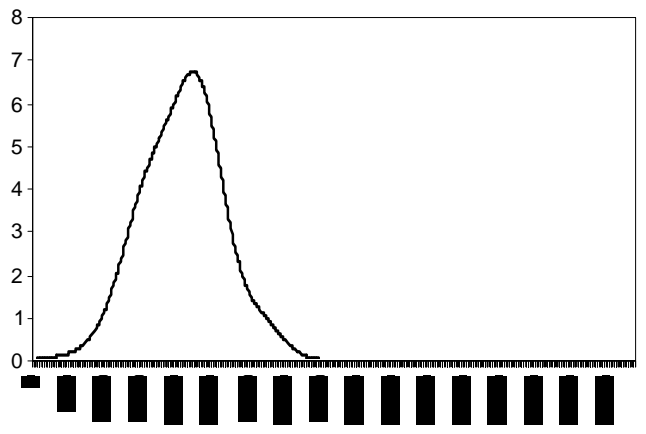

Figura 65 - Comparação das densidades não-paramétricas $\left(10^{-4}\right)$ para as culturas do milho, soja e trigo, em função da distância d escolhida

Fonte: resultados da pesquisa 
Para a cultura do milho, o município com maior produção média é Guarapuava, com pouco menos de 172 mil ton. Para a cultura da soja e trigo, os municípios são, respectivamente, Cascavel, com pouco mais de 210 mil ton. e Tibagi, com aproximadamente, 60 mil ton.

A fim de comparar o efeito da escolha da distância d na estimação das densidades plotou-se os gráficos para as distâncias de 30 e 40 milhas para as respectivas culturas e municípios, utilizando-se as séries não corrigidas para a heteroscedasticia.

Pela figura, percebe-se que existem diferenças significativas na concentração de massa na calda inferior, em função da escolha da distância. Diferenças mais pronunciadas podem ser observadas no caso do milho e trigo.

No primeiro caso, a probabilidade da produtividade ser menor do que certo valor de garantia é maior no caso em que $d=30$ do que quando $d=40$. O mesmo ocorre no caso do trigo. Lembrando que a taxa de prêmio é diretamente proporcional a este valor de probabilidade, consequentemente, espera-se que maiores taxas serão encontradas para o milho e trigo, nos municípios de Guarapuava e Tibagi, em relação a soja. De fato isto ocorre como será visto em seção posterior.

Algumas características interessantes podem ser observadas nas densidades, na figura 65. A bimodalidade é bastante pronunciada no caso do milho, de modo que espera-se que altas produtividades sejam mais frequentes do que baixas produtividades para o municípios de Guarapuava.

Para a soja, nota-se a bimodalidade próximos a média, para $\mathrm{d}=30$, mas não quando $\mathrm{d}=40$ e a baixa variância, sugerindo que valores próximos a média são mais prováveis do que valores extremos.

O trigo no município de Tibagi, mostra pouca evidência de bimodalidade, mas percebe-se que para níveis de cobertura mais elevadas, a taxa de prêmio tende a ser mais alta do que para níveis de cobertura mais baixas, em função da probabilidade de perda ser maior quando $\mathrm{d}=30$.

Além da distância escolhida para se levar em conta a variabilidade da produtividade nos municípios vizinhos, outro fator deve ser investigado na pesquisa. $\mathrm{O}$ 
fato da série estudada ser relativamente curta, cria dificuldades no momento da verificação da presença de heteroscedasticia.

Desta forma, nos próximos parágrafos serão investigados as densidades em dois casos. O primeiro deles quando as séries são ajustadas através da correção dos resíduos, obtendo-se erros proporcionais e o segundo quando as séries são analisadas sem qualquer tipo de correção para a heteroscedasticia, ou seja, considera-se que as séries são homoscedásticas.

Nos dois casos as séries foram corrigidas para a tendência e normalizadas, de modo a refletirem os níveis de tecnologia de 2002.

Pela figura 66, abaixo, nota-se que para o milho, no município de Guarapuava, a bimodalidade é aparente nos dois casos, mas pouca diferença existe na probabilidade de perda, sendo que para a série corrigida tal probabilidade é um pouco menor que no outro caso.

No caso da soja, as diferenças são mais aparentes. Para a série não corrigida, a densidade tem forma mais achatada que a densidade obtida com a série corrigida, sendo que esta última apresenta sinais de bimodalidade e possui variância menor.

Além disso, percebe-se que produtividades acima da média, em torno de $2514 \mathrm{~kg} / \mathrm{ha}$, para o município de Cascavel, são bem mais frequentes do que produtividades baixas, consequentemente, para este município espera-se taxas de prêmio baixas em relação a outros municípios.

Para o trigo, no município de Tibagi, nota-se alguma diferença na probabilidade de perda para diferentes níveis de cobertura entre os dois gráficos. As probabilidades de perda para os níveis de cobertura de 70, 80 e $90 \%$ são para a série não corrigida $0,21,0,32$ e 0,45 e igual a $0,15,0,23$ e 0,33 para a série corrigida. Percebe-se, portanto, que o gráfico da esquerda apresenta valores em torno de $30 \%$ maiores do que a série corrigida. 
Milho: série não corrigida

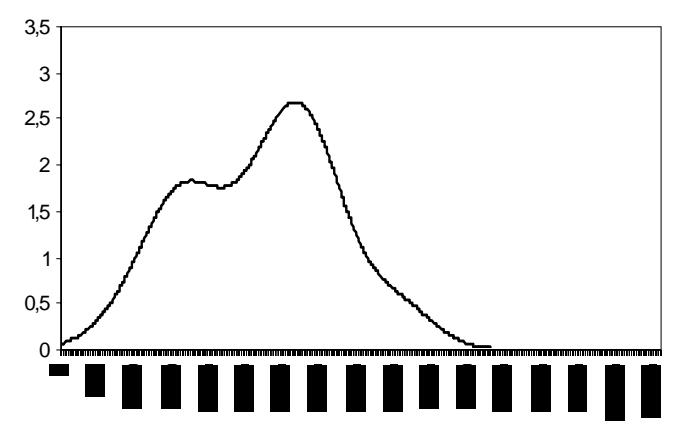

Soja: série não corrigida

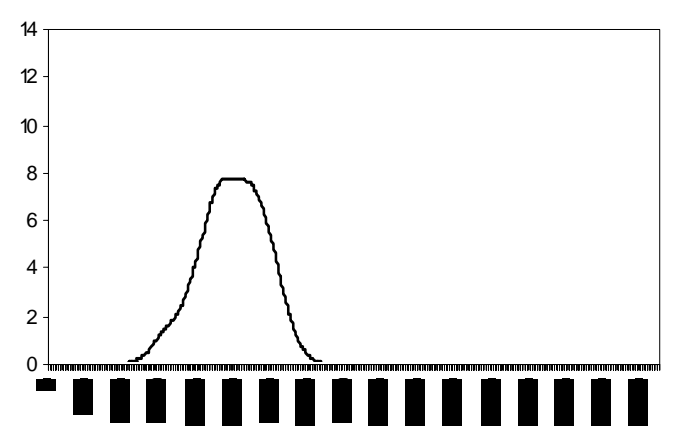

Trigo: série não corrigida

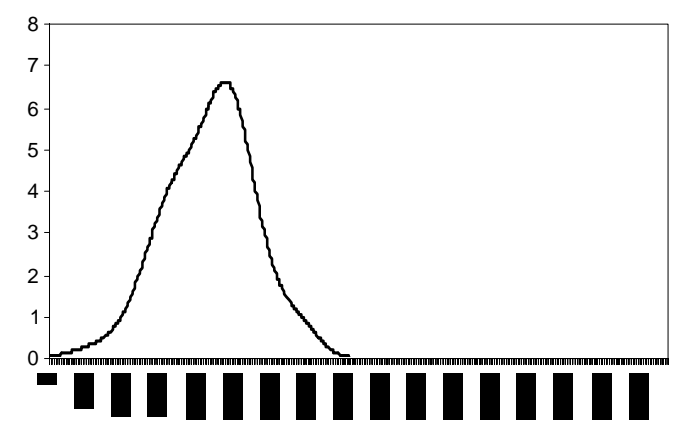

Milho: série corrigida

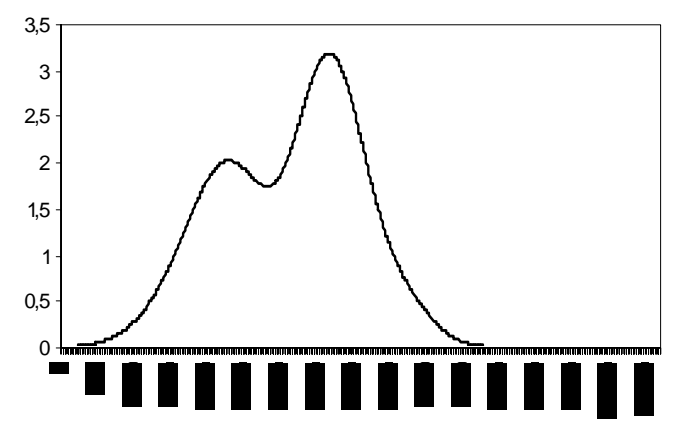

Soja: série corrigida

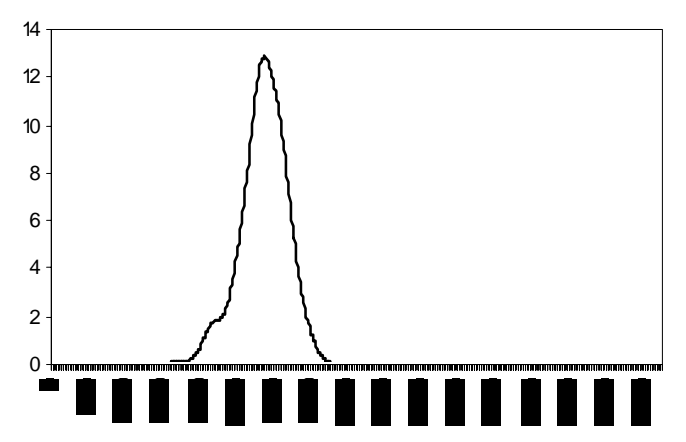

Trigo: série corrigida

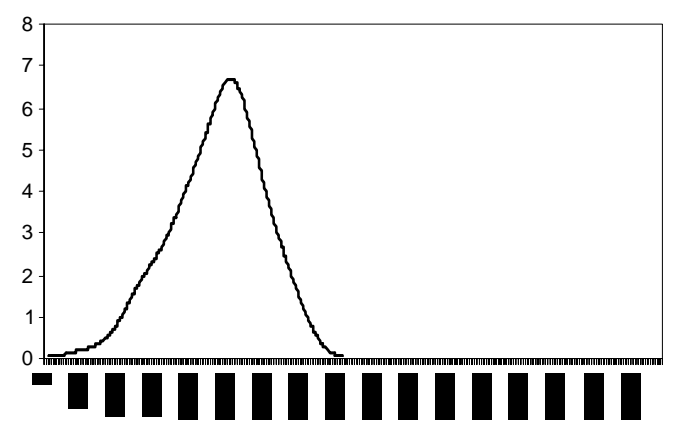

Figura 66 - Comparação das densidades não-paramétricas $\left(10^{-4}\right)$ para as culturas do milho, soja e trigo, das séries corrigidas e não corrigidas para a heteroscedasticia $(\mathrm{d}=30)$

Fonte: resultados da pesquisa 
A probabilidade da perda pode ser calculada através da área sob a curva menor do que a produtividade gararantida. Desta forma, se definirmos a produtividade crítica como um percentual $\alpha$, tal que $0<\alpha<1$, da produtividade esperada $y^{e}$, então a probabilidade da produtividade ser menor do que $\alpha y^{e}$ será calculada através da área sob a densidade, numericamente estimada através da regra do trazepóide. A taxa de prêmio será dada pela equação 73 (Goodwin e Ker, 1998):

$$
\text { Taxa de Prêmio }=\frac{F_{Y}\left(\alpha y^{e}\right) E_{Y}\left[\alpha y^{e}-\left(Y \mid y<\alpha y^{e}\right)\right]}{\alpha y^{e}}
$$

onde $E$ é o operador de esperança e $F$ a distribuição cumulativa da produtividade.

As taxas de prêmio serão apresentadas a seguir, separadas por métodos estatísticos utilizados, tendo em vista as séries ajutadas, não ajustadas, as distâncias relativas ao município central e os níveis de cobertura para os maiores municípios produtores de soja, milho e trigo, ou seja, Cascavel, Guarapuava e Tibagi, respectivamente.

Nas tabelas 11 a 16, abaixo estão representadas as taxas de prêmios para as culturas da soja, milho e trigo, para diferentes níveis de cobertura. Para comparar as taxas calculadas pelo método empírico e pela abordagem não-paramétrica, ajustou-se as séries de dados através da abordagem paramétrica, especificamente, a distribuição Normal e Beta $^{215}$. As taxas estão divididas, de acordo com a distância utilizada no alisamento das taxas e a correção ou não à heteroscedasticia.

As tabelas 11 e 12, abaixo mostram as taxas para a cultura da soja no município de Cascavel. Pelas tabelas nota-se que as taxas Beta são bem maiores do que as taxas calculadas através do método empírico, não-paramétrico e Normal, sugerindo

\footnotetext{
215 Daqui para frente, as taxas calculadas seguindo a pressuposição de que a produtividade segue uma distribuição Normal e Beta serão denominadas, respectivamente, taxas Normal e taxas Beta.
} 
que a produtividade da soja, no município de Cascavel, se for ajustada uma distribuição Beta aos dados apresenta assimetria positiva.

Além disso, nota-se que as taxas para a série não-ajustada apresentaramse bem maiores do que as taxas para a série ajustada, para ambas as distâncias de 30 e 40 milhas, sugerindo que erros no diagnóstico e correção da heteroscedasticia podem afetar sobremaneira o cálculo da taxa de prêmio.

A escolha da distância também exerce elevada influência no cálculo da taxa de prêmio. Percebe-se que, se distâncias maiores em relação ao centróide de um município forem consideradas, a taxa será influenciada pelos municípios mais afastados ao municípios central e nesse caso, especificamente, quanto maior a distância maior a taxa de prêmio para ambas as séries.

A tabela 11, abaixo revela que as taxas para a série ajustada são, em média, 35\% maiores para $d=40$ em relação a $d=30$ e 12\% maiores para a série nãoajustada. Na tabela 12, abaixo as taxas são maiores, em média, respectivamente, para as séries ajustada e não-ajustada, 28 e $18 \%$.

Tabela 11. Taxas de prêmio (\%) para soja, no município de Cascavel, calculadas pelo método empírico

\begin{tabular}{|c|c|c|c|c|c|c|}
\hline \multirow{2}{*}{$\mathbf{N C}$} & \multicolumn{2}{|c|}{ Série Ajustada } & \multicolumn{2}{c|}{ Série Não-ajustada } & \multirow{2}{*}{ Normal } & \multirow{2}{*}{ Beta } \\
\cline { 2 - 5 } & $\mathbf{d}=\mathbf{3 0}$ & $\mathbf{d}=\mathbf{4 0}$ & $\mathbf{d}=\mathbf{3 0}$ & $\mathbf{d}=\mathbf{4 0}$ & & \\
\hline 70 & 0,0513 & 0,1169 & 0,6120 & 0,6759 & 0,3501 & 1,1364 \\
\hline 75 & 0,0830 & 0,2118 & 1,0840 & 1,1121 & 0,6965 & 1,8961 \\
\hline 80 & 0,3813 & 0,5099 & 1,4970 & 1,6848 & 1,2288 & 2,9264 \\
\hline 85 & 0,7263 & 0,9049 & 2,0600 & 2,5404 & 1,9712 & 4,4149 \\
\hline 90 & 1,3001 & 1,5077 & 2,9120 & 3,5944 & 3,1059 & 6,3614 \\
\hline
\end{tabular}

Fonte: resultados da pesquisa 
Tabela 12. Taxas de prêmio (\%) para soja, no município de Cascavel, calculadas pelo método não-paramétrico

\begin{tabular}{|c|c|c|c|c|c|c|}
\hline \multirow{2}{*}{$\mathbf{N C}$} & \multicolumn{2}{|c|}{ Série Ajustada } & \multicolumn{2}{|c|}{ Série Não-ajustada } & \multirow{2}{*}{ Normal } & \multirow{2}{*}{ Beta } \\
\cline { 2 - 5 } & $\mathbf{d}=\mathbf{3 0}$ & $\mathbf{d}=\mathbf{4 0}$ & $\mathbf{d}=\mathbf{3 0}$ & $\mathbf{d}=\mathbf{4 0}$ & & \\
\hline 70 & 0,0689 & 0,1400 & 0,7198 & 0,8979 & 0,3501 & 1,1364 \\
\hline 75 & 0,1807 & 0,2819 & 1,1814 & 1,4252 & 0,6965 & 1,8961 \\
\hline 80 & 0,4244 & 0,5561 & 1,7041 & 2,0766 & 1,2288 & 2,9264 \\
\hline 85 & 0,8518 & 1,0213 & 2,4641 & 3,0094 & 1,9712 & 4,4149 \\
\hline 90 & 1,5062 & 1,7025 & 3,4764 & 4,2388 & 3,1059 & 6,3614 \\
\hline
\end{tabular}

Fonte: resultados da pesquisa

As tabelas 13 e 14, abaixo revelam as taxas para a cultura do milho no município de Guarapuava. Contrariamente ao caso da soja, no caso do milho as taxas são menores quanto maior a distância considerada na série ajustada, mas o se mantém igual no caso da série não ajustada, apresentando valores bem superiores para $d=40$.

As taxas Normal se mostram menores do que as taxas Beta, revelando que a distribuição Beta é positivamente assimétrica, também neste caso. Além disso, quando se comparam as séries, nota-se que para a distância $d=30$, a série ajustada apresenta taxas maiores do que a série não-ajustada, para todos os níveis de cobertura, nas duas tabelas e tal comportamento se reverte quando $d=40$.

Nesta caso, as taxas para a série não-ajustada quando $d=40$ são maiores do que as taxas Beta para ambos os métodos. Isto sugere que especificações incorretas da forma paramétrica da distribuição podem afetar o cálculo da taxa de prêmio.

Em outras palavras, mesmo que a distribuição Beta possa apresentar assimetria positiva, a bimodalidade não é captada na abordagem paramétrica. Retomando a figura 66, ressalta-se que em função da bimodalidade, maior massa foi concentrada na calda esquerda da distribuição acarretando em taxas mais elevadas. 
Na tabela 13, abaixo observa-se que para a série ajustada, as taxas são maiores em média $21 \%$ para $d=30$ e tal aumento ocorre de maneira proporcional ao aumento do nível de cobertura. Na tabela 14 , abaixo tais taxas são em média $24 \%$ maiores para $\mathrm{d}=30$ considerando a série ajustada. Para a série não-ajustada, as taxas são maiores em média 46\% e 48\%, para d $=40$, respectivamente, para as tabelas 13 e 14 .

Tabela 13. Taxas empíricas de prêmio (\%) para milho, no município de Guarapuava

\begin{tabular}{|c|c|c|c|c|c|c|}
\hline \multirow{2}{*}{$\mathbf{N C}$} & \multicolumn{2}{|c|}{ Série Ajustada } & \multicolumn{2}{c|}{ Série Não-ajustada } & \multirow{2}{*}{ Normal } & \multirow{2}{*}{ Beta } \\
\cline { 2 - 5 } & $\mathbf{d}=\mathbf{3 0}$ & $\mathbf{d = 4 0}$ & $\mathbf{d = 3 0}$ & $\mathbf{d}=\mathbf{4 0}$ & & \\
\hline 70 & 3,224 & 2,260 & 2,7038 & 5,4815 & 2,083 & 3,635 \\
\hline 75 & 4,355 & 3,470 & 3,5492 & 6,8271 & 2,791 & 4,739 \\
\hline 80 & 5,797 & 4,960 & 4,2889 & 8,0417 & 3,778 & 6,217 \\
\hline 85 & 7,643 & 6,280 & 5,0048 & 9,1484 & 4,901 & 7,963 \\
\hline 90 & 9,403 & 7,450 & 6,3087 & 10,1873 & 6,330 & 9,815 \\
\hline
\end{tabular}

Fonte: resultados da pesquisa

Tabela 14. Taxas de prêmio (\%) para milho, no município de Guarapuava, calculadas pelo método não-paramétrico

\begin{tabular}{|c|c|c|c|c|c|c|}
\hline \multirow{2}{*}{$\mathbf{N C}$} & \multicolumn{2}{|c|}{ Série Ajustada } & \multicolumn{2}{c|}{ Série Não-ajustada } & \multirow{2}{*}{ Normal } & \multirow{2}{*}{ Beta } \\
\cline { 2 - 5 } & $\mathbf{d}=\mathbf{3 0}$ & $\mathbf{d = 4 0}$ & $\mathbf{d}=\mathbf{3 0}$ & $\mathbf{d}=\mathbf{4 0}$ & & \\
\hline 70 & 4,518 & 3,270 & 2,7993 & 6,4311 & 2,083 & 3,635 \\
\hline 75 & 5,706 & 4,280 & 3,6722 & 7,5549 & 2,791 & 4,739 \\
\hline 80 & 7,021 & 5,400 & 4,5412 & 8,6799 & 3,778 & 6,217 \\
\hline 85 & 8,431 & 6,540 & 5,5478 & 9,9206 & 4,901 & 7,963 \\
\hline 90 & 9,906 & 7,790 & 6,7250 & 11,2357 & 6,330 & 9,815 \\
\hline
\end{tabular}

Fonte: resultados da pesquisa 
As tabelas 15 e 16, abaixo revelam as taxas de prêmio para o trigo no município de Tibagi. Embora existam diferenças nas taxas, pode-se considerar que tais diferenças são menos expressivas do que no caso da soja e milho.

Comparando as duas séries, observa-se que as taxas para a série ajustada na tabela 15 são maiores para os níveis de cobertura de 70 e $75 \%$, para ambas as distâncias e menores para os níveis de cobertura restantes. Na tabela 16, as taxas obtidas através da série ajustada são menores, para todos os níveis de cobertura. Em relação as taxas Normal, as taxas Beta também são maiores. Neste caso, quando a distância é analisada, nota-se que ocorre o inverso da soja, ou seja, quanto maior a distância, menor será a taxa.

$\mathrm{Na}$ tabela 15 , as taxas para a série ajustada são em média $15 \%$ maiores para a distância $d=30$ em relação a $d=40$, além disso, a taxa aumenta de maneira decrescente quanto maior o nível de cobertura, ou seja, para os níveis de 70 a 90, as diferenças são, repectivamente, de 21, 18, 16, 13 e 9\%. O mesmo comportamento ocorre na tabela 16. As taxas para a série ajustada são, em média, 13\% maiores quando $d=30$ e tal aumento ocorre de maneira decrescente.

Analisando a série não-ajustada, nota-se que as taxas são maiores para d $=30$, em média 14 e $12 \%$, respectivamente, para as tabelas 15 e 16 .

Tabela 15. Taxas empíricas de prêmio (\%) para o trigo, no município de Tibagi

\begin{tabular}{|c|c|c|c|c|c|c|}
\hline \multirow{2}{*}{$\mathbf{N C}$} & \multicolumn{2}{|c|}{ Série Ajustada } & \multicolumn{2}{|c|}{ Série Não-ajustada } & \multirow{2}{*}{ Normal } & \multirow{2}{*}{ Beta } \\
\cline { 2 - 5 } & $\mathbf{d = 3 0}$ & $\mathbf{d}=\mathbf{4 0}$ & $\mathbf{d}=\mathbf{3 0}$ & $\mathbf{d}=\mathbf{4 0}$ & & \\
\hline 70 & 2,9897 & 2,3477 & 2,7410 & 2,1906 & 1,1889 & 2,4382 \\
\hline 75 & 3,7435 & 3,0671 & 3,6470 & 3,0301 & 1,7825 & 3,4711 \\
\hline 80 & 4,6911 & 3,9635 & 4,7255 & 4,1162 & 2,5453 & 4,7907 \\
\hline 85 & 5,7267 & 4,9860 & 6,0738 & 5,4861 & 3,5976 & 6,4816 \\
\hline 90 & 7,1103 & 6,4530 & 7,5325 & 6,9222 & 4,9642 & 8,4299 \\
\hline
\end{tabular}

Fonte: resultados da pesquisa 
Tabela 16. Taxas de prêmio (\%) para o trigo, no município de Tibagi, calculadas pelo método não-paramétrico

\begin{tabular}{|c|c|c|c|c|c|c|}
\hline \multirow{2}{*}{$\mathbf{N C}$} & \multicolumn{2}{|c|}{ Série Ajustada } & \multicolumn{2}{c|}{ Série Não-ajustada } & \multirow{2}{*}{ Normal } & \multirow{2}{*}{ Beta } \\
\cline { 2 - 6 } & $\mathbf{d}=\mathbf{3 0}$ & $\mathbf{d = 4 0}$ & $\mathbf{d = 3 0}$ & $\mathbf{d}=\mathbf{4 0}$ & & \\
\hline 70 & 3,4987 & 2,8571 & 3,7526 & 3,1213 & 1,1889 & 2,4382 \\
\hline 75 & 4,3912 & 3,7330 & 4,7152 & 4,0751 & 1,7825 & 3,4711 \\
\hline 80 & 5,4253 & 4,6800 & 5,8450 & 5,1020 & 2,5453 & 4,7907 \\
\hline 85 & 6,5087 & 5,8878 & 7,0129 & 6,4051 & 3,5976 & 6,4816 \\
\hline 90 & 7,8486 & 7,2912 & 8,4467 & 7,8854 & 4,9642 & 8,4299 \\
\hline
\end{tabular}

Fonte: resultados da pesquisa

Observando as tabelas 11 a 16, nota-se que as taxas calculadas pela abordagem não-paramétrica são maiores do que as taxas empíricas. Isto devido ao fato das taxas não-paramétricas serem versões alisadas das taxas empíricas. O processo de alisamento tende a adicionar massa na calda inferior da distribuição e, consequentemente, aumentar a taxa de prêmio, neste caso.

Apenas a nível ilustrativo serão comparadas as taxas de prêmio dos contratos ofercidos pela COSESP, para a soja e milho, nos municípios de Cascavel e Guarapuava.

É importante ressaltar que o seguro da COSESP tem como âmbito da cobertura o orçamento de custeio direto das culturas periódicas, portanto não é um seguro de produtividade, apesar do mecanismo de compensação estar atrelado a redução da produção em relação a produção esperada.

Embora o tipo de contrato abordado nesta pesquisa seja diferente do contrato ofertado pela COSESP, esta última tem como base de cálculo do prêmio as produtividades regionais ou municipais do IBGE. Desta forma, para a soja no município de Cascavel e para o milho em Guarapuava, as taxas são, respectivamente, de 4 e 4,5\%. 
Nota-se que para a soja, as taxas calculadas pela abordagem nãoparamétrica são, em média, iguais a 1,6 e 3,9\%, respectivamente, para as séries ajustada e não-ajustada, para o nível de cobertura de $90 \%$. Para o milho, as taxas médias são iguais a 8,85 e $8,95 \%$, bem maiores do que as taxas fixadas pela COSESP.

\subsection{Resultados do modelo espaço-temporal}

Os resultados obtidos, de acordo com a metodologia desenvolvida na subseção 4.2, serão mostrados e discutidos nesta subseção.

\subsubsection{Análise empírica}

Para aplicação da metodologia discutida na subseção 4.2, optou-se por utilizar os dados de produtividade municipal provenientes do IBGE (Instituto Brasileiro de Geografia e Estatística), correspondentes ao período de 1990 a 2002, para a cultura do milho no estado do Paraná, localizada na região Sul do Brasil, conforme apontado na subseção 4.1.1.

O estado do Paraná é o maior produtor de milho no país, com um total produzido em 2002 igual a 9.797 .816 toneladas, pouco mais de $27 \%$ de toda produção brasileira e quarto maior em termos de produtividade média do milho (3.987 Kilogramas por hectare) neste mesmo ano.

O estado abrange 399 municípios, sendo que destes apenas 290 municípios apresentam 13 anos de observações. Deste modo, procedeu-se a análise apenas com os municípios com o maior número de observações. A nível ilustrativo, a análise dos 5 municípios com maior produtividade média foi realizada, ou seja, Castro (6142), Ponta Grossa (5629), Marilândia do Sul (5488), Tibagi (5346), Catanduvas (4923) e Rolândia (4797). 
Inicialmente, a análise empírica será realizada tendo em vista a escolha do modelo. Dentre os diversos modelos ajustados (25 ao todo), apresentar-se-á apenas os 10 melhores, de acordo com o critério acima, apresentando os detalhes de cada modelo.

Pela tabela 17, abaixo, percebe-se que todos os modelos apresentam a componente de tendência estocástica, de modo que fica perceptível que o efeito temporal é necessário na análise.

Tabela 17. Escolha dos modelos

\begin{tabular}{ccc}
\hline $\mathrm{M}$ & $\mathrm{D}_{\mathrm{m}}$ & Modelo para $u_{i t}$ \\
\hline 1 & 667800 & $\rho_{i} y_{t-1}+\zeta_{1_{i}}+\zeta_{2_{i}}^{C} t^{*}$ \\
2 & 673200 & $\rho_{i} y_{t-1}+\zeta_{1_{i}}^{C}+\zeta_{2_{i}}^{C} t^{*}$ \\
3 & 700100 & $\mathrm{R}-\mathrm{W}$ \\
4 & 728500 & $\rho_{i} y_{t-1}+\zeta_{1_{i}}+\zeta_{2_{i}} t^{*}+v_{i}$ \\
5 & 736800 & $\mathrm{AR}(1)$ \\
6 & 737900 & $\rho_{i} y_{t-1}+\xi_{i}$ \\
7 & 739900 & $\rho_{i} y_{t-1}+\xi_{i}^{t}$ \\
8 & 751400 & $\rho_{i} y_{t-1}+\zeta_{1_{i}}+\zeta_{2_{i}} t^{*}+\xi_{i}^{t}$ \\
9 & 751700 & $\rho_{i} y_{t-1}+\zeta_{1_{i}}+\zeta_{2_{i}} t^{*}+\xi_{i}$ \\
10 & 761300 & Modelo permutável \\
\hline
\end{tabular}

Fonte: resultados da pesquisa

Pela tabela, nota-se que o melhor modelo, ou seja, aquele que minimiza o erro predito quadrático apresenta a componente estocástica e a determinística. Além disso, o parâmetro de intercepto foi permitido variar de município para município e ao parâmetro de inclinação foi atrelado a dependência espacial. 
A diferença entre os modelos 1 e 2 é devido à distribuição à priori designada aos $\zeta$ 's. O superescrito $C$ indica que uma priori condicional auto-regressiva foi designada ao parâmetro. Caso contrário, $\zeta$ recebe uma priori Normal.

Comparando-se os modelos 4 e 9, percebe-se que a efeito de heterogeneidade apresenta melhores resultados do que o efeito clustering e a inclusão da variável latente correlacionada espacialmente variando no tempo apresenta $D_{m}$ maior do que se considerar o efeito clustering constante no decorrer dos anos, como pode ser visto nos modelos 6 e 7 .

Com a inclusão da componente determinística, o efeito clustering variando no tempo se torna levemente superior a este mesmo efeito constante no tempo (modelos 8 e 9), ou seja, $D_{8}<D_{9}$.

Pela tabela 17, percebe-se que não foram incluídos os modelos de tendência determinística quadrática e de mistura de Normais, que aprentaram resultados insatisfatórios, levando-se em conta o referido critério.

Tendo em vista que o melhor modelo foi aquele apresentando a componente temporal determinística e estocástica conjuntamente, dar-se-á um maior detalhamento deste modelo. Inicialmente, para melhor visualização e compreensão, o modelo 1 será escrito na forma gráfica, de acordo com a figura 67.

Os nós correspondem a variáveis estocásticas, os retângulos menores as constantes, as setas com retas simples e paralelas representam, respectivamente, parâmetros das distribuições e ligações lógicas entre as variáveis. Os índices $i$ e $t$ nos retângulos maiores denotam, respectivamente, as variáveis de espaço e tempo.

O parâmetro $\zeta_{2}$, formado pela variável estocástica $c$ e por $\kappa$ (kappa), foi redefinido, de modo a ser recentralizado. A primeira recebe uma distribuição a priori Normal e a segunda uma priori condicional auto-regressiva.

As constantes atreladas a zeta, denominadas neigh, wei, e num são, respectivamente, os j-ésimos municípios adjacentes a determinado município $i$, os pesos correspondentes aos municípios vizinhos, ou seja, municípios vizinhos recebem valor 
igual a 1 e 0 , caso contrário, e a soma dos municípios adjacentes a um certo município. A precisão da variável $\kappa$ foi atrelada uma distribuição à priori Gamma.

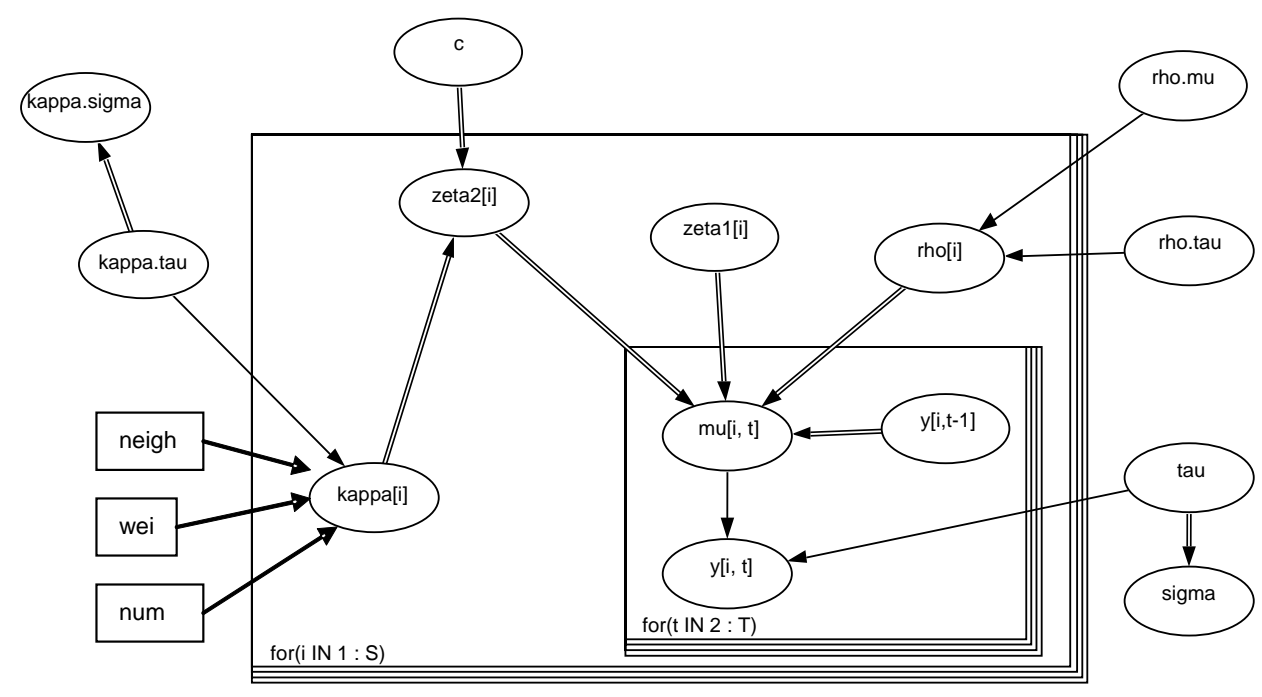

Figura 67 - Modelo 1 expresso graficamente

Fonte: resultados da pesquisa

Três cadeias foram rodadas para verificar a mistura das sequências. Para todos os parâmetros, verificou-se o diagnóstico gráfico de convergência e constatou-se que todos apresentaram boa convergência e mistura.

A seguir, na figura 68 , é mostrado a decomposição de $u_{i t}$, de acordo com o modelo 1, em sua componente temporal, determinística e estocástica, para os municípios de Castro, Ponta Grossa, Marilândia do Sul, Tibagi, Catanduvas e Rolândia. Percebe-se que nos cinco primeiros municípios, o termo estocástico tem peso maior na composição de $u_{i t}$. Os resíduos evoluem ao redor de zero para os seis municípios. 

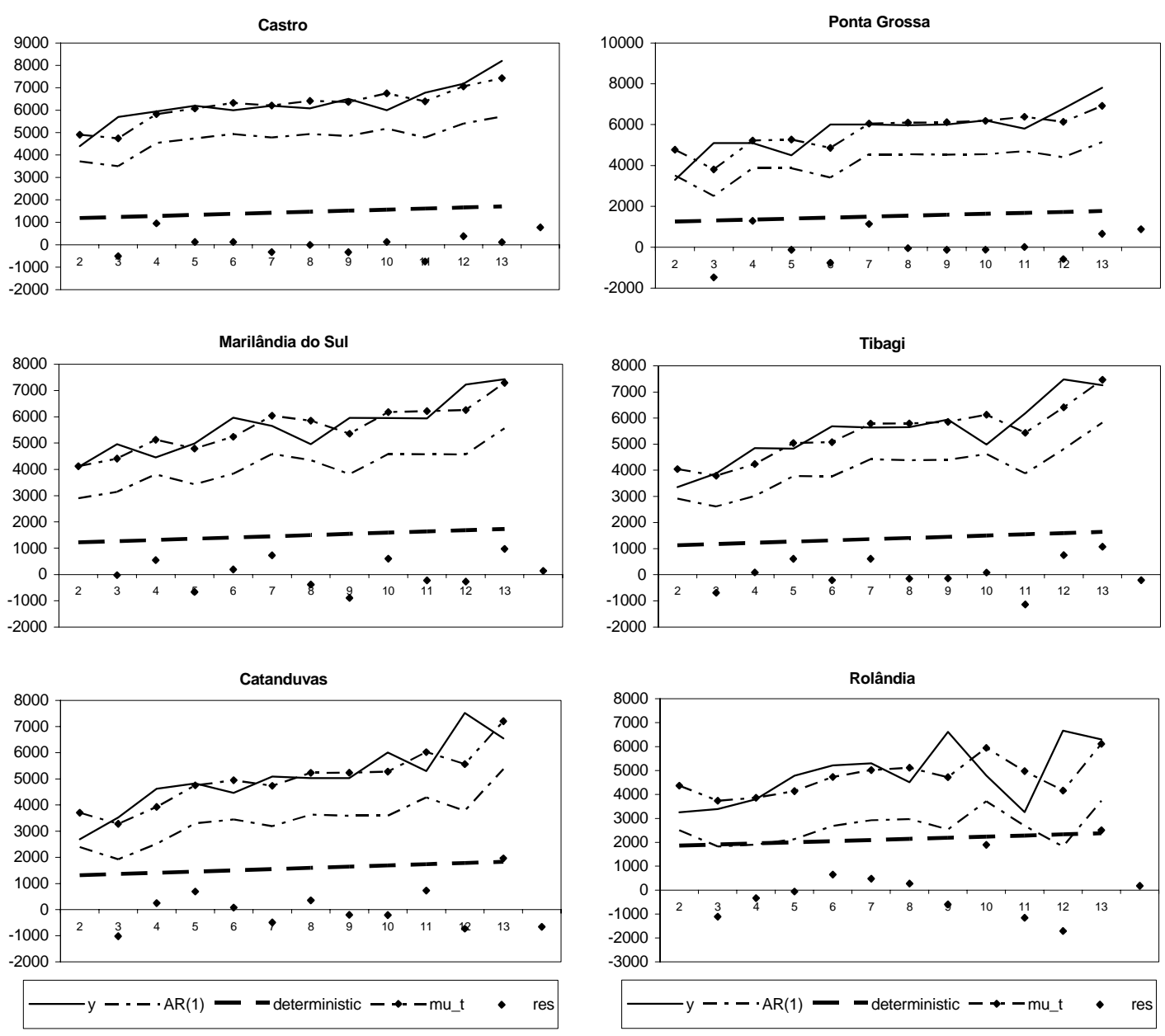

Figura 68 - Decomposição de $u_{i t}$ em suas componentes determinística e estocástica Fonte: resultados da pesquisa

Como pode ser visto na figura 69 , abaixo a probabilidade dos parâmetros $\zeta_{1}, \zeta_{2}$ e $\rho$ serem 0 é praticamente nula. Desta forma, confirma-se que de fato o termo de inclinação da componente determinística é diferente de zero e os parâmetros de correlação foram, em média, igual a 0,73 para estes seis municípios. 
$\zeta_{1}$
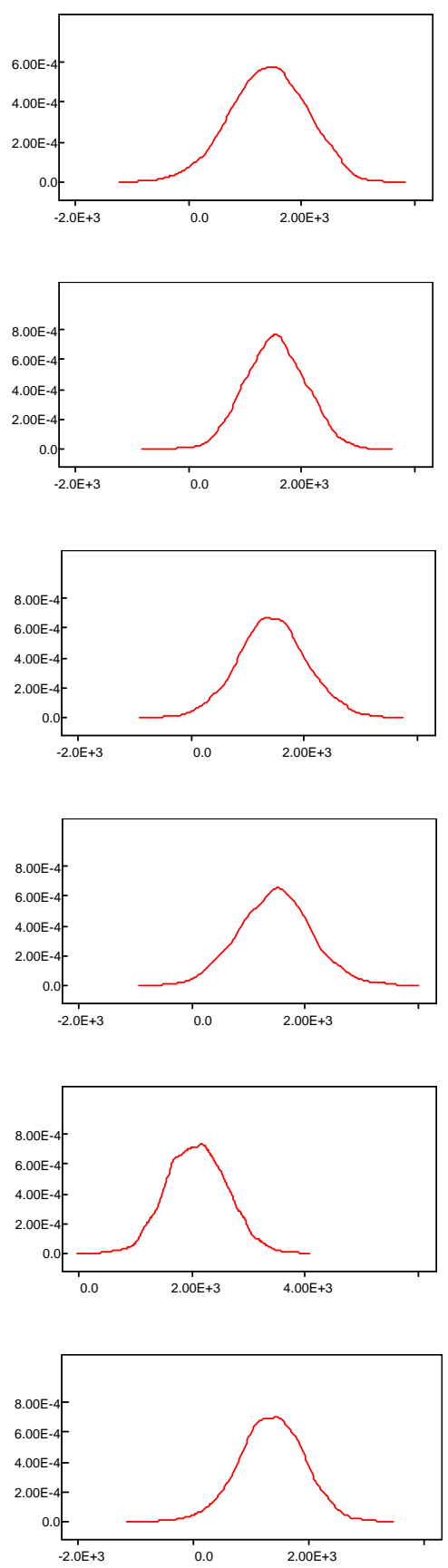

$\zeta_{2}$
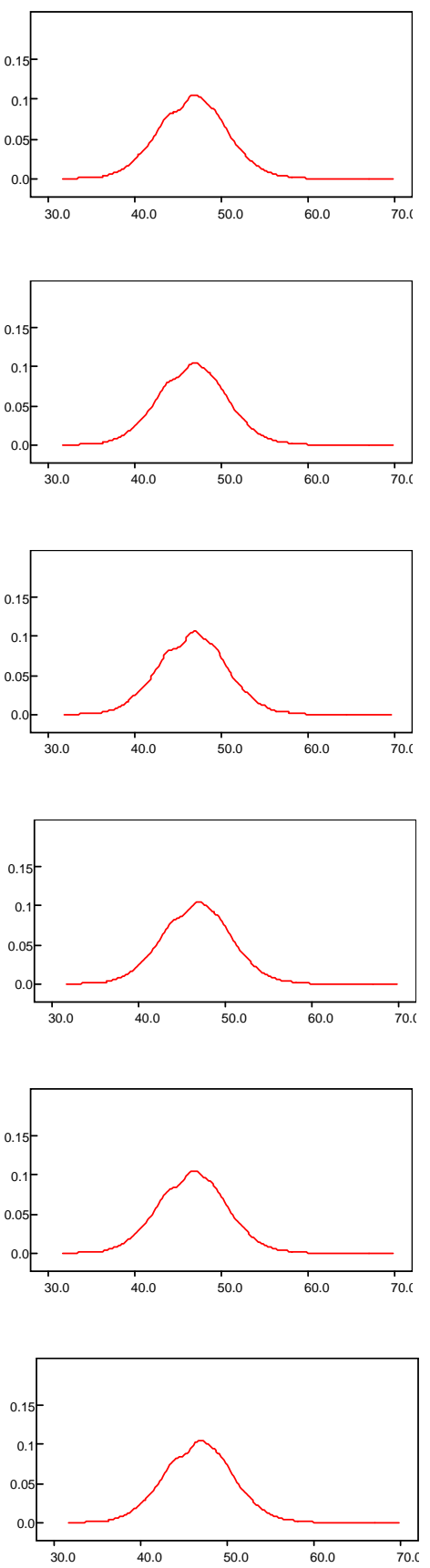
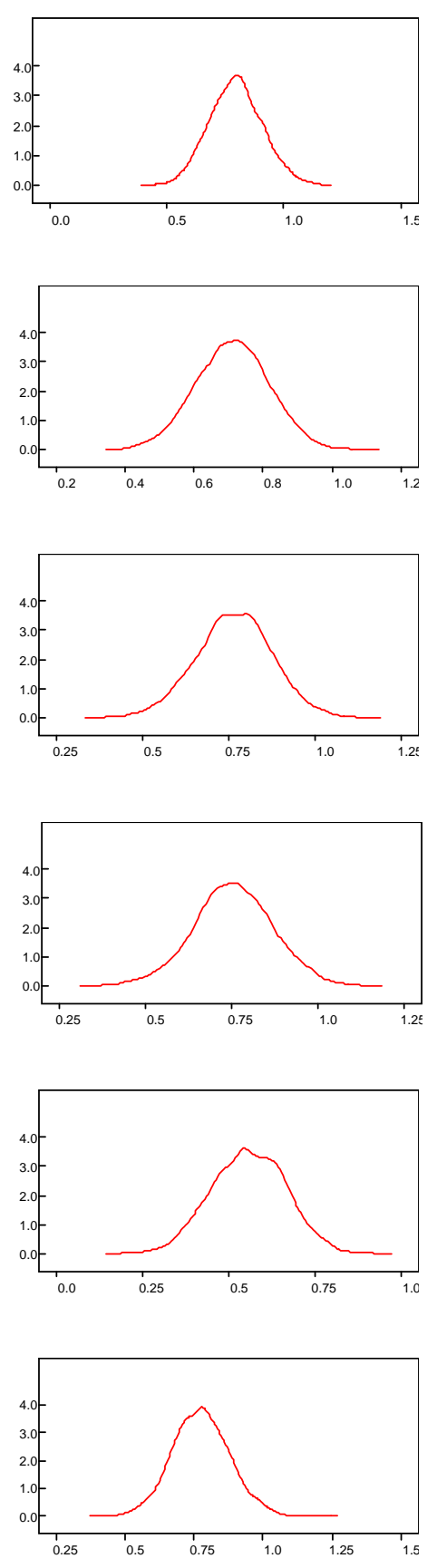

Figura 69 - Densidades a posteriori de $\zeta_{1}, \zeta_{2}$ e $\rho$, respectivamente, para os municípios de

Castro, Ponta Grossa, Marilândia do Sul, Tibagi, Catanduvas e Rolândia

Fonte: resultados da pesquisa 
Devido as séries serem relativamente curtas, não foram realizadas correções para a heteroscedasticia. Supos-se que as séries são homoscedásticas. Se as séries fossem mais longas, um procedimento que poderia ser utilizado para verificar a heteroscedasticia seria atrelar ao parâmetro de precisão tau (figura 67) os índices $i$ e $t$, ou seja, fazer com que variasse no tempo e para cada município e, posteriormente, monitorar tal parâmetro para verificar a variação na precisão e realizar as devidas correções, quando necessário.

A seguir, mostra-se na tabela 18 , abaixo os valores de produtividade preditos, seus respectivos desvios-padrões e percentis 5, 50 e 95\%. Percebe-se que a variância aumenta conforme aumenta-se o lag de tempo.

Tabela 18. Valores preditos da produtividade, desvio padrão e percentis 5, 50 e 95\%, para os municípios selecionados, nos anos de 2003 e 2004

\begin{tabular}{ccccccc}
\hline \multirow{2}{*}{ Município } & Ano & $\begin{array}{c}\text { Produtiv. } \\
\text { predita }\end{array}$ & Desvio-padrão & 0,05 & mediana & 0,95 \\
& 2003 & 8301 & 791 & 6990 & 8303 & 9591 \\
Castro & 2004 & 8455 & 1114 & 6647 & 8443 & 10280 \\
& 2003 & 6553 & 760 & 5296 & 6550 & 7793 \\
\multirow{3}{*}{ Ponta Grossa } & 2004 & 6638 & 1008 & 5021 & 6628 & 8338 \\
\multirow{3}{*}{ Marilândia do Sul } & 2003 & 7499 & 786 & 6208 & 7492 & 8784 \\
\multirow{2}{*}{ Tibagi } & 2004 & 7624 & 1074 & 5883 & 7614 & 9405 \\
& 2003 & 7730 & 793 & 6419 & 7733 & 9019 \\
Catanduvas & 2004 & 7779 & 1094 & 6035 & 7753 & 9613 \\
& 2003 & 5968 & 758 & 4716 & 5972 & 7195 \\
Rolândia & 2004 & 5833 & 903 & 4350 & 5813 & 7316 \\
& 2003 & 7336 & 777 & 6068 & 7342 & 8615 \\
& 2004 & 7461 & 1079 & 5745 & 7433 & 9280 \\
\hline
\end{tabular}

Fonte: resultados da pesquisa 


\subsubsection{Aplicação: precificação de um contrato de seguro agrícola}

A correta precificação de um contrato é essencial para a existência de um mercado de seguro agrícola. Taxas de prêmio mais altas selecionam apenas aqueles mais propensos a demandar pelo contrato, que são os indivíduos do grupo de alto risco.

Consequentemente, manter um contrato de seguro apenas para indivíduos que tem maior propensão a receber a indenização não torna o negócio atrativo para as seguradoras. Tal problema é conhecido no mercado segurador como seleção adversa e na literatura de economia do seguro, como informação oculta.

Desta forma, a taxa de prêmio $(P R)$ será calculada levando-se em conta certo percentual $\alpha$, tal que $0 \leq \alpha \leq 1$, da produtividade esperada $y^{e}$. Relembrando que a taxa de prêmio é dada pela eq. (73):

Taxa de Prêmio $(P R)=\frac{F_{Y}\left(\alpha y^{e}\right) E_{Y}\left[\alpha y^{e}-\left(Y \mid y<\alpha y^{e}\right)\right]}{\alpha y^{e}}$

onde $E$ é o operador de esperança e $F$ a distribuição cumulativa da produtividade.

A partir da equação 73, acima derivar-se-á a taxa de prêmio de uma maneira um pouco diferente. Se $y$ for reparametrizado, de forma que, $y^{*}=y / \alpha y^{e}$, então a eq. 73 será:

$$
P R=P\left(y^{*}<1\right) E_{y *}\left[1-\left(y^{*} \mid y^{*}<1\right)\right]
$$

Percebe-se que o suporte da variável aleatória $Y$ permanece inalterada nesta mudança. Se considerarmos que $w=1-y^{*}$, então a equação 74 poderá ser reescrita, de tal forma que:

$$
\begin{aligned}
& P R=P(w>0)\left[1-E_{w}(1-w \mid w>0)\right] \\
& \left.P R=P(w>0) E_{w}[w \mid w>0)\right]
\end{aligned}
$$


Após algumas simplificações, a equação da taxa de prêmio se reduz a equação 76 :

$$
P R=\int w f(w) d w
$$

Colocada de outra maneira, a equação 76 pode ser vista como: $P R=$ $E[w \mathrm{I}(0<w<1)]$. Nota-se que, em função da mudança de variável, o suporte também mudou, de forma que, $w$ se situa entre 0 e 1 .

As taxas de prêmio foram monitoradas através da média a posteriori de $w$. A tabela 19, abaixo mostra as taxas de prêmio calculadas para os municípios de Castro, Ponta Grossa, Marilândia do Sul, Tibagi, Catanduvas e Rolândia.

Tabela 19. Taxas de prêmio atuarialmente justas (\%), calculadas para os municípios de Castro, Ponta Grossa, Marilândia do Sul, Tibagi, Catanduvas e Rolândia

\begin{tabular}{lccccc}
\hline \multirow{2}{*}{ Município } & \multicolumn{5}{c}{$\alpha(\%)$} \\
\cline { 2 - 6 } & 70 & 75 & 80 & 85 & 90 \\
\hline Castro & 0,01389 & 0,08361 & 0,31770 & 0,89650 & 2,04100 \\
Catanduvas & 0,01684 & 0,09556 & 0,34150 & 0,90490 & 1,92000 \\
Marilândia do Sul & 0,01284 & 0,07567 & 0,31400 & 0,89860 & 2,00700 \\
Ponta Grossa & 0,00564 & 0,03877 & 0,17770 & 0,55270 & 1,32600 \\
Rolândia & 0,00104 & 0,01288 & 0,06320 & 0,22030 & 0,59290 \\
Tibagi & 0,01630 & 0,09599 & 0,35610 & 0,98040 & 2,12000 \\
\hline
\end{tabular}

Fonte: resultados da pesquisa 


\subsection{Quantificação do risco sistêmico e da correlação entre a produtividade individual e regional}

De acordo com a metodologia desenvolvida no item 4.3, os resultados serão mostrados, inicialmente, no nível de agregação "municipal” e, posteriormente, no nível de agregação "cluster".

Desta forma, nesta subseção serão investigados a influência do nível de agregação na redução do risco sistêmico e na correlação entre a produtividade individual e a produtividade regional. As séries foram corrigidas para a tendência, ao nível de significância de 5\%, conforme método descrito em seção anterior.

Posteriormente, será analisado o comportamento da correlação espacial presente nos dados, através da estimação de semivariogramas e parâmetros de alcance ou, também, denominados "range", que mostram a distância, na qual a correlação se aproxima de zero.

\subsubsection{Nível de agregação: "municipal"}

As tabelas 19 e 20, abaixo mostram os coeficientes de correlação, $\beta_{i}$ 's, em ordem decrescente, a redução do risco resultante da aquisição do contrato de seguro regional e calculada, a partir da equação (52) e percentual da redução em relação ao risco total. A redução do risco foi calculada para os níveis de produtividade crítica, $\alpha_{i}$ igual a 60 a $120 \%$, em múltiplos de $5^{216}$.

Maiores valores de correlação não significam, necessariamente, maiores valores de $\beta_{i}$, como pode ser visto nos números 17 e 18 , na tabela 19 . O valor de $\beta_{i}$ é afetado também pelo valor da variabilidade da produtividade de cada produtor.

\footnotetext{
${ }^{216}$ Em função da série ser relativamente curta, para $\alpha_{i}$ igual a 60 a $90 \%$ as indenizações dadas por $I=$ $\phi \max \left(\mathrm{y}_{\mathrm{c}}-\tilde{y}, 0\right)$, onde $\phi$ é o nível de cobertura, resultaram em valores nulos para todos os anos, ou seja, esta é a situação em que $\tilde{y}$ é maior do que $\mathrm{y}_{\mathrm{c}}$ em todos os anos. Consequentemente, não se define $\beta_{c}$ nem $\Delta_{i}$, nestes casos.
} 
Os cinco últimos produtores apresentaram valores de $\beta_{i}$ negativos, na tabela 19. Isto quer dizer que a cobertura do seguro regional não implica em redução do risco, pelo contrário, significa aumento do risco deste produtor. O mesmo ocorre para os onze últimos produtores na tabela 20 .

Produtores que possuem alta correlação com a produtividade regional e alta variabilidade na produtividade poderiam se beneficiar do seguro agrícola regional, pois maior seria a redução do risco sistêmico.

$\mathrm{Na}$ situação oposta, produtores com baixa correlação e baixa variabilidade não se beneficiariam com tal mecanismo de seguro. Aqueles com correlação negativa seriam prejudicados se demandassem pelo contrato de seguro.

Pelas tabelas, acima, nota-se que a aquisição deste contrato de seguro pode ser risco redutor ou risco crescente, para um mesmo produtor, em função do beta crítico $\beta_{c}$, definido pela equação (51).

Caso $\beta_{c}$ seja maior do que $\beta_{i}$, então o contrato de seguro será risco crescente. Por exemplo, o beta crítico com $\alpha_{i}=95 \%$ é de 0,1923 . Pela tabela 19 , acima, percebe-se que o $\beta_{i}$ do produtor 1 é igual a 0,2122 , maior que o beta crítico. Mas com $\alpha_{i}$ $=100 \%$, este mesmo $\beta_{i}$ é menor do que o beta crítico $(0,3373)$, por isso a redução do risco negativa para este produtor aos níveis de 100 a $120 \%$.

Pelas tabelas 20 e 21, acima, nota-se que quanto maior o $\beta_{i}$, maior será a redução do risco, para todos os níveis de $\mathrm{y}_{c}$. Além disso, percebe-se que o beta crítico estabiliza em um valor máximo de 0,5 , com o aumento da produtividade crítica, conforme já apontava Miranda. 
Tabela 20. Coeficiente de correlação, $\beta_{i}$, redução do risco e percentual da redução do risco, em relação ao risco total das séries de produtividade de milho, para diferentes $\alpha_{i}{ }^{\text {s }}$, tal que $i=1$ a 26, no município de Castro, no Estado do Paraná, no período de 1994 a 2002

\begin{tabular}{|c|c|c|c|c|c|c|c|c|c|c|c|c|c|c|}
\hline \multirow{2}{*}{ Núm } & \multirow{2}{*}{$\rho_{i}$} & \multirow{2}{*}{$\beta_{i}$} & \multicolumn{12}{|c|}{ Redução do Risco } \\
\hline & & & 0,95 & $\%$ & 1 & $\%$ & 1,05 & $\%$ & 1,1 & $\%$ & 1,15 & $\%$ & 1,2 & $\%$ \\
\hline 14 & 0,7749 & 1,8267 & 125999 & 11,4 & 305628 & 27,6 & 487759 & 44,0 & 540274 & 48,8 & 540274 & 48,8 & 540274 & 48,8 \\
\hline 18 & 0,3835 & 1,5109 & 101655 & 3,3 & 240834 & 7,8 & 376166 & 12,2 & 411683 & 13,3 & 411683 & 13,3 & 411683 & 13,3 \\
\hline 17 & 0,7160 & 1,3093 & 86110 & 12,9 & 199458 & 29,9 & 304907 & 45,7 & 329568 & 49,4 & 329568 & 49,4 & 329568 & 49,4 \\
\hline 12 & 0,4055 & 1,2284 & 79878 & 4,4 & 182870 & 10,0 & 276339 & 15,1 & 296649 & 16,2 & 296649 & 16,2 & 296649 & 16,2 \\
\hline 22 & 0,2810 & 1,0953 & 69611 & 2,3 & 155544 & 5,1 & 229276 & 7,6 & 242417 & 8,0 & 242417 & 8,0 & 242417 & 8,0 \\
\hline 19 & 0,4219 & 1,0742 & 67989 & 5,3 & 151227 & 11,7 & 221840 & 17,2 & 233848 & 18,1 & 233848 & 18,1 & 233848 & 18,1 \\
\hline 24 & 0,4802 & 1,0672 & 67450 & 6,8 & 149793 & 15,2 & 219371 & 22,3 & 231003 & 23,5 & 231003 & 23,5 & 231003 & 23,5 \\
\hline 16 & 0,6005 & 1,0194 & 63764 & 11,1 & 139981 & 24,4 & 202472 & 35,2 & 211530 & 36,8 & 211530 & 36,8 & 211530 & 36,8 \\
\hline 23 & 0,4615 & 0,9735 & 60220 & 6,8 & 130547 & 14,7 & 186225 & 21,0 & 192808 & 21,7 & 192808 & 21,7 & 192808 & 21,7 \\
\hline 9 & 0,3466 & 0,7723 & 44710 & 4,5 & 89266 & 9,0 & 115128 & 11,6 & 110881 & 11,2 & 110881 & 11,2 & 110881 & 11,2 \\
\hline 2 & 0,2831 & 0,7123 & 40089 & 3,2 & 76966 & 6,1 & 93944 & 7,4 & 86470 & 6,9 & 86470 & 6,9 & 86470 & 6,9 \\
\hline 21 & 0,2554 & 0,6537 & 35571 & 2,7 & 64941 & 5,0 & 73235 & 5,6 & 62607 & 4,8 & 62607 & 4,8 & 62607 & 4,8 \\
\hline 11 & 0,1089 & 0,6289 & 33653 & 0,5 & 59838 & 0,9 & 64445 & 1,0 & 52478 & 0,8 & 52478 & 0,8 & 52478 & 0,8 \\
\hline 3 & 0,2896 & 0,5878 & 30490 & 3,7 & 51417 & 6,3 & 49944 & 6,1 & 35767 & 4,4 & 35767 & 4,4 & 35767 & 4,4 \\
\hline 25 & 0,1127 & 0,5781 & 29740 & 0,6 & 49421 & 0,9 & 46506 & 0,9 & 31806 & 0,6 & 31806 & 0,6 & 31806 & 0,6 \\
\hline 15 & 0,2415 & 0,5478 & 27403 & 2,7 & 43203 & 4,2 & 35795 & 3,5 & 19464 & 1,9 & 19464 & 1,9 & 19464 & 1,9 \\
\hline 5 & 0,3650 & 0,4992 & 23659 & 6,3 & 33237 & 8,9 & 18633 & 5,0 & -313 & $-0,1$ & -313 & $-0,1$ & -313 & $-0,1$ \\
\hline 4 & 0,2307 & 0,3947 & 15604 & 2,7 & 11798 & 2,0 & -18292 & $-3,1$ & -42862 & $-7,3$ & -42862 & $-7,3$ & -42862 & $-7,3$ \\
\hline 13 & 0,1473 & 0,3830 & 14697 & 1,1 & 9382 & 0,7 & -22453 & $-1,7$ & -47657 & $-3,5$ & -47657 & $-3,5$ & -47657 & $-3,5$ \\
\hline 1 & 0,0862 & 0,2122 & 1534 & 0,1 & -25652 & $-2,1$ & -82790 & $-6,8$ & -117185 & $-9,7$ & -117185 & $-9,7$ & -117185 & $-9,7$ \\
\hline 10 & 0,1099 & 0,1702 & -1707 & $-0,4$ & -34279 & $-7,2$ & -97647 & $-20,4$ & -134306 & $-28,1$ & -134306 & $-28,1$ & -134306 & $-28,1$ \\
\hline 6 & $-0,0252$ & $-0,0840$ & -21302 & $-1,0$ & -86433 & $-3,9$ & -187470 & $-8,5$ & -237811 & $-10,7$ & -237811 & $-10,7$ & -237811 & $-10,7$ \\
\hline 26 & $-0,0632$ & $-0,1242$ & -24401 & $-3,2$ & -94682 & $-12,3$ & -201676 & $-26,2$ & -254181 & $-33,1$ & -254181 & $-33,1$ & -254181 & $-33,1$ \\
\hline 8 & $-0,0352$ & $-0,1345$ & -25197 & $-0,9$ & -96801 & $-3,3$ & -205327 & $-7,1$ & -258388 & $-8,9$ & -258388 & $-8,9$ & -258388 & $-8,9$ \\
\hline 7 & $-0,1296$ & $-0,1970$ & -30015 & $-6,5$ & -109624 & $-23,8$ & -227410 & $-49,3$ & -283834 & $-61,6$ & -283834 & $-61,6$ & -283834 & $-61,6$ \\
\hline 20 & $-0,3161$ & $-0,6443$ & -64505 & $-7,8$ & -201423 & $-24,3$ & -385512 & $-46,5$ & -466020 & $-56,2$ & -466020 & $-56,2$ & -466020 & $-56,2$ \\
\hline Média & & & 50991 & 4,6 & 112913 & 10,0 & 176587 & 15,4 & 193078 & 16,6 & 193078 & 16,6 & 193078 & 16,6 \\
\hline$\beta_{c}$ & & & 0,1923 & & 0,3373 & & 0,4465 & & 0,5000 & & 0,5000 & & 0,5000 & \\
\hline
\end{tabular}

Fonte: resultados da pesquisa 
Tabela 21. Coeficiente de correlação, $\beta_{i}$, redução do risco e percentual da redução do

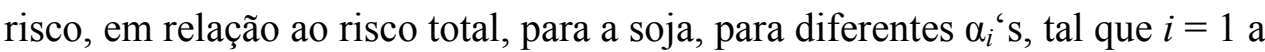
40, no período de 1994 a 2002

\begin{tabular}{|c|c|c|c|c|c|c|c|c|c|c|c|c|c|c|}
\hline \multirow{2}{*}{ Núm. } & \multirow{2}{*}{$\rho_{i}$} & \multirow{2}{*}{$\boldsymbol{\beta}_{i}$} & \multicolumn{12}{|c|}{ Redução do Risco } \\
\hline & & & 0,95 & $\%$ & 1 & $\%$ & 1,05 & $\%$ & 1,1 & $\%$ & 1,15 & $\%$ & 1,2 & $\%$ \\
\hline 33 & 0,7275 & 4,1534 & 8939 & 3,1 & 62537 & 21,6 & 113038 & 39,1 & 143216 & 49,5 & 146868 & 50,8 & 146868 & 50,8 \\
\hline 21 & 0,7417 & 2,9738 & 6340 & 4,4 & 43301 & 30,4 & 77359 & 54,3 & 97149 & 68,1 & 99446 & 69,8 & 99446 & 69,8 \\
\hline 25 & 0,5895 & 2,8232 & 6009 & 3,0 & 40845 & 20,1 & 72805 & 35,8 & 91269 & 44,9 & 93393 & 45,9 & 93393 & 45,9 \\
\hline 10 & 0,5895 & 2,6250 & 5572 & 3,2 & 37613 & 21,4 & 66811 & 38,0 & 83528 & 47,5 & 85425 & 48,6 & 85425 & 48,6 \\
\hline 12 & 0,5526 & 2,2875 & 4829 & 3,2 & 32110 & 21,1 & 56605 & 37,2 & 70350 & 46,3 & 71860 & 47,3 & 71860 & 47,3 \\
\hline 32 & 0,4525 & 2,1880 & 4609 & 2,2 & 30488 & 14,7 & 53595 & 25,8 & 66464 & 32,1 & 67860 & 32,7 & 67860 & 32,7 \\
\hline 31 & 0,3701 & 2,0849 & 4382 & 1,6 & 28807 & 10,2 & 50477 & 17,9 & 62438 & 22,2 & 63715 & 22,6 & 63715 & 22,6 \\
\hline 30 & 0,7867 & 1,9709 & 4131 & 7,4 & 26947 & 48,4 & 47028 & 84,5 & 57985 & 104,2 & 59131 & 106,2 & 59131 & 106,2 \\
\hline 38 & 0,4808 & 1,7100 & 3556 & 3,2 & 22693 & 20,2 & 39138 & 34,9 & 47797 & 42,6 & 48644 & 43,4 & 48644 & 43,4 \\
\hline 17 & 0,5156 & 1,2155 & 2467 & 5,0 & 14628 & 29,7 & 24179 & 49,1 & 28482 & 57,8 & 28762 & 58,4 & 28762 & 58,4 \\
\hline 3 & 0,4951 & 1,1585 & 2341 & 4,8 & 13699 & 28,2 & 22457 & 46,3 & 26258 & 54,1 & 26473 & 54,5 & 26473 & 54,5 \\
\hline 36 & 0,5111 & 1,1444 & 2310 & 5,2 & 13469 & 30,3 & 22030 & 49,5 & 25707 & 57,8 & 25905 & 58,3 & 25905 & 58,3 \\
\hline 39 & 0,5258 & 1,1233 & 2263 & 5,6 & 13124 & 32,4 & 21390 & 52,9 & 24881 & 61,5 & 25055 & 61,9 & 25055 & 61,9 \\
\hline 34 & 0,2488 & 1,1005 & 2213 & 1,3 & 12753 & 7,4 & 20702 & 11,9 & 23993 & 13,8 & 24141 & 13,9 & 24141 & 13,9 \\
\hline 15 & 0,1926 & 1,0898 & 2190 & 0,8 & 12579 & 4,4 & 20378 & 7,2 & 23575 & 8,3 & 23710 & 8,4 & 23710 & 8,4 \\
\hline 13 & 0,2224 & 0,8922 & 1754 & 1,2 & 9356 & 6,6 & 14401 & 10,1 & 15857 & 11,1 & 15766 & 11,0 & 15766 & 11,0 \\
\hline 37 & 0,2302 & 0,8001 & 1551 & 1,4 & 7854 & 7,3 & 11615 & 10,8 & 12259 & 11,4 & 12062 & 11,3 & 12062 & 11,3 \\
\hline 26 & 0,3707 & 0,7715 & 1488 & 3,9 & 7387 & 19,2 & 10750 & 28,0 & 11143 & 29,0 & 10913 & 28,4 & 10913 & 28,4 \\
\hline 27 & 0,2872 & 0,7375 & 1414 & 2,4 & 6834 & 11,7 & 9723 & 16,6 & 9817 & 16,8 & 9548 & 16,3 & 9548 & 16,3 \\
\hline 16 & 0,2392 & 0,5390 & 976 & 2,2 & 3597 & 8,0 & 3720 & 8,3 & 2065 & 4,6 & 1568 & 3,5 & 1568 & 3,5 \\
\hline 11 & 0,2244 & 0,4120 & 696 & 2,3 & 1526 & 5,1 & -121 & $-0,4$ & -2894 & $-9,7$ & -3536 & $-11,8$ & -3536 & $-11,8$ \\
\hline 28 & 0,2921 & 0,3790 & 624 & 4,2 & 988 & 6,6 & -1120 & $-7,5$ & -4183 & $-28,0$ & -4864 & $-32,6$ & -4864 & $-32,6$ \\
\hline 18 & 0,1138 & 0,3348 & 526 & 0,7 & 267 & 0,3 & -2457 & $-3,2$ & -5910 & $-7,7$ & -6641 & $-8,7$ & -6641 & $-8,7$ \\
\hline 19 & 0,0661 & 0,2478 & 335 & 0,3 & -1151 & $-0,9$ & -5087 & $-4,1$ & -9307 & $-7,5$ & -10138 & $-8,1$ & -10138 & $-8,1$ \\
\hline 22 & 0,0927 & 0,1757 & 176 & 0,6 & -2328 & $-7,3$ & -7269 & $-22,8$ & -12124 & $-38,0$ & -13037 & $-40,9$ & -13037 & $-40,9$ \\
\hline 20 & 0,0497 & 0,1629 & 148 & 0,2 & -2536 & $-2,7$ & -7655 & $-8,0$ & -12622 & $-13,2$ & -13550 & $-14,2$ & -13550 & $-14,2$ \\
\hline 24 & 0,0919 & 0,1435 & 105 & 0,5 & -2852 & $-13,2$ & -8242 & $-38,1$ & -13379 & $-61,9$ & -14330 & $-66,3$ & -14330 & $-66,3$ \\
\hline 29 & 0,0415 & 0,1218 & 57 & 0,1 & -3206 & $-4,2$ & -8899 & $-11,7$ & -14228 & $-18,7$ & -15203 & $-19,9$ & -15203 & $-19,9$ \\
\hline 8 & 0,0075 & 0,0294 & -147 & $-0,1$ & -4713 & $-3,4$ & -11693 & $-8,5$ & -17836 & $-12,9$ & -18918 & $-13,7$ & -18918 & $-13,7$ \\
\hline 6 & $-0,0320$ & $-0,0452$ & -311 & $-1,8$ & -5930 & $-33,5$ & -13950 & $-78,9$ & -20751 & $-117,4$ & -21918 & $-124,0$ & -21918 & $-124,0$ \\
\hline 2 & $-0,0666$ & $-0,2110$ & -676 & $-0,8$ & -8633 & $-9,7$ & -18965 & $-21,3$ & -27225 & $-30,6$ & -28582 & $-32,1$ & -28582 & $-32,1$ \\
\hline 1 & $-0,0979$ & $-0,3408$ & -962 & $-0,9$ & -10751 & $-10,0$ & -22892 & $-21,3$ & -32295 & $-30,1$ & -33802 & $-31,5$ & -33802 & $-31,5$ \\
\hline 14 & $-0,1608$ & $-0,5617$ & -1449 & $-1,3$ & -14353 & $-13,3$ & -29573 & $-27,3$ & -40922 & $-37,8$ & -42682 & $-39,4$ & -42682 & $-39,4$ \\
\hline 7 & $-0,1991$ & $-0,6781$ & -1705 & $-1,7$ & -16250 & $-15,8$ & -33091 & $-32,2$ & -45465 & $-44,2$ & -47358 & $-46,0$ & -47358 & $-46,0$ \\
\hline 40 & $-0,2445$ & $-1,1698$ & -2789 & $-1,4$ & -24269 & $-12,0$ & -47964 & $-23,6$ & -64669 & $-31,9$ & -67126 & $-33,1$ & -67126 & $-33,1$ \\
\hline 5 & $-0,4558$ & $-1,4042$ & -3305 & $-3,9$ & -28091 & $-33,4$ & -55054 & $-65,4$ & -73824 & $-87,7$ & -76550 & $-90,9$ & -76550 & $-90,9$ \\
\hline 23 & $-0,7416$ & $-1,4108$ & -3320 & $-10,3$ & -28198 & $-87,9$ & -55252 & $-172,2$ & -74079 & $-230,8$ & -76813 & $-239,3$ & -76813 & $-239,3$ \\
\hline 35 & $-0,3869$ & $-1,4176$ & -3335 & $-2,8$ & -28310 & $-23,8$ & -55459 & $-46,6$ & -74346 & $-62,5$ & -77088 & $-64,8$ & -77088 & $-64,8$ \\
\hline 9 & $-0,3601$ & $-2,4459$ & -5600 & $-1,4$ & -45079 & $-11,0$ & -86561 & $-21,2$ & -114505 & $-28,0$ & -118427 & $-28,9$ & -118427 & $-28,9$ \\
\hline 4 & $-0,4894$ & $-2,7181$ & -6200 & $-2,3$ & -49516 & $-18,1$ & -94792 & $-34,7$ & -125133 & $-45,7$ & -129367 & $-47,3$ & -129367 & $-47,3$ \\
\hline Média & & & 2572 & 2,6 & 19278 & 17,6 & 37910 & 32,9 & 46212 & 39,2 & 47012 & 39,7 & 47012 & 39,7 \\
\hline$\beta_{c}$ & & & 0,10 & & 0,32 & & 0,42 & & 0,49 & & 0,50 & & 0,50 & \\
\hline
\end{tabular}

Fonte: resultados da pesquisa 
As tabela 22 e 23 , mostram o nível ótimo de cobertura $^{217}$ calculada através da eq. (58). Na escolha ótima, $\phi_{i}^{*}$ será no mínimo $\beta_{i}$ quando $\beta_{c}$ atingir seu valor máximo. Percebe-se, desta forma, que quando $\beta_{c}$ for igual a $0,5, \alpha_{i}=1,1$, na tabela 20 .

O valor de $\phi_{i}^{*}$ para o produtor 14 para este valor de $\alpha_{i}$, na tabela 22 , é igual a 1,8267, o mesmo valor de $\beta_{i}$ encontrado na tabela 20 . Este resultado já era esperado, pois conforme ressalta Mahul (1999), se $\beta_{i}>0$, então o nível de cobertura ótimo $\phi_{i}^{*}=\beta_{i}$. Além disso, o nível ótimo de cobertura será inversamente proporcional ao aumento da produtividade crítica, como pode ser visto na tabelas 22 .

Tabela 22. Nível ótimo de cobertura $\phi_{i}^{*}$, para o milho

\begin{tabular}{|c|c|c|c|c|c|c|}
\hline Número & 0,95 & 1 & 1,05 & 1,1 & 1,15 & 1,2 \\
\hline 14 & 4,7485 & 2,7082 & 2,0455 & 1,8267 & 1,8267 & 1,8267 \\
\hline 18 & 3,9277 & 2,2400 & 1,6919 & 1,5109 & 1,5109 & 1,5109 \\
\hline 17 & 3,4035 & 1,9411 & 1,4661 & 1,3093 & 1,3093 & 1,3093 \\
\hline 12 & 3,1934 & 1,8212 & 1,3756 & 1,2284 & 1,2284 & 1,2284 \\
\hline 22 & 2,8472 & 1,6238 & 1,2265 & 1,0953 & 1,0953 & 1,0953 \\
\hline 19 & 2,7925 & 1,5926 & 1,2029 & 1,0742 & 1,0742 & 1,0742 \\
\hline 24 & 2,7743 & 1,5823 & 1,1951 & 1,0672 & 1,0672 & 1,0672 \\
\hline 16 & 2,6500 & 1,5114 & 1,1416 & 1,0194 & 1,0194 & 1,0194 \\
\hline 23 & 2,5305 & 1,4432 & 1,0901 & 0,9735 & 0,9735 & 0,9735 \\
\hline 9 & 2,0076 & 1,1449 & 0,8648 & 0,7723 & 0,7723 & 0,7723 \\
\hline 2 & 1,8517 & 1,0561 & 0,7977 & 0,7123 & 0,7123 & 0,7123 \\
\hline 21 & 1,6994 & 0,9692 & 0,7321 & 0,6537 & 0,6537 & 0,6537 \\
\hline 11 & 1,6347 & 0,9323 & 0,7042 & 0,6289 & 0,6289 & 0,6289 \\
\hline 3 & 1,5281 & 0,8715 & 0,6583 & 0,5878 & 0,5878 & 0,5878 \\
\hline 25 & 1,5028 & 0,8571 & 0,6474 & 0,5781 & 0,5781 & 0,5781 \\
\hline 15 & 1,4240 & 0,8121 & 0,6134 & 0,5478 & 0,5478 & 0,5478 \\
\hline 5 & 1,2978 & 0,7401 & 0,5590 & 0,4992 & 0,4992 & 0,4992 \\
\hline 4 & 1,0262 & 0,5852 & 0,4420 & 0,3947 & 0,3947 & 0,3947 \\
\hline 13 & 0,9956 & 0,5678 & 0,4289 & 0,3830 & 0,3830 & 0,3830 \\
\hline 1 & 0,5517 & 0,3147 & 0,2377 & 0,2122 & 0,2122 & 0,2122 \\
\hline 10 & 0,4424 & 0,2523 & 0,1906 & 0,1702 & 0,1702 & 0,1702 \\
\hline 6 & 0 & 0 & 0 & 0 & 0 & 0 \\
\hline 26 & 0 & 0 & 0 & 0 & 0 & 0 \\
\hline 8 & 0 & 0 & 0 & 0 & 0 & 0 \\
\hline 7 & 0 & 0 & 0 & 0 & 0 & 0 \\
\hline 20 & 0 & 0 & 0 & 0 & 0 & 0 \\
\hline
\end{tabular}

Fonte: resultados da pesquisa

\footnotetext{
${ }^{217}$ Valores nulos para o nível de cobertura ótimo significam que $\beta \mathbf{i}<0$ para estes produtores, implicando em $<0$. Como estes valores não tem sentido foram substituídos por zero.
} 
Tabela 23. Nível ótimo de cobertura $\phi_{i}^{*}$, para a soja

\begin{tabular}{|c|c|c|c|c|c|c|}
\hline Número & 0,95 & 1 & 1,05 & 1,1 & 1,15 & 1,2 \\
\hline 33 & 21,6484 & 6,5216 & 4,9917 & 4,2718 & 4,1534 & 4,1534 \\
\hline 21 & 15,4999 & 4,6693 & 3,5740 & 3,0586 & 2,9738 & 2,9738 \\
\hline 25 & 14,7151 & 4,4329 & 3,3930 & 2,9037 & 2,8232 & 2,8232 \\
\hline 10 & 13,6820 & 4,1217 & 3,1548 & 2,6998 & 2,6250 & 2,6250 \\
\hline 12 & 11,9232 & 3,5919 & 2,7493 & 2,3528 & 2,2875 & 2,2875 \\
\hline 32 & 11,4045 & 3,4356 & 2,6297 & 2,2504 & 2,1880 & 2,1880 \\
\hline 31 & 10,8672 & 3,2737 & 2,5058 & 2,1444 & 2,0849 & 2,0849 \\
\hline 30 & 10,2728 & 3,0947 & 2,3687 & 2,0271 & 1,9709 & 1,9709 \\
\hline 38 & 8,9131 & 2,6851 & 2,0552 & 1,7588 & 1,7100 & 1,7100 \\
\hline 17 & 6,3353 & 1,9085 & 1,4608 & 1,2501 & 1,2155 & 1,2155 \\
\hline 3 & 6,0385 & 1,8191 & 1,3923 & 1,1916 & 1,1585 & 1,1585 \\
\hline 36 & 5,9649 & 1,7969 & 1,3754 & 1,1770 & 1,1444 & 1,1444 \\
\hline 39 & 5,8547 & 1,7637 & 1,3500 & 1,1553 & 1,1233 & 1,1233 \\
\hline 34 & 5,7361 & 1,7280 & 1,3226 & 1,1319 & 1,1005 & 1,1005 \\
\hline 15 & 5,6803 & 1,7112 & 1,3098 & 1,1209 & 1,0898 & 1,0898 \\
\hline 13 & 4,6503 & 1,4009 & 1,0723 & 0,9176 & 0,8922 & 0,8922 \\
\hline 37 & 4,1701 & 1,2562 & 0,9615 & 0,8229 & 0,8001 & 0,8001 \\
\hline 26 & 4,0210 & 1,2113 & 0,9272 & 0,7935 & 0,7715 & 0,7715 \\
\hline 27 & 3,8441 & 1,1580 & 0,8864 & 0,7585 & 0,7375 & 0,7375 \\
\hline 16 & 2,8095 & 0,8464 & 0,6478 & 0,5544 & 0,5390 & 0,5390 \\
\hline 11 & 2,1477 & 0,6470 & 0,4952 & 0,4238 & 0,4120 & 0,4120 \\
\hline 28 & 1,9755 & 0,5951 & 0,4555 & 0,3898 & 0,3790 & 0,3790 \\
\hline 18 & 1,7451 & 0,5257 & 0,4024 & 0,3444 & 0,3348 & 0,3348 \\
\hline 19 & 1,2917 & 0,3891 & 0,2978 & 0,2549 & 0,2478 & 0,2478 \\
\hline 22 & 0,9158 & 0,2759 & 0,2112 & 0,1807 & 0,1757 & 0,1757 \\
\hline 20 & 0,8493 & 0,2558 & 0,1958 & 0,1676 & 0,1629 & 0,1629 \\
\hline 24 & 0,7481 & 0,2254 & 0,1725 & 0,1476 & 0,1435 & 0,1435 \\
\hline 29 & 0,6349 & 0,1913 & 0,1464 & 0,1253 & 0,1218 & 0,1218 \\
\hline 8 & 0,1533 & 0,0462 & 0,0354 & 0,0303 & 0,0294 & 0,0294 \\
\hline 6 & 0 & 0 & 0 & 0 & 0 & 0 \\
\hline 2 & 0 & 0 & 0 & 0 & 0 & 0 \\
\hline 1 & 0 & 0 & 0 & 0 & 0 & 0 \\
\hline 14 & 0 & 0 & 0 & 0 & 0 & 0 \\
\hline 7 & 0 & 0 & 0 & 0 & 0 & 0 \\
\hline 40 & 0 & 0 & 0 & 0 & 0 & 0 \\
\hline 5 & 0 & 0 & 0 & 0 & 0 & 0 \\
\hline 23 & 0 & 0 & 0 & 0 & 0 & 0 \\
\hline 35 & 0 & 0 & 0 & 0 & 0 & 0 \\
\hline 9 & 0 & 0 & 0 & 0 & 0 & 0 \\
\hline 4 & 0 & 0 & 0 & 0 & 0 & 0 \\
\hline
\end{tabular}

Fonte: resultados da pesquisa 
O nível ótimo de cobertura permite conhecer a máxima redução do risco de produtividade em virtude da aquisição de um contrato de seguro regional, de acordo com as tabelas 24 e 25 .

Se o produtor optar pelo nível de cobertura ótimo, então tal redução será igual a 49,75 e $97 \%$ para $\alpha_{i}=0,95,1,1,05$ e de $100 \%$ para os demais $\alpha_{i}$ 's, no caso do milho e de 29, 64 e 90\% para $\alpha_{i}=0,95,1,1,05$ e de 100\% para os demais $\alpha_{i}$ 's. Pois, percebe-se que a redução do risco, dada pela eq. (59), é uma proporção do componente sistêmico, $\beta_{i}^{2} \sigma_{\widetilde{y}}^{2}$ e igual a $\rho=\operatorname{corr}(I, \tilde{y})$.

Tabela 24. Máxima redução do risco sistêmico em virtude da aquisição do seguro, para o milho

\begin{tabular}{|c|c|c|c|c|c|c|}
\hline Número & 0,95 & 1 & 1,05 & 1,1 & 1,15 & 1,2 \\
\hline 14 & 327363 & 496931 & 646432 & 665207 & 665207 & 665207 \\
\hline 18 & 223967 & 339979 & 442260 & 455106 & 455106 & 455106 \\
\hline 17 & 168177 & 255291 & 332094 & 341740 & 341740 & 341740 \\
\hline 12 & 148052 & 224740 & 292352 & 300843 & 300843 & 300843 \\
\hline 22 & 117692 & 178655 & 232403 & 239153 & 239153 & 239153 \\
\hline 19 & 113214 & 171857 & 223559 & 230052 & 230052 & 230052 \\
\hline 24 & 111746 & 169629 & 220661 & 227070 & 227070 & 227070 \\
\hline 16 & 101956 & 154768 & 201330 & 207177 & 207177 & 207177 \\
\hline 23 & 92968 & 141124 & 183581 & 188913 & 188913 & 188913 \\
\hline 9 & 58513 & 88821 & 115543 & 118899 & 118899 & 118899 \\
\hline 2 & 49782 & 75568 & 98302 & 101157 & 101157 & 101157 \\
\hline 21 & 41928 & 63646 & 82794 & 85199 & 85199 & 85199 \\
\hline 20 & 40733 & 61832 & 80434 & 82770 & 82770 & 82770 \\
\hline 11 & 38798 & 58895 & 76614 & 78839 & 78839 & 78839 \\
\hline 3 & 33900 & 51460 & 66942 & 68886 & 68886 & 68886 \\
\hline 25 & 32788 & 49771 & 64745 & 66625 & 66625 & 66625 \\
\hline 15 & 29440 & 44689 & 58134 & 59823 & 59823 & 59823 \\
\hline 5 & 24451 & 37117 & 48283 & 49686 & 49686 & 49686 \\
\hline 4 & 15288 & 23206 & 30188 & 31065 & 31065 & 31065 \\
\hline 13 & 14389 & 21843 & 28414 & 29239 & 29239 & 29239 \\
\hline 1 & 4419 & 6709 & 8727 & 8980 & 8980 & 8980 \\
\hline 7 & 3807 & 5778 & 7517 & 7735 & 7735 & 7735 \\
\hline 10 & 2842 & 4314 & 5612 & 5775 & 5775 & 5775 \\
\hline 8 & 1775 & 2694 & 3504 & 3606 & 3606 & 3606 \\
\hline 26 & 1512 & 2296 & 2987 & 3073 & 3073 & 3073 \\
\hline 6 & 692 & 1050 & 1366 & 1405 & 1405 & 1405 \\
\hline
\end{tabular}

Fonte: resultados da pesquisa 
Tabela 25. Máxima redução do risco sistêmico em virtude da aquisição do seguro, para a soja

\begin{tabular}{|c|c|c|c|c|c|c|}
\hline Número & 0,95 & 1 & 1,05 & 1,1 & 1,15 & 1,2 \\
\hline 33 & 43700 & 97438 & 138327 & 152851 & 152980 & 152980 \\
\hline 21 & 22402 & 49950 & 70911 & 78356 & 78422 & 78422 \\
\hline 25 & 20191 & 45020 & 63912 & 70623 & 70682 & 70682 \\
\hline 4 & 18715 & 41730 & 59241 & 65461 & 65516 & 65516 \\
\hline 10 & 17456 & 38920 & 55253 & 61054 & 61106 & 61106 \\
\hline 9 & 15155 & 33792 & 47972 & 53009 & 53054 & 53054 \\
\hline 12 & 13256 & 29557 & 41961 & 46366 & 46405 & 46405 \\
\hline 32 & 12128 & 27042 & 38389 & 42420 & 42456 & 42456 \\
\hline 31 & 11012 & 24553 & 34857 & 38517 & 38549 & 38549 \\
\hline 30 & 9840 & 21941 & 31148 & 34419 & 34448 & 34448 \\
\hline 38 & 7408 & 16517 & 23449 & 25911 & 25932 & 25932 \\
\hline 35 & 5091 & 11351 & 16114 & 17806 & 17821 & 17821 \\
\hline 23 & 5042 & 11242 & 15959 & 17635 & 17650 & 17650 \\
\hline 5 & 4995 & 11138 & 15811 & 17472 & 17486 & 17486 \\
\hline 17 & 3743 & 8345 & 11846 & 13090 & 13101 & 13101 \\
\hline 40 & 3467 & 7729 & 10973 & 12125 & 12135 & 12135 \\
\hline 3 & 3400 & 7581 & 10762 & 11892 & 11902 & 11902 \\
\hline 36 & 3318 & 7397 & 10502 & 11604 & 11614 & 11614 \\
\hline 39 & 3196 & 7127 & 10117 & 11180 & 11189 & 11189 \\
\hline 34 & 3068 & 6841 & 9712 & 10731 & 10740 & 10740 \\
\hline 15 & 3009 & 6708 & 9524 & 10523 & 10532 & 10532 \\
\hline 13 & 2016 & 4496 & 6383 & 7053 & 7059 & 7059 \\
\hline 37 & 1622 & 3615 & 5133 & 5672 & 5676 & 5676 \\
\hline 26 & 1508 & 3362 & 4772 & 5273 & 5278 & 5278 \\
\hline 27 & 1378 & 3072 & 4362 & 4820 & 4824 & 4824 \\
\hline 7 & 1165 & 2597 & 3687 & 4074 & 4077 & 4077 \\
\hline 14 & 799 & 1782 & 2530 & 2796 & 2798 & 2798 \\
\hline 16 & 736 & 1641 & 2330 & 2574 & 2576 & 2576 \\
\hline 11 & 430 & 959 & 1361 & 1504 & 1506 & 1506 \\
\hline 28 & 364 & 811 & 1152 & 1273 & 1274 & 1274 \\
\hline 1 & 294 & 656 & 931 & 1029 & 1030 & 1030 \\
\hline 18 & 284 & 633 & 899 & 993 & 994 & 994 \\
\hline 19 & 156 & 347 & 492 & 544 & 545 & 545 \\
\hline 2 & 113 & 251 & 357 & 394 & 395 & 395 \\
\hline 22 & 78 & 174 & 248 & 274 & 274 & 274 \\
\hline 20 & 67 & 150 & 213 & 235 & 235 & 235 \\
\hline 24 & 52 & 116 & 165 & 183 & 183 & 183 \\
\hline 29 & 38 & 84 & 119 & 131 & 132 & 132 \\
\hline 6 & 5 & 12 & 16 & 18 & 18 & 18 \\
\hline 8 & 2 & 5 & 7 & 8 & 8 & 8 \\
\hline
\end{tabular}

Fonte: resultados da pesquisa 
Nota-se, desta forma, que quanto maior $\alpha_{i}$, maior será a redução do risco sistêmico e maior o prêmio cobrado pelo seguro. De modo que, ao nível de 1,05 , quase todo o risco será eliminado pela aquisição do seguro, nos dois casos. Para níveis maiores do que 1,05 , todo o risco é elimado. Nota-se que, o seguro regional elimina certa proporção do risco sistêmico, mas não elimina o risco não sistêmico. O produtor se responsabiliza por administrar este risco remanescente.

Todos os produtores com correlação positiva (tabelas 20 e 21) poderiam demandar pelo seguro regional, com diferentes níveis de cobertura e dedutibilidades, mas aqueles com maior correlação e variabilidade na produtividade poderiam ter um benefício maior em função da aquisição deste tipo de seguro.

\subsubsection{Nível de agregação: "cluster"}

Até agora a análise foi realizada utilizando-se o nível de agregação da produtividade regional $\tilde{y}$ municipal. Conforme aponta Halcrow, o cálculo de $\tilde{y}$ poderia ser realizado através da seleção de 15 a 20 propriedades e o resultado estendido para compreender toda a área.

Desta forma, nesta subseção, $\tilde{y}=\Sigma_{i} w_{i} \tilde{y}_{i}$, onde $w_{i}$ é a proporção da área cultivada pelo produtor $i$ na área cultivada total, $\Sigma_{i} w_{i}=1$ e $i=26$ e 40, para a cultura do milho e soja, respectivamente.

A tabela 26, abaixo, mostra a diferença nas produtividades, em relação ao nível de agregação. A produtividade cluster reflete a agregação de 26 produtores de milho e 40 de soja, situados no município de Castro. A produtividade do município corresponde a média municipal. Como pode ser observado na tabela quanto menor o nível de agregação, maior a variabilidade da produtividade. 
Tabela 26. Comparação das produtividades $(\mathrm{kg} / \mathrm{ha})$ de soja e milho, por nível de agregação municipal e cluster, para Castro

\begin{tabular}{ccccc}
\hline \multirow{2}{*}{ Ano } & \multicolumn{2}{c}{ Milho } & \multicolumn{2}{c}{ Soja } \\
\cline { 2 - 5 } & cluster & município & cluster & município \\
\hline 1994 & 8237 & 8700 & 3413 & 3234 \\
1995 & 8745 & 8279 & 3407 & 3182 \\
1996 & 8169 & 8258 & 3259 & 3130 \\
1997 & 7552 & 7921 & 3086 & 2978 \\
1998 & 8395 & 8115 & 3242 & 3027 \\
1999 & 7542 & 7394 & 3163 & 3082 \\
2000 & 8294 & 7948 & 3048 & 3123 \\
2001 & 9658 & 8130 & 3280 & 3271 \\
2002 & 8816 & 8931 & 3440 & 3170 \\
2003 & 8564 & - & 3481 & - \\
Média & 8397 & 8186 & 3282 & 3133 \\
Variância & 383037 & 199356 & 22981 & 8868 \\
\hline
\end{tabular}

Fonte: resultados da pesquisa

O fato de se reduzir consideravelmente o nível de agregação fez com que a correlação entre a produtividade individual e a regional aumentasse. A correlação média aumentou de 0,25 , no nível de agregação municipal para 0,51 , na agregação cluster.

Além disso, dos 26 produtores de milho, somente 3 apresentaram correlação maior do que 0,5 e 5 produtores tiveram tal coeficiente menor do que zero, na tabela 20, enquanto que 16 produtores apresentaram valor maior do que 0,5 e apenas 2 com coeficiente menor do que zero, na tabela 27. 
Tabela 27. Coeficiente de correlação, $\beta_{i}$ e redução do risco e percentual da redução do risco, em relação ao risco total, das séries de produtividade de milho, ao nível de agregação cluster, em 26 fazendas, no município de Castro, no Estado do Paraná, no período de 1994 a 2003

\begin{tabular}{|c|c|c|c|c|c|c|c|c|c|c|c|c|c|c|}
\hline \multirow{2}{*}{ Núm. } & \multirow{2}{*}{$\rho_{i}$} & \multirow{2}{*}{$\beta_{i}$} & \multicolumn{12}{|c|}{ Redução do Risco } \\
\hline & & & 0,95 & $\%$ & 1 & $\%$ & 1,05 & $\%$ & 1,1 & $\%$ & 1,15 & $\%$ & 1,2 & $\%$ \\
\hline 25 & 0,70 & 2,58 & 385855 & 7,4 & 760954 & 14,5 & 1148126 & 21,9 & 1386457 & 26,4 & 1589532 & 30,3 & 1590072 & 30,3 \\
\hline 18 & 0,89 & 2,52 & 377502 & 12,2 & 743443 & 24,0 & 1120874 & 36,2 & 1353161 & 43,7 & 1550193 & 50,1 & 1550716 & 50,1 \\
\hline 11 & 0,52 & 2,17 & 320677 & 4,8 & 624318 & 9,4 & 935480 & 14,1 & 1126656 & 17,0 & 1282575 & 19,3 & 1282978 & 19,3 \\
\hline 22 & 0,68 & 1,91 & 277839 & 9,2 & 534515 & 17,6 & 795720 & 26,3 & 955903 & 31,6 & 1080831 & 35,7 & 1081143 & 35,7 \\
\hline 9 & 0,88 & 1,41 & 197007 & 19,9 & 365063 & 36,9 & 532003 & 53,7 & 633705 & 64,0 & 700152 & 70,7 & 700294 & 70,7 \\
\hline 13 & 0,69 & 1,30 & 177960 & 13,2 & 325134 & 24,1 & 469861 & 34,9 & 557783 & 41,4 & 610449 & 45,3 & 610551 & 45,3 \\
\hline 24 & 0,71 & 1,14 & 151821 & 15,4 & 270338 & 27,4 & 384582 & 39,0 & 453593 & 46,1 & 487348 & 49,5 & 487395 & 49,5 \\
\hline 23 & 0,73 & 1,11 & 147093 & 16,6 & 260425 & 29,4 & 369155 & 41,6 & 434745 & 49,0 & 465079 & 52,4 & 465116 & 52,4 \\
\hline 16 & 0,90 & 1,10 & 145355 & 25,3 & 256783 & 44,7 & 363486 & 63,3 & 427819 & 74,5 & 456896 & 79,5 & 456929 & 79,5 \\
\hline 14 & 0,56 & 0,95 & 122117 & 11,0 & 208068 & 18,8 & 287672 & 26,0 & 335193 & 30,3 & 347458 & 31,4 & 347442 & 31,4 \\
\hline 12 & 0,43 & 0,94 & 120334 & 6,6 & 204330 & 11,2 & 281853 & 15,4 & 328084 & 17,9 & 339058 & 18,5 & 339039 & 18,5 \\
\hline 1 & 0,51 & 0,91 & 115295 & 9,5 & 193767 & 16,0 & 265416 & 22,0 & 308001 & 25,5 & 315330 & 26,1 & 315300 & 26,1 \\
\hline 19 & 0,49 & 0,91 & 114655 & 8,9 & 192425 & 14,9 & 263326 & 20,4 & 305448 & 23,6 & 312314 & 24,2 & 312283 & 24,2 \\
\hline 10 & 0,81 & 0,91 & 114288 & 23,9 & 191656 & 40,1 & 262130 & 54,8 & 303986 & 63,6 & 310587 & 65,0 & 310555 & 65,0 \\
\hline 2 & 0,49 & 0,88 & 110621 & 8,8 & 183969 & 14,6 & 250166 & 19,8 & 289369 & 22,9 & 293317 & 23,2 & 293277 & 23,2 \\
\hline 5 & 0,88 & 0,87 & 108137 & 29,0 & 178761 & 47,9 & 242061 & 64,9 & 279467 & 75,0 & 281617 & 75,5 & 281572 & 75,5 \\
\hline 3 & 0,55 & 0,80 & 96937 & 11,8 & 155281 & 18,9 & 205520 & 25,0 & 234823 & 28,6 & 228870 & 27,9 & 228801 & 27,9 \\
\hline 17 & 0,57 & 0,75 & 89379 & 13,4 & 139437 & 20,9 & 180862 & 27,1 & 204697 & 30,7 & 193276 & 29,0 & 193191 & 29,0 \\
\hline 15 & 0,46 & 0,75 & 88292 & 8,6 & 137158 & 13,4 & 177315 & 17,3 & 200363 & 19,5 & 188155 & 18,3 & 188068 & 18,3 \\
\hline 4 & 0,58 & 0,72 & 84413 & 14,5 & 129028 & 22,1 & 164662 & 28,2 & 184904 & 31,7 & 169891 & 29,1 & 169795 & 29,1 \\
\hline 26 & 0,23 & 0,33 & 20852 & 2,7 & -4218 & $-0,5$ & -42708 & $-5,6$ & -68451 & $-8,9$ & -129450 & $-16,8$ & -129679 & $-16,9$ \\
\hline 6 & 0,10 & 0,24 & 5396 & 0,2 & -36621 & $-1,7$ & -93136 & $-4,2$ & -130062 & $-5,9$ & -202243 & $-9,1$ & -202505 & $-9,1$ \\
\hline 7 & 0,16 & 0,17 & -5072 & $-1,1$ & -58564 & $-12,7$ & -127286 & $-27,6$ & -171785 & $-37,3$ & -251540 & $-54,6$ & -251824 & $-54,6$ \\
\hline 20 & 0,04 & 0,05 & -24244 & $-2,9$ & -98756 & $-11,9$ & -189837 & $-22,9$ & -248206 & $-30,0$ & -341832 & $-41,3$ & -342156 & $-41,3$ \\
\hline 8 & $-0,12$ & $-0,33$ & -86430 & $-3,0$ & -229119 & $-7,9$ & -392721 & $-13,5$ & -496082 & $-17,0$ & -634698 & $-21,8$ & -635153 & $-21,8$ \\
\hline 21 & $-0,21$ & $-0,39$ & -96217 & $-7,4$ & -249636 & $-19,1$ & -424652 & $-32,5$ & -535093 & $-41,0$ & -680790 & $-52,1$ & -681266 & $-52,2$ \\
\hline média & & & 153265 & 12 & 302743 & 23 & 435013 & 33 & 515208 & 38 & 560146 & 40 & 560226 & 40 \\
\hline$\beta_{c}$ & & & 0,2025 & & 0,3431 & & 0,4112 & & 0,4363 & & 0,4998 & & 0,5000 & \\
\hline
\end{tabular}

Fonte: resultados da pesquisa 
No caso da soja, a correlação média aumentou de 0,17 , no caso da agregação municipal, para 0,41 , na agregação cluster. Além disso, dos 40 produtores de milho, 9 apresentaram correlação maior do que 0,5 e 11, valores menores do que zero para este coeficiente, na tabela 20, enquanto que 19 apresentaram valores maiores do que 0,5 e 5, cujo coeficiente de correlação foi menor do zero, na tabela 28 .

As tabelas 27 e 28, ainda mostram a redução do risco de cada produtor como percentual do risco total. A redução média para os níveis de 95 a $120 \%$ é de 12 , 23,33, 38, 40 e 40\%, na tabela 27 e de 5, 21, 31, 31, 31 e 31\%, na tabela 28 .

Retomando as tabelas 18 e 19, observa-se que a redução média para os mesmos $\alpha_{i}$ 's foi de 4,6,10,15,4,16,6,16,6 e 16,6\%, na tabela 18 e de 2,6, 17,6, 32,9, 39,2, 39,7 e 39,7\%, na tabela 19. Desta forma, nota-se que quanto maior o nível de agregação utilizado no design do contrato, maior será a redução do risco médio, dado o valor de $\alpha$. 
Tabela 28. Coeficiente de correlação, $\beta_{i}$ e redução do risco e percentual da redução do risco, em relação ao risco total das séries de produtividade de soja, ao nível de agregação cluster, em 40 fazendas, no período de 1994 a 2003

\begin{tabular}{|c|c|c|c|c|c|c|c|c|c|c|c|c|c|c|}
\hline \multirow{2}{*}{ Num. } & \multirow{2}{*}{$\boldsymbol{\rho}_{i}$} & \multirow{2}{*}{$\boldsymbol{\beta}_{i}$} & \multicolumn{12}{|c|}{ Redução do Risco } \\
\hline & & & 0,95 & $\%$ & 1 & $\%$ & 1,05 & $\%$ & 1,1 & $\%$ & 1,15 & $\%$ & 1,2 & $\%$ \\
\hline 32 & 0,7672 & 2,3044 & 11020 & 5,3 & 48045 & 23,2 & 80771 & 39,0 & 82933 & 40,0 & 82933 & 40,0 & 82933 & 40,0 \\
\hline 33 & 0,6111 & 2,1674 & 10332 & 3,6 & 44714 & 15,5 & 74687 & 25,8 & 76634 & 26,5 & 76634 & 26,5 & 76634 & 26,5 \\
\hline 21 & 0,8517 & 2,1212 & 10101 & 7,1 & 43592 & 30,6 & 72638 & 51,0 & 74514 & 52,3 & 74514 & 52,3 & 74514 & 52,3 \\
\hline 12 & 0,8181 & 2,1038 & 10013 & 6,6 & 43169 & 28,4 & 71866 & 47,3 & 73714 & 48,5 & 73714 & 48,5 & 73714 & 48,5 \\
\hline 34 & 0,6814 & 1,8724 & 8852 & 5,1 & 37543 & 21,6 & 61591 & 35,5 & 63078 & 36,4 & 63078 & 36,4 & 63078 & 36,4 \\
\hline 25 & 0,6213 & 1,8484 & 8732 & 4,3 & 36960 & 18,2 & 60527 & 29,8 & 61976 & 30,5 & 61976 & 30,5 & 61976 & 30,5 \\
\hline 31 & 0,5040 & 1,7639 & 8308 & 3,0 & 34905 & 12,4 & 56773 & 20,2 & 58091 & 20,6 & 58091 & 20,6 & 58091 & 20,6 \\
\hline 9 & 0,4008 & 1,6912 & 7943 & 1,9 & 33138 & 8,1 & 53547 & 13,1 & 54750 & 13,4 & 54750 & 13,4 & 54750 & 13,4 \\
\hline 37 & 0,7549 & 1,6301 & 7637 & 7,1 & 31652 & 29,5 & 50832 & 47,4 & 51941 & 48,5 & 51941 & 48,5 & 51941 & 48,5 \\
\hline 38 & 0,7101 & 1,5687 & 7329 & 6,5 & 30160 & 26,9 & 48108 & 42,9 & 49120 & 43,8 & 49120 & 43,8 & 49120 & 43,8 \\
\hline 19 & 0,6381 & 1,4866 & 6917 & 5,5 & 28164 & 22,6 & 44463 & 35,6 & 45348 & 36,4 & 45348 & 36,4 & 45348 & 36,4 \\
\hline 15 & 0,3696 & 1,2988 & 5975 & 2,1 & 23597 & 8,3 & 36122 & 12,7 & 36713 & 12,9 & 36713 & 12,9 & 36713 & 12,9 \\
\hline 8 & 0,4867 & 1,1926 & 5442 & 3,9 & 21016 & 15,2 & 31409 & 22,8 & 31834 & 23,1 & 31834 & 23,1 & 31834 & 23,1 \\
\hline 10 & 0,4162 & 1,1511 & 5234 & 3,0 & 20007 & 11,4 & 29565 & 16,8 & 29925 & 17,0 & 29925 & 17,0 & 29925 & 17,0 \\
\hline 30 & 0,7368 & 1,1467 & 5211 & 9,4 & 19899 & 35,8 & 29369 & 52,8 & 29722 & 53,4 & 29722 & 53,4 & 29722 & 53,4 \\
\hline 17 & 0,7635 & 1,1180 & 5067 & 10,3 & 19201 & 39,0 & 28094 & 57,0 & 28403 & 57,6 & 28403 & 57,6 & 28403 & 57,6 \\
\hline 13 & 0,4256 & 1,0606 & 4780 & 3,3 & 17807 & 12,5 & 25547 & 17,9 & 25766 & 18,1 & 25766 & 18,1 & 25766 & 18,1 \\
\hline 18 & 0,5704 & 1,0425 & 4689 & 6,1 & 17366 & 22,6 & 24743 & 32,2 & 24933 & 32,5 & 24933 & 32,5 & 24933 & 32,5 \\
\hline 3 & 0,6323 & 0,9191 & 4070 & 8,4 & 14366 & 29,6 & 19264 & 39,7 & 19262 & 39,7 & 19262 & 39,7 & 19262 & 39,7 \\
\hline 39 & 0,6833 & 0,9068 & 4008 & 9,9 & 14068 & 34,8 & 18719 & 46,3 & 18698 & 46,2 & 18698 & 46,2 & 18698 & 46,2 \\
\hline 29 & 0,4208 & 0,7664 & 3304 & 4,3 & 10654 & 14,0 & 12485 & 16,4 & 12244 & 16,1 & 12244 & 16,1 & 12244 & 16,1 \\
\hline 36 & 0,5454 & 0,7587 & 3265 & 7,3 & 10467 & 23,5 & 12144 & 27,3 & 11891 & 26,7 & 11891 & 26,7 & 11891 & 26,7 \\
\hline 24 & 0,7429 & 0,7206 & 3074 & 14,2 & 9540 & 44,1 & 10450 & 48,3 & 10138 & 46,9 & 10138 & 46,9 & 10138 & 46,9 \\
\hline 11 & 0,6026 & 0,6873 & 2907 & 9,7 & 8731 & 29,2 & 8973 & 30,0 & 8609 & 28,8 & 8609 & 28,8 & 8609 & 28,8 \\
\hline 16 & 0,4580 & 0,6410 & 2674 & 5,9 & 7605 & 16,9 & 6917 & 15,4 & 6480 & 14,4 & 6480 & 14,4 & 6480 & 14,4 \\
\hline 14 & 0,2382 & 0,5169 & 2052 & 1,9 & 4588 & 4,2 & 1407 & 1,3 & 776 & 0,7 & 776 & 0,7 & 776 & 0,7 \\
\hline 27 & 0,3197 & 0,5100 & 2017 & 3,4 & 4420 & 7,6 & 1100 & 1,9 & 459 & 0,8 & 459 & 0,8 & 459 & 0,8 \\
\hline 28 & 0,5605 & 0,4517 & 1725 & 11,6 & 3004 & 20,1 & -1488 & $-10,0$ & -2220 & $-14,9$ & -2220 & $-14,9$ & -2220 & $-14,9$ \\
\hline 2 & 0,1995 & 0,3924 & 1427 & 1,6 & 1562 & 1,8 & -4120 & $-4,6$ & -4945 & $-5,6$ & -4945 & $-5,6$ & -4945 & $-5,6$ \\
\hline 26 & 0,2363 & 0,3055 & 991 & 2,6 & -550 & $-1,4$ & -7978 & $-20,8$ & -8938 & $-23,3$ & -8938 & $-23,3$ & -8938 & $-23,3$ \\
\hline 20 & 0,1450 & 0,2954 & 941 & 1,0 & -795 & $-0,8$ & -8426 & $-8,8$ & -9402 & $-9,9$ & -9402 & $-9,9$ & -9402 & $-9,9$ \\
\hline 7 & 0,1331 & 0,2816 & 871 & 0,8 & -1133 & $-1,1$ & -9042 & $-8,8$ & -10039 & $-9,8$ & -10039 & $-9,8$ & -10039 & $-9,8$ \\
\hline 6 & 0,2779 & 0,2438 & 682 & 3,9 & -2052 & $-11,6$ & -10720 & $-60,6$ & -11777 & $-66,6$ & -11777 & $-66,6$ & -11777 & $-66,6$ \\
\hline 22 & 0,1473 & 0,1734 & 329 & 1,0 & -3762 & $-11,8$ & -13843 & $-43,4$ & -15010 & $-47,1$ & -15010 & $-47,1$ & -15010 & $-47,1$ \\
\hline 1 & 0,0760 & 0,1643 & 283 & 0,3 & -3985 & $-3,7$ & -14250 & $-13,3$ & -15431 & $-14,4$ & -15431 & $-14,4$ & -15431 & $-14,4$ \\
\hline 23 & $-0,2589$ & $-0,3059$ & -2076 & $-6,5$ & -15415 & $-48,0$ & -35126 & $-109,5$ & -37042 & $-115,4$ & -37042 & $-115,4$ & -37042 & $-115,4$ \\
\hline 4 & $-0,1087$ & $-0,3749$ & -2422 & $-0,9$ & -17093 & $-6,2$ & -38190 & $-14,0$ & -40213 & $-14,7$ & -40213 & $-14,7$ & -40213 & $-14,7$ \\
\hline 40 & $-0,2003$ & $-0,5951$ & -3527 & $-1,7$ & -22445 & $-11,1$ & -47965 & $-23,6$ & -50332 & $-24,8$ & -50332 & $-24,8$ & -50332 & $-24,8$ \\
\hline 5 & $-0,3207$ & $-0,6138$ & -3621 & $-4,3$ & -22901 & $-27,2$ & -48796 & $-58,0$ & -51193 & $-60,8$ & -51193 & $-60,8$ & -51193 & $-60,8$ \\
\hline 35 & $-0,3658$ & $-0,8325$ & -4718 & $-4,0$ & -28217 & $-23,7$ & -58505 & $-49,1$ & -61242 & $-51,4$ & -61242 & $-51,4$ & -61242 & $-51,4$ \\
\hline Média & & & 4806 & 5,2 & 22067 & 20,9 & 36004 & 30,6 & 36591 & 30,8 & 36591 & 30,8 & 36591 & 30,8 \\
\hline$\beta_{c}$ & & & 0,11 & & 0,33 & & 0,49 & & 0,50 & & 0,50 & & 0,50 & \\
\hline
\end{tabular}

Fonte: resultados da pesquisa 
Novamente, neste caso, quanto maior $\beta_{i}$, maior será a redução do risco dado $\beta_{c}$ e a variabilidade da indenização, proveniente da aquisição de um contrato regional.

Pela tabela 26, acima, percebe-se que a variabilidade cluster é maior do que a variabilidade municipal. Neste caso, de acordo com a eq. (60), se o $\beta_{i}^{2}$ for maior para todos os produtores quando o nível de agregação for cluster do que no caso municipal, então o componente sistêmico será maior para o primeiro nível de agregação.

Mas no caso em que o $\beta_{i}^{2}$ for menor, o risco sistêmico poderá ou não ser maior na agregação municipal. Isto de fato ocorre para 4 dos 26 produtores de milho e para 11 dos 40 produtores de soja.

\subsection{Resultados da correlação espacial}

Dentre as diversas funções de correlação (5 para cada semivariograma, gerando no total 130 semivariogramas) ajustadas aos modelos, optou-se pela função de correlação esférica, visto que o valor do logaritmo da função de verossimilhança (critério de seleção de modelos) ficou bastante próximo para as diferentes funções de correlação utilizadas para o cálculo do semivariograma de cada uma das 26 séries.

A tabela 29, abaixo mostra a máxima distância, na qual o semivariograma estabiliza em torno de $\gamma^{e}(0)$. Percebe-se que, dos treze anos analisados, em oito anos a distância, no caso do milho, é menor do que na soja.

A mínima e a máxima distância ocorreram nos anos de 2002 e 1993, respectivamente, no caso do milho e nos anos de 1995 e 2000, no caso da soja. Na média a distância, na qual a covariância tende a zero, é de 124,6 e de $139 \mathrm{Km}$, para o milho e a soja, respectivamente. 
Tabela 29. Distância, em Km, estimado pelo método da máxima verossimilhança, no período de 1990 a 2002, no Estado do Paraná

\begin{tabular}{lcc}
\hline Ano & Milho & Soja \\
\hline 1990 & 164,6 & 173,8 \\
1991 & 128,5 & 133,5 \\
1992 & 118,1 & 156,8 \\
1993 & 122,7 & 168,4 \\
1994 & 129,6 & 132,4 \\
1995 & 129,3 & 56,6 \\
1996 & 132,1 & 113,4 \\
1997 & 124,7 & 153,3 \\
1998 & 124,4 & 202,7 \\
1999 & 113,3 & 106,8 \\
2000 & 144,1 & 194,2 \\
2001 & 137,1 & 166,6 \\
2002 & 126,9 & 124,4 \\
média & 124.6 & 139 \\
\hline
\end{tabular}

Fonte: resultados da pesquisa

A figura 70, abaixo mostra, a nível ilustrativo, o semivariograma ajustado para a série de milho, no ano de 2002. Nota-se que, neste ano particularmente, a estimativa de $\gamma_{p}^{e}$, por máxima verossimilhança, utilizando a função de correlação esférica foi de 0,14 e $\tau^{2}=0,014$. 


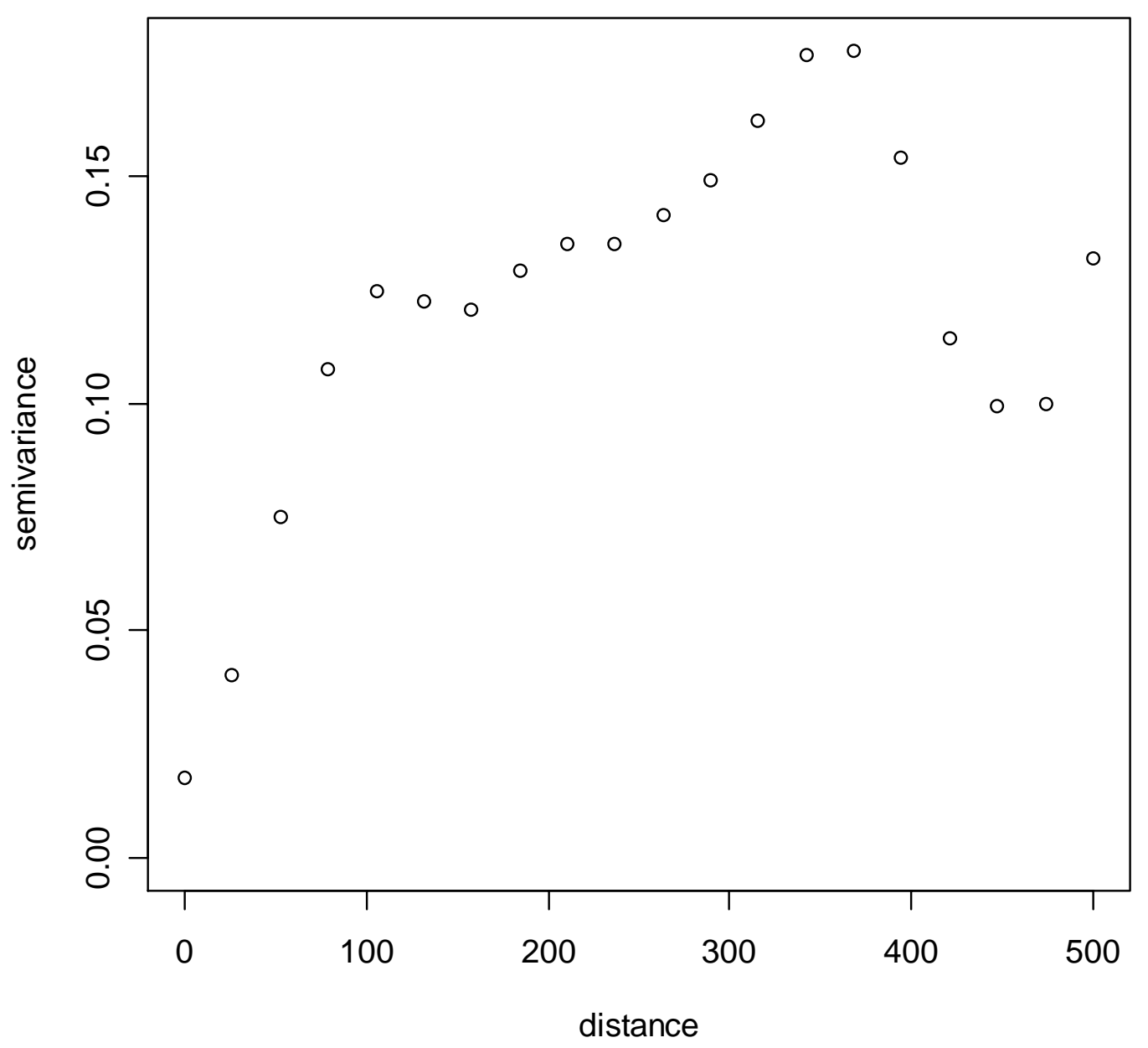

Figura 70 - Semivariograma ajustado para o milho, em 2002 (distâncias em km) Fonte: resultados da pesquisa 


\section{CONCLUSÕES}

Esta pesquisa mostra que, nos estágios iniciais, o programa de seguros agrícolas nos EUA, apresentou elevados déficits. Nos últimos anso, após sucessivos ajustamentos, conseguiu-se equilibrar o volume total de prêmios arrecadados com o total de indenizações pagas.

Tal equilíbrio ocorreu devido a dois fatores principais: ao forte apoio governamental (traduzido na forma de subsídios ao prêmio e ao custo administrativo e operacional das seguradoras); e, a grande diversificação dos tipos de contratos de seguro existentes atualmente.

No Brasil, a estrutura do mercado segurador rural é bem diferente daquele encontrado no mercado norte-americano. Enquanto neste, o governo é o responsável por grande parte das atividades (através de sua agência de administração do risco) naquele, a oferta de contratos é bem menor e comercializado através de algumas poucas seguradoras privadas. Porém, da mesma forma que nos EUA, o seguro rural no Brasil têm apresentado um problema crônico de déficits que tem impedido a expansão desse mercado.

Para tentar resolver esse problema, recentemente, o governo brasileiro decidiu retomar algumas iniciativas voltadas ao mercado segurador agrícola. Para tornar o seguro atrativo aos produtores, através da Lei $\mathrm{n}^{\circ} 10.823$, de 2003, o governo federal pretende subvencionar parte do prêmio pago pelo produtor. Algumas iniciativas estaduais de subvenção, ainda recentes, foram colocadas em prática nos estados do Rio Grande do Sul e São Paulo.

Além do programa de subvenção, novos tipos de contratos também começam a ser utilizados no país Esse é o caso, por exemplo, de um seguro agrícola 
regional, comercializado no sul do país, por uma seguradora privada e com apoio governamental.

Alertado sobre a grande importância do seguro agrícola para o desenvolvimento do setor, o governo brasileiro tem procurado reduzir o número de empecilhos, que dificultam a expansão do mercado segurador rural no país. Da mesma forma que ocorreu historicamente nos EUA, a subenção ao prêmio e a diversificação de produtos tendem a incentivar a maior demanda de contratos pelos produtores agrícolas e, consequentemente, popularizar este mecanismo de administração de risco.

Assumindo que os produtores tenham aversão ao risco, teoricamente, um contrato de seguro justo e completo é preferível a uma situação sem seguro. A prática mostra, entretanto, que existe pouca demanda pelo seguro. Isso é devido, entre outros fatores, por atrasos no pagamento das indenizações, das elevadas taxas de prêmio (vis-avis os mecanismos alternativos de gerenciamento do risco), ou até mesmo pela completa ignorância dos produtores.

Infelizmente, as tímidas e limitadas experiências de seguro rural no Brail resultaram em vultuosos déficits, acumulados no decorrer dos anos. Programas como o PROAGRO e o seguro agrícola oferecido pela Cosesp, apresentaram elevados índices de sinistralidade. Em parte, isso foi resultado das altas taxas de sinistralidade relacionadas com problemas de risco moral, fraudes, eventos generalizados, mas principalmente pela seleção adversa.

Este último é causado, principalmente, pela determinação incorreta da taxa de prêmio. Uso de metodologia inadequada, falta de dados confiáveis (suficientemente longa e precisa) de produtividade agrícola acabam resultando no pagamento de indenizações em volume muito maiores do que prêmios recebidos.

Neste sentido, o presente estudo contribui para o avanço da literatura através da aplicação de três métodos alternativos de cálculo do prêmio desse tipo de seguro. Dois deles são bem conhecidos na literatura. O terceiro é inovador e permite obter melhorias significativas no cálculo desta taxa.

A análise empírica mostra que os três métodos apresentam resultados significativamente diferentes. No caso dos dois primeiros métodos, ou seja, as 
abordagens paramétrica e não-paramétrica, a escolha da distância requerida para determinar a estrutura de vizinhança e o diagnóstico e a correção para a variabilidade não constante das observações também têm impacto expressivo sobre o valor do prêmio.

O terceiro método, que incorpora - de maneira relativamente simples e intuitiva - o componente espacial e o efeito temporal, aprimora as estimativas das distribuições de probabilidade.

Esses métodos mostraram-se capazes de gerar resultados mais satisfatórios do que as metodologias atualmente utilizadas. Estes, embora sejam extremamente fáceis de implementar, podem resultar em taxas incorretas se a série de dados for relativamente curta.

Dos três, o modelo que incorpora a dimensão espaço-temporal resulta em menores taxas. Em parte, isto se deve ao fato dos produtores demandarem maior volume de seguro, pagando menores prêmios. Porém, deve-se destacar que, nesse caso, os prêmios são calculados através de uma metodologia melhor fundamentada tecnicamente e, com maior garantia contra os riscos em momentos adversos.

Teoricamente, a aplicação desta metodologia na região do estudo (Municípios da região de Castro, PR) deve incentivar a demanda por contratos de seguro. Primeiro, em virtude do menor prêmio relativo e, em segundo lugar, pela viabilidade do seguro. A grande maioria dos produtores teriam benefícios em razão da considerável redução do risco sistêmico. Apesar deste tipo de seguro eliminar, parcial ou totalmente, o risco sistêmico, é importante destacar que ele não elimina o risco nãosistêmico.

Adicionalmente, deve-se destacar que a utilização de um esquema de agregação cluster, baseado em um indicador que reflete a produtividade média dos produtores (com pesos proporcionais à área correspondente a cada produtor), resultou em maior correlação entre a produtividade regional e a individual do que no caso do nível de agregação municipal. Esta é uma característica desejável para que o seguro de produtividade regional possa ser operacionalizado de maneira sustentável a médio-longo prazo. Em um program-piloto, poder-se-ia optar por um esquema de agregação cluster 
dos dados, pois quanto maior a correlação entre as produtividades individual e regional (ou, em outras palavras, quanto menor o risco de base), maior será a redução do risco.

Para aumentar as chances de sucesso, no programa de seguro rural o governo poderia priorizar, inicialmente, as regiões em que esta característica seja marcante. Teoricamente, os maiores benefícios seriam recebidos pelos produtores com bom histórico de produtividade, mais tecnificados e mais eficientes. Este é um fato desejável do ponto de vista econômico. Neste ponto é importante ressaltar que, em se tratando de políticas públicas, existe um importante aspecto social que não deve ser esquecido. Pequenos produtores como, por exemplo, os da agricultura familiar podem não ser muito beneficiados. Neste caso, a subvenção parcial do prêmio poderia permitir a compra do seguro pelos pequenos produtores e minorar os problemas distributivos do programa.

Na análise empírica observou-se que a correlação espacial é bastante pronunciada como, teoricamente, esperado. Essa correlação atingiu distâncias variadas nos diversos anos analisados. Isto indica que alguns fatores, tais como, seca e o excesso de chuva, afetaram a produtividade da soja e do milho nos respectivos municípios de maneira acentuada.

Infelizmente, ao longo do estudo, foram encontrados alguns problemas limitantes. Entre eles destacam-se: dados de produtividade municipal incompletos e com poucas observações; e, inexistência de série histórica de dados de produtividade a nível de talhão ou propriedade rural. Com dados de produtividade, por propriedade, seria possível precificar o seguro para cada produtor individualmente. Naturalmente, taxas mais elevadas seriam cobradas dos agricultores com maior risco e taxas bem menores, dos produtores mais eficientes e com história de menor ocorrência de perdas.

Um outro problema foi a escolha subjetiva da distância na determinação da estrutura de vizinhança. Idealmente, os fenômenos adversos deveriam ser estudados para se estimar essas distâncias com maior precisão.

Adicionalmente, na linha da administração de risco, diversas pesquisas poderiam ser desenvolvidas. Por exemplo, o estudo dos fatores que afetam a participação efetiva dos produtores nos programas de seguro (tais como, a aversão ao 
risco de cada produtor e a utilização de outras formas de gerenciamento de risco) seria de relevância para o entendimento da demanda pelo seguro agrícola. Além disso, poderse-ia analisar como tais fatores influenciam a disponibilidade à pagar pelo prêmio do seguro.

Uma outra área de interesse é a análise da utilização conjunta de mecanismos que possam reduzir simultaneamente o risco sistêmico e não-sistêmico. Isto é, o uso conjugado do seguro agrícola regional com outros tipos de mecanismos, que cobririam parte do risco não-sistêmico. É o caso, por exemplo, do seguro agrícola cobrindo perdas individuais, juntamente com a diversificação cultural, espacial, intersetorial, etc. Estes últimos são amplamente utilizados pelos produtores.

Como considerações finais, pode-se dizer que, o avanço da pesquisa nesta área e o conjunto de medidas verificadas recentemente poderão tornar o seguro agrícola um importante instrumento de gerenciamento de risco e garantia da produção e da renda do setor agropecuário. 


\section{REFERÊNCIAS BIBLIOGRÁFICAS}

ACKERMAN, K. New agricultural risk management insurance tools. Agricultural Outlook, n.261, p.16-21, May 1999.

AHSAN, S.M.; ALI, A.A.G.; KURIAN, N.J. Toward a theory of agricultural insurance. American Journal of Agricultural Economics, v.64, n.3, p.520-529, 1982.

AKAIKE, H. Information theory and an extension of the maximum likelihood principle. In: INTERNATIONAL SYMPOSIUM ON INFORMATION, 2., Budapest. Proceedings. Budapest: Academia Kiado, 1973. p.267-281.

AKERLOF, G.A. The market for "lemons": quality uncertainty and the market mechanism. Quarterly Journal of Economics, v.84, n.3, p.488-500, Aug. 1970.

ANDRADE JUNIOR, C.C. Seguros para o agronegócio. /Apresentado ao Workshop ANSP, São Paulo, 2002/

ANDERSON, T.W. An introduction to multivariate statistical analysis. New York: Wiley, 1984. 675p.

ANSELIN, L. Spatial econometrics: methods and models. Boston: Kluwer Academic Publishers, 1988. 284p.

ARROW, K.J. Essays in the theory of risk bearing. Chicago: North-Holland Publishing Company, 1971. 248p.

ARROW, K.J. The economics of agency. In: PRATT, J.W.; ZECKHAUSER, R.J. Principals and agents: the structure of business. Boston: Harvard Business School Press, 1991. 278p.

ARROW, K.J. The economics of moral hazard: further comment. American Economic Review, v.58, n.3, p.537-538, June 1968. 
AZEVEDO, R.G.R. A necessidade de criação de seguros para o agribusiness. Seguros \& Riscos, v.12, n.122, p.60-63, maio 1998.

AZEVEDO, R.G.R. O seguro rural e novas formas de resseguro. In: SIMPÓSIO INTERNACIONAL DE SECURIDADE E ZONEAMENTO AGRÍCOLA DO MERCOSUL, 1., Brasília, 1998. Anais. Brasília: Ministério da Agricultura e Abastecimento/CER/PROAGRO/GM, 1998. p.11-13.

AZEVEDO-FILHO, A.J.B.V. Seguro agrícola no Brasil: evolução e perspectivas. In: CONGRESSO DE TECNOLOGIA E COMPETITIVIDADE DE SOJA NO MERCADO GLOBAL, Cuiabá, 2000. Anais. Cuiabá: Fundação Mato Grosso, 2000. p.95-105.

AZEVEDO-FILHO, A.J.B.V Seguros fundamentados em índices de produtividade e renda agrícola regional como instrumentos para administração de riscos no Brasil. Piracicaba: FAPESP/CNPQ, 2001. 141p. (Relatório de Pesquisa. Subprojeto, 8)

BARDSLEY, P.; ABEY, A.; DAVENPORT, S. The economics of insuring crops against drought. The Australian Journal of Agricultural Economics, v.28, n.1, p.1-14, Apr. 1984.

BARNABY, A.G. Multiple peril crop insurance. Manhattan: Kansas State University, 2002. 2p. (Farm management guide, 907)

BARNETT, B.J.; COBLE, K.H. Understanding crop insurance principles: a primer for farm leaders. Starkville: Mississipi State University, 1999. 14p. (Agricultural economics research report, 209)

BARNETT, B.J.; SKEES, J. An empirical analysis of the demand for multiple peril crop insurance: comment. American Journal of Agricultural Economics, v.76, p.948951, Nov. 1994.

BARROS, F.A.P.A cobertura de resseguro do IRB e o Fundo de Estabilidade do Seguro Rural. In: SIMPÓSIO INTERNACIONAL DE SECURIDADE E ZONEAMENTO AGRÍCOLA DO MERCOSUL, 1., Brasília, 1998. Anais. Brasília: Ministério da Agricultura e Abastecimento/CER/PROAGRO/GM, 1998. p.25-26.

BERNOULLI, D. Exposition of a new theory on the measurement of risk. Econometrica, v.22, p.23-36, Jan. 1954.

BERNARDINELLI, L.; CLAYTON, D.; MONTOMOLI, C. Bayesian estimates of disease maps: how important are priors? Statistics in Medicine, v.14, p.2411-2431, 1995a. 
BERNARDINELLI, L.; CLAYTON, D.; PASCUTTO, C.; MONTOMOLI, C.; GHISLAND, M.; SONGINI, M. Bayesian analysis of space-time variation in disease risk. Statistics in Medicine, v.14, p.2433-2443, 1995 b.

BESAG, J. Spatial interaction and the statistical analysis of lattice systems. Journal of the Royal Statistical Society, Ser. B, v.36, p.192-236, 1974.

BESAG, J.; YORK, J.; MOLLIÉ, A. Bayesian image restoration, with applications in spatial statistics. Annals of the Institute of Statistical Mathematics, v.43, p.1-59, 1991.

BOOTH, P.; CHADBURN, R.; COOPER, D.; HABERMAN, S.; JAMES, D. Modern actuarial theory and practice. London: Chapman \& Hall/CRC, 1999. 716p.

BORCH, K.H. The economics of uncertainty. Princeton: Princeton University Press, 1968. 227p.

BOTTS, R.R.; BOLES, J.N. Use of normal-curve theory in crop insurance ratemaking. Journal of Farm Economics, v.40, n.2, p.733-740, 1958.

BRASIL. Leis, decretos, etc. Decreto-Lei $n^{\circ} 1.186$ de 3 de abril de 1939. http://www.senado.gov.br /legisla.htm (03 set. 2002)

BRASIL. Leis, decretos, etc. Lei $\mathbf{n}^{\circ} \mathbf{2 . 1 6 8}$ de 11 de janeiro de 1954. http://www.senado.gov.br/legisla.htm (03 set. 2002)

BRASIL. Leis, decretos, etc. Decreto $n^{\circ}$ 35.370, de 12 de abril de 1954. http://www.senado.gov.br/ legisla.htm (03 set. 2002)

BRASIL. Leis, decretos, etc. Decreto $n^{\circ}$ 35.409, de 28 de abril de 1954. http://www.senado.gov.br/ legisla.htm (03 set. 2002)

BRASIL. Leis, decretos, etc. Decreto $n^{\circ}$ 37.043, de 16 de março de 1955. http://www.senado.gov.br/ legisla.htm (03 set. 2002)

BRASIL. Leis, decretos, etc. Decreto $n^{\circ}$ 37.272, de 28 de abril de 1955. http://www.senado.gov.br/ legisla.htm (03 set. 2002)

BRASIL. Leis, decretos, etc. Decreto $n^{\circ}$ 37.449, de 7 de junho de 1955. http://www.senado.gov.br/ legisla.htm (03 set. 2002)

BRASIL. Leis, decretos, etc. Declara em vigor as condições da apólice do seguro agrícola da videira. Decreto $\mathrm{n}^{\circ} 37.600$, de 12 de julho de 1955. http://www.senado.gov.br/ legisla.htm (03 set. 2002). 
BRASIL. Leis, decretos, etc. Decreto $n^{\circ}$ 37.847, de 2 de setembro de 1955. http://www.senado.gov.br/ legisla.htm (03 set. 2002)

BRASIL. Leis, decretos, etc. Decreto $n^{\circ}$ 37.882, de 13 setembro de 1955. http://www.senado.gov.br/ legisla.htm (03 set. 2002)

BRASIL. Leis, decretos, etc. Decreto $n^{\circ}$ 40.810, de 23 de janeiro de 1957. http://www.senado.gov.br/ legisla.htm (03 set. 2002)

BRASIL. Leis, decretos, etc. Decreto $n^{\circ}$ 44.041, de 12 de julho de 1958. http://www.senado.gov.br/ legisla.htm (03 set. 2002)

BRASIL. Leis, decretos, etc. Decreto $n^{\circ}$ 44.872, de 26 de novembro de 1958. http://www.senado.gov.br/ legisla.htm (03 set. 2002)

BRASIL. Leis, decretos, etc. Decreto $n^{\circ}$ 48.946, de 15 de setembro de 1960. http://www.senado.gov.br/ legisla.htm (03 set. 2002)

BRASIL. Leis, decretos, etc. Decreto $n^{\circ}$ 1.224, de 22 de junho de 1962. http://www.senado.gov.br/ legisla.htm (03 set. 2002)

BRASIL. Leis, decretos, etc. Decreto $n^{\circ}$ 52.435, de 2 de setembro de 1963. http://www.senado.gov.br/ legisla.htm (03 set. 2002)

BRASIL. Leis, decretos, etc. Lei $\mathbf{n}^{\circ} 4.430$, de 20 de outubro de 1964. http://www.senado.gov.br/legisla.htm (03 set. 2002)

BRASIL. Leis, decretos, etc. Decreto $n^{\circ}$ 55.801, de 26 de fevereiro de 1965. http://www.senado.gov.br/ legisla.htm (03 set. 2002)

BRASIL. Leis, decretos, etc. Decreto-lei $n^{\circ}$ 73, de 21 de novembro de 1966. http://www.senado.gov.br/ legisla.htm (03 set. 2002)

BRASIL. Leis, decretos, etc. Lei $\mathbf{n}^{\circ}$ 10.420, de 10 de Abril de 2002. http://www.pronaf.gov.br/seguro_safra (15 mar. 2003)

BRASIL. Leis, decretos, etc. Resolução CNSP no 46, de 12 de fevereiro de 2001. http://www.susep.gov.br/menuatendimento/Seguro_Rural.asp (15 mar. 2003)

BRASIL. Leis, decretos, etc. Resolução CNSP n $^{0}$ 50, de 3 de setembro de 2001. http://www.susep.gov.br/menuatendimento/Seguro_Rural.asp (15 mar. 2003) 
BRASIL. Leis, decretos, etc. Resolução CNSP no 95, de 30 de setembro de 2002. http://www.susep.gov.br/menuatendimento/Seguro_Rural.asp (15 mar. 2003)

CAFFAGNI, L.C. Seguro rural no Brasil: evoluções, alternativas e sugestões. Piracicaba, 1998. 173p. Dissertação (M.S.) - Escola Superior de Agricultura "Luiz de Queiroz", Universidade de São Paulo.

CAFFAGNI, L.C.; MARQUES, P.V. Seguro agropecuário no Brasil: instituições e problemas. Preços Agrícolas, v.14, n.152, p.16-18, jun. 1999.

CARLIN, B.P.; LOUIS, T.A. Bayes and empirical bayes methods for data analysis. New York: NChapman \& Hall/CRC, 2000. 440p.

CASELLA, G.; BERGER, R.L. Statistical inference. Belmont: Duxbury Press, 1990. $650 \mathrm{p}$.

CHAMBERS, R.G. Insurability and moral hazard in agricultural insurance markets. American Journal of Agricultural Economics, v.71, n.3, p.604-616, Aug. 1989.

CLAPP, J. Expansão do seguro agrícola atinge o Rio de Janeiro. Seguros \& Riscos, v.4, n.34, p.16, ago. 1989.

CLAYTON, D.G.; KALDOR, J. Empirical bayes estimates of age-standardized relative risks for use in disease mapping. Biometrics, v.43, p.671-681, 1987.

COBLE, K.H.; KNIGHT, T.O. Crop insurance as a tool for price and yield risk management. In: JUST, R.E.; POPE, R.D. A comprehensive assessment of the role of risk in U.S. agriculture. Boston: Kluwer Academic Publisher, 2002. 586p.

COLES, M.; MALCOMSON, J.M. Contract theory and incentive compatibility. In: HEY, J.D. Current issues in microeconomics. London: Ed. Macmillan, 1989. $320 \mathrm{p}$.

CRESSIE, N.A.C. Geostatistics. The American Statistician, v.43, n.4, p.197-202, Nov. 1989.

CRESSIE, N.A.C. Statistics for spatial data. New York: John Wiley \& Sons, 1993. $900 \mathrm{p}$.

CRESSIE, N.A.C.; CHAN, N.H. Spatial modeling of regional variables. Journal of the American Statistical Association, v.84, p.393-401, 1989.

CRESSIE, N.A.C.; HAWKINS, D.M. Robust estimation of the variogram, I. Journal of the International Association for Mathematical Geology, v.12, p.115-125, 1980. 
CROP INSURANCE HANDBOOK. http://www.rma.usda.gov/FTP/Publications/ directives/18000/pdf/03_18010-3.pdf (15 Apr. 2003)

CUNHA, G.R. Seguro rural e garantia da atividade agropecuária no Brasil. http://www.cnpt.embrapa.br (23 mar. 2003)

DANDEKAR, V.M. Crop insurance in India: a review, 1976-77 to 1984-85. Economic and Political Weekly, v.20, n.25-26, p.A46-A59, 1985.

DAY, R.H. Probability distributions of field crop yields. Journal of Farm Economics, v.47, n.3, p.713-741, 1965.

DEBREU, G. Theory of value: an axiomatic analysis of general equilibrium. New Haven: Yale University Press, 1959. 114p.

DEGROOT, M.H. Optimal statistical decisions. New York: McGraw-Hill, 1970. $489 \mathrm{p}$.

DIGGLE, P.J.; RIBEIRO JUNIOR, P.J. Model-based geostatistics. Caxambu: ABE, 2000. 129p.

DIGGLE, P.J.; RIBEIRO JUNIOR, P.J; CHRISTENSEN, O.F. An introduction to model-based geostatistics. In: MǿLLER, J. Spatial statistics and computational methods. New York: Springer Verlag, 2003. 216p.

DISMUKES, R. Crop insurance in the United States. http://enesa.mapya.es/ DOCUMENTOS/CONFE/DISMUKES_ING.PDF (22 July 2003)

DISMUKES, R. Recent developments in crop yield and revenue insurance. Agricultural Outlook, n.261, p.16-21, May 1999.

DISMUKES, R.; VANDEVEER, M. U.S. crop insurance: premiums, subsidies, and participaticion. Agricultural Outlook, n.287, p.21-24, Dec. 2001.

DREASSI, E. Space-time analysis of the relationship between material deprivation and mortality for lung cancer. Envirometrics, v.14, p.511-521, 2003.

EDWARDS, W. Actual production history and insurance units for multiple peril crop insurance. Iowa: Iowa State University, 2003. 5p. (Extension publication, 1860)

EDWARDS, W. Group risk plan and group risk income plan. Iowa: Iowa State University, 1999. 3p. (Extension publication, 1850)

FIGUEIREDO, C.S. Seguro agrícola. Revista do IRB, v.54, n.265, p.41, dez. 1993. 
FORMIGA, T.N. Proagro - Programa de garantia da atividade agropecuária - avaliação de seus objetivos na micro-região homogênea de Passo Fundo - RS. Rio de Janeiro, 1983. 219p. Dissertação (M.S.) - Fundação Getúlio Vargas.

FUNDAÇÃO ESCOLA NACIONAL DE SEGUROS (FUNENSEG). Noções do direito do seguro. Rio de Janeiro, 1996a. 63p.

FUNDAÇÃO ESCOLA NACIONAL DE SEGUROS (FUNENSEG). Teoria geral do seguro. Rio de Janeiro, 1996b. 63p.

GALLAGHER, P. U.S. soybean yields: estimation and forecasting with nonsymmetric disturbances. American Journal of Agricultural Economics, v.69, n.4, p.796-803, 1987.

GARDNER, B. Crop insurance in U.S. farm policy. In: HUETH, D.L.; FURTAN, W.H. Economics of agricultural crop insurance: theory and evidence. Boston: Kluwer Academic Publishers, 1994. 380p.

GARNER, B.L; KRAMER, R.A. Experience with crop insurance programs in the United States. In: HAZELL, P.; POMAREDA, C.; VALDÉS, A. Crop insurance for agricultural development. Baltimore: The Johns Hopkins University Press, 1986. 322p.

GELFAND, A.E.; GHOSH, S.K. Model choice: a minimum posterior predictive loss approach. Biometrika, v.85, p.1-11, 1998.

GELFAND, A.E.; GHOSH, S.K.; KNIGHT, J.R.; SIRMANS, C.F. Spatio-temporal modeling of residential sales data. Journal of Business \& Economic Statistics, v.16, p.312-321, 1998.

GELFAND, A.E.; SMITH, A.F.M. Sampling-based approaches to calculating marginal densities. Journal of the American Statistical Association, v.85, p.398-409, 1990.

GELMAN, A.; CARLIN, J.B.; STERN, H.S.; RUBIN, D.B. Bayesian data analysis. London: Chapman \& Hall/CRC, 2003. 668p.

GIMENES, A.C.F. Painel 2: O seguro de custeio agrícola no estado de São Paulo. In: SEMINÁRIO SOBRE SEGURO RURAL E PROAGRO, 1., Campinas, 1979. Anais. Campinas: Secretaria de Agricultura do Estado de São Paulo, Coordenadoria de Assistência Técnica Integral (CATI)/Companhia de Seguros do Estado de São Paulo, 1979. p.1-14. 
GOODWIN, B.K. An empirical analysis of the demand for multiple peril crop insurance. American Journal of Agricultural Economics, v.75, p.425-434, May 1993.

GOODWIN, B.K. An empirical analysis of the demand for multiple peril crop insurance: reply. American Journal of Agricultural Economics, v.76, p.952-953, Nov. 1994.

GOODWIN, B.K. Premium rate determination in the federal crop insurance program: what do averages have to say about risk? Journal of Agricultural and Resource Economics, v. 19, n.2, p.382-396, 1994.

GOODWIN, B.K. Problems with market insurance in agriculture. American Journal of Agricultural Economics, v.83, n.3, p.643-649, Aug. 2001.

GOODWIN, B.K.; KER, A.P. Modeling price and yield risk. In: JUST, R.E.; POPE, R.D. A comprehensive assessment of the role of risk in U.S. agriculture. Boston: Kluwer Academic Publisher, 2002. 586p.

GOODWIN, B.K.; KER, A.P. Nonparametric estimation of crop yield distributions: implications for rating group-risk crop insurance contracts. American Journal of Agricultural Economics, v.80, p.139-153, Feb. 1998.

GOODWIN, B.K.; MAHUL, O. Risk modeling concepts relating to the design and rating of agricultural insurance contracts. Washington: World Bank, 2004. 32p.

GOODWIN, B.K.; SMITH, V.H. Crop insurance, moral hazard and agricultural chemical use. American Journal of Agricultural Economics, v.78, p.428-438, May 1998.

GOODWIN, B.K.; SMITH, V.H. The economics of crop insurance and disaster aid. Washington: American Enterprise Institute, 1995. 153p.

GUYON, X. Random fields on a network: modeling, statistics and applications. New York: Springer Verlag, 1995. 255p.

HALCROW, H.G. Actuarial structures for crop insurance. Journal of Farm Economics, v.31, n.3, p.418-443, Aug. 1949.

HART, D.G.; BUCHANAN, R.A.; HOWE, B.A. The actuarial practice of general insurance. 5.ed. Sydney: The Institute of Actuaries of Australia, 1996. 592p.

HARWOOD, J.; HEIFNER, D.; COBLE, K.; PERRY, J. Alternatives for producer risk management. Agricultural Outlook, p.16-21, May 1999. 
HAZELL, P.; LARSON, D.; MACISAAC, D.; ZUPI, M. Weather insurance project study: Ethiopia feasibility assessment. http://alphaweb.economia.uniroma2.it/ sichelgaita/forum/session221.htm (13 Jan. 2003)

HOBERT, J.P.; CASELLA, G. The effect of improper priors on Gibbs sampling in hierarchical linear mixed models. Journal of the American Statistical Association, v.91, p.1461-1473, 1996.

HOFSTRAND, D.; EDWARDS, W. Multiple peril crop insurance. Iowa: Iowa State University, 2003. 5p. (Extension publication, 1826)

HOY, M. Categorizing risks in the insurance industry. Quarterly Journal of Economics, v.97, n.2, p.321-336, May 1982.

INSTITUTO BRASILEIRO DE GEOGRAFIA E ESTATÍSTICA (IBGE). Servidor de mapas. http://www.ibge.gov.br (10 jul. 2004)

JUST, R.; CALVIN, L. An empirical analysis of U.S. participation in crop insurance. In: HUETH, D.L.; FURTAN, W.H. Economics of agricultural crop insurance: theory and evidence. Boston: Kluwer Academic Publishers, 1994. 380p.

JUST, R.E.; WENINGER, Q. Are crop yields normally distributed? American Journal of Agricultural Economics, v.81, p.287-304, 1999.

KER, A.P.; COBLE, K. Modeling conditional yield densities. American Journal of Agricultural Economics, v.85, p.291-304, 2003.

KER, A.P.; GOODWIN, B.K. Nonparametric estimation of crop insurance rates revisited. American Journal of Agricultural Economics, v.83, p.463-478, May 2000.

KNIGHT, T.O.; COBLE, K.H. Survey of U.S. multiple peril crop insurance literature since 1980. Review of Agricultural Economics, v.19, n.1, p.128-156, 1997.

KRAMER, R.A. Federal crop insurance: 1938-1982. Agricultural History, v.57, n.2, p.181-200, Apr. 1983.

LÁ, como aqui. Seguros \& Riscos, v.133, n.17, abr. 1999.

LAUD, P.W.; IBRAHIM, J.G. Predictive model seletion. Journal of the Royal Statistical Society, Ser. B, v.57, p.247-262, 1995.

LEE, I.M. Temperature insurance: an alternative to frost insurance in citrus. Journal of Farm Economics, v.35, p.15-28, 1953. 
LIPSEY, R.G.; LANCASTER, K. The general theory of second best. Review of Economics Studies, v.24, n.63, p.11-32, 1956-57.

LOPES, M.R.; DIAS, G.L.S. The brazilian experience with crop insurance programs. In: HAZELL, P.; POMAREDA, C.; VALDÉS, A. Crop insurance for agricultural development. Baltimore: The Johns Hopkins University Press, 1986. 322p.

LUENBERGER, D.G. Microeconomic theory. New York: McGraw-Hill Inc., 1995. $486 \mathrm{p}$.

LUZ FILHO, F. Seguros agro-pecuários. Brasília: Ministério da Agricultura, Serviço de Economia Rural, 1949. 80p.

MACHO-STADLER, I.; PÉRES-CASTRILLO, J.D. An introduction to the economics of information. New York: Oxford University Press, 1997. 277p.

MAHUL, O. Optimum area yield crop insurance. American Journal of Agricultural Economics, v.81, n.1, p.75-82, Feb. 1999.

MARTINS, S.S. Risco e seguro das atividades agrícolas. São Paulo, 1987. 72p. Dissertação (M.S.) - Escola de Administração de Empresas de São Paulo, Fundação Getúlio Vargas.

MARTINS, S.S. A extinção do seguro obrigatório da lavoura do algodão no Estado de São Paulo. Informações Econômicas, v.21, n.11, p.15-18, nov. 1991.

MAS-COLELL, A.; WHINSTON, M.D.; GREEN, J.R. Microeconomic theory. New York: Oxford University Press, 1995. 981p.

MATHERON, G. Principles of geostatistics. Economic Geology, v.58, p.1246-1266, 1963.

McCARTY, D.E. Wheat yield insurance. Journal of Farm Economics, v.23, p.664$667,1941$.

MIGON, H.S.; LOPES, H.F. Análise bayesiana de decisões: aspectos práticos. São Paulo: Associação Brasileira de Estatística, 2002. 186p.

MILGROM, P.; ROBERTS, J. Economics, organization and management. New Jersey: Prentice-Hall, 1992. 620p.

MIRANDA, M.J. Area-yield crop insurance reconsidered. American Journal of Agricultural Economics, v.73, n.2, p.233-242, May 1991. 
MIRANDA, M.J.; GLAUBER, J.W. Systemic risk, reinsurance, and the failure of crop insurance markets. American Journal of Agricultural Economics, v.79, n.1, p.206-215, Feb. 1997.

MIRANDA, M.; SKEES, J.; HAZELL, P. Innovations in agricultural and natural disaster insurance for developing countries. Ohio: The Ohio State University, Department of Agriculture, Environment and Development, 1999. (Working paper)

MOSLEY, P.; KRISHNAMURTHY, R. Can crop insurance work? The case of India. The Journal of Development Studies, v.31, p.428-450, 1995.

MOSS, C.B.; SHONKWILER, J.S. Estimating yield distributions with a stochastic trend and nonnormal errors. American Journal of Agricultural Economics, v.75, n.4, p.1056-1062, 1993.

MUSSER, W.N.; PATRICK, G.F. How much does risk really matter to farmers? In: JUST, R.E.; POPE, R.D. A comprehensive assessment of the role of risk in U.S. agriculture. Boston: Kluwer Academic Publisher, 2002. 586p.

NELSON, C.H.; LOEHMAN, E.T. Further toward a theory of agricultural insurance. American Journal of Agricultural Economics, v.69, n.3, p.523-531, Aug. 1987.

NELSON, C.H.; PRECKEL, P.V. The conditional beta distribution as a stochastic production function. American Journal of Agricultural Economics, v.71, n.2, p.370-378, 1989.

NELSON, R.R; Uncertainty, prediction and competitive equilibrium. Quarterly Journal of Economics, v.75, p.41-62, 1961.

O IRB e o seguro rural. Seguros \& Riscos, n.148, p.12, ago. 2000.

PAIM, A. Seguro cooperativo da produção. Porto Alegre: Superintendência Plano Valorização Econômica da Região Fronteira Sudoeste do País/Editora Sulina, 1960. cap.1, p.13-54.

PAULY, M.V. Overinsurance and public provision of insurance: the roles of moral hazard and adverse selection. Quarterly Journal of Economics, v.88, n.1, p.44-62, Feb. 1974.

PAULY, M.V. The economics of moral hazard: comment. American Economic Review, v.58, n.3, p.531-537, June 1968.

POPE, R.D.; KRAMER, R.A. Production uncertainty and factor demands for the competitive firm. Southern Economic Journal, v.45, p.489-501, 1979. 
PORTO, C.B. O seguro agrícola privado no Brasil. Revista de Política Agrícola, v.8, n.2, p.3-6, abr./jun. 1999.

PRATT, J. Risk aversion in the small and in the large. Econometrica, v.32, p.122 -136, Jan. 1964.

QUIGGIN, J. A note on the viability of rainfall insurance. The Australian Journal of Agricultural Economics, v.30, n.1, p.63-69, Apr. 1986.

QUIGGIN, J.; KARAGIANNIS, G.; STANTON, J. Crop insurance and crop production: an empirical study of moral hazard and adverse selection. In: HUETH, D.L.; FURTAN, W.H. Economics of agricultural crop insurance: theory and evidence. Boston: Kluwer Academic Publishers, 1994. 380p.

RAIN \& HAIL. Products. http://www.rainhail.com (12 July 2003)

RAMASWAMI, B.; ROE, T.L. Aggregation in area-yield crop insurance: the linear additive model. American Journal of Agricultural Economics, v.86, n.2, p.420431, 2004.

RAMÍREZ, O.A. Estimation and use of a multivariate parametric model for simulating heteroskedastic, correlated, non Normal random variables: the case of corn belt corn, soybean and wheat yields. American Journal of Agricultural Economics, v.79, p.191-205, 1997.

RAMIREZ, O.A.; MISRA, S.; FIELD, J. Crop-yield distributions revisited. American Journal of Agricultural Economics, v.85, n.1, p.108-120, 2003.

RAY, P.K. Economics of crop insurance. Calcuta: Central Publishing Concern, 1981. $333 p$.

REDJA, G.E. Principles of risk management and insurance. New York: Harder Collins College Publishers, 1995. 784p.

REES, R. Uncertainty, information and insurance. In: HEY, J.D. Current issues in microeconomics. London: Ed. Macmillan, 1989. 320p.

RIO GRANDE DO SUL (Estado). Governo do Estado do Rio Grande do Sul. Mensagem à Assembléia Legislativa. Porto Alegre, 2002. 439p.

ROCHA, I.A.S. O desenvolvimento do seguro rural. Seguros \& Riscos, v.4, n.34, p.6-7, ago. 1989. 
RODRIGUES, C.E.C. O seguro rural em São Paulo. In: SIMPÓSIO INTERNACIONAL DE SECURIDADE E ZONEAMENTO AGRÍCOLA DO MERCOSUL, 1., Brasília, 1998. Anais. Brasília: Ministério da Agricultura e Abastecimento/CER/PROAGRO/GM, 1998. p.15-20.

ROSS, S. The economic theory of agency: the principal's problem. American Economic Review, v.63, n.2, p.134-139, May 1973.

ROSSETTI, L.A. Seguridade e zoneamento agrícola no Brasil: novos rumos. In: SIMPÓSIO INTERNACIONAL DE SECURIDADE E ZONEAMENTO AGRÍCOLA DO MERCOSUL, 1., Brasília, 1998. Anais. Brasília: Ministério da Agricultura e Abastecimento/CER/PROAGRO/GM, 1998. p.1-10.

ROSSETTI, L.A. Zoneamento agrícola em aplicações de crédito e securidade rural no Brasil: aspectos atuariais e de política agrícola. Revista Brasileira de Agrometeorologia, v.9, n.3, p.386-399, 2001.

ROTHSCHILD, M.; STIGLITZ, J. Equilibrium in competitive insurance markets: an essay on the economics of imperfect information. Quarterly Journal of Economics, v.90, n.4, p.629-649, Nov. 1976.

SALANIÉ, B. The economics of contracts: primer. Cambridge: The MIT Press, 1997. $223 p$.

SANDERSON, F.H. A specific-risk scheme for wheat crop insurance. Journal of Farm Economics, v.25, p.759-776, 1943.

SANTOS, C.G. O seguro rural. Revista do IRB, v.28, n.166, p.17-29, dez. 1967.

SAFRA agrícola, mais problemas este ano. Seguros \& Riscos, v.4, n.34, p.8, ago. 1989.

SÃO PAULO (Estado). Leis, decretos, etc. Decreto $\mathrm{n}^{\circ}$ 9.865, de 27 de dezembro de 1938. Coleção das Leis e Decretos do Estado de São Paulo, Tomo 48, v. 4.

SÃO PAULO (Estado). Leis, decretos, etc. Decreto n ${ }^{\circ}$ 10.554, de 4 de outubro de 1939. Coleção das Leis e Decretos do Estado de São Paulo, Tomo 49, v. 4.

SÃO PAULO (Estado). Leis, decretos, etc. Decreto $\mathrm{n}^{\circ}$ 18.437, de 30 de dezembro de 1948. Coleção das Leis e Decretos do Estado de São Paulo, Tomo 57, v. 4.

SÃO PAULO (Estado). Leis, decretos, etc. Lei n ${ }^{\circ}$ 8.375, de 28 de outubro de 1964.

Coleção das Leis e Decretos do Estado de São Paulo, Tomo 74, v. 4. 
SÃO PAULO. Secretaria da Agricultura. Comissão de Produção Agropecuária. Aspectos do seguro agrícola em São Paulo. São Paulo: PROAGRI, 1971. 120p.

SATTLER, R. Seguro mútuo de granizo. In: SIMPÓSIO INTERNACIONAL DE SECURIDADE E ZONEAMENTO AGRÍCOLA DO MERCOSUL, 1., Brasília, 1998. Anais. Brasília: Ministério da Agricultura e Abastecimento/CER/PROAGRO/GM, 1998. p.27-28.

SAVAGE, L. The foundations of statistics. New York: John Wiley, 1954. 294p.

SCHNITKEY, G. Income protection (IP) insurance. Urbana-Champaign: University of Illinois at Urbana-Champaign, 2002. 4p. (Farm economics: facts \& opinions)

SCHWARZ, G. Estimating the dimension of a model. The Annals of Statistics, v.6, p.461-464, 1978.

SEFFRIN, G. O fumo no Brasil e no mundo. Santa Cruz do Sul: AFUBRA, 1995. $186 \mathrm{p}$.

SEGURO rural em vias de solução. Revista do IRB, v.51, n.255, p.6, jan./mar. 1991.

SHAVELL, S. On moral hazard and insurance. Quarterly Journal of Economics, v.93, n.4, p.541-562, 1979.

SHERRICK, B.J.; ZANINI, F.C.; SCHNITKEY, G.D.; IRWIN, S.H. Crop insurance valuation under alternative yield distributions. American Journal of Agricultural Economics, v.86, p.406-419, 2004.

SIGURDSON, D.; SIN, R. An aggregate analysis of canadian crop insurance policy. In: HUETH, D.L.; FURTAN, W.H. Economics of agricultural crop insurance: theory and evidence. Boston: Kluwer Academic Publishers, 1994. 380p.

SILBERBERG, E. The structure of economics: a mathematical analysis. New York: McGraw-Hill Publishing Company, 1995. 592p.

SILVERMAN, B.W. Density estimation for statistics and data analysis. London: Chapman and Hall, 1986. 175p.

SKEES, J.R.; BARNETT, B.J. Conceptual and practical considerations for sharing catastrophic risks. Review of Agricultural Economics, v.21, n.2, p.424-441, 1999.

SKEES, J.R.; BLACK, J.R.; BARNETT, B.J. Designing and rating an area yield crop insurance. American Journal of Agricultural Economics, v.79, n.2, p.430-438, May 1997. 
SKEES, J.R.; GOBER, S.; VARANGIS, P.; LESTER, R.; KALAVAKONDA, V. Developing rainfall-based index insurance in Morocco. http://econ.worldbank.org/files/ 1686_wps2577.pdf(10 Nov. 2002)

SKEES, J.R.; REED, M.R. Rate making for farm-level crop insurance: implications for adverse selection. American Journal of Agricultural Economics, v.68, p.653-659, Aug. 1986.

SMITH, V.H.; CHOUINARD, H.H.; BAQUET, A.E. Almost ideal area yield crop insurance contracts. Agricultural and Resource Economics Review, v.23, n.1, Apr. 1994.

SOARES JUNIOR, H.O.; FONSECA, O.L.; SOUZA, N.A. Seguro rural. Revista do IRB, v.32, n.186, p.54-59, abr. 1971.

SOBRINHO, A.G. As implicações do seguro agrícola. Seguros \& Riscos, p.16-17, set. 1999.

SOMA JUNIOR, M. Caráter social da carteira afugenta seguradoras. Seguros \& Riscos, v.7, n.65, p.10-11, jul. 1992.

SOUZA, J.C. Agricultores devem ter auxílio federal. http://www.an.com.br /1999/ mar/ 28/0eco.htm (12 abr. 2003)

SOUSA, I.J.M. Banerj garante a safra no Rio de Janeiro. Seguros \& Riscos, v.5, n.45, p.42-43, ago. 1990 .

SPENCE, M.; ZECKHAUSER, R. Insurance, information, and individual action. American Economic Review, v.61, n.2, p.380-387, May 1971.

SPIEGEHALTER, D.; THOMAS, A.; BEST, N.; LUNN, D. Winbugs user manual. Cambridge: Medical Research Council Biostatistics Unit, 2003.

STIGLER, G. The economics of information. Journal of Political Economy, v.69, n.3, p.213-225, June 1961.

STIGLITZ, J.E. Information and economic analysis: a perspective. Economic Journal, v.95, p.21-41, 1985. Supplement.

STIGLITZ, J.E. Principal and agent. In: EATWELL, J.; MLGATE, M.; NEWMAN, P. The new palgrave. London: The Macmillan Press, 1987.

TAYLOR, C.R. Two practical procedures for estimating multivariate non Normal probability density functions. American Journal of Agricultural Economics, v.72, p.210-217, 1990. 
THOMAS, A.; BEST, N.; ARNOLD, R. SPIEGEHALTER, D. GeoBugs user manual. Cambridge: Medical Research Council Biostatistics Unit, 2002.

TROWBRIDGE, C.L. Fundamental concepts of actuarial science. Actuarial Education and Research Fund, 1989. 90p.

TURVEY, C.G. Weather derivatives for specific event risks in agriculture. Review of Agriculture Economics, v.23, n.2, p.333-351, 2001.

TURVEY, C.; ZHAO, C. Parametric and nonparametric crop yield distributions and their effects on all-risk crop insurance premiums. Guelf: University of Guelf, Department of Agricultural Economics and Business, 1999. (Working paper)

UNITED STATES DEPARTMENT OF AGRICULTURE. 1999 revenue crop insurance plans: crop revenue coverage, income protection and revenue assurance. http://www.rma.usda.gov (10 July 2003a)

UNITED STATES DEPARTMENT OF AGRICULTURE. Adjusted gross revenue (AGR): a risk management agency fact sheet. http://www.rma.usda.gov (10 July 2003b)

UNITED STATES DEPARTMENT OF AGRICULTURE. Adjusted gross revenue standards handbook: 2003 and succeeding insurance years. http://www.rma.usda.gov (10 July 2003c)

UNITED STATES DEPARTMENT OF AGRICULTURE. Crop revenue coverage: common questions and answers. http://www.rma.usda.gov (10 July 2003d)

UNITED STATES DEPARTMENT OF AGRICULTURE. Crop revenue coverage: underwriting rules. http://www.rma.usda.gov (10 July 2003e)

UNITED STATES DEPARTMENT OF AGRICULTURE. Group risk plan: basic provisions. http://www.rma.usda.gov (10 July 2003f)

UNITED STATES DEPARTMENT OF AGRICULTURE. Group risk plan insurance standards handbook: general and individual crops 2000 and succeeding crop years. http://www.rma.usda.gov (10 July 2003g)

UNITED STATES DEPARTMENT OF AGRICULTURE. Group risk income plan: underwriting rules. http://www.rma.usda.gov (10 July 2003h)

UNITED STATES DEPARTMENT OF AGRICULTURE. Revenue assurance: common questions and answers. http://www.rma.usda.gov (10 July 2003i) 
UNITED STATES DEPARTMENT OF AGRICULTURE. Revenue assurance: underwriting rules. http://www.rma.usda.gov (10 July 2003j)

YAARI, M. Some measures of risk aversion and their uses. Journal of Economic Theory, v.1, n.2, p.315-329, 1969.

YAMAUCHI, T. Evolution of the crop insurance program in Japan. In: HAZELL, P.; POMAREDA, C.; VALDÉS, A. Crop insurance for agricultural development. Baltimore: The Johns Hopkins University Press, 1986. 322p.

WALlER, L.A.; CARLIN, B.P.; XIA, H.; GELFAND, A.E. Hierarchical spatiotemporal mapping of disease rates. Journal of the American Statistical Association, v.92, p.607-617, 1997.

WANG, H.W.; ZHANG, H. On the possibility of private crop insurance market: a spatial statistics approach. The Journal of Risk and Insurance, v.70, n.1, p.111$124,2003$.

WRIGHT, B.D.; HEWITT, J.A. All-risk crop insurance: lessons from theory and experience. In: HUETH, D.L.; FURTAN, W.H. Economics of agricultural crop insurance: theory and evidence. Boston: Kluwer Academic Publishers, 1994. 380p.

ZINI, A.A. Painel 1: fundamentos do seguro rural. In: SEMINÁRIO SOBRE SEGURO RURAL E PROAGRO, 1., Campinas, 1979. Anais. Campinas: Secretaria de Agricultura do Estado de São Paulo, Coordenadoria de Assistência Técnica Integral (CATI)/Companhia de Seguros do Estado de São Paulo, 1979. p.1-16. 